$$
\begin{gathered}
\text { Universidade de SÃo Paulo } \\
\text { Instituto de Geociências } \\
\text { Departamento de MineRAlogia E GeOtectônica }
\end{gathered}
$$

Os distintos tipos petrográficos da intrusão kimberlítica Pântano, Província Alcalina Alto Paranaíba (MG): evidências de um sistema magmático aberto

\author{
Dissertação de Mestrado \\ Programa de pós-graduação em mineralogia e petrologia
}

Camila Sayuri Vasconcelos Shibata

Orientador: Prof. Dr. Rogério G. Azzone 


$$
\begin{aligned}
& \text { UNIVERSIDADE DE SÃO PAULO } \\
& \text { INSTITUTO DE GEOCIÊNCIAS }
\end{aligned}
$$

\title{
OS DISTINTOS TIPOS PETROGRÁFICOS DA INTRUSÃO KIMBERLÍTICA PÂNTANO, PROVÍNCIA ALCALINA ALTO \\ PARANAÍBA (MG): EVIDÊNCIAS DE UM SISTEMA \\ MAGMÁTICO ABERTO
}

\section{CAMILA SAYURI VASCONCELOS SHIBATA}

Orientador: Prof. Dr. Rogério Guitarrari Azzone

\author{
Dissertação de Mestrado \\ № 838 \\ COMISSÃO JULGADORA \\ Dr. Rogério Guitarrari Azzone \\ Dr. José Paulo Donatti Filho \\ Dr. Darcy Pedro Svizzero
}

SÃO PAULO 
Autorizo a reprodução e divulgação total ou parcial deste trabalho, por qualquer meio convencional ou eletrônico, para fins de estudo e pesquisa, desde que citada a fonte.

Serviço de Biblioteca e Documentação do IGc/USP

Ficha catalográfica gerada automaticamente com dados fornecidos pelo(a) autor(a) via programa desenvolvido pela Seção Técnica de Informática do ICMC/USP

Bibliotecários responsáveis pela estrutura de catalogação da publicação: Sonia Regina Yole Guerra - CRB-8/4208 | Anderson de Santana - CRB-8/6658

Shibata, Camila

Os distintos tipos petrográficos da intrusão

kimberlítica Pântano, Província Alcalina Alto Paranaíb

(MG) : evidências de um sistema magmático aberto /

Camila Shibata; orientador Rogério Azzone. -- São

Paulo, 2019.

$231 \mathrm{p}$.

Dissertação (Mestrado - Programa de Pós-Graduação em Mineralogia e Petrologia) -- Instituto de Geociências, Universidade de São Paulo, 2019.

1. kimberlitos. 2. contaminação crustal. 3. xenólitos do manto. I. Azzone, Rogério, orient. II. Título. 


\section{AGRADECIMENTOS}

É difícil de acreditar que finalmente estou escrevendo meus agradecimentos. Em muitos momentos, duvidei que essa hora chegaria, mas chegou, graças a primeira pessoa a qual eu gostaria de agradecer pela execução deste trabalho: meu orientador. Agradeço ao Rogério por trabalharmos juntos desde 2015, por todo o conhecimento que ele foi capaz de me passar, pela paciência, dedicação e amizade. Sou grata e me sinto muito privilegiada por ter tido a oportunidade de ter um orientador como o Rogério.

Agradeço muito ao meu companheiro, Matheus, que me apoiou em todos os momentos difíceis, trabalhou ao meu lado e teve a maior paciência em todo o processo que foi a escrita dessa dissertação. Sem você, eu não teria tido forças para terminar, obrigada. Você é minha pessoa favorita no mundo.

Agradeço à minha famíia pela base e apoio durante a graduação, que me permitiram ingressar na pós-graduação, fazendo com que eu seja a primeira mestra da família. Obrigada por perdoarem as ausências em tantos finais de semana e feriados.

Sou muito grata aos poucos e bons amigos da pós-graduação, mesmo com a distância, tivemos ótimos momentos juntos. Agradeço muito ao Nicholas Lima pela conspiração do universo de termos estudado o mesmo tema... a sua contribuição para esse trabalho foi fundamental. Agradeço também, especialmente, ao Júlio Lopes, pela ajuda durante a obtenção dos dados e pelo incentivo. À Mariana e Bruna, fica também meu muito obrigada pelas conversas, discussões e momentos durante esses anos de convivência. Um agradecimento especial à Bárbara pela amizade, companhia e pela ajuda fundamental na etapa final de execução desse trabalho.

À Fundação de Amparo à Pesquisa do Estado de São Paulo (projetos 2012/06082-6 e 2017/03768-8), agredeço pelo fornecimento do auxílio financeiro para realização dessa pesquisa. Aos funcionários do IGc-USP pelo imenso apoio durante a obtenção dos dados analíticos, principalmente Marcos e Leandro (microssonda), Vinícius (LA-ICP-MS) e Isaac (MEV). 
"You're not late, You're not early, You're very much on time and in your time zone."

(Marie-Claire Kuja) 


\section{Resumo}

A intrusão Pântano pode ser classificada como um kimberlito hipoabissal, associado ao magmatismo Cretácico da Província Alcalina Alto Paranaíba, no Estado de Minas Gerais. Foram identificados três principais tipos para intrusão Pântano, controlados por diferentes níveis de contaminação crustal, sendo estes caracterizados pelas fases minerais predominantes. O tipo menos contaminado da intrusão é constituído por monticelita disseminada na matriz (Kmtc) e a granada como constituinte traço apresenta evidência de que o magma teria passado por níveis mantélicos profundos, caracterizando a natureza kimberlítica do corpo. O tipo com menor grau de contaminação crustal é caracterizado pela presença de flogopita poiquilítica na matriz (Kphl), interpretada como produto da interação do corpo kimberlítico com material crustal em estágios finais da cristalização. O tipo petrográfico mais contaminado apresenta diopsídio na matriz (Kdiop) em regiões próximas a enclaves félsicos e monticelita sendo substituída por diopsídio, corroborando com a adição de sílica no sistema. Geoquimicamente, os tipos petrográficos das rochas da intrusão Pântano não apresentam diferenças marcantes, sendo caracterizadas por altos teores de $\mathrm{CaO}$, $\mathrm{MgO}, \mathrm{K}_{2} \mathrm{O}$ e TiO 2 , baixos teores de $\mathrm{SiO}_{2}$ e expressivo enriquecimento em elementostraços incompatíveis. O tipo petrográfico mais contaminado apresenta o índice de contaminação crustal mais elevado $(1,4)$ em relação às demais amostras. Os enclaves, xenólitos crustais, texturas sugestivas de desequilíbrio em olivina e feições de fusão parcial observadas nas rochas da intrusão Pântano indicam a evolução de um magma em sistema aberto. Os tipos petrográficos caracterizados permitem a interpretação de que houve três eventos de contaminação, que poderiam ocorrer através da assimilação de granitos, filitos e/ou quartzitos. A partir da modelagem geoquímica, é estimada a incorporação de 10 a $40 \%$ de fundidos crustais a partir de um magma progenitor com a composição dos fundidos calculados para a intrusão Pântano. Com o auxílio de petrografia de detalhe, foram caracterizadas as populações mineralógicas cognatas e xenocristalinas do corpo intrusivo. Os núcleos das populações de olivina (Fo89-92,5) sugerem origem de um manto da região dos granadaespinélio peridotitos, já as bordas são consideradas sobrecrescimentos cognatos ao fundido kimberlítico. A população de antecristais de olivina caracteriza-se pelos núcleos enriquecidos em $\mathrm{Fe}$. As populações de flogopita possuem origens distintas, podendo ser caracterizadas como cognatas, antecristais ou xenocristais (alto $\mathrm{Ti} \mathrm{e} \mathrm{Cr}$ ) similares àqueles descritos para a suíte MARID. A partir do desconto das populações xenocristalinas, foi calculada a possível composição do fundido que daria origem a intrusão. As composições estimadas para os fundidos são enriquecidas em $\mathrm{TiO}_{2}$, $\mathrm{Al}_{2} \mathrm{O}_{3}, \mathrm{CaO}$ e $\mathrm{K}_{2} \mathrm{O}$ e em elementos-traço incompatíveis quando comparadas aos valores de rocha total, e tais fundidos assemelham-se às composições de fundidos de olivina lamproítos estimadas mundo afora. Os fundidos calculados para intrusão Pântano possuem caráter ultrapotássico, similarmente à fundidos kamafugíticos, o que corrobora com a hipótese de que kimberlitos contaminados poderiam ter composições semelhantes às de kamafugitos.

Palavras chave: kimberlitos, contaminação crustal, xenocristais mantélicos 


\section{Abstract}

The Pântano intrusion can be classified as a hypabyssal kimberlite, associated with the Cretaceous magmatism of the Alto Paranaíba Alkaline Province, in the State of Minas Gerais. Three main petrographic types of Pântano intrusion were identified, controlled by different levels of crustal contamination, characterized by the predominant mineral phases. The least contaminated type of intrusion is constituted by widespread monticellite in the matrix (Kmtc) and the garnet as a trace constituent shows evidence that the magma had gone through deep mantle levels, characterizing the kimberlitic nature of the intrusion. The type with a lower degree of crustal contamination is characterized by the presence of poikilitic phlogopite in the matrix (Kphl), interpreted as a product of the interaction of the kimberlitic intrusion with crustal material in the final stages of crystallization. The most contaminated petrographic type presents diopside in matrix (Kdiop) in regions near felsic enclaves, and monticellite being replaced by diopside, corroborating the addition of silica in the system. Geochemically, the petrographic types of the Pântano intrusion rocks do not present marked differences, being characterized by high $\mathrm{CaO}, \mathrm{MgO}, \mathrm{K}_{2} \mathrm{O}$ and $\mathrm{TiO}_{2}$ contents, low $\mathrm{SiO}_{2}$ contents and expressive enrichment in incompatible trace elements. The most contaminated petrographic type presents the highest crustal contamination index $(1,4)$ in relation to the other samples. The enclaves, crustal xenoliths, textures suggestive of olivine disequilibrium and partial fusion features observed in the Pântano intrusion rocks indicate the evolution of an open system magma. The petrographic types characterized allow the interpretation that there were three contamination events, which could occur through the assimilation of granites, phyllites and/or quartzites. From geochemical modeling, it is estimated an addition of 10 to $40 \%$ of crustal melts from a parental magma with the melt composition calculated for the Pântano intrusion. With detailed petrography, the cognate and xenocrystalline mineralogical populations of the intrusive body were characterized. Olivine core population (Fo89-92,5) suggest origin of a mantle from the peridotite garnet-spinel region, whereas the rims are considered cognate overgrowths to the kimberlitic pulse. The population of olivine antecrystals is characterized by Fe-enriched cores. Phlogopite populations have distinct origins and can be characterized as cognate, antecrystals or xenocrystals (high $\mathrm{Ti}$ and $\mathrm{Cr}$ ) similar to those described for MARID suite. From the xenocrystalline population discount, the possible melt composition that would give rise to the intrusion was calculated. Estimated melt compositions are enriched in $\mathrm{TiO}_{2}$, $\mathrm{Al}_{2} \mathrm{O}_{3}, \mathrm{CaO}$ and $\mathrm{K}_{2} \mathrm{O}$ and incompatible trace elements when compared to whole-rock values, and such melts resemble the estimated olivine lamproit melt compositions worldwide. Pântano intrusion melts have an ultrapotassic character, similar to kamafugitic melts, which corroborates the hypothesis that contaminated kimberlite could have similar compositions to kamafugites.

Key words: kimberlites, crustal contamination, mantle xenocrysts 


\section{Sumário}

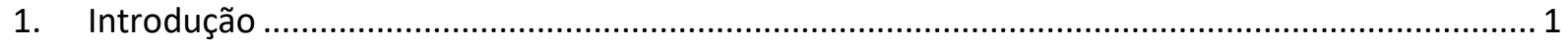

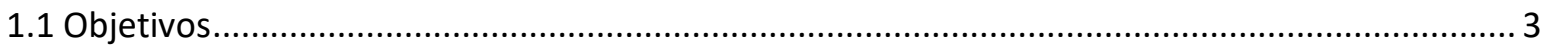

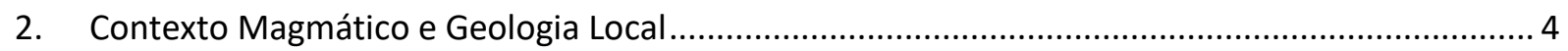

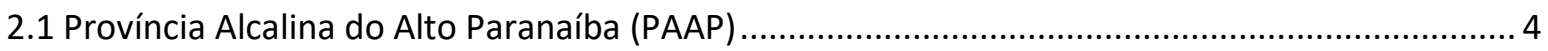

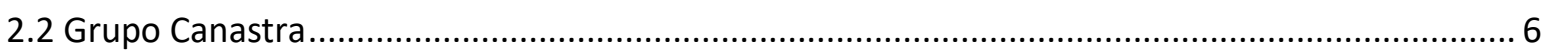

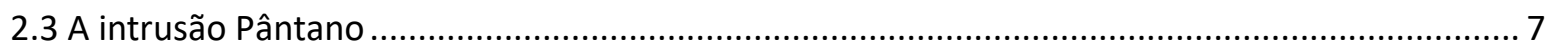

3. Kimberlitos hipoabissais e a distinção entre populações e assembléias minerais......................... 12

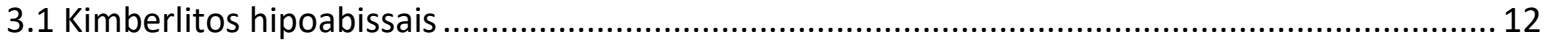

3.2 Cristais cognatos versus xenocritais: evidências em zonamentos e texturas ............................. 13

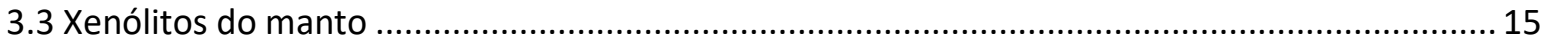

3.4 Xenólitos do manto na região Sudoeste de Minas Gerais......................................................... 17

4. Química mineral e elementos-traço como ferramentas para elucidação de processos em

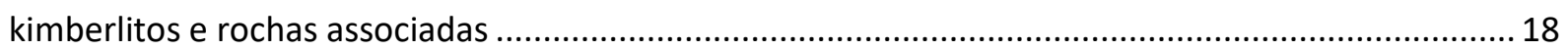

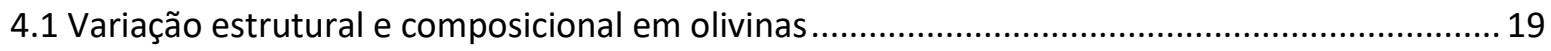

4.1.1 Estrutura e composição da olivina em kimberlitos ................................................................ 19

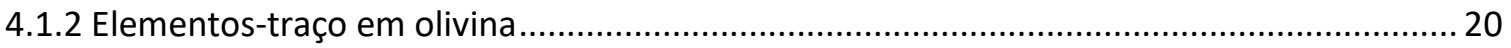

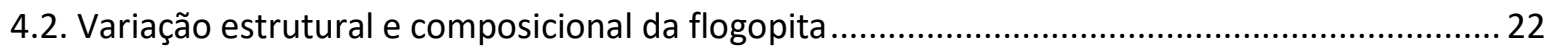

4.2.1 Estrutura e composição de micas trioctaédricas: flogopita e biotita ...................................... 22

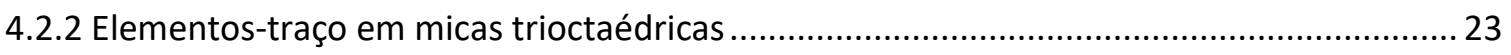

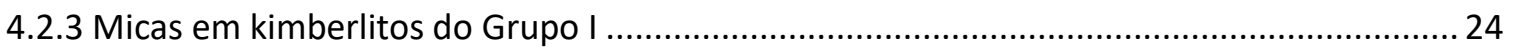

5. Reconstituições de líquidos pristinos em rochas de afinidade kimberlítica .................................. 25

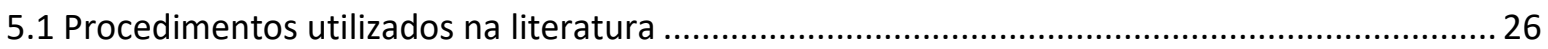

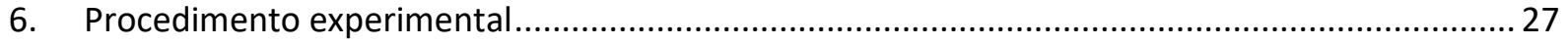

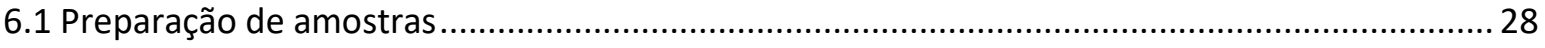

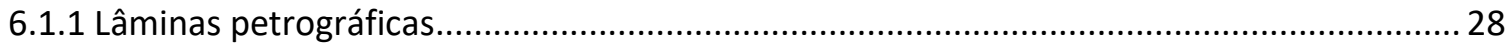

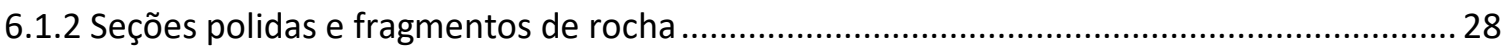

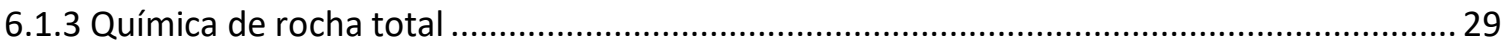

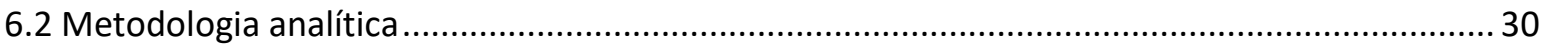

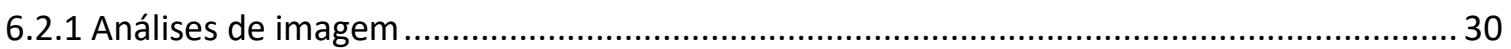

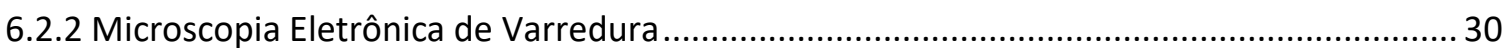

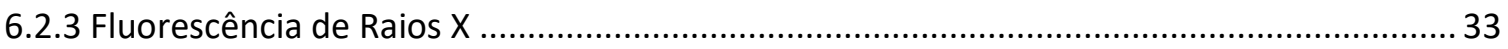

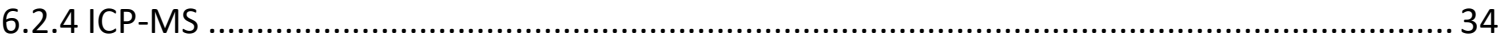




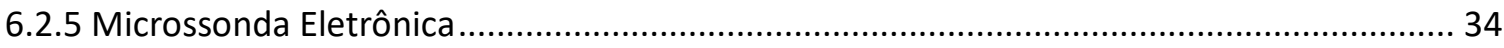

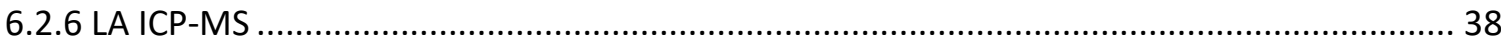

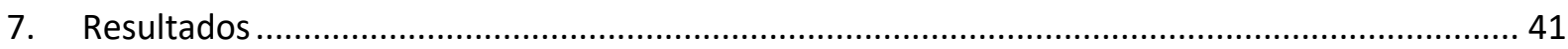

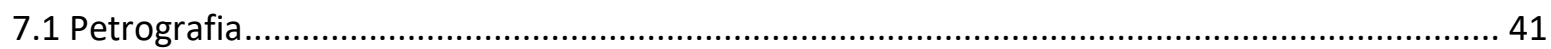

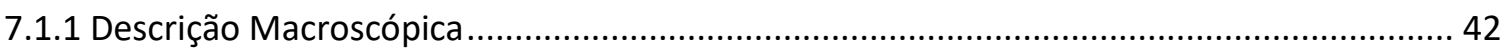

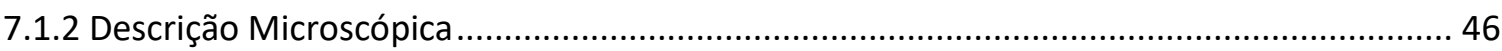

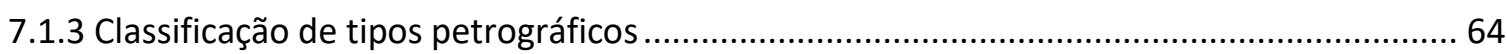

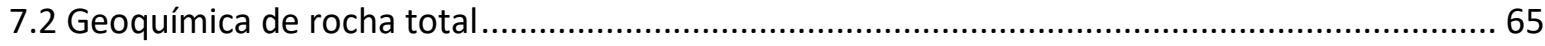

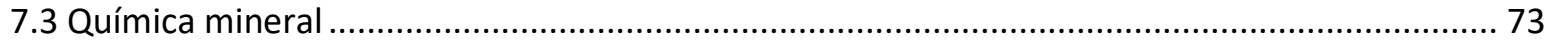

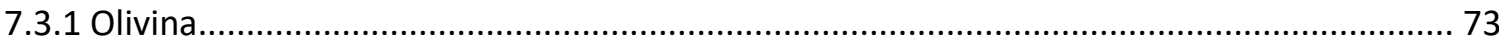

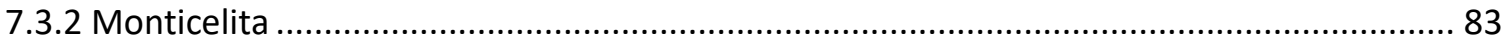

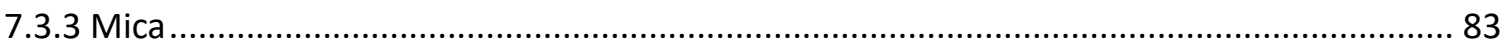

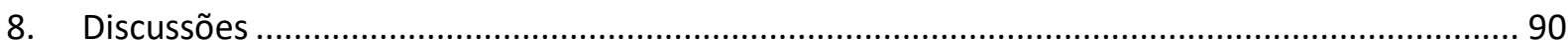

8.1. Distintas populações de xenólitos, xenocristais, antecristais e cristais cognatos .................... 90

8.2 Estimativa de magma kimberlítico sem a influência de xenocristais......................................... 94

8.3 Evidências de processos de sistema aberto e contaminação crustal ....................................... 105

8.3.1 Modelagem do processo de contaminação crustal ........................................................... 108

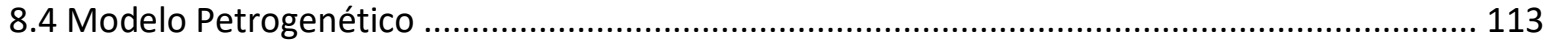

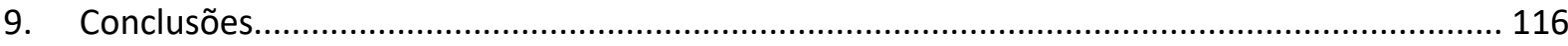

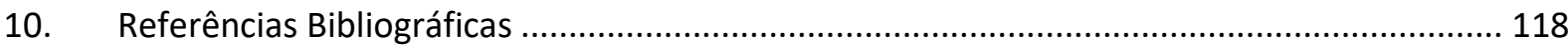




\section{Lista de Figuras}

Figura 2.1: Mapa geológico da Província Alcalina Alto Paranaíba considerando as regiões próximas à Coromandel e Patos de Minas e intrusões kimberlíticas mapeadas pela CPRM (Projeto Diamante, Cabral Neto et al., 2017). Destaque para intrusão Pântano. 10

Figura 2.2: Representação esquemática da intrusão Pântano, apresentando dimensões do corpo intrusivo e os pontos em que foram coletadas as amostras utilizadas no presente trabalho. As amostras foram coletadas de acordo com os tipos petrográficos caracterizados por Meyer et al. (1991) 11

Figura 6.1: Mapeamento de fragmento de rocha obtido através da matriz de fotomicrografias de MEV. Destaque para os cristais selecionados para as análises de ME e LA-ICP-MS. .32

Figura 7.1: a) aspectos gerais da rocha: maciça, com textura pseuporfirítica, com mega e macrocristais dispersos na matriz; b) Lâmina petrográfica digitalizada, aonde é possível observar as venulações de carbonato e serpentina (setas vermelhas), megacristais (seta azul) e macrocristais (setas verdes) de olivina (OI), bem como microcristais em uma matriz inequigranular; c) Detalhe de macrocristal de granada com borda kelifítica descrito para amostra PNT-3 (monticelita kimberlito); d) Xenólito crustal arredondado de coloração rósea e branca. Este tipo de xenólito pode ser observado em todos os tipos petrográficos descritos para intrusão. Os xenólitos podem ter ou não bordas de reação de colorações bege ou

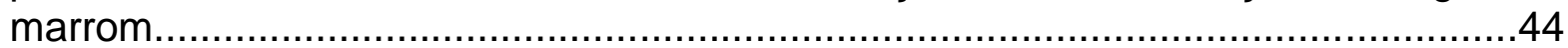

Figura 7.2: a) cristais de monticelita (setas vermelhas) distinguíveis com o auxílio de MEV; b) cristais de olivina recristalizados formando neoblasto; c) microcristais de olivina serpentinizados (setas amarelas) ao redor de xenólito crustal; d) macrocristal de olivina com alto grau de fraturamento e bordas serrilhadas (setas azuis); e) microcristais de olivina de tamanhos variados; f) microcristais de olivina formando agregados em macrocristal. As fotomicrografias $\mathrm{c}$ e d foram tiradas com polarizadores em paralelo e as fotomicrografias e e f, com polarizadores cruzados; cristais de olivina g) sem zonamento; h) com zonamento normal, apresentando núcleos mais escuros ricos em $\mathrm{Fe}$; i) com zonamento reverso, apresentando núcleos mais claros, mais ricos em Mg; j) com zonamento intermediário caracterizado por uma coloração clara entre núcleo e borda; k) cristal de monticelita sendo substituído por diopsídio; I) cristal de monticelita com inclusões de diopsídio e apatita. Fotomicrografias obtidas com 0 auxílio de MEV

Figura 7.3: a) macrocristal de flogopita (polarizadores cruzados); b) microcristal zonado de flogopita (polarizadores paralelos); c) flogopita poiquilítica da matriz (polarizadores cruzados); d) microcristais de flogopita de granulação fina no interior de pseudomorfo (polarizadores cruzados); e) flogopita totalmente alterada substituindo possíveis pseudomorfos de leucita (descrita na intrusão Pântano por Danni e Scartezini, 1990); f) flogopita substituindo pseudomorfo de uma fase mineral possivelmente não estabilizada no momento da cristalização. Fotomicrografias e e f tiradas com polarizadores paralelos; g) microcristal de flogopita com inclusões de minerais opacos e rútilo; $\mathbf{h}$ ) microcristal de flogopita que apresenta indício de que 
houve algum tipo de deformação. Fotomicrografias obtidas com polarizadores cruzados; i) microcristal de flogopita sem zonamento; j) microcristal de flogopita zonado, que não demonstra padrão específico entre núcleos e bordas. Fotomicrografias obtidas com o auxílio de microssonda eletrônica. 54

Figura 7.4: a) microcristais de perovskita zonados e microcristais de espinélio na matriz do tipo petrográfico com flogopita poiquilítica; b) perovskitas ao redor de microcristais de olivina formando textura do tipo necklace; Fotomicrografias $a$ e $b$ obtidas com polarizadores paralelos. c) perovskita com zonamento irregular oscilatório; d) microcristal de espinélio com zonamentos irregulares entre núcleos e bordas, sendo observados três horizontes. Fotomicrografias $c$ e d obtidas com $o$ auxílio de microssonda eletrônica.

Figura 7.5: a) trilha de diopsídio (setas vermelhas) ao redor de enclave observado no tipo petrográfico diopsídio kimberlito. Fotomicrografia obtida com polarizadores paralelos; b) diopsídio na matriz observado ao redor de xenólito crustal (setas vermelhas) no tipo petrográfico monticelita kimberlito. Nota-se diopsídio também no interior do xenólito crustal (setas azuis). Fotomicrografia obtida com polarizadores paralelos

Figura 7.6: a) xenólito crustal constituído por quartzo e espurrita, formada a partir de reação metassomática entre fragmentos quartzíticos e a encaixante; b) interior do xenólito crustal em maior escala. Ambas as fotomicrografias foram obtidas com polarizadores em paralelo e as setas vermelhas e azuis indicam espurrita e quartzo, respectivamente. 61

Figura 7.7: a) quartzito com quartzo recristalizado (setas azuis) apresentando textura compatível com rochas areníticas afetadas por metamorfismo de contato na Bacia Potiguar, descrita por Santos et al., 2014. b) quartzito alterado com quartzo com textura fina, minerais máficos não identificados em lâmina petrográfica. Ambas as fotomicrografias foram obtidas com polarizadores cruzados. c) dissolução dos cristais de quartzo recristalizados (setas pretas) e d) destruição da foliação constituída de biotita em biotita quartzito encaixante da intrusão Pântano. Fotomicrografias obtidas com polarizadores paralelos. .61

Figura 7.8: Diagramas bivariantes das composições químicas mineralógicas, de rocha total e do possível fundido kimberlítico (líquido) para intrusão Pântano. Ol: olivina; Prv: perovskita; Phl: flogopita; Mtc: monticelita. 69

Figura 7.9: a) Padrão de variação de elementos terras raras dos distintos tipos petrográficos para a intrusão Pântano normalizados pelo condrito de Boynton (1984). Kmtc: monticelita kimberlito; Kphl: flogopita kimberlito; Kdiop: diopsídio kimberlito; b) Padrão de variação de elementos terras raras normalizados pelo condrito de Boynton (1984) para as rochas da intrusão Pântano e para o quartzito encaixante. Campos da PAAP de Guarino et al. (2013) e referências lá citadas. .70

Figura 7.10: a) Diagrama multielementar de elementos-traço dos distintos tipos petrográficos observados para intrusão Pântano normalizados pelo manto primitivo de McDonough and Sun (1995). Kmtc: monticelita kimberlito; Kphl: flogopita kimberlito; Kdiop: diopsídio kimberlito; b) Diagrama multielementar de elementos-traço das 
rochas da intrusão Pântano e do quartzito encaixante normalizados pelo manto primitivo de McDonough and Sun (1995). Campos da PAAP de Guarino et al. (2013) e referências lá citadas. 71

Figura 7.11: Diagrama multielementar de elementos traços dos minerais em comparação às rochas da intrusão Pântano normalizados pelo manto primitivo. Prv: perovskita; Phl: flogopita; Spn: espinélio; Ol: olivina; PAN: Pântano. Dados deste trabalho e de Melluso et al. (2008). 72

Figura 7.12: histogramas de distribuição de Mg\# dos núcleos e bordas das populações de olivina analisadas. As linhas representam o modelo de distribuição gaussiana baseadas nas médias e variâncias calculadas para cada população. a) Nota-se uma tendência bimodal para a população de núcleos dos microcristais; b) As bordas dos macrocristais possuem o maior número de amostras com Mg\# entre 87 e 89 e os c) núcleos dos macrocristais, com valores acima de

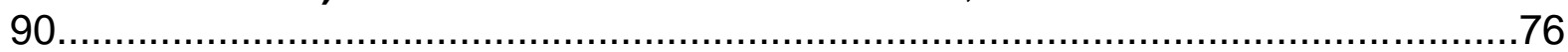

Figura 7.12 (continuação): histogramas de distribuição de Mg\# dos núcleos e bordas das populações de olivina analisadas. As linhas representam o modelo de distribuição gaussiana baseadas nas médias e variâncias calculadas para cada população. d) As bordas dos macrocristais apresentam maior número de amostras com Mg\# entre 85 e 87; e) Os núcleos dos megacristais apresentam Mg\# em sua maioria, acima de 90; f) As bordas dos megacristais apresentam ampla distribuição de valores de Mg\#, sendo os maiores valores observados entre 85 e 86 . .77

Figura 7.13: Diagramas bivariantes de $\mathrm{Mg \#}$ vs a) $\mathrm{NiO}$, b) $\mathrm{CaO}$ e c) $\mathrm{MnO}$ e d) $\mathrm{NiO}$ vs $\mathrm{CaO}$, refletindo a distribuição composicional dos cristais de olivina da intrusão Pântano. Nota-se que os núcleos das populações compõem o trend mantélico e as bordas das populações o trend do fundido kimberlítico. Dados em porcentagem em massa. 78

Figura 7.14: Diagramas bivariantes Ni vs a) $\mathrm{Co}, \mathrm{b}) \mathrm{Sc}$, c) Al e d) Mn. Campos de kimberlitos e lamproítos de Foley et al. (2013); e) Diagrama bivariante Ni/Co vs Mg\#. Valores Ni/Co maiores que 20 podem indicar fracionamento (Sobolev et al., 2007); f) Diagrama bivariante Ni vs $100^{*} \mathrm{Mn} / \mathrm{Fe}$. Os campos indicam mistura entre peridotitos e piroxenitos que são originados pela reciclagem de crosta oceânica (Sobolev, 2017). 81

Figura 7.15: a) Diagrama Ni vs V/Sc utilizado para caracterização do estado de oxidação durante a fusão (Foley et al., 2013). Os núcleos das olivinas indicam fusão em ambiente oxidante; b) Composição de núcleos de olivina em relação a $\mathrm{Ca}$ vs $\mathrm{Ti}$ como indicador da natureza do agente metassomático na fonte mantélica; Diagramas bivariantes Fo (\% em massa) vs c) Mn d) Zn e) Co f) Ni. Campos de granada peridotito, granada-espinélio peridotito e espinélio-peridotito e linha do manto primitivo de De Hoog et al., (2010). 82

Figura 7.16: Composição dos cristais de monticelita da matriz da Intrusão Pântano no sistema $\mathrm{Ca}_{2} \mathrm{SiO}_{4}-\mathrm{Mg}_{2} \mathrm{SiO}_{4}-\mathrm{Fe}_{2} \mathrm{SiO}_{4}$. Campos da Província Alcalina Alto Paranaíba (PAAP) de Melluso et al. (2018), Araújo et al. (2001), Meyer et al. (1994) e Guarino et al. (2013). 
Figura 7.17: Diagrama ternário representativo da composição dos macro e microcristais de flogopita no sistema Al-Mg-Fe. Campo dos kimberlitos da PAAP de Melluso et al. (2008), Araújo et al. (2001), Meyer et al. (1994) e Guarino et al. (2013)

Figura 7.18: Diagramas bivariantes de macro e microcristais e flogopita poiquilítica da matriz da Intrusão Pântano. Campos de a): sem preenchimento (Mitchell, 1995); campos preenchidos Ki: kimberlitos; Ug uganditos; Ma: mafuritos da PAAP (Araújo, 2001). Campos de b) a f): xenólitos de granada peridotito metassomatizados (M); matriz kimberlítica $(\mathrm{K})$ e xenólitos mantélicos alto Ti-Cr (Hti) de Giuliani et al. (2016). Campos pontilhados de distintas populações de flogopitas kimberlíticas (Kargin et al., 2019).... 88

Figura 8.1: Diagrama bivariante Al vs $\mathrm{Mn}$ identificando os campos dos granada peridotitos, granada espinélio-peridotitos e espinélio peridotitos. Campos de De Hoog et al.(2010).

Figura 8.2: Diagrama bivariante $\mathrm{Al}_{2} \mathrm{O}_{3}$ vs $\mathrm{TiO}_{2}$ (\% peso) com os campos representativos de kimberlitos com maior e menor grau de contaminação e trends das populações de flogopita encontrados por Meyer et al. (1991), que corroboram com as populações encontradas nas análises do presente trabalho. Os kimberlitos mais contaminados possuem flogopita associada a melilita e diopsídio e os menos contaminados flogopita associada a monticelita e serpentina (Caro et al., 2004)..93

Figura 8.3: Comparação dos fundidos calculados para Pântano e outros fundidos calculados na literatura (Patterson et al., 2009; Soltys et al., 2018) em termos de $\mathrm{SiO}_{2}$, $\mathrm{MgO}$ e FeO. Os campos representam amostras de kimberlitos afaníticos (cinza) e de kimberlitos macrocristalinos (Le Roex, 2003). As linhas representam os trends das suítes, onde a mudança na inclinação aproxima a composição do magma parental, de acordo com Le Roex (2003). .97

Figura 8.4: Diagramas box and whisker para fundidos de kimberlitos, orangeítos e olivina lamproítos mundo afora comparados ao fundido da intrusão Pântano. A barra central indicada nas caixas é a mediana do valor e as linhas rosadas indicam a média e intervalos das composições dos fundidos primários. O círculo verde representa o ocelo de Meyer (1991), considerado como vidro contaminado descrito na intrusão Pântano. Diagrama modificado de Pearson et al. (2019). Observa-se que a composição do fundido da intrusão Pântano possui maiores semelhanças aos fundidos de olivina lamproítos. .98

Figura 8.5: a) Padrão de variação de elementos terras raras normalizados pelo condrito de Boynton (1984); b) Padrão de variação de elementos terras raras normalizados pelo manto primitivo de McDonough and Sun (1995). Os diagramas apresentam dados para as rochas da intrusão Pântano, seus fundidos calculados e seu quartzito encaixante e para kimberlitos e kamafugitos da Província Alcalina Alto 
Paranaíba (PAAP). Dados da PAAP compilados de Melluso et al. (2008) e Guarino et al. (2013).

Figuras 8.6: Diagrama de Gufinnson e Presnall (2005) para estimativa de pressão de geração do fundido de Pântano a partir da fusão de um peridotito carbonatado. Foram considerados apenas os fundidos calculados interpretados como menos contaminados (Kmtc). Campos de kamafugitos, flogopita picritos e kimberlitos da PAAP. Modificado de Guarino et al. (2013). 102

Figura 8.7: Diagrama $\mathrm{MgO} / \mathrm{CaO}$ versus $\mathrm{SiO}_{2} / \mathrm{MgO}$ para as rochas de Pântano classificadas como kimberlito (este trabalho, Meyer et al. 1991, Carlson et al. 1996 e Guarino et al., 2013) e classificadas como leucitito (Danni e Scartezini, 1990). O ocelo trata-se do vidro descrito por Meyer et al. (1991). Campos e trends de Sparks et al. (2009) apresentando evidências de contaminação crustal. 102

Figura 8.8: Diagrama bivariante do índice de contaminação crustal (C.I.) versus In Si/Al. Campo de "sem contaminação crustal" de Kjarsgaard et al. (2009). Mesma simbologia da Figura 8.6. Kdiop: diopsídio kimberlito; Kphl: flogopita kimberlito; Kmtc: monticelita kimberlito. Nota-se trend indicativo de contaminação crustal dos diferentes tipos petrográficos observados para intrusão Pântano e para o leucitito (Danni e Scartezini, 1990) 103

Figuras 8.9: Diagrama C.I. (contaminação crustal) versus $\mathrm{Rb} / \mathrm{Sr}$ ilustrando as composições dos diferentes tipos petrográficos da intrusão Pântano em relação aos níveis de contaminação crustal. Nota-se que o tipo menos contaminada possui menor C.I. e menor razão Rb/Sr. Kmtc: monticelita kimberlito; Kphl: flogopita kimberlito; Kdiop: diopsídio kimberlito. 103

Figura 8.10: Diagrama $\mathrm{Gd} / \mathrm{Lu}$ versus $\mathrm{SiO}_{2}$ ilustrando o decaimento da razão $\mathrm{Gd} / \mathrm{Lu}$ em amostras contaminadas. Campos e trend de contaminação crustal de Le Roex et al. (2003). Nota-se diferenças composicionais entre os diferentes tipos petrográficos classificados para intrusão. 104

Figura 8.11: Diagrama ternário proposto por Sparks et al. (2009) para representar fundidos kimberlíticos a $1 \mathrm{Kbar}$ e pressões em $\mathrm{CO}_{2}$ e $\mathrm{H}_{2} \mathrm{O}$. Nele estão inseridos os fundidos reconstituídos para intrusão Pântano, o possível fundido granítico contaminante e o fundido de Indaiá I, intrusão kimberlítica da PAAP interpretada como livre de contaminação (Lima, 2019). Os pólos do fundido granítico calculado e de Indaiá I (Lima, 2019) formam uma linha de amarração onde o fundido de Pântano corresponderia a um ponto intermediário com a incorporação de uma componente crustal. Os tipos petrográficos mais contaminados (Kphl e Kdiop) plotam no campo de cristalização do diopsídio, enquanto o menos contaminado plota no campo de cristalização da forsterita. 111

Figura 8.12: Diagramas bivariantes apresentando linhas de mistura de elementos maiores e elementos-traço. a) e b) apresentam misturas entre os fundidos calculados 
para intrusão Pântano e o possível filito encaixante do Grupo Canastra. A partir destes modelos nota-se que os fundidos de Pântano estariam misturados com até $12 \%$ do contaminante proposto; c) e d) apresentam misturas entre os fundidos calculados para intrusão Pântano e o fundido do possível granito encaixante (Lima, 2019). A partir destes modelos nota-se que os fundidos de Pântano estariam misturados em taxas de 10 a $40 \%$ do contaminante proposto. Também foram plotados os fundidos de Pântano de Guarino et al. (2013), Meyer (1991) e Danni e Scartezini (1990), além do fundido calculado para intrusão Indaiá II (Lima, 2019) também considerada como kimberlito contaminado da PAAP. Os campos de granitos alto (Pimentel et al., 1996) foram inseridos para representação de possíveis contaminantes em maiores profundidades.

Figura 8.13: Modelo petrogenético esquemático proposto para intrusão Pântano, ilustrando a contaminação crustal em diferentes níveis: a partir da interação com o fundido da rocha encaixante quartzítica (Kdiop), a partir da interação com o filito encaixante (possívelmente em um outro pulso kimberlítico), caracterizando o tipo petrográfico Kphl e a partir da contaminação em profundidade com granitos de alto K, que levaria à possível formação de leucita. 115

\section{Lista de Tabelas}

Tabela 3.1: Síntese de zonamentos, texturas e termos genéticos utilizados no presente trabalho.

Tabela 6.1a: Condições analíticas para análise de olivina durante as quantificações WDS por microssonda eletrônica.

Tabela 6.1b: Condições analíticas para análise de mica durante as quantificações WDS por microssonda eletrônica. 36

Tabela 6.2: Quantitativos de análises de microssonda eletrônica.

Tabela 6.3: Condições experimentais do laser para obtenção das análises de olivina e flogopita.

Tabela 7.1: Médias das porcentagens de matriz, macrocristais, megacristais, pseudomorfos, xenólitos e vênulas encontradas para os diferentes pontos amostrados na intrusão Pântano

Tabela 7.2: Sumário petrográfico com as descrições de cada tipo petrográfico observado para as rochas da intrusão Pântano e descrição da rocha encaixante (quartzito). Os pontos de coleta de cada tipo podem ser observados na Figura 2.2 . 62

Tabela 7.3: Composições das populações de olivina estudadas .74 


\section{Lista de Equações}

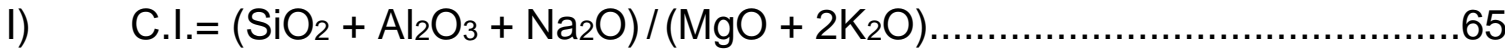

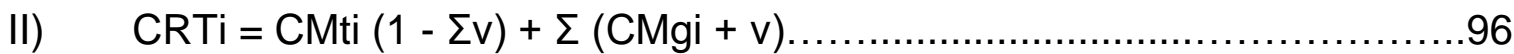

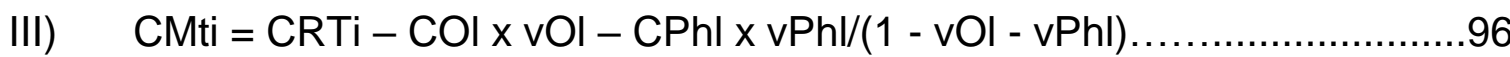

IV) $\mathrm{CaMgSiO}_{4}+\mathrm{CaCO}_{3}+\mathrm{MgO}+4 \mathrm{SiO}_{2}=3 \mathrm{CaMgSi}_{2} \mathrm{O}_{6}+\mathrm{CO}_{2} \ldots \ldots \ldots \ldots \ldots \ldots . . .108$

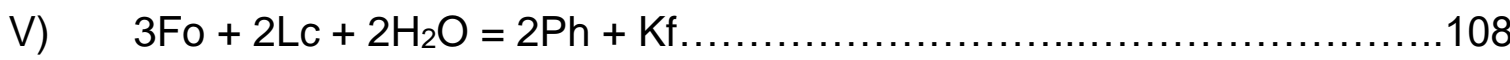

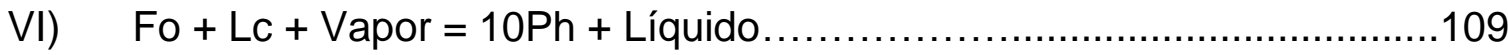

\section{Lista de Apêndices}

Apêndice A - Análises de geoquímica de rocha total.

Tabela A.I: resultados de química de rocha total obtidos por FRX.

Tabela A.II: resultados de química de rocha total obtidos por ICP-MS.

Apêndice B - Análises obtidas por microssonda eletrônica. 130

Tabela B.I: Composição em óxidos (\% massa) e fórmula estrutural das olivinas da intrusão Pântano.

Tabela B.II: Composição em óxidos (\% massa) e fórmula estrutural das monticelitas da intrusão Pântano.

Tabela B.III: Composição em óxidos (\% massa) e fórmula estrutural das flogopitas da intrusão Pântano.

Apêndice C - Análises obtidas por LA-ICP-MS .164

Tabela C.I: Concentrações do padrão primário BHVO-2G obtidas a partir das análises de olivinas no fragmento 1 (LA-ICP-MS).

Tabela C.II: Concentrações do padrão secundário NIST-610 obtidas a partir das análises de olivinas no fragmento 1 (LA-ICP-MS).

Tabela C.III: Limites de detecção do padrão secundário NIST-612 obtidas a partir das análises de olivinas do fragmento 1 (LA-ICP-MS).

Tabela C.IV: Concentrações do padrão secundário NIST-612 obtidas a partir das análises de olivinas do fragmento 1 (LA-ICP-MS).

Tabela C.V: Concentrações de elementos-traço obtidas para as olivinas do fragmento 1, limites de detecção (LD) e erros associados $(2 \sigma)$ utilizados como padrão de qualidade.

Tabela C.VI: Concentrações do padrão primário BHVO-2G obtidas a partir das análises de olivina do fragmento 2, limites de detecção (LD) e erros associados $(2 \sigma)$ utilizados como padrão de qualidade.

Tabela C.VII: Concentrações do padrão secundário NIST-610 obtidas a partir das análises de olivina do fragmento 2 , limites de detecção (LD) e erros associados $(2 \sigma)$ utilizados como padrão de qualidade. 
Tabela C.VIII: Limites de detecção (LD) do padrão secundário NIST-612 obtidas a partir das análises de olivina do fragmento 2 .

Tabela C.IX: Concentrações do padrão secundário NIST-612 obtidas a partir das análises de olivina do fragmento 2 .

Tabela C.X: Concentrações de elementos-traço obtidas para de olivina do fragmento 2 , limites de detecção (LD) e erros associados $(2 \sigma)$ utilizados como padrão de qualidade.

Tabela C.XI: Concentrações do padrão primário BHVO-2G obtidas a partir das análises de flogopita do fragmento 2 , limites de detecção (LD) e erros associados (2 $\sigma$ ) utilizados como padrão de qualidade.

Tabela C.XII: Concentrações do padrão secundário NIST-612 obtidas a partir das análises de flogopita do fragmento 2 , limites de detecção (LD) e erros associados $(2 \sigma)$ utilizados como padrão de qualidade.

Tabela C.XIII: Limites de detecção do padrão secundário NIST-610 obtidas a partir das análises de flogopita do fragmento 2 , limites de detecção (LD) e erros associados $(2 \sigma)$ utilizados como padrão de qualidade.

Tabela C.XIV: Concentrações do padrão secundário NIST-610 obtidas a partir das análises de flogopita do fragmento 2 .

Tabela C.XV: Concentrações de elementos-traço obtidas partir das análises de flogopita do fragmento 2 , limites de detecção (LD) e erros associados $(2 \sigma)$ utilizados como padrão de qualidade.

Tabela C.XVI: Concentrações do padrão primário BHVO-2G obtidas a partir das análises de flogopita poiquilítica da lâmina PNT-4.

Tabela C.XVII: Concentrações do padrão secundário NIST-612 obtidas a partir das análises de flogopita poiquilítica da lâmina PNT-4.

Tabela C.XVIII: Limites de detecção do padrão secundário NIST-610 obtidas a partir das análises de flogopita poiquilítica da lâmina PNT-4.

Tabela C.XIX: Concentrações do padrão secundário NIST-612 obtidas a partir das análises de flogopita poiquilítica da lâmina PNT-4.

Tabela C.XX: Concentrações de elementos-traço obtidas para de flogopita poiquilítica da lâmina PNT-4, limites de detecção (LD) e erros associados $(2 \sigma)$ utilizados como padrão de qualidade.

Tabela C.XXI: Concentrações do padrão primário BHVO-2G obtidas a partir das análises de flogopita da lâmina PNT-8.

Tabela C.XXII: Concentrações do padrão secundário NIST-612 obtidas a partir das análises de flogopita da lâmina PNT-8.

Tabela C.XXIII: Limites de detecção do padrão secundário NIST-610 obtidas a partir das análises de flogopita da lâmina PNT-8. 
Tabela C.XXIV: Concentrações do padrão secundário NIST-612 obtidas a partir das análises de flogopita da lâmina PNT-8.

Tabela C.XXV: Concentrações de elementos-traço obtidas para de flogopita da lâmina PNT8 , limites de detecção (LD) e erros associados $(2 \sigma)$ utilizados como padrão de qualidade.

\section{Apêndice D - Fundidos calculados para intrusão Pântano e fundidos utilizados}

na modelagem de contaminação 207

Tabela D.I: fundidos calculados para intrusão Pântano obtidos através do desconto das populações xenocristalinas de olivina e flogopita.

Tabela D.II: composição do granito utilizado como possível encaixante na modelagem de contaminação crustal e fundido da rocha, calculado a partir do RhyoliteMelts. Dados de Lima, 2019.

Tabela D.III: dados do possível filito encaixante do Grupo Canastra (Saar, 2009) utilizado na modelagem de contaminação. 



\section{Introdução}

O Brasil tem sido alvo de importantes estudos relacionados à geoquímica e petrologia de kimberlitos e de uma outra rara série de rochas potássicas derivadas do manto, incluindo kamafugitos e lamproítos. O magmatismo alcalino na plataforma brasileira se deu principalmente durante o Cretáceo, dando origem às maiores províncias ultrabásicas potássicas a ultrapotássicas brasileiras: a Província Alcalina de Goiás (PAG) e a Província Alcalina do Alto do Paranaíba (PAAP) (CominChiaramonti \& Gomes, 2005).

Os primeiros kimberlitos foram descritos no Brasil no século XX (Roberts, 1976) e fazem parte de um amplo grupo de rochas ultramáficas e ultrabásicas alcalinas, sendo diferenciados essencialmente por sua mineralogia e geoquímica singulares (Le Maitre, 2002).

Apesar de não serem rochas de volume expressivo na crosta terrestre, os kimberlitos possuem grande importância econômica devido à exploração de diamantes. As regiões diamantíferas de Minas Gerais destacam-se por abranger o maior número de corpos kimberlíticos diamantíferos no território brasileiro. Além da importância econômica, os kimberlitos representam um grupo de rochas muito significativo no estudo da evolução de magmas primitivos (Sparks, 2013). Por ascenderem de diferentes profundidades do manto até a crosta muito rapidamente, os magmas kimberlíticos carregam fragmentos de diversas porções do manto, o que os torna muito importantes na compreensão dos processos de evolução mantélica (Mitchell, 1986; Sparks, 2013). Além de interações mantélicas, ocorrem também a incorporação de material crustal, contribuindo para que haja mudanças nas características isotópicas e de elementos-traço destes litotipos (Faure, 2001).

A discussão sobre a natureza petrográfica e classificação das rochas alcalinas e suas diversidades, bem como a origem e evolução dos magmas que geraram essas rochas, mantém-se como um tópico discutido desde o final do século XIX em virtude do grande interesse econômico e científico dessas associações (Mitchel, 1986). A presente dissertação manteve seu escopo sob o ponto de vista científico, onde o estudo petrográfico de algumas fases minerais e tipos petrogenéticos da intrusão Pântano, visa uma maior compreensão relativa a origem e evolução do magma 
progenitor da mesma, bem como os processos de interação entre líquido kimberlítico, manto e crosta.

Considerando-se que as rochas kimberlíticas possuem natureza híbrida (e.g., Russell et al., 2012), carregando tanto xenólitos crustais quanto de outras distintas porções do manto, as análises petrográficas e petrológicas devem ser feitas utilizando-se uma série de critérios específicos. Tais critérios permitem a distinção entre as fases cognatas e não cognatas neste tipo de rocha, bem como fazer interpretações sobre os processos que originaram fases cristalinas em equilíbrio ou desequilíbrio com a matriz. Em rochas kimberlíticas, é possível diferenciar uma série de populações de cristais que apresentam feições de reabsorção e/ou zonamentos químicos, sendo estas denominadas como antecristais ou xenocristais (Charlier et al., 2005) e estão, portanto, em desequilíbrio com o material circundante. Uma maior compreensão acerca do zonamento químico das fases cristalinas de um corpo intrusivo, pode auxiliar na obtenção da composição química do líquido em equilíbrio com as populações cristalinas em estudo. A composição do fundido kimberlítico no momento de sua colocação na crosta e como este fundido é modificado pela interação e/ou assimilação do material da rocha circundante são aspectos ainda não completamente esclarecidos (Giuliani et al., 2016).

A combinação de estudos texturais e químicos de detalhe utilizando técnicas analíticas modernas como microssonda eletrônica e LA-ICP-MS tem revelado que os elementos incompatíveis ocorrem com frequência em fases minerais de limites de grãos, inclusões fluídas ou líquidos aprisionados (Zindler and Jagoutz, 1988; Condie et al., 2004). Mesmo nos casos mais comuns em que as dimensões dessas fases são muito pequenas para a sua identificação ou quantificação de sua composição química, tem sido possível identificar assinaturas geoquímicas características, que permitem associar a sua geração com processos de modificação do manto singulares e ou com interação com o magma hospedeiro (Condie, 2004; lonov et al., 2002). Neste âmbito, a geoquímica de rocha total excluindo-se as fases minerais não cognatas (associada à paragênese mineral), permite a caracterização da intrusão Pântano como kimberlito do Grupo I (Shibata et al., 2016), seguindo-se a classificação proposta por Mitchell (1995) e Le Maitre (2002).

A química mineral, obtida a partir de técnicas analíticas avançadas, permite interpretações relacionadas aos tipos de manto ao qual o líquido kimberlítico interagiu durante a sua ascensão à crosta. Mesmo após a fragmentação da olivina 
xenocristalina no magma hospedeiro, os xenocristais preservam as características químicas das rochas parentais, podendo agir, portanto como uma ferramenta para medição de composições próximas do manto litosférico (Shaikh, 2018). Cristais zonados de olivina $(0,5-5 \mathrm{~mm})$ com duas diferentes populações de núcleos, uma com núcleos enriquecidos em $\mathrm{Mg}$ e outra com núcleos enriquecidos em $\mathrm{Fe}$, são amplamente reconhecidas em diversos kimberlitos mundo afora (Bussweiler et al., 2015; Howarth \& Taylor, 2016; Lim et al., 2018). Os núcleos enriquecidos em Mg são em geral interpretados como derivados de xenólitos do manto (Arndt et al., 2010; Brett et al., 2009; Pilbeam et al., 2013), enquanto núcleos enriquecidos em Fe são considerados "fenocristais cognatos" geneticamente relacionados a fundidos de protokimberlitos/lamproítos (Howarth \& Taylor, 2016; Kamenetsky et al., 2008; Shaikh et al., 2018). Outra fase mineral importante que caracteriza processos nos kimberlitos é a flogopita, que preserva a assinatura geoquímica da interação do magma kimberlítico durante o transporte através do manto e crosta, além de possuir ampla variação composicional, provendo um repositório útil de informações na evolução de kimberlitos e fundidos relacionados (Giuliani et al., 2016).

A partir de estudos petrográficos de detalhe em fases minerais específicas, pode-se decifrar, portanto, uma série de processos evolutivos complexos, permitindo a inferência de um modelo petrogenético para intrusão Pântano e seus diferentes tipos petrográficos.

\subsection{Objetivos}

O presente trabalho teve como objetivo o estudo das distintas tipos petrográficos encontradas para as rochas da intrusão Pântano, na tentativa de identificar processos petrológicos que podem ocorrer em um kimberlito ou em outras rochas magmáticas alcalinas associadas, como kamafugitos e lamproítos. A variação composicional de elementos-traço em minerais cognatos e xenocristais mantélicos da intrusão permitem a elucidação de possíveis processos de assimilação e contaminação, tanto do manto, quanto da crosta. No estudo de rochas kimberlíticas, trabalhos recentes têm questionado os critérios iniciais de Mitchell $(1986,1995)$ para classificação genética entre cristais cognatos e xenocristais, principalmente devido à maior precisão de análises da composição de elementos-traço em minerais 
combinada à reinterpretação de aspectos petrográficos (e.g., Davies et al., 1999; Reguir et al., 2009; Bussweiller et al., 2015).

Especialmente no estudo de olivinas, a fase mais abundante para estes magmas, trabalhos como os de Arndt et al. (2010), Brett et al. (2009) e Bussweiller et al. (2015) evidenciam que os zonamentos químicos de elementos maiores e traços observados para as diferentes populações deste mineral, são explicados por núcleos representativos de xenocristais e bordas representativas de sobrecrescimentos cristalizados a partir do líquido kimberlítico. Não somente as olivinas são comuns às populações de xenocristais e cristais cognatos e podem ser diferenciadas a partir da combinação de aspectos petrográficos e tendências de evolução composicional; o mesmo ocorre para o grupo das flogopitas (Grégoire et al., 2002; Reguir et al., 2009). Deste modo, foi necessária a reavaliação petrográfica das diferentes populações de cristais que constituem estas rochas, bem como a caracterização das variações composicionais que permitam diferenciar xenocristais de cristais cognatos. As populações xenocristalinas podem estar associadas a processos de contaminação crustal, que acarretam na formação de diferentes tipos petrográficos para uma mesma rocha, que é o caso da intrusão Pântano.

As interpretações relacionadas às diferentes fases cognatas ou não cognatas identificadas permitiram fazer uma tentativa de reconstituição da evolução petrogenética da intrusão, traçar inferências sobre a sequência de cristalização das fases minerais, sobre processos de contaminação crustal, além da busca por estimativas buscando a composição do líquido mais pristino possível associado ao magma ultrabásico originador da intrusão.

\section{Contexto Magmático e Geologia Local}

\subsection{Província Alcalina do Alto Paranaíba (PAAP)}

A Província Alcalina do Alto Paranaíba (PAAP) está localizada entre as províncias São Francisco e Paraná, e é caracterizada pelo magmatismo cretáceo relacionado ao soerguimento do Arco do Alto Paranaíba (Almeida, 1983; Campos \& Dardenne, 1997). O soerguimento dessa feição estrutural, que é alongada na direção NW-SE, iniciou no Cretáceo Inferior e alcançou seu ápice no Cretáceo Superior, tendo influenciado a tectônica estratigráfica das bacias sedimentares das províncias Paraná 
(bacias Paraná, Serra Geral e Bauru) e São Francisco (Bacia do São Francisco) (Campos \& Dardenne, 1997). Este magmatismo ocorreu predominantemente no período entre 80 e $90 \mathrm{Ma}$, sendo representado por kimberlitos, lamproítos, lamprófiros, carbonatitos e kamafugitos; este último é o mais expressivo derrame deste tipo no mundo, com $23.000 \mathrm{~km}^{3}$ (Gibson et al., 1995a).

A PAAP faz parte do conjunto de Províncias Alcalinas Minas-Goiás agrupadas por Sgarbi \& Gaspar (2002) juntamente com as províncias Mata da Corda, Iporá e Santo Antônio da Barra. Posteriormente, baseando-se em estudos isotópicos, Gaspar et al. (2003) dividiram essas províncias em dois grandes grupos: (i) Província Alcalina do Alto Paranaíba, para as rochas que afloram no oeste de Minas Gerais e próximo a Catalão (GO); e (ii) Província Alcalina de Goiás, a qual designaram as rochas da região de Iporá e Rio Verde.

A PAAP é constituída de rochas vulcânicas da Formação Mata da Corda, grandes complexos formados por magmatismo carbonático e intrusões alcalinas, entre elas, a intrusão Pântano (Araújo et al., 2001). Segundo James et al. (1993), o Arco Alto Paranaíba corresponde a uma anomalia indicativa de uma provável zona de sutura entre o cráton São Francisco e a Bacia do Paraná. As diferentes rochas constituintes da província variam de potássicas a ultrapotássicas, máficas a ultramáficas, fortemente subsaturadas em sílica, além de intrusões hipoabissais de idade Cenozoica.

Quatro grupos principais de rochas silicáticas foram descritos nesta província: kamafugitos, kimberlitos, peridotitos e flogopita picritos (Gibson et al., 1995a; Guarino et al., 2013). Os kamafugitos geralmente formam fluxos de lava caracterizados por altas proporções de clinopiroxênio (diopsídio), que é encontrado não apenas na forma de fenocristais mas também na matriz, associada à perovskita, magnetita, olivina, flogopita e melilita. Pseudomorfos de kalsilitita, nefelina e leucita podem também coexistir, tendo apatita e wadeita como minerais acessórios. As rochas consideradas mais desenvolvidas contem aegerina-augita. Diques kamafugíticos também são muito difundidos e apresentam olivina e flogopita tanto na forma de fenocristais como na matriz (Sgarbi \& Valença, 1993; Sgarbi et al., 2000; Brod et al., 2001). Os kimberlitos são caracterizados pela alta proporção modal em olivina, que aparece tanto na forma de cristais cognatos como de xenocristaise menores proporções de ilmenita, flogopita e cromita como microcristais da matriz. Ocasionalmente, pode-se observar granada presente em uma matriz carbonática, eventualmente associada a serpentina, 
perovskita, apatita e monticelita (Meyer et al., 1994; Carlson et al., 1996). Os peridotitos são encontrados geralmente na forma de xenólitos em kimberlitos e representados por espinélios Iherzolitos, hazburgitos e dunitos.

O Cretáceo Superior no oeste de Minas Gerais é marcado por derrames kamafugíticos, piroclásticas e sedimentos epiclásticos (Sgarbi et al., 2001). O Grupo Mata da Corda ocorre em discordância sobre as rochas de idade correspondentes ao Meso-Neoproterozoico dos grupos Vazante, Canastra, Ibiá e Araxá. O Grupo Mata da Corda foi dividido nas formações Patos e Capacete (Sgarbi et al., 2001). A Formação Patos é composta por kimberlitos, kamafugitos e rochas ultramáficas semelhantes, ocasionalmente incluindo rochas sedimentares e piroclásticas. A Formação Capacete ocorre acima da Formação Patos, sendo composta por sucessões de rochas epiclásticas, derrames kamafugíticos e vulcanoclásticos atingindo uma espessura de até $65 \mathrm{~m}$ (Sgarbi et al., 2001; Fernandes et al., 2014).

Geoquimicamente, as altas taxas de elementos terras raras dos magmas da PAAP sugerem uma alta demanda de fusão parcial de um magma peridotítico com altas proporções de granada, metassomatizado por veios de flogopita e carbonato (Melluso et al., 2008). Acredita-se que as lavas da PAAP se formaram a partir de altas taxas de fusão parcial relacionadas a metassomatismo do manto (Bizzi et al., 1995; Guarino et al., 2013).

\subsection{Grupo Canastra}

A intrusão Pântano encontra-se inserida em quartzitos do Grupo Canastra, sendo este grupo constituído predominantemente por um conjunto de filitos carbonosos e intercalações de filitos e quartzitos (Freitas-Silva \& Dardenne, 1994). Segundo o mesmo autor, as rochas deste grupo afloram desde a região Sudoeste de Minas Gerais até o Sudeste de Goiás e Sul do Distrito Federal, abrangendo uma área de mais de $650 \mathrm{~km}$.

O Grupo Canastra é constituído pelas Formações Serra do Landim, Paracatu e Chapada dos Pilões e representa parte de uma bacia de margem passiva, aberta no fim do Mesoproterozóico (Dardenne, 2000). A unidade basal é a Formação Serra do Landim, composta por calci-filitos e calci-xistos, podendo atingir até 250 metros de espessura (Freitas-Silva, 1996). A Formação Paracatu, unidade estratigraficamente 
intermediária do Grupo Canastra, apresenta intercalação de filitos e xistos carbonosos que apresentam deformação significativa, representada sigmoides de quartzo. Há intercalações de quartzito e carbonato, além de venulações de quartzo associadas a mineralizações de ouro (Freitas-Silva \& Dardenne, 1994). A Formação Chapada dos Pilões é a unidade basal, composta pela intercalação de filitos e quarzitos, sendo estes observados principalmente no topo da formação (Rodrigues, 2008). Alguns trabalhos descrevem a Formação Chapada dos Pilões como Serra da Batalha, dividindo-a entre membro superior e inferior (Freitas-Silva \& Dardenne, 1994).

Os quartzitos e filitos do Grupo Canastra encontram-se metamorfizados na fácies xisto verde, zona da clorita até zona da granada (Valeriano et al., 2004). As idades U-Pb obtidas em zircões detríticos do Grupo Canastra sugerem fontes principais de 2,1-1,8 Ga e idade máxima de deposição de 1,03 Ga (Rodrigues et al., 2010; Pimentel et al., 2011).

\subsection{A intrusão Pântano}

A intrusão Pântano está localizada a cerca de $43 \mathrm{~km}$ a leste da cidade de Coromandel e $32 \mathrm{~km}$ a oeste de Patos de Minas, no estado de Minas Gerais, ocupando uma área de aproximadamente $500-700$ metros. A intrusão foi datada pela primeira vez por Hasui e Cordani (1968) utilizando-se a metodologia K-Ar em rocha total, quando foi obtida a idade de 77,9 +- 3,9 Ma. Sonoki e Garda (1988) obtiveram uma idade de 79,7 Ma através da mesma metodologia, retificando a idade obtida por Hasui e Cordani (1968). Posteriormente, Meyer et al. (1991) obteve idades entre 85 e $95 \mathrm{Ma}$ para intrusão Pântano a partir da metologia $\mathrm{Pb} / \mathrm{Pb}$ em rocha total. Recentemente, foi utilizada a metodologia $\mathrm{U} / \mathrm{Pb}$ em perovskita para datação, em que foram obtidas idades de $84 \pm 1$ Ma por Guarino et al. (2013) e de 79,9 $\pm 3,2$ Ma por Felgate (2014).

Petrograficamente, a intrusão foi descrita por diversos autores (Barbosa et al., 1970, Danni \& Scartezini 1990, Meyer et al. 1991, Bizzi et al. 1991, Bizzi et al. 1995, Gibson et al., 1995, Carlson et al., 1996, Azzone et al. 2002, Melluso et al. 2008, Guarino et al., 2013, Felgate, 2014), porém as descrições variam entre si. A Figura 2.1 apresenta o mapa geológico da região considerando as intrusões kimberlíticas proximais às cidades de Coromandel e Patos de Minas, com destaque para intrusão 
Pântano. O mapa geológico foi confeccionado a partir das cartas de Coromandel, Largamar, Monte Carmelo e Pato de Minas, que puderam ser acessadas pelo GeoBank da CPRM. Nas descrições da CPRM (Projeto Diamante, Cabral Neto et al., 2017), a intrusão Pântano encontra-se descrita como Limpeza-18, no entanto, utiliza a classificação de rocha de Felgate (2014).

Segundo Barbosa et al. (1970), Pântano seria um neck vulcânico com composição de olivina basalto, já para Danni \& Scartezini (1990), a intrusão Pântano trata-se de um olivina leucitito, correspondente a uma rocha com textura microporfirítica, rica em xenocristais de olivina. A descrição petrográfica feita por Bizzi et al. (1991 e 1995) classifica a intrusão Pântano como mica peridotito. Segundo o autor, a intrusão poderia ser classificada texturalmente como kimberlito afanítico hipoabissal, sendo o termo "rocha alcalina de afinidade kimberlítica" ambíguo. Bizzi aponta como principais constituintes da rocha os macro e fenocristais de olivina (maiores que $5 \mathrm{~mm}$ ), em uma matriz formada predominantemente de monticelita, perovskita e minerais opacos. O autor cita ainda a presença de flogopita e espinélio em menores quantidades em relação às fases minerais principais. Gibson et al. (1995) descreve a intrusão Pântano como um kimberlito de alto Ti, o que é também descrito pela autora para outras intrusões kimberlíticas e kamafugíticas da província Alto Paranaíba. Carlson et al. (1996) também classifica Pântano como kimberlito.

Azzone et al. (2002) atribui afinidade kimberlítica à intrusão Pântano devido a presença de monticellita, perovskita com baixas concentrações de ETRs, além de olivina, flogopita, opacos e diopsídio. Guarino et al. (2013) descreve o "plug" de Pântano como uma rocha de textura porfirítica com olivina, flogopita, perovskita, magnetita, cromita, apatita e carbonatos, porém, não foi detectado piroxênio, a autora caracteriza, portanto, a intrusão como kimberlito. A classificação de Melluso et al. (2008) para a intrusão Pântano é de um kimberlito porfirítico, constituído de macro e microcristais de olivina, perovskita particularmente abundante, monticelita e flogopita. Felgate (2014) classifica a intrusão Limpeza 18 (em seu trabalho, utiliza nomenclatura da CPRM) como um kimberlito de fácies hipoabissal.

Meyer et al. (1991) divide a intrusão em três tipos mineralógicos principais de acordo com as texturas petrográficas identificadas. Os minerais comuns aos três tipos petrográficos são macrocristais de olivina, perovskitas e espinélios. O primeiro tipo petrográfico presente é caracterizado por apresentar monticelita como fase mineral predominante na matriz e flogopita ocorrendo na forma de pequenos cristais. A 
segunda fase é caracterizada pela presença de placas de micas e ocellos. A mica engloba os demais minerais da matriz (olivina, perovskita, espinélio e monticelita) em uma textura poiquilítica. Na terceira fase petrográfica, há pequenos cristais de diopsídio $(<5 \mathrm{~mm})$ que predominam na matriz, e uma perovskita de coloração mais alaranjada que, nas demais fases petrográficas, onde é descrita por possuir coloração marrom e zonamento do núcleo e das bordas. Meyer et al. (1991) reconhece que a geoquímica de elementos maiores da intrusão Pântano é similar à de kimberlitos, alnoítos e alguns peridotitos e que as fases minerais predominantes são similares às descritas em kimberlitos. No entanto, o autor considera um nome não-genético de monticelita-peridotito para intrusão Pântano, concluindo que a rocha foi derivada do mesmo magma parental que produziu uma série de rochas alcalinas ultrabásicas relacionadas a kamafugitos.

A Figura 2.2 faz uma representação esquemática da intrusão Pântano e suas dimensões, bem como a localização dos pontos aonde foram coletadas as amostras utilizadas no presente trabalho. As amostras foram coletadas de acordo com a divisão de tipos petrográficos feita por Meyer et al. (1991), sendo este o principal trabalho utilizado como base para as descrições e comparações feitas nessa dissertação. 


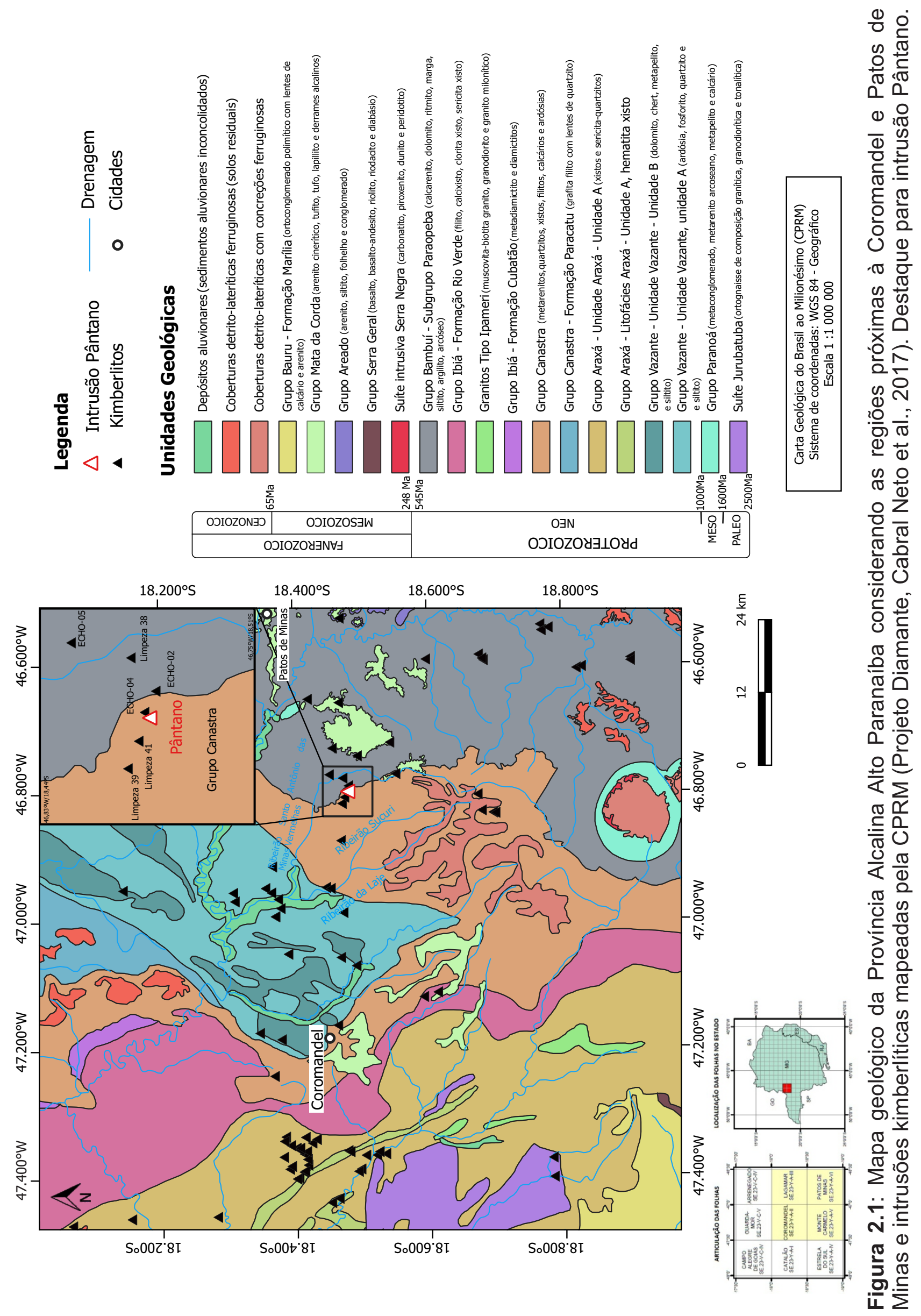




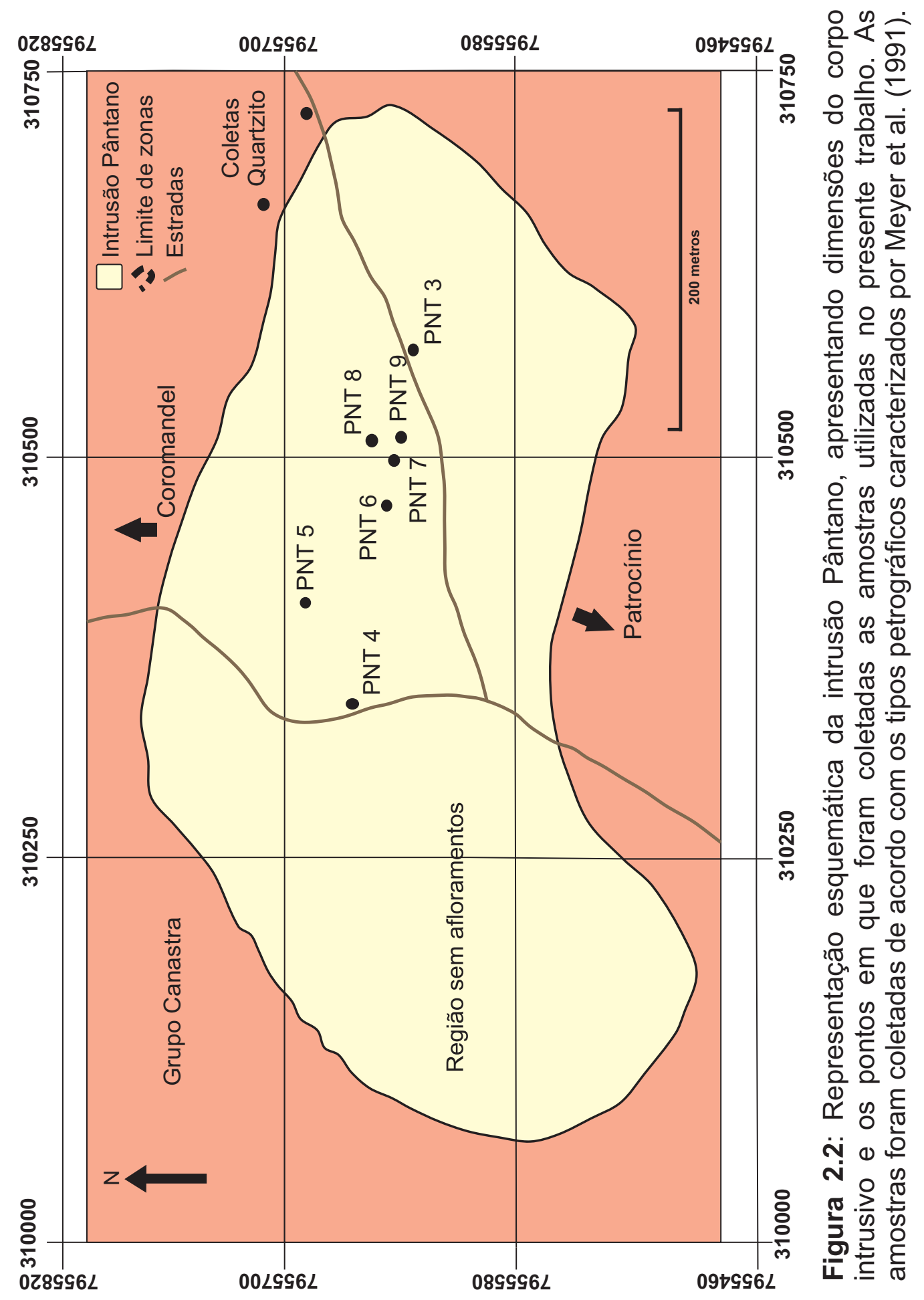




\section{Kimberlitos hipoabissais e a distinção entre populações e assembléias minerais}

\subsection{Kimberlitos hipoabissais}

De acordo com Le Maitre (2002), o termo hipoabissal é pertinentemente empregado para rochas que foram colocadas em uma região intermediária entre plutônica e vulcânica, sendo tal termo frequentemente empregado para rochas de intrusões menores, como diques e sills. Segundo Patterson et al. (2009) e Cas et al. (2008), as rochas alcalinas ultramáficas da fácies hipoabissal ou zonas de raiz (root zones) podem ser descriminadas basicamente pelo seu caráter maciço e macrocristalino.

Mitchell (2008) propõe que kimberlitos hipoabissais são rochas ígneas holocristalinas que foram cristalizadas a partir de um magma kimberlitico. O termo "hipoabissal" é utilizado para descrever rochas formadas a partir de magmas que se cristalizaram em condições subterrâneas/subvulcânicas sem referências da profundidade ou pressão de formação. Geralmente, as intrusões kimberliticas hipoabissais formam-se a partir de pequenos volumes de magma (a ausência de plútons kimberlíticos de granulação grossa indica que o magmatismo kimberlítco não abrange grandes volumes de magma) e são cristalizadas em pressões próximas da superfície do manto. Ainda segundo o autor, os kimberlitos de fácies hipoabissal são importantes pois tratam-se de produtos de cristalização de um magma que não foi submetido à degaseificação, logo, fornecem o melhor material para compreensão do caráter do magma kimberlítico primeiramente à formação das fácies diatrema e piroclásticas.

As investigações geoquímicas de kimberlitos são muito difíceis por ocorrer frequente metassomatismo e contaminação crustal, além de processos intempéricos acelerados, principalmente por reação com a água freática e subterrânea. O melhor material para estudos geoquímicos e classificação mineralógica são aqueles precedentes de fácies hipoabissal, pois estes kimberlitos contém poucos xenólitos crustais e a cristalização é suficientemente lenta para permitir o desenvolvimento da associação mineral típica (Provenzano, 2016). 
Desta maneira, o estudo de kimberlitos hipoabissais é importante pois fornece informações de um magma pouco contaminado, sendo o mais indicado para realizarse a estimativa de composições aproximadas de um magma/líquido kimberlítico, utilizando geoquímica de rocha total, desde que descontadas as populações de xenocristais e xenólitos.

\subsection{Cristais cognatos versus xenocritais: evidências em zonamentos e texturas}

Somente nas duas últimas décadas tem se discutido o significado das diferentes populações de cristais em kimberlitos e rochas associadas baseando-se em diferentes tipos de zonamentos em um mesmo cristal (Brett et al., 2009; Bussweiler et al., 2015; Shaikh et al., 2018). Historicamente, sabe-se que Mitchell (1995) classificava os cristais a partir de seus tamanhos e morfologia, no entanto, a origem de muitos desses cristais não era satisfatoriamente determinada. $O$ autor descreve que, sem dúvidas, muitas das fases reconhecidas em kimberlitos seriam xenocristais, no entanto outras poderiam ser fenocristais.

Em petrologia ígnea, utiliza-se o termo fenocristal, sendo esta a fase que cresceu em equilíbrio químico com o líquido magmático formador da rocha e que se distingue da matriz fanerítica ou afanítica pelo tamanho maior, caracterizando, neste caso, uma textura porfírica ou porfirítica em uma determinada rocha ígnea (Gill, 2010). $\mathrm{Na}$ presente dissertação, o termo designado para fases que foram formadas em equilíbrio com o líquido originador do kimberlito será "cognato" e não fenocristal, uma vez que um mesmo mineral pode representar diferentes estágios de evolução magmática na rocha.

Mitchell (1995) recomenda que "pseufenocristais criptogênicos" sejam divididos entre megacristais, macrocristais e microcristais, que seriam termos não correlacionados à gênese dos mesmos. Desta maneira, durante as descrições feitas no presente trabalho, serão utilizadas as seguintes terminologias (Mitchell, 1995), relacionadas às características:

- Megacristais: cristais subédricos a anédricos, maiores que $1 \mathrm{~cm}$;

- Macrocristais: cristais euédricos a anédricos com uma dimensão entre 0,5 e $1 \mathrm{~cm}$;

- Microcristais: cristais anédricos, com dimensões inferiores a 0,5 cm. 
Os xenocristais são aqueles estranhos à rocha magmática em que ocorrem e são originados seja pela incorporação de cristais de rochas encaixantes, como pela desagregação de xenólitos do manto (Davidson et al., 2007). Segundo o autor, a incorporação desses cristais ocorre a partir de minerais fracionados em estágios anteriores e envolvidos por novo afluxo magmático da intrusão, com evidências de ter ocorrido desequilíbrio químico entre xenocristais e o líquido magmático que envolveu esses corpos estranhos.

As fases primárias serão designadas como "cristais cognatos" a partir de sua variação composicional, que refletem a característica de seus respectivos magmas parentais. Os kimberlitos possuem, portanto, uma textura inequigranular, resultado da presença de mega e macrocristais em uma matriz fina constituída por microcristais. Menos comuns, mas ainda importantes constituintes de kimberlitos uma vez que indicam processos petrogenéticos singulares, são os denominados antecristais. Os antecristais são minerais cristalizados precocemente que não se encontram mais em equilíbrio com o líquido que os carrega, mas que mantém vínculo com o mesmo sistema magmático (Charlier et al., 2005). Esta população é representativa de cristais reciclados de estágios magmáticos mais precoces em profundidade.

A Tabela 3.1 sintetiza as feições petrográficas de zonamentos e texturas e definições dos termos genéticos utilizadas no presente trabalho. 
Tabela 3.1: Síntese de zonamentos, texturas e termos genéticos utilizados no presente trabalho.

\begin{tabular}{|c|c|}
\hline \multicolumn{2}{|r|}{ Zonamentos } \\
\hline Normal & $\begin{array}{l}\text { Inclui mudanças composicionais no mineral do centro para a borda do } \\
\text { cristal. A mudança na composição mineral durante a cristalização reflete a } \\
\text { progressiva evolução da composição do fundido durante o processo de } \\
\text { solidificação em sistema fechado. }\end{array}$ \\
\hline Step & $\begin{array}{l}\text { Ocorre em etapas ao longo do cristal, com limites entre os horizontes } \\
\text { adjacentes bem definidos (contato abrupto). }\end{array}$ \\
\hline Reverso & $\begin{array}{l}\text { Inversão composicional ao longo do crescimento do centro para a borda do } \\
\text { cristal, não podendo ocorrer em um processo de cristalização em sistema } \\
\text { fechado. }\end{array}$ \\
\hline Concêntrico & $\begin{array}{l}\text { Variação composicional observada a partir do centro do cristal; acompanha } \\
\text { a forma do cristal. }\end{array}$ \\
\hline Irregular & $\begin{array}{l}\text { Variação composicional irregular distribuída pelo cristal; pode acompanhar } \\
\text { ou não a forma do cristal. }\end{array}$ \\
\hline \multicolumn{2}{|r|}{ Texturas } \\
\hline Poiquilítica & $\begin{array}{l}\text { Cristais grandes da matriz que englobam cristais menores de outras fases } \\
\text { minerais. }\end{array}$ \\
\hline Dissolução superficial & $\begin{array}{l}\text { Dissolução do mineral no contato cristal-líquido, formando hábito } \\
\text { irregularmente arredondado ou em forma de baía (embayment). }\end{array}$ \\
\hline Necklace & $\begin{array}{l}\text { Bordas de cristais formando uma "coroa"/borda de reação com cristais } \\
\text { adjacentes. }\end{array}$ \\
\hline Substituição & $\begin{array}{l}\text { Formação de pseudomorfos, houve dissolução e substituição do mineral } \\
\text { anteriormente cristalizado. }\end{array}$ \\
\hline \multicolumn{2}{|r|}{ Termos genéticos } \\
\hline Cristal cognato & $\begin{array}{l}\text { Cristal em equilíbrio químico e cognático ao líquido hospedeiro. Na literatura } \\
\text { em geral, referido como fenocristal. }\end{array}$ \\
\hline Antecristal & $\begin{array}{l}\text { Mineral cristalizado precocemente, que não se encontram mais em } \\
\text { equilíbrio com o líquido que os carrega, mas mantém vínculo com o sistema } \\
\text { magmático. Representam cristais reciclados de estágios magmáticos mais } \\
\text { precoces em profundidade. }\end{array}$ \\
\hline Xenocristal & Cristal sem relação genética com o sistema magmático. \\
\hline
\end{tabular}

Zonamentos e texturas adaptados de Streck (2008) e Gill (2010). Termos genéticos adaptados de Davidson et al. (2007).

\subsection{Xenólitos do manto}

Os "xenólitos do manto" são todas as inclusões de agregados minerais ou de rocha com presumida derivação mantélica encontradas em rocha encaixante de origem vulcânica (Pearson et al., 2003). Estes xenólitos, quando encontrados em áreas estáveis (on cráton e regiões adjacentes), podem ser encontrados em 
kimberlitos e rochas relacionadas, como kamafugitos, lamproítos e orangeítos. Em ambientes fora dos crátons (off cráton), os xenólitos mantélicos podem ser encontrados em rochas como basaltos alcalinos, nefelinitos, lamprófiros, etc. Os xenólitos do manto auxiliam na caracterização dos xenocristais observados em intrusões em intrusões kimberlíticas, dando informações importantes sobre profundidade, pressão e temperatura do manto que contribuiu para formação da assembleia mineral em questão. De acordo com Dawson (1980), xenólitos mantélicos em kimberlitos são subdivididos em cinco principais grupos:

- Suíte peridotítica-piroxenítica: constituem o grupo predominante, compreendendo os Iherzolitos, harzburgitos, dunitos, websteritos e piroxenitos. As texturas desses xenólitos são bastante variáveis e refletem a temperatura, pressão e esforço diferencial do momento em que são acidentalmente coletados e transportados pelo magma (Pearson et al., 2003).

- Eclogitos e grospyditos: em geral, indicativos de temperaturas e pressões de mantos subcratônicos, possui como constituintes principais minerais como granada, onfacita e cianita (Jacob, 2004);

- Peridotitos metassomatizados ricos e anfibólio e/ou mica: representam os peridotitos com evidência de formação de novos minerais, tais quais flogopita, ilmenita, rutilo, sulfetos, richterita e carbonato, a partir da interação dos minerais préexistentes com fluídos/fundidos. A formação desses novos minerais é evidência de metassomatismo modal, mas pode ocorrer também o metassomatismo por enriquecimento dos cristais pré-existentes por elementos maiores, menores e traços (Harte, 1987). Quando ocorre enriquecimento exclusivamente de elementos-traço sem envolvimento de formação de novos minerais, ocorre o metassomatismo críptico (Dawson, 1982).

- Suíte MARID e glimmeritos: o termo "glimmerito" é utilizado para xenólitos compostos dominantemente por flogopita. A suíte MARID consiste em xenólitos com variadas proporções de flogopita, anfibólio (K-richterita), rutilo, ilmenita e diopsídio com composições peculiares.

- Miscelânia de xenólitos: alkremitos (rochas de granulação grossa compostas por granada e espinélio) e rocha com ortopiroxênio e ilmenita em desequilíbrio.

Os xenólitos do manto podem ser considerados amostras diretas dos reservatórios aos quais derivam-se os magmas constituintes da crosta terrestre, 
trazendo uma contribuição relevante para caracterização do magmatismo alcalino da Província do Alto Paranaíba.

Os principais xenólitos derivados do manto encontrados em kimberlitos e orangeítos são de granada-Iherzolito, granada harzburgito, cromita harzburgito, espinélio Iherzolito, websterito, eclogito, peridotitos metassomatizados e rochas da suíte MARID (mica-anfibólio-rutilo-ilmenita-diopsídio). A desagregação desses xenólitos durante a incorporação e o transporte de kimberlitos nos magmas, resulta na adição de uma ampla variedade de xenocristais. Outros xenocristais, em particular olivina e flogopita, tem composições idênticas a àqueles minerais considerados como cristalizados do magma como fases primárias. Uma vez que esses minerais, antigamente, não podiam ser classificados sem instrumentação de petrografia de detalhe e não há simples indicadores texturais para divisão dos mesmos, essas fases eram simplesmente incluídas na suíte macrocristalina.

A variação composicional, bem como as relações texturais em uma intrusão ou pipe kimberlítico, sugere que os megacristais representem cristais oriundos de uma série magmática diferenciada. Essa assembleia é considerada híbrida e formada a partir da mistura de cristais derivados de uma série de distintos episódios de cristalização.

\subsection{Xenólitos do manto na região Sudoeste de Minas Gerais}

Nas regiões de Coromandel e Monte Carmelo (SW de Minas Gerais), inseridas na Província Alcalina do Alto Paranaíba, a ocorrência de xenólitos do manto é reportada com frequência em kimberlitos, kamafugitos, lamproítos e rochas relacionadas (Meyer et al., 1991; Leonardos et al., 1993; Carvalho, 1997; Carlson et al., 2007; Nannini, 2016). Os principais xenólitos descritos são os de granada Iherzolito, dunitos, harzburgitos e peridotitos. Segundo Carlson et al. (2007) os xenólitos de Coromandel representam restitos antigos de fusão parcial ocorrida no Arqueano a Paleoproterozóico com metassomatismo no Ciclo Brasiliano. São descritos também xenólitos de peridotitos com granada, espinélio e eclogito na região de Córrego da Cachoeira (MG), na borda sul do Cráton São Francisco, inclusos no kimberlito mineralizado Canastra 1 (Chaves et al., 2008).

Xenólitos de espinélio Iherzolitos, dunitos, harzburgitos e glimmeritos ocorrem na maior parte das intrusões e pipes aflorantes na região próxima de Coromandel e 
Bambuí, onde afloram corpos como Indaiá 1 e 2, Limeira 1 e 2, Pântano, Serra do Bueno e Três Ranchos (Gibson et al., 1995a). A maioria dos xenólitos mantélicos descritos para a PAAP parecem ter origem de profundidades relativamente rasas (dunitos e espinélio Iherzolitos), o que levou Bizzi et al., (1995) e Meyer et al. (1994) a propor que alguns magmas da província poderiam ter origem rasa. Contrariamente, a pressão e temperatura relativas ao campo de estabilidade do diamante obtidas através de xenólitos da intrusão Três Ranchos, indicariam que ao menos uma parte dos magmas da região teriam sido originados de uma fonte profunda, de aproximadamente $150 \mathrm{~km}$ (Gibson et al, 1995a).

Para o kimberlito Limeira I, foram descritos xenólitos do manto de até $15 \mathrm{~cm}$ com composição de dunito, harzburgito e espinélio Iherzolito (Svisero \& Ulbrich, 1992; Almeida, 2009), em parte portadores de flogopita (Meyer et al., 1991). Ainda segundo os autores, evidências de substituição mineral e metassomatismo modal similar ao registrado por xenólitos presentes em kimberlitos da Africa do Sul são descritos nos xenólitos do kimberlito Limeira I. Os xenólitos oriundos dos kimberlitos Indaiá I e Forca podem ser descritos como peridotitos com espinélio (fragmentos de fácies espinélio no manto litosférico raso), xenólitos com flogopita e/ou clinopiroxênio secundário, dunitos e harzburgitos (Nannini et al., 2016).

\section{Química mineral e elementos-traço como ferramentas para elucidação de processos em kimberlitos e rochas associadas}

O refinamento das metodologias analíticas de detalhe (tal qual LA-ICP-MS) na última década permitiu a quantificação mais precisa dos elementos-traço em rochas alcalinas. As análises de elementos-traço in situ em olivina, particularmente dos elementos $\mathrm{Ni}, \mathrm{Al}, \mathrm{Ca}, \mathrm{Mn}$ e Ti permite a discriminação entre diferentes populações desta fase mineral em kimberlitos (Bussweiler et al., 2017, De Hoog et al., 2010; Howarth and Taylor, 2016), lamproítos (Jaques \& Foley, 2018; Shaik et al., 2018) e lamprófiros ultramáficos (Nosova et al., 2018; Tappe et al., 2006; Veter et al., 2017).

As composições de olivinas também foram utilizadas para contestar a natureza e a evolução de regiões mantélicas fontes para o magmatismo lamproítico (Ammannati et al., 2016; Prelevic et al., 2010; Prelevic \& Foley, 2007). Os elementostraço podem fornecer ainda, o estado termal do manto litosférico sub-continental (SCLM) no momento da erupção, a partir de temperaturas calculadas utilizando Al em 
olivina como geotermômetro (Bussweiler et al. 2017; De Hoog et al., 2010). Esses elementos auxiliam ainda na identificação de diferentes tipos de rochas ultramáficas não peridotíticas, incluindo aquelas que não foram formadas por reciclagem da crosta oceânica (Foley et al., 2013). A correlação com outros elementos-traço como Zn, Ti e Ca auxiliam na identificação dos minerais na fonte dessas, como flogopita, espinélio, granada e anfibólio.

A flogopita é um dos poucos minerais que preserva a história de migração dos fluídos, além dos eventos de magmatismo no manto e na crosta, sendo uma fase mineral indicadora da evolução de um magma kimberlítico (Giuliani et al., 2016). A flogopita é uma das primeiras fases a cristalizar a partir de fundidos mantélicos e é geralmente um pré-requisito para geração de fundidos ultrapotássicos (Foley, 1992). Essas micas carregam importantes informações sobre a história do fracionamento precoce em rochas ultrapotássicas, além da composição de fonte mantélica lamproítica. Elementos-traço quantificados em bordas de flogopita como altas concentrações de $\mathrm{Ti}, \mathrm{Al}$ e $\mathrm{Ba}$ além de baixo $\mathrm{Cr}$ são indicadores de uma matriz kimberlítica.

\subsection{Variação estrutural e composicional em olivinas}

\subsubsection{Estrutura e composição da olivina em kimberlitos}

Os diferentes membros do grupo da olivina cristalizam com simetria ortorrômbica, com estruturas que consistem de tetraedros independentes de $\mathrm{SiO}_{4}$ ligados por átomos bivalentes (Mg, Fe, Ca) em coordenação octaédrica (Deer et al., 1992). Ainda segundo o autor, a distribuição de $\mathrm{Mg}^{2+}$ e $\mathrm{Fe}^{2+}$ ocorre com ordenamento variável e ocorre uma solução sólida completa entre a composição da forsterita $\left(\mathrm{Mg}_{2} \mathrm{SiO}_{4}\right)$ e da faialita $\left(\mathrm{Fe}_{2} \mathrm{SiO}_{4}\right)$, já a monticelita $\left(\mathrm{CaMgSiO}_{4}\right)$ não ocorre em soluções sólidas consideráveis em relação à composição química ideal.

A monticelita é basicamente formada pela mesma estrutura das olivinas ( $\mathrm{Mg}$, Fe), mas possui malha unitária expandida devido à substituição de metade dos sítios de Mg e Fe por Ca (Deer et al., 1992).

Segundo Mitchell (1995), as olivinas em kimberlitos do Grupo I podem ser caracterizadas por: 
- Macrocristais ou xenocristais que possuem um amplo intervalo de composição (Fo84 a Fo95);

- Há uma população constituída de xenocristais de olivina derivadas de desagregados de harzburgitos e Iherzolitos;

- Independente da composição, macrocristais podem ocorrer com um fino manteamento (ou zoneamento) de olivina de composição semelhante às olivinas euédricas da matriz (Fo87 a Fo89).

\subsubsection{Elementos-traço em olivina}

Apesar do grande potencial para elucidação de processos ocorrentes no manto superior, elementos-traço em olivina não foram estudados extensivamente (Foley et al., 2013). As aplicações potenciais para o mapeamento desses elementos em olivinas kimberlíticas são principalmente a caracterização da composição dos fundidos mantélicos primários pelo fato de a olivina ser o primeiro mineral silicático e a se cristalizar e a evolução do fundido estudada a partir dos diferentes zonamentos químicos.

A estrutura simples da olivina implica que tais cristais oferecem espaços a um número restrito de elementos-traço, sendo que os sítios octaédricos M1 e M2 são similares em tamanho (73 e 76,7 pm; Zanetti et al., 2004), ou seja, ambos muito pequenos para alocação da maioria dos elementos incompatíveis. Os ocupantes principais dos referidos sítios octaédricos são $0 \mathrm{Mg}^{2+}$ e $\circ \mathrm{Fe}^{2+}$. A incorporação de elementos-traço nesses sítios é dependente dos raios iônicos e das cargas desses elementos, sendo que seus tamanhos pequenos (M1 73 picômetros, MW 76,7 picômetros) oferece uma fácil substituição do Mg e do Fe por alguns elementos-traço (De Hoog et al., 2010; Foley et al., 2011).

Poucos elementos-traço possuem a cargas e raio iônicos compatíveis em olivina e, além disso, tais elementos são influenciados pela pressão, temperatura e composição do fundido. Alguns dos cátions que exibem tamanho e valência similares aos sítios M1 e M2 que podem ser incorporados em olivinas são $\mathrm{Ni}^{2+}$ (69 pm) e $\mathrm{Mn}^{2+}$ (67 pm), que são os cátions mais abundantes na lista de elementos-traço, embora $\mathrm{Co}^{2+}(74,5 \mathrm{pm})$ e $\mathrm{Zn}^{2+}(74 \mathrm{pm})$ possuam cargas e raios com tamanhos mais similares aos sítios octaédricos da olivina. Alguns cátions possuem um tamanho compatível, 
porém diferem nas cargas iônicas, como o $\mathrm{Zr}^{4+}, \mathrm{Sc}^{3+}$ e o $\mathrm{Li}^{1+}$ (Foley et al., 2011; Zanetti et al., 2004).

Alguns elementos, em particular $\mathrm{Ca}, \mathrm{Al}, \mathrm{Ti}$ e $\mathrm{Ni}$ são especialmente úteis na distinção entre olivinas ígneas de olivinas mantélicas e podem ser utilizados no reconhecimento da proporção de olivinas xenocristalinas em rochas ígneas ricas em Mg como kimberlitos e picritos, reconhecidamente famosas por carregarem xenocristais do manto (Brett et al., 2009). Os teores de Ti possuem uma média de 340 ppm em olivinas ígneas, comparado a $<70$ ppm para a maioria das olivinas mantélicas, já para Ni, olivinas mantélicas possuem concentrações entre 2200 e 3400 ppm, enquanto as olivinas ígneas possuem valores mais altos ou mais baixos que este intervalo (Foley et al., 2013). Altos teores de Ni podem ser interpretados como indicativo de baixa abundância em olivinas (Sobolev et al., 2007), enquanto altas razões $\mathrm{Mn} / \mathrm{Fe}$ indicam maiores abundâncias de olivina em relação a um peridotito normal (Ammanati et al., 2016; Sobolev et al., 2007).

Altos teores de Li e Zn são utilizados como sensor para o envolvimento de crosta continental reciclada (Foley et al., 2013; Prelevic et al., 2013). Al também é um elemento importante, pois aparece em concentrações mais elevadas em olivinas ígneas, podendo chegar a até 800 ppm, diferentemente do Al em olivinas mantélicas, que possuem em geral, menos de 130 ppm (De Hoog et al., 2010).

Estudos sobre a solubilidade de Ti em olivina tem sido desenvolvidos pois altos teores de $\mathrm{Ti}$ inferidos a partir da presença de exsoluções de ilmenita foram interpretados como indicativos de uma origem muito profunda (Dobrzhinetskaya et al., 1996; Green et al., 1997). Em uma dada temperatura, a máxima solubilidade de Ti em $\mathrm{MgSiO}_{4}$ é obtida quando tamponada com o espinélio $\mathrm{Mg}_{2} \mathrm{TiO}_{4}$, o que sugere que Ti substitui Si em olivina (Hermann et al., 2005).

Núcleos possuem baixas concentrações características de um forte empobrecimento, enquanto bordas possuem altas concentrações de $\mathrm{Ca}, \mathrm{Ti}, \mathrm{Cr}, \mathrm{V}$ e $\mathrm{Zn}$ retiradas do fundido (Foley et al., 2006). 


\subsection{Variação estrutural e composicional da flogopita}

4.2.1 Estrutura e composição de micas trioctaédricas: flogopita e biotita

A biotita e a flogopita formam uma importante série contínua, sendo a diferença entre os dois minerais arbitrária, baseando-se no teor de ferro e magnésio: quando $\mathrm{Mg}: \mathrm{Fe}<2: 1$ classifica-se a biotita e quando Mg:Fe $>2: 1$ classifica-se a flogopita. Segundo Deer et al. (1992), as biotitas e flogopitas são formadas com composições que oscilam entre 4 componentes principais nas posições I, M e T.

As micas são caracterizadas pelos cátions tetraédricos $\mathrm{Si}, \mathrm{Al}$ ou $\mathrm{Fe}^{3+}$, sendo os cátions das camadas intermediárias normalmente $\mathrm{K}$ ou $\mathrm{Na}$. Os cátions octaédricos são normalmente $\mathrm{Mg}, \mathrm{Al}, \mathrm{Fe}^{2+}$ e $\mathrm{Fe}^{3+}$, mas outros cátions de tamanho "médio" como Li, Ti, V, Cr, Mn, Co, Ni, Cu e Zn também ocorrem em algumas espécies (Bailey et al., 1984). Entre as possíveis substituições tetraédricas, $\mathrm{Fe}^{3+}<->\mathrm{Al}^{3+}$ é de suma importância em rochas alcalinas e carbonatitos. Essa substituição define as séries flogopita - tetraferriflogopita e annita - tetraferriannita, e é geralmente indicada por (Brod et al., 2001):

i. $\quad$ Forte correlação negativa entre $\mathrm{Fe}^{+3}$ e $\mathrm{Al}^{+3}$;

ii. Deficiência na soma dos cátions tetraédricos comuns (i.e. $\mathrm{Si}+\mathrm{Al}<8$ );

iii. E excesso de cargas octaédricas, provocada por Fe2+ superestimado em análises de microssonda eletrônica.

A substituição de $\mathrm{Ti}$ em biotita e flogopita despertam interesse e geram controvérsias há pelo menos 4 décadas. Diversos estudos (Dymek, 1983; Labotka, 1983; Brod et al., 2001) foram feitos para análise de possíveis substituições para explicar a ocorrência natural de biotitas enriquecidas em Ti. Na década de 80 foi assumida a dificuldade no desenvolvimento da fórmula estrutural de biotita e flogopita principalmente pelo fato de que as análises eram tipicamente incompletas (tipicamente sem $\mathrm{Fe}_{2} \mathrm{O}_{3}$ e $\mathrm{H}_{2} \mathrm{O}$ ), fazendo com que o cálculo da fórmula estrutural do mineral se tornasse duvidoso. Mesmo com uma análise completa, há normalmente múltiplas possibilidades de trocas disponíveis. O Ti ocupa sítios octaédricos quando substitui como um elemento menor em minerais formadores de rocha como anfibólios e micas (Waychunas, 1987). 
A maioria das flogopitas lamproíticas possui teor de Al inferior a 14\%, sendo a evolução magmática dessas flogopitas acompanhadas por um decréscimo neste teor (Fritschle, 2013). Concentrações de Ti e Fe podem variar bastante, no entanto, há aumento desses elementos durante a cristalização devido ao seu relativo enriquecimento no fundido (Mitchell, 1986; Brod et al., 2001). Esses trends evolutivos são preservados como zonamentos entre núcleos e bordas. As flogopita lamproíticas são caracteristicamente deficientes em Si e Al, que são elementos insuficientes para preencher os sítios tetraédricos. Essa deficiência no sítio tetraédrico foi explicada por Wendlandt (1977) e Arima \& Edgar (1981) pela entrada do $\mathrm{Fe}^{3+}$ nessa posição, sendo apoiada posteriormente por Brigatti et al. (1996). Os sítios octaédricos de cristais de flogopita lamproíticas são comumente deficientemente ocupados (Mitchell et al., 1986) devido a substituição de $2 \mathrm{Mg}^{2+}$ por $\mathrm{Ti}^{4+}$ resultando na criação de vacância no sítio, aonde podem ocorrer substituições entre $2 \mathrm{~K}^{+}$e $\mathrm{Ba}^{2+}$ ou $2 \mathrm{Rb}^{+}$, respectivamente (Fritschle et al., 2013).

\subsubsection{Elementos-traço em micas trioctaédricas}

Os mecanismos de substituição de elementos menores e traços e particionamento em micas trioctaédricas foram estudados extensivamente e explicados por fatores como mudanças de fugacidade, pressões de água e $\mathrm{CO}_{2}$, temperatura de cristalização e composição de magmas (Edgar e Arima, 1983; Bailey, 1984;). A estrutura da flogopita é extremamente flexível e pode apreentar uma alta variabilidade nos valores de coeficientes de partição (Foley et al., 1996).

A estrutura das micas ferromagnesianas trioctaédricas oferecem três sítios cristalinos para alocação de elementos-traço. O sítio tetraédrico é ocupado pelos cátions como Si e Al e em alguns casos $\mathrm{Fe}^{3+}$ e Ti (Abrecht \& Hewitt, 1988), mas não é ocupável pelos cátions dos elementos-traço. Os sítios octaédricos $\mathrm{M}$ (ocupados principalmente por $\mathrm{Mg}, \mathrm{Fe}^{2+}$ e $\mathrm{Al}$ ) possuem uma média de raio de 68 picômetros e acomoda muitos dos elementos- traço ( $\mathrm{Li}$, Sc, V, Co, Ni, Zr e Nb) com concentrações a partir de alguns ppm até alguns milhares de ppm como pode ser observado em flogopitas lamproíticas. O terceiro sítio é o da camada intermediária, com um tamanho maior, de 176 pm, que acomoda cátios maiores como $\mathrm{Ba}, \mathrm{Rb}, \mathrm{Cs}, \mathrm{Sr}, \mathrm{Pb}$ e REE (Fritschle, 2013). 
A composição de elementos-traço na flogopita é uma indicação de processos petrogenéticos associados a evolução de uma rocha kimberlítica (Reguir et al., 2009). Micas ferromagnesianas são comuns como macrocristais ou microcristais em kimberlitos e carbonatitos. Tais macrocristais seguem dois principais trends de evolução: primário (envolvendo altas concentrações de $\mathrm{Ba}, \mathrm{Al}, \mathrm{Ti}, \mathrm{Nb}$ e $\mathrm{Sr}$, apresentando decréscimo de $\mathrm{Mg}$ em direção às bordas) e transicional (macrocristais da matriz), envolvendo o aumento da componente kinoshitalita e decréscimo dos teores de $\mathrm{Fe}$, Ti e $\mathrm{Cr}$. Os elementos $\mathrm{Rb}$, Ba e V são predominantes de substituição em micas octaédricas, porém, não podem ser utilizados como indicador petrogenético pela sobreposição de valores que tais elementos apresentam em relação as micas de carbonatitos (Kargin et al., 2019).

\subsubsection{Micas em kimberlitos do Grupo I}

As características típicas da composição de micas primárias em kimberlitos do Grupo I não são amplamente conhecidas, uma vez que não há uma distinção bem estabelecida entre as micas descritas para kimberlitos dos Grupos I e II. Desta maneira, a tendência evolutiva flogopita-tetraferriflogopita descrita como uma característica de kimberlitos do Grupo II (Mitchel, 1995) é considerada típica para kimberlitos em geral.

Ainda segundo o autor, muitas micas em kimberlitos do Grupo I ocorrem como macro ou megacristais de origem desconhecida, com composições bem caracterizadas como flogopitas aluminosas ( 10 a $15 \%$ de $\mathrm{Al}_{2} \mathrm{O}_{3}$ ), com amplo intervalo de $\mathrm{TiO}_{2}(0,5 \%$ a $5,5 \%)$ e $\mathrm{Cr}_{2} \mathrm{O}_{3}(0,1 \%$ a 2,0\%). Mitchell (1995) descreve dois trends principais em relação às flogopitas kimberlíticas:

- Trend caraterizado pelo enriquecimento em Al: no diagrama ternário $\mathrm{Al}$ x Mg $\mathrm{x}$ $\mathrm{Fe}$, as composições das micas plotam distantes do limite flogopita/biotita e na direção do campo das flogopitas aluminosas e/ou da composição hipotética da eastonita. Associada a essa característica, há enriquecimento de Ba e o conteúdo de Ti é inferior a $4 \%$;

- Trend em direção à tetraferriflogopita: micas pobres em Al, cristalizadas como mantos discretos e finos sobre núcleos de micas da matriz rica em Al. A formação da tetraferriflogopita é rara ou não ocorre na maioria dos kimberlitos do Grupo I e a troca 
abrupta da composição indicaria a ocorrência de mudanças abruptas nas condições de oxirredução durante a cristalização.

Shee (1985) identificou altas concentrações de $\mathrm{Ti}$ e $\mathrm{Cr}$ para bordas de microcristais de flogopitas, zonas estas que seriam indicativas de um fundido kimberlítico. Giuliani et al. (2016) descreve as micas kimberlíticas como flogopitas de alto $\mathrm{Ti}, \mathrm{Al}$ e $\mathrm{Ba}$, com teores variáveis de Cr. Kargin et al. (2019) descreve duas populações principais paras micas kimberliticas e de seus respectivos xenólitos: população 1, referente a grãos grossos de xenólitos do manto $\left(\mathrm{TiO}_{2}<1 \%\right.$; $\mathrm{Cr}_{2} \mathrm{O}_{3}<1 \%$; Mg\#>92) e população 2, representativa de flogopitas kimberlíticas, apresentando-se como bordas da população 1, com teores de $\mathrm{TiO}_{2}>2 \%, \mathrm{Cr}_{2} \mathrm{O}_{3}>1 \%$ e $\mathrm{Mg \# <}<2$.

\section{Reconstituições de líquidos pristinos em rochas de afinidade kimberlítica}

A composição de fundidos kimberlíticos e as profundidades de colocação desses corpos na crosta superior é um tema que ainda gera controvérsias na comunidade científica. Os múltiplos processos de alteração, assimilação e contaminação contribuem para que haja certa dificuldade nesse tipo de reconstituição: qual seria a composição do fundido que dá origem aos kimberlitos? Quais seriam suas fontes?

Os pesquisadores, em geral, combinam análises de rocha total em kimberlitos, incluindo a descriminação de fases xenocristalinas de fases magmáticas a partir de determinações de química mineral, com o objetivo de tentar reconstruir a composição do fundido original (e.g. Le Roex et al., 2003; Becker e Le Roex, 2006; Nielsen \& Sand (2008), Patterson et al., 2009; Kjarsgaard et al. (2009) Guarino et al., 2013; Kamenetsky et al., 2014, Soltys et al. (2018)). Os debates em relação ao assunto giram em torno de duas metodologias principais: a primeira é baseada no cálculo através de rochas minimamente contaminadas, corrigidas pelos teores variáveis de incorporação de peridotito (em geral de 30 a 50\%), com variáveis níveis de sofisticação nas correções (Patterson et al. 2009; Soltys et al., 2018); a segunda se dá principalmente pela subtração de olivina xenocristalina e outras fases não cognatas identificadas (Becker e Le Roex, 2006; Kamenetsky et al, 2014).

Sabe-se que a zona mais interessante para se trabalhar neste tipo de estimativa são as hipoabissais, por se tratarem de regiões intermediárias entre 
plutônicas e vulcânicas, possuindo caráter maciço e macrocristalino. Segundo Mitchell (2008), os kimberlitos hipoabissais são produtos de cristalização de um magma que não foi submetido à degaseificação, logo, fornecem o melhor material para compreensão do caráter do magma kimberlítico primeiramente à formação das fácies diatrema e piroclásticas. Para o presente trabalho, foi aplicada metodologia similar a fim de reconstituir um possível fundido originador da intrusão Pântano, no entanto, algumas considerações devem ser feitas anteriormente ao desenvolvimento das estimativas.

\subsection{Procedimentos utilizados na literatura}

Na década passada, Patterson (2009) conduziu um estudo em que analisou rochas kimberlíticas de 3 diferentes zonas (cratera, diatrema e raiz) de um mesmo campo kimberlítico (Foxtrot, Québec), com o intuito de analisar as químicas mineral e de rocha total e, a partir delas, obter constituições dos fundidos descontando-se o volume de xenocristais (basicamente olivina). O autor considerou ainda, um segundo cálculo para o líquido, descontando-se também proporções (80/20) de olivina e ortopiroxênio. Como fases minerais principais em suas amostras, o autor descreveu olivina (principal), carbonato como fase principal secundária, flogopita e clinopiroxênio (diopsídio). Os diques do pipe kimberlítico de Foxtrot possuem índices de contaminação (Clement, 1982) entre 0,9 e 1,5 e as composições encontradas para ambos os líquidos calculados apresentaram menores teores de magnésio ( 15 wt\%) e sílica ( 24 wt\%), além de maior teor de $\mathrm{CO}_{2}$ ( 17\%) em relação às composições originais de rocha total. O autor não considerou os elementos-traço em suas estimativas (não foram analisados estes elementos na química mineral). Nota-se que o teor de $\mathrm{CO}_{2}$ é consideravelmente alto se comparado a este tipo de estudo em outras ocorrências kimberlíticas mundo afora. Outros autores como Le Roex et al. (2003), Nielsen \& Sand (2008), Kjarsgaard et al. (2009) e Soltys et al. (2018) utilizaram metodologias similares para este tipo de reconstituição.

Becker et Le Roex (2006) também fizeram estimativas de composições "próximas-a-magmas-primários" (tradução literal), levando em consideração aspectos como a remoção de xenólitos crustais e macrocristais, interpretados como xenocristais de manto peridotítico. Para os macrocristais de olivina, os autores consideraram que todos se tratavam de xenólitos desagregados de granada-lherzolitos e, portanto, 
subtraíram o volume destas populações. Os autores inferem composições entre 22 a 28 wt\% de $\mathrm{MgO}, 21$ a 30 wt\% de $\mathrm{SiO}_{2}, 2,2$ a 3,1 wt\% de $\mathrm{Al}_{2} \mathrm{O}_{3}, 10$ a 17 wt\% de $\mathrm{CaO}, 5$ a 14 wt\% de $\mathrm{CO}_{2}, 0,2$ a 1,7\% de $\mathrm{K}_{2} \mathrm{O}$ e Ni entre 660 e 1190 ppm. Os autores utilizaram dados de 12 kimberlitos sul-africanos classificados como pertencentes ao Grupo I, com uma ampla porcentagem de volume de macrocristais (2 a $30 \%$ ) e mineralogia predominantemente constituída por calcita, serpentina, flogopita, óxidos opacos e perovskita. Foram considerados nos balanços de massa, os kimberlitos menos afetados por alteração, contaminação crustal e cristalização fracionada, no entanto, não foram bem especificados quais os critérios utilizados nos cálculos. Kamenetsky et al. (2014) também utilizou metologia similar, fazendo a subtração da olivina xenocristalina.

Vale ressaltar que as diferentes metologias apresentam composições também diferentes para os fundidos calculados. Na primeira metologia descrita, os fundidos apresentam composições enriquecidas em água (1-3\%) e $\mathrm{CO}_{2}$ (10-20\%), são altamente magnesianos ( $20-31 \% \mathrm{MgO})$, com teores baixo a moderados de $\mathrm{SiO}_{2}(17-$ $32 \%)$, baixo $\mathrm{K}_{2} \mathrm{O}(0,5$ a $2 \%)$ e $\mathrm{Na}_{2} \mathrm{O}$ muito baixo (<2\%), apresentando boa correlação entre os diferentes estudos. Utilizando-se a segunda metologia, encontram-se fundidos de composições empobrecidas em $\mathrm{CaO}$ e $\mathrm{MgO}$, com elevados teores de $\mathrm{Na}$, $\mathrm{K}, \mathrm{Cl}$ e $\mathrm{S}$, além de baixos teores de $\mathrm{SiO}_{2}$.

Para a província Alto Paranaíba, Guarino et al. (2013) apresenta composições de possíveis líquidos calculados para kimberlitos, considerando o desconto de 5 a $30 \%$ de olivina xenocristalina. Para o cálculo do líquido da intrusão Pântano, a autora desconta apenas $5 \%$ de olivina, ou seja, uma porcentagem muito baixa considerando os percentuais de olivina não cognata registrados no presente trabalho.

\section{Procedimento experimental}

Todas amostras utilizadas no desenvolvimento deste trabalho foram preparadas no Laboratório de Tratamento de Amostras (LTA) do NAP GeoAnalíticaUSP, vinculado ao Instituto de Geociências da Universidade de São Paulo (IGc USP). As amostras preparadas para laminação e geoquímica foram preferencialmente escolhidas dos respectivos conjuntos de cada um dos 8 pontos (Figura 2.2) em que foi realizada a amostragem. Foram escolhidas sete das amostras mais bem 
preservadas da intrusão, retirando-se as porções superficiais da rocha que ficavam expostas ao intemperismo, além dos xenólitos crustais que puderam ser identificados pela coloração bege/rosa. Para a rocha encaixante (quartzito), foi selecionada apenas uma amostra.

\subsection{Preparação de amostras}

\subsubsection{Lâminas petrográficas}

A preparação de lâminas delgadas se deu a partir do corte, desbaste e polimento das diferentes porções da intrusão em que foi possível a obtenção de amostras. Para as interpretações petrográficas realizadas no presente trabalho, foram confeccionadas 29 lâminas petrográficas. Também, pôde-se utilizar de 14 lâminas adicionais da intrusão Pântano já trabalhadas pelo orientador e tendo-se como foco amostragem realizada pelo Prof. Darcy P. Svisero. As lâminas novas destinadas ao estudo petrográfico produzidas para o presente trabalho possuem 30 um de espessura, já as lâminas do professor Darcy, possuem espessura mais fina. Posteriormente à descrição das lâminas da coleção do professor Darcy, havia a intenção de se fazer análises de microssonda eletrônica, porém, não foi possível devido à espessura das mesmas.

O estudo de lâminas petrográficas foi feito utilizando-se o microscópio petrográfico ZEISS Axioplan (luz transmitida e refletida) do Instituto de Geociências da Universidade de São Paulo, com a finalidade de caracterizar as fases minerais bem como suas relações texturais e zonamentos, além de definir os distintos tipos petrográficos existentes na intrusão.

\subsubsection{Seções polidas e fragmentos de rocha}

As lâminas destinadas à análise por Microssonda Eletrônica e MEV foram recobertas com carbono metalizador até a formação de uma camada de $250 \mathrm{~nm}$ de espessura. Foram utilizadas 8 seções polidas de porções distintas da rocha. Adicionalmente às lâminas, foram preparados 2 fragmentos de rocha representativos da zona menos contaminada/zona caracterizada pela maior ocorrência de monticelita da intrusão Pântano. Os fragmentos de rocha foram envoltos em resina epóxi (araudite) com o tamanho de 1". 


\subsubsection{Química de rocha total}

$\mathrm{Na}$ preparação das pastilhas utilizadas na geoquímica de rocha total, primeiramente, recorreu-se do uso de uma prensa hidráulica de aço de 30 ton força (Shwing Siwa Equipamentos Industriais, São Paulo) para quebra das amostras macroscópicas. Após prensagem, foram retiradas as porções superficiais passíveis de serem identificadas, assim como os xenólitos crustais que podiam ser identificados (pela cor bege/rósea) a olho nu. Posteriormente, as amostras foram quarteadas em folha de papel sulfite branca e levadas ao moinho de anéis de ágata para pulverização durante quinze minutos, duas vezes cada amostra, até a obtenção de material com granulometria inferior a 200 mesh. O modelo de moinho utilizado foi o Planetary Mono Mill - Pulverisette 6 (Fritsch, Alemanha) e possui uma capacidade volumétrica de 1 a $30 \mathrm{ml}$ de amostras.

Convém lembrar que tanto a prensa quanto o moinho foram devidamente limpos e ambientados com as amostras de interesse. No moinho de ágata, após a pulverização da amostra de cada ponto, foi feita a limpeza utilizando-se uma mistura de areia e água, que foi passada no moinho durante 1 minuto. O equipamento apresenta uma velocidade acima de $1500 \mathrm{rpm}$. Depois do descarte da lama gerada a partir deste procedimento, o moinho foi limpado cuidadosamente com álcool, procurando evitar qualquer tipo de contaminação. Após a pulverização de todas as amostras, as mesmas foram micronizadas com álcool por aproximadamente 20 minutos e deixadas na estufa durante dois dias. Acrescentou-se ao pó gerado $20 \%$ em peso de parafina e homogeneizou-se manualmente, a fim de confeccionar as pastilhas de pó prensadas para análise dos elementos-traço por FRX.

Para obtenção das análises dos elementos maiores, as amostras pulverizadas a partir do moinho de ágata foram pesadas $(1 \pm 0,001 \mathrm{~g})$ e posteriormente foram acrescentados fundentes químicos (metaborato e tetraborato de lítio, $9 \pm 0,001 \mathrm{~g}$ ) e pequenos cristais volatizáveis para produção de pastilhas fundidas em cadinhos de platina (após a homogeneização do material) no NAP GeoAnalítica-USP. Foram feitas duplicatas a cada 5 amostras visando o controle de possíveis oscilações na análise geoquímica do equipamento utilizado. As pastilhas fundidas ficaram prontas após aproximadamente 30 minutos. 


\subsection{Metodologia analítica}

\subsubsection{Análises de imagem}

Primeiramente, todas as lâminas petrográficas foram escaneadas utilizando-se o scanner Epson Perfection V500 PHOTO. Por utilizar luz transmitida, as imagens obtidas através do scanner preservam a aparência que as lâminas teriam ao serem analisadas em um microscópio óptico. Para a obtenção das análises de imagem, utilizou-se o o Programa Corel Draw, sendo selecionada uma lâmina de cada ponto, desconsiderando-se as bordas das mesmas no tratamento da imagem, a fim de evitar que o programa confundisse a cola da lâmina com o material rochoso. Com o objetivo de estimar a composição das rochas a partir de análises visuais das lâminas petrográficas, a porcentagem de matriz foi separada dos demais elementos formadores do corpo kimberlítico, gerando uma imagem dividida puramente entre os tons "claros" e "escuros" e posteriormente em tons RGB.

O programa basicamente conta os pixels da imagem pelas cores e guarda $O$ número de pixels total contados, fazendo os cálculos das proporções na forma de porcentagem. Desta maneira, após a divisão automática entre tons claros e escuros, selecionou-se individualmente quais seriam os megacristais e macrocristais, os xenólitos, os pseudomorfos ou enclaves e as venulações a partir das imagens geradas em tons claros e escuros. As porcentagens encontradas para tais análises serviram de auxílio para descrição petrográfica em microscópio ótico e foram fundamentais para o cálculo estimado do magma kimberlítico progenitor.

\subsubsection{Microscopia Eletrônica de Varredura}

As análises de Microscopia Eletrônica de Varredura (MEV) foram realizadas visando principalmente a caracterização dos zonamentos das fases minerais da intrusão, bem como as relações texturais entre monticelita e diopsídio, não identificáveis ao microscópio de luz refletida. As análises de MEV foram úteis também na identificação da apatita, mineral ainda não descrito para a intrusão Pântano, pois 
encontra-se como fase muito fina e/ou de substituição de outros minerais na matriz, além da identificação de espurrita, mineral gerado nos xenólitos de quartzito da intrusão.

As análises foram realizadas no Laboratório de MEV da Poli Minas do LCTUSP, além do Laboratório de MEV do IGC-USP. As condições de operação do Laboratório de MEV do IGC-USP foram: tensão de aceleração de 15 a $20 \mathrm{kV}$ e distância de trabalho de 10 a $40 \mathrm{~mm}$ a depender do cristal ou porção da rocha a ser imageada. As condições de operação do Laboratório de MEV da Poli Minas do LCTUSP foram: tensão de aceleração de 5 a $25 \mathrm{kV}$ e distância de trabalho de $14 \mathrm{~mm}$. Em ambos os laboratórios, para os dois fragmentos de rocha, foi feito o mapeamento dos mesmos através de uma "matriz" $7 \times 9$ de fotomicrografias. As matrizes foram obtidas com o auxílio do programa Image Compositor Editor (ICE), da Microsoft. O programa faz a sobreposição de fotomicrografias identificando as bordas semelhantes, gerando o "mapeamento" dos fragmentos de rocha, possibilitando, portanto, uma caracterização da matriz em alto nível de detalhe. A Figura 6.1 apresenta o mapeamento de um dos fragmentos, bem como os cristais selecionados para as análises de microssonda eletrônica e, posteriormente, análise de LA-ICP-MS. 


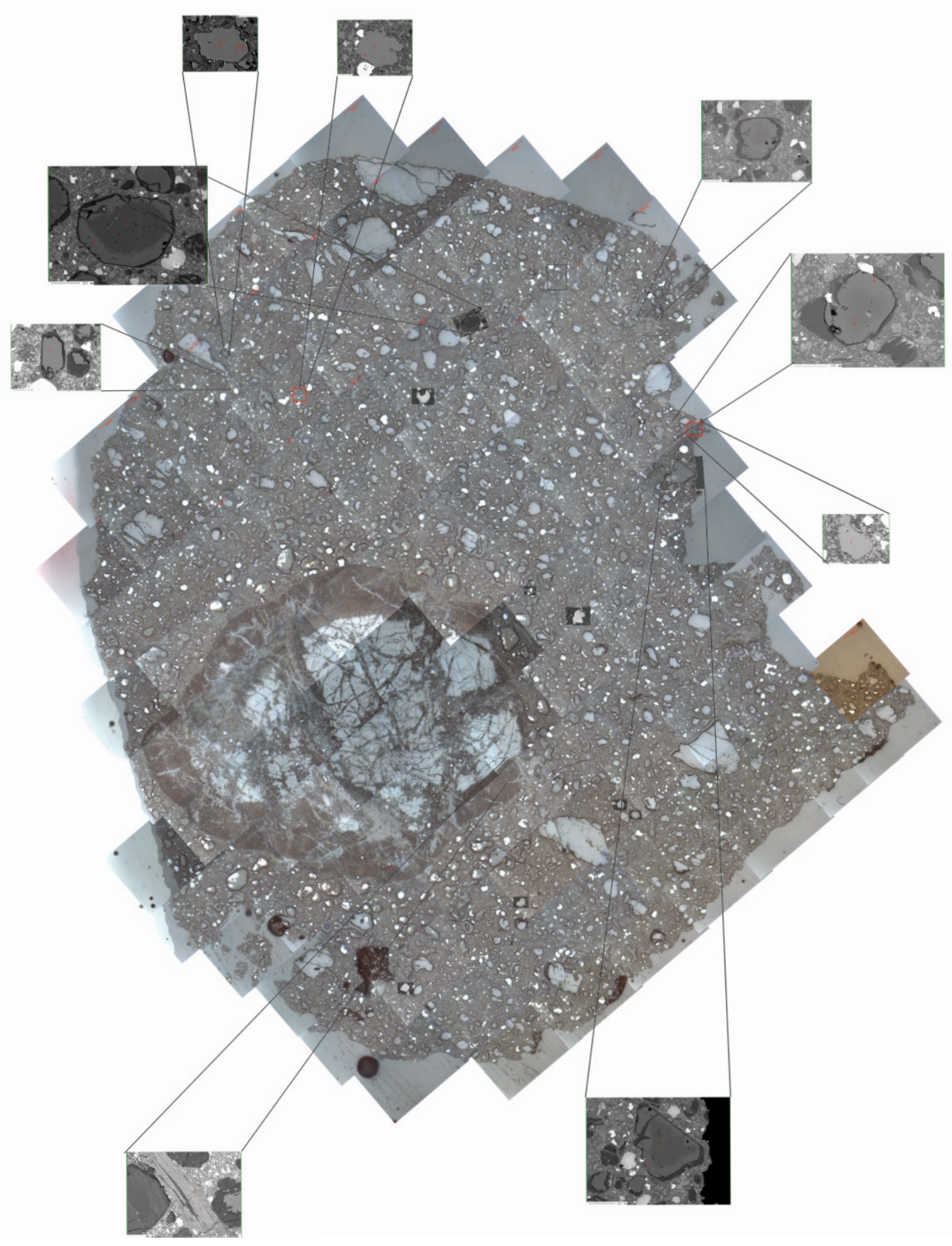

Figura 6.1: Mapeamento de fragmento de rocha obtido através da matriz de fotomicrografias de MEV. Destaque para os cristais selecionados para as análises de ME e LA-ICP-MS. 


\subsubsection{Fluorescência de Raios $\mathrm{X}$}

A espectrometria de fluorescência de raios $X(F R X)$ foi realizada no Laboratório de fluorescência de raios X do NAP Geoanalítica-USP utilizando-se o equipamento Pananalytical AxiosMax Advanced. A aplicação principal desta técnica é a determinação de elementos maiores, menores e traços, auxiliando na caracterização geoquímica das rochas da intrusão Pântano. Para a análise das amostras, foram confeccionadas pastilhas fundidas de vidro para obtenção dos elementos maiores e menores ( $\mathrm{Na}, \mathrm{Mg}, \mathrm{Al}, \mathrm{Si}, \mathrm{P}, \mathrm{K}, \mathrm{Ca}, \mathrm{Ti}, \mathrm{Mn}, \mathrm{Fe}$ ). As pastilhas prensadas são produzidas diretamente a partir das amostras pulverizadas e micronizadas, sendo possível obter os elementos-traço ( $\mathrm{Ba}, \mathrm{Ce}, \mathrm{Co}, \mathrm{Cr}, \mathrm{Cu}, \mathrm{Ga}, \mathrm{La}, \mathrm{Nb}, \mathrm{Nd}, \mathrm{Ni}, \mathrm{Pb}, \mathrm{Rb}, \mathrm{Sc}, \mathrm{Sr}, \mathrm{Th}, \mathrm{U}, \mathrm{V}$, $\mathrm{Y}, \mathrm{Zn}, \mathrm{Zr}$ ). Os procedimentos utilizados nestas análises podem ser encontrados em Mori et al (1999).

Diversos problemas foram encontrados na determinação dos elementos maiores por FRX. Na primeira leitura realizada, os totais obtidos, adicionando-se os valores de perda ao fogo, apresentaram valores abaixo do esperado, um pouco abaixo de $98 \%$ em massa. Por se tratar de uma rocha ultrapotássica e insaturada em sílica, com altos teores de magnésio, trabalhou-se para encontrar as possíveis fontes de erro e maneiras de se otimizar as leituras.

Um dos problemas poderia estar relacionado às determinações de perda ao fogo. As análises de perda ao fogo (P.F.) foram obtidas também no laboratório de FRX do Geoanalítica - USP, por meio de técnica de gravimetria, utilizando-se de balança de precisão $0,0001 \mathrm{~g}$, mufla e estufa. As amostras foram colocadas em estufa, sendo retirada a água não estrutural, seguido pela pesagem inicial e colocadas em mufla para aquecimento por uma hora a $1000^{\circ} \mathrm{C}$ para remoção de $\mathrm{H}_{2} \mathrm{O}$ e voláteis estruturais. Por fim, as amostras foram novamente pesadas, sendo obtida a perda ao fogo pela diferença de massa inicial e final. Possíveis erros decorrentes do procedimento dependem da precisão da balança utilizada, sua correta manipulação, e da premissa de que todas as fases voláteis tenham sido liberadas sob as condições de temperatura impostas. Primeiramente, as análises de perda ao fogo foram realizadas em mais de uma etapa, expondo-se as amostras a diferentes períodos maiores de calcinação. Desta maneira, a perda ao fogo foi realizada por duas vezes, e os resultados 
apresentaram melhora após a exposição das amostras por maior tempo (aproximadamente 12 horas) no forno à $1000^{\circ} \mathrm{C}$. Houve incremento de aproximadamente $1 \%$ em massa com tais determinações.

Mesmo após esta etapa, as análises ainda não apresentavam fechamentos idealmente satisfatórios. Após a consulta de estudos que também utilizaram geoquímica de rocha total para litologias similares às encontradas na intrusão Pântano (e.g., Melluso et al., 2008), foi entendido que os elementos $\mathrm{Ba}, \mathrm{Cr}$, Ni, $\mathrm{Sr}$ e $\mathrm{Zr}$ se comportavam como elementos menores nestes sistemas. Por isso, suas concentrações foram transformadas para suas respectivas porcentagens em peso na forma de óxidos. Ao considerar os referidos elementos como menores, os fechamentos das análises foram julgados satisfatórios. Os resultados das análises de rocha total obtidas por FRX encontram-se na Tabela A.I, no Apêndice A.

\subsubsection{ICP-MS}

As análises dos elementos $\mathrm{Ba}, \mathrm{Be}, \mathrm{Ce}, \mathrm{Co}, \mathrm{Cs}$, Dy, Er, Eu, Ga, Gd, Hf, Ho, La, Lu, Nb, Nd, Pr, Rb, Sm, Sn, Sr, Ta, Tb, Th, Tm, U, V, W, Y, Yb e Zr também foram obtidas através do método de ICP-MS (Espectrometria de massas por plasma acoplado indutivamente) no laboratório AcmeLabs, no Canadá. As amostras utilizadas nesse processo são aquelas previamente prensadas e pulverizadas para o processo de fluorescência de raios $X$. Para verificação de precisão e exatidão, para o conjunto de oito análises, foi realizada uma duplicata e utilizou-se os dois materiais de referência internacional STD SO-18 e STD-19 como controle. Os resultados das análises de rocha total obtidas por ICP-MS encontram-se na Tabela A.II, no Apêndice A.

\subsubsection{Microssonda Eletrônica}

As análises quantitativas de minerais foram realizadas no Laboratório de Microssonda Eletrônica do IGc-USP, através de um equipamento JEOL JXA-8600S, provido de cinco espectrômetros de dispersão de comprimento de onda (WDS), cada um com dois cristais analisadores (TAP/STE), (TAP/PET, PET/LiF e LiF/PET). As correções para os efeitos de matriz (absorção e número atômico e fluorescência secundária), bem como conversões para óxidos foram efetuadas automaticamente com o programa PROZA. 
As análises foram feitas em seções obtidas através das seções polidas e dos fragmentos de rocha descritos na Seção 6.1.2. A utilização do fragmento se deu como controle e precaução para tentativa de caracterização da granada, que foi identificada apenas em uma porção muito específica da intrusão. Uma análise em seção polida convencional poderia perder qualidade na hora da quantificação. Esta preocupação se deu também, pelo fato de que era previsto que as análises de LA-ICP-MS fossem feitas nos mesmos cristais em que as análises de ME. Desta maneira, um fragmento de rocha poderia minimizar os efeitos de criação de "cratera" durante a ablação do laser.

Foram analisadas as diferentes populações dos minerais olivina e flogopita. Ao todo foram três dias de análises (utilizadas para caracterização de outras fases minerais da intrusão, que não são o foco da presente dissertação) e as regiões de maior interesse nos cristais selecionados foram divididas entre núcleos e bordas. Regiões intermediárias em cristais de flogopita também foram analisadas quando apresentavam dimensões suficientes para acomodação do spot de 5 um de diâmetro. As análises foram realizadas com um feixe eletrônico de $15 \mathrm{kV}$ de voltagem e aceleração e 20 nA de corrente, sendo o diâmetro do feixe utilizado de 5 um. As rotinas analíticas empregadas foram disponibilizadas pelo laboratório: linhas espectrais, cristais analisadores, padrões e tempos totais de integração e de contagem (pico e background). Os elementos quantificados, o espectrômetro (canal), a radiação característica emitida, o cristal utilizado, a posição do pico $(\mathrm{mm})$, o tempo de leitura do pico e do background, os padrões utilizados e suas respectivas referências encontram-se nas Tabela 6.1a e 6.1b. 
Tabela 6.1a: Condições analíticas para análise de olivina durante as quantificações WDS por microssonda eletrônica.

\begin{tabular}{|l|l|l|l|l|l|l|l|l|l|l|l|}
\hline \multicolumn{10}{|c|}{ Olivina } \\
\hline Elemento $^{1}$ & $\mathrm{Si}$ & $\mathrm{Al}$ & $\mathrm{Fe}$ & $\mathrm{Mn}$ & $\mathrm{Ni}$ & $\mathrm{Ca}$ & $\mathrm{K}$ & $\mathrm{Ti}$ & $\mathrm{Cr}$ & $\mathrm{Mg}$ & $\mathrm{Na}$ \\
\hline Espectro $^{2}$ & $\mathrm{Ka}$ & $\mathrm{Ka}$ & $\mathrm{Ka}$ & $\mathrm{Ka}$ & $\mathrm{Ka}$ & $\mathrm{Ka}$ & $\mathrm{Ka}$ & $\mathrm{Ka}$ & $\mathrm{Ka}$ & $\mathrm{Ka}$ & $\mathrm{Ka}$ \\
\hline Canal $^{3}$ & 1 & 1 & 2 & 2 & 2 & 3 & 3 & 4 & 4 & 5 & 5 \\
\hline Cristal $^{4}$ & $\mathrm{TAP}$ & $\mathrm{TAP}$ & $\mathrm{LIFL}$ & LIFL & LIFL & PETJ & PETJ & LIFL & LIFL & TAPH & TAPH \\
\hline Pico (mm) $^{5}$ & 77,6 & 90,7 & 134,5 & 146,5 & 115,3 & 107,5 & 119,5 & 191,1 & 159,3 & 107,5 & 129,6 \\
\hline Tpico (s) $^{6}$ & 10 & 20 & 10 & 40 & 50 & 20 & 10 & 10 & 10 & 5 & 20 \\
\hline T bcg (s) $^{7}$ & 5 & 10 & 5 & 20 & 25 & 10 & 5 & 5 & 5 & 2,5 & 5 \\
\hline Padrão $^{8}$ & Dio. & An. & Fai. & Fai. & V\#37 & Woll. & Ort. & Rul. & Crt. & B\#8 & Alb. \\
\hline
\end{tabular}

1: Elemento analisado; ${ }^{2}$ : nível do espectro característico; ${ }^{3}$ : Canal (WDS) utilizado; ${ }^{4}$ : cristal aplicado na reflexão da onda dispersada; ${ }^{5}$ : posição em milímetros $(\mathrm{mm})$ do cristal na reflexão; 6 : Tempo $(\mathrm{T})$ de leitura do pico em segundos (s); ${ }^{7}$ : Tempo (T) em segundos (s) de leitura do background (bcg); ${ }^{8}$ : padrões do Smithsonian utilizados: Dio (diopsídio), An (anortita), Fai (faialita), V\#37 (vidro riolítico), Woll (wollastonita), Ort (ortoclásio), Rul. (rutilo), Crt (cromita), B\#8 (basalto), Alb. (albita).

Tabela 6.1b: Condições analíticas para análise de mica durante as quantificações WDS por microssonda eletrônica.

\begin{tabular}{|l|l|l|l|l|l|l|l|l|l|l|l|l|l|}
\hline \multicolumn{10}{|c|}{ Mica } \\
\hline Elemento $^{1}$ & $\mathrm{Si}$ & $\mathrm{Al}$ & $\mathrm{Fe}$ & $\mathrm{Mn}$ & $\mathrm{Zn}$ & $\mathrm{Cl}$ & $\mathrm{K}$ & $\mathrm{Ca}$ & $\mathrm{Ti}$ & $\mathrm{Ba}$ & $\mathrm{F}$ & $\mathrm{Na}$ & $\mathrm{Mg}$ \\
\hline Espectro $^{2}$ & $\mathrm{Ka}$ & $\mathrm{Ka}$ & $\mathrm{Ka}$ & $\mathrm{Ka}$ & $\mathrm{Ka}$ & $\mathrm{Ka}$ & $\mathrm{Ka}$ & $\mathrm{Ka}$ & $\mathrm{Ka}$ & $\mathrm{La}$ & $\mathrm{Ka}$ & $\mathrm{Ka}$ & $\mathrm{Ka}$ \\
\hline Canal $^{3}$ & 1 & 1 & 2 & 2 & 2 & 3 & 3 & 3 & 4 & 4 & 5 & 5 & 5 \\
\hline Cristal $^{4}$ & TAP & TAP & LIFL & LIFL & LIFL & PETJ & PETJ & PETJ & LIFL & LIFL & TAPH & TAPH & TAPH \\
& & & & & & & & & & & & & \\
\hline Pico $^{5}$ & 77,5 & 90,7 & 134 & 146 & 99,7 & 151,2 & 119,6 & 107,5 & 191,2 & 192 & 200,5 & 129,6 & 107 \\
\hline Tpico (s) $^{6}$ & 10 & 15 & 10 & 20 & 30 & 10 & 10 & 10 & 10 & 30 & 10 & 10 & 10 \\
\hline Tbcg (s) $^{7}$ & 5 & 7,5 & 5 & 10 & 15 & 5 & 5 & 5 & 5 & 15 & 5 & 5 & 5 \\
\hline Padrão $^{8}$ & Dio. & An. & Fai. & Fai. & IIm. & Sdl. & Ort. & Woll. & Rul. & Be. & Apt. & Alb. & Dio. \\
\hline
\end{tabular}

1: Elemento analisado; ${ }^{2}$ : nível do espectro característico; ${ }^{3}$ : Canal (WDS) utilizado; 4 : cristal aplicado na reflexão da onda dispersada; ${ }^{5}$ : posição em milímetros $(\mathrm{mm})$ do cristal na reflexão; 6 : Tempo $(\mathrm{T})$ de

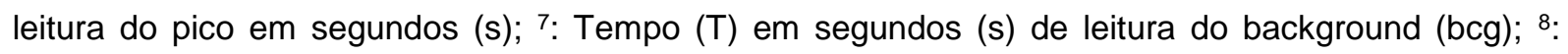
padrões do Smithsonian utilizados: Dio (diopsídio), An (anortita), Fai (faialita), IIm. (ilmenita), Sdl. (sodalita), Ort (ortoclásio), Woll (wollastonita), Rul. (rutilo), Be. (benitoíta), Apt. (fluorapatita), Alb. (albita).

Foram feitas 35 análises de microssonda para olivina, distribuídas entre núcleos e bordas de mega, macro e microcristais de olivina. As análises de monticelita foram feitas em núcleos, bordas e zonas intermediárias, embora a granulometria do 
mineral fosse muito fina (inferior a $1 \mathrm{~mm}$ ). Além das análises feitas para o presente estudo, também foram considerados os resultados analíticos obtidos previamente pelo orientador. Considera-se que os resultados obtidos para a presente dissertação foram satisfatórios, no entanto, optou-se por utilizar todos os dados disponíveis ao grupo de pesquisa, com o intuito de se ampliar a representatividade estatística dos dados. As condições analíticas utilizadas pelos autores citados foram as mesmas que as utilizadas na obtenção dos dados deste trabalho. Os resultados apresentados contam com um total de 171 análises de olivina e monticelita.

Para flogopita, foram efetuadas 49 análises de microssonda, sendo 29 feitas entre núcleos e bordas de macro e microcristais e 20 análises em flogopita poiquilítica em porções distintas da matriz.

A Tabela 6.2 apresenta os quantitativos das análises realizadas para cada mineral e a porção do cristal relacionada. Para as análises de flogopita, considera-se como núcleos as análises em cristais e nas placas poiquilíticas.

Tabela 6.2: Quantitativos de análises de microssonda eletrônica.

\begin{tabular}{|c|c|c|c|}
\hline Mineral & Núcleos & $\begin{array}{c}\text { Zonas } \\
\text { Intermediárias }\end{array}$ & Bordas \\
\hline Olivina & 83 & - & 74 \\
\hline Monticelita & 8 & 3 & 3 \\
\hline Flogopita & 30 & 10 & 9 \\
\hline
\end{tabular}

Os resultados de química mineral são apresentados na forma de porcentagem em peso de óxidos, expressos em proporções catiônicas, fórmulas químicas e estruturais, componentes moleculares e diagramas de variação química. O cálculo das fórmulas estruturais seguiu as recomendações de Deer et al. (1992), sendo os cristais de olivina calculados na base de 4 átomos de oxigênio e classificados a partir dos componentes moleculares forsterita $\left(\mathrm{MgSiO}_{4}\right)$ e faialita $\left(\mathrm{Fe}_{2} \mathrm{SiO}_{4}\right)$. Os cálculos da fórmula estrutural da flogopita foram efetuados de acordo com as recomendações de Brod et al. (2001), utilizando-se 22 átomos de oxigênio. As Tabelas B.I, B.Il e B.III do Apêndice $B$ apresentam os cálculos das fórmulas estruturais dos minerais olivina, monticelita e flgopita, respectivamente. Foram utilizados para o tratamento de dados os programas Petrograph, GCDkit e Excel e o tratamento dos gráficos e diagramas pelo programa Corel Draw. 


\subsubsection{LA ICP-MS}

As análises por laser ablation foram feitas nas mesmas lâminas delgadas e fragmentos de rocha analisados previamente por microssonda eletrônica, procurandose abranger a mesma zona caracterizada para obtenção dos elementos maiores. Estas análises foram realizadas no Laboratório de Química e ICP-AES/MS do NAP GeoAnalítica-USP. Para tal, foi utilizado o ICP-MS da Perkin Elmer/Sciex modelo Elan 6100DRC (quadrupolo) acoplado ao sistema de ablação a laser da New Wave, modelo UP-213. Este sistema de ablação possui laser com cristal Y(Nd)AG, com luz de 213 $\mathrm{nm}$ de amplitude e pulso de 5 ns.

Análise de elementos-traço reflete a possibilidade de determinar a composição de elementos incompatíveis de grande significado na petrologia de magmas derivados do manto (ETR, Nb, Ta, Th, U, etc). Além disso, há uma grande vantagem em identificar zonamentos químicos que podem ser preservados devido aos baixos coeficientes de difusão desses elementos em determinadas fases minerais, como é o caso da olivina, por exemplo (Foley et al., 2011). Além de estimativas de parâmetros físico-químicos como temperatura e pressão, as quantificações de elemento-traços obtidas por Laser Ablation permitem estimar o controle de processos como taxas de fusão parcial, adição de fluídos metassomáticos sobre a composição do manto e calcular a partição dos elementos-traço entre fases minerais (Norman et al., 1998, Bianchini et al., 2007, Eggins et al., 1998).

Para as amostras da intrusão Pântano estudadas no presente trabalho, foram analisados os minerais olivina e flogopita. A rotina analítica utilizada foi descrita em Andrade et al. (2014). Os padrões de referência para a calibração destas fases minerais foram o SRM-612 (NIST, vidro silicático) e BHVO-2 (USGS, basalto). Antes e depois de cada conjunto de cristais analisados, o padrão certificado SRM-610 (NIST, vidro silicático) era analisado como controle de qualidade analítico. Para a redução dos dados, foi utilizado o software Glitter, desenvolvido pelo GEMOC e comercializado pela Access MacQuarie Ltd. (Jackson et al., 2001).

Foi estabelecido como padrão de qualidade para utilização das análises, que os valores obtidos estivessem três vezes acima do valor do limite de quantificação (LQ) do equipamento e que estivessem também, acima do valor de $2 \sigma$. Em geral, as análises apresentaram-se dentro dos padrões de qualidade adotados, à exceção de 
alguns elementos como $\mathrm{U}$, Th e $\mathrm{Pb}$. As análises obtidas por LA-ICP-MS encontramse nas Tabelas C.I a C.XXV do Apêndice C. A Tabela 6.3 abaixo apresenta as condições experimentais do laser para as análises de olivina e flogopita.

Tabela 6.3: Condições experimentais do laser para obtenção das análises de olivina e flogopita.

\begin{tabular}{c|c|c}
\hline Condições & Olivina & Flogopita \\
\hline Potência $(\%)$ & 80 & 75 \\
\hline Frequência (Hz) & 12 & 12 \\
\hline Densidade (J/cm²) & 0,73 & 0,43 \\
\hline Diâmetro spot (um) & 40 & 40 \\
\hline \multirow{2}{*}{ Dwell time (s) } & 8,3 & 16,7 \\
& (Mg, Si e Ni) & (todos os elementos) \\
\hline Branco (s) & (Demais elementos) & 60 \\
\hline
\end{tabular}

Como padrões internos, foram utilizados teores de Si obtidos na microssonda eletrônica para normalização das análises de olivina. Em relação à normalização das análises de flogopita, houve questionamento sobre qual elemento usar para quantificação, se o ideal seria $\mathrm{Si}$ ou $\mathrm{Mg}$. Tal questionamento se deu devido ao fracionamento de cada elemento devido ao seu comportamento geoquímico, sendo tal fracionamento, bem como suas implicações, aprofundados na seção 6.2.6.1 abaixo.

\subsubsection{Comparativo entre a utilização de Si e Mg como padrão interno para análise em flogopita}

Sabe-se que os elementos químicos exibem comportamentos diferentes durante uma análise de laser ablation, o que significa que estes elementos podem fracionar mais ou menos um em relação ao outro, resultando em intensidades de sinal que não são necessariamente representativas do material analisado. Os índices de fracionamento (IF), inicialmente caracterizados por Fryer et al. (1995) permitiram a medição comparativa entre os fracionamentos que ocorrem em relação ao elemento Ca. Este índice demonstrou que a magnitude do fracionamento segue a classificação geoquímica de Goldschmidt (Wedepohl, 1991), ou seja, litófilos, siderófilos e calcófilos 
possuem índices de fracionamento intrínseco similares. Longerich et al. (1996) recomendaram, por isso, a escolha de um padrão interno para cada grupo.

Nos últimos anos, foi demonstrado que os IFs correlacionam fortemente com a condensação da temperatura (Jackson, 2001), levando a conclusão de que o fracionamento ocorre, em partes, devido a dois diferentes processos controlados pela volatilidade dos elementos: (1) transporte diferencial de nanopartículas condensadas em fase vapor e micropartículas em gotículas líquidas e (2) volatilização diferencial de elementos durante a vaporização incompleta de micropartículas no ICP (Kuhn \& Günther, 2004). Os valores relativos do IF são independentes da matriz e das condições de operação do laser, no entanto, o grau absoluto ao qual o fracionamento ocorre durante uma ablação é altamente dependente de numerosos fatores incluindo as condições de operação (tamanho do spot, comprimento de onda, energia e largura do pulso) e da matriz da amostra (Günther et al., 1999).

A discussão a respeito dos índices de fracionamento dos elementos químicos deve ser considerada, pois implica em 2 fatores extremamente importantes:

1) Se um elemento possui um IF diferente do elemento padrão interno utilizado, a proporção medida será incorreta e resultados imprecisos poderão ser esperados, a menos que o fracionamento seja o mesmo para amostra e padrão utilizado;

2) Se um elemento possui um IF semelhante ao elemento padrão interno utilizado, resultados precisos podem ser esperados, independentemente de matrizes, condições de ablação e tempos de integração de sinal.

A magnitude do erro associado ao fracionamento dependerá fortemente do tipo do laser utilizado, condições de ablação e a magnitude da diferença de matriz entre amostra e padrão utilizado. Segundo Jackson (2001), os elementos alcalinos terrosos, REEs e actinídeos possuem IFs muito similares aos dos elementos $\mathrm{Mg}, \mathrm{Al}$ e $\mathrm{Ca}$, que são, portanto, os mais apropriados a serem utilizados como padrões internos. Ainda segundo o autor, o Si possui um comportamento de fracionamento significativamente diferente em relação a esses elementos e é o melhor padrão interno a ser utilizado, apenas, para calibração de metais de transição.

Pelos motivos mencionados acima, optou-se por fazer um comparativo entre 0 uso do elemento Mg e do elemento Si para retirada dos dados de flogopita utilizandose o programa Glitter. Segundo Jackson (2001) quando os elementos analisados compartilham do mesmo IF que o padrão interno utilizado, dados com uma maior 
acurácia podem ser obtidos, mesmo que haja grandes diferenças entre as matrizes da amostra e do padrão.

Observa-se que utilizando o Si como padrão interno, as concentrações obtidas tornam-se, em geral, menores do que aquelas recomendadas pelo GeoRem. Além disso, os valores de $2 \sigma$ (desvio padrão) apresentam-se mais elevados quando comparados aos valores obtidos utilizando-se o $\mathrm{Mg}$ como padrão interno. As concentrações obtidas para o padrão de referência primário BHVO não demonstraram grandes diferenças em relação a utilização de Si ou Mg como padrão interno para retirada dos dados. Já os padrões NIST 612 e 610 indicaram uma diferença significativa, apresentando concentrações mais próximas àquelas recomendadas pela GeoRem.

Observa-se a partir dos dados de flogopita da intrusão Pântano, que o Si é, realmente, o melhor padrão interno a ser utilizado para calibração de metais de transição, no entanto, para os demais elementos, o Mg é a melhor opção, apresentando uma diferença mais relevante principalmente para os REEs. Vale mencionar que o grupo de pesquisa já obteve dados insatisfatórios utilizando o Si como padrão interno, obtendo análises de elementos-traço para flogopitas que apresentaram concentrações muito baixas e que não puderam ser utilizadas, pois não apresentaram os critérios de qualidade (citados na seção 6.2.6) desejáveis. Desta maneira, optou-se pela utilização do Mg como padrão na obtenção das concentrações de elementos-traço para flogopita. Embora a comunidade científica utilize, em geral, o Si como padrão interno, o presente trabalho visa contribuir para obtenção de dados analíticos de LA-ICP-MS, mencionando sobre a alternativa da utilização do Mg.

\section{Resultados}

\subsection{Petrografia}

Este item destina-se à descrição das feições petrográficas encontradas nas rochas constituintes da intrusão Pântano. Para o interior do corpo intrusivo, foram descritas as amostras de 7 diferentes localidades e 1 localidade correspondente à rocha encaixante, (Mapa de Pontos de Amostragem da Intrusão, Figura 2.2). 


\subsubsection{Descrição Macroscópica}

As amostras macroscópicas apresentam coloração cinza escura, constituindo uma rocha ultramáfica, maciça (Figura 7.1a), localmente venulada e de matriz inequigranular fina a muito fina. A rocha possui textura pseudoporfirítica, caracterizada pela presença de cristais de diferentes dimensões (micrométricos a centimétricos) dispersos em uma massa fundamental, também inequigranular, mas com granulação predominante fina a muito fina. O termo "pseudoporfirítico" é comumente empregado em rochas de afinidade kimberlítica (Mitchell, 1986, 1995) devido ao fato de que a maioria dos mega e macrocristais não são representativos de cristais cognatos, mas de xenocristais e/ou pseudomorfos completamente substituídos. Os microcristais e a matriz perfazem de 70 a $80 \%$ da rocha, com algumas variações nessa porcentagem a depender da amostra.

Os mega e macrocristais mantélicos (10 - 25\% em volume) são, em sua maior parte, de olivina (Figura 7.1b); macrocristais de flogopita são encontrados subordinadamente, e os de granada são ainda mais escassos. Os cristais de olivina apresentam forma anédrica a subédrica e coloração verde escura a preta, muitos deles parcialmente ou totalmente serpentinizados. Os megacristais de olivina variam de 1,0 a $1,5 \mathrm{~cm}$ e os macrocristais entre 0,5 e 0,9 cm. Os macrocristais de flogopita ( 2\% em volume) apresentam coloração variável de bege a marrom e forma subédrica a euédrica. Alguns cristais são pseudomorfos, que já foram parcialmente (das bordas para o centro) ou completamente substituídos por flogopita microcristalina. Estes cristais possuem até $0,5 \mathrm{~cm}$, sendo bem mais escassos e menores comparativamente aos macrocristais de olivina. Os macrocristais de granada (coloração vermelha a vinho, anédricos) ocorrem em baixa concentração (traços) e invariavelmente apresentam borda kelifítica (Figura 7.1c). Há presença de pseudomorfos completamente preenchidos por esse agregado kelifítico, que aparentemente foram granadas no passado. Com o auxílio de microscópio eletrônico de varredura (MEV), pôde-se comprovar a presença de granada reliquiar em pseudomorfo.

Xenólitos crustais (cerca de $3 \%$ da rocha, Figura 7.1d) apresentam-se como fragmentos arredondados de 0,5 a $2 \mathrm{~cm}$, de coloração rósea e branca, com borda de reação de coloração bege ou marrom. Alguns xenólitos não apresentam extensas bordas de reação e suas proporções modais não são distinguíveis a olho nu. 
Localmente, as amostras apresentam aproximadamente 5\% de venulações de espessura milimétrica, com colorações brancas e pretas, sendo as escuras predominantemente constituídas por serpentina e as claras possivelmente por carbonatos. Em alguns pontos estas venulações apresentam-se mais concentradas. Macroscopicamente, não são observadas mudanças de tipos petrográficos devido a matriz escura das rochas, é possível distinguir apenas, variações heterogêneas em relação a concentração de xenólitos e megacristais. 


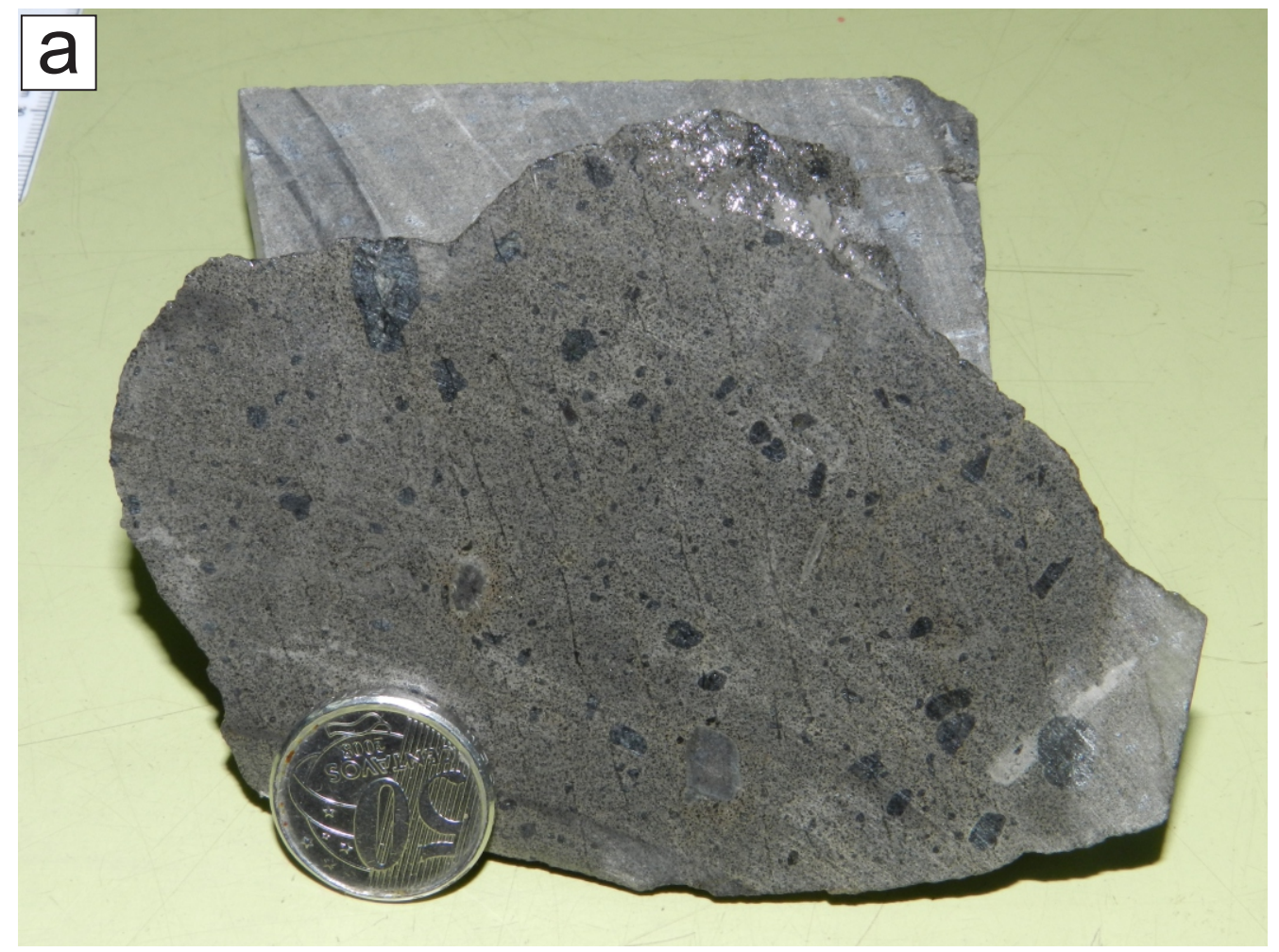

Figura 7.1a: aspectos gerais da rocha: maciça, com textura pseudoporfirítica, com mega e macrocristais dispersos na matriz.

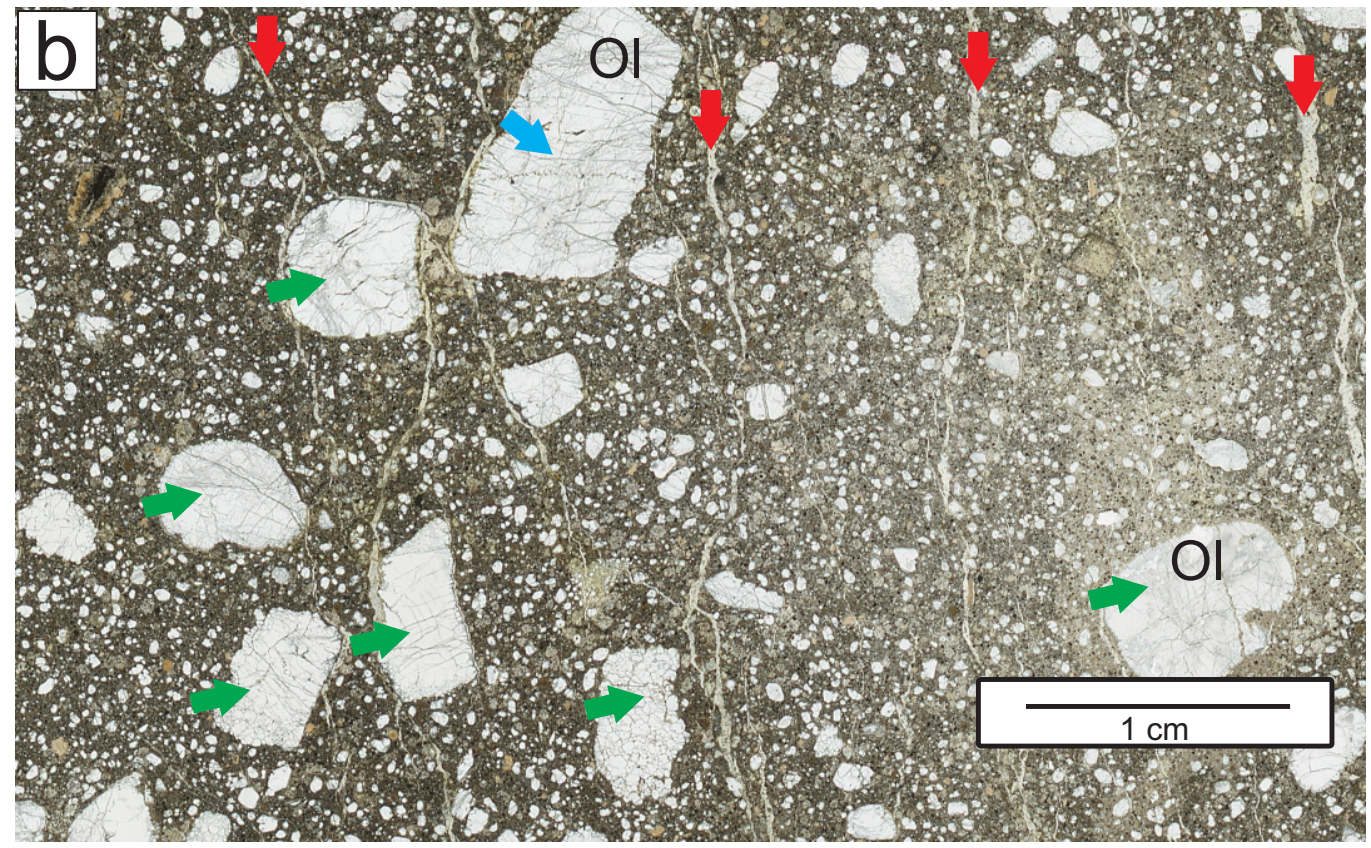

Figura 7.1b: Lâmina petrográfica digitalizada, aonde é possível observar as venulações de carbonato e serpentina (setas vermelhas), megacristais (seta azul) e macrocristais (setas verdes) de olivina (Ol), bem como microcristais em uma matriz inequigranular. 


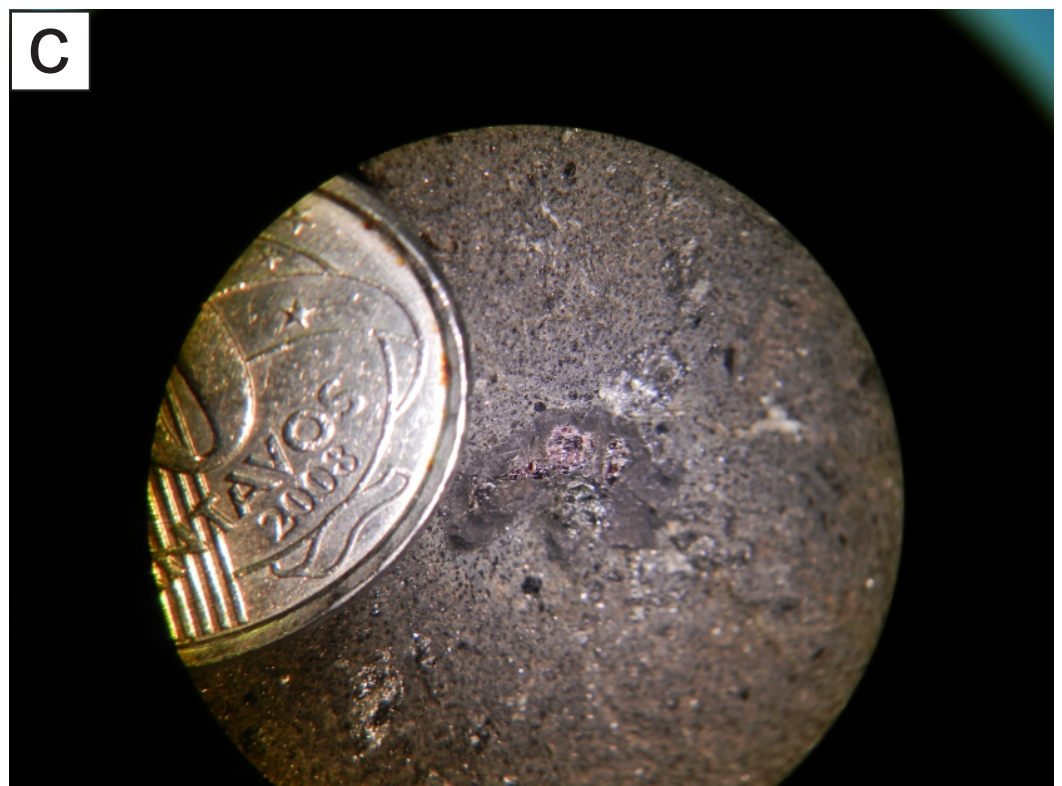

Figura 7.1c: Detalhe de macrocristal de granada com borda kelifítica descrito para amostra PNT-3 (monticelita kimberlito).

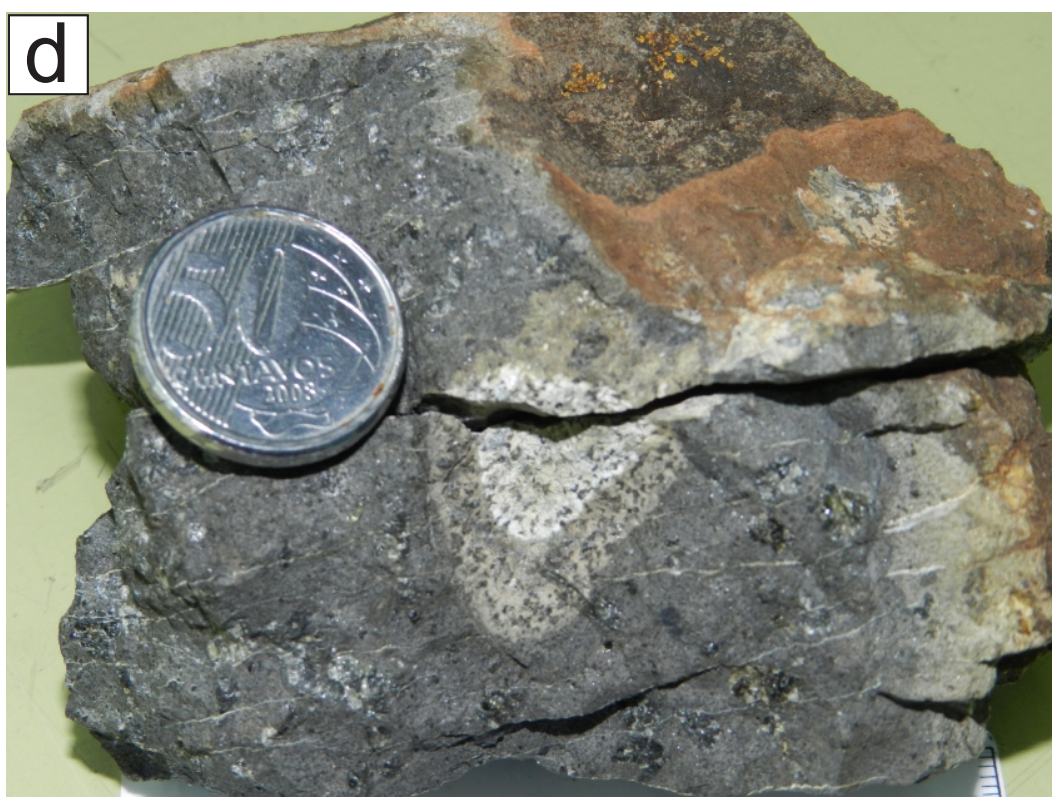

Figura 7.d: Xenólito crustal arredondado de coloração rósea e branca. Este tipo de xenólito pode ser observado em todos os tipos petrográficos descritos para intrusão. Os xenólitos podem ter ou não bordas de reação de colorações bege ou marrom. 


\subsubsection{Descrição Microscópica}

Nas descrições microscópicas, pôde-se observar heterogeneidades bastante demarcadas, relacionadas eminentemente a diferentes proporções de matriz, mega, macro e microcristais de olivina, monticelita, perovskita, flogopita, espinélio e magnetita, além das evidências texturais de desequilíbrio, que são descritas para porções específicas da rocha. A partir das diferenças descritas para cada região da intrusão, puderam ser definidos três diferentes tipos petrográficos. Nota-se também diferenças na concentração de venulações e xenólitos e, localmente, puderam ser identificados pequenos enclaves e uma matriz amarelada, caracterizada por um material isotrópico, interpretado como vítreo. A mineralogia principal é constituída por distintas populações de olivina, monticelita (cristais milimétricos a submilimétricos contidos na matriz), perovskita, flogopita e espinélios (cromita e magnetita). As fases acessórias podem ser caracterizadas principalmente por diopsídio, apatita, espurrita, barita e granada.

Apesar das heterogeneidades, pôde-se distinguir, em constituições gerais e excluindo-se os xenólitos crustais, os intervalos das proporções dos minerais da intrusão Pântano, quais sejam:

- 50 - 60\% olivina (5 - 7\% megacristais, 10 - 20\% macrocristais e 30 - $40 \%$ matriz podendo aparecer na forma de monticelita, dado que pôde ser comprovado por imagens de microscopia eletrônica de varredura);

- 10 - 25\% flogopita (na forma de macro e microcristais, na matriz com textura poiquilítica ou no preenchimento de pseudomorfos);

- 10 - 20\% perovskita (como microcristais e na matriz);

- 5 - 10\% espinélios (como microcristais e na matriz);

- 2 - 3\% serpentina (somente nas venulações);

- 1 - $2 \%$ de carbonato (somente nas venulações);

- $1-2 \%$ de pseudomorfos de leucita (como microcristais, dispersos na matriz em tipo petrográfico específico);

- Traços de apatita;

- Traços de diopsídio (na matriz apenas) e granada (como macrocristais).

Para uma melhor quantificação de cada população de olivina, foram realizadas análises de imagem para 29 lâminas da intrusão, conforme procedimento descrito no item 6.2.1, que descreve o procedimento de obtenção das mesmas. Foi feita a média 
das porcentagens encontradas em cada análise de imagem, conforme apresentado na Tabela 7.1.

Tabela 7.1: Médias das porcentagens de matriz, macrocristais, megacristais, pseudomorfos, xenólitos e vênulas encontradas para os diferentes pontos amostrados na intrusão Pântano.

\begin{tabular}{ccccccc}
\hline Ponto & \% Matriz & \% Microcristais & $\begin{array}{c}\text { \% Macrocristais/ } \\
\text { Megacristais }\end{array}$ & \% Pseudomorfos & \% Xenólitos & \% Vênulas \\
\hline PNT 3 & 72 & 18 & 6,3 & 0,4 & 2,6 & 0 \\
\hline PNT 4 & 83 & 10,5 & 6,5 & 0 & 0 & 0 \\
\hline PNT 5 & 82 & 11 & 4,8 & 0 & 1,6 & 0,6 \\
\hline PNT 6 & 61,5 & 27,4 & 5,7 & 7,1 & 0 & 0 \\
\hline PNT 7 & 68 & 22,2 & 6,9 & 1,4 & 0 & 2,3 \\
\hline PNT 8 & 78 & 13,1 & 6,6 & 2 & 0 & 0,6 \\
\hline PNT 9 & 62 & 26,4 & & & 0 & 3 \\
\hline
\end{tabular}

Nas seções a seguir, são detalhadas as descrições petrográficas para as principais fases minerais que são descritas na presente dissertação.

\subsubsection{Olivina}

Os cristais de olivina apresentam-se incolores, com alto relevo e alta birrefringência e estão subdividas em populações de megacristais, macrocristais e microcristais que variam de euédricos a anédricos. Além dos cristais facilmente reconhecíveis de olivina, também é possível distinguir a monticelita (Figura 7.2a), que ocorre disseminada em pequenos cristais arredondados $(0,01$ e 0,05 $\mathrm{mm})$ na matriz. Alguns cristais de olivina encontram-se recristalizados (neoblastos), conforme pode ser observado na Figura 7.2b, outros cristais parcialmente ou completamente substituídos por serpentina, principalmente quando se encontram em bordas de reação com xenólitos (Figura 7.2c). Alguns cristais apresentam evidências de deformação, como extinção ondulante e alto grau de faturamento, além de bordas serrilhadas (Figura 7.2d). A Figura 7.2e apresenta a variação na dimensão dos tamanhos dos microcristais dispersos na matriz. Em muitos casos, é possível notar que os microcristais se acumulam em bordas de cristais maiores, formando agregados em macrocristais (Figura 7.2f). Embora haja cristais sem zonamento (Figura 7.2g), o zonamento dos cristais de olivina é proeminente, característica que pode ser observada em luz polarizada analisada no microscópio ótico, mas principalmente, com o auxílio de MEV. 
A partir das fotomicrografias obtidas por MEV, puderam ser identificados dois principais tipos de zonamento para as populações de olivina:

- Normal: tons de cinza mais escuros no núcleo dos cristais e tons de cinza mais claros nas bordas, sendo estas mais ricas em Fe (Figura 7.2h);

- Reverso: tons de cinza mais escuros nas bordas dos cristais e tons mais claros nos núcleos, sendo estes mais ricos em Mg (Figura 7.2i);

A morfologia dos zonamentos apresenta-se de maneira muito variável: por vezes há apenas uma fina borda mais clara (cristal majoritariamente escuro), para outros cristais, a porção escura abrange apenas uma porção central restrita. Os zonamentos são, em geral, irregulares e raramente acompanham a forma do cristal. O contato entre a zona mais escura caracteriza em sua maioria zonamentos abruptos do tipo step, observado principalmente para os macrocristais. Em alguns cristais, é possível notar que há uma gradação entre as diferentes zonas de núcleo e borda, sugerindo um tempo maior de estabilização entre os horizontes cristalinos, já outros microcristais apresentam uma zona intermediária, caracterizando uma zona de coloração mais clara entre núcleo e borda (Figura 7.2j).

Os cristais de olivina apresentam algumas feições de desequilíbrio, evidenciadas pelas bordas dos macro e microcristais, que em determinadas localidades da intrusão, apresentam corrosão, terminações arredondadas/serrilhadas e embayment. Alguns cristais apresentam inclusões de minerais observados na matriz, como perovskita e espinélios. As inclusões minerais milimétricas são observadas principalmente nas bordas de cristais que se apresentam bastante corroídos.

A partir da Tabela 7.1 apresentada na seção anterior, observa-se que a população de microcristais de olivina varia entre 10,5 a $27,4 \%$ e a de macro e megacristais de olivina entre 4,8 a 7,1\%. Ressalta-se que as referidas porcentagens são estimadas, uma vez que são muitas as heterogeneidades registradas para as rochas da intrusão, dificultando uma precisão assertiva da quantificação de cada população caracterizada.

A monticelita é incolor e possui baixa birrefringência, ocorrendo como microcristais da matriz. São encontrados grãos com dimensões entre 0,02 e 0,04mm, sendo possível fazer sua distinção através de microssonda eletrônica. Somente através desta, é possível notar que há cristais anédricos, que predominam sobre a olivina na matriz. Em algumas porções da rocha, nota-se que a monticelita predomina 
sobre os cristais de olivina e pode estar também sendo substituída por diopsídio (Figura 7.2k). Os microcristais de monticelita também podem apresentar inclusões de apatita (Figura 7.2l) Através da microssonda, é possível distinguir que alguns cristais também possuem zonamentos, caracterizados por núcleos mais claros e bordas levemente mais escuras. 

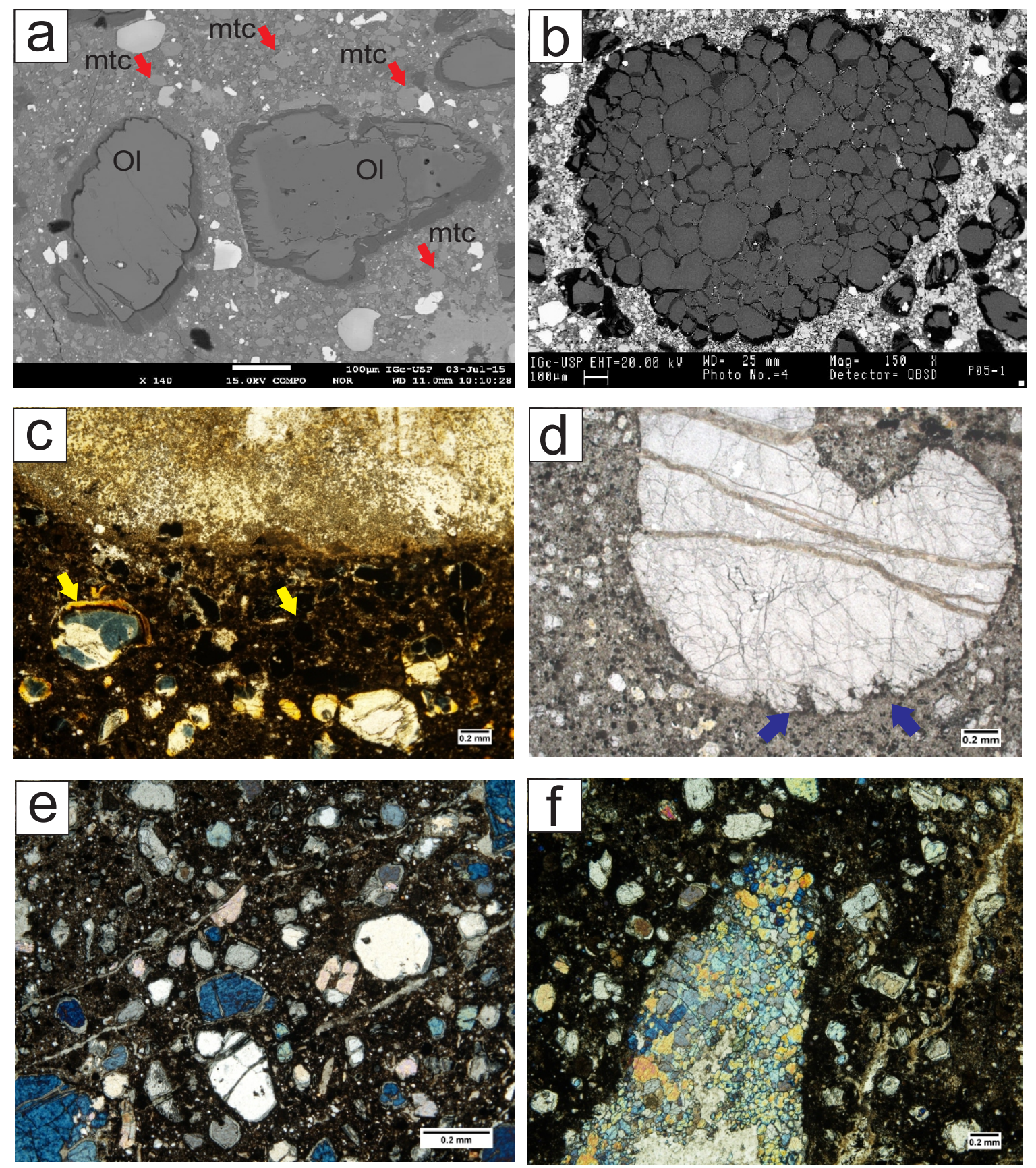

Figura 7.2: a) cristais de monticelita (setas vermelhas) distinguíveis com o auxílio de MEV. b) cristais de olivina recristalizados formando neoblasto; c) microcristais de olivina serpentinizados (setas vermelhas) ao redor de xenólito crustal; d) macrocristal de olivina com alto grau de fraturamento e bordas serrilhadas (setas azuis); e) microcristais de olivina de tamanhos variados; f) microcristais de olivina formando agregados em macrocristal. As fotomicrografias $\mathrm{c}$ e $\mathrm{d}$ foram tiradas com polarizadores em paralelo e as fotomicrografias e e f, com polarizadores cruzados. 

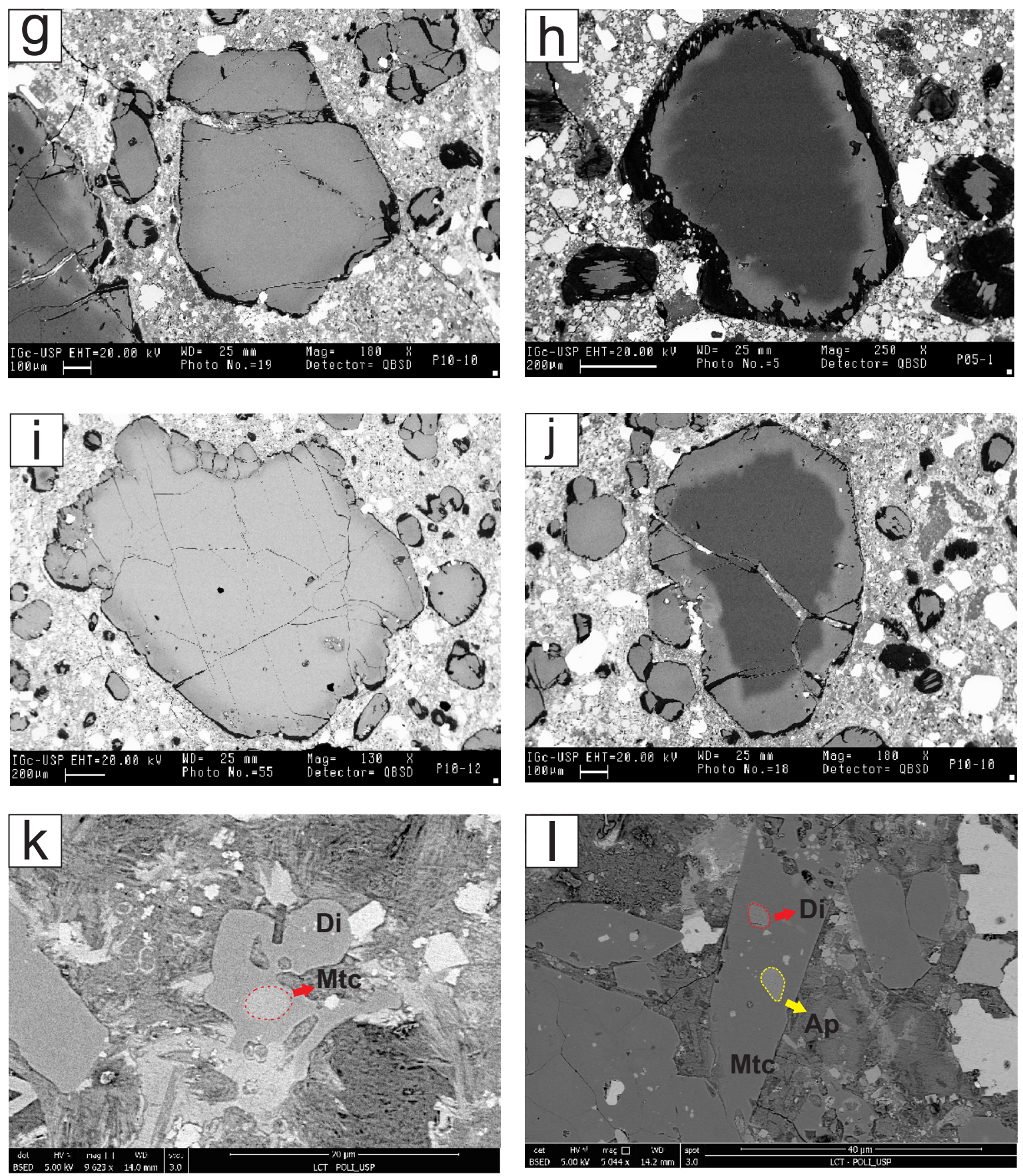

Figura 7.2: cristais de olivina g) sem zonamento; h) com zonamento normal, apresentando núcleos mais escuros ricos em Fe; i) com zonamento reverso, apresentando núcleos mais claros, mais ricos em Mg; j) com zonamento intermediário caracterizado por uma coloração clara entre núcleo e borda; k) cristal de monticelita sendo substituído por diopsídio; I) cristal de monticelita com inclusões de diopsídio e apatita. Fotomicrografias obtidas com o auxílio de MEV. 


\subsubsection{Flogopita}

Os cristais de flogopita caracterizam-se pela coloração bege - creme, alta birrefringência, extinção mosqueada e clivagem em uma direção. A flogopita aparece sob quatro principais formas:

- Macro e microcristais subédricos a euédricos (Figuras 7.3a e 7.3b, respectivamente);

- Constituintes da matriz formando textura poiquilítica intersticial (Figura 7.3c);

- Microcristais de granulação fina no interior de diversos pseudomorfos, substituindo cristais reliquiares (Figura 7.3d) e;

- Em sua forma totalmente alterada preenchendo pseudomorfos, em tons de bege/pastéis, substituindo cristais de uma possível leucita (descriminada a partir das descrições de Danni e Scartezini, 1990) conforme ilustrado na Figura 7.3e, podendo também substituir outros psedomorfos de fases minerais não estabilizadas no momento da cristalização (Figura 7.3f).

Os macro e microcristais são euédricos a subédricos, com hábito lamelar. A flogopita poiquilítica apresenta-se como "placas" dispersas na matriz, com alta birrefringência e constituem um tipo específico observado na intrusão, que foi considerado como resultado de uma região que sofreu pouca influência de contaminação crustal. Alguns cristais apresentam muitas inclusões, principalmente de minerais opacos e rútilo (Figura $7.3 \mathrm{~g}$ ) e feições indicativas de algum tpo de deformação (Figura 7.3h). As feições de deformação são caracterizadas por ondulações, faturamento e, por vezes, extinção ondulante, conforme foi observado também para alguns cristais de olivina.

Os zonamentos nos cristais de flogopita ocorrem apenas nos macro e microcristais, embora alguns microcristais não apresentem nenhum tipo de zonamento (Figura 7.3i). Quando presentes, os zonamentos podem ser normais, abruptos (tipo step) ou complexos, já que para alguns cristais é possível notar diversos horizontes, sem um padrão específico (Figura 7.3j). Os zonamentos normais caracterizam-se por possuir centro de coloração escura e bordas mais claras. Poucos cristais apresentam zonamentos reversos em que o centro possui coloração mais clara em relação às bordas.

O zonamento mais comum observado para os cristais de flogopita é descrito por um centro de coloração marrom mais escura e borda mais clara, que pôde ser observado na microscopia ótica (Figura 7.3b). Este zonamento, em geral, acompanha 
a morfologia do cristal. Há também o zonamento irregular, entre porções claras e escuras aleatórias, não sendo observado padrão ou acompanhamento com a forma do cristal. A flogopita poiquilítica não apresenta nenhum tipo de zonamento.

Para as flogopitas que preenchem os pseudomorfos e os cristais de pseudoleucita, foi possível a caracterização apenas a partir de EDS, uma vez que estas apresentam-se muito alteradas, não sendo observáveis a alta birrefringência ou extinção característica no microscópio ótico. 

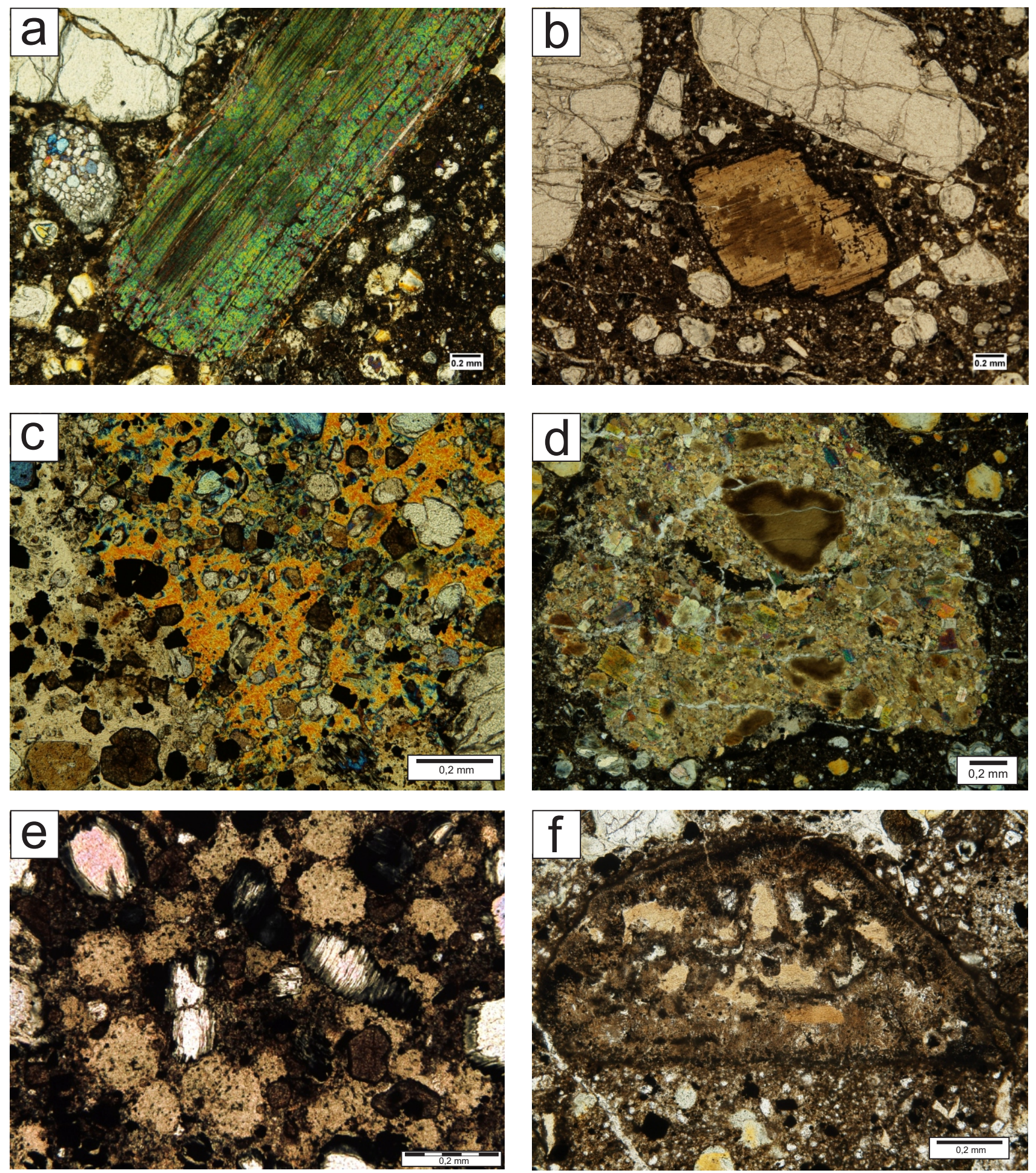

Figura 7.3: a) macrocristal de flogopita (polarizadores cruzados); b) microcristal zonado de flogopita (polarizadores paralelos); c) flogopita poiquilítica da matriz (polarizadores cruzados); d) microcristais de flogopita de granulação fina no interior de pseudomorfo (polarizadores cruzados); e) flogopita totalmente alterada substituindo possíveis pseudomorfos de leucita (descrita na intrusão Pântano por Danni e Scartezini, 1990); f) flogopita substituindo pseudomorfo de uma fase mineral possivelmente não estabilizada no momento da cristalização. Fotomicrografias e e f tiradas com polarizadores paralelos. 

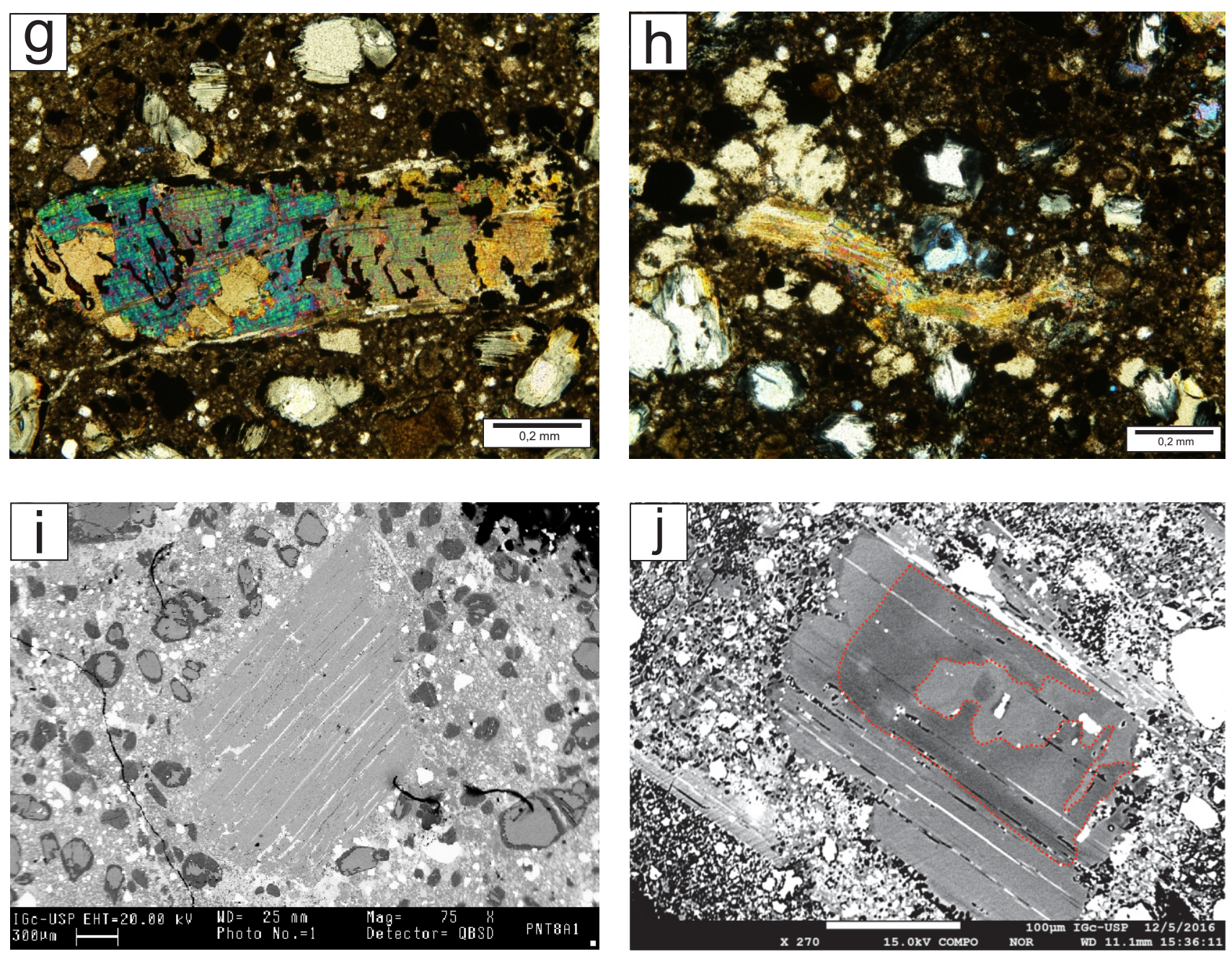

Figura 7.3: g) microcristal de flogopita com inclusões de minerais opacos e rútilo; h) microcristal de flogopita que apresenta indício de que houve algum tipo de deformação. Fotomicrografias obtidas com polarizadores cruzados; i) microcristal de flogopita sem zonamento; j) microcristal de flogopita zonado, que não demonstra padrão específico entre núcleos e bordas. Fotomicrografias obtidas com o auxílio de microssonda eletrônica. 


\subsubsection{Perovskita e Espinélio}

Os cristais de perovskita apresentam coloração marrom e constituem microcristais anédricos a subédricos arredondados dispersos na matriz, conforme pode ser observado na Figura 7.4a. A dimensão desses cristais é uma particularidade das perovskitas da intrusão Pântano, podendo chegar a até $0,3 \mathrm{~cm}$. Muitas dessas perovskitas apresentam zonamento, variando em tons de marrom claro a escuro, tons alaranjados nos horizontes centrais e intermediários, com alguns cristais apresentando bordas mais escuras (coloração marrom escura/esverdeada). As perovskitas aparecem muitas vezes ao redor de micro e macrocristais de olivina formando textura do tipo "necklace", sendo provavelmente posteriores à população de olivina as quais bordeja (Figura 7.4b).

Nota-se que os zonamentos dos cristais não necessariamente acompanham a forma dos mesmos, tratando-se de zonamentos em geral abruptos, bem demarcados, do tipo step, ou zonamentos oscilatórios (Figura 7.4c). Os zonamentos da perovskita tornam-se muito visíveis com o auxílio de MEV, aonde nota-se, em geral, diversos zonamentos em forma de losangos concêntricos, que não acompanham o formato dos cristais. Alguns cristais apresentam uma geminação complexa em forma de ampulheta.

Cristais menores de perovskita podem ser encontrados como inclusões em macrocristais de olivina e, em alguns casos, nota-se espinélios formando necklaces ao redor de microcristais de perovskita. Em alguns destes cristais, é possível observar inclusões de minerais opacos, principalmente nas bordas.

Os minerais opacos foram descritos por Meyer et al. (1991) e Azzone (2002) como espinélios de composições variáveis correspondentes entre cromita e titanomagnetita. Tais minerais opacos variam de anédricos a euédricos, nas dimensões de 0,1 a 0,3 mm na matriz, podendo aparecer também como inclusões nos cristais de perovskita ou de flogopita em dimensões inferiores a $0,1 \mathrm{~mm}$. Com o auxílio de microssonda eletrônica, nota-se que os microcristais de espinélio também podem possuir zonamentos irregulares entre núcleos e bordas, sendo observados dois ou mais horizontes (Figura 7.4d). 

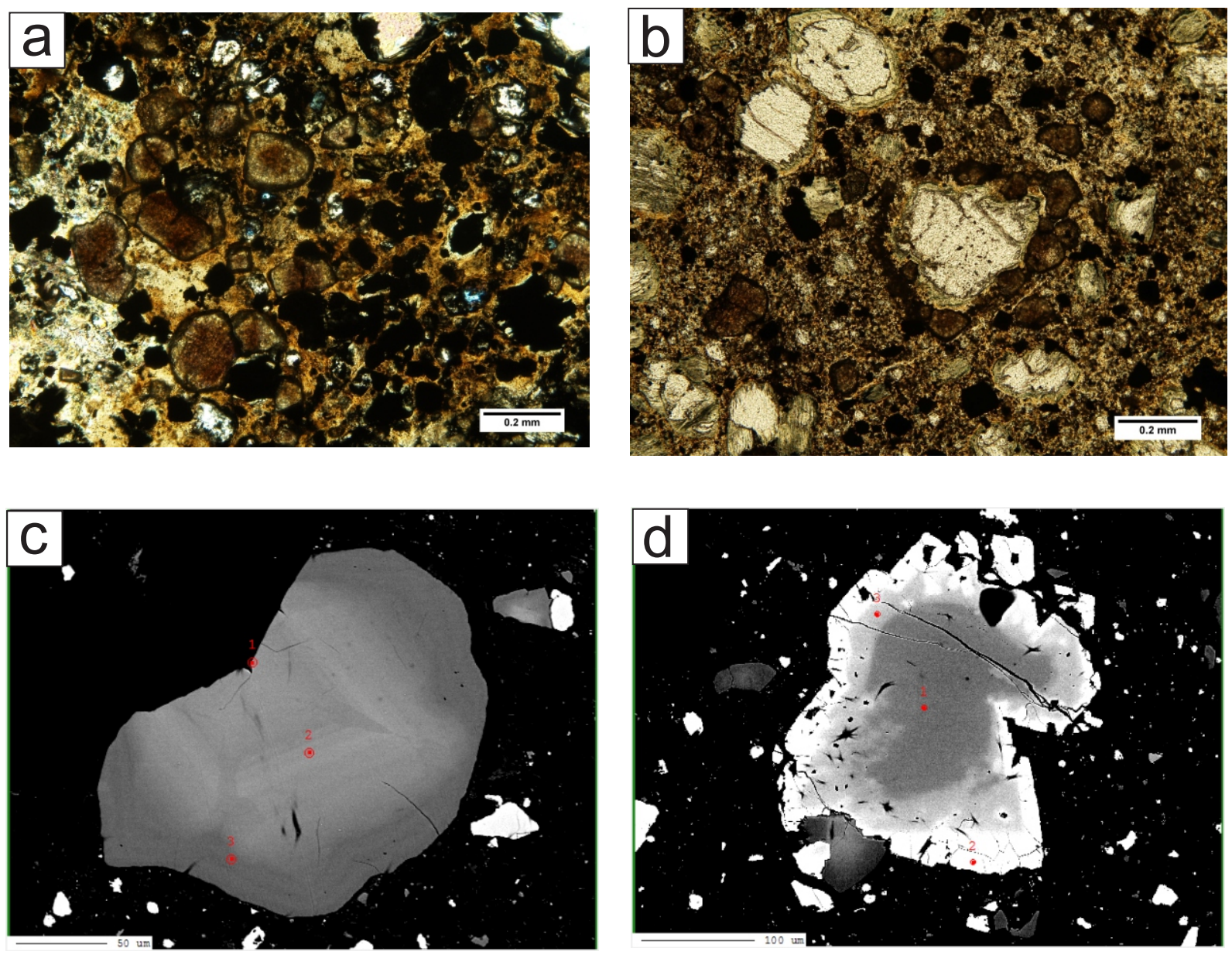

Figura 7.4: a) microcristais de perovskita zonados e microcristais de espinélio na matriz das rochas do tipo petrográfico com flogopita poiquilítica; b) perovskitas ao redor de microcristais de olivina formando textura do tipo necklace; Fotomicrografias a e b obtidas com polarizadores paralelos; c) perovskita com zonamento irregular oscilatório; d) microcristal de espinélio com zonamentos irregulares entre núcleos e bordas, sendo observados três horizontes. Fotomicrografias $\mathrm{c}$ e d obtidas com o auxílio de microssonda eletrônica. 
Os traços de diopsídio são observados apenas como microcristais euédricos (prismáticos) de aproximadamente $0,1 \mathrm{~mm}$, que se apresentam ou dispersos na matriz ou formando "trilhas" ou bordas ao redor dos enclaves (Figura 7.5a) e xenólitos crustais (Figura 7.5b). Esses cristais são incolores, possuem alto relevo e, em geral, alta birrefringência. Estão concentrados apenas em um tipo petrográfico específico da intrusão, que foi considerado o mais contaminado por material crustal. Com o auxílio de MEV e WDS, foi possível identificar a associação entre o diopsídio e a monticelita em um cristal de diopsídio que apresenta composição de monticelita em seu núcleo (conforme observado nas figuras 7.2 da seção anterior), indicando que a mesma pode ser modificada no caso de uma adição de sílica no sistema.

A mineralogia dos xenólitos crustais (Figura 7.6a) é constituída de quartzo, espurrita (composição ideal $\mathrm{Ca}_{5}\left(\mathrm{SiO}_{4}\right)_{2}\left(\mathrm{CO}_{3}\right)$, identificada qualitativamente por $\mathrm{MEV}$ ) e barita, sendo encontrados macro e microcristais de olivina completamente ou parcialmente serpentinizados no entorno destes. Possivelmente, a espurrita é formada por uma reação metassomática entre os fragmentos quartzíticos da encaixante e o magma kimberlítico rico em $\mathrm{Ca}$. Ocorrências deste mineral em rochas de afinidade kimberlítica com contaminação crustal não são comuns, porém, são bem documentadas as ocorrências de espurrita em hornfels, skarns e rochas cálciosilicáticas (Reverdatto, 1970, Zhang et al., 2013) devido a metamorfismo de contato. Pode-se observar a espurrita no interior de um xenólito quartzítico na Figura 7.6b.

Além dos xenólitos, há também agregados anédricos e euédricos arredondados variáveis nas dimensões de 1 a $10 \mathrm{~mm}$, sendo a maioria deles formados por cristais euédricos de flogopita, sugestivos de contexto reacional. Outros pseudomorfos aparecem substituídos por mineralogia não identificável devido a alteração ou por estarem substituídos por minerais opacos. Possivelmente, tais pseudomorfos seriam representativos de xenólitos e/ou xenocristais em desequilíbrio com o líquido de afinidade kimberlítica. 
Uma das rochas encaixantes da intrusão Pântano é um quartzito já bastante alterado. Nas lâminas delgadas deste quartzito pode-se observar que os cristais de quartzo encontram-se parcialmente ou totalmente recristalizados (Figura 7.7a), sendo este composto de aproximadamente $95 \%$ de quartzo, $3 \%$ de feldspato e $2 \%$ de minerais opacos e minerais máficos alterados não identificáveis a partir de lâmina petrográfica (Figura 7.7b). Observa-se traços de espurrita, possivelmente resultado de ação metassomática do líquido kimberlítico no quartzito. As amostras do quartzito encaixante foram coletadas no contato com a intrusão. Há também uma variedade mais aluminosa, coletada nas adjacências, de um biotita quartzito, com quartzo recristalizado, sericita, feldspato potássico, plagioclásio, biotita e clorita de granulação muito fina. Algumas texturas associadas a estas variedades são compatíveis com as apresentadas para rochas areníticas afetadas por metamorfismo de contato na Bacia Potiguar, RN (Santos et al., 2014), embora não seja encontrado vidro preservado, mas apenas uma granulação muito fina para algumas porções, sugestivas de vidro devitrificado. Adicionalmente, podem ser observadas algumas texturas compatíveis com evidências de fusão parcial apresentadas por Sawyer \& Brown (2008), como a dissolução de grãos de quartzo recristalizados (Figura 7.7c) e destruição de foliação (neste caso constituída por biotita) a partir da fusão da porção quartzítica da rocha (Figura 7.7d). A passagem de um magma kimberlítico suficientemente quente durante sua ascensão à crosta pode ter levado a fusão parcial dos metassedimentos encaixantes, sendo observada a destruição da foliação que a o biotita quartzito possuía anteriormente.

Os dois tipos de rocha encaixante identificados para intrusão Pântano são coerentes com a literatura, que descreve as intercalações de filito e quartzito para o Grupo Canastra. 


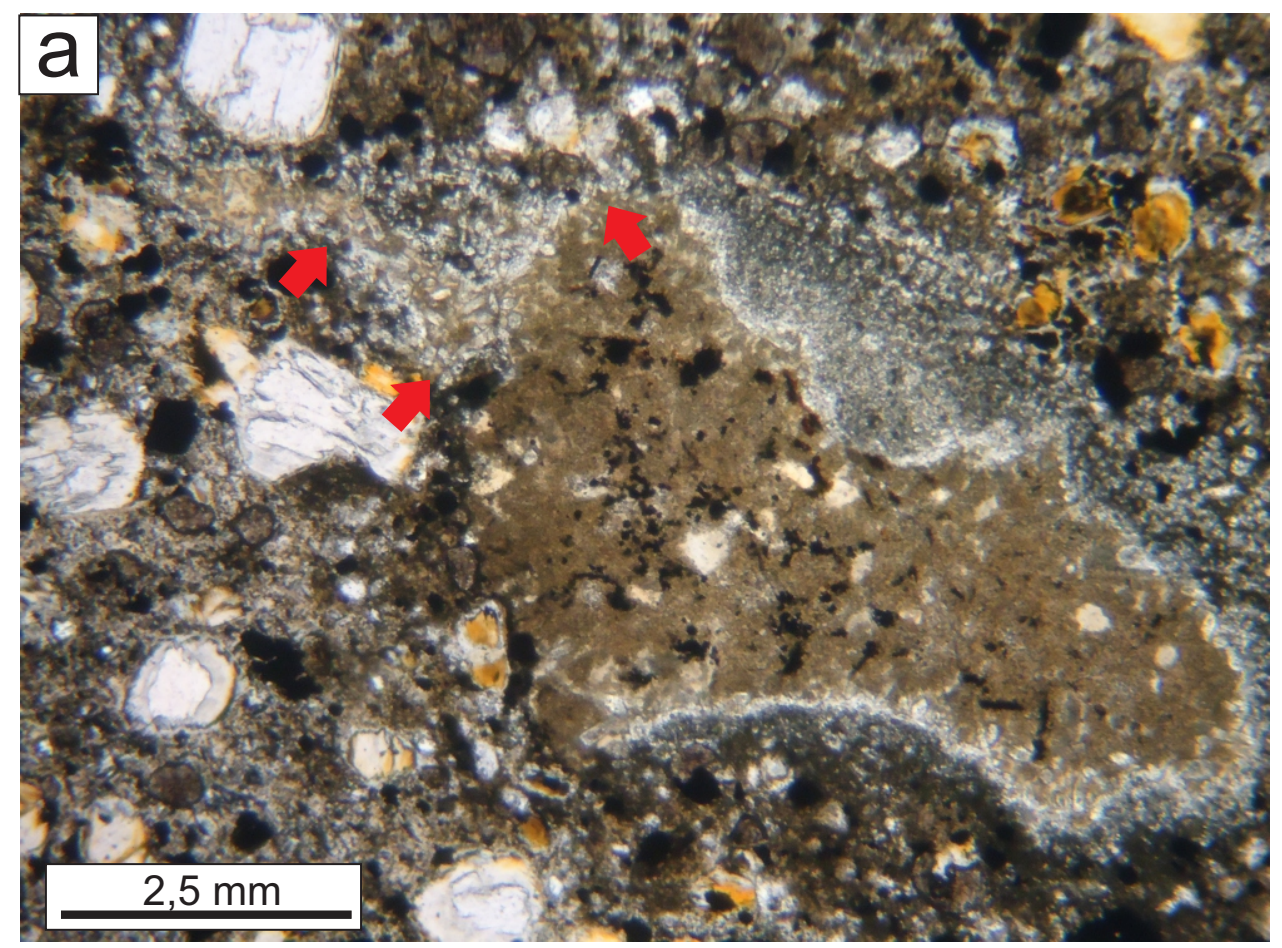

Figura 7.5a: trilha de diopsídio (setas vermelhas) ao redor de enclave observado no tipo petrográfico diopsídio kimberlito. Fotomicrografia obtida com polarizadores paralelos.

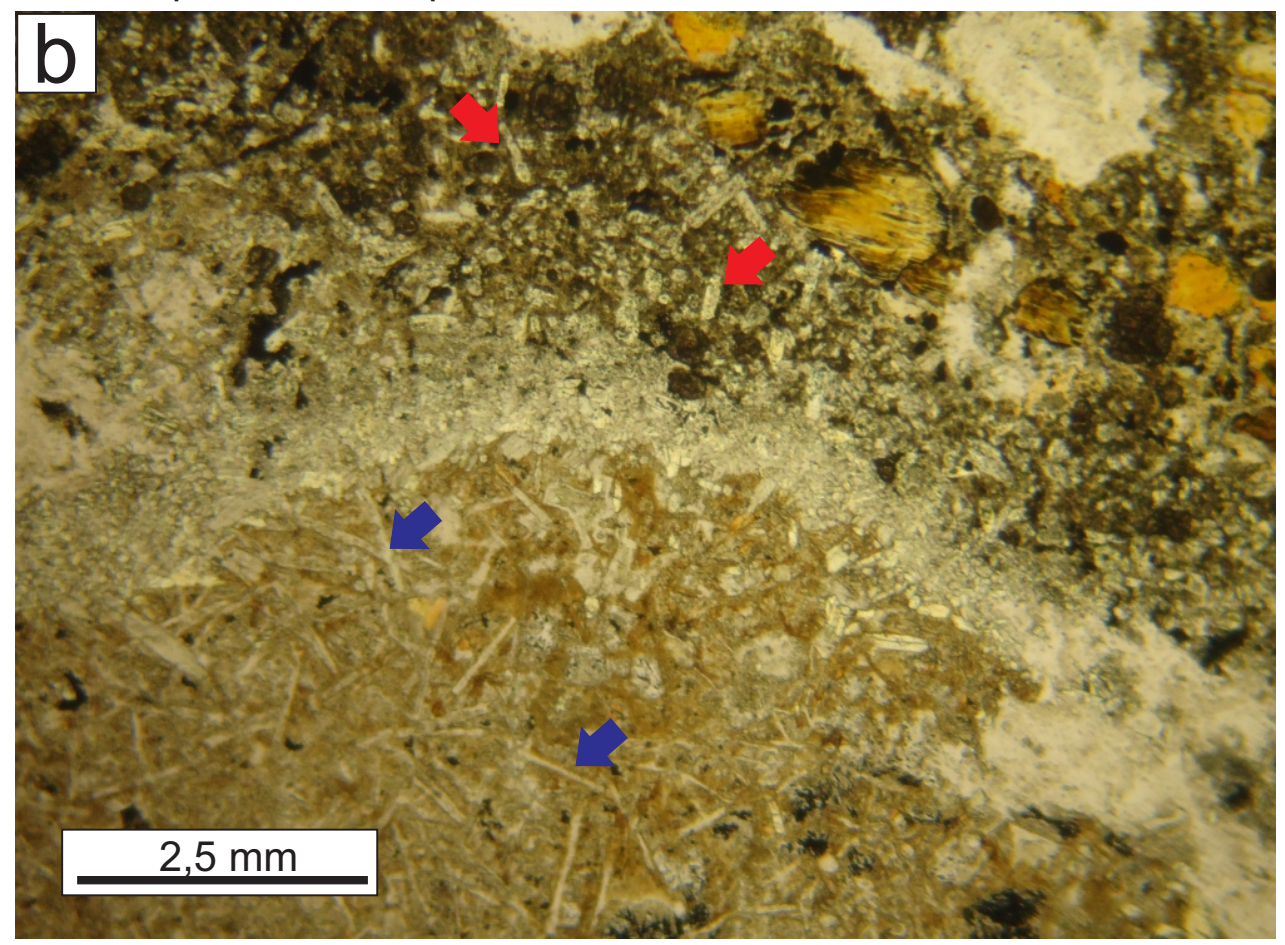

Figura 7.5b: diopsídio na matriz observado ao redor de xenólito crustal (setas vermelhas) no tipo petrográfico monticelita kimberlito. Nota-se diopsídio também no interior do xenólito crustal (setas azuis). Fotomicrografia obtida com polarizadores paralelos. 

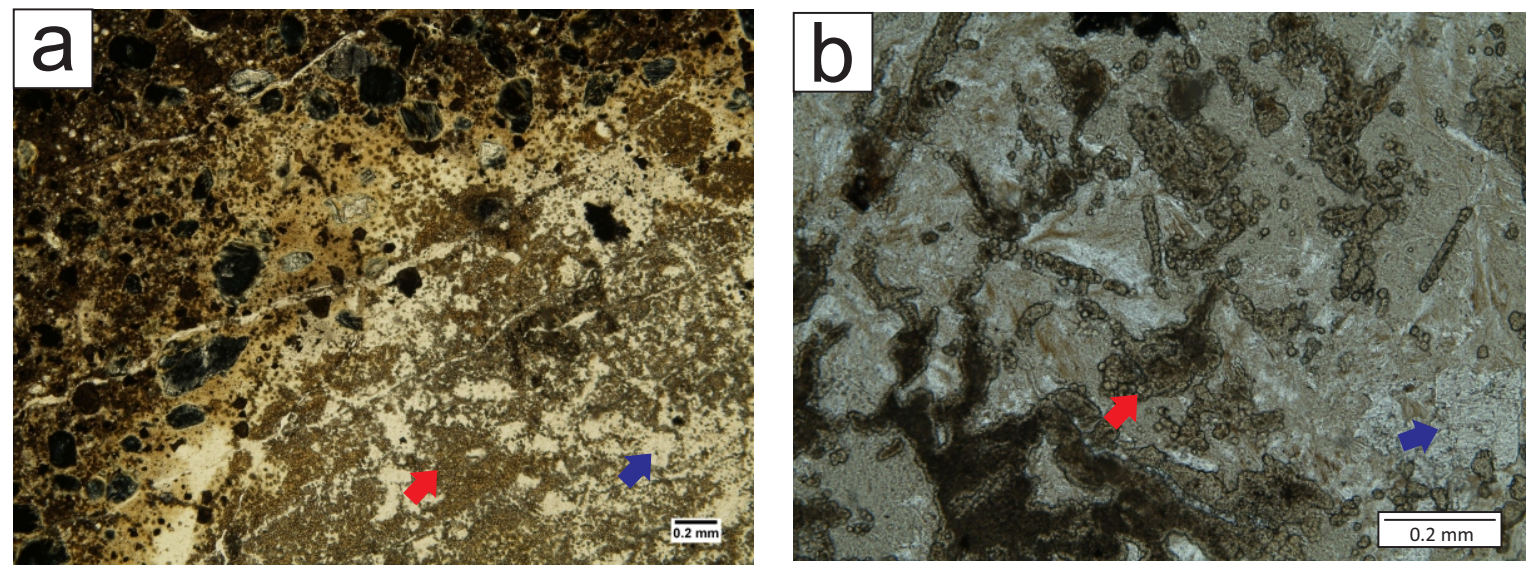

Figura 7.6: a) xenólito crustal constituído por quartzo e espurrita, formada a partir de reação metassomática entre fragmentos quartzíticos e a encaixante; b) interior do xenólito crustal em maior escala. Ambas as fotomicrografias foram obtidas com polarizadores em paralelo e as setas vermelhas e azuis indicam espurrita e quartzo, respectivamente.
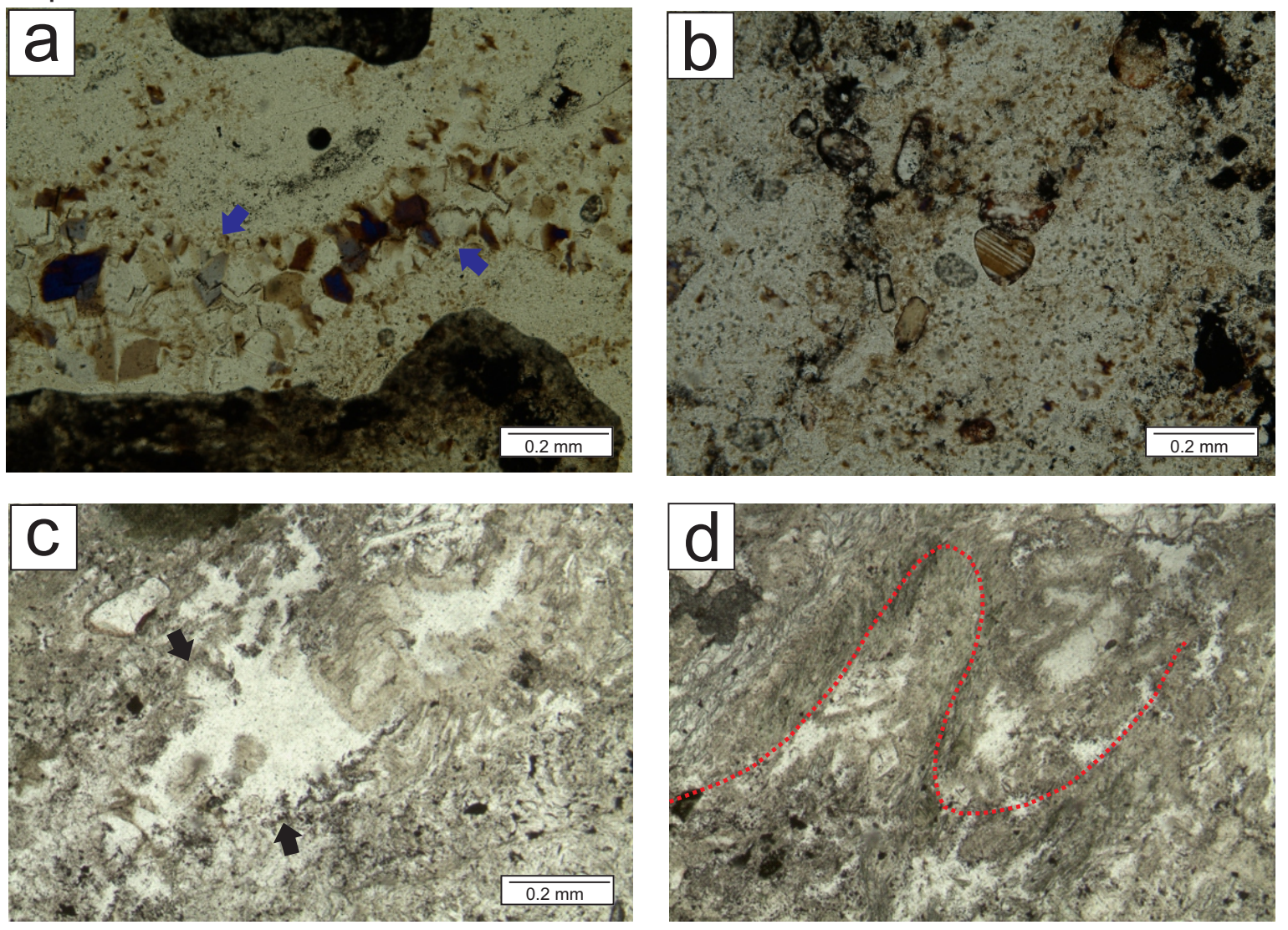

Figura 7.7: a) quartzito com quartzo recristalizado (setas azuis) apresentando textura compatível com rochas areníticas afetadas por metamorfismo de contato na Bacia Potiguar, descrita por Santos et al., 2014. b) quartzito alterado com quartzo com textura fina, minerais máficos não identificados em lâmina petrográfica. Ambas as fotomicrografias foram obtidas com polarizadores cruzados. c) dissolução dos cristais de quartzo recristalizados (setas pretas) e d) destruição da foliação constituída de biotita em biotita quartzito encaixante da intrusão Pântano. Fotomicrografias obtidas com polarizadores paralelos. 
$\mathrm{Na}$ Tabela 7.2 consta um sumário com as informações petrográficas mais relevantes de cada ponto de amostragem da Intrusão Pântano. As estimativas das porcentagens de mega, macro e microcristais e matriz foram feitas com o auxílio das análises de imagem descritas no item 6.2.1. A partir da caracterização petrográfica feita em detalhe, observando cada aspecto e heterogeneidade presentes, pôde-se dividir a intrusão em três diferentes tipos petrográficos, conforme descrito na seção 7.1.3 abaixo. 


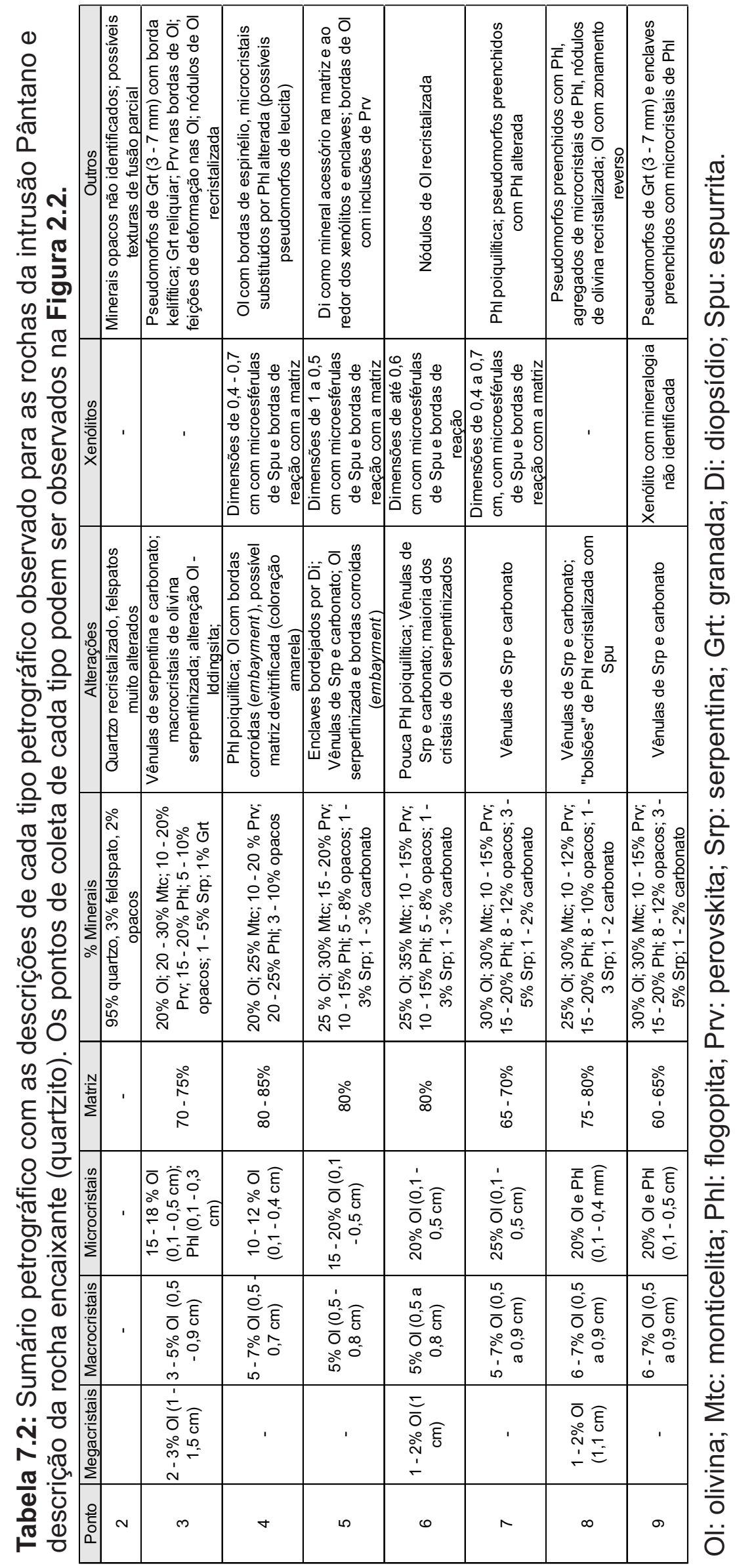




\subsubsection{Classificação de tipos petrográficos}

A partir das heterogeneidades mineralógicas e texturais descritas para cada porção das rochas da intrusão Pântano, foi possível classificar 3 principais tipos petrográficos distintos:

- Monticelita kimberlito: associado ao kimberlito que sofreu pouca interação com a rocha encaixante, apresentando apenas pequenos enclaves como evidência de contaminação crustal. A monticelita é descrita como fase mineralógica dominante na matriz e não é observado diopsídio;

- Flogopita kimberlito: associado às porções da rocha aonde a flogopita ocorre com textura poiquilítica na matriz. Neste tipo petrográfico, observa-se alguns microenclaves de coloração amarela e considera-se uma zona da rocha em que houve pouca contaminação;

- Diopsídio kimberlito: associado à porção aonde ocorre diopsídio na matriz, seja ao redor de xenólitos ou enclaves, seja como substituição de monticelita. Este tipo é interpretado como o kimberlito que sofreu maior influência de contaminação crustal. 


\subsection{Geoquímica de rocha total}

A intrusão Pântano pode ser caracterizada geoquimicamente por seus baixos teores de $\mathrm{SiO}_{2}$ (31 a 34,48\% em massa), altos teores de $\mathrm{MgO}(19,07$ a 24,84\% em massa), $\mathrm{CaO}$ (9,27 a 11,40\% em massa) e $\mathrm{TiO}_{2}$ (4,76 a 6,21\% em massa). Os valores de $\mathrm{Al}_{2} \mathrm{O}_{3}$ variam entre 2,26 a 3,08\% (em massa), $\mathrm{K}_{2} \mathrm{O}$ entre 2,18 e 3,15\% (em massa), valores de $\mathrm{Na}_{2} \mathrm{O}$ possuem uma média de $0,15 \%$ e de $\mathrm{Fe}_{2} \mathrm{O}_{3}$ uma média de $14,6 \%$ (em massa). Os conteúdos (em massa) de $\mathrm{BaO}(0,1$ a $0,34 \%), \mathrm{Cr}_{2} \mathrm{O}_{3}(0,13$ a $0,33 \%), \mathrm{NiO}$ $(0,07$ a $0,19 \%), \operatorname{SrO}(0,12$ a $0,24 \%)$ e $\mathrm{ZrO}_{2}(0,09$ a 0,22$)$ são significativamente altos e, portanto, foram considerados como elementos menores na geoquímica de rocha total.

Os kimberlitos são em geral caracterizados pelos baixos teores de $\mathrm{SiO}_{2}$ (<35\%), alto $\mathrm{MgO}(20-38 \%)$, alto $\mathrm{CaO}(5-14 \%)$, teores moderados de $\mathrm{FeO}(6-16 \%)$, baixo $\mathrm{Al}_{2} \mathrm{O}_{3}(<3 \%)$, baixo $\mathrm{TiO}_{2}(<4 \%), \mathrm{Na}_{2} \mathrm{O}(<0,3 \%)$ e $\mathrm{K}_{2} \mathrm{O}(<2)$, embora os teores de $\mathrm{K}_{2} \mathrm{O}$ possam atingir até $7 \%$ em kimberlitos do grupo II devido ao alto conteúdo de flogopita (Mitchell, 1986; Mitchell, 1995). Nota-se que em geral a intrusão Pântano possui teores similares aos kimberlitos descritos por Mitchell (1995), observa-se, contudo, teores mais elevados dos elementos $\mathrm{TiO}_{2}$ e $\mathrm{K}_{2} \mathrm{O}$.

Além das evidências geoquímicas, a intrusão Pântano pôde ser classificada como kimberlito por ter sido descrita a granada (piropo) como macrocristal. A intrusão foi classificada como kimberlito do tipo I (segundo a classificação de Mitchell, 1995), devido aos seus constituintes mineralógicos, principalmente macrocristais de olivina de alto Mg\#, presença de monticelita em abundância (Tappe et al., 2005), implicando a geração destes magmas no campo de estabilidade da granada (Shirey et al., 2013).

Além da caracterização geoquímica, a partir do cálculo do índice de contaminação, C.I. (Contamination Index, Clement, 1982), pode-se determinar a influência de possíveis contaminações crustais nas rochas da intrusão. A equação para o cálculo do C.I. é:

$$
\text { I) } \quad \mathrm{C} . \mathrm{I}=\left(\mathrm{SiO}_{2}+\mathrm{Al}_{2} \mathrm{O}_{3}+\mathrm{Na} 2 \mathrm{O}\right) /\left(\mathrm{MgO}+2 \mathrm{~K}_{2} \mathrm{O}\right)
$$

Segundo Clement (1982), quando o valor de C.I. é inferior a 1, a amostra pode ser considerada como livre de contaminação. Estudos mais recentes sugerem um novo valor de C.I. (Nowicki et al., 2008), sendo consideradas livres de contaminação 
as amostras que apresentam valores de C.I. de até 1,5. Kjarsgaard et al. (2009) também propôs um limiar de 1,5 para a razão calculada para o valor de C.I. Desta maneira, valores de C.I. entre 1,0 e 1,5 estariam levemente contaminados, mas não o suficiente para alterar a assinatura geoquímica de rocha total.

Os índices de contaminação crustal calculados para intrusão Pântano variam de 1,18 a 1,35, sendo tais valores consideravelmente baixos se comparados a índices calculados para outros kimberlitos hipoabissais descritos na literatura (Howarth, 2011). Estes índices podem chegar a valores próximos de 5 em rochas altamente contaminadas e alteradas. Nota-se que o maior valor calculado para o índice de contaminação foi encontrado para o tipo com diopsídio na matriz, caracterizando esta como a região da intrusão que mais interagiu com o quartzito encaixante. A presença de diopsídio como fase mineral oriunda de contaminação crustal é descrita por Caro et al. (2004) como resultado de um enriquecimento de sílica no sistema kimberlítico. O segundo valor mais alto obtido para a razão de C.I. foi o do tipo petrográfico contendo flogopita poiquilítica, indicando que esta seria uma região que passou por um menor grau de contaminação. As Tabelas A.I e A.II (Apêndice A) apresentam os resultados de química de rocha total para as sete regiões amostras para a intrusão Pântano.

As rochas de afinidade kimberlítica são colocadas na crosta por meio de intrusões vulcânicas, estando elas sujeitas, portanto, a diversos processos de alteração, que podem variar de momentos sin a imediatamente pós-eruptivos (Cas, 2008). Assim, podem ocorrer alterações deutéricas, hidrotermais e diagenéticas causadas devido à água meteórica ou a fluídos do próprio sistema, por exemplo. Os kimberlitos, por serem rochas ultrabásicas e ultramáficas, são altamente reativos e suscetíveis a alteração e, como resultado, nenhum kimberlito preserva todas as suas texturas e componentes originais (Sparks, 2013). Segundo o limiar de 1,5 (C.I.) sugerido por Kjarsgaard et al. (2009), as rochas da intrusão Pântano, embora apresentem alguma alteração deutérica (presença de vênulas de carbonato e serpentina), não estariam suficientemente afetadas a ponto de haver uma grande alteração na assinatura geoquímica da rocha.

A fim de reconhecer os processos geoquímicos pelos quais as rochas da intrusão Pântano foram submetidas, foram confeccionados diagramas bivariantes dos elementos maiores versus teor de $\mathrm{MgO}$ (\% peso), por se tratarem de rochas ultrabásicas. O teste de controle mineralógico das rochas foi feito a partir dos 
diagramas de variação da Figura 7.8, obtidos a partir dos dados de química mineral obtidos no presente trabalho. Nestes gráficos, foram plotadas as composições químicas das fases minerais, juntamente com as composições obtidas a partir da geoquímica de rocha total da intrusão. O Mg\# (100* $\mathrm{MgO} / \mathrm{MgO}+\mathrm{FeO}$, em proporções moleculares) das rochas da intrusão Pântano varia de 0,70 a 0,77, sendo estes valores muito semelhantes aos descritos por Carlson et al. (2007) para kimberlitos e kamafugitos da província alcalina Alto Paranaíba.

A fase mineralógica dominante (olivina), teoricamente controlaria a geoquímica global da rocha, mas nota-se que a composição da mesma está sempre mais próxima aos campos de cristalização da monticelita e da flogopita. Embora a olivina seja a fase dominante da rocha, sabe-se que a mesma constitui duas populações distintas: a de xenocristais e a de cristais cognatos. Desta maneira, a geoquímica de rocha total não é representativa no magma kimberlítico original, mas de uma mistura entre cristais carregados e fundido. Uma parcela significativa da população de olivina é de xenocristais, dificultando a interpretação de trends de rocha total que estejam relacionados aos cristais de olivina cognatos. A monticelita pode ser considerada fase cognata no magma kimberlítico, denotando que as rochas da intrusão Pântano, justamente por serem pouco contaminadas $($ C.I.<1,5), podem refletir um controle mineralógico dado por seus constituintes originais.

A distribuição de ETRs normalizada por condritos mostra valores similares para todas as amostras da intrusão Pântano (Figura 7.9a) e é possível notar que rocha encaixante (quartzito) não influencia no processo de empobrecimento ou enriquecimento destes elementos (Figura 7.9b). Os perfis encontrados são subparalelos e caracterizados por enriquecimento em ETRs leves se comparados a ETRs pesados. Os padrões encontrados são similares aos encontrados por Meyer et al. (1991), que encontrou as mesmas distribuições para intrusões Limeira e Indaiá. Os elementos-traço normalizados pelo manto primitivo (Figura 7.10a) mostram expressivo enriquecimento em elementos incompatíveis, principalmente $\mathrm{La}, \mathrm{Nb}, \mathrm{Nd}$ e Ba. Os tipos petrográficos com monticelita (Kmtc) e flogopita (Kphl) possuem maior enriquedicmento em Ba em relação ao tipo com diopsídio (Kdiop). Os elementos Cs, $\mathrm{Rb}, \mathrm{Ba}, \mathrm{Th}, \mathrm{U}, \mathrm{Nb}, \mathrm{Ta}$, La, Ce, Pb e Pr mostram-se enriquecidos em mais de cem vezes se relacionados ao manto primitivo, denotando padrões similares aos perfis encontrados para ETRs. Há um enriquecimento expressivo em Ti, além de uma anomalia negativa em $\mathrm{P}$ comum para todas as amostras. Nota-se que as amostras da 
intrusão Pântano estão inseridas no campo de kimberlitos da província e que o quartzito encaixante não possui enriquecimento em elementos-traço (Figura 7.10b).

Os elementos-traço dos minerais da intrusão Pântano (dados deste trabalho e compilados de Melluso et al., 2008) normalizados pelo manto primitivo (Figura 7.11) mostram que a perovskita possui alto enriquecimento em ETRs leves, P e Ti. Os elementos-traço para as rochas da intrusão denotam padrão similar ao da perovskita, indicando que esta fase mineral controla o teor de traços e o enriquecimento da rocha principalmente em ETRs leves e Ti. A flogopita apresenta enriquecimento menos expressivo em ETRs e em elementos incompatíveis, já a olivina e o espinélio apresentam-se extremamente empobrecidos nos elementos-traço em geral.

O quartzito encaixante da intrusão Pântano constitui-se de aproximadamente 97\% de $\mathrm{SiO}_{2}$ (em massa), sendo pobremente enriquecido em elementos-traço. Esta rocha possui pouca influência no enriquecimento de elementos-traço da intrusão, apresentando um enriquecimento de aproximadamente dez vezes de $\mathrm{Ba}$ e $\mathrm{U}$ em relação ao manto primitivo. Nota-se que a composição geoquímica da rocha encaixante não é refletida nas rochas da intrusão Pântano, a não ser pelos tipos caracterizados presença de diopsídio na matriz. 
(a)

(b)
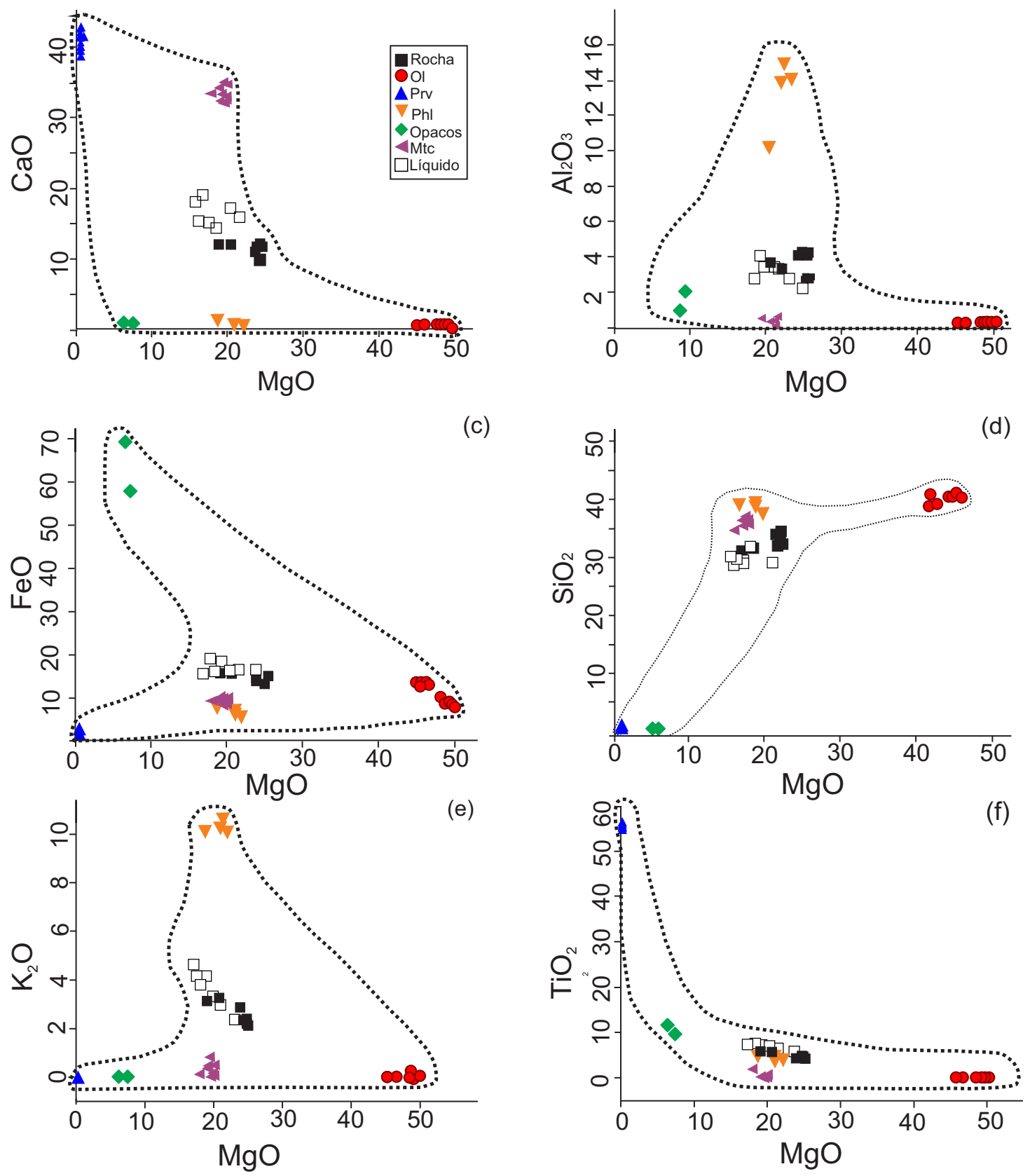

(g)
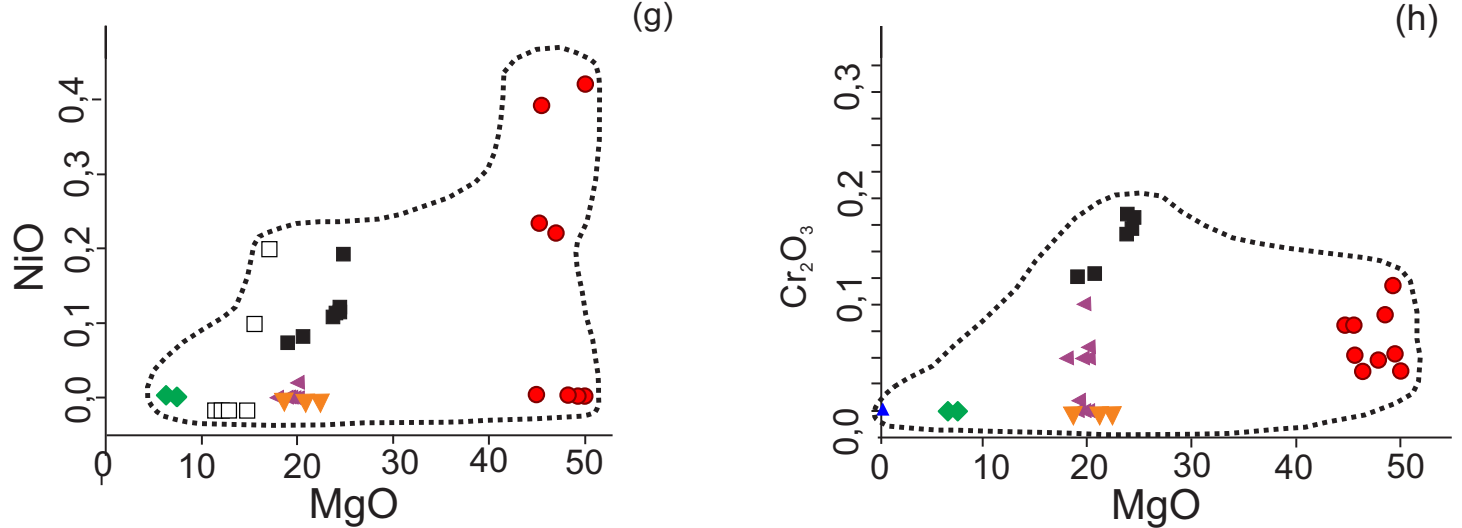

Figura 7.8: Diagramas bivariantes das composições químicas mineralógicas de rocha-total e do possível fundido kimberlítico (líquido) para intrusão Pântano. Ol: olivina; Prv: perovskita; Phl: flogopita; Mtc: monticelita. 


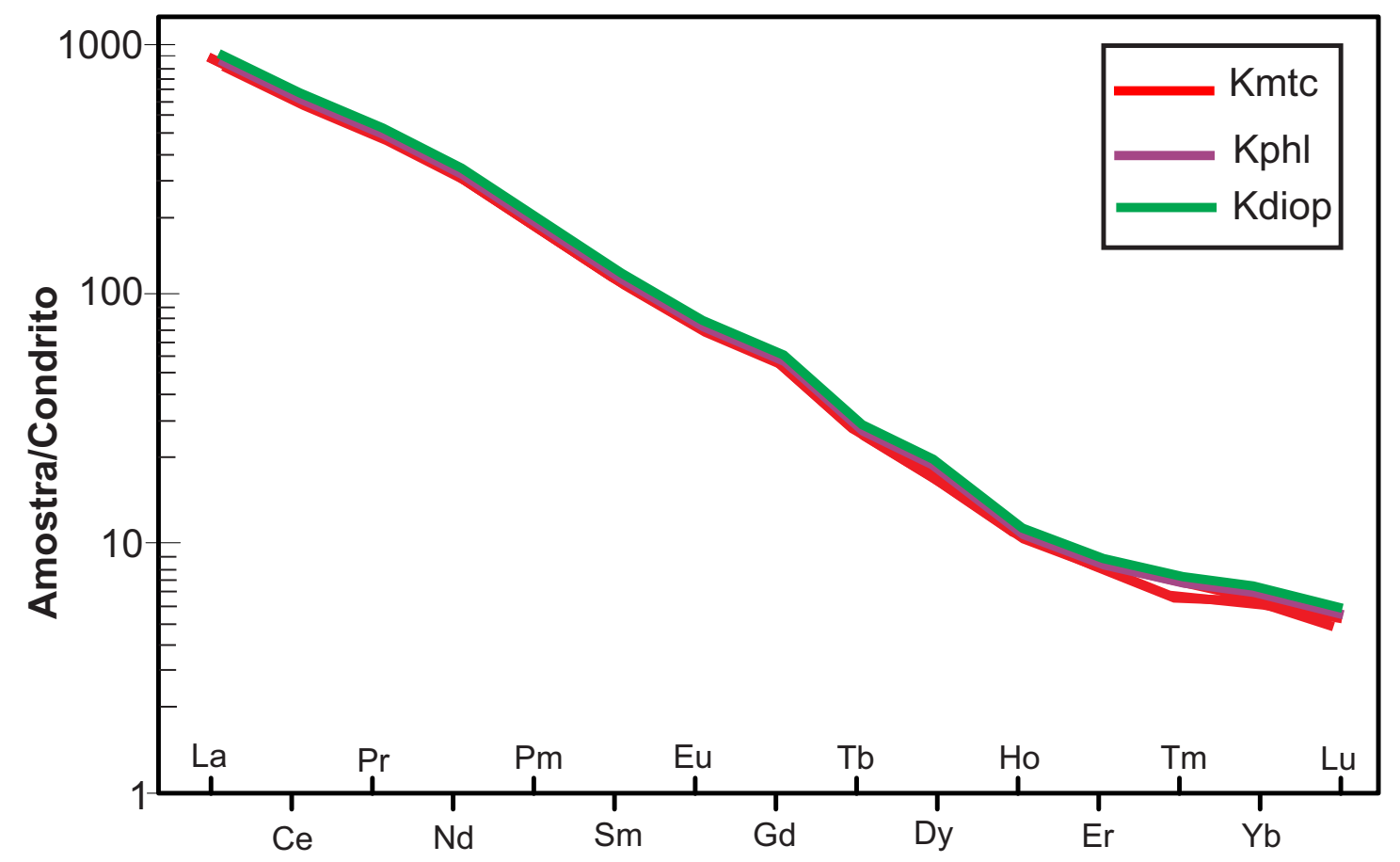

Figura 7.9a: Padrão de variação de elementos terras raras dos distintos tipos petrográficos para a intrusão Pântano normalizados pelo condrito de Boynton (1984). Kmtc: monticelita kimberlito; Kphl: flogopita kimberlito; Kdiop: diopsídio kimberlito.

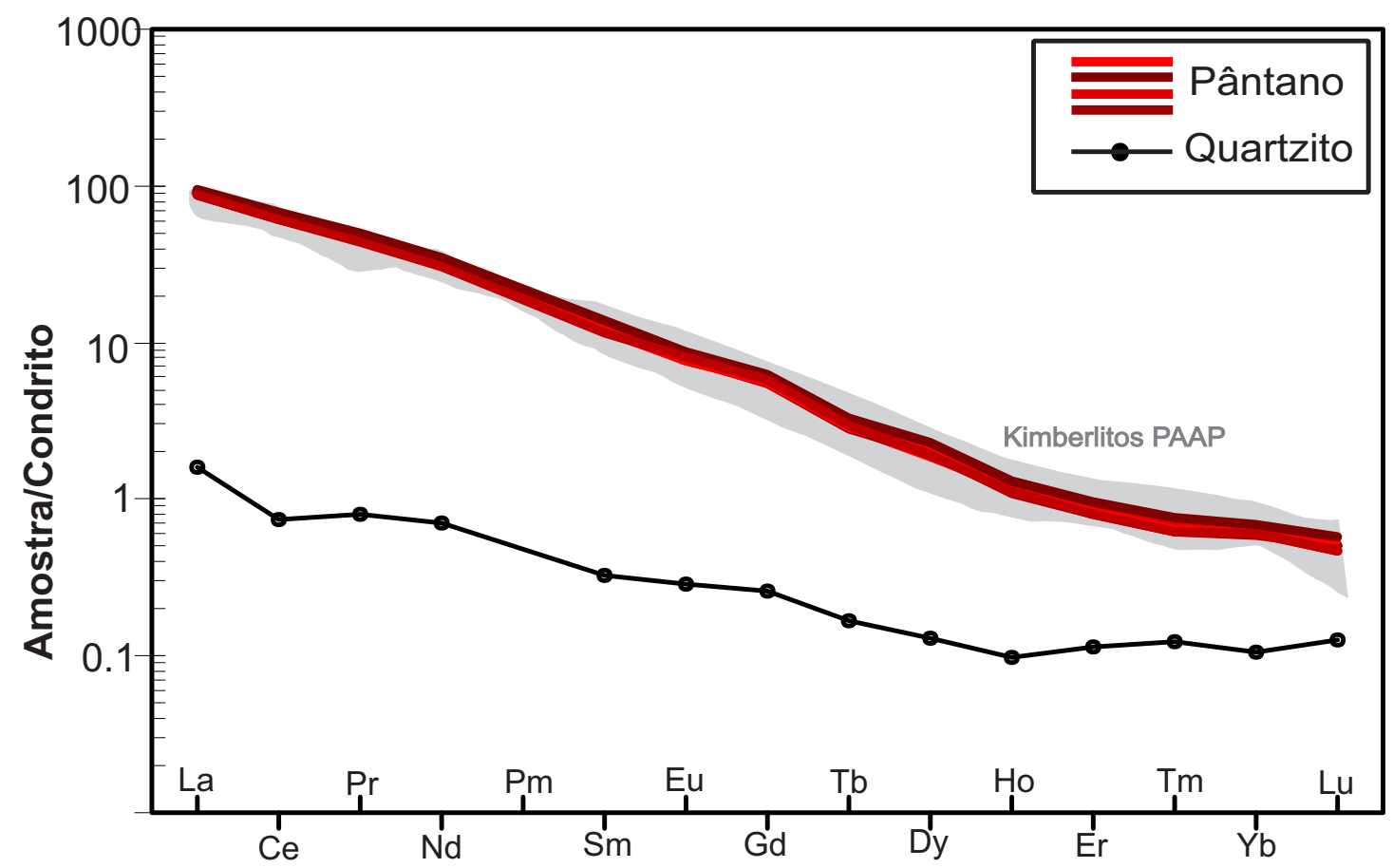

Figura 7.9b: Padrão de variação de elementos terras raras normalizados pelo condrito de Boynton (1984) para as rochas da intrusão Pântano e para o quartzito encaixante. Campos da PAAP de Guarino et al. (2013) e referências lá citadas. 


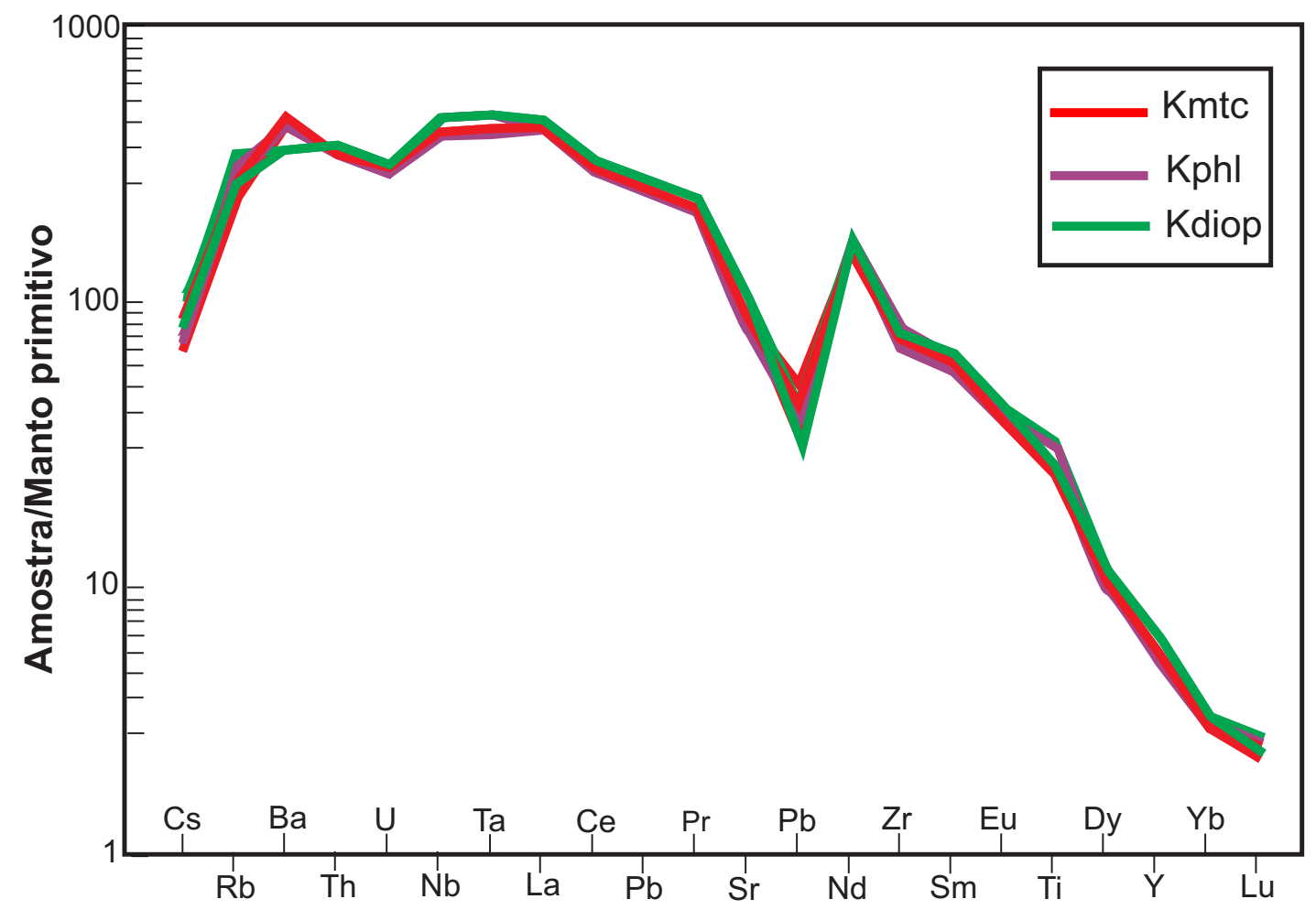

Figura 7.10a: Diagrama multielementar de elementos-traço dos distintos tipos petrográficos observados para intrusão Pântano normalizados pelo manto primitivo de McDonough and Sun (1995). Kmtc: monticelita kimberlito; Kphl: flogopita kimberlito; Kdiop: diopsídio kimberlito.

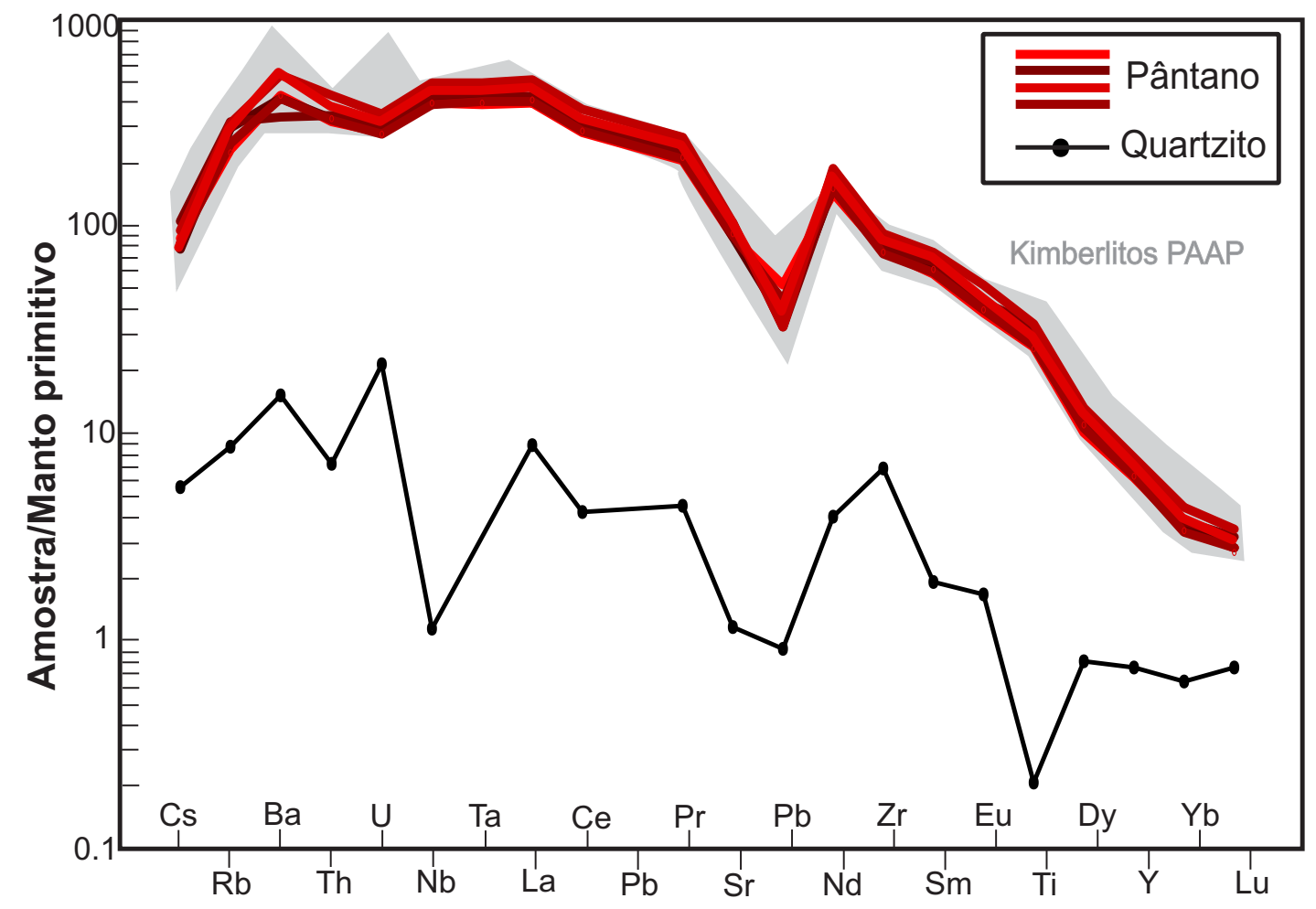

Figura 7.10b: Diagrama multielementar de elementos-traço das rochas da intrusão Pântano e do quartzito encaixante normalizados pelo manto primitivo de McDonough and Sun (1995). Campos da PAAP de Guarino et al. (2013) e referências lá citadas. 


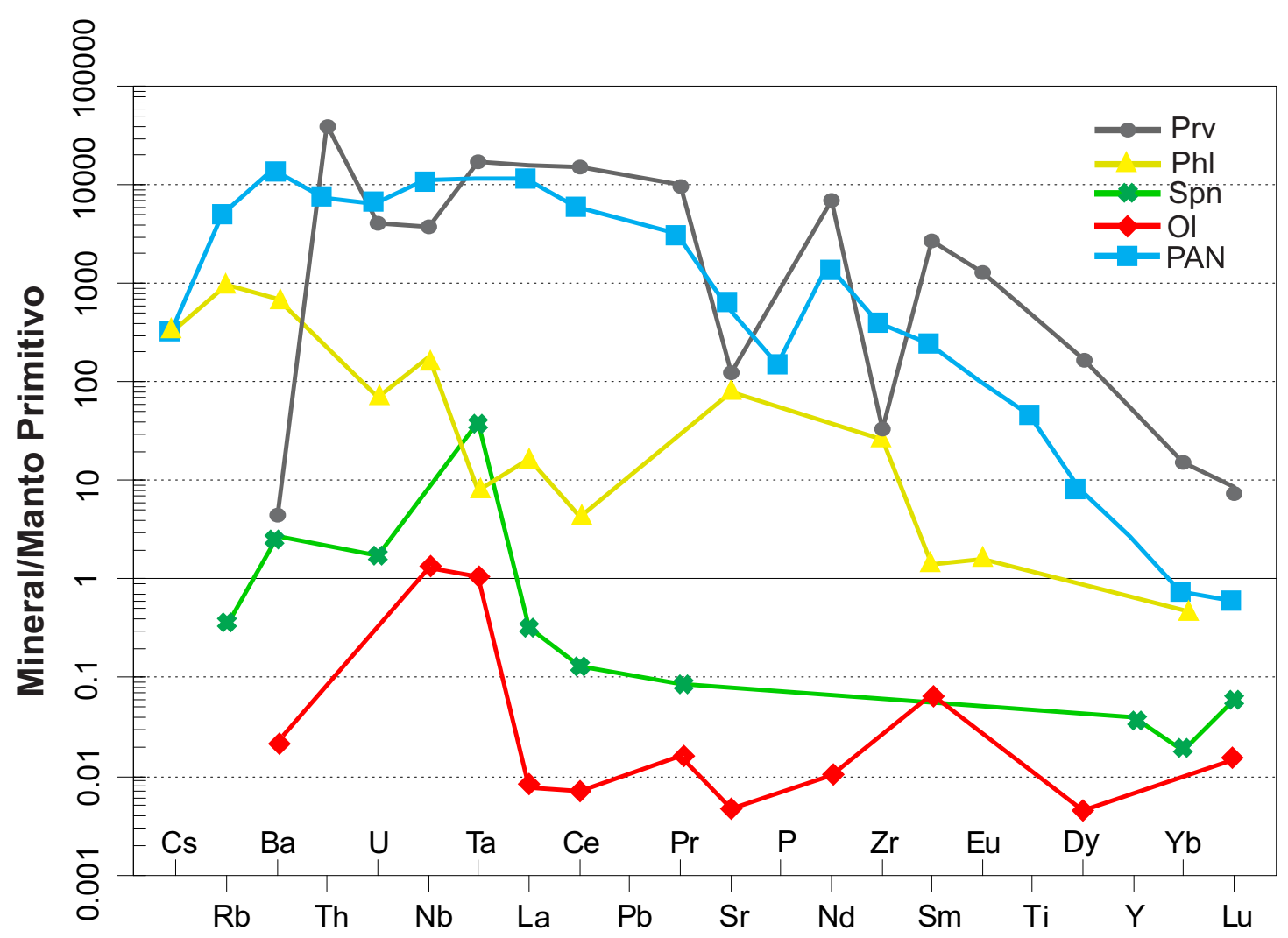

Figura 7.11: Diagrama multielementar de elementos-traço dos minerais em comparação às rochas da intrusão Pântano normalizados pelo manto primitivo. Prv: perovskita; Phl: flogopita; Spn: espinélio; OI: olivina; PAN: Pântano. Dados deste trabalho e de Melluso et al. (2008). 


\subsection{Química mineral}

Conforme mencionado nas Seção 6.2.5, foram efetuadas análises de química mineral em distintas populações nos minerais olivina, monticelita e flogopita. Os resultados analíticos obtidos por microssonda eletrônica podem ser consultados nas Tabelas B.I a B.III, no Apêndice B.

\subsubsection{Olivina}

As fórmulas estruturais dos cristais de olivina foram calculadas com base nos membros finais forsterita e faialita e 4 átomos de oxigênio, seguindo as recomendações de Deer et al., (1992). As análises químicas tinham como intuito a discriminação através das morfologias e zonamentos, caracterizando os distintos grupos de olivina. Com o objetivo de facilitar o controle químico das análises, os cristais de olivina foram divididos entre as seguintes populações:

- Microcristais: núcleos e bordas $(<0,5 \mathrm{~cm})$;

- Macrocristais: núcleos e bordas (0,5 - 0,9 cm);

- Megacristais: núcleos e bordas (>1,0 cm).

A Figura 7.12 apresenta os histogramas em que constam as distribuições de Mg\# nos diferentes tipos morfológicos caracterizados. A variação composicional dos grupos identificados pode ser observada na Figura 7.13, a partir dos diagramas bivariantes de $\mathrm{NiO}, \mathrm{CaO}$ e $\mathrm{MnO}$ versus $\mathrm{Mg \#}$ e $\mathrm{NiO}$ versus $\mathrm{CaO}$, indicativos das tendências químicas de cada grupo. A Tabela 7.3 apresenta os valores estatísticos obtidos para cada população estudada, considerados para confecção dos histogramas. 
Tabela 7.3: Composições das populações de olivina estudadas.

\begin{tabular}{cccccccc}
\hline & \multicolumn{2}{c}{ Microcristais } & \multicolumn{2}{c}{ Macrocristais } & \multicolumn{2}{c}{ Megacristais } \\
& Núcleo & Borda & Núcleo & Borda & Núcleo & Borda \\
\hline Número de amostras & 40 & 32 & 27 & 27 & 15 & 15 \\
\hline Média Fo & 87.8 & 85.9 & 89.5 & 85.3 & 88.6 & 85.2 \\
DP (10) & 2.85 & 1.98 & 2.65 & 1.78 & 3.17 & 1.1 \\
Máximo & 92.5 & 91.8 & 92.1 & 90.2 & 92 & 87.1 \\
Mínimo & 82.9 & 80.4 & 83.5 & 79.4 & 83.5 & 83.2 \\
\hline
\end{tabular}

Os valores de Fo considerando todas as populações variaram entre 79,4 e 92,5 , sendo os maiores valores encontrados para os núcleos de micro e macrocristais, que apresentaram médias de 87,8 e 89,5 , respectivamente. Há uma distribuição bimodal entre os núcleos e bordas de todas as populações estudadas, sendo os valores iguais ou superiores a Fogo, provavelmente, representativos de xenocristais mantélicos. Os intervalos dos valores de Fo observados para os núcleos dos microcristais foram de 82,9 a 92,5 para os núcleos dos macrocristais, de 83,5 a 92,1 e para os megacristais, de 83,5 a 92,0. Em geral, bserva-se o empobrecimento de $\mathrm{Mg}$ nas bordas das três populações analisadas. As olivinas têm composição variável entre forsterita e crisólita, cuja molécula predominante também é a forsterita.

Os teores de $\mathrm{CaO}$ e $\mathrm{MnO}$ são mais empobrecidos nos núcleos dos mega, macro e microcristais, já para o $\mathrm{NiO}$, os núcleos apresentam-se mais enriquecidos (3000 a 3500 ppm), principalmente nos megacristais. Nota-se uma correlação

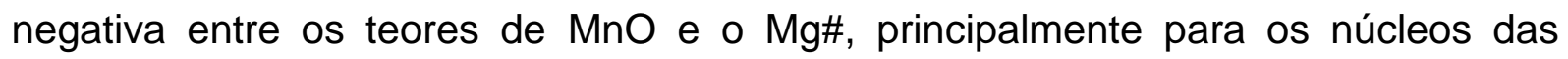
populações de olivina, além de uma correlação positiva entre $\mathrm{NiO}$ e Mg\#, também observada para os núcleos. Há, em geral, um leve enriquecimento de $\mathrm{TiO}_{2}$ nas bordas dos micro e megacristais, no entanto, nos macrocristais observa-se leve

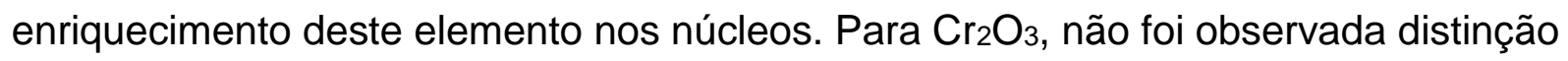
nos teores entre núcleos e bordas. Em relação ao $\mathrm{Al}_{2} \mathrm{O}_{3}$, foi notada diferença apenas nos teores entre núcleos e bordas dos microcristais, em que há enriquecimento deste elemento nas bordas. Para as demais populações, não houve diferença na distribuição de $\mathrm{Al}_{2} \mathrm{O}_{3}$. As bordas de todos os cristais apresentam enriquecimento em $\mathrm{FeO}$.

O amplo intervalo de valores de $\mathrm{Mg \#}$ observados reflete a presença de cristais de distintas origens, que se desenvolveram em estágios diferentes durante a evolução do magma kimberlítico. As bordas das três populações de olivina estudadas denotam o equilíbrio destas porções com o fundido kimberlítico, enquanto os núcleos 
aparentam possuir uma origem xenocristalina. Segundo Deer (1992), olivinas com Fo entre 89 e 96 seriam de origem mantélica, enquanto outros autores como Bussweiler et al. (2015) e Shaikh et al. (2018) consideram que olivinas xenocristalinas possuam Fo $>90$. Dos 40 núcleos de microcristais analisados, 13 apresentaram Fo $>90$, dos 27 núcleos de macrocristais analisados, 15 apresentaram Fo>90 e, por fim, 7 das 15 análises de núcleos dos megacristais também denotaram esta condição. Nota-se, portanto, que até $40 \%$ das análises de núcleos de olivina seriam indicativas de uma população originada a partir de xenólitos do manto.

Observando-se a variação estatística representada pelos histogramas da Figura 7.12, é possível observar uma tendência bimodal para os núcleos da população de microcristais, em que as maiores frequências podem ser encontradas tanto para os valores de $\mathrm{Mg \#}$ de 86 quanto 92 . Pode-se sugerir, portanto, que esta população não pode ser considerada inteiramente como xenocristalina. Para os núcleos dos macrocristais e dos megacristais, é possível notar uma tendência melhor delineada para interpretação de que estas populações são constituídas majoritariamente por cristais não cognatos, sendo os valores de Mg\# em sua maioria, acima de 90.

A partir dos diagramas bivariantes (Figura 7.13) obtidos para as 3 populações de olivina estudadas, foi possível observar dois trends composicionais distintos: xenocristais do manto, representados pelos núcleos e fundido kimberlítico, representado pelas bordas. Estes trends são similares às tendências de olivinas kimberlíticas descritas por Bussweiler et al. (2015) como mantle trend (xenocristais mantélicos) e melt trend (olivinas cristalizadas a partir de um fundido kimberlítico). 


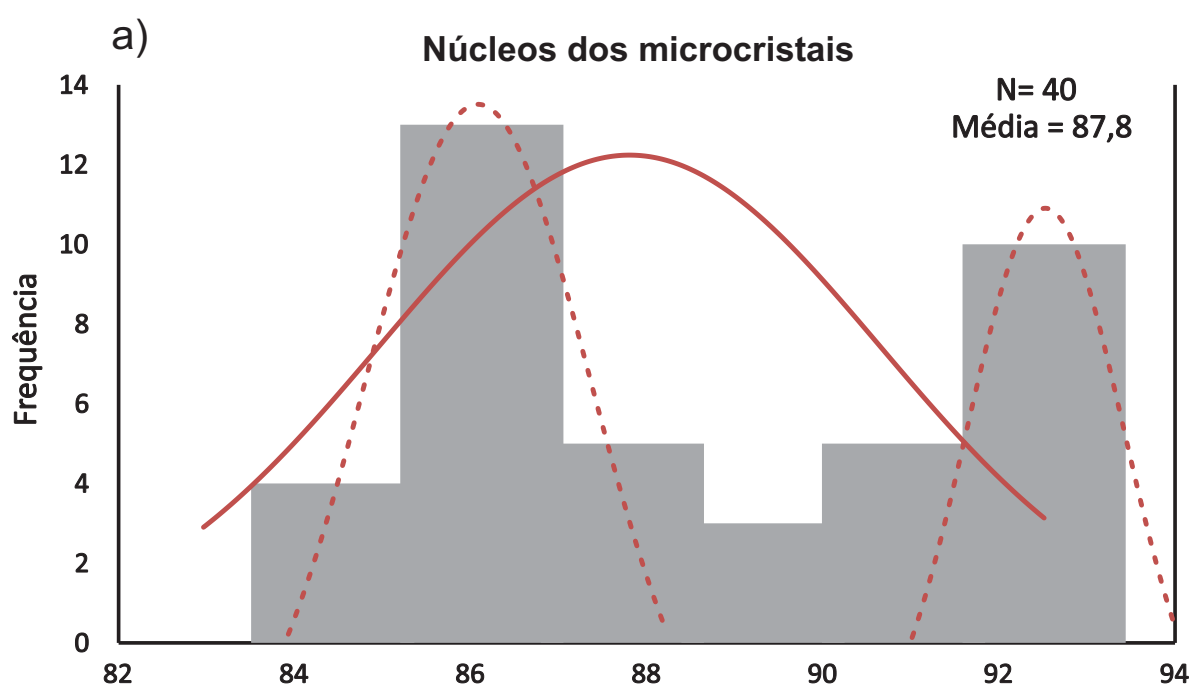

b)

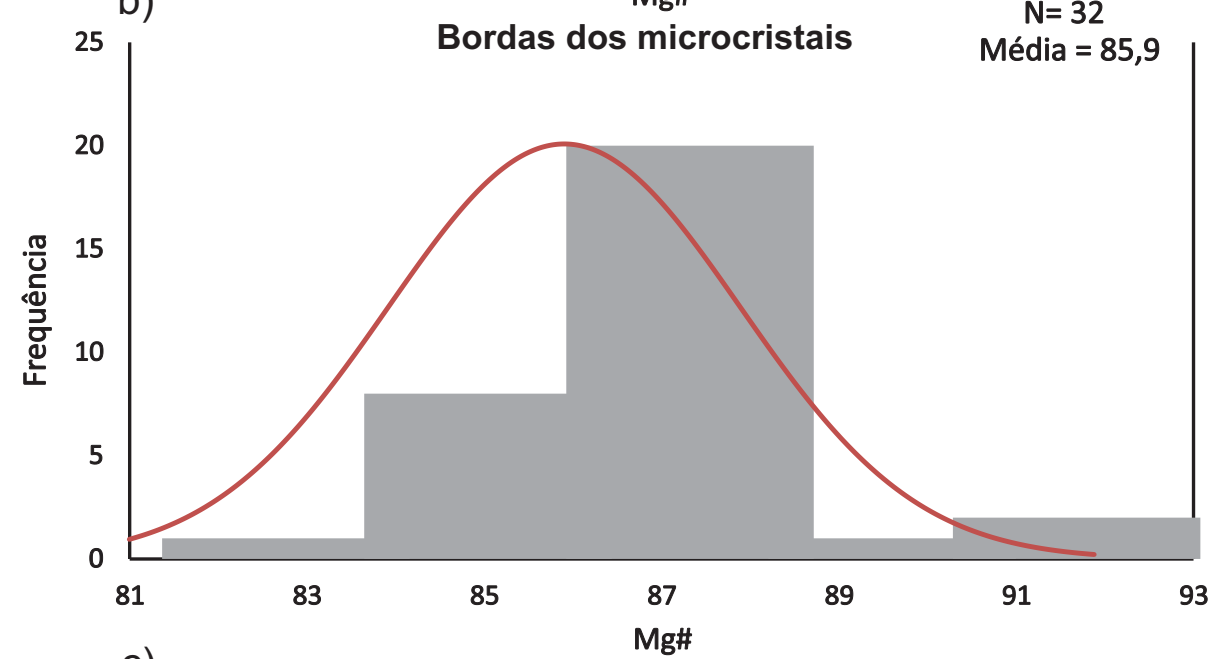

c)

Núcleos dos macrocristais

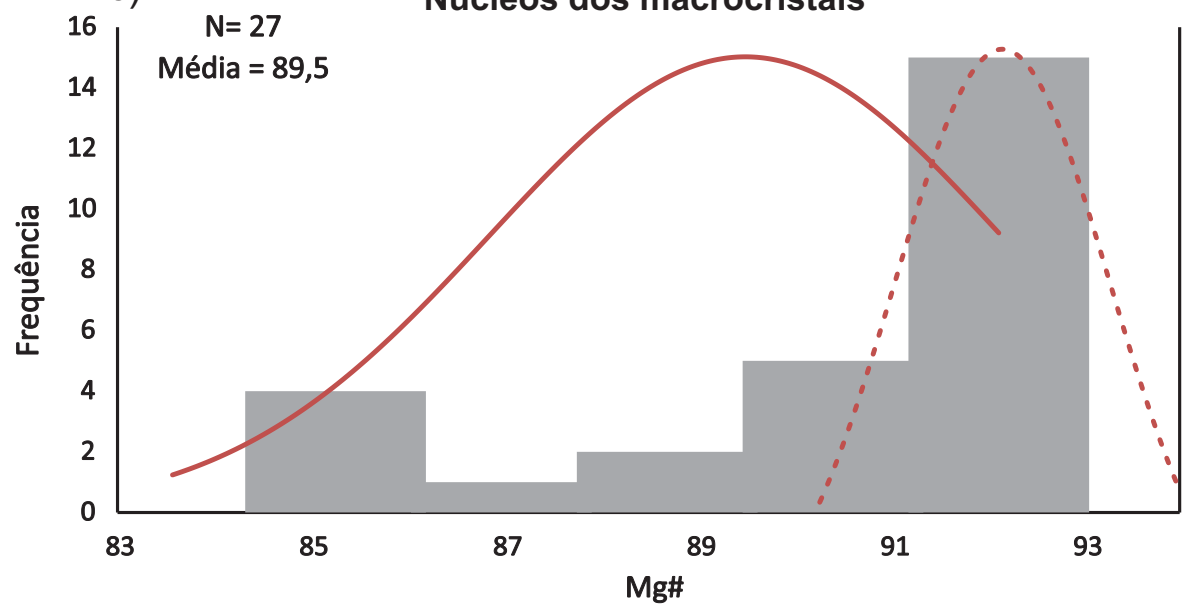

Figura 7.12: histogramas de distribuição de Mg\# dos núcleos e bordas das populações de olivina analisadas. As linhas representam o modelo de distribuição gaussiana baseadas nas médias e variâncias calculadas para cada população. a) Nota-se uma tendência bimodal para a população de núcleos dos microcristais; b) As bordas dos macrocristais possuem o maior número de amostras com Mg\# entre 87 e 89 e os c) núcleos dos macrocristais, com valores acima de 90. 

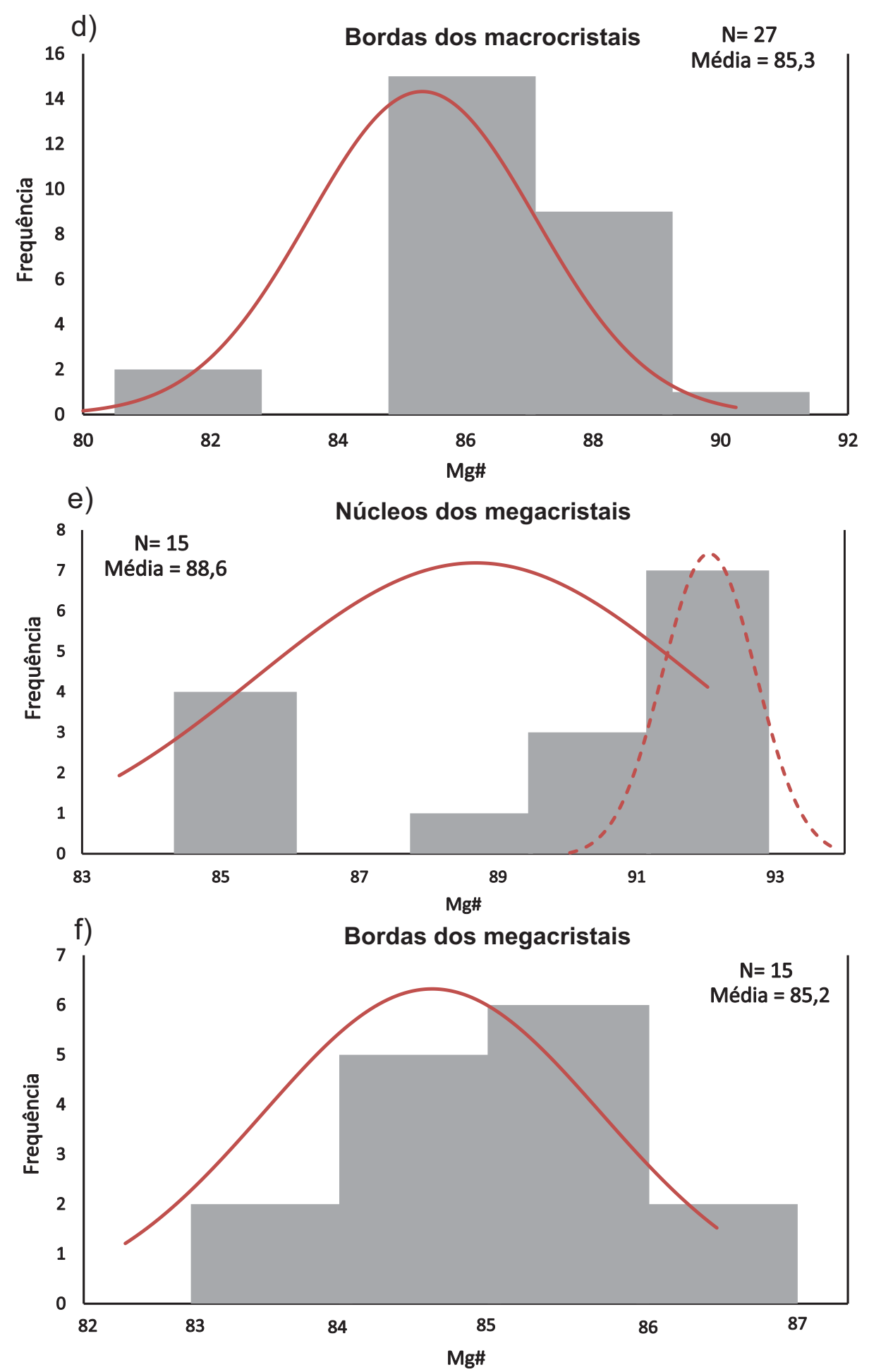

Figura 7.12 (continuação): histogramas de distribuição de Mg\# dos núcleos e bordas das populações de olivina analisadas. As linhas representam o modelo de distribuição gaussiana baseadas nas médias e variâncias calculadas para cada população. d) As bordas dos macrocristais apresentam maior número de amostras com Mg\# entre 85 e 87; e) Os núcleos dos megacristais apresentam Mg\# em sua maioria, acima de 90; f) As bordas dos megacristais apresentam ampla distribuição de valores de Mg\#, sendo os maiores valores observados entre 85 e 86. 

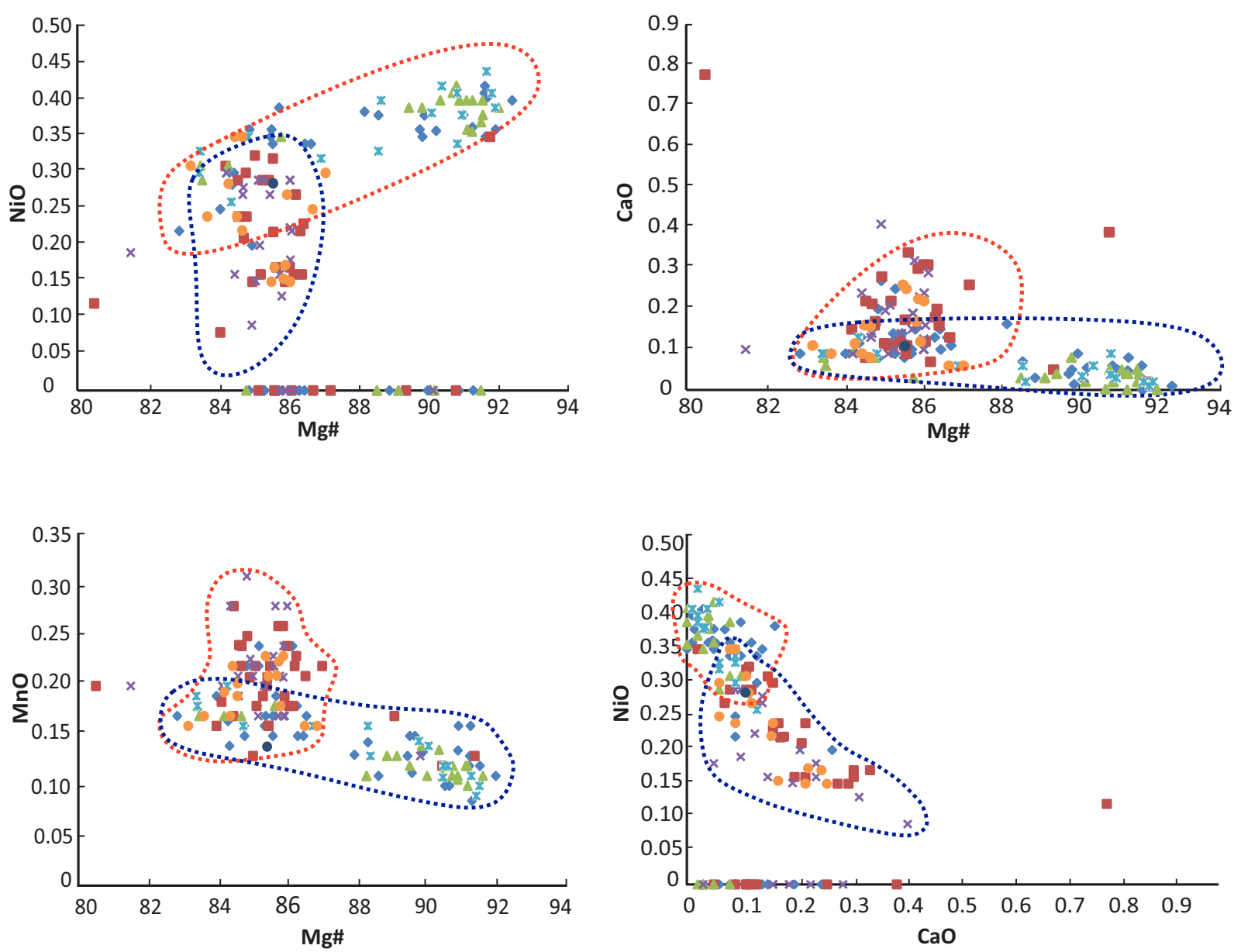

Núcleos dos microcristais

Nódulo

Trend mantélico

- Bordas dos microcristais * Núcleos dos megacristais

Núcleos dos macrocristais Bordas dos megacristais

Trend do fundido kimberlítico

X Bordas dos macrocristais

Figura 7.13: Diagramas bivariantes de $\mathrm{Mg} \#$ vs a) $\mathrm{NiO}$, b) $\mathrm{CaO}$ e c) $\mathrm{MnO}$ e d) $\mathrm{NiO}$ vs $\mathrm{CaO}$, refletindo a distribuição composicional dos cristais de olivina da intrusão Pântano. Nota-se que os núcleos das populações compõem o trend mantélico e as bordas das populações o trend do fundido kimberlítico. Dados em porcentagem em massa. 
Além dos teores de $\mathrm{Fo}, \mathrm{NiO}, \mathrm{CaO}, \mathrm{MnO}$ e $\mathrm{FeO}$, os elementos-traço também possuem um papel importante na diferenciação entre olivinas mantélicas e olivinas cognatas ao fundido. Por ser, geralmente, o primeiro mineral silicático a se cristalizar a partir de magmas gerados no manto, a composição dos elementos-traço em olivina possui potencial para elucidar a história dos processos de fusão e metassomatismo no manto e a história inicial de cristalização desses magmas (Foley et al., 2013).

Embora as concentrações de elementos-traço sejam muito baixas em olivina, a análise de alta precisão de LA-ICP-MS possui limites de detecção adequados para a quantificação destes elementos. Com esta finalidade, foram efetuadas 19 análises pontuais de elementos menores e traços nas mesmas populações de olivina (também em núcleos e bordas) em que foram feitas análises por microssonda eletrônica. Os dados completos, bem como os limites de detecção e erros associados encontram-se nas Tabela C.I a C.XXV do Apêndice C.

As concentrações detectadas para os elementos $P, R b, Y$ e REE não apresentaram valores em conformidade com o padrão de qualidade adotado (valores maiores que a incerteza $2 \sigma$ ) ou mantiveram-se abaixo dos limites de quantificação (LQ) do equipamento. Os cristais de olivina apresentam enriquecimento em $\mathrm{Ni}$ nos núcleos (>2200 ppm) e os elementos Mn, Ti, V e Sc apresentam enriquecimento nas bordas. Estas características corroboram com a interpretação de que as bordas são indicativas de sobrecrescimentos magmáticos. As bordas da população de megacristais apresentaram enriquecimento em $\mathrm{Na}$ e $\mathrm{Zr}$. Para os elementos $\mathrm{Co}, \mathrm{Cr}$, Zn e Al, não foram observadas diferenças de concentrações na distribuição entre núcleos e bordas.

Segundo Foley et al., (2013), olivinas mantélicas podem ser distinguidas de olivinas vulcânicas pelas baixas concentrações de $\mathrm{Ca}(<700$ ppm), $\mathrm{Ti}(<70$ ppm), Ni (<2200 ppm) e frequentemente, Cr. Brett et al. (2009) também menciona sobre os elementos $\mathrm{Ca}$ e $\mathrm{Ti}$, incluindo $\mathrm{Al}$ e $\mathrm{Ni}$ como sendo úteis na distinção de olivinas xenocristalinas. Enquanto olivinas do manto peridotítico apresentam médias restritas para os elementos citados, as concentrações em olivinas ígneas tendem a ser mais elevadas (e variáveis), definindo trends específicos que podem revelar processos metassomáticos (De Hoog et al., 2010). A Figura 7.14 apresenta os diagramas bivariantes de distribuição de elementos-traço para os cristais de olivina.

A razão V/Sc pode ser utilizada como indicador do estado de oxidação durante a fusão no manto para a população de núcleos de olivina, considerada xenocristalina. 
Os elementos $\mathrm{V}$ e Sc possuem compatibilidades similares com a estrutura da olivina, porém, em ambientes oxidantes o $V$ pode se encontrar no estado de valência $V^{5+}$, que possui menor compatibilidade na olivina, reduzindo, portanto, a razão V/Sc (Foley et al., 2013). Os dados das olivinas de Pântano indicam uma fusão em ambiente oxidante (Figura 7.15). Os elementos $\mathrm{Ca}$ e Ti podem ser úteis na determinação da natureza do agente metassomático infiltrado no manto, neste caso, porém, aparentemente essa infiltração ocorreu principalmente no fundido kimberlítico. A Figura 7.15 também apresenta o diagrama $\mathrm{Ti}$ versus $\mathrm{Ca}$ que sugere que a entrada de agentes metassomáticos ricos nesses elementos ocorreu nos sobrecrescimentos dos cristais de olivina, representativos da população de olivina cognata ao kimberlito. Os elementos $\mathrm{Ca}$ e $\mathrm{Ti}$ podem ser representativos de fundidos carbonatíticos de altas pressões (Foley et al., 2013), ou para o caso específico da intrusão Pântano, o enriquecimento em Ti pode destar relacionado ao processo de contaminação crustal.

Fundidos de piroxenitos derivados a partir de crosta oceânica reciclada podem ser reconhecidos em olivinas vulcânicas pelas correlações de $\mathrm{Mn}, \mathrm{Al}, \mathrm{Sc}$ e Co em adição ao Ni (Foley et al., 2013), enquanto granada peridotitos, espinélios peridotitos e granada-espinélio peridotitos podem ser reconhecidos a partir de correlações de Li, $\mathrm{Mn}, \mathrm{Zn}, \mathrm{Co}, \mathrm{Cu}, \mathrm{Ni}$ versus Fo (De Hoog et al., 2010). Nos gráficos bivariantes dos elementos $\mathrm{Mn}, \mathrm{Zn}$, Co e Ni (Figura 7.15) versus Fo, observa-se que os núcleos xenocristalinos estão inseridos principalmente nos campos dos espinélios peridotitos, embora para alguns elementos, haja correlação também com os campos dos granada peridotitos. 
(a)
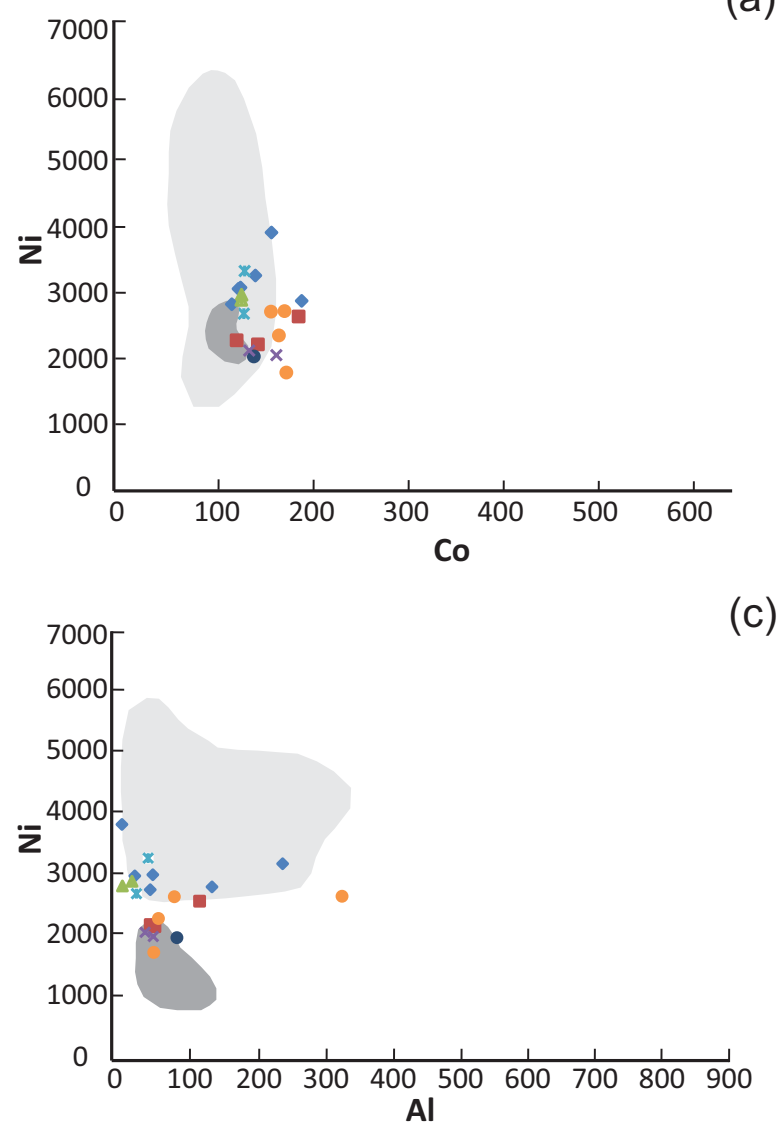

(e)

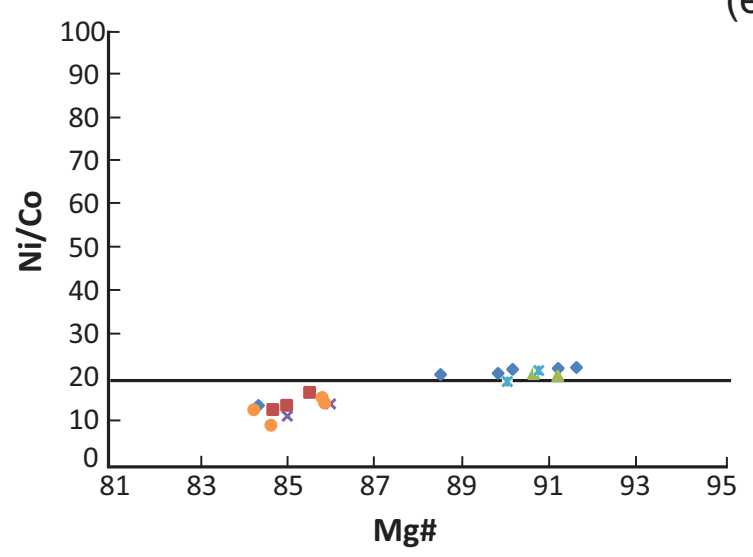

Núcleos dos microcristais

Bordas dos microcristais

Núcleos dos macrocristais

$X$ Bordas dos macrocristais

(c)

Nódulo (b)
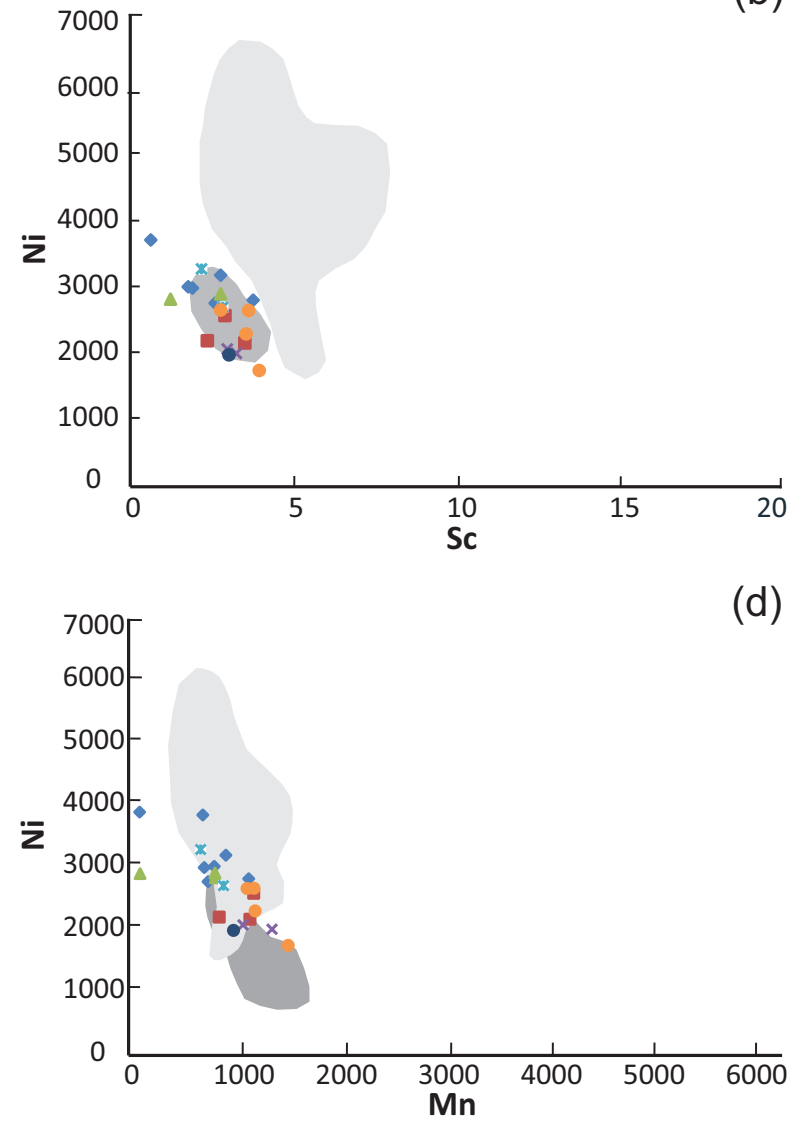

(f)

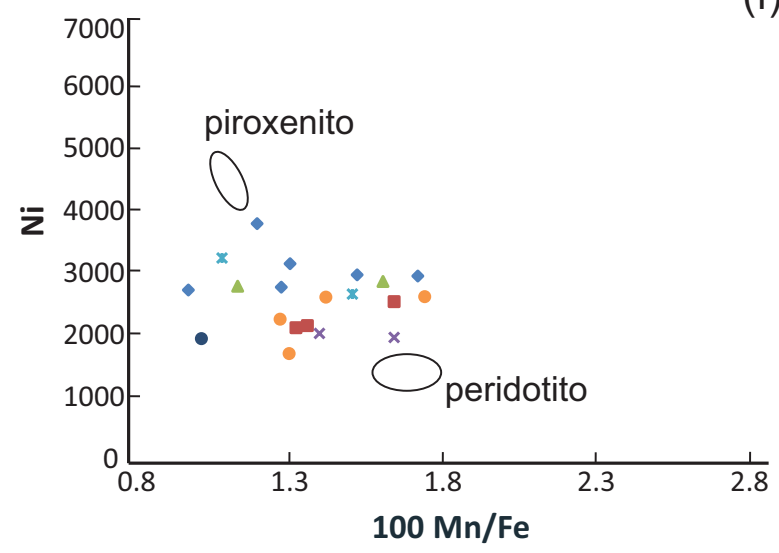

Campo dos lamproítos

Bordas dos megacristais

(d)

Figura 7.14: Diagramas bivariantes Ni vs a) Co, b) Sc, c) Al e d) Mn. Campos de kimberlitos e lamproítos de Foley et al. (2013); e) Diagrama bivariante Ni/Co vs Mg\#. Valores Ni/Co maiores que 20 podem indicar fracionamento (Sobolev et al., 2007); f) Diagrama bivariante Ni vs $100^{*} \mathrm{Mn} / \mathrm{Fe}$. Os campos indicam mistura entre peridotitos e piroxenitos que são originados pela reciclagem de crosta oceânica (Sobolev, 2007). 

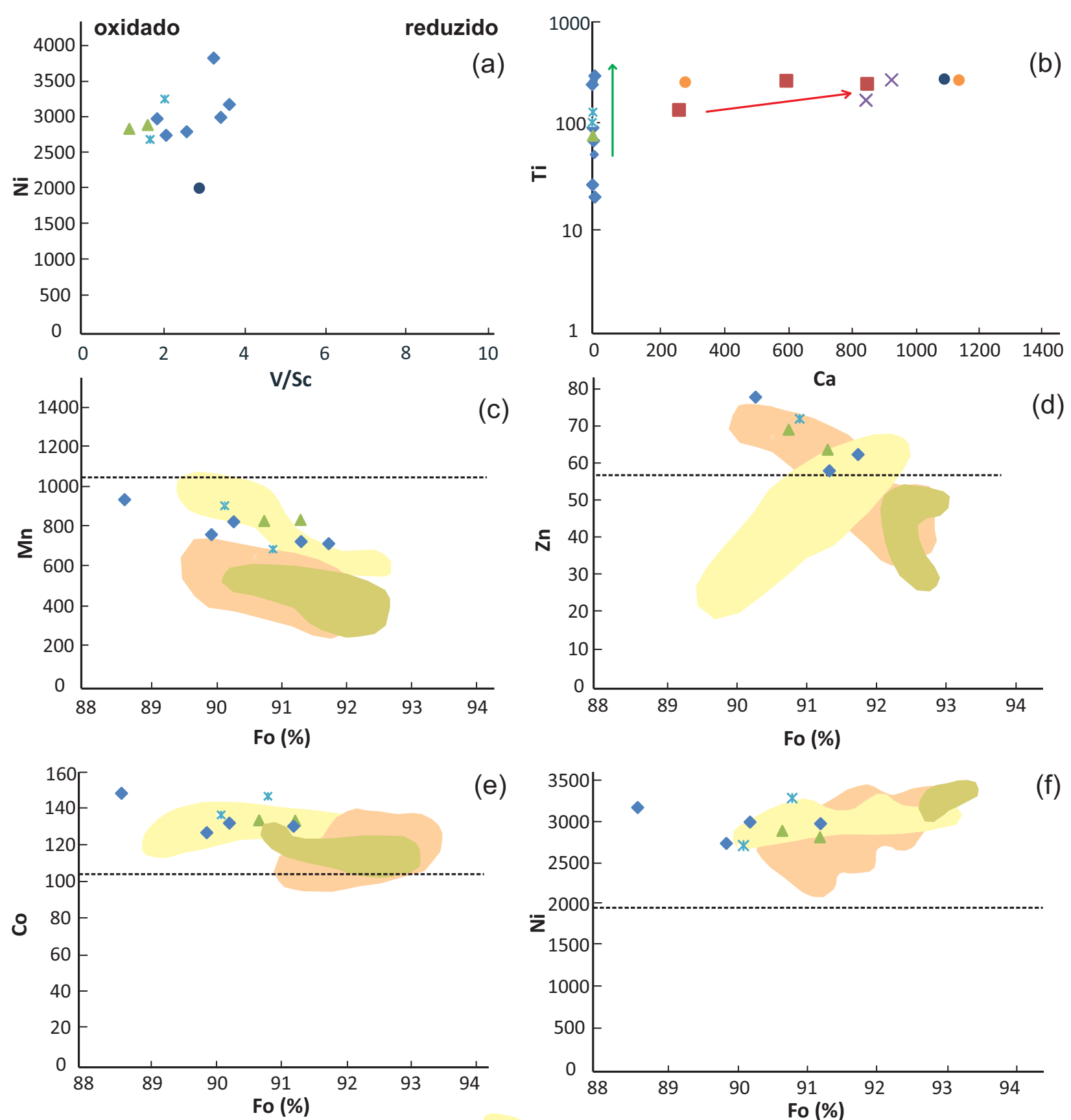

(e)

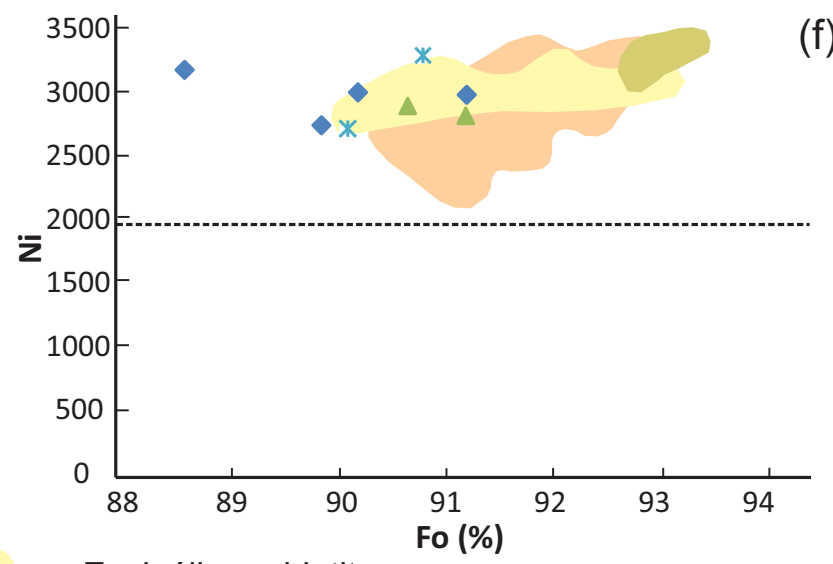

Núcleos dos microcristais

Espinélio peridotito

Bordas dos microcristais

$\triangle$ Núcleos dos macrocristais

$\times$ Bordas dos macrocristais

* Núcleos dos megacristais

Bordas dos megacristais

Nódulo

Figura 7.15: a) Diagrama Ni vs V/Sc utilizado para caracterização do estado de oxidação durante a fusão (Foley et al., 2013). Os núcleos das olivinas indicam fusão em ambiente oxidante; b) Composição de núcleos de olivina em relação a Ca vs Ti como indicador da natureza do agente metassomático na fonte mantélica; Diagramas bivariantes Fo (\% em massa) vs c) Mn d) Zn e) Co f) Ni. Campos de granada peridotito, granada-espinélio peridotito e espinélio-peridotito e linha do manto primitivo de De Hoog et al., (2010). 


\subsubsection{Monticelita}

A monticelita é um mineral petrograficamente muito semelhante a olivina forsterítica, sendo geralmente diferenciada pelas dimensões $(0,02-0,04 \mathrm{~mm})$ e baixa birrefringência. A distinção desta fase mineral é possível apenas a partir de MEV e microssonda eletrônica. Apesar de as dimensões de monticelita serem muito reduzidas, as análises foram efetuadas em núcleos, zonas intermediárias e bordas dos grãos. Foram realizadas 14 análises de monticelita na intrusão Pântano.

Segundo Deer et al. (1992), a monticelita possui uma estrutura molecular semelhante à da olivina, nas quais os íons de Ca ocupam as posições octaedrais situadas nos planos de reflexão paralelos a (001) e os íons de Mg ocupam as posições octaédricas localizadas nos centros de simetria. Podem ocorrer ocasionais substituições de $\mathrm{Ca}$ e $\mathrm{Mg}$ por $\mathrm{Fe}^{2+}$, mas a maior parte das monticelitas não se afastam de maneira significativa da composição ideal $\mathrm{CaMgSiO}_{4}$.

A fórmula estrutural das monticelitas foi calculada na base de 4 átomos de oxigênio e possuem valores similares àqueles encontrados para monticelitas de outros kimberlitos da província (Araújo et al., 2001; Melluso et al., 2008; Guarino et al., 2013). A Figura 7.16 apresenta a composição dos cristais de monticelita da matriz.

Os valores de Mg\# das monticelitas varia entre 76,2 e 81,2. Devido à dimensão dos cristais de monticelita (menores do que a dimensão do spot do laser), foi possível efetuar apenas uma análise de LA-ICP-MS em monticelita. A análise demonstrou enriquecimento principalmente para os elementos Al, Ti e Mn, com concentrações de 13.263 ppm, 1.048 ppm e 2.937 ppm respectivamente, refletindo provavelmente, alguma inclusão de outra fase mineral. Diferentemente dos demais cristais de olivina analisados, os valores encontrados para os elementos $\mathrm{Ba}, \mathrm{Rb}, \mathrm{Sr}, \mathrm{Y}, \mathrm{Nb}, \mathrm{Zr}$ e para os elementos terras raras, ficaram acima do padrão de qualidade utilizado (incerteza 2sigma), de modo que há um leve enriquecimento destes elementos na monticelita.

\subsubsection{Mica}

Foram efetuadas 49 análises por microssonda eletrônica para as populações de micas observadas como macro e microcristais, ou sob forma poiquilítica nas rochas da intrusão Pântano. Do total de análises, 29 foram efetuadas em cristais bem formados e outras 20 foram feitas em zonas dispersas das micas poiquilíticas da 
matriz, no tipo petrográfico flogopita kimberlito. As análises foram efetuadas nos diferentes tipos de zonamento detectados para os cristais, na tentativa de caracterizar cada horizonte cristalino estudado. As populações analisadas foram:

- Núcleos dos microcristais;

- Zonas intermediárias dos microcristais;

- Bordas dos microcristais;

- Núcleos dos macrocristais;

- Zonas intermediárias dos macrocristais;

- Bordas dos macrocristais;

- Zonas centrais de floopita poiquilítica da matriz

A classificação de Rieder et al. (1998), baseia-se na composição química das micas e incorpora generalizações derivadas de determinações da estrutura do mineral. Se há apenas dados químicos disponíveis, o procedimento recomendado para o cálculo da fórmula estrutural, conforme Rieder et al. (1998), é descrito a seguir:

i. Se há uma determinação confiável do conteúdo de $\mathrm{H}_{2} \mathrm{O}$, a fórmula deve ser com base em 120 mais os átomos de $\mathrm{F}$;

ii. Se não houver nenhuma determinação de $\mathrm{H}_{2} \mathrm{O}$, como em análises obtidas através de microssonda, um grupo idealizado de ânion deve ser assumido e a fórmula deverá ser baseada em 22 cargas positivas;

iii. Se não houve determinação de $\mathrm{H}_{2} \mathrm{O}$ e há razões para suspeitar que ocorreu oxidação do Fe na mica, o que causa desprotonação do grupo dos ânions, a fórmula deve ser fundamentada em 22 cargas positivas $+z$, onde $z$ é a quantidade de $\mathrm{Fe}^{3+}$.

Desta maneira, a fórmula estrutural das flogopitas foi calculada utilizando-se 22 átomos de oxigênio, seguindo-se também as recomendações de Brod et al. (2001). As micas da intrusão Pântano classificam-se composicionalmente como flogopita, uma vez que ambas as populações estudadas possuem relação Mg:Fe superior a 2:1 (principalmente para a mica poiquilítica), situando-se em uma região próxima da flogopita-tetraferriflogopita, conforme demonstrado no diagrama ternário Al-Mg-Fe (Figura 7.17).

A população de macro e microcristais possui enriquecimento em $\mathrm{TiO}_{2} \mathrm{em}$ relação a poiquilítica, com teores variáveis de 0,8 a $5,1 \%$ em massa. Nota-se que os 
microcristais possuem um ligeiro enriquecimento de $\mathrm{TiO}_{2}$ nas zonas intermediárias e as bordas dos macrocristais possuem empobrecimento em relação às demais populações de cristais, que possuem média de 3,6\% para este elemento. A flogopita poiquilítica possui teores de $\mathrm{TiO}_{2}$ entre 0,12 e 1,41\%, ou seja, empobrecida em relação aos macro e microcristais, o que é um padrão anômalo para as micas kimberlíticas que, em geral, possuem enriquecimento em $\mathrm{TiO}_{2}$.

Os teores de $\mathrm{Al}_{2} \mathrm{O}_{3}$ e $\mathrm{FeO}$ são também diferenciados entre ambas as populações estudadas, sendo os macro e microcristais mais enriquecidos em $\mathrm{Al}_{2} \mathrm{O}_{3} \mathrm{e}$ a população poiquilítica, enriquecida em $\mathrm{FeO}$ (7,85 a 13,87\%). Algumas análises de flogopita poiquilítca apresentaram empobrecimento neste elemento em relação aos valores encontrados para os cristais. Nota-se um empobrecimento no teor de $\mathrm{Al}_{2} \mathrm{O}_{3}$ observado nas bordas dos macrocristais e um enriquecimento de $\mathrm{FeO}$ nos núcleos, zonas intermediárias e bordas dos macrocristais em relação aos microcristais. Os cristais apresentam uma média de $\mathrm{Al}_{2} \mathrm{O}_{3}$ de $12,09 \%$, já a população de flogopita poiquilítica, uma média de 6,86\% para este elemento, além de maiores teores encontrados também para os elementos $\mathrm{F}$ e $\mathrm{Na}_{2} \mathrm{O}$.

A Figura 7.18 apresenta os gráficos $\mathrm{Al}_{2} \mathrm{O}_{3}, \mathrm{Na} 2 \mathrm{O}, \mathrm{BaO}, \mathrm{F}$ e $\mathrm{Mg} \#$ versus $\mathrm{TiO}_{2}$, que ilustram as diferenças composicionais observadas para as populações de flogopita. Observando-se os valores de $\mathrm{TiO}_{2}$ e $\mathrm{Al}_{2} \mathrm{O}_{3}$, é possível notar que os trends encontrados não coincidem com os trends clássicos de evolução de micas em kimberlitos e orangeítos apresentados por Mitchell (1995). As populações de macro e microcristais de micas da intrusão Pântano, quando comparadas às ocorrências de kimberlitos e kamafugitos da PAAP (campos de Araújo et al., 2001), localizam-se majoritariamente no campo dos uganditos (ou kamafugitos) descritos para a província.

As composições obtidas não se assemelham com as descrições de micas kimberlíticas e lamproíticas de outros autores como Shaikh et al. (2018), Giuliani et al. (2016) e Reguir et al., (2009), embora estes autores não tenham descrito fase poiquilítica em suas rochas. Um dos fatores responsáveis pela inexistência desta correlação com outras micas kimberlíticas é o enriquecimento em $\mathrm{Ti}$ e 0 empobrecimento em Cr. A Figura 7.18 apresenta os campos utilizados por Giuliani et al. (2016) para a descriminação das seguintes populações de flogopita encontradas em kimberlitos: xenólitos de granada peridotito metassomatizados, matriz kimberlítica e xenólitos mantélicos alto $\mathrm{Ti}$ e $\mathrm{Cr}$. A partir dos diagramas, observa-se que principalmente os núcleos e zonas intermediárias dos macrocristais estão inseridos 
no campo dos xenólitos mantélicos alto $\mathrm{Ti}$ e $\mathrm{Cr}$. As análises de bordas dos macrocristais não apresentam um trend específico, porém a maioria delas possui enriquecimento em Ti.

Os microcristais, principalmente os núcleos, apresentam-se nos campos de flogopita kimberlíticas encontrado para uma $2^{\underline{a}}$ geração desta população descrita para kimberlitos por Kargin et al. (2019). Esta população se caracteriza principalmente

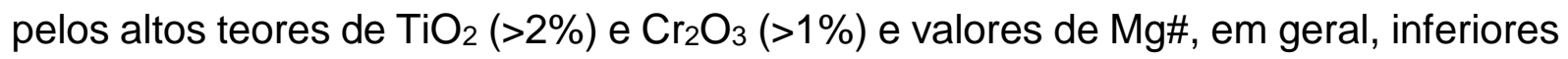
a 92. Nenhuma das análises de flogopita da intrusão Pântano apresentou Mg\# acima de 90 , o que não contribui para hipótese de que as populações sejam oriundas do manto.

Para as populações mais enriquecidas em $\mathrm{TiO}_{2}$ (que plotam além dos campos dos xenólitos mantélicos alto $\mathrm{Ti}$ e $\mathrm{Cr}$ de Giuliani et al., 2016), que é o caso de quatro análises de microcristais (dois núcleos, uma zona intermediária e uma borda) e uma borda de macrocristal, acredita-se que estas tenham se cristalizado em equilíbrio com o líquido kimberlítico hospedeiro ou podem ser produtos da interação do magma kimberlítico com rochas mantélicas em profundidade. Esta hipótese foi também sugerida por Kargin et al. (2019) para a população de $2^{\underline{a}}$ geração de flogopita, que é caracterizada pelas bordas e sobrecrescimentos nos cristais da $1^{1}$ geração. A flogopita poiquilítica não apresenta similaridade com nenhuma das populações de mica descritas para kimberlitos, o que leva a crer que esta é um produto da interação entre a crosta e o fundido kimberlítico.

Conceição et al. (2019) descreve uma população de flogopita intersticial na matriz em um kimberlito hipoabissal de assembleia mineralógica similar a da intrusão Pântano, no entanto, as composições não são similares em termos de $\mathrm{TiO}_{2}, \mathrm{Al}_{2} \mathrm{O}_{3} \mathrm{e}$ $\mathrm{Cr}_{2} \mathrm{O}_{3}$, embora sejam semelhantes nos teores de $\mathrm{FeO}$. 

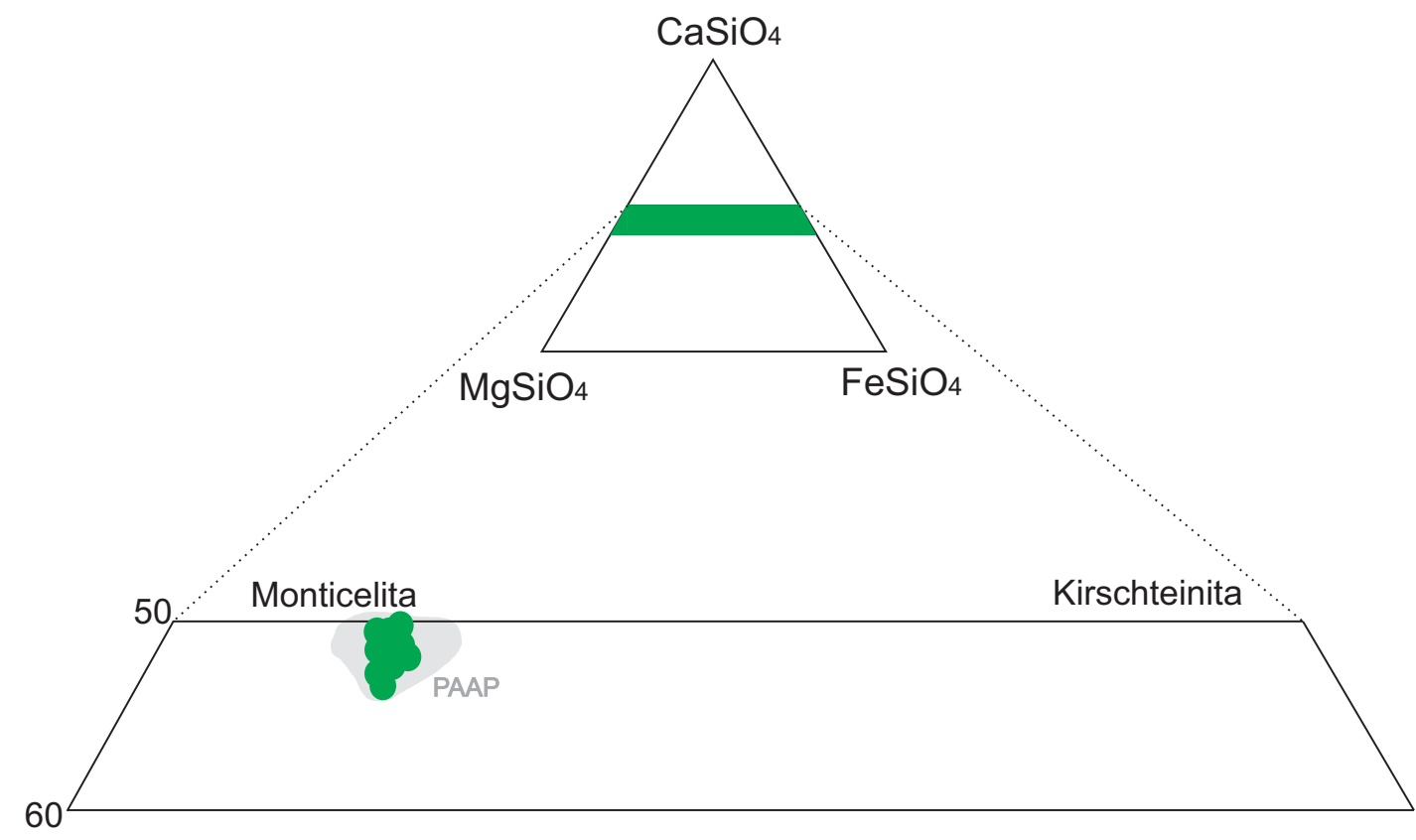

Figura 7.16: Composição dos cristais de monticelita da matriz da Intrusão Pântano no sistema $\mathrm{Ca}_{2} \mathrm{SiO}_{4}-\mathrm{Mg}_{2} \mathrm{SiO}_{4}-\mathrm{Fe}_{2} \mathrm{SiO}_{4}$. Campos da Província Alcalina Alto Paranaíba (PAAP) de Melluso et al. (2018), Araújo et al. (2001), Meyer et al. (1994) e Guarino et al. (2013).

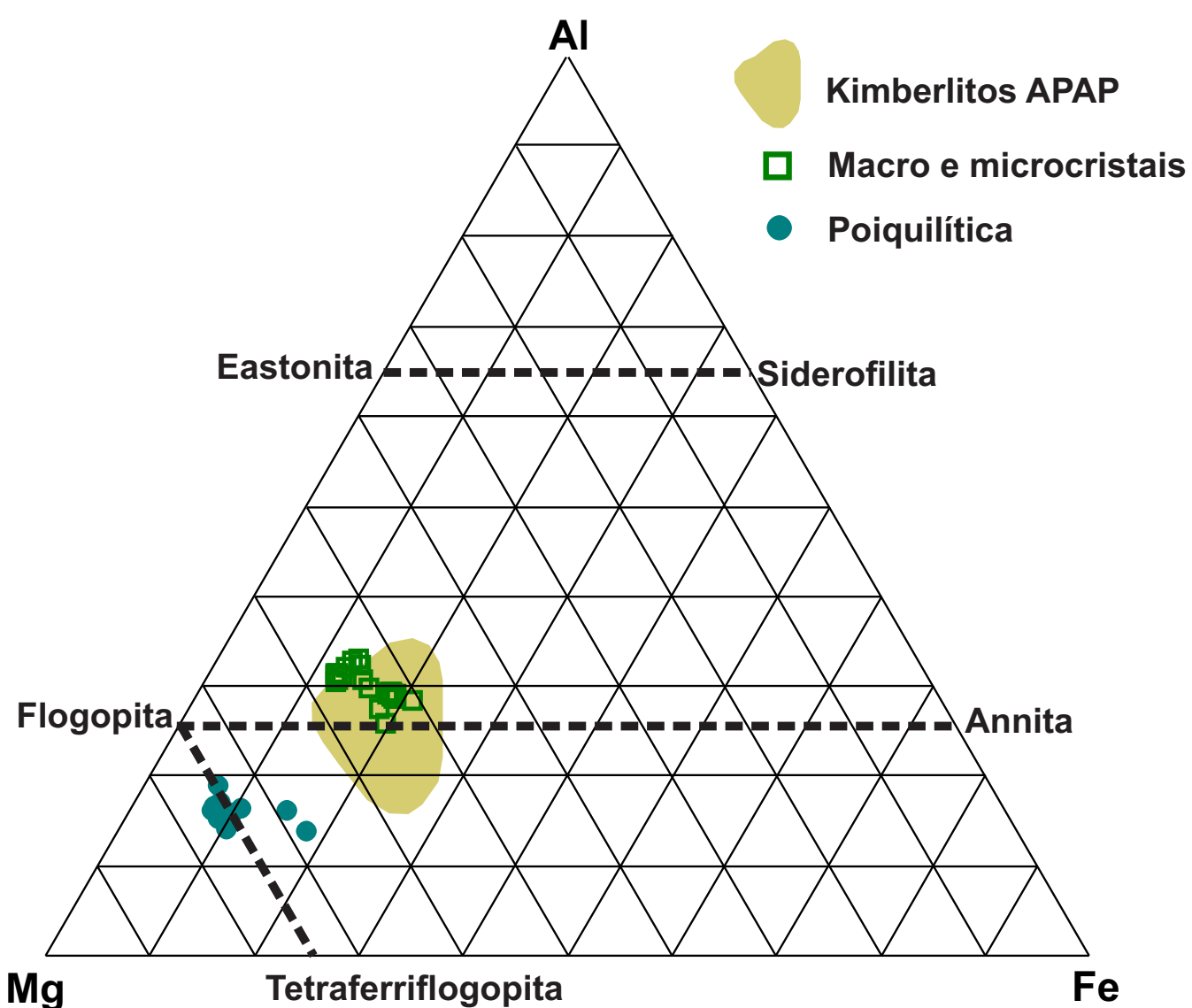

Figura 7.17: Diagrama ternário representativo da composição dos macro e microcristais de flogopita no sistema Al-Mg-Fe. Campo dos kimberlitos da PAAP de Melluso et al. (2008), Araújo et al. (2001), Meyer et al. (1994) e Guarino et al. (2013). 

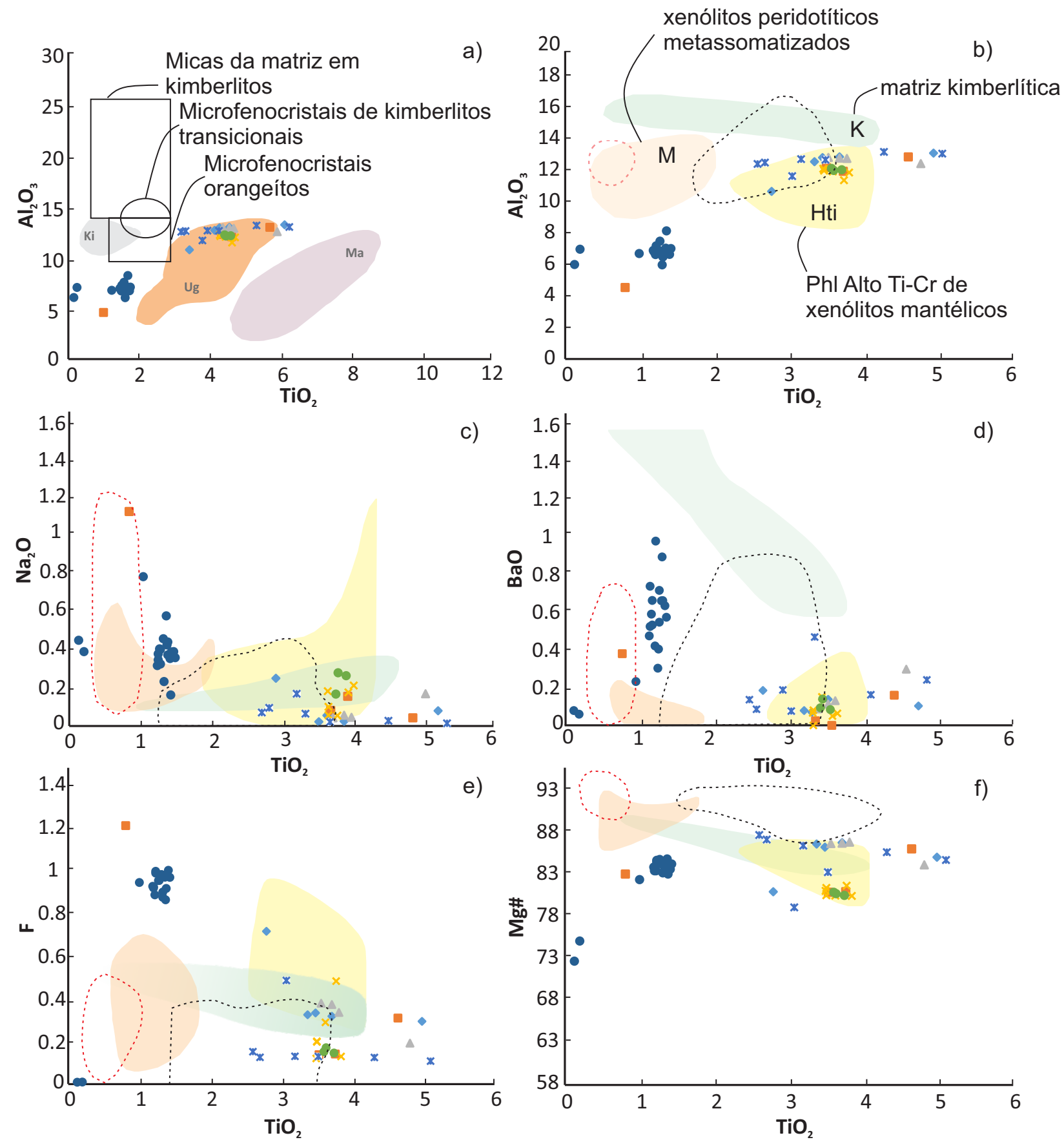

Bordas microcristais $\triangle$ Zonas intermediárias microcristais $*$ Núcleos microcristais

Bordas macrocristais $\times$ Zonas intermediárias macrocristais $\bigcirc$ Núcleos macrocristais

Poiquilítica da matriz

Ph1 flogopita kimberlítica (Kargin et al., 2018)

Phl 2 flogopita kimberlítica (Kargin et al., 2018)

Figura 7.18: Diagramas bivariantes de macro e microcristais e flogopita poiquilítica da matriz. Campos de a): sem preenchimento (Mitchell, 1995); campos preenchidos Ki: kimberlitos; Ug: uganditos; Ma: mafuritos da PAAP (Araújo, 2001). Campos de b) a f): xenólitos de granada peridotito metassomatizados (M); matriz kimberlítica (K) e xenólitos mantélicos alto Ti-Cr (Hti) de Giuliani et al. (2016). Campos pontilhados de distintas populações de flogopitas kimberlíticas (Kargin et al., 2019). 
As análises de LA-ICP-MS indicam que os núcleos dos microcristais representam a população que possui o maior enriquecimento em $\mathrm{Cr}$, com uma média de $4.272 \mathrm{ppm}$ (aproximadamente $0,62 \%$ em $\mathrm{Cr}_{2} \mathrm{O}_{3}$ ). Em geral, as bordas são empobrecidas neste elemento, embora uma análise de borda de microcristal tenha apresentado um valor de 10.480 ppm (1,53\% em $\left.\mathrm{Cr}_{2} \mathrm{O}_{3}\right)$. A maioria das análises de $\mathrm{Cr}$ para flogopita poiquilítica apresentaram valores abaixo do padrão de qualidade

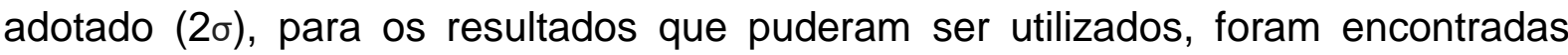
concentrações com uma média de 285 ppm.

Alguns cristais apresentaram análises com altas concentrações de $\mathrm{Ba}$, sendo os maiores valores detectados para as bordas dos micro e macrocristais (544 a 16.904 ppm). As concentrações de Ba encontradas para flogopita poiquilítica são bastante variáveis, com valores entre 10 a 5.874 ppm. As concentrações de $\mathrm{Cr}$ e Ni não apresentam valores similares àqueles já descritos para outros kimberlitos da literatura que apresentam, em geral, concentrações mais elevadas para estes elementos. Reguir et al. (2009) encontrou valores de $\mathrm{Cr}>12.030$ ppm e Ni>1.600 ppm para kimberlitos em outras localidades do mundo, no entanto, outros autores como Giuliani et al. (2016), já descreveram suítes empobrecidas em $\mathrm{Cr}$ (bordas de microcristais e cristais da matriz).

Há enriquecimento nas concentrações de $\mathrm{Mn}$ em todas as populações estudadas, além de enriquecimento também dos elementos $\mathrm{Sr}$, Sc e Cs principalmente nas bordas dos cristais e em algumas análises de flogopita poiquilítica. 


\section{Discussões}

8.1. Distintas populações de xenólitos, xenocristais, antecristais e cristais cognatos

A composição do manto superior tem implicação direta na formação de magmas de naturezas distintas, de basálticos a alcalinos. Os fragmentos do manto superior são transportados em magmas básicos a ultrabásicos, sobretudo magmas alcalinos como kimberlitos, lamproítos e lamprófiros, além de membros da série dos basaltos alcalinos, nefelinitos e melilititos (Nixon 1987; Mitchell, 1986).

Magmas primários em equilíbrio com mineralogia típica do manto superior (olivina + ortopiroxênio + clinopiroxênio +- granada +- espinélio) devem ter alto número de $\mathrm{Mg}$ (Mg\#>0.7), alto $\mathrm{Ni}$ (>400-500 ppm), alto $\mathrm{Cr}$ (>1000 ppm) e $\mathrm{SiO}_{2}$ inferior a 50\%, mas ocorrem casos de magmas derivados de regiões mantélicas metassomatizadas, aonde esses critérios já não podem ser aplicados (Wilson, 1989). Os peridotitos contem abundante olivina e quantidades menores e variáveis de ortopiroxênio e clinopiroxênio, podendo apresentar fases aluminosas como plagioclásio, espinélio ou granada e representam o tipo de rocha mais abundante no manto (Pearson et al., 2003).

Para o caso das olivinas, os critérios para que estas sejam discriminadas como oriundas de peridotitos do manto são (e.g., Arndt et al., 2010; Brett et al., 2009; Bussweiler et al., 2015; Foley et al., 2013; Kamenetsky et al., 2008):

- Mg\# maior ou igual a 0,90

- NiO maior ou igual a 0,3 wt\% ( 2350 ppm)

- MnO menor ou igual a 0,15 wt\% ( 1160 ppm)

- CaO menor ou igual a 0,1 wt\% ( 715 ppm)

Esses filtros devem excluir as olivinas magmáticas que se apresentam tanto como bordas quanto como cristais cognatos/fenocristais (Arndt et al., 2010; Brett et al., 2009; Bussweiler et al., 2015; Howarth and Taylor, 2016; Kamenetsky et al., 2008) e também olivinas pertencentes a suíte megacristalina pobre em Cr (Moore, 2012; Moore \& Costin, 2016). 
Considerando os filtros mencionados, as análises químicas das populações de olivina permitiram a distinção entre dois trends: os núcleos, com zonamentos normais, abruptos, representativos de xenocristais do manto e as bordas, interpretadas como cognatas ao fundido kimberlítico. As características químicas observadas para os núcleos, tais como teores de Fo (>89), Ni, Al, Ca e Cr corroboram com a hipótese de que esta população seja oriunda do manto, conforme já foi descrito por uma série de autores (Brett et al., 2009; Bussweiler et al., 2015; Ammanatti et al., 2016; Shaikh et al., 2018).

De acordo com a Figura 7.15, nota-se que os núcleos de olivina estão inseridos principalmente nos campos dos espinélio peridotitos, definindo, portanto, a origem xenocristalina mantélica desta população. Outros cristais de olivina foram interpretados como oriundos da desagregação de cristais maiores, como macro e megacristais peridotíticos. A Figura 8.1 demonstra que alguns núcleos plotam nos campos dos granada peridotitos, o que é observado principalmente para os microcristais.

Em relação aos núcleos de olivina mais ricos em $\mathrm{Fe}$ (Fo82,9-84,9), acredita-se que os mesmos sejam antecristais, geneticamente relacionados ao fundido kimberlítico, porém, formados em um estágio inicial do magmatismo, conforme já foi cogitado por outros autores (Howarth \& Taylor, 2016; Kamenetsky et al., 2014; Kopylova et al., 2009; Moore \& Belousova, 2005; Shaikh et al., 2018). Uma outra possibilidade para origem destes núcleos seria a cristalização a partir de um pulso inicial do magmatismo kimberlítico.

Para as populações de flogopita, a interpretação se torna mais complexa, pois as composições desta fase mineral encontradas para intrusão Pântano não se encaixam perfeitamente em nenhum modelo já descrito para outros kimberlitos na literatura. Para a população de flogopita poiquilítica da matriz, nota-se uma similaridade com as flogopitas de tipos kimberlíticos contaminados descritos por Caro et al. (2004). O enriquecimento em Ti dos macro e microcristais sugere que estes estejam relacionados ao fundido kimberlítico.

A Figura 8.2 apresenta o gráfico bivariante em que constam os campos composicionais de flogopitas em kimberlitos contaminados em relação a seus teores de $\mathrm{Al}_{2} \mathrm{O}_{3}$ e $\mathrm{TiO}_{2}$. Os referidos campos foram apresentados por Caro et al. (2004), que descreveram kimberlitos contaminados em maior grau representados pela associação de flogopita, melilita e diopsídio e os kimberlitos contaminados em menor grau pela 
associação de flogopita, monticelita e serpentina. Adicionalmente, o gráfico apresenta os campos e o trend de flogopita descritos para intrusão Pântano por Meyer et al. (1991) e observa-se que as populações de flogopita estudadas no presente trabalho acompanham o trend e os campos descritos pelo autor.

Nota-se que as composições de flogopita poiquilítica da intrusão Pântano plotam no campo dos kimberlitos com menor grau de contaminação. As populações de cristais não estão inseridas nos campos de kimberlitos contaminados, apresentando mais um indício de que estes podem ter sido gerados no fundido kimberlítico, caracterizando estas populações como cognatas. Os zonamentos complexos observados em flogopita podem ser representativos de diferentes pulsos kimberlíticos, levando à geração dos antecristais, ou podem estar relacionados a interação do fundido com fluídos mantélicos metassomatizados.

A interação do fundido kimberlítico com peridotitos metassomatizados ricos em mica, pode levar a formação de novos minerais como a flogopita, evidenciando metassomatismo modal (Nannini, 2016). No entanto, as populações de cristais de flogopita da intrusão Pântano, se associadas a "xenocristais mantélicos clássicos", assemelham-se de maneira mais coerente às micas da suíte MARID (Dawson, 1977) por possuírem baixo $\mathrm{Cr}$, Mg\# entre 82 e 88 e porque esta suíte é representativa de rochas que cristalizaram em um magma similar ao kimberlítico, em um ambiente oxidante do manto superior. Como nenhum dos cristais de flogopita apresenta Mg\#>92, não é possível afirmar que estes seriam oriundos de um manto peridotítico. Para análise de flogopita que apresentou concentração de $\mathrm{Cr}$ acima de 10.000 ppm, associada ao alto teor de $\mathrm{Ti}$, esta poderia se encaixar como oriunda de xenólito mantélico de alto $\mathrm{Ti}$ e $\mathrm{Cr}$ (conforme citado na Seção 7.3.3) do campo descrito por Kargin et al (2019). 


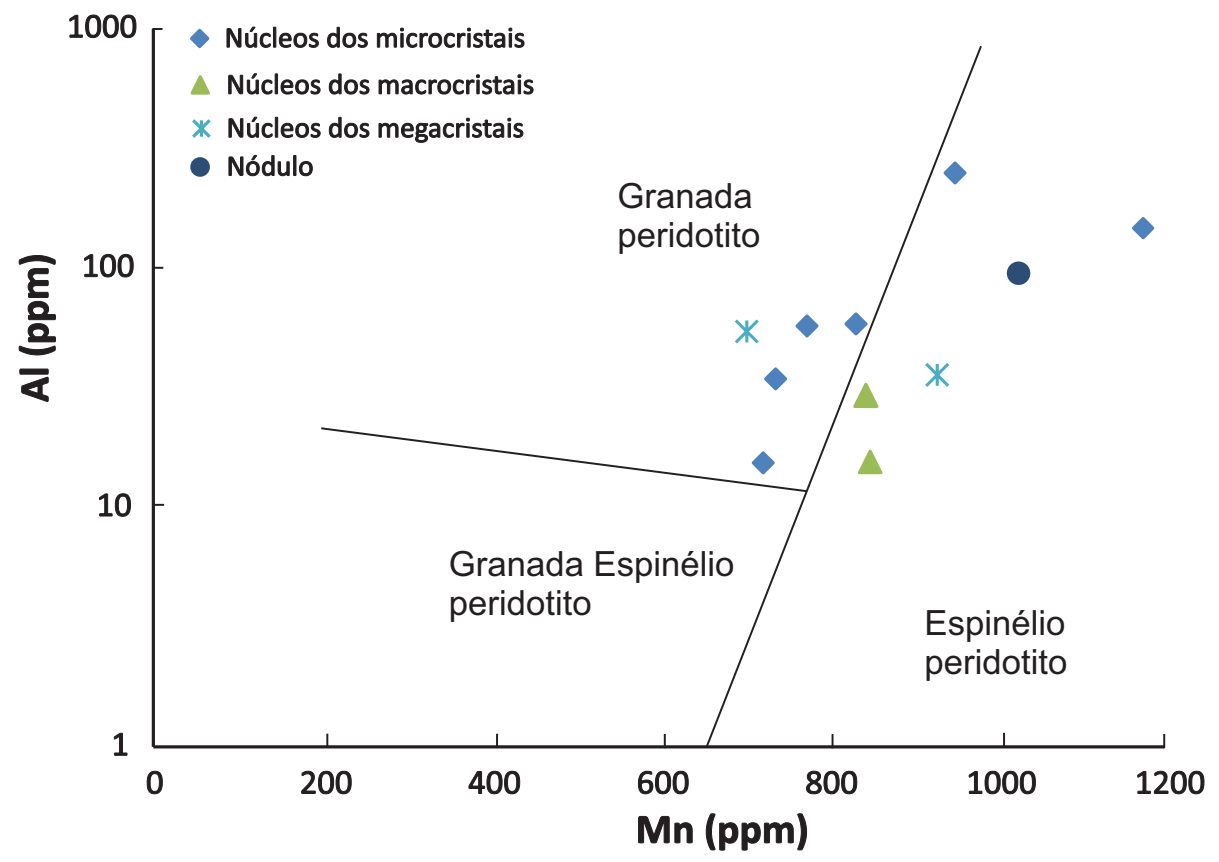

Figura 8.1: Diagrama bivariante Al vs $\mathrm{Mn}$ identificando os campos dos granada peridotitos, granada espinélio-peridotitos e espinélio peridotitos. Campos de De Hoog et al. (2010).

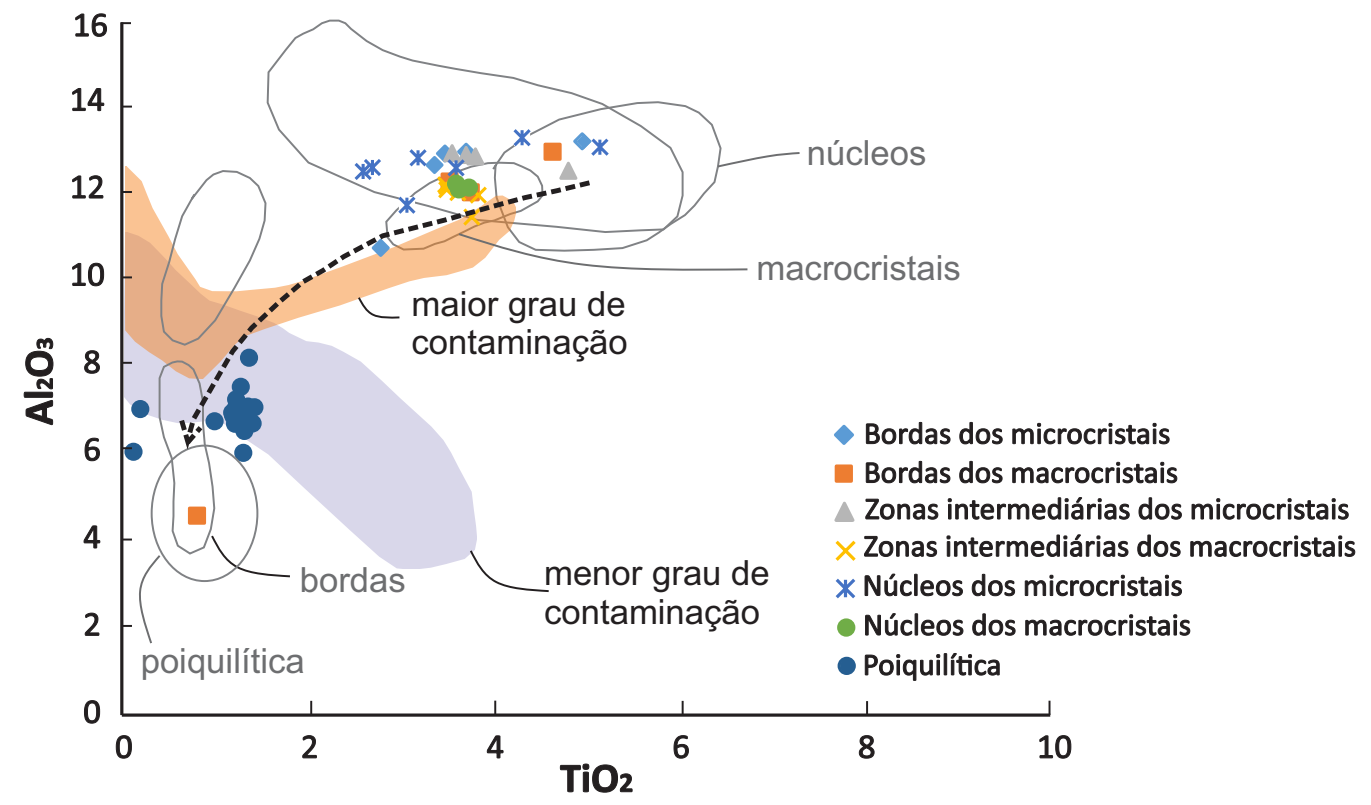

Figura 8.2: Diagrama bivariante $\mathrm{Al}_{2} \mathrm{O}_{3}$ vs $\mathrm{TiO}_{2}$ (\% peso) com os campos representativos de kimberlitos com maior e menor grau de contaminação e trends das populações de flogopita encontrados por Meyer et al. (1991), que corroboram com as populações encontradas nas análises do presente trabalho. Os kimberlitos mais contaminados possuem flogopita associada a melilita e diopsídio e os menos contaminados flogopita associada a monticelita e serpentina (Caro et al., 2004). 


\subsection{Estimativa de magma kimberlítico sem a influência de xenocristais}

Conforme apresentado nas seções anteriores, foram identificadas diversas populações de olivina, que podem ser classificadas, em grande parte, como xenocristais. No passado, acreditava-se que os macrocristais anédricos de olivina representariam xenocristais derivados do manto, enquanto cristais euédricos deste mineral na matriz representariam fenocristais (Mitchell, 1986), no entanto, essa perspectiva foi modificada nas duas últimas décadas (Brett et al., 2009; Bussweiler et al., 2016).

Para a intrusão em estudo, a partir da combinação de critérios petrográficos e de química mineral, uma porcentagem muito representativa das olivinas (de 16 a 33\% em volume deste mineral na rocha) pode ser considerada representativa de xenocristais. Logo, estas populações devem ser descontadas (deixando as bordas, consideradas cognatas) no cálculo estimado de um possível fundido kimberlítico originador da intrusão Pântano. Sparks (2013) mostra que o caráter híbrido dos kimberlitos ocorre desde os seus estágios mais profundos de formação, quando assume-se que líquidos carbonatíticos ricos em $\mathrm{CO}_{2}$ reagem progressivamente com reservatórios mantélicos, consumindo ortopiroxênio e levando ao enriquecimento do líquido em $\mathrm{SiO}_{2}$ e $\mathrm{MgO}$. Desta maneira, entende-se que estas estimativas ainda sejam representativas de um magma híbrido e, portanto, possuem limitações.

Apesar de serem rochas híbridas, kimberlitos habissais não passaram por processos significativos de degaseificação ou de brechamento, muito menos por estágios explosivos (Cas et al., 2008). Assim, a reconstituição proposta pretende eliminar das composições de rocha total apenas as proporções volumétricas que são representativas de xenocristais e xenólitos. Este tipo de estudo já foi aplicado para outras ocorrências, como nos estudos de Patterson et al. (2009), Kjarsgaard et al. (2009), Howarth et al. (2011), Guarino et al. (2013) e Soltys et al. (2018). Adicionalmente ao que foi apresentado nos trabalhos mencionados, a presente dissertação inclui o cálculo para os elementos-traço, utilizando-se o mesmo balanço de massa considerado para elementos maiores e menores.

A partir das análises de imagem descritas na seção 6.2.1, obteve-se uma estimativa da percentagem de megacristais, macrocristais e microcristais de olivina, a fase mineral dominante na intrusão. Tais análises de imagem englobaram também alguns macrocristais de flogopita, considerando uma estimativa de que $2 \%$ dessa 
população seria de origem xenocristalina. Descontando-se a porcentagem das populações de olivina e flogopita consideradas representativas de xenocristais, foi realizado um balanço de massa para o cálculo de um possível líquido kimberlítico primitivo (Tabela D.I, Apêndice D). O cálculo foi realizado através da aplicação da equação II (Ubide et al., 2012):

$$
\text { II) } \quad \mathrm{CRTi}=\mathrm{CMti}(1-\Sigma \mathrm{v})+\Sigma(\mathrm{CMgi}+\mathrm{v})
$$

onde, CRTi, CMti e CMgi são as concentrações do elemento i na rocha total, na matriz e nos mega/macrocristais, respectivamente, e $v$ é o volume modal dos megacristais de flogopita e olivina. Desta forma, a equação aplicada (equação III) para as rochas da intrusão Pântano é:

$$
\mathrm{CMti}=\mathrm{CRTi}-\mathrm{COI} \times \mathrm{vOl}-\mathrm{CPhl} \times \mathrm{vPhl}
$$

III)

$$
(1-\mathrm{vOl}-\mathrm{vPhl})
$$

A composição deste líquido foi comparada com a possível composição de líquidos de outros kimberlitos hipoabissais da literatura. As composições estimadas para os possíveis magmas kimberlíticos apresentam menores quantidades de $\mathrm{SiO}_{2}$, $\mathrm{MgO}$ e $\mathrm{Fe}_{2} \mathrm{O}_{3}$, sendo o empobrecimento mais expressivo dado pelo teor de $\mathrm{MgO}$. A Figura 8.3 apresenta a variação da composição calculada para os fundidos de Pântano comparativamente aos fundidos da literatura calculados (Patterson et al., 2009; Kjarsgaard et al., 2009; Soltys et al., 2018) em relação aos elementos MgO, $\mathrm{SiO}_{2}$ e $\mathrm{FeO}$. Os maiores enriquecimentos do possível fundido kimberlítico em relação a rocha total são de $\mathrm{TiO}_{2}, \mathrm{Al}_{2} \mathrm{O}_{3}, \mathrm{CaO}$ e $\mathrm{K}_{2} \mathrm{O}$, com os respectivos valores de $7 \%$, $3,2 \%, 15 \%$ e 3,5\%. A partir desta composição, segundo a classificação de Foley et al. (1987), o magma gerador da intrusão Pântano pode ser considerado como ultrapotássico, ou seja, de afinidade kamafugítica.

Nos estágios finais de cristalização, já em regiões próximas à superfície, a monticelita torna-se a fase silicática dominante (Mitchell, 2008). A ocorrência de monticelita com perovskita na matriz indica que o magma possuía atividade de sílica muito baixa do sistema (Carmichael et al., 1970), com teores elevados de cálcio, ferro e titânio. 
A Figura 8.4 apresenta o diagrama box and whisker para fundidos de kimberlitos, orangeítos e olivina lamproítos mundo afora (Pearson, 2019) comparados aos fundidos calculados para intrusão Pântano. Nota-se que em relação aos fundidos das demais ocorrências, o teor de $\mathrm{TiO}_{2}$ é mais elevado para o possível fundido da intrusão Pântano, sendo também notáveis as diferenças entre o teor de $\mathrm{MgO}$. De maneira geral, o fundido da intrusão assemelha-se melhor aos fundidos de olivina lamproítos. Neste diagrama também foi plotado o ocelo descrito por Meyer (1991). Segundo o autor, esta análise seria representativa de uma porção da rocha com ocelo e flogopita abundante, ou seja, representativa de um fundido contaminado. Observase que em relação aos fundidos da intrusão Pântano, o ocelo possui maiores teores de $\mathrm{SiO}_{2}$ e $\mathrm{Al}_{2} \mathrm{O}_{3}$, o que sugere a interação do líquido kimberlítico com uma componente crustal enriquecida nestes elementos.

$\mathrm{O} \mathrm{TiO}_{2}$ ocorre em altas concentrações nos magmas alcalinos e em flogopitas de leucititos, melilititos e lamproítos (Mitchell \& Bergman, 1991; Mitchell, 1995). Para o caso do fundido de Pântano, esse enriquecimento pode estar associado aos altos valores de $\mathrm{TiO}_{2}$ encontrados para as flogopitas e à distribuição de perovskita encontrada no kimberlito.

A Figura 8.5 ilustra a composição de elementos-traço para o quartzito encaixante da intrusão Pântano, para as amostras de kamafugitos e kimberlitos da PAAP normalizadas por condritos, além das composições de rocha total e dos líquidos calculados para intrusão, descontando-se as fases xenocristalinas. Nota-se pela Figura 8.5a que kimberlitos e kamafugitos possuem enriquecimento em elementostraços bastante semelhantes. A Figura $8.5 \mathrm{~b}$ denota que os kamafugitos são mais enriquecidos em Cs e Eu e não possuem anomalia negativa em $P$, porém as distribuições químicas para os outros elementos são muito similares. Os líquidos calculados para intrusão Pântano apresentaram aumento principalmente nas concentrações de La e Ce. 

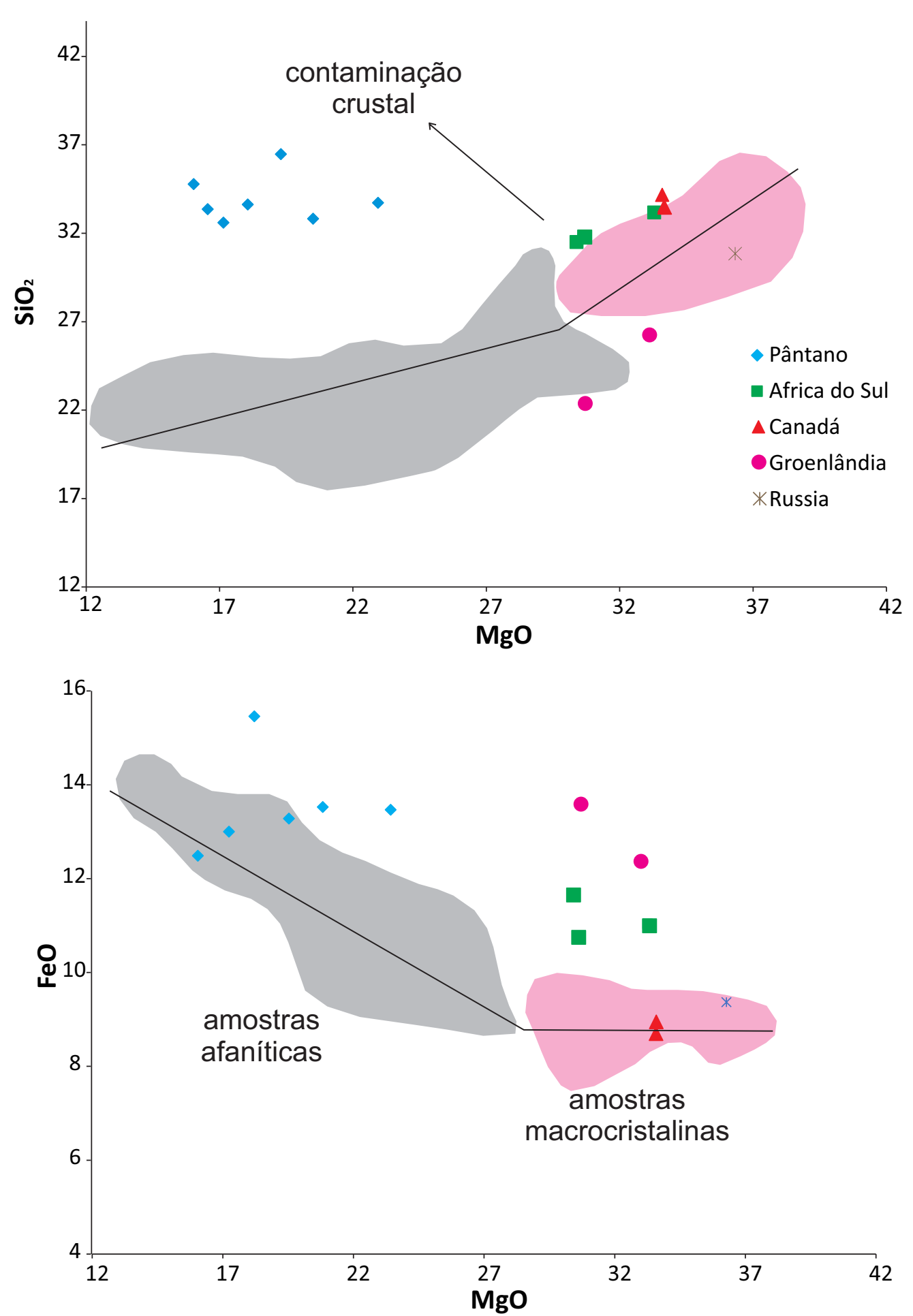

Figura 8.3: Comparação dos fundidos calculados para Pântano e outros fundidos calculados na literatura (Patterson et al., 2009; Soltys et al., 2018) em termos de $\mathrm{SiO}_{2}, \mathrm{MgO}$ e $\mathrm{FeO}$. Os campos representam amostras de kimberlitos afaníticos (cinza) e de kimberlitos macrocristalinos (Le Roex, 2003). As linhas representam os trends das suítes, onde a mudança na inclinação aproxima a composição do magma parental, de acordo com Le Roex (2003). 

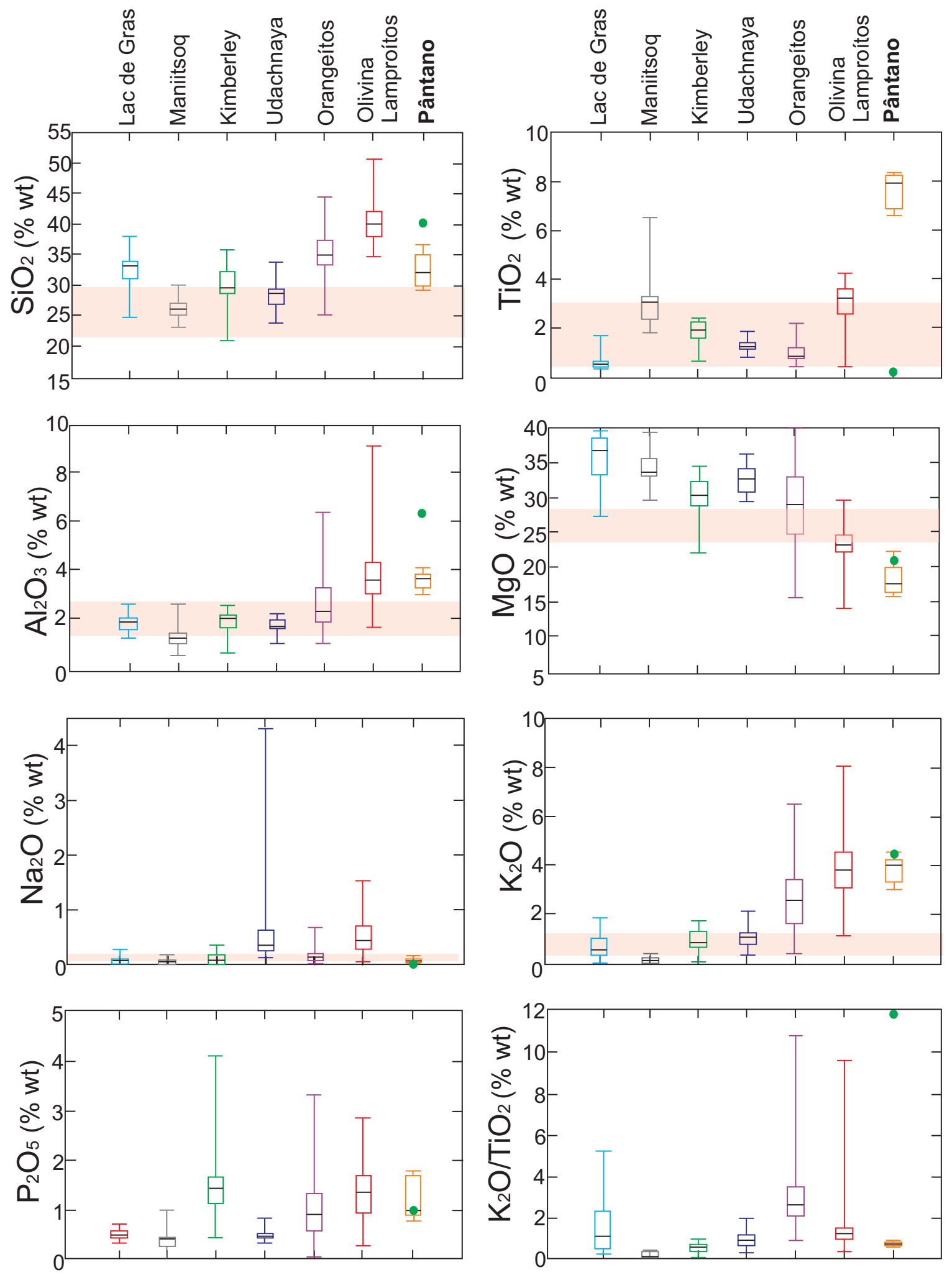

Figura 8.4: Diagramas box and whisker para fundidos de kimberlitos, orangeítos e olivina lamproítos mundo afora comparados ao fundido da intrusão Pântano. A barra central indicada nas caixas é a mediana do valor e as linhas rosadas indicam a média e intervalos das composições dos fundidos primários. O círculo verde representa o ocelo de Meyer (1991), considerado como vidro contaminado descrito na intrusão Pântano. Diagrama modificado de Pearson et al. (2019). Observa-se que a composição do fundido da intrusão Pântano possui maiores semelhanças aos fundidos de olivina lamproítos. 
a)

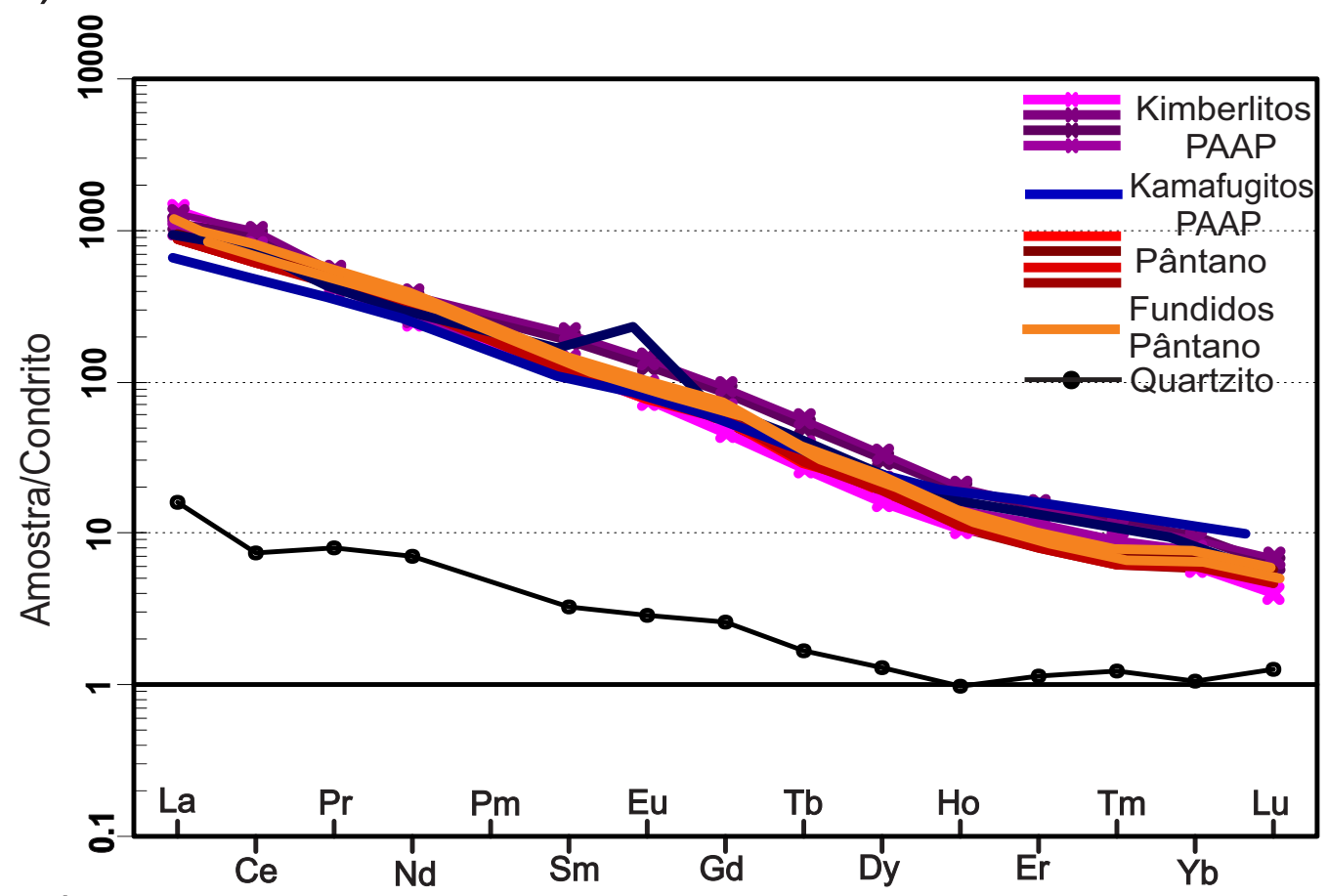

b)

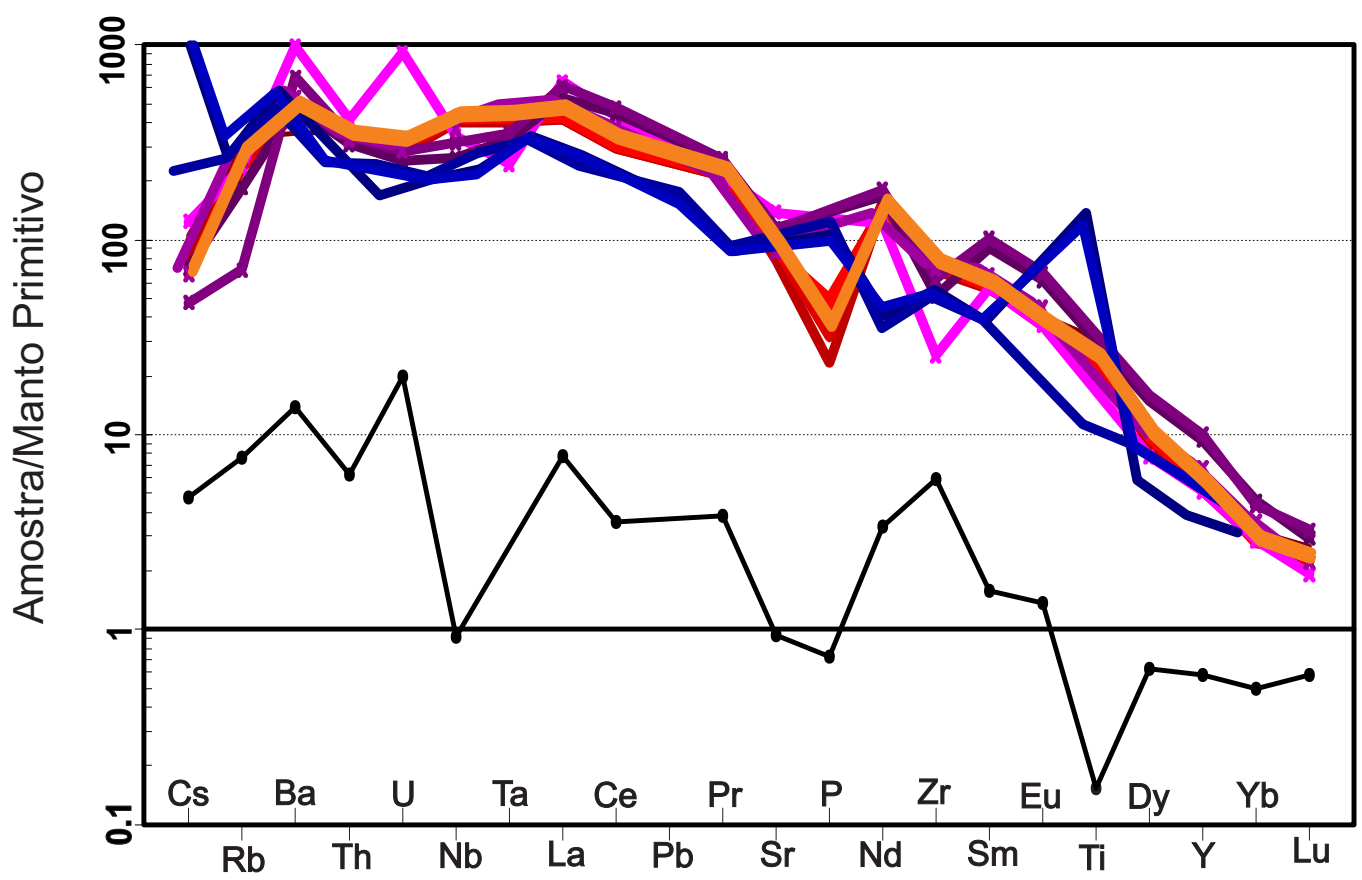

Figura 8.5: a) Padrão de variação de elementos terras raras normalizados pelo condrito de Boynton (1984). b) Padrão de variação de elementos terras raras normalizados pelo manto primitivo de McDonough and Sun (1995). Os diagramas apresentam dados para as rochas da intrusão Pântano, seus fundidos calculados e seu quartzito encaixante e para kimberlitos e kamafugitos da Província Alcalina Alto Paranaíba (PAAP). Dados da PAAP compilados de Melluso et al. (2008) e Guarino et al. (2013). 
O critério de classificação entre kimberlitos e kamafugitos é predominantemente mineralógico, sendo tal classificação dada pelas proporções modais e composicionais encontradas nas rochas (Le Maitre, 2002). Os kamafugitos são caracterizados pela presença de melilita, kalsilita e leucita, sendo que a leucita foi descrita para intrusão Pântano por Danni e Scartezini (1990).

Através das composições calculadas é possível fazer algumas inferências acerca da pressão de geração e temperatura dessas rochas. Ao ser plotada a composição de dos fundidos de Pântano no diagrama $\mathrm{MgO} / \mathrm{CaO}$ vs $\mathrm{SiO}_{2} / \mathrm{Al}_{2} \mathrm{O}_{3}$ baseado em Gudfinnson e Presnall (2005), é possível estimar uma pressão para geração desse magma a partir da fusão de um peridotito carbonatado de pouco mais de 5GPa (Figura 8.6). Foram consideradas neste gráfico apenas as amostras menos contaminadas (Kmtc), que plotam no campo dos kimberlitos da PAAP.

À título de comparação com os líquidos obtidos da intrusão Pântano no presente trabalho, foi feito o cálculo do possível líquido gerador do "leucitito" de Pântano (Danni e Scartezini, 1990) e das rochas analisadas por Meyer et al. (1991), descontando-se as porcentagens de olivina xenocristalina descrita pelos autores. As composições obtidas pelo trabalho de Meyer et al. (1991) são muito similares às obtidas no presente trabalho, o que é coerente, já que foram descritos tipos petrográficos similares em ambos os estudos. O fundido obtido para o leucitito, descontando-se as porcentagens de olivina de $24,8 \%$ e $27,9 \%$ apresentaram composições que sugerem um maior grau de contaminação para estas rochas. A Figura 8.7 apresenta as composições dos fundidos de Pântano e do leucitito no diagrama $\mathrm{MgO} / \mathrm{CaO}$ vs $\mathrm{SiO}_{2} / \mathrm{MgO}$ de Sparks et al. (2009), aonde é possível notar que os leucititos são, realmente, mais contaminados, corroborando com a hipótese de que a leucita seria formada a partir de contaminação crustal. Adicionalmente, foram plotadas as amostras da intrusão Pântano descritas por Guarino et al. (2013) e Carlson et al. (1996). Ambas as amostras estão inseridas no campo de kimberlitos enriquecidos em sílica, conforme ocorre para as amostras do tipo petrográfico Kmtc.

Complementarmente aos gráficos apresentados para os fundidos calculados, a Figura 8.9 apresenta o diagrama de C.I. versus In Si/Al utilizado por Kjarsgaard et al. (2009) para separação de kimberlitos contaminados dos não contaminados crustalmente. Observa-se que as amostras do tipo petrográfico monticelita kimberlito plotam no campo "sem contaminação", enquanto as amostras dos tipos flogopita e diopsídio juntamente com as do leucitito, apresentam um trend na direção da região 
aonde estariam plotadas as composições das possíveis rochas encaixantes (quartzito do presente trabalho, filito de Saar, 2009 e granito de Lima, 2019).

Razões de elementos-traços também são úteis na distinção de processos de contaminação. A Figura 8.10 apresenta o diagrama de C.I. vs $\mathrm{Rb} / \mathrm{Sr}$ ilustrando os diferentes graus de contaminação observados para os tipos monticelita, flogopita e diopsídio. É possível notar que o tipo monticelita é o menos contaminado, seguido pelos tipos flogopita e diopsídio. Essas diferenças corroboram com as composições encontradas para flogopita poiquilítica, que estaria associada a um menor grau de contaminação. A Figura 8.9 ilustra que a maioria das amostras da intrusão Pântano plotam no campo indicativo de contaminação crustal (Le Roex, 2003). 


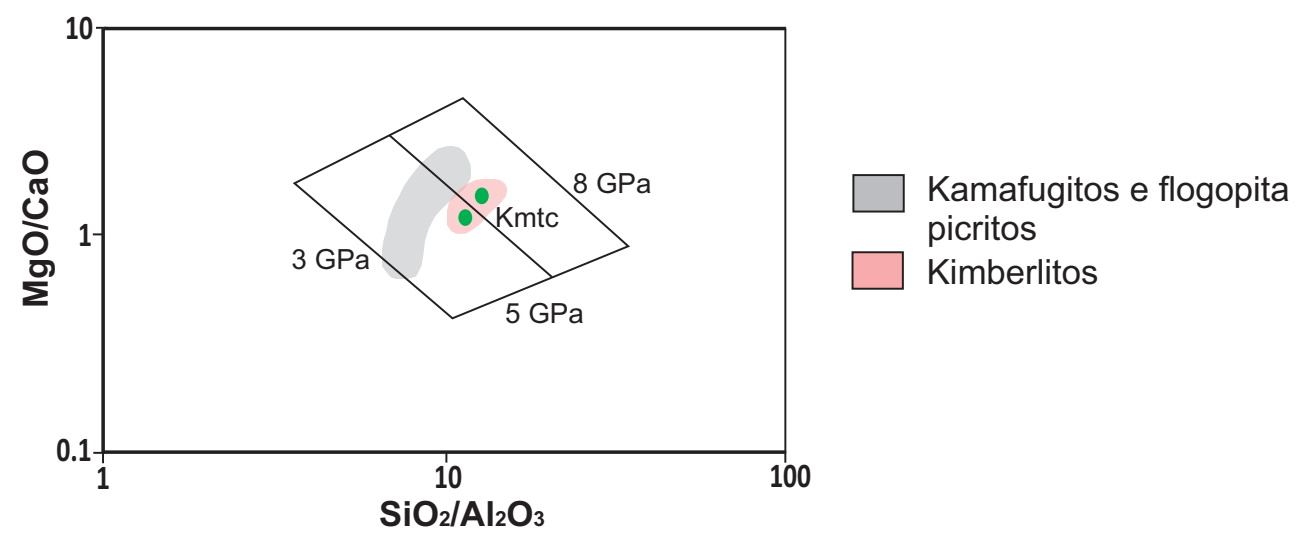

Figura 8.6: Diagrama de Gufinnson e Presnall (2005) para estimativa de pressão de geração do fundido de Pântano a partir da fusão de um peridotito carbonatado. Foram considerados apenas os fundidos calculados interpretados como menos contaminados (Kmtc). Campos de kamafugitos, flogopita picritos e kimberlitos da PAAP. Modificado de Guarino et al. (2013).

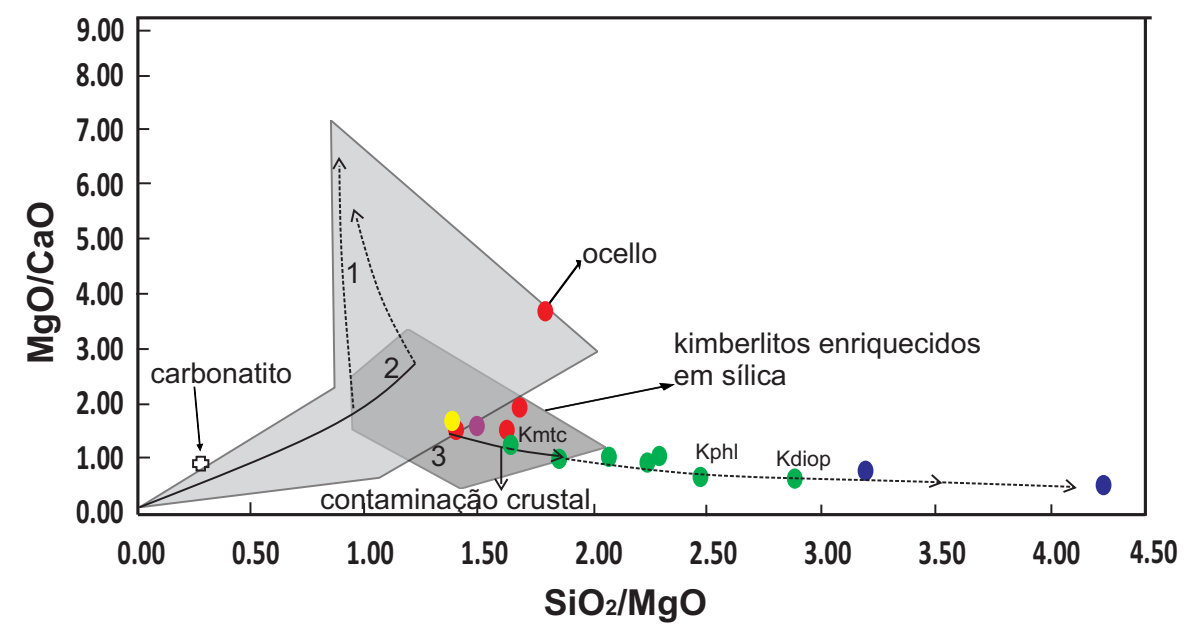
- Kimberlito Carlson et
Trends de contaminação
- Leucitito al. (1996)
1) Xenocristais de olivina
- Meyer et Guarino et
2) Assimilação Opx
al. (1991) al. (2013)
3) Xenólitos crustais

Figura 8.7: Diagrama $\mathrm{MgO} / \mathrm{CaO}$ versus $\mathrm{SiO}_{2} / \mathrm{MgO}$ para as rochas de Pântano classificadas como kimberlito (este trabalho, Meyer et al. 1991, Carlson et al. 1996 e Guarino et al., 2013) e classificadas como leucitito (Danni e Scar tezini, 1990). O ocelo trata-se do vidro descrito por Meyer et al. (1991). Campos e trends de Sparks et al. (2009) apresentando evidências de contaminação crustal. 


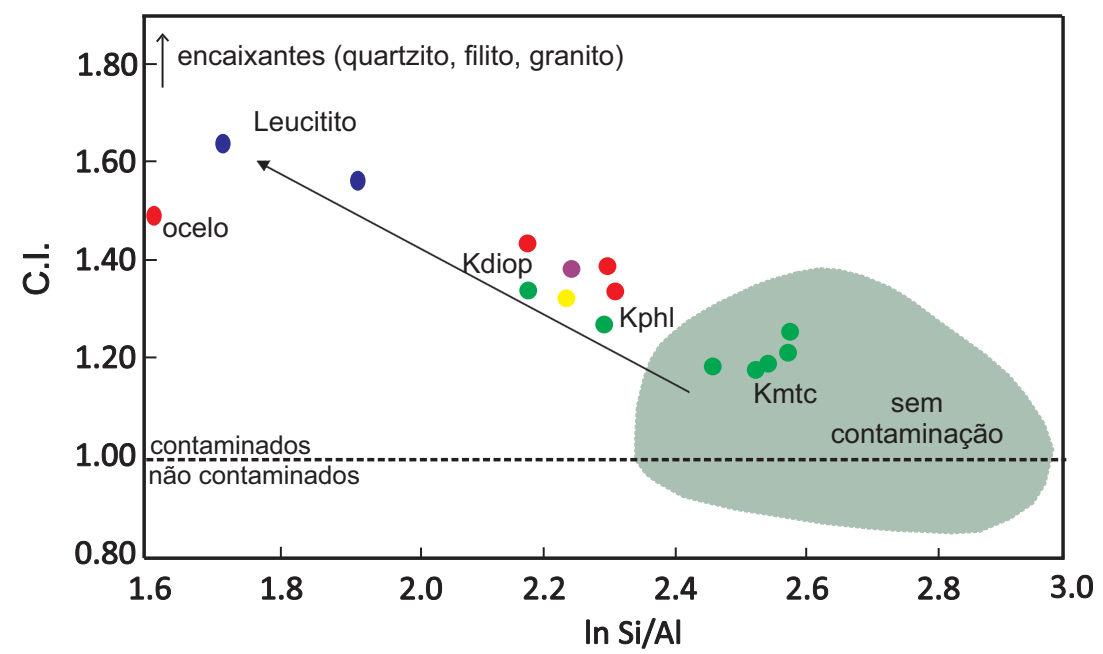

Figura 8.8: Diagrama bivariante do índice de contaminação crustal (C.I.) versus In Si/Al. Campo de "sem contaminação crustal" de Kjarsgaard et al. (2009). Mesma simbologia da Figura 8.7. Kdiop: diopsídio kimberlito; Kphl: flogopita kimberlito; Kmtc: monticelita kimberlito. Nota-se trend indicativo de contaminação crustal (em direção às encaixantes) dos diferentes tipos petrográficos observados para intrusão Pântano e para o leucitito (Danni e Scartezini, 1990).

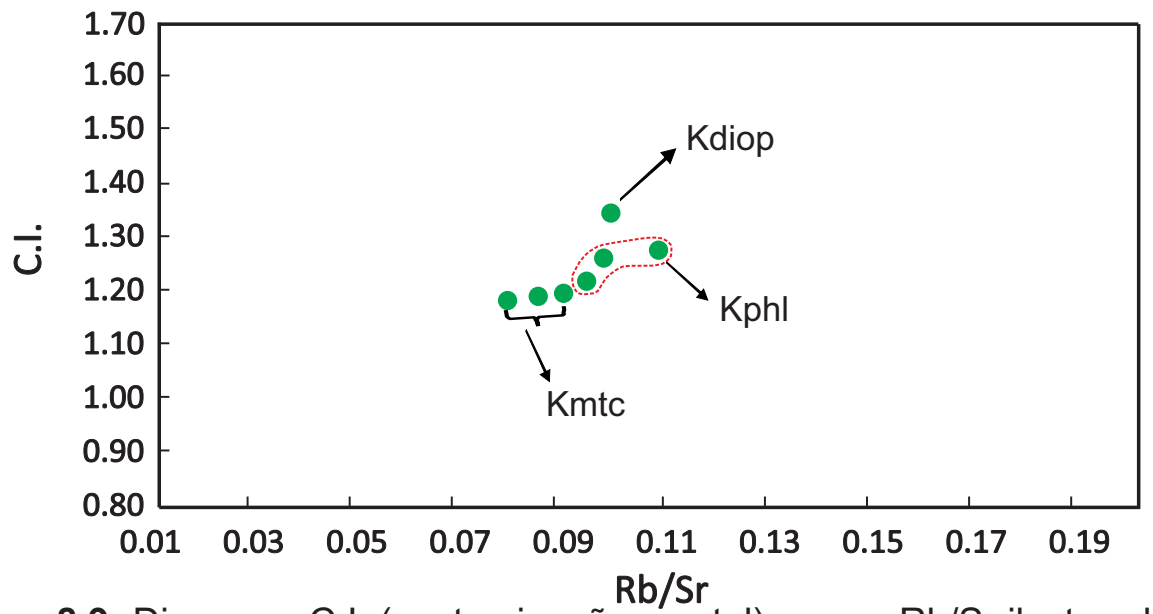

Figura 8.9: Diagrama C.I. (contaminação crustal) versus $\mathrm{Rb} / \mathrm{Sr}$ ilustrando as composições dos diferentes tipos petrográficos da intrusão Pântano em relação aos níveis de contaminação crustal. Nota-se que o tipo menos contaminado possui menor C.I. e menor razão Rb/Sr. Kmtc: monticelita kimberlito; Kphl: flogopita kimberlito; Kdiop: diopsídio kimberlito. 


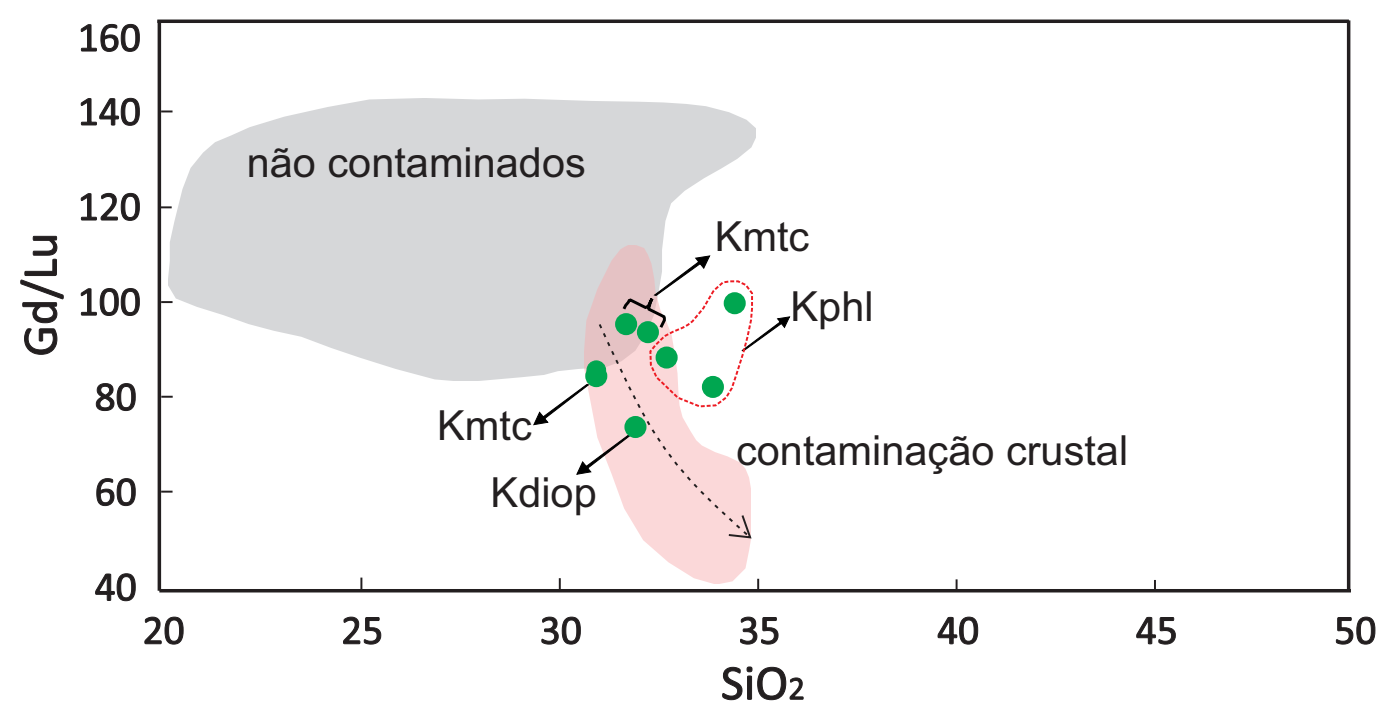

Figura 8.10: Diagrama $\mathrm{Gd} / \mathrm{Lu}$ versus $\mathrm{SiO}_{2}$ ilustrando o decaimento da razão $\mathrm{Gd} / \mathrm{Lu}$ em amostras contaminadas. Campos e trend de contaminação crustal de Le Roex et al. (2003). Nota-se diferenças composicionais entre os diferentes tipos petrográficos classificados para intrusão. 


\subsection{Evidências de processos de sistema aberto e contaminação crustal}

Os processos de mistura tendem a ser intensificados pela combinação de fenômenos físicos e químicos. A atuação de fatores dinâmicos, embora ocorra também em câmaras magmáticas, tende a ser mais efetiva durante a ascensão e transporte dos magmas a níveis crustais mais rasos (Blake e Campbell, 1986; Zorpi et al., 1989; Collins et al., 2000). Aspectos mineralógicos e geoquímicos fornecem evidências de que a intrusão Pântano passou por processos de contaminação crustal. Em termos de petrografia, é possível observar diversas feições e texturas que sugerem a ocorrência de processos ocorridos em sistema aberto:

- Enclaves magmáticos com borda de reação com diopsídio e flogopita (Figura 7.5) sugerem que houve interação de um líquido magmático com material externo, evidenciando um processo de mingling. Observa-se "trilhas" de diopsídio ao redor dos xenólitos crustais, indicando tanto o fluxo magmático quanto a reação entre a matriz kimberlítica e o material crustal;

- Substituição de monticelita por diopsídio indicativa da adição de sílica ao sistema (Figura 7.2I);

- Xenólitos quartzíticos apresentam feições sugestivas de fusão parcial e reação com o magma ultrabásico. No interior dos xenólitos observa-se espurrita (figuras 7.6a e b), mineral relacionado ao metamorfismo de contato entre líquidos carbonáticos e rochas silicáticas. Ocorrências deste mineral em rochas de afinidade kimberlítica com contaminação crustal não são comuns, porém são bem documentadas as ocorrências de espurrita em hornfels, skarns e rochas cálcio-silicáticas (Reverdatto, 1970; Zhang et al., 2013) devido a metamorfismo de contato;

- Corrosão dos cristais de olivina (textura do tipo embayment), além de olivinas parcialmente ou completamente serpentinizadas, principalmente nas regiões circundantes aos xenólitos crustais (Figura 7.2c);

- Perovskitas parecem ser "capturadas" por um líquido que é gerado, aparentemente, a partir da fusão de xenólitos crustais. Esta "captura" de cristais ao redor dos xenólitos sugerem que ocorreu fusão parcial dos xenólitos crustais;

- Pseudomorfos de leucitas (Figura 7.3e) são descritas nas zonas consideradas como contaminadas (tipo flogopita kimberlito), aonde é possível encontrar cristais de olivina desagregados, xenólitos crustais, além de material vítreo. A ocorrência de pseudomorfos de leucita, várias destas às bordas de xenólitos crustais sugere 
interação do magma kimberlítico com uma rocha que teria feldspatos em sua composição, como por exemplo, granitoides que ocorrem na região;

- Regiões com altas porcentagens de flogopita poiquilítica (com composições diferenciadas das observadas para os macro e microcristais) sugerem que houve assimilação de xenólitos no líquido kimberlítico, como descrito por Caro et al. (2004);

- São observadas diferentes feições de matriz a depender dos tipos petrográficos das rochas descritas. Claras diferenças podem ser notadas em porções aonde são descritos xenólitos crustais (matriz amarelada e possivelmente com algum componente vítreo com flogopita ou matriz escura com finos cristais de diopsídio) e no tipo monticelita (menos contaminada, que apresenta matriz escura e homogênea).

- Segundo Danni \& Scartezini (1990), no interior do corpo intrusivo, em meio a um espesso solo argiloso, afloram blocos métricos de silexitos representativos de restos de teto da intrusão. Localmente, também são encontrados filitos aonde observa-se perturbações nas atitudes das foliações, além da ocorrência de silicificação de origem hidrotermal. Estas são evidências de que houve interação da intrusão com uma rocha rica sílica e com um filito, possivelmente do Grupo Canastra.

Conforme descrito por Mitchell (1995), diopsídio como fase primária é ausente em kimberlitos, no entanto, pode ocorrer em uma matriz contaminada. Quando presente, o diopsídio da matriz é uma fase secundária, sendo a cristalização deste mineral induzida pela assimilação de xenólitos silícicos (Clement, 1982). Em uma matriz em que é observada alta porcentagem de monticelita, como é o caso da descrita para intrusão Pântano, a adição de sílica no sistema pode ser representada pela seguinte equação (Skinner \& Marsh, 2004):

$$
\text { IV) } 2 \mathrm{CaMgSiO}_{4}+\mathrm{CaCO}_{3}+\mathrm{MgO}+4 \mathrm{SiO}_{2}=3 \mathrm{CaMgSi}_{2} \mathrm{O}_{6}+\mathrm{CO}_{2}
$$

$$
\text { (Monticellita) (Calcita) (Diopsídio) }
$$

A perda de $\mathrm{CO}_{2}$ em kimberlitos leva a formação de monticelita e diopsídio no lugar de calcita (Caro et al., 2004). O aumento das porcentagens de $\mathrm{SiO}_{2}$ oriundas de fundidos crustais, poderia levar a exsolução de $\mathrm{CO}_{2}, \mathrm{o}$ que inclusive, explicaria o fato de não ser observada nenhuma fase carbonatada nos minerais constituintes da intrusão.

Em relação aos pseudomorfos de leucita descritos para o tipo mais contaminado da intrusão, as mesmas puderam ser identificadas pois Danni e 
Scartezini (1990), que inicialmente haviam descrito a intrusão Pântano como um leucitito, contendo cerca de $12-13 \%$ de leucita. Os autores descrevem que muitas vezes as leucitas (apenas pseudomorfos) encontravam-se substituídas por zeólitas, mas no caso das rochas analisadas para o presente trabalho, todos os cristais apresentaram-se substituídos por flogopita muito alterada.

Conforme discutido na Seção 7.2, os valores dos índices de contaminação crustal (C.I.) calculados para intrusão Pântano com a geoquímica de rocha total, denotaram valores de 1,2 a 1,4, sendo este último encontrado para o tipo petrográfico que possui diopsídio da matriz. Os valores de C.I. calculados com a geoquímica de rocha total do trabalho de Danni e Scartezini (1990) apontam valores de 1,5 e 1,6, ou seja, indicando que estas rochas estariam mais contaminadas. Acredita-se que a leucita possa estar também relacionada a contaminação crustal a partir da assimilação de uma rocha granítica com feldspato potássico em sua composição, conforme a equação V, descrita por Yoder (1986):

V)

$$
\begin{aligned}
& 3 \mathrm{Fo}+2 \mathrm{Lc}+2 \mathrm{H}_{2} \mathrm{O}=2 \mathrm{Ph}+\mathrm{Kf} \\
& \text { (Forsterita) (Leucita) (Flogopita) (K Feldspato) }
\end{aligned}
$$

A equação acima é representativa de uma assembleia típica de minettes. Gupta (1972) estudou as relações de fase de forsterita, diopsídio e leucita, concluindo que a coexistência destas três fases + líquido poderiam coexistir em equilíbrio a uma temperatura de $1296 \pm 3^{\circ} \mathrm{C}$. A posterior desestabilização da leucita nesse sistema seria oriunda tanto do resfriamento durante a ascensão do magma, quanto de um evento adicional de contribuição crustal através da adição de sílica, que liberaria voláteis do líquido e levou a desestabilização do feldspatóide através da equação VI (Luth, 1967):

VI) $\quad$ Fo + Lc + Vapor $=10 \mathrm{Ph}+$ Líquido

(Forsterita) (Leucita) (Flogopita)

É sugerido, portanto, que as possíveis leucitas identificadas para intrusão Pântano retratam um processo de contaminação crustal pela incorporação de rochas encaixantes em um magma kimberlítico. Este tipo de contaminação envolveu a geração de uma nova fase mineral que ocorreu quando o magma estaria ainda suficientemente quente para iniciar a fusão em sítios preferenciais incorporando 
fundidos parciais das rochas encaixantes (Beard et al., 2005), e estes fundidos ao interagirem com líquidos kimberlíticos, precipitariam leucita.

\subsubsection{Modelagem do processo de contaminação crustal}

Modelagens geoquímicas podem simular as taxas de contaminação e cristalização de magmas máficos/primitivos na crosta terrestre. A partir das evidências petrográficas, buscou-se a obter um modelo geoquímico de mistura, baseando-se no processo de mixing entre dois componentes, um kimberlítico e um crustal. Foram utilizados para a modelagem de mistura do presente trabalho, os líquidos calculados a partir do desconto das populações xenocristalinas conforme discutidos na seção acima e, como pólo crustal, foram utilizados os modelos de fundidos parciais de granitos encaixantes obtidos por Lima (2019), além de dados de possíveis encaixantes locais compiladas da literatura. Também foram incluídos na modelagem, os líquidos obtidos a partir do desconto das populações de olivina dos leucititos da intrusão Pântano descritas por Danni \& Scartezini (1990).

A partir da geoquímica de rocha total do granito encaixante das intrusões kimberlíticas Indaiá I e II, Lima (2019) calculou modelos termodinâmicos com o software Rhyolite MELTS 1.2 (Gualda e Ghiorso, 2015), determinando-se a composição de elementos maiores do fundido, os constituintes restíticos da fusão parcial e suas proporções em condições de equilíbrio a partir da composição de rocha total da encaixante. Foram utilizados como parâmetros intensivos de cristalização a temperatura de $750^{\circ} \mathrm{C}$, na zona de quebra da biotita e a pressão de $1 \mathrm{Kbar}$. Os constituintes voláteis foram estimados a partir dos valores de LOI das análises de rocha total. Para determinação da concentração de elementos-traço no fundido, foi efetuado um balanço de massa, levando-se em consideração as proporções entre líquido e fases residuais obtidas a partir da modelagem termodinâmica dos elementos maiores. Os detalhes e equações utilizadas no cálculo do fundido granítico constam em Lima (2019) e as composições obtidas para elementos maiores e traços e o percentual de fusão e das fases restíticas estão sumarizados na Tabela D.II do Apêndice D.

Com os dados dos fundidos calculados de Pântano do presente trabalho, dos possíveis fundidos calculados do leucitito do trabalho de Danni \& Scartezini (1990) e do fundido calculado para o granito contaminante, puderam ser efetuados testes para 
obtenção de curvas de mistura. Plotando-se as composições dos fundidos no diagrama ternário de fases de Sparks et al. (2009), conforme pode ser observado na Figura 8.11, as composições reconstituídas do tipo monticelita kimberlito encontramse entre os campos de cristalização da forsterita, já as amostras do tipo flogopita e diopsídio kimberlito encontram-se no campo de cristalização do diopsídio. Neste gráfico, foram também plotadas as composições do fundido granítico calculado e da intrusão kimberlítica considerada como livre de contaminação crustal, Indaiá I (Lima, 2019). Os fundidos calculados de Indaiá I e do possível granito contaminante formam uma linha de amarração que interceptam as amostras da intrusão Pântano, sugerindo que estas teriam sido influenciadas por um processo de contaminação crustal pelo granito.

A partir dos dados obtidos é possível obter curvas de mixing para elementos maiores e traços a partir da planilha de modelagem PETROMODELER (Ersoy, 2013), utilizando-se o fundido da rocha encaixante como polo final da mistura. Conforme mencionado nas seções acima, acredita-se que a intrusão Pântano tenha passado por diferentes graus de contaminação, o que pode sugerir a interação entre diferentes tipos de contaminante, tanto em superfície, como em profundidade, resultando nos diferentes tipos petrográficos descritos. Portanto, com o objetivo de se obter as curvas de mistura considerando a geologia local e a possibilidade de interação entre outros possíveis contaminantes, foi compilada a geoquímica de um filito do Grupo Canastra (Saar, 2009) e granitos de alto K da Faixa Brasília (Pimentel et al., 1996).

Finalmente, foram utilizados como polos de mistura, além do fundido granítico de Lima (2019), o quartzito encaixante da intrusão Pântano e dados de rocha total do filito de Saar (2009). Os granitos de Pimentel et al. (1996) são apresentados como campos nas curvas de mixing, representativos de uma possível contaminação em profundidade. Como polo inicial do modelo, foi considerada a amostra do líquido considerado menos contaminado, representativo do tipo monticelita kimberlito. $\mathrm{Na}$ modelagem, foram considerados ainda os fundidos calculados para intrusão Pântano a partir dos dados de Meyer et al., (1991) e do fundido de Indaiá II, também descrito por Lima et al. (2019) como um kimberlito contaminado. Nos modelos de mistura gerados a partir da concentração de elementos maiores utilizando-se o filito como contaminante (Figura 8.12 a e b), nota-se que os fundidos dos leucititos (Danni e Scarztezini, 1990) e das rochas de Meyer et al. (1991) possuem um trend que evolui na direção de rochas que tivessem menores porcentagens de sílica. $O$ fundido de 
Indaiá II cai perfeitamente na curva de mistura com o filito, considerando uma interação de 30\% com este contaminante. Os fundidos de Pântano seguem o trend de mistura, considerando uma contaminação de menos de $10 \%$ com o filito. A curva de $\mathrm{CaO}$ por $\mathrm{SiO}_{2}$ apresenta um trend coerente com uma contaminação de até $12 \%$ pelo possível filito encaixante. O fundido de Guarino et al. (2013) e do leucitito apresentam-se com os maiores teores de contaminação.

As curvas obtidas utilizando-se razões de traços (Figura $8.12 \mathrm{c} \mathrm{e} \mathrm{d}$ ) utilizando o fundido granítico de Lima (2019) como polo final indica que os fundidos da intrusão Pântano teriam de 10 a 40\% de contaminação, já o líquido calculado por Guarino et al. (2013) não se apresenta como contaminado; no entanto, ressalta-se que a autora não descreveu diopsídio em suas amostras. Para as razões $\mathrm{Rb} / \mathrm{Sr}$ considerando a mistura com o fundido granítico, obteve-se uma curva indicativa de 10 a $40 \%$ de contaminação. Não foi possível plotar as amostras do leucitito (Danni e Scarztezini., 1990) e dos dados de Pântano de Meyer et al. (1991), pois os autores não apresentam dados de elementos-traços. 


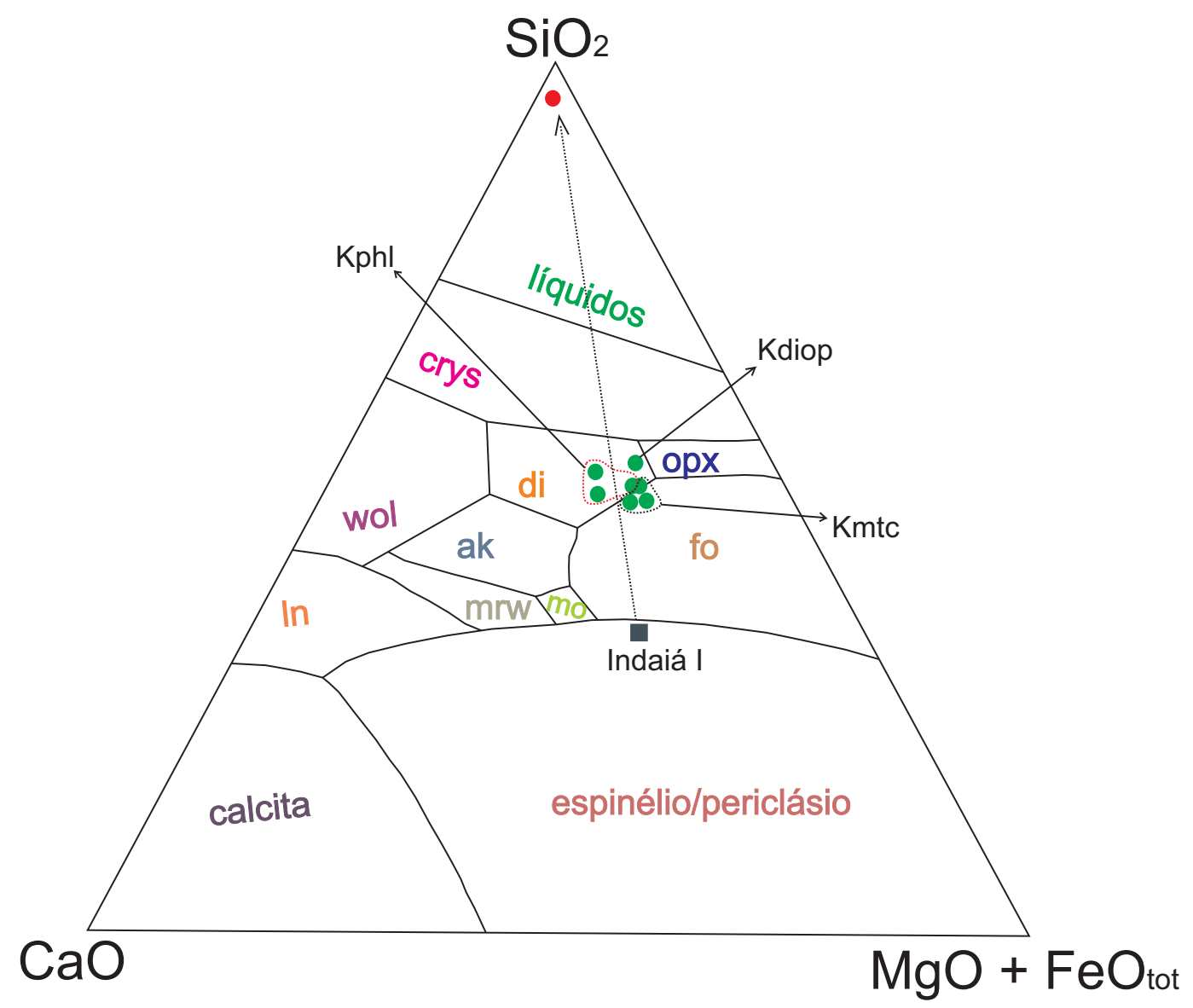

Figura 8.11: Diagrama ternário proposto por Sparks et al. (2009) para representar fundidos kimberlíticos a $1 \mathrm{Kbar}$ e pressões em $\mathrm{CO}_{2}$ e $\mathrm{H}_{2} \mathrm{O}$. Nele estão inseridos os fundidos reconstituídos para intrusão Pântano, o possível fundido granítico contaminante e o fundido de Indaiá I, intrusão kimberlítica da PAAP interpretada como livre de contaminação (Lima, 2019). Os pólos do fundido granítico calculado e de Indaiá I (Lima, 2019) formam uma linha de amarração onde o fundido de Pântano corresponderia a um ponto intermediário com a incorporação de uma componente crustal. Os tipos petrográficos mais contaminados (Kphl e Kdiop) plotam no campo de cristalização do diopsídio, enquanto o menos contaminado plota no campo de cristalização da forsterita. 

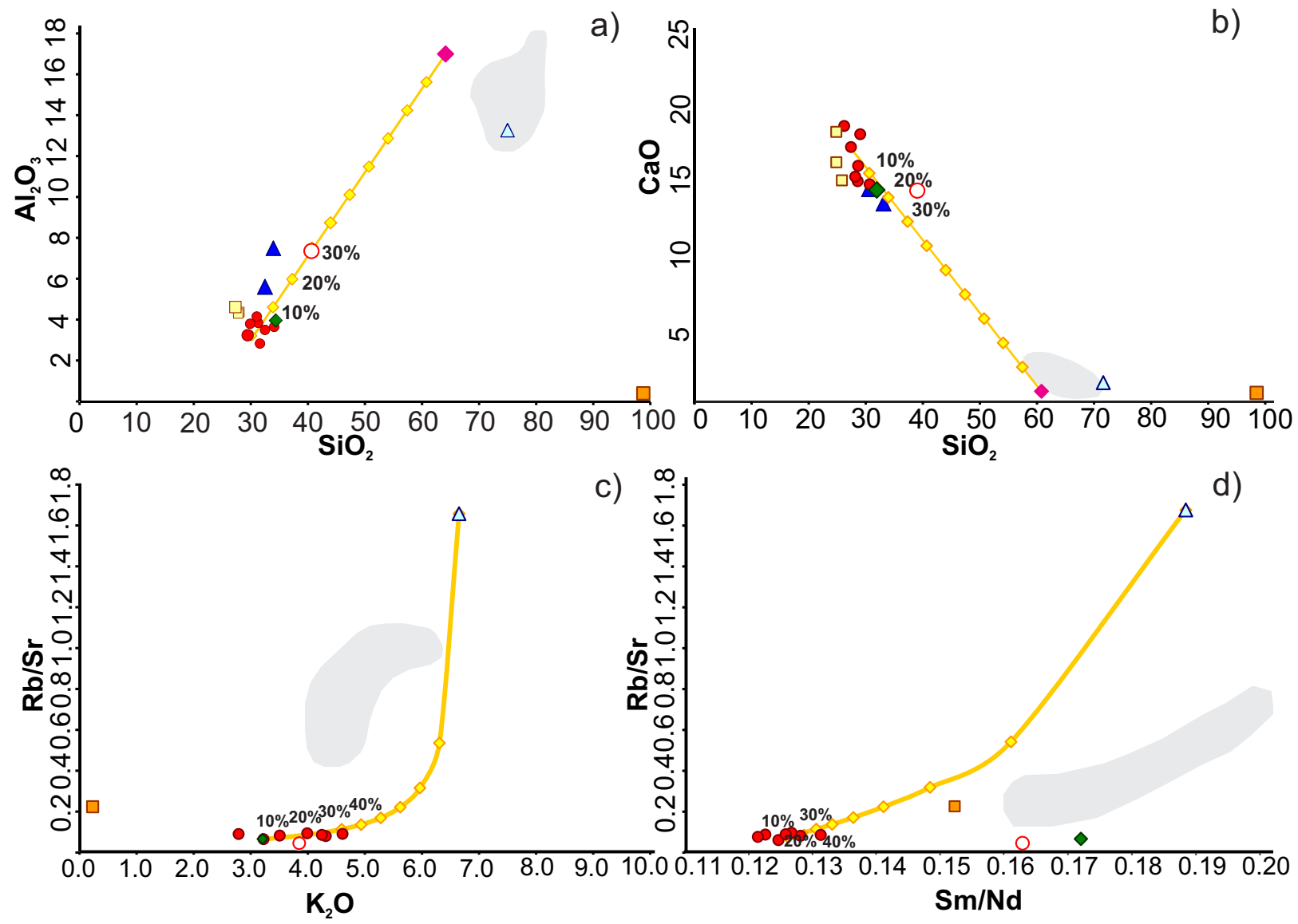

- Fundidos calculados Pântano

Fundido Pântano (Guarino et al., 2013)

Quartzito (rocha total)

Fundido Indaiá II

Filito (rocha total, Saar, 2009)

$\triangle$ Fundido granítico (Lima, 2019)

$\square$ Fundidos calculados Pântano (Meyer, 1991)

A Fundidos calculados Pântano (Danni \& Scartezini, 1990)

Granitos alto K da Faixa Brasília (Pimentel et al., 1996)

Figura 8.12: Diagramas bivariantes apresentando linhas de mistura de elementos maiores e elementos-traço. a) e b) apresentam misturas entre os fundidos calculados para intrusão Pântano e o possível filito encaixante do Grupo Canastra. A partir destes modelos nota-se que os fundidos de Pântano estariam misturados com até $12 \%$ do contaminante proposto; c) e d) apresentam misturas entre os fundidos calculados para intrusão Pântano e o fundido do possível granito encaixante (Lima, 2019). A partir destes modelos nota-se que os fundidos de Pântano estariam misturados em taxas de 10 a $40 \%$ do contaminante proposto. Também foram plotados os fundidos de Pântano de Guarino et al. (2013), Meyer (1991) e Danni e Scartezini (1990), além do fundido calculado para intrusão Indaiá II (Lima, 2019) também considerada como kimberlito contaminado da PAAP. Os campos de granitos alto $\mathrm{K}$ (Pimentel et al., 1996) foram inseridos para representação de possíveis contaminantes em maiores profundidades. 


\subsection{Modelo Petrogenético}

O modelo geológico sugerido a partir da observação dos diferentes tipos petrogenéticos observados para a intrusão Pântano é de que o fundido kimberlítico evoluiu em um contexto de sistema magmático aberto, sofrendo contribuições de contaminações mantélicas (principalmente peridotíticas, com base no estudo dos xenocristais) e crustais, em diferentes níveis e, possivelmente, em distintos momentos e profundidades.

Neste modelo, o magma kimberlítico, ao interagir ou com uma possível rocha granítica com altos valores de $\mathrm{K}$ em sua composição e com rochas quartzíticas da encaixante local, teria parte de sua monticelita desestabilizada e, sobretudo aonde encontram-se enclaves e xenólitos, houve reação entre estas fases e o líquido kimberlítico, resultando na formação de diopsídio e flogopita poiquilítica na rocha final; possivelmente, com formação de leucita em estágio intermediário da reação do liquido kimberlítico com o fundido das encaixantes mais ricas em potássio. Acredita-se que este tipo de interação tenha ocorrido em níveis crustais de maior profundidade, uma vez que o potencial de assimilação é maximizado em regiões mais profundas (Tegner et al., 2005). Porém, há evidências de que a contaminação também ocorreu em níveis crustais mais rasos, ao considerar as interações com o quartzito e o filito. Descrições anteriores (e.g., Danni \& Scartezini, 1990) já reportavam a presença de blocos de silexito (possível quartzito fundido) e atribuíam a estes uma zona de teto da intrusão.

As feições de metamorfismo de contato associadas à possível fusão parcial nos quartzitos examinados petrograficamente confirmam este cenário, explicando principalmente a formação do diopsídio encontrado no tipo petrográfico diopsídio kimberlito. O tipo petrográfico flogopita kimberlito pode ser explicado por uma menor taxa de digestão de xenólitos graníticos (mais ricos em K), ou ser um reflexo da incorporação de material fundido do filito em um segundo pulso, o que poderia explicar o aumento da porcentagem de $\mathrm{Fe}, \mathrm{K}$ e Ti nos líquidos calculados, considerando que a flogopita poiquilítica possui teores consideráveis destes elementos. A Figura 8.13 apresenta 0 modelo petrogenético esquemático proposto para a intrusão Pântano. Neste modelo, a contaminação começou provavelmente em profundidade e se manteve durante a colocação em níveis mais rasos da câmara magmática, provavelmente como um "blind pipe" (intrusão cega). 
A partir das argumentações apresentadas, é possível cogitar a hipótese de que as composições kamafugíticas de rocha total observadas para a intrusão sejam, na verdade, decorrentes de kimberlitos contaminados, ou seja, magmas kimberlíticos que passaram por diferentes graus de contaminação crustal. $O$ fato de a intrusão Pântano possuir composições consideradas na literatura (Foley et al., 1987; Araújo et al., 2001) como de afinidade kamafugítica (enriquecido em $\mathrm{K} \mathrm{e} \mathrm{Ti),} \mathrm{e} \mathrm{que} \mathrm{tenha} \mathrm{sido} \mathrm{previamente}$ descrita como um leucitito (a partir de amostragem de outras zonas do corpo), corroboram para esta hipótese. Como um outro exemplo de intrusão em que foi apresentada a possibilidade de contaminação crustal, tem-se Indaiá II, em que foi descrita kalsilita. Os kamafugitos são distintivos dos kimberlitos petrograficamente pela presença de leucita, kalsilita e melilita, que podem ocorrer em kamafugitos, porém, não são observadas em kimberlitos (Le Maitre, 2002). Caro et al. (2004) descreveram a ocorrência de kalsilita e melilita em kimberlitos contaminados do Canadá, fortalecendo a argumentação apresentada.

Há uma certa tendência do ser humano em simplificar a natureza, bem como os processos geológicos que ocorrem abaixo da crosta terrestre, como se as classificações pudessem ser feitas apenas dividindo-se "aglomerado de minerais" em "rochas". Sabe-se que em geologia as classificações de rochas refletem distintos momentos científicos e os petrólogos utilizam-se das ferramentas e metodologias disponíveis na época para que sejam feitas tais classificações. O que não pode ser esquecido, no entanto, é que os processos devem ser compreendidos antes de serem feitas as classificações e que os modelos geológicos não são tão simples de serem explicados, de modo que, talvez, haja ainda espaço para revisão das classificações desse "misterioso clã" de rochas alcalinas. Desta maneira, o presente trabalho procurou apresentar evidências de que kimberlitos e kamafugitos podem ter a mesma fonte magmática, mas que os diferentes processos ocorridos durante sua ascensão à crosta afetam sensivelmente suas composições. 


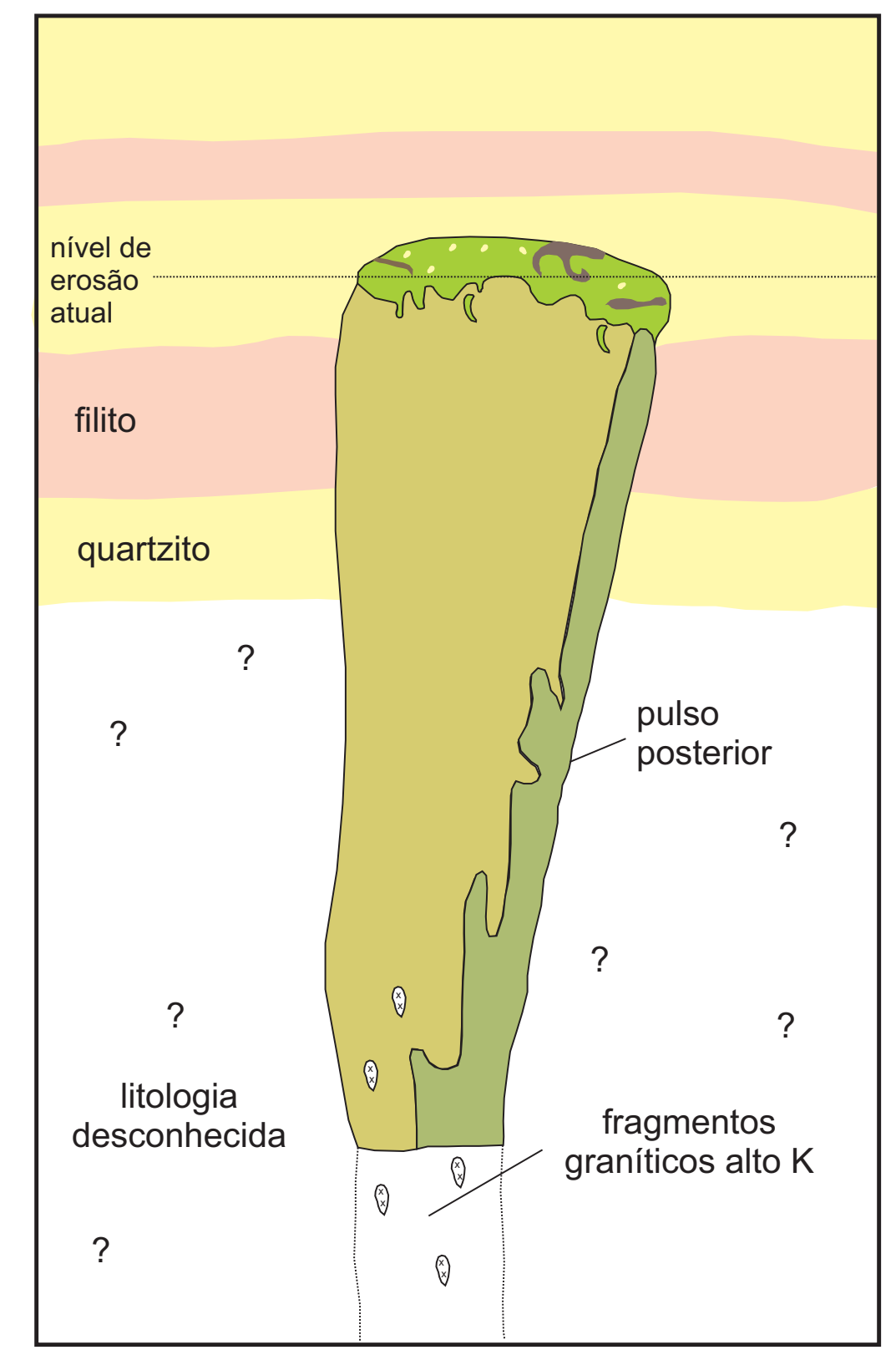

Rochas encaixantes do Grupo Canastra (intercalação de filitos e quartzitos)

Monticelita kimberlito (Kmtc - menos contaminado entre os tipos petrográficos descritos)

Flogopita kimberlito (Kphl - menor grau de contaminação em um pulso kimberlítico posterior)

Diopsídio kimberlito (Kdiop - mais contaminado entre os tipos petrográficos descritos)

$\square$ Fundido da rocha encaixante quartzítica

Figura 8.13: Modelo petrogenético esquemático proposto para intrusão Pântano, ilustrando a contaminação crustal em diferentes níveis: a partir da interação com o fundido da rocha encaixante quartzítica (Kdiop), a partir da interação com o filito encaixante (possívelmente em um outro pulso kimberlítico), caracterizando o tipo petrográfico Kphl e a partir da contaminação em profundidade com granitos de alto $\mathrm{K}$, que levaria à possível formação de leucita. 


\section{Conclusões}

Com base nos estudos petrográficos e químicos da intrusão Pântano, é possível concluir que:

i) Há ocorrência de três populações principais de olivinas, que podem ser descritas como trend mantélico, trend do fundido kimberlítico e antecristais. O trend mantélico é caracterizado principalmente pelos altos teores de $\mathrm{Ni} \mathrm{e}$ Ca e Mg\#>90. A população de xenocristais é derivada de um manto da região da granada a espinélio peridotito. Os antecristais são representados pela população que possui núcleos enriquecidos em Fe (zonamento reverso);

ii) A intrusão apresenta de 16 a $33 \%$ de olivina xenocristalina e esta população deve ser descontada para estimativa de um líquido kimberlítico pristino;

iii) O cálculo da composição estimada do fundido kimberlítico da intrusão Pântano descontando-se a população de olivina xenocristalina aponta para composições enriquecidas em $\mathrm{TiO}_{2}, \mathrm{Al}_{2} \mathrm{O}_{3}, \mathrm{CaO}$ e $\mathrm{K}_{2} \mathrm{O}$ e nos elementostraço incompatíveis quando comparadas aos valores de rocha total.

iv) Para as populações de flogopita também são descritos três grupos: cristais cognatos, poiquilítica originada através de processos de contaminação e antecristais. Os xenocristais podem ser originados a partir de micas de xenólitos da suíte MARID ou a partir de xenólitos mantélicos que possuem micas de alto Ti e Cr;

v) Os diferentes tipos petrográficos identificados para a intrusão Pântano associados aos índices de contaminação crustal (C.I.), permitem o levantamento de ao menos três eventos de contaminação, que poderiam ocorrer através da assimilação de granitos, filitos e/ou quartzito;

vi) A modelagem geoquímica indica a incorporação de 10 a $40 \%$ de fundidos crustais a partir de um magma progenitor com a composição do fundido da intrusão Pântano;

vii) A similaridade de composição entre o fundido calculado para Pântano e fundidos kamafugíticos, a presença de feldspatóide e evidências de sistema magmático aberto, contribuem para hipótese de que kimberlitos contaminados podem ter composições semelhantes às de kamafugitos; 
viii) As diferenças na classificação da intrusão Pântano encontradas na literatura, se dão pelo fato de que os pesquisadores amostraram porções da intrusão que refletem distintos processos petrogenéticos, sendo o mais importante, o de contaminação crustal. 


\section{Referências Bibliográficas}

Albrecht J., Hewitt, D.A., 1988. Experimental evidence of the substitution of Ti in biotite. American Mineralogist, 73: 1275-1284

Almeida F.F.M., 1983. Relações tectônicas das Rochas Alcalinas Mesozóicas da Região Meridional da Plataforma Sul-Americana. Revista Brasileira de Geociências, vol. 13 p.139-158.

Almeida, V.V., 2009. Mineralogia e petrologia de xenólitos mantélicos das regiões de Ubatuba (SP) e Monte Carmelo (MG): evidências de fusão parcial e metassomatismo no manto superior do sudeste do Brasil. Dissertação de Mestrado. Instituto de Geociências, Universidade de São Paulo, 153p.

Ammannati, E., Jacob, D.E., Avanzinelli, R., Foley, S.F., Conticelli, S., 2016. Low Ni olivine in silica-undersaturated ultrapotassic igneous rocks as evidence for carbonate metasomatism in the mantle. Earth and Planetary Science Letters 444, 64-74.

Amarak G., Bushee J., Cordani U.G., Kawashita H., Reynolds J.H. 1967. Potassium-argon ages of alkalines rocks from southern Brazil. Geoch. Cosmoch. Acta, 31:117-142.

Andrade, S., Ulbrich, H.H., de Barros Gomes, C., and Martins, L., 2014, Methodology for the determination of trace and minor elements in minerals and fused rock glasses with laser ablation associated with quadrupole inductively coupled plasma mass spectrometry (LAQ-ICPMS): American Journal of Analytical Chemistry, v. 5, p. 701.

Araújo, A. L. N, Carlson, R. W, Gaspar, J. C., Bizzi, L. A, 2001. Petrology of kamafugites and kimberlites from the Alto Paranaíba Alkaline Province, Minas Gerais, Brazil. Contributions to Mineralogy and Petrology 142: p. 163 - 177.

Arndt, N. T., Guitreau, M., Boullier, A.-M., Le Roex, A., Tommasi, A., Cordier, P., Sobolev, A., 2010. Olivine, and the Origin of Kimberlite. Journal of Petrology, 51(3), 573-602.

Arima, M. \& Edgar, A.D. (1983a). A high pressure experimental study on a Mg-rich leucitelamproite from West Kimberley area, Australia: petrogenetic implications. Contributions to Mineralogy and Petrology 84: p. 228-234.

Azzone, R.G., Ruberti, E., Svisero, D.P., Alves, F.R. 2002. Intrusão Pântano: Kamafugito, orangeíto ou kimberlito? In Anais XLI Congresso Brasileiro de Geologia, João Pessoa, p. 534.

Bailey S.W. 1984. Classification and structures of the micas. In: S.W. Bailey (ed.) Micas. Review in Mineralogy. 13, Washington, Mineralogical Society of America, p. 1-12.

Barbosa, O.; Braun, O.P.G., Dyer, R.C., Cunha C. 1970. Geologia da região do Triângulo Mineiro. Rio de Janeiro, DNPM/DPFM. 140p.

Barbosa, O.; Svisero, D.P.; Hasui, Y. 1976. Kimberlitos da região do Alta Paranaíba, MG. 1976. In: CONGRESSO BRASILEIRO DE GEOLOGIA. Ouro Preto. Boletim de Resumos, Ouro Preto: SBG, p.323.

Beard, J.S., Ragland, P.C., and Crawford, M.L., 2005, Reactive bulk assimilation: A model for crust-mantle mixing in silicic magmas: Geology, v. 33, p. 681-684.

Becker, M., Le Roex, A.P. 2006. Geochemistry of South African on- and off craton, group I and group II kimberlites: petrogenesis and source region evolution. Journal of Petrology v.47, p. 673-703.

Bianchini, G.; Beccaluva, L.; Bonadiman, C.; Nowell, G.; Pearson, G.; Siena, F. \& Wilson, M., 2007. Evidence of diverse depletion and metasomatic events in harzburgiteIherzolite mantle xenoliths from the Iberian plate (Olot, NE Spain): Implications for litosphere accretionary processes. Lithos, 94: 25-45.

Bizzi, L. A., Smith, C. B., Meyer, H. O. A., Armstrong, R. A. \& Wit, M. J. 1991. Mesozoic kimberlites and related alkalic rocks in southwestern São Francisco craton, Brazil: a case for local mantle reservoirs and their interaction. In O.H. LEONARDOS; H.O.A. MEYER, \& J.C. GASPAR, (eds.). Inter. Kimberlite Conf, 5, Araxá, Extend. Abstr., CPRM-Spec. Publ., 2/91, p. 17- 19. 
Bizzi, L.A., A. Armstrong, A., De Wit, M.J., Smith, C.B., Mcdonald, I. 1995. Heterogeneous enriched mantle materials and dupal-type magmatism along the SW margin of the São Francisco Craton, Brazil. Journal of Geodynnmics. Vol. 20, No. 4, pp. 469-491.

Blake S, Campbell IH (1986) The dynamics of magma mixing during flow in volcanic conduits. Contrib Mineral Petrol 94:72-81

Boynton, W.V., 1984. Geochemistry of the rare earth elements: meteorite studies. In: Henderson, P. (Ed.), Rare Earth Element Geochemistry. Elsevier, Amsterdam, pp. 63114.

Brett, R. C., Russell, J. K., \& Moss, S., 2009. Origin of olivine in kimberlite: Phenocryst or impostor? Lithos, 112:201-212.

Brigatti, M.F., Medici, L., Poppi, L., 1996. Refinement of the structure of natural ferriphlogopite. Clays Minerals, 4454-5450.

Brod J.A., Gibson S.A., Thompson R.N., Junqueira-Brod T.C., Seer H.J., Moraes L.C., Boaventura G.R. 2000. The kamafugite-carbonatite association in the Alto Paranaíba Igneous Province, southeastern Brazil. Rev. Bras. Geoc., n. 30, p. 408-412.

Brod, J.A., Gaspar, J.C., Araújo, D.P., Gibson, S.A., Thompson, R.N., Junqueira-Brod, T.C., 2001. Phlogopite and tetra-ferriphlogopite from Brazilian carbonatite complexes: petrogenetic constraints and implications for mineral-chemistry systematics. Journal of Asian Earth Sciences 19 (2001) 265-296

Bussweiler, Y., Foley, S. F., Prelevic, D., \& Jacob, D. E., 2015. The olivine macrocryst problem: New insights from minor and trace element compositions of olivine from Lac de Gras kimberlites, Canada. Lithos, 220-223:238-252.

Bussweiler, Y., Brey, G.P., Pearson, D.G., Stachel, T., Stern, R.A., Hardman, M.F., Kjarsgaard, B.A., and Jackson, S.E., 2017, The aluminum-in-olivine thermometer for mantle peridotites - Experimental versus empirical calibration and potential applications: Lithos, v. 272-273, p. 301-314.

Campos, J.E.G \& Dardenne, M.A. 1997. Estratigrafia e Sedimentação da Bacia Sanfranciscana: Uma Revisão. Revista Brasileira de Geociências, 27 (3): 269-282.

Carlson, R. W., Esperança, S., Svisero, D. P., 1996. Chemical and Os isotopic study of Cretaceous potassic rocks from Southern Brazil. Contrib Mineral Petrol (1996) 125: 393-405.

Carlson, R. W., Araújo, A L. N., Junqueira-Brod, T., C.; Gaspar, J.C., Brod, J.A., Petrinovic, I.A., Hollanda, M.H.B.M., Pimentel. M.M., Sichel. S. 2007. Chemical and isotopic relationships between peridotite xenoliths and mafic-ultrapotassic rocks from Southern Brazil. Chemical Geology 242 415-434.

Carmichael, L.S., Nicholls, J., Smith, A.L., 1970. Silica activity in igneous rocks. Am. Mineral, 55, 246-263.

Caro, G., Kopylova, M., G., Craser, R.A., 2004. The hypabyssal 5034 kimberlite of the Gahcho Hue Cluster, Southeastern Slave Craton, Northwest Territories, Canada: a granite-contamined group I kimberlite. The Canadian Mineralogist, Vol. 42, pp. 183 207.

Carvalho, J.B., 1997. Petrologia de xenólitos mantélicos da Província do Alto Paranaíba, Minas Gerais. Tese de Doutorado.Instituto de Geociências. Universidade de Brasília.

Cas, R.A.F., Hayman, P., Pittari, A., and Porritt, L., 2008a, Some major problems with existing models and terminology associated with kimberlite pipes from a volcanological perspective, and some suggestions: Journal of Volcanology and Geothermal Research, v. 174 , p. 209-225

Chackhmouradian, A.R., Reguir, E.P., Vadim, S.K., Sharygin, V.V., Golovin, A.V. Traceelement partitioning in perovskite: Implications for the geochemistry of kimberlites and other mantle-derived undersaturated rocks. 2013. Chemical Geology 353: 112 - 131.

Charlier B.L.A., Wilson C.J.N., Lowenstern J.B., Blake S., Van Calsteren P.W., Davidson J.P. 2005. Magma generation at a large, hyperactive silicic volcano (Taupo, New Zealand) revealed by $\mathrm{U}-\mathrm{Th}$ and $\mathrm{U}-\mathrm{Pb}$ systematics in zircons. Journal of Petrology, 46(1):3-32. 
Chaves, M.L.S.C., Brandão, P.R.G., Girodo, A.C., Benitez, L., 2008. Kimberlito Canastra 1 (São Roque de Minas, MG): geologia, mineralogia e reservas diamantíferas. Revista Escola de Minas, 61 (3): 357-364.

Clement, C.R. 1982. A comparative geological study of some major kimberlite pipes in the northern Cape and Orange Free State. Unpublished PhD thesis, University of Cape Town, South Africa, 431.

Clement, C.R., SKINNER, E.M.W. 1985. A textural-genetic classification of kimberlites. Transactions Geological Society of South Africa 88, $403-409$.

Comin-Chiaramonti, P., Gomes, C.B., 1996. Alkaline magmatism in central-eastern Paraguay. Relationships with coeval magmatism in Brazil. São Paulo, Edusp/Fapesp, 464p.

Comin-Chiaramonti, P., Gomes, C.B., 2005. Mesozoic to Cenozoic alkaline magmatism in the Brazilian Platform. São Paulo, Edusp/Fapesp, 752p.

Conceição, R. M., Carniel, L. C., Jalowitzki, T., Gervasoni, F., Cedeño, D. G., 2019. Geochemistry and geodynamic implications on the source of Paraná-Etendeka Large Igneous Province evidenced by the $128 \mathrm{Ma}$ Rosário-6 kimberite, southern Brazil. Lithos, 328-329: 130-145.

Collins, W.J., Richards, S.R., Healy, B.E. Ellison, P.I., 2000. Origin of heterogeneous mafic enclaves by two-stage hybridization in magma conduits (dykes) below and in granitic magma chambers transactions of the Royal Society of Edinburg: Earth Sciences 91, pp. 27-45.

Condie, K.C., 2004. Supercontinents and superplume events: distinguishing signals in the geologic record. Phys. Earth Planet. Inter. 146, 319-332.

Danni, J. C. M. \& Scartezini, A. A. 1990. O Olivina Leucitito de Pântano e a Natureza do Vulcanismo da Formação Mata da Corda, MG. Rev. Bras. Geociências, vol. 20 (1-4), p. 83- 87.

Dardenne, M.A., 2000. The Brasilia Fold Belt. In: Cordani U.G., Milani, E.J., Tomas Filho A. and Campos D.A., (eds.) 2000. Tectonic Evolution of South America. Proceedings of the XXXI International Geological Congress, 231-263p.

Davidson, J.P., Morgan, D.J., Charlier, B.L.A., Harlou, R., Hora, J.M., 2007. Microsampling and isotopic analysis of igneous rocks: implications for the study of magmatic systems: Annual Review of Earth and Planetary Sciences, v. 35, p. 273-311.

Davies, G.R., Spriggs, A.J., Nixon, P.H., 1999. A non-cognate Origin for the Gibeon Kimberlite Megacryst Suite, Namibia: Implications for the Origin of Namibian Kimberlites. Journal of Petrology, 32: $159-172$.

Dawson, J.B., 1977. The MARID (mica-amphibole-rutile-ilmenite-diopside) suite of xenoliths in kimberlite. Geochim Cosmochim Acta 41: 309-322.

Dawson, J.B.(ed) 1980. Kimberlites and their xenoliths. Springer-Verlag, Berlin, 252p.

Dawson, J.B., 1982. Contrasting types of mantle metasomatism. Terra Cognita 2: 232.

Dawson, J.B., 1987. The MARID suite of xenoliths in kimberlite: relationship to veined and metasomatised peridotite xenoliths. In: Nixon, P.H. (ed.). Mantle xenoliths. John Wiley \& Sons, 465-473.

Deer, W.A., Howie, R.A., Zussman, J., 1992. An introduction to the rock forming minerals. Engleand Editors. Longamn Scientific and Technical, Harlow, 695 p.

De Hoog, C.M.J., Gall, L., Cornell, D.H., 2010. Trace-element geochemistry of mantle olivine and application to mantle petrogenesis and geothermobarometry. Chemical Geology, 270: 196-2015.

Dobrzhinetskaya, L., Green, H.W., Wang, S., 1996. Alpe Arami: a peridotite massif from depths of more than $300 \mathrm{~km}$. Science 271, 1841-1845.

Dymek, R.F. (1983) Titanium, aluminium and interlayer cátion substitutions in biotite from high-grade gneisses, West Greenland. American Mineralogist, 68, 880-899.

Edgar, A.D. \& Arima, M. Substitution mechanisms and solubility of titanium in phlogopites from rocks of probable mantle origin, 1981. Contributions to Mineral Petrology 77: 288295. 
Eggins, S.M.; Rudnick, R.L. \& McDonough, W.F. 1998. The composition of peridotite and their minerals: a laser-ablation ICP-MS study. Earth and Planetary Science Letters, 154: 53-71.

Ersoy, E.Y., 2013, PETROMODELER (Petrological Modeler): a Microsoft Excel spreadsheet program for modelling melting, mixing, crystallization and assimilation processes in magmatic systems: Turkish Journal of Earth Sciences, v. 22, p. 115-125.

Faure, G., 2001, Origin of Igneous Rocks: The Isotopic Evidence: Springer Science \& Business Media, 496 p., doi:10.1007/978-3-662-04474-2.

Felgate, M.R., 2014. The petrogenesis of Brazilian kimberlites and kamafugites intruded along the 125 lineament: improved geochemical and geochronological contraints on magmatism in Rondônia and the Alto Panaiba Igneous Province. PhD Thesis, University of Melbourne.

Fernandes, A.F., Karfunkel, J., Hoover, D.B., Sgarbi, P.B.A., Sgarbi, G.N.C., Oliveira, G.D., Gomes, J.C.S.P., Kambrock, K., 2014. The Basal Conglomerate of the Capacete Formation (Mata da Corda Group) and its Relation to Diamond Distributions in Coromandel, Minas Gerais State, Brazil. Brazilian Journal of Geology, 44(1): 91-103

Foley, S.F., Venturelli, G., Green, D.H, Toscani, L. 1987. The Ultrapotassic Rocks: Characteristics, Classification and Contraints for Petrogenetic models. Earth-Science Reviews, 24: 81 - 134.

Foley, S.F., 1992, Vein-plus-wall-rock melting mechanisms in the lithosphere and the origin of potassic alkaline magmas: Lithos, v. 28, p. 435-453.

Foley, S.F., Jackson, S.E., Fryer, B.G., Greenouch, G.D., Jenner, G.A., 1996. Trace element partition coefficients for clinopyroxene and phlogopite in an alkaline lamprophyre from Newfoundland by LA-ICP-MS. Geochimica e Cosmochimica Acta, 60: 629-638.

Foley, S.F., Andronikov, A.V., Jacob, D.E., Melzer, S., 2006. Evidence from Antarctic mantle peridotite xenoliths for changes in mineralogy, geochemistry and geothermal gradients beneath a developing rift. Geochim. Cosmochim. Acta 70, 3096-3120.

Foley, S.F., Jacob, D.E., O'Neill, H.S.C., 2011. Trace element variations in olivines from Ugandan potassic rocks as clues to the chemical characteristics of parental magmas. Contrib. Mineral. Petrol. 162, 1-20.

Foley, S.F., Prelevic, D., Rehfeldt, T., and Jacob, D.E., 2013, Minor and trace elements in olivines as probes into early igneous and mantle melting processes: Earth and Planetary Science Letters, v. 363, p. 181-191.

Forbes, W.C. \& Flower, M.F.J. (1974) Phase relations of titan-phlogopite, $\mathrm{K}_{2} \mathrm{Mg}_{4} \mathrm{TiAl}_{2} \mathrm{Si}_{6} \mathrm{O}_{2}(\mathrm{OH})_{4}$ : a refractory phase in the upper mantle? Earth Planet Science Letter, 22, 60-66.

Freitas-Silva, F.H., 1996. Metalogênese do depósito do Morro do Ouro, Paracatu, MG. Inst. De Geociências, Universidade de Brasília, Brasília. Tese de Doutorado, 339p.

Freitas-Silva, F.H. \& Dardenne, M.A., 1994. Proposta de subdivisão estratigráfica formal para o Grupo Canastra no oeste de Minas Gerais e leste de Goiás. In: SBG, SIMP. GEOLOG. CENTRO-OESTE, 4, Anais, 161-163p.

Fritschle, T., Prelevic, D., Foley, S.F., Jacob, D.E., 2013. Petrological characterization of the mantle source of Mediterranean lamproites: indications from major and trace elements of phlogopite. Chemical Geology 353, 267-279.

Fryer, B.J., Jackson, S.E., Longerich, H.P., 1995. The design, operation and role of the laser-ablation microprobe coupled with an inductively coupled plasma-mass spectrometer (LAM-ICP-MS) in the earth sciences. Can. Mineral. 33, 303-312.

Gaspar, J. C., Araújo, A. L. N., Carlson, R. W., Sichel, S. E., Brod, J. A., Sgarbi, P. B., Danni, J. C. M., 2003. Mantle xenoliths and new constraints of the origin of alkaline ultrapotassic rocks from the Alto Paranaíba and Goiás Igneous Province, Brasil. $8^{\text {th }}$ International Kimberlite Conference Long Abstract, Toronto, Canadá.

Gibson, S.A., Thompson, R.N., Leonardos, O.H., Dicken, A.P., Mitchell, J.B., 1995a. The late Cretaceous impact of the Trindade mantle plume: evidence from large-volume, mafic, potassic magmatism in SE Brazil. Journal of Petrology 36, 189-229. 
Gibson, S.A., Thompson, R.N., Leonardos, O.H., Dicken, A.P., Mitchell, J.B, 1995b. High$\mathrm{Ti}$ and low-Ti mafic potassic magmas: key to plume-lithosphere interaction and continental flood-basalt genesis. Earth and Planetary Science Letters 136, 149-165.

Gibson, S.A., Thompson, R.N., Leonardos, O.H., Dicken, A.P., Mitchell, J.B., 1999. The limited extent of plume-litosphere interactions during continental flood-basalt genesis: geochemical evidence from Cretaceous magmatism in Southern Brazil. Contributions to Mineralogy and Petrology, 137 (1-2): 147 - 169.

Gill, R. 2010. Rochas e Processos ígneos - Um Guia Prático.

Giuliani, A., Phillips, D., Kamenetsky, V.S., Goemann, K., 2016. Constraints on kimberlite ascent mechanisms revealed by phlogopite compositions in kimberlites and mantle xenoliths. Lithos 240-243, 189-201.

Green, H.W., Dobrzhinetskaya, L., Riggs, E.M., Zhen-Ming, J., 1997. Alpe Arami: a peridotite massif from the mantle transition zone. Tectonphysics 279, 1-21.

Grégoire, M., Bell, D.R., Le Roex, A.P. 2002. Trace element geochemistry of phlogopiterich mafic mantle xenoliths: their classification and their relationship to phlogopitebearing peridotites and kimberlites revisited. Contribution Mineral Petrology. 142: 603 $-625$.

Guarino, V., Wu, F.Y., Lustrino, M., Melluso, L., Brotzu, P., Gomes, C. de B., Ruberti, E., Tassinari, C.C.G., and Svisero, D.P., 2013. U-Pb ages, Sr-Nd- isotope geochemistry, and petrogenesis of kimberlites, kamafugites and phlogopite-picrites of the Alto Paranaíba Igneous Province, Brazil: Chemical Geology, v. 353, p. 65-82.

Gualda, G.A.R., and Ghiorso, M.S., 2015, MELTS_Excel: A Microsoft Excel - based MELTS interface for research and teaching of magma properties and evolution: Geochemistry, Geophysics, Geosystems, v. 16, p. 315-324.

Gudfinnsson, G.H., and Presnall, D.C., 2005, Continuous gradations among primary carbonatitic, kimberlitic, melilititic, basaltic, picritic, and komatiitic melts in equilibrium with garnet Iherzolite at 3-8 GPa: Journal of Petrology, v. 46, p. 1645-1659

Gunther, D., Jackson, S.E. \& Longerich, H.P. (1999): Laser ablation and arc/spark solid sample introduction into inductively coupled plasma mass spectrometers. Spectrochim. Acta B 54, 381-409.

Gupta, A. K., 1972. The system forsterite-diopside-akermanite-leucite and its significance in the origino f potassium-rich mafic and ultramafic rocks. American Mineralogist, 57: pp. 1242-1259.

Harte, B. 1977. Rock nomenclature with particular relation to deformation and recrystallisation textures in olivine-bearing xenoliths. Journal of Geology, 85: 279-288.

Harte, B., 1987. Metasomatic events recorded in mantle xenoliths: an overview. In: Nixon, P.H. (ed.). Mantle xenoliths. John Wiley \& Sons, 625-640.

Hasui, Y., Cordani, U.G. 1968. Idades Potássio Argônío de Rochas Eruptivas Mesozóicas do Oeste Mineiro e Sul de Goiás, In: CONG. BRAS. GEOL., 22. Belo Horizonte, SBG. v.l ,p. $139-143$.

Hermann, J., O'Neill, H.St.C., Berry, A.J., 2005. Titanium solubility in olivine in the system TiO2-MgO-SiO2: no evidence for an ultradeep origin of Ti-bearing olivines. Contributions to Mineralogy and Petrology 148, 746-760.

Howarth, G.H., Michael, E., Skinner, W., Prevec, S.A. 2011. Petrology of the hypabyssal kimberlite of the Kroonstad group II kimberlite (orangeite) cluster, South Africa: Evolution of the magma within the cluster. Lithos 125, pp $795-808$.

Howarth, G.H., Taylor, L.A., 2016. Multi-stage kimberlite evolution tracked in zoned olivine from the Benfontein sill, South Africa. Lithos 262, 384-397.

Ionov, D.A., Bodinier, J., Mukasa, S.B., Zanett, A., 2002. Mechanisms and sources of mantle metasomatism: major and trace elements compositions of peridotite xenoliths from Spitsbergen in the context of numerical modelling. Journal of Petrology, 43, 22192259. 
Jackson, S.E. (2001): The application of Nd: YAG lasers in LA-ICP-MS, in, Laser AblationICP-Mass Spectrometry in the Earth Sciences: Principles and Applications (Sylvester, P.J., Ed.), Mineralogical Association of Canada (MAC) Short Course Series 29, 29-45. Jackson, S.E., 2004. Calibration strategies for elemental analysis by LA-ICP-MS. Lithos 77, $295-316$.

Jacob, D.E. (2004). Nature and origin of eclogite xenoliths from kimberlites. Lithos, 77(1-4 SPEC. ISS.), 295-316.

James, D.E.; Assumpção, M.; Snoke, J.A.; Ribotta, L.C.; Kuehnel, R. 1994. Seismic studies of continental lithosphere beneath SE Brazil. Anais da Academia Brasileira de Ciências.

Jaques, L.A., Foley, S.F., 2018. Insights into the petrogenesis of the West Kimberley lamproites from trace elements in olivine. Proceedings of the 11th International Kimberlite Conference, Mineralogy and Petrology, in press

Kamenetsky, V. S., Kamenetsky, M. B, Sobolev, A. V., Golovin, A. V., Demouchy, S., Faure, K., Sharygin, V. V., Kuzmin, D. V. (2008) Olivine in the Udachnaya-East kimberlite (Yakutia, Russia): types, compositions and origins. Journal of Petrology 49(4): 823839.

Kamenetsky, V.S., Golovin, A. V, Maas, R., Giuliani, A., Kamenetsky, M.B., and Weiss, Y., 2014, Towards a new model for kimberlite petrogenesis: Evidence from unaltered kimberlites and mantle minerals: Earth-Science Reviews, v. 139, p. 145-167.

Kargin, A.V., Sazonova, L.V., Nosova, A.A., Lebedeva, N.M., Kostitsyn, Y.A., Kovalchuk, E.V., Tretyachenko, V.V., Tikhomirova, Y.S., 2019. Phlogopite in mantle xenoliths and kimberlite from the Grib pipe, Arkhangelsk province, Russia: Evidence for multi-stage mantle metasomatism and origin of phlogopite in kimberlite. Geosciences Frontiers, 10 in press.

Kopylova, M. G., Matveev, S., \& Raudsepp, M. (2007). Searching for parental kimberlite melt. Geochimica et Cosmochimica Acta, 71(14), 3616-3629.

Kjarsgaard, B.A., Pearson, D.G., Tappe, S., Nowell, G.M., Dowall, D.P., 2009. Geochemistry of hypabyssal kimberlites from Lac de Gras, Canada: Comparisons to a global database and applications to the parent magma problem. Lithos, 112, Supplement 1(0): 236-248.

Kuhn, H.-R. \& Gunther, D., 2004. Laser ablation-ICP-MS: particle size dependent elemental composition studies on filter-collected and online measured aerosols from glass. J. Analyt. Atom. Spectrom. 19, 1158-1164.

Labotka, T.C., 1983. Analysis of the compositional variations of biotite in pelitic hornfelses from northeastern Minnesota. American Mineralogist, 68, 900-914.

Le Maitre, R.W. 2002. Igneous rocks. A classification of igneous rocks and glossary of terms. 2 ed. Cambridge, Cambridge University Press, 236 p.

Le Roex, A. P., Bell, D. R. \& Davis, P. (2003). Petrogenesis of group I kimberlites from Kimberley, South Africa: evidence from bulk-rock geochemistry. Journal of Petrology 44, 2261-2286.

Leonardos, O.H.; Carvalho, J.B.; Tallarico, F.H.B.; Gibson, S.A.; Thompson, R.N.; Meyer, H.O.A \& Dickin, A.P., 1993. O xenólito de Granada Iherzolito de Três Ranchos 4: uma rocha matriz do diamante na província magmática cretácea do Alto Paranaíba, Goiás. In: R. Weska; O.H. Leonardos \& G.M. Ginzaga (eds.). Simpósio Brasileiro de Geologia do Diamante, I, Cuiabá. Anais. Publicação Especial UFMT 2/93, 3-16.

Lim, E., Giuliani, A., Phillips, D., Goemann, K., 2018. Origin of complex zoning in olivine from diverse, diamondiferous kimberlites and tectonic settings: Ekati (Canada), Alto Paranaiba (Brazil) and Kaalvallei (South Africa). Mineralogy and Petrology, 112, 539554.

Lima, N.M., 2019. A intrusão ultrapotássica Indaiá II, Província Alcalina Alto Paranaíba (MG): processos magmáticos de sistema aberto e implicações petrogenéticas. Instituto de Geociências. Universidade de São Paulo, 183 p. 
Longerich, H.P., Jackson, S.E., Gunther, D., 1996. Laser ablation-inductively coupled plasma-mass spectrometric transient signal data acquisition and analyte concentration calculation. J. Anal. Atom. Spectrom. 11, 899-904.

Luth, W.C., 1967. Studies in the system KAISiO $4-\mathrm{Mg}_{2} \mathrm{SiO}_{4}-\mathrm{SiO}_{2}-\mathrm{H}_{2} \mathrm{O}$ : I. Inferred phase relations and applications. Journal of Petrology 8: 372-416.

McDonough, W.F. and Sun, S.-S., 1995. Composition of the Earth. Chemical Geology 120: 223-253.

Melluso, L., Lustrino, M., Ruberti, E., Brotzu, P., Gomesc.B., Morbidelli, L., Morra, V., Svisero, D.P., D'Amelio, F., 2008. Major- And Trace-Element Composition of olivine, perovskite, clinopyroxene, $\mathrm{Cr}-\mathrm{Fe}-\mathrm{Ti}$ oxides and host kamafugites and kimberlites, Alto Paranaíba, Brazil. Canadian Mineralogist, 46: 19-40.

Meyer, H.O.A., Garwood, B.L., Svisero, D. P., 1991. The Pântano Intrusion. In: Fifth Int. Kimberlite Conf., Field Guide Book, CPRM, Special Publication 3/91, pp. 59-63

Meyer, H.O.A., Garwood, B.L., Svisero, D. P., Smith, C.B., 1994. Alkaline ultrabasic intrusions in western Minas Gerais, Brazil. Proceedings of the Fifth International Kimberlite Conference pp .140-155.

Mitchell, R. H. \& Bergman, S. C., 1991. Petrology of Lamproites. New York: Plenum, 447 $\mathrm{pp}$

Mitchell, R.H. 1995. Kimberlites, Orangeites, and Related Rocks. New York, Plenum Press. 410p.

Mitchell R.H., 1986. Kimberlites: mineralogy, geochemistry, and petrology. New York, Plenum Press. 442p.

Mitchell, R.H., 2008. Petrology of hypabyssal kimberlites: Relevance to primary magma compositions. Journal of Volcanology and Geothermal Research, 174 (1-3): 1-8.

Moore, A.E., Belousova, E., 2005. Crystallization of Cr-poor and Cr-rich megacryst suites from the host kimberlite magma: Implications for mantle structure and the generation of kimberlite magmas. Contrib Mineral Petrol, 149: 462-481.

Moore, A. E., 2012. The case for a cognate, polybaric origin for kimberlitic olivines. Lithos, 128, 1-10.

Moore, A. E., Costin, C., 2016. Kimberlitic olivines derived from the Cr-poor and Cr-rich megacryst suites. Lithos 258-259, 215-227.

Mori, P.E., Reeves, S., Correia, C.T., Haukka, M., 1999. Development of a fused glass disc XRF facility and comparison with the pressed powder pellet technique at Instituto de Geociências, São Paulo University. Revista Brasileira de Geociências, 29:441-446.

Nannini, F., 2016. Geologia e petrologia de xenólitos mantélicos da Província Ígnea Alto Paranaíba, Minas Gerais. Tese de Doutorado. Instituto de Geociências. Universidade de São Paulo.

Nielsen, T.F., Sand, K.K., 2008. The Majuagaa kimberlite dike, Maniitsoq region, West Greenland: constraints on an Mg-rich silicocarbonatitic melt composition from groundmass mineralogy and bulk compositions. The Canadian Mineralogist 46 (4), 1043-1061.

Nixon, P.H. (ed.), 1987. Mantle xenoliths, John Wiley \& Sons, New York, 844 p.

Norman, M.D. 1998. Melting and metasomatism in the continental litosphere: laser ablation ICP-MS analysis of minerals in spinel Iherzolites from eastern Australia. Contributions to Mineralogy and Petrology, 130: 240-255.

Nosova, A.A., Sazonova, L.V., Kargin, A.V., Smirnova, MD., Lapin, A.V., Shcherbakov, V.D., 2018. Olivine in ultramafic lamprophyres: chemistry, crystallisation, and melt sources of Siberian Pre- and post-trap aillikites. Contribution to Mineralogy and Petrology --, 173-55.

Nowicki, T., Porritt, L., Crawford, B., Kjarsgaard, B. 2008. Geochemical trends in kimberlites of the Ekati property, Northwest Territories, Canada: Insights on volcanic and resedimentation processes. Journal of volcanology and geothermal research 174, $\mathrm{p}$ $117-127$.

Patterson, M., Francis, D., Mccandless, T., 2009. Kimberlites: Magmas or mixtures? Lithos, $112,191-200$. 
Pearson, D.G.; Canil, D. \& Shirey, S.B. 2003. Mantle samples included in volcanic rocks: xenoliths and Diamonds. In: Carlson, R.W. (ed), Treatise on Geochemistry, The Mantle and Core, 2: 171-275.

Pearson, D.G., Woodhead, J., Janney, P. E., 2019. Kimberlites as Geochemical Probes of Earth's Mantle. Element, aprovado para publicação.

Pilbeam LH, Nielsen TFD, Waight TE (2013) Digestion fractional crystallization (DFC): an important process in the genesis of kimberlites: evidence from olivine in the Majuagaa kimberlite, southern West Greenland. J Petrol 54(7):1399-1425.

Pimentel, M.M., Reinhardt, A.F., Alvarenga, C.J.S., 1996. Post-Brasiliano (Pan-African) high-K granitic magmatism in Central Brazil: the role of Late Precambrian-early Palaeozoic extension. Precambrian Research, 80: 217-238.

Pimentel, M.M., Rodrigues, J.B., Dellagiustina, M.E.S., Jungue, S.L., Matteini, M., Armstrong, R. 2011. The tectonic evolution of the Neoproterozoic Brasilia Belt, central Brazil, based on SHRIMP and LA-ICPMS U-Pb sedimentary provenance data: A review. J. South Am. Earth Sc., 31: 345-357.

Prelević, D., Akal, C., Romer, R.L., Foley, S.F., 2010. Lamproites as indicators of accretion and/or shallow subduction in the assembly of south-western Anatolia, Turkey. Terra Nova 22, 443-452.

Prelevic, D., Foley, S.F., 2007. Accretion of arc-oceanic lithospheric mantle in the Mediterranean: Evidence from extremely high-Mg olivines and $\mathrm{Cr}$-rich spinel inclusions in lamproites. Earth and Planetary Science Letters 256, 120-135.

Prelevic, D., Jacob, D.E., Foley, S.F., 2013. Recycled continental crust is an essential ingredient of Mediterranean orogenic mantle lithosphere. Earth Planet. Sci. Lett., 362, 187-197.

Provenzano, C.A.S., 2016. Caracterização petrográfica, química mineral e petrogênese do kimberlito Alfeu I - Canguçu/RS e uma revisão conceitual do magmatismo e rochas kimberlíticas. Dissertação de Mestrado. Instituto de Geociências. Universidade Federal do Rio Grande do Sul.

Reguir, E.P., Chakhmouradian, A.R., Halden, N.M., Malkovets, V.G., Yang, P., 2009. Major-and trace-element compositional variation of phlogopite from kimberlites and carbonatites as a petrogenetic indicator. 112: $372-384$.

Reverdatto, V.V. 1970. Pyrometamorphism of limestones and the temperature of basaltic magmas. Lithos Volume 3 pp. 135 - 143.

Rieder, M. et al., 1998, Nomenclature of the micas: Canadian Mineralogist, v. 36, p. 905912.

Rodrigues, J.B. 2008. Proveniência de sedimentos dos grupos Canastra, Ibiá, Vazante e Bambuí - Um estudo de zircões detríticos e Idades Modelo Sm-Nd. Tese de doutorado, Instituto de Geociências, Universidade de Brasília.

Rodrigues, J.B., Pimentel, M.M., Dardenne, M.A., Armstrong, R.A., 2010. Age, provenance and tectonic setting of the Canastra and lbiá groups (Brasilia belt, Brazil): implications for the age of a Neoproterozoic glacial event in central Brazil. J. South Ame. Earth Sc., 29: 512-521.

Russell, J.K., Porritt, L.A., Lavallée, Y., and Dingwell, D.B., 2012, Kimberlite ascent by assimilation-fuelled buoyancy: Nature, v.481, p.352-356, doi:10.1038/nature10740.

Saar, B. A. 2009. Geoquímica dos filitos carbonosos do depósito Morro do Ouro, Paracatu, Minas Gerais. Dissertação de Mestrado. Instituto de Geociências. Universidade de Brasília, 93 p.

Santos, L., Souza, Z., S, Botelho, N. F., Viana, R. R., 2014. Pirometamorfismo ígneo na Bacia Potiguar, Nordeste do Brasil. Geol. USP, Sér, Cient. 14, 121-138.

Sawyer, E.W.; Brown, M. 2008. Working with migmatites.

Sgarbi P.B.A. \& Valença J.G., 1993. Kalsilite in Brazilian kamafugitic rocks. Mineral. Mag., 57:165-171.

Sgarbi, G. N. C., 2000. The Cretaceous Sanfranciscan Basin, Eastern Plateau of Brazil. Revista Brasileira de Geociências, 30 (3): 450-452. 
Sgarbi, G.N.C., Sgarbi, P.B.A., Campos, J.E.G., Dardenne, M.A., Penha, U.C. 2001. Bacia Sanfranciscana: O Registro Fanerozóico da Bacia do São Francisco. In: PINTO CP \& MARTINS NETO MA (Ed.). Bacia do São Francisco: Geologia e Recursos Naturais. SBG MG, Belo Horizonte, p. 93-138.

Sgarbi P.B.A. \& Gaspar J.C. 2002. Geochemistry of Santo Antônio da Barra Kamafugites, Goiás, Brazil. J. Sou. Am. Ear. Sci., 14:889-901.

Shaikh, A. M., Patel, S. C., Bussweiler, Y., Kumar, S. P., Tappe, S., Ravi, S., Mainkar, D., 2018. Olivine trace element compositions in diamondiferous lamproites from India: Proxies for magma origins and the nature of the lithospheric mantle beneath the Bastar and Dharwar cratons. Lithos, 324-325, 501-518.

Shee, S., 1985. The petrogenesis of the Wesselton Mine kimberlites, Kimberley, Cape Province, R.S.A. Unpublished PhD Thesis, University of Cape Town, p. 220.

Shibata, C.S.V., 2015. Petrografia e geoquímica da intrusão kimberlítica Pântano, Província Alcalina Alto Paranaíba, MG. Trabalho de Conclusão de Curso, Unicamp, 70 p.

Shirey S.B., Cartigny P., Frost D.J., Keshav S., Nestola F., Nimis P., Pearson D.G., Sobolev N.V., Walter MJ, 2013. Diamonds and the geology of mantle carbon. Rev Mineral Geochem 75(1):355-421.

Sobolev, A.V., Hofmann, A.W., Kuzmin, D.V., Yaxley, G.M., Arndt, N.T., Chung, S.L., Danyushevsky, L.V., Elliott, T., Frey, F.A., Garcia, M.O., Gurenko, A.A., Kamenetsky, V.S., Kerr, A.C., Krivolutskaya, N.A., Matvienkov, V.V., Nikogosian, I.K., Rocholl, A., Sigurdsson, I.A., Sushchevskaya, N.M., Teklay, M., 2007. The amount of recycled crust in sources of mantle-derived melts. Science 316, 412-417.

Soltys, A., Giuliani, A., Phillips, D., 2018. A new approach to reconstructing the composition and evolution of kimberlite melts: A case study of the archetypal Bultfontein kimberlite (Kimberley, South Africa). Lithos, 304-307: 1-15.

Skinner, E.M.W., Marsh, J.S., 2004. Distinct kimberlite pipe classes with contrasting eruption processes. Proceedings of the 8th International Kimberlite Conference. Lithos, vol. 76, pp. 183-200.

Sonoki I.K. \& Garda G.M. 1988. Idades K-Ar de rochas alcalinas do Brasil Meridional e Paraguai Oriental: compilação e adaptação as novas constantes de decaimento. Boletim IG-USP, Série Científica, 19:63-85.

Sparks, R.S.J., Brooker, R.A., Field, M., Kavanagh, J.L., Schumacher, J.C., Walter, M.J., and White, J., 2009, The nature of erupting kimberlite melts: Lithos, v. 112S, p. 429438.

Sparks, R.S.J., 2013. Kimberlite Volcanism. Earth Planet. Sci. 2013.41:497-528.

Streck, M.J., 2008, Mineral textures and zoning as evidence for open system processes: Reviews in Mineralogy and Geochemistry, v. 69, no. 1, p. 595-622.

Svisero, D.P. \& Ulbrich, M.N.C., 1992. Mineralogia, petrografia e geologia do kimberlito Limeira e intrusões associadas, município de Monte Carmelo, Minas Gerais. Boletim IG-USP. Série Especial, São Paulo, 12: 127-129.

Tappe, S., Foley, S.F., Jenner, G.A., Heaman, L.M., Kjarsgaard, B.A., 2005. Integrating Ultramafic Lamprophyres into IUGS Classification of Igneous Rocks: Rationale and Implications. Journal of Petrology, 46: 1893-1900.

Tappe, S., Foley, S.F., Jenner, G.A., Heaman, L.M., Kjarsgaard, B.A., Romer, R.L., Stracke, A., Joyce, N., Hoefs, J., 2006. Genesis of ultramafic lamprophyres and carbonatites at Aillik Bay, Labrador: A consequence of incipient lithospheric thinning beneath the North Atlantic Craton. Journal of Petrology 47, 1261-1315.

Tegner, C., Wilson, J.R., and Robins, B., 2005, Crustal assimilation in basalt and jotunite: Constraints from layered intrusions: Lithos, v. 83, p. 299-316.

Ubide, T., Arranz, E., Lago, M., Galé, C., Larrea, P., 2012. The influence of crystal settling on the compositional zoning of a thin lamprophyre sill: A multi-method approach. Lithos, 132-133, 37-49.

Valeriano M.C., Dardenne M.A., Fonseca M.A., Simões L.S.A., Seer H.J. 2004. A evolução tectônica da Faixa Brasília. In: Mantesso-Neto V., Bartorelli A., Carneiro C. Dal Ré, 
Brito-Neves B.B. de (org.) Geologia do Continente Sul-Americano: evolução da obra de Fernando Flávio Marques de Almeida. São Paulo: Ed. Beca, p. 575-592.

Veter M., Foley S.F., Mertz-Kraus R., Groschopf N., 2017. Trace elements in olivine of ultramafic lamprophyres controlled by phlogopite-rich mineral assemblages in the mantle source. Lithos 292-293, 81-95.

Waychunas G. A., 1987.Synchrotron radiation XANES spectroscopy of Ti in minerals: Effect of Ti bonding distances, $\mathrm{Ti}$ valence, and site geometry on absorption edge structure. Am. Miner., 72: 89-101.

Wedepohl K. H., 1991. Chemical composition and fractionation of the continental crust. Geol. Rundsch. 80, 207-223.

Wendlandt, R.F., 1977. Barium-phlogopite from Haystack Butte, Highwood mountains, Montana. Carnegie Institution of Washington Year Book. 76. 534-539.

Wilson, M. 1989. Igneous petrogenesis: A global tectonic approach, Unwin and Hyman, London.

Yoder, H.S. (1986): Potassium-rich rocks: phase analysis and heteromorphic relations. J. Petrol. 5, 228p.

Zanetti, A., Tiepolo, M., Oberti, R., Vannucci, R., 2004. Trace-element partitioning in olivine: modelling of a complete data set from a synthetic hydrous basanite melt. Lithos 75, 3954.

Zhang, Y., Radha, A.V., Navrotsky, A. 2013. Thermochemistry of two calcium silicate carbonate minerals: scawtite, $\mathrm{Ca} 7(\mathrm{Si} 6 \mathrm{O} 18)(\mathrm{CO} 3) \cdot 2 \mathrm{H} 2 \mathrm{O}$, and spurrite, $\mathrm{Ca}_{5}\left(\mathrm{SiO}_{4}\right) 2\left(\mathrm{CO}_{3}\right)$. Geochimica et Cosmochimica Acta. Volume 115, pp. 92 -99.

Zindler, A. and Jagoutz, E. (1988). Mantle Cryptology. Geochimica et Cosmochimica Acta 52(2): 319-333.

Zorpil, M.J., Coulon, C., Orsini, J.B.; Cocirta, C., 1989. Magma mingling, zoning and emplacement in calc-alkaline granitoid plutons. Tectonophysics, 157: 315-329. 
Apêndice A - Análises de Geoquímica de Rocha Total 
Tabela A.I: resultados de química de rocha total obtidos por FRX.

\begin{tabular}{|c|c|c|c|c|c|c|c|c|c|}
\hline \% em massa & L.D. & PNT 3 & PNT 4 & PNT 5 & PNT 6 & PNT 7 & PNT 8 & PNT 9 & Qtz \\
\hline $\mathrm{SiO}_{2}$ & 0,03 & 32,0 & 31,8 & 32,0 & 32,8 & 34,5 & 32,3 & 33,9 & 97,25 \\
\hline $\mathrm{TiO}_{2}$ & 0,003 & 4,87 & 5,91 & 6,21 & 4,96 & 4,88 & 4,79 & 4,76 & 0,031 \\
\hline $\mathrm{Al}_{2} \mathrm{O}_{3}$ & 0,02 & 2,4 & 2,8 & 3,1 & 2,3 & 2,3 & 2,3 & 2,3 & 0,20 \\
\hline $\mathrm{Fe}_{2} \mathrm{O}_{3}$ & 0,01 & 14,2 & 15,6 & 15,9 & 14,4 & 14,3 & 14,1 & 13,9 & 0,45 \\
\hline MnO & 0,002 & 0,2 & 0,2 & 0,2 & 0,2 & 0,2 & 0,2 & 0,2 & 0,04 \\
\hline MgO & 0,01 & 24,2 & 20,6 & 19,1 & 24,5 & 24,6 & 24,8 & 23,9 & $<$ L.D. \\
\hline $\mathrm{CaO}$ & 0,01 & 11,4 & 11,4 & 11,5 & 11,4 & 9,3 & 11,2 & 10,4 & 0,02 \\
\hline $\mathrm{Na}_{2} \mathrm{O}$ & 0,02 & 0,02 & 0,02 & 0,09 & 0,02 & 0,02 & 0,02 & 0,02 & $<$ L.D. \\
\hline $\mathrm{K}_{2} \mathrm{O}$ & 0,01 & 2,4 & 3,2 & 3,2 & 2,4 & 2,3 & 2,2 & 2,9 & $<$ L.D. \\
\hline $\mathrm{P}_{2} \mathrm{O}_{5}$ & 0,003 & 1,0 & 0,7 & 0,6 & 0,9 & 0,5 & 0,7 & 0,9 & 0,22 \\
\hline $\mathrm{BaO}$ & 0,004 & 0,3 & 0,3 & 0,3 & 0,3 & 0,3 & 0,1 & 0,3 & 0,009 \\
\hline $\mathrm{Cr}_{2} \mathrm{O}_{3}$ & 0,001 & 0,2 & 0,1 & 0,1 & 0,2 & 0,2 & 0,3 & 0,2 & $<$ L.D. \\
\hline $\mathrm{NiO}$ & 0,005 & 0,1 & 0,1 & 0,1 & 0,1 & 0,1 & 0,2 & 0,1 & $<$ L.D. \\
\hline SrO & 0,002 & 0,2 & 0,2 & 0,2 & 0,2 & 0,2 & 0,1 & 0,2 & 0,002 \\
\hline $\mathrm{ZrO}_{2}$ & 0,002 & 0,1 & 0,1 & 0,1 & 0,1 & 0,1 & 0,2 & 0,1 & 0,006 \\
\hline LOI & 0,01 & 5,5 & 6,2 & 6,8 & 5,4 & 5,6 & 6,3 & 5,5 & 0,6 \\
\hline Total & - & 99,0 & 99,3 & 98,4 & 100,2 & 99,3 & 99,8 & 99,6 & 98,8 \\
\hline$S c_{p p m}$ & 14 & 34,0 & 38,0 & 35,0 & 32,0 & 34,0 & 35,0 & 34,0 & $<$ L.D. \\
\hline V & 9 & 76 & 74 & 111 & 48 & 85 & 85 & 61 & 29 \\
\hline Co & 6 & 93 & 90 & 92 & 95 & 94 & 93 & 93 & $<$ L.D. \\
\hline $\mathrm{Cu}$ & 5 & 118 & 137 & 137 & 120 & 119 & 119 & 113 & 6 \\
\hline $\mathrm{Zn}$ & 2 & 89 & 103 & 106 & 91 & 92 & 91 & 90 & 4 \\
\hline Ga & 9 & 9 & 14 & 14 & 10 & $<9$ & 9 & 9 & $<$ L.D. \\
\hline $\mathbf{R b}$ & 3 & 145 & 199 & 196 & 164 & 163 & 162 & 143 & 7 \\
\hline $\mathbf{Y}$ & 2 & 24 & 26 & 25 & 23 & 25 & 24 & 25 & 3 \\
\hline Nb & 9 & 258 & 287 & 285 & 262 & 261 & 259 & 260 & $<$ L.D. \\
\hline La & 28 & 227 & 248 & 260 & 225 & 244 & 239 & 242 & $<$ L.D. \\
\hline $\mathrm{Ce}$ & 35 & 348 & 395 & 438 & 351 & 386 & 374 & 396 & $<$ L.D. \\
\hline Nd & 14 & 116 & 141 & 161 & 122 & 135 & 131 & 136 & $<$ L.D. \\
\hline Th & 7 & $<7$ & $<7$ & $<7$ & $<7$ & $<7$ & $<7$ & $<7$ & $<$ L.D. \\
\hline $\mathbf{U}$ & 3 & $<3$ & $<3$ & $<3$ & $<3$ & $<3$ & $<3$ & $<3$ & 3 \\
\hline Mg\# & & 0,77 & 0,72 & 0,70 & 0,77 & 0,77 & 0,77 & 0,77 & \\
\hline Cl & - & 1,2 & 1,3 & 1,4 & 1,2 & 1,3 & 1,3 & 1,2 & \\
\hline
\end{tabular}

L.D.: Limite de detecção; Qtz: quartzito encaixante. 
Tabela A.II: resultados de química de rocha total obtidos por ICP-MS.

\begin{tabular}{|c|c|c|c|c|c|c|c|c|c|}
\hline & L.D. & PNT 3 & PNT 4 & PNT 5 & PNT 6 & PNT 7 & PNT 8 & PNT 9 & Qtz \\
\hline $\mathrm{V}_{\mathrm{ppm}}$ & 8,0 & 79,0 & 72,0 & 100,0 & 58,0 & 78,0 & 55,0 & 85,0 & 30,0 \\
\hline Co & 0,2 & 84,6 & 77,4 & 79,3 & 79,2 & 78,1 & 84,1 & 83,9 & 5,9 \\
\hline $\mathrm{Be}$ & 1,0 & 4,0 & 4,0 & 6,0 & 3,0 & 2,0 & 5,0 & 3,0 & $<$ L.Q. \\
\hline $\mathbf{G a}$ & 0,5 & 9,5 & 11,9 & 12,6 & 8,6 & 8,6 & 8,4 & 10,2 & 0,6 \\
\hline $\mathbf{R b}$ & 0,1 & 144,5 & 187,2 & 198,4 & 156,5 & 150,0 & 140,3 & 163,6 & 4,6 \\
\hline $\mathrm{Sr}$ & 0,5 & 1731,9 & 1754,4 & 2035,3 & 1772,2 & 1561,0 & 1810,8 & 1762,9 & 18,7 \\
\hline $\mathbf{Y}$ & 0,1 & 22,9 & 24,1 & 25,7 & 23,4 & 22,1 & 23,3 & 23,3 & 2,5 \\
\hline $\mathrm{Zr}$ & 0,1 & 785,5 & 854,5 & 797,7 & 745,7 & 727,4 & 762,4 & 771,2 & 62,3 \\
\hline $\mathrm{Nb}$ & 0,1 & 272,9 & 291,9 & 300,0 & 266,3 & 260,6 & 273,0 & 270,3 & 0,6 \\
\hline Sn & 1,0 & 4,0 & 4,0 & 4,0 & 3,0 & 2,0 & 3,0 & 3,0 & $<$ L.Q. \\
\hline Cs & 0,1 & 1,8 & 1,6 & 2,2 & 1,7 & 1,5 & 1,4 & 1,4 & 0,1 \\
\hline $\mathrm{Ba}$ & 1,0 & 2973 & 2866 & 2308 & 2902 & 2907 & 3010 & 3082 & 91 \\
\hline La & 0,1 & 269,7 & 279,3 & 287,4 & 272,5 & 269,0 & 278,2 & 273,6 & 5,0 \\
\hline $\mathrm{Ce}$ & 0,1 & 489,4 & 512,5 & 538,1 & 496,3 & 488,6 & 504,4 & 499,4 & 6,0 \\
\hline $\mathrm{Pr}$ & 0,1 & 54,25 & 56,69 & 59,13 & 54,52 & 53,52 & 55,76 & 54,75 & 0,98 \\
\hline $\mathbf{N d}$ & 0,3 & 182,3 & 193,3 & 201,5 & 190,5 & 185,9 & 191,4 & 184,3 & 4,2 \\
\hline $\mathrm{Sm}$ & 0,05 & 22,81 & 24,76 & 26,48 & 23,35 & 22,63 & 24,22 & 23,20 & 0,64 \\
\hline Eu & 0,02 & 5,58 & 6,02 & 6,31 & 5,73 & 5,85 & 5,76 & 5,51 & 0,21 \\
\hline Gd & 0,05 & 14,90 & 15,37 & 15,87 & 14,26 & 15,07 & 14,16 & 14,09 & 0,66 \\
\hline $\mathrm{Tb}$ & 0,01 & 1,38 & 1,47 & 1,50 & 1,33 & 1,39 & 1,39 & 1,33 & 0,08 \\
\hline Dy & 0,05 & 6,00 & 6,96 & 7,15 & 6,37 & 6,17 & 6,59 & 6,44 & 0,42 \\
\hline Ho & 0,02 & 0,84 & 0,89 & 0,91 & 0,79 & 0,81 & 0,82 & 0,79 & 0,07 \\
\hline $\mathrm{Er}$ & 0,03 & 1,70 & 1,87 & 1,94 & 1,66 & 1,67 & 1,80 & 1,69 & 0,24 \\
\hline $\mathrm{Tm}$ & 0,01 & 0,23 & 0,24 & 0,24 & 0,20 & 0,20 & 0,23 & 0,20 & 0,04 \\
\hline $\mathbf{Y b}$ & 0,05 & 1,28 & 1,33 & 1,40 & 1,24 & 1,27 & 1,27 & 1,23 & 0,22 \\
\hline Lu & 0,01 & 0,16 & 0,16 & 0,18 & 0,16 & 0,15 & 0,15 & 0,17 & 0,04 \\
\hline $\mathbf{R b}$ & 0,1 & 144,5 & 187,2 & 198,4 & 156,5 & 150,0 & 140,3 & 163,6 & 4,6 \\
\hline $\mathrm{Sr}$ & 0,5 & 1731,9 & 1754,4 & 2035,3 & 1772,2 & 1561,0 & 1810,8 & 1762,9 & 18,7 \\
\hline $\mathbf{Y}$ & 0,1 & 22,9 & 24,1 & 25,7 & 23,4 & 22,1 & 23,3 & 23,3 & 2,5 \\
\hline $\mathrm{Hf}$ & 0,1 & 19,1 & 21,1 & 19,0 & 18,3 & 18,2 & 18,1 & 18,9 & 1,2 \\
\hline $\mathrm{Ta}$ & 0,1 & 15,1 & 17,2 & 17,3 & 15,6 & 14,9 & 15,3 & 15,5 & $<$ L.Q. \\
\hline W & 0,5 & 0,7 & 0,5 & 0,8 & 0,8 & 0,7 & 0,9 & $<$ L.Q. & 0,7 \\
\hline Th & 0,2 & 26,6 & 27,7 & 28,6 & 27,3 & 27,7 & 27,8 & 26,6 & 0,5 \\
\hline $\mathbf{U}$ & 0,1 & 5,9 & 6,0 & 6,3 & 5,8 & 5,6 & 5,8 & 6,2 & 0,4 \\
\hline
\end{tabular}

L.D.: Limite de detecção; Qtz: quartzito encaixante. 
Apêndice B - Análises de Microssonda Eletrônica 
Apêndice B - Tabela B.I: Composição em óxidos (\% massa) e fórmula estrutural das olivinas da intrusão Pântano (continua).

\begin{tabular}{|c|c|c|c|c|c|c|c|}
\hline Amostra & P06-04 & P06-04 & P06-04 & P10-10 & P10-10 & P10-10 & P10-10 \\
\hline Grão' & MicroR15 & MicroR17 & MicroR19 & MicroR1 & MicroR11 & MicroR13 & MicroR3 \\
\hline Localização² $^{2}$ & $\mathrm{~N}$ & $\mathrm{~N}$ & $\mathrm{~N}$ & $\mathrm{~N}$ & $\mathrm{~N}$ & $\mathrm{~N}$ & $N$ \\
\hline $\mathrm{SiO}_{2}$ & 40,3 & 39,82 & 41,02 & 40,61 & 39,3 & 40,25 & 39,41 \\
\hline $\mathrm{Al}_{2} \mathrm{O}_{3}$ & 0,01 & 0,07 & 0,05 & 0,02 & 0,06 & 0,03 & 0,05 \\
\hline $\mathrm{TiO}_{2}$ & & & 0,17 & & 0,1 & 0,01 & 0,07 \\
\hline $\mathrm{FeO}$ & 10,81 & 14,19 & 9,82 & 8,05 & 13,44 & 12,44 & 13,47 \\
\hline MnO & 0,11 & 0,18 & 0,15 & 0,13 & 0,17 & 0,17 & 0,15 \\
\hline $\mathrm{MgO}$ & 49,01 & 46,34 & 50,04 & 50,1 & 45,57 & 45,99 & 45,7 \\
\hline $\mathrm{CaO}$ & 0,03 & 0,14 & 0,09 & 0,06 & 0,09 & 0,11 & 0,1 \\
\hline $\mathrm{Na}_{2} \mathrm{O}$ & 0,01 & 0,02 & 0,04 & 0,02 & 0,03 & 0,03 & 0,03 \\
\hline $\mathrm{K}_{2} \mathrm{O}$ & & & 0,01 & 0,02 & & 0,02 & 0,01 \\
\hline $\mathrm{NiO}$ & & & & 0,42 & & & 0,39 \\
\hline $\mathrm{Cr}_{2} \mathrm{O}_{3}$ & & 0,03 & 0,1 & 0,04 & 0,03 & 0,06 & 0,08 \\
\hline Total & 100,28 & 100,79 & 101,49 & 99,47 & 98,79 & 99,11 & 99,46 \\
\hline \multicolumn{8}{|c|}{ Fórmula estrutural na base de 4 oxigênios (a.p.f.u.) } \\
\hline Si & 0,99 & 0,989 & 0,991 & 0,995 & 0,993 & 1,007 & 0,991 \\
\hline Al & & 0,002 & 0,001 & 0,001 & 0,002 & 0,001 & 0,001 \\
\hline $\mathrm{Ti}$ & & & 0,003 & & 0,002 & & 0,001 \\
\hline $\mathrm{Fe}^{2+}$ & 0,222 & 0,295 & 0,198 & 0,165 & 0,284 & 0,26 & 0,283 \\
\hline Mn & 0,002 & 0,004 & 0,003 & 0,003 & 0,004 & 0,004 & 0,003 \\
\hline Mg & 1,795 & 1,716 & 1,802 & 1,83 & 1,716 & 1,715 & 1,713 \\
\hline $\mathrm{Ca}$ & 0,001 & 0,004 & 0,002 & 0,002 & 0,002 & 0,003 & 0,003 \\
\hline $\mathrm{Na}$ & & 0,001 & 0,002 & 0,001 & 0,001 & 0,001 & 0,001 \\
\hline K & & & & 0,001 & & 0,001 & \\
\hline $\mathrm{Ni}$ & & & & 0,008 & & & 0,008 \\
\hline$\Sigma$ Cátions & 3,01 & 3,011 & 3,002 & 3,006 & 3,004 & 2,992 & 3,004 \\
\hline \multicolumn{8}{|c|}{ Componentes moleculares (\%) } \\
\hline Fo & 88,99 & 85,34 & 90,08 & 91,73 & 85,80 & 86,82 & 85,81 \\
\hline $\mathbf{F a}$ & 11,01 & 14,66 & 9,92 & 8,27 & 14,20 & 13,18 & 14,19 \\
\hline
\end{tabular}


Apêndice B - Tabela B.I (continuação): Composição em óxidos (\% massa) e fórmula estrutural das olivinas da intrusão Pântano (continua).

\begin{tabular}{|c|c|c|c|c|c|c|c|}
\hline $\begin{array}{l}\text { Amostra } \\
\text { Grão }\end{array}$ & $\begin{array}{l}\text { P10-10 } \\
\text { FMicroR5 }\end{array}$ & $\begin{array}{c}\text { P10-10 } \\
\text { FMicroR7 }\end{array}$ & $\begin{array}{c}\text { P10-10 } \\
\text { FMicroR9 }\end{array}$ & $\begin{array}{l}\text { P10-10 } \\
\text { MicrocR1 }\end{array}$ & $\begin{array}{l}\text { P10-10 } \\
\text { MicrocR2 }\end{array}$ & $\begin{array}{c}\text { P10-10 } \\
\text { MicrocR3 }\end{array}$ & $\begin{array}{c}\text { P10-10 } \\
\text { MicrocR4 }\end{array}$ \\
\hline Localização² & $\mathrm{N}$ & $\mathrm{N}$ & $\mathrm{N}$ & $\mathrm{N}$ & $\mathrm{N}$ & $N$ & $\mathrm{~N}$ \\
\hline $\mathrm{SiO}_{2}$ & 40,9 & 40,13 & 38,32 & 39,44 & 39,49 & 39,8 & 40,1 \\
\hline $\mathrm{Al}_{2} \mathrm{O}_{3}$ & 0,01 & 0,05 & 0,08 & 0,03 & 0,02 & 0,07 & 0,04 \\
\hline $\mathrm{TiO}_{2}$ & & 0,01 & 0,04 & 0,08 & 0,05 & 0,03 & 0,04 \\
\hline $\mathrm{FeO}$ & 8,72 & 8,36 & 13,72 & 13,54 & 13,94 & 13,21 & 12,7 \\
\hline MnO & 0,1 & 0,16 & 0,22 & 0,16 & 0,22 & 0,19 & 0,18 \\
\hline $\mathrm{MgO}$ & 49,37 & 49,8 & 44,96 & 45,02 & 44,42 & 45,17 & 45,8 \\
\hline $\mathrm{CaO}$ & 0,06 & 0,08 & 0,09 & 0,14 & 0,27 & 0,15 & 0,15 \\
\hline $\mathrm{Na}_{2} \mathrm{O}$ & 0,01 & 0,09 & 0,05 & 0,04 & 0,02 & 0,04 & 0,01 \\
\hline $\mathrm{K}_{2} \mathrm{O}$ & 0,01 & 0,04 & & 0,03 & 0,02 & 0,04 & 0,03 \\
\hline $\mathrm{NiO}$ & & & & 0,35 & 0,2 & & \\
\hline $\mathrm{Cr}_{2} \mathrm{O}_{3}$ & 0,12 & 0,05 & 0,08 & 0,08 & 0,05 & 0,07 & 0,09 \\
\hline Total & 99,3 & 98,77 & 97,56 & 98,91 & 98,7 & 98,77 & 99,14 \\
\hline
\end{tabular}

Fórmula estrutural na base de 4 oxigênios (a.p.f.u.)

\begin{tabular}{|c|c|c|c|c|c|c|c|}
\hline Si & 1,004 & 0,991 & 0,984 & 0,997 & 1,002 & 1,004 & 1,005 \\
\hline Al & & 0,001 & 0,002 & 0,001 & 0,001 & 0,002 & 0,001 \\
\hline $\mathrm{Ti}$ & & & 0,001 & 0,002 & 0,001 & 0,001 & 0,001 \\
\hline $\mathrm{Fe}^{2+}$ & 0,179 & 0,173 & 0,295 & 0,286 & 0,296 & 0,279 & 0,266 \\
\hline Mn & 0,002 & 0,003 & 0,005 & 0,003 & 0,005 & 0,004 & 0,004 \\
\hline Mg & 1,806 & 1,833 & 1,721 & 1,697 & 1,68 & 1,698 & 1,71 \\
\hline $\mathrm{Ca}$ & 0,002 & 0,002 & 0,002 & 0,004 & 0,007 & 0,004 & 0,004 \\
\hline $\mathrm{Na}$ & & 0,004 & 0,002 & 0,002 & 0,001 & 0,002 & \\
\hline $\mathrm{K}$ & & 0,001 & & 0,001 & 0,001 & 0,001 & 0,001 \\
\hline $\mathrm{Ni}$ & & & & 0,007 & 0,004 & & \\
\hline$\Sigma$ Cátions & 2,993 & 3,008 & 3,012 & 3 & 2,998 & 2,995 & 2,992 \\
\hline \multicolumn{8}{|c|}{ Componentes moleculares } \\
\hline Fo & 90,98 & 91,39 & 85,38 & 85,56 & 85,03 & 85,90 & 86,53 \\
\hline $\mathbf{F a}$ & 9,02 & 8,61 & 14,62 & 14,44 & 14,97 & 14,10 & 13,47 \\
\hline
\end{tabular}

${ }^{1}$ Abreviações: Micro (microcristal).

'Localização da análise do grão: N (Núcleo). 
Apêndice B - Tabela B.I (continuação): Composição em óxidos (\% massa) e fórmula estrutural das olivinas da intrusão Pântano (continua).

\begin{tabular}{|c|c|c|c|c|c|c|c|}
\hline $\begin{array}{l}\text { Amostra } \\
\text { Grão }\end{array}$ & $\begin{array}{l}\text { P10-10 } \\
\text { MicrocR5 }\end{array}$ & $\begin{array}{c}\text { P10-10 } \\
\text { MicrocR6 }\end{array}$ & $\begin{array}{c}\text { P10-10 } \\
\text { MicrocR7 }\end{array}$ & $\begin{array}{l}\text { P10-10 } \\
\text { MicrocR8 }\end{array}$ & $\begin{array}{c}\text { PNT3A1 } \\
\text { micro27 }\end{array}$ & $\begin{array}{c}\text { PNT3A1 } \\
\text { micro31 }\end{array}$ & $\begin{array}{c}\text { PNT3A1 } \\
\text { micro33 }\end{array}$ \\
\hline Localização² $^{2}$ & $\mathrm{~N}$ & $\mathrm{~N}$ & $\mathrm{~N}$ & $\mathrm{~N}$ & $\mathrm{~N}$ & $\mathrm{~N}$ & $\mathrm{~N}$ \\
\hline $\mathrm{SiO}_{2}$ & 39,77 & 38,81 & 39,15 & 39,69 & 39,36 & 41 & 40,09 \\
\hline $\mathrm{Al}_{2} \mathrm{O}_{3}$ & 0,04 & 0,05 & 0,04 & 0,08 & 0,03 & & 0,04 \\
\hline $\mathrm{TiO}_{2}$ & 0,03 & 0,04 & 0,06 & 0,05 & 0,06 & & 0,08 \\
\hline $\mathrm{FeO}$ & 13,75 & 13,67 & 12,79 & 14,08 & 14,8 & 8,07 & 13,74 \\
\hline MnO & 0,18 & 0,24 & 0,24 & 0,16 & 0,14 & 0,16 & 0,16 \\
\hline $\mathrm{MgO}$ & 44,87 & 44,84 & 45,59 & 44,57 & 45,29 & 50,37 & 45,91 \\
\hline $\mathrm{CaO}$ & 0,12 & 0,25 & 0,13 & 0,2 & 0,13 & & 0,08 \\
\hline $\mathrm{Na}_{2} \mathrm{O}$ & 0,02 & 0,02 & 0,01 & 0,02 & 0,01 & & 0,02 \\
\hline $\mathrm{K}_{2} \mathrm{O}$ & & 0,01 & 0,01 & 0,03 & 0,02 & 0,01 & 0,03 \\
\hline $\mathrm{NiO}$ & & & & & 0,3 & 0,35 & 0,34 \\
\hline $\mathrm{Cr}_{2} \mathrm{O}_{3}$ & 0,11 & 0,04 & 0,11 & 0,12 & 0,02 & & \\
\hline Total & 98,89 & 97,97 & 98,13 & 99 & 100,16 & 99,96 & 100,49 \\
\hline \multicolumn{8}{|c|}{ Fórmula estrutural na base de 4 oxigênios (a.p.f.u.) } \\
\hline Si & 1,004 & 0,991 & 0,994 & 1,003 & 0,988 & 0,998 & 0,997 \\
\hline Al & 0,001 & 0,002 & 0,001 & 0,002 & 0,001 & & 0,001 \\
\hline $\mathrm{Ti}$ & 0,001 & 0,001 & 0,001 & 0,001 & 0,001 & & 0,001 \\
\hline $\mathrm{Fe}^{2+}$ & 0,29 & 0,292 & 0,271 & 0,297 & 0,311 & 0,164 & 0,286 \\
\hline Mn & 0,004 & 0,005 & 0,005 & 0,003 & 0,003 & 0,003 & 0,003 \\
\hline Mg & 1,688 & 1,708 & 1,725 & 1,678 & 1,695 & 1,829 & 1,702 \\
\hline $\mathrm{Ca}$ & 0,003 & 0,007 & 0,004 & 0,005 & 0,003 & & 0,002 \\
\hline $\mathrm{Na}$ & 0,001 & 0,001 & & 0,001 & & & 0,001 \\
\hline K & & & & 0,001 & 0,001 & & 0,001 \\
\hline $\mathrm{Ni}$ & & & & & 0,006 & 0,007 & 0,007 \\
\hline$\Sigma$ Cátions & 2,992 & 3,007 & 3,001 & 2,991 & 3,009 & 3,001 & 3,001 \\
\hline \multicolumn{8}{|c|}{ Componentes moleculares } \\
\hline Fo & 85,33 & 85,39 & 86,40 & 84,94 & 84,50 & 91,75 & 85,62 \\
\hline $\mathbf{F a}$ & 14,67 & 14,61 & 13,60 & 15,06 & 15,50 & 8,25 & 14,38 \\
\hline
\end{tabular}

${ }^{1}$ Abreviações: Micro (microcristal).

²Localização da análise do grão: N (Núcleo). 
Apêndice B - Tabela B.I (continuação): Composição em óxidos (\% massa) e fórmula estrutural das olivinas da intrusão Pântano (continua).

\begin{tabular}{|c|c|c|c|c|c|c|c|}
\hline $\begin{array}{l}\text { Amostra } \\
\text { Grão }\end{array}$ & $\begin{array}{l}\text { PNT3A1 } \\
\text { micro35 }\end{array}$ & $\begin{array}{l}\text { PNT3A1 } \\
\text { micro37 }\end{array}$ & $\begin{array}{l}\text { pnt3f1 } \\
\text { ol1_mic_n }\end{array}$ & $\begin{array}{c}\text { pnt3f1 } \\
\text { ol3_mic_n }\end{array}$ & $\begin{array}{l}\text { pnt3f1 } \\
\text { ol4_mic }\end{array}$ & $\begin{array}{l}\text { pnt3f1 } \\
\text { ol5_mic }\end{array}$ & $\begin{array}{l}\text { pnt3f1 } \\
\text { ol6_mic }\end{array}$ \\
\hline Localização $^{2}$ & $\mathrm{~N}$ & $\mathrm{~N}$ & $\mathrm{~N}$ & $\mathrm{~N}$ & $\mathrm{~N}$ & $\mathrm{~N}$ & $\mathrm{~N}$ \\
\hline $\mathrm{SiO}_{2}$ & 39,74 & 41,27 & 41,17 & 40,95 & 40,46 & 40,94 & 39,85 \\
\hline $\mathrm{Al}_{2} \mathrm{O}_{3}$ & 0,02 & & & & 0,01 & & 0,03 \\
\hline $\mathrm{TiO}_{2}$ & 0,03 & & & & 0,03 & 0,01 & 0,02 \\
\hline $\mathrm{FeO}$ & 13,72 & 7,88 & 8,1 & 8,46 & 11,01 & 9,54 & 14,66 \\
\hline MnO & 0,17 & 0,12 & 0,08 & 0,13 & 0,14 & 0,13 & 0,16 \\
\hline $\mathrm{MgO}$ & 45,73 & 51,09 & 50,86 & 50,27 & 48,32 & 49,98 & 44,7 \\
\hline $\mathrm{CaO}$ & 0,12 & 0,01 & 0,01 & 0,04 & 0,07 & 0,05 & 0,11 \\
\hline $\mathrm{Na}_{2} \mathrm{O}$ & 0,03 & & 0,02 & & 0,02 & 0,02 & 0,02 \\
\hline $\mathrm{K}_{2} \mathrm{O}$ & & & 0,01 & & & & \\
\hline $\mathrm{NiO}$ & 0,36 & 0,36 & 0,40 & 0,36 & 0,37 & 0,35 & 0,28 \\
\hline $\mathrm{Cr}_{2} \mathrm{O}_{3}$ & 0,1 & 0,01 & & & 0,07 & & 0,05 \\
\hline Total & 100,02 & 100,74 & 100,68 & 100,23 & 100,53 & 101,05 & 99,91 \\
\hline \multicolumn{8}{|c|}{ Fórmula estrutural na base de 4 oxigênios (a.p.f.u.) } \\
\hline Si & 0,994 & 0,996 & 0,996 & 0,996 & 0,994 & 0,993 & 1,001 \\
\hline Al & 0,001 & & & & & & 0,001 \\
\hline $\mathrm{Ti}$ & 0,001 & & & & 0,001 & & 0,001 \\
\hline $\mathrm{Fe}^{2+}$ & 0,287 & 0,159 & 0,164 & 0,172 & 0,226 & 0,194 & 0,308 \\
\hline Mn & 0,004 & 0,002 & 0,002 & 0,003 & 0,003 & 0,003 & 0,004 \\
\hline Mg & 1,705 & 1,839 & 1,834 & 1,824 & 1,769 & 1,808 & 1,674 \\
\hline $\mathrm{Ca}$ & 0,003 & & & 0,001 & 0,002 & 0,001 & 0,003 \\
\hline $\mathrm{Na}$ & 0,001 & & 0,001 & & 0,001 & 0,001 & 0,001 \\
\hline K & & & 0,001 & & & & \\
\hline $\mathrm{Ni}$ & 0,007 & 0,007 & 0,008 & 0,007 & 0,008 & 0,007 & 0,006 \\
\hline$\Sigma$ Cátions & 3,003 & 3,003 & 3,006 & 3,003 & 3,004 & 3,007 & 2,999 \\
\hline \multicolumn{8}{|c|}{ Componentes moleculares } \\
\hline Fo & 85,59 & 92,03 & 91,80 & 91,37 & 88,66 & 90,32 & 84,46 \\
\hline $\mathbf{F a}$ & 14,41 & 7,97 & 8,20 & 8,63 & 11,34 & 9,68 & 15,54 \\
\hline
\end{tabular}

${ }^{1}$ Abreviações: Mic e micro (microcristal). Amostras pnt3f1 (análises realizadas no fragmento 1). 2Localização da análise do grão: N (Núcleo). 
Apêndice B - Tabela B.I (continuação): Composição em óxidos (\% massa) e fórmula estrutural das olivinas da intrusão Pântano (continua).

\begin{tabular}{|c|c|c|c|c|c|c|c|}
\hline $\begin{array}{l}\text { Amostra } \\
\text { Grão }{ }^{1}\end{array}$ & $\begin{array}{l}\text { pnt3f2 } \\
\text { ol1_mic }\end{array}$ & $\begin{array}{l}\text { pnt3f2 } \\
\text { ol2_mic }\end{array}$ & $\begin{array}{l}\text { PNT4A4 } \\
\text { micro14 }\end{array}$ & $\begin{array}{l}\text { PNT4A4 } \\
\text { micro16 }\end{array}$ & $\begin{array}{c}\text { PNT4A4 } \\
\text { micro18 }\end{array}$ & $\begin{array}{l}\text { PNT5B } \\
\text { micro20 }\end{array}$ & $\begin{array}{l}\text { PNT5B } \\
\text { micro22 }\end{array}$ \\
\hline Localização $^{2}$ & $\mathrm{~N}$ & $\mathrm{~N}$ & $\mathrm{~N}$ & $\mathrm{~N}$ & $\mathrm{~N}$ & $\mathrm{~N}$ & $\mathrm{~N}$ \\
\hline $\mathrm{SiO}_{2}$ & 40,35 & 40,37 & 41,12 & 40,1 & 40,62 & 40,25 & 40,2 \\
\hline $\mathrm{Al}_{2} \mathrm{O}_{3}$ & 0,0001 & 0,0493 & 0,01 & 0,01 & 0,01 & 0,05 & 0,04 \\
\hline $\mathrm{TiO}_{2}$ & 0,0278 & 0,0539 & 0,01 & 0,05 & 0,04 & 0,04 & 0,03 \\
\hline $\mathrm{FeO}$ & 9,83 & 11,54 & 7,38 & 15,15 & 9,84 & 12,88 & 12,73 \\
\hline MnO & 0,1131 & 0,1312 & 0,11 & 0,19 & 0,15 & 0,15 & 0,15 \\
\hline $\mathrm{MgO}$ & 49,59 & 48,69 & 51,17 & 45 & 49,31 & 46,53 & 46,68 \\
\hline $\mathrm{CaO}$ & 0,0141 & 0,1634 & 0,01 & 0,09 & 0,05 & 0,1 & 0,13 \\
\hline $\mathrm{Na}_{2} \mathrm{O}$ & & 0,019 & 0,01 & 0,01 & 0,02 & 0,03 & 0,02 \\
\hline $\mathrm{K}_{2} \mathrm{O}$ & & & & 0,02 & & 0,02 & \\
\hline $\mathrm{NiO}$ & 0,3794 & 0,3844 & 0,4 & 0,25 & 0,35 & 0,34 & 0,34 \\
\hline $\mathrm{Cr}_{2} \mathrm{O}_{3}$ & 0,0073 & 0,0162 & 0,05 & 0,05 & 0,01 & 0,09 & 0,03 \\
\hline Total & 100,31 & 101,42 & 100,27 & 100,92 & 100,4 & 100,48 & 100,35 \\
\hline \multicolumn{8}{|c|}{ Fórmula estrutural na base de 4 oxigênios (a.p.f.u.) } \\
\hline Si & 0,988 & 0,986 & 0,996 & 0,999 & 0,993 & 0,997 & 0,997 \\
\hline Al & & 0,001 & & & & 0,001 & 0,001 \\
\hline Ti & 0,001 & 0,001 & & 0,001 & 0,001 & 0,001 & 0,001 \\
\hline $\mathrm{Fe}^{2+}$ & 0,201 & 0,236 & 0,149 & 0,316 & 0,201 & 0,267 & 0,264 \\
\hline Mn & 0,002 & 0,003 & 0,002 & 0,004 & 0,003 & 0,003 & 0,003 \\
\hline Mg & 1,811 & 1,773 & 1,847 & 1,671 & 1,798 & 1,719 & 1,725 \\
\hline $\mathrm{Ca}$ & & 0,004 & & 0,002 & 0,001 & 0,003 & 0,003 \\
\hline $\mathrm{Na}$ & & 0,001 & & & 0,001 & 0,001 & 0,001 \\
\hline K & & & & 0,001 & & 0,001 & \\
\hline $\mathrm{Ni}$ & 0,007 & 0,008 & 0,008 & 0,005 & 0,007 & 0,007 & 0,007 \\
\hline$\Sigma$ Cátions & 3,01 & 3,013 & 3,002 & 2,999 & 3,005 & 3 & 3,002 \\
\hline \multicolumn{8}{|c|}{ Componentes moleculares } \\
\hline Fo & 89,99 & 88,26 & 92,51 & 84,11 & 89,93 & 86,55 & 86,73 \\
\hline $\mathbf{F a}$ & 10,01 & 11,74 & 7,49 & 15,89 & 10,07 & 13,45 & 13,27 \\
\hline
\end{tabular}

${ }^{1}$ Abreviações: Mic e micro (microcristal). Amostras pnt3f2 (análises realizadas no fragmento 2).

²Localização da análise do grão: N (Núcleo). 
Apêndice B - Tabela B.I (continuação): Composição em óxidos (\% massa) e fórmula estrutural das olivinas da intrusão Pântano (continua).

\begin{tabular}{|c|c|c|c|c|c|c|c|}
\hline $\begin{array}{l}\text { Amostra } \\
\text { Grão }^{1}\end{array}$ & $\begin{array}{l}\text { PNT5B } \\
\text { micro24 }\end{array}$ & $\begin{array}{l}\text { PNT7B1 } \\
\text { micro1 }\end{array}$ & $\begin{array}{c}\text { PNT7B1 } \\
\text { micro3 }\end{array}$ & $\begin{array}{c}\text { PNT7B1 } \\
\text { micro5 }\end{array}$ & $\begin{array}{l}\text { PNT8A1 } \\
\text { micro11 }\end{array}$ & $\begin{array}{c}\text { P06-04 } \\
\text { MicroR16 }\end{array}$ & $\begin{array}{c}\text { P06-04 } \\
\text { MicroR18 }\end{array}$ \\
\hline Localização² & $\mathrm{N}$ & $\mathrm{N}$ & $\mathrm{N}$ & $\mathrm{N}$ & $\mathrm{N}$ & $\mathrm{B}$ & B \\
\hline $\mathrm{SiO}_{2}$ & 39,9 & 40,85 & 39,65 & 40,45 & 41,02 & 40,42 & 40,38 \\
\hline $\mathrm{Al}_{2} \mathrm{O}_{3}$ & 0,02 & 0,01 & 0,03 & 0,02 & 0,02 & 0 & 0,01 \\
\hline $\mathrm{TiO}_{2}$ & 0,05 & 0,01 & 0,02 & 0,04 & 0,04 & 0,04 & 0,07 \\
\hline $\mathrm{FeO}$ & 16,25 & 8,16 & 14,38 & 9,83 & 8,87 & 14,17 & 13,82 \\
\hline MnO & 0,17 & 0,12 & 0,15 & 0,13 & 0,1 & 0,13 & 0,16 \\
\hline $\mathrm{MgO}$ & 44,31 & 50,7 & 45,57 & 48,87 & 51,02 & 45,82 & 46,35 \\
\hline $\mathrm{CaO}$ & 0,09 & 0,03 & 0,08 & 0,04 & 0,05 & 0,11 & 0,09 \\
\hline $\mathrm{Na}_{2} \mathrm{O}$ & 0,01 & & 0,05 & 0,01 & 0,02 & 0,01 & 0,01 \\
\hline $\mathrm{K}_{2} \mathrm{O}$ & & & 0,03 & & 0,01 & 0,02 & 0,01 \\
\hline $\mathrm{NiO}$ & 0,22 & 0,41 & 0,36 & 0,36 & 0,38 & & \\
\hline $\mathrm{Cr}_{2} \mathrm{O}_{3}$ & 0,01 & & 0,02 & 0,05 & & 0,02 & 0,01 \\
\hline Total & 101,03 & 100,29 & 100,34 & 99,8 & 101,53 & 100,74 & 100,91 \\
\hline \multicolumn{8}{|c|}{ Fórmula estrutural na base de 4 oxigênios (a.p.f.u.) } \\
\hline Si & 0,998 & 0,993 & 0,992 & 0,995 & 0,988 & 1,002 & 0,998 \\
\hline Al & 0,001 & & 0,001 & 0,001 & 0,001 & & \\
\hline $\mathrm{Ti}$ & 0,001 & & & 0,001 & 0,001 & 0,001 & 0,001 \\
\hline $\mathrm{Fe}^{2+}$ & 0,34 & 0,166 & 0,301 & 0,202 & 0,179 & 0,294 & 0,286 \\
\hline Mn & 0,004 & 0,002 & 0,003 & 0,003 & 0,002 & 0,003 & 0,003 \\
\hline Mg & 1,651 & 1,837 & 1,699 & 1,792 & 1,832 & 1,694 & 1,708 \\
\hline $\mathrm{Ca}$ & 0,002 & 0,001 & 0,002 & 0,001 & 0,001 & 0,003 & 0,002 \\
\hline $\mathrm{Na}$ & & & 0,002 & & 0,001 & & \\
\hline $\mathrm{K}$ & & & 0,001 & & & 0,001 & \\
\hline $\mathbf{N i}$ & 0,004 & 0,008 & 0,007 & 0,007 & 0,007 & & \\
\hline$\Sigma$ Cátions & 3,001 & 3,007 & 3,008 & 3,002 & 3,012 & 2,998 & 2,998 \\
\hline \multicolumn{8}{|c|}{ Componentes moleculares } \\
\hline Fo & 82,93 & 91,72 & 84,96 & 89,86 & 91,11 & 85,21 & 85,67 \\
\hline $\mathbf{F a}$ & 17,07 & 8,28 & 15,04 & 10,14 & 8,89 & 14,79 & 14,33 \\
\hline
\end{tabular}

${ }^{1}$ Abreviações: Micro (microcristal).

2Localização da análise do grão: N (Núcleo); B (Borda). 
Apêndice B - Tabela B.I (continuação): Composição em óxidos (\% massa) e fórmula estrutural das olivinas da intrusão Pântano (continua).

\begin{tabular}{|c|c|c|c|c|c|c|c|}
\hline $\begin{array}{l}\text { Amostra } \\
\text { Grão }\end{array}$ & $\begin{array}{l}\text { P06-04 } \\
\text { MicroR1 }\end{array}$ & $\begin{array}{l}\text { P10-10 } \\
\text { MicroR10 }\end{array}$ & $\begin{array}{l}\text { P10-10 } \\
\text { MicroR20 }\end{array}$ & $\begin{array}{l}\text { P10-10 } \\
\text { MicroR14 }\end{array}$ & $\begin{array}{l}\text { P10-10 } \\
\text { MicroR2 }\end{array}$ & $\begin{array}{l}\text { P10-10 } \\
\text { MicrocR4 }\end{array}$ & $\begin{array}{l}\text { P10-10 } \\
\text { MicroR6 }\end{array}$ \\
\hline Localização² $^{2}$ & B & B & B & B & B & B & B \\
\hline $\mathrm{SiO}_{2}$ & 39,85 & 39,85 & 39,64 & 40,1 & 39,96 & 40,03 & 39,12 \\
\hline $\mathrm{Al}_{2} \mathrm{O}_{3}$ & 0,01 & 0,01 & 0,03 & & 0,04 & 0,01 & 0,05 \\
\hline $\mathrm{TiO}_{2}$ & 0,05 & 0,03 & 0,08 & 0,05 & 0,09 & 0,05 & \\
\hline $\mathrm{FeO}$ & 13,92 & 13,17 & 12,14 & 12,52 & 12,65 & 13,06 & 8,72 \\
\hline MnO & 0,16 & 0,19 & 0,22 & 0,21 & 0,23 & 0,18 & 0,12 \\
\hline $\mathrm{MgO}$ & 46,75 & 46 & 46,79 & 46,15 & 45,53 & 46,62 & 48,85 \\
\hline $\mathrm{CaO}$ & 0,11 & 0,12 & 0,26 & 0,13 & 0,16 & 0,18 & 0,39 \\
\hline $\mathrm{Na}_{2} \mathrm{O}$ & 0,02 & 0,04 & 0,02 & 0,01 & 0,04 & 0,02 & 0,23 \\
\hline $\mathrm{K}_{2} \mathrm{O}$ & 0,01 & 0,04 & 0,04 & 0,04 & 0,02 & 0,04 & 0,19 \\
\hline $\mathrm{NiO}$ & & & & & 0,23 & 0,22 & \\
\hline $\mathrm{Cr}_{2} \mathrm{O}_{3}$ & 0,07 & 0,05 & 0,05 & 0,06 & 0,08 & 0,04 & 0,09 \\
\hline Total & 100,95 & 99,5 & 99,27 & 99,27 & 99,03 & 100,45 & 97,76 \\
\hline \multicolumn{8}{|c|}{ Fórmula estrutural na base de 4 oxigênios (a.p.f.u.) } \\
\hline Si & 0,987 & 0,998 & 0,991 & 1,003 & 1,004 & 0,993 & 0,982 \\
\hline Al & & & 0,001 & & 0,001 & & 0,001 \\
\hline Ti & 0,001 & 0,001 & 0,002 & 0,001 & 0,002 & 0,001 & \\
\hline $\mathrm{Fe}^{2+}$ & 0,288 & 0,276 & 0,254 & 0,262 & 0,266 & 0,271 & 0,183 \\
\hline Mn & 0,003 & 0,004 & 0,005 & 0,004 & 0,005 & 0,004 & 0,003 \\
\hline Mg & 1,726 & 1,717 & 1,745 & 1,72 & 1,705 & 1,725 & 1,827 \\
\hline $\mathrm{Ca}$ & 0,003 & 0,003 & 0,007 & 0,003 & 0,004 & 0,005 & 0,01 \\
\hline $\mathrm{Na}$ & 0,001 & 0,002 & 0,001 & & 0,002 & 0,001 & 0,011 \\
\hline K & & 0,001 & 0,001 & 0,001 & 0,001 & 0,001 & 0,006 \\
\hline $\mathrm{Ni}$ & & & & & 0,005 & 0,004 & \\
\hline$\Sigma$ Cátions & 3,009 & 3,002 & 3,007 & 2,994 & 2,995 & 3,005 & 3,023 \\
\hline \multicolumn{8}{|c|}{ Componentes moleculares } \\
\hline Fo & 85,68 & 86,16 & 87,29 & 86,79 & 86,51 & 86,42 & 90,89 \\
\hline $\mathbf{F a}$ & 14,32 & 13,84 & 12,71 & 13,21 & 13,49 & 13,58 & 9,11 \\
\hline
\end{tabular}

${ }^{1}$ Abreviações: Micro (microcristal);

2Localização da análise do grão: B (Borda). 
Apêndice B - Tabela B.I (continuação): Composição em óxidos (\% massa) e fórmula estrutural das olivinas da intrusão Pântano (continua).

\begin{tabular}{|c|c|c|c|c|c|c|c|}
\hline $\begin{array}{l}\text { Amostra } \\
\text { Grão }\end{array}$ & $\begin{array}{l}\text { P10-10 } \\
\text { MicroR8 }\end{array}$ & $\begin{array}{c}\text { PNT3A1 } \\
\text { micro26 }\end{array}$ & $\begin{array}{c}\text { PNT3A1 } \\
\text { micro28 }\end{array}$ & $\begin{array}{l}\text { PNT3A1 } \\
\text { micro29 }\end{array}$ & $\begin{array}{c}\text { PNT3A1 } \\
\text { micro30 }\end{array}$ & $\begin{array}{c}\text { PNT3A1 } \\
\text { micro32 }\end{array}$ & $\begin{array}{c}\text { PNT3A1 } \\
\text { micro34 }\end{array}$ \\
\hline Localização² & B & $B$ & $\mathrm{~B}$ & B & $\mathrm{B}$ & $\mathrm{B}$ & $\mathrm{B}$ \\
\hline $\mathrm{SiO}_{2}$ & 40,08 & 36,34 & 40,12 & 40,63 & 41,26 & 41,65 & 39,91 \\
\hline $\mathrm{Al}_{2} \mathrm{O}_{3}$ & 0,04 & 3,84 & 0,03 & 0,02 & 0,01 & 0,01 & 0,02 \\
\hline $\mathrm{TiO}_{2}$ & & 0,55 & 0,05 & 0,13 & 0 & 0,05 & 0,09 \\
\hline $\mathrm{FeO}$ & 10,14 & 7,42 & 13,3 & 13,45 & 7,99 & 12,74 & 14,83 \\
\hline MnO & 0,17 & 0,16 & 0,26 & 0,22 & 0,13 & 0,24 & 0,28 \\
\hline $\mathrm{MgO}$ & 48,3 & 22,04 & 45,74 & 45,31 & 50,73 & 44,76 & 45,82 \\
\hline $\mathrm{CaO}$ & 0,05 & & 0,3 & 0,34 & 0,02 & 0,31 & 0,22 \\
\hline $\mathrm{Na}_{2} \mathrm{O}$ & 0,01 & 0,12 & & 0,01 & & 0,01 & 0,01 \\
\hline $\mathrm{K}_{2} \mathrm{O}$ & 0,02 & 2,47 & & & 0,01 & & \\
\hline $\mathrm{NiO}$ & & 0,08 & 0,15 & 0,17 & 0,35 & 0,16 & 0,24 \\
\hline $\mathrm{Cr}_{2} \mathrm{O}_{3}$ & 0,05 & 0,02 & & 0,01 & & 0,06 & 0,04 \\
\hline Total & 98,86 & 84,28 & 99,95 & 100,29 & 100,5 & 99,99 & 101,46 \\
\hline \multicolumn{8}{|c|}{ Fórmula estrutural na base de 4 oxigênios (a.p.f.u.) } \\
\hline Si & 0,996 & 1,09 & 1,001 & 1,009 & 0,999 & 1,031 & 0,989 \\
\hline Al & 0,001 & 0,136 & 0,001 & 0,001 & 0 & 0 & 0,001 \\
\hline $\mathrm{Ti}$ & & 0,012 & 0,001 & 0,002 & 0 & 0,001 & 0,002 \\
\hline $\mathrm{Fe}^{2+}$ & 0,211 & 0,186 & 0,277 & 0,279 & 0,162 & 0,264 & 0,307 \\
\hline Mn & 0,004 & 0,004 & 0,005 & 0,005 & 0,003 & 0,005 & 0,006 \\
\hline Mg & 1,789 & 0,986 & 1,701 & 1,678 & 1,83 & 1,652 & 1,693 \\
\hline $\mathrm{Ca}$ & 0,001 & 0,361 & 0,008 & 0,009 & 0,001 & 0,008 & 0,006 \\
\hline $\mathrm{Na}$ & & 0,007 & & & & & \\
\hline $\mathrm{K}$ & 0,001 & 0,095 & & & & & \\
\hline $\mathrm{Ni}$ & & 0,002 & 0,003 & 0,003 & 0,007 & 0,003 & 0,005 \\
\hline$\Sigma$ Cátions & 3,003 & 2,879 & 2,997 & 2,986 & 3,002 & 2,964 & 3,009 \\
\hline \multicolumn{8}{|c|}{ Componentes moleculares } \\
\hline Fo & 89,46 & 84,11 & 85,97 & 85,72 & 91,88 & 86,23 & 84,63 \\
\hline $\mathbf{F a}$ & 10,54 & 15,89 & 14,03 & 14,28 & 8,12 & 13,77 & 15,37 \\
\hline
\end{tabular}


Apêndice B - Tabela B.I (continuação): Composição em óxidos (\% massa) e fórmula estrutural das olivinas da intrusão Pântano (continua).

\begin{tabular}{|c|c|c|c|c|c|c|}
\hline $\begin{array}{l}\text { Amostra } \\
\text { Grão' }\end{array}$ & $\begin{array}{c}\text { PNT3A1 } \\
\text { micro36 }\end{array}$ & $\begin{array}{l}\text { pnt3f1 } \\
\text { ol4_mic }\end{array}$ & $\begin{array}{l}\text { pnt3f1 } \\
\text { ol5_mic }\end{array}$ & $\begin{array}{l}\text { pnt3f2 } \\
\text { ol1_micr }\end{array}$ & $\begin{array}{l}\text { pnt3f2 } \\
\text { ol2_mic }\end{array}$ & $\begin{array}{c}\text { PNT4A4 } \\
\text { micro3 }\end{array}$ \\
\hline Localização² & B & B & B & B & B & B \\
\hline $\mathrm{SiO}_{2}$ & 40,68 & 40,2 & 39,39 & 39,95 & 40,37 & 40,36 \\
\hline $\mathrm{Al}_{2} \mathrm{O}_{3}$ & 0,01 & 0,01 & 0,01 & & 0,03 & 0,01 \\
\hline $\mathrm{TiO}_{2}$ & 0,03 & 0,03 & 0,05 & 0,06 & 0,05 & 0,03 \\
\hline $\mathrm{FeO}$ & 13,78 & 14,35 & 13,82 & 14,28 & 14,93 & 13,16 \\
\hline MnO & 0,18 & 0,24 & 0,20 & 0,20 & 0,18 & 0,18 \\
\hline MgO & 44,92 & 44,89 & 46,25 & 45,8 & 44,86 & 46,48 \\
\hline $\mathrm{CaO}$ & 0,11 & 0,21 & 0,17 & 0,11 & 0,15 & 0,07 \\
\hline $\mathrm{Na}_{2} \mathrm{O}$ & 0,02 & 0,03 & 0,01 & 0,01 & & 0,02 \\
\hline $\mathrm{K}_{2} \mathrm{O}$ & 0,01 & 0,02 & 0,04 & 0,01 & 0,02 & \\
\hline $\mathrm{NiO}$ & 0,29 & 0,21 & 0,21 & 0,32 & 0,30 & 0,27 \\
\hline $\mathrm{Cr}_{2} \mathrm{O}_{3}$ & & 0,02 & 0,05 & 0,06 & & 0,02 \\
\hline Total & 100,03 & 100,25 & 100,24 & 100,83 & 100,92 & 100,6 \\
\hline
\end{tabular}

\begin{tabular}{lcccccc}
\hline \multicolumn{7}{c}{ Fórmula estrutural na base de 4 oxigênios (a.p.f.u.) } \\
\hline $\mathbf{S i}$ & 1,014 & 1,004 & 0,985 & 0,993 & 1,004 & 0,999 \\
$\mathbf{A l}$ & & 0,001 & & & 0,001 & \\
$\mathrm{Ti}$ & 0,001 & 0,001 & 0,001 & 0,001 & 0,001 & 0,001 \\
$\mathbf{F e}$ & 0,287 & 0,3 & 0,289 & 0,297 & 0,311 & 0,272 \\
$\mathbf{M n}$ & 0,004 & 0,005 & 0,004 & 0,004 & 0,004 & 0,004 \\
$\mathbf{M g}$ & 1,67 & 1,672 & 1,723 & 1,698 & 1,663 & 1,715 \\
$\mathbf{C a}$ & 0,003 & 0,006 & 0,005 & 0,003 & 0,004 & 0,002 \\
$\mathbf{N a}$ & 0,001 & 0,002 & 0,001 & 0,001 & & 0,001 \\
$\mathbf{K}$ & & 0,001 & 0,001 & & 0,001 & \\
$\mathbf{N i}$ & 0,006 & 0,004 & 0,004 & 0,006 & 0,006 & 0,005 \\
$\mathbf{\Sigma}$ Cátions & 2,986 & 2,996 & 3,013 & 3,003 & 2,995 & 2,999 \\
\hline Fo & 85,31 & 84,79 & 85,64 & 85,11 & 84,26 & 86,29 \\
Fa & 14,69 & 15,21 & 14,36 & 14,89 & 15,74 & 13,71
\end{tabular}

${ }^{1}$ Abreviações: Mic e micro (microcristal). Amostras pnt3f1 e pnt3f2 (análises realizadas nos fragmentos 1 e 2).

2Localização da análise do grão: B (Borda). 
Apêndice B - Tabela B.I (continuação): Composição em óxidos (\% massa) e fórmula estrutural das olivinas da intrusão Pântano (continua).

\begin{tabular}{|c|c|c|c|c|c|c|c|}
\hline $\begin{array}{l}\text { Amostra } \\
\text { Grão }\end{array}$ & $\begin{array}{c}\text { PNT4A4 } \\
\text { micro17 }\end{array}$ & $\begin{array}{c}\text { PNT4A4 } \\
\text { micro38 }\end{array}$ & $\begin{array}{l}\text { PNT5B } \\
\text { micro19 }\end{array}$ & $\begin{array}{l}\text { PNT5B } \\
\text { micro21 }\end{array}$ & $\begin{array}{l}\text { PNT5B } \\
\text { micro23 }\end{array}$ & $\begin{array}{c}\text { PNT7B1 } \\
\text { micro2 }\end{array}$ & $\begin{array}{c}\text { PNT7B1 } \\
\text { micro25 }\end{array}$ \\
\hline Localização $^{2}$ & B & B & B & B & B & B & B \\
\hline $\mathrm{SiO}_{2}$ & 40,12 & 39,65 & 40,41 & 39,66 & 40,44 & 39,9 & 39,83 \\
\hline $\mathrm{Al}_{2} \mathrm{O}_{3}$ & 0,02 & 0,01 & 0,03 & 0,02 & 0,02 & & 0,03 \\
\hline $\mathrm{TiO}_{2}$ & 0,07 & 0,06 & 0,07 & 0,05 & 0,01 & & 0,01 \\
\hline $\mathrm{FeO}$ & 14,15 & 14,15 & 14,51 & 14,68 & 14,16 & 13,77 & 13 \\
\hline MnO & 0,25 & 0,22 & 0,22 & 0,17 & 0,24 & 0,19 & 0,22 \\
\hline $\mathrm{MgO}$ & 45,13 & 45,98 & 45,6 & 45,33 & 44,57 & 45,6 & 46,59 \\
\hline $\mathrm{CaO}$ & 0,28 & 0,22 & 0,16 & 0,08 & 0,17 & 0,12 & 0,2 \\
\hline $\mathrm{Na}_{2} \mathrm{O}$ & 0,02 & 0,02 & 0,01 & 0,02 & 0,03 & 0,02 & 0,02 \\
\hline $\mathrm{K}_{2} \mathrm{O}$ & 0,01 & & 0,02 & & & & \\
\hline $\mathrm{NiO}$ & 0,15 & 0,16 & 0,3 & 0,29 & 0,24 & 0,29 & 0,16 \\
\hline $\mathrm{Cr}_{2} \mathrm{O}_{3}$ & & 0,03 & 0,01 & 0,09 & 0,06 & 0,06 & 0,05 \\
\hline Total & 100,2 & 100,5 & 101,34 & 100,39 & 99,94 & 99,95 & 100,11 \\
\hline \multicolumn{8}{|c|}{ Fórmula estrutural na base de 4 oxigênios (a.p.f.u.) } \\
\hline Si & 1,002 & 0,989 & 0,999 & 0,992 & 1,012 & 0,998 & 0,992 \\
\hline Al & 0,001 & & 0,001 & 0,001 & 0,001 & & 0,001 \\
\hline $\mathrm{Ti}$ & 0,001 & 0,001 & 0,001 & 0,001 & & & \\
\hline $\mathrm{Fe}^{2+}$ & 0,296 & 0,295 & 0,3 & 0,307 & 0,296 & 0,288 & 0,271 \\
\hline Mn & 0,005 & 0,005 & 0,005 & 0,004 & 0,005 & 0,004 & 0,005 \\
\hline Mg & 1,68 & 1,709 & 1,681 & 1,691 & 1,662 & 1,7 & 1,729 \\
\hline $\mathrm{Ca}$ & 0,007 & 0,006 & 0,004 & 0,002 & 0,005 & 0,003 & 0,005 \\
\hline $\mathrm{Na}$ & 0,001 & 0,001 & & 0,001 & 0,001 & 0,001 & 0,001 \\
\hline $\mathrm{K}$ & & & 0,001 & & & & \\
\hline $\mathbf{N i}$ & 0,003 & 0,003 & 0,006 & 0,006 & 0,005 & 0,006 & 0,003 \\
\hline$\Sigma$ Cátions & 2,996 & 3,009 & 2,998 & 3,005 & 2,987 & 3 & 3,007 \\
\hline \multicolumn{8}{|c|}{ Componentes moleculares } \\
\hline Fo & 85,04 & 85,27 & 84,85 & 84,62 & 84,87 & 85,51 & 86,46 \\
\hline $\mathbf{F a}$ & 14,96 & 14,73 & 15,15 & 15,38 & 15,13 & 14,49 & 13,54 \\
\hline
\end{tabular}

${ }^{1}$ Abreviações: Micro (microcristal).

2Localização da análise do grão: B (Borda). 
Apêndice B - Tabela B.I (continuação): Composição em óxidos (\% massa) e fórmula estrutural das olivinas da intrusão Pântano (continua).

\begin{tabular}{|c|c|c|c|c|c|c|c|}
\hline $\begin{array}{l}\text { Amostra } \\
\text { Grão }{ }^{1}\end{array}$ & $\begin{array}{l}\text { PNT7B } \\
\text { micro4 }\end{array}$ & $\begin{array}{l}\text { PNT8A } \\
\text { micro10 }\end{array}$ & $\begin{array}{l}\text { P06-04 } \\
\text { Macro13 }\end{array}$ & $\begin{array}{l}\text { P06-04 } \\
\text { Macro15 }\end{array}$ & $\begin{array}{c}\text { P06-04 } \\
\text { MacroR21 }\end{array}$ & $\begin{array}{l}\text { P06-04 } \\
\text { MacroR5 }\end{array}$ & $\begin{array}{l}\text { P06-04 } \\
\text { MacroR7 }\end{array}$ \\
\hline Localização² $^{2}$ & B & B & $N$ & $\mathrm{~N}$ & $\mathrm{~N}$ & $N$ & N \\
\hline $\mathrm{SiO}_{2}$ & 40,4 & 40,49 & 41,18 & 40,65 & 41,57 & 41,18 & 40,65 \\
\hline $\mathrm{Al}_{2} \mathrm{O}_{3}$ & 0,02 & & 0,01 & 0,02 & & 0,01 & 0,02 \\
\hline $\mathrm{TiO}_{2}$ & 0,13 & 0,01 & & & 0,04 & & \\
\hline $\mathrm{FeO}$ & 13,12 & 13,69 & 10,47 & 11,11 & 8,27 & 10,47 & 11,11 \\
\hline MnO & 0,26 & 0,2 & 0,13 & 0,11 & 0,12 & 0,13 & 0,11 \\
\hline $\mathrm{MgO}$ & 45,66 & 45,77 & 48,72 & 48,56 & 50,7 & 48,72 & 48,56 \\
\hline $\mathrm{CaO}$ & 0,31 & 0,11 & 0,03 & 0,03 & 0,05 & 0,03 & 0,03 \\
\hline $\mathrm{Na}_{2} \mathrm{O}$ & 0,01 & 0,01 & 0,02 & 0,01 & 0,02 & 0,02 & 0,01 \\
\hline $\mathrm{K}_{2} \mathrm{O}$ & & & 0,01 & & & 0,01 & \\
\hline $\mathrm{NiO}$ & 0,17 & 0,32 & & & & & \\
\hline $\mathrm{Cr}_{2} \mathrm{O}_{3}$ & 0,02 & 0,03 & & 0,02 & & & 0,02 \\
\hline Total & 100,1 & 100,63 & 100,57 & 100,51 & 100,77 & 100,57 & 100,51 \\
\hline \multicolumn{8}{|c|}{ Fórmula estrutural na base de 4 oxigênios (a.p.f.u.) } \\
\hline Si & 1,005 & 1,004 & 1,005 & 0,996 & 1,002 & 1,005 & 0,996 \\
\hline Al & 0,001 & & & 0,001 & & & 0,001 \\
\hline $\mathrm{Ti}$ & 0,002 & & & & 0,001 & & \\
\hline $\mathrm{Fe}^{2+}$ & 0,273 & 0,284 & 0,214 & 0,228 & 0,167 & 0,214 & 0,228 \\
\hline Mn & 0,005 & 0,004 & 0,003 & 0,002 & 0,002 & 0,003 & 0,002 \\
\hline Mg & 1,693 & 1,692 & 1,772 & 1,775 & 1,823 & 1,772 & 1,775 \\
\hline $\mathrm{Ca}$ & 0,008 & 0,003 & 0,001 & 0,001 & 0,001 & 0,001 & 0,001 \\
\hline $\mathrm{Na}$ & & & 0,001 & & 0,001 & 0,001 & \\
\hline \multicolumn{8}{|l|}{ K } \\
\hline $\mathrm{Ni}$ & 0,003 & 0,006 & & & & & \\
\hline$\Sigma$ Cátions & 2,99 & 2,993 & 2,996 & 3,003 & 2,997 & 2,996 & 3,003 \\
\hline \multicolumn{8}{|c|}{ Componentes moleculares } \\
\hline Fo & 86,11 & 85,63 & 89,24 & 88,62 & 91,61 & 89,24 & 88,62 \\
\hline $\mathbf{F a}$ & 13,89 & 14,37 & 10,76 & 11,38 & 8,39 & 10,76 & 11,38 \\
\hline
\end{tabular}

${ }^{1}$ Abreviações: Micro (microcristal); Macro (macrocristal).

²Localização da análise do grão: N (Núcleo); B (Borda). 
Apêndice B - Tabela B.I (continuação): Composição em óxidos (\% massa) e fórmula estrutural das olivinas da intrusão Pântano (continua).

\begin{tabular}{|c|c|c|c|c|c|c|c|}
\hline $\begin{array}{l}\text { Amostra } \\
\text { Grão }\end{array}$ & $\begin{array}{l}\text { P10-10 } \\
\text { MacroR1 }\end{array}$ & $\begin{array}{c}\text { P10-10 } \\
\text { MacroR11 }\end{array}$ & $\begin{array}{c}\text { P10-10 } \\
\text { MacroR17 }\end{array}$ & $\begin{array}{c}\text { P10-10 } \\
\text { MacroR19 }\end{array}$ & $\begin{array}{l}\text { P10-10 } \\
\text { MacroR3 }\end{array}$ & $\begin{array}{l}\text { P10-10 } \\
\text { MacroR9 }\end{array}$ & $\begin{array}{c}\text { PNT3A1 } \\
\text { macro27 }\end{array}$ \\
\hline Localização & $\mathrm{N}$ & $\mathrm{N}$ & $\mathrm{N}$ & $\mathrm{N}$ & $\mathrm{N}$ & $\mathrm{N}$ & N \\
\hline $\mathrm{SiO}_{2}$ & 40,57 & 40,81 & 39,97 & 40,79 & 40,81 & 40,57 & 39,71 \\
\hline $\mathrm{Al}_{2} \mathrm{O}_{3}$ & & 0,02 & 0,06 & 0,01 & 0,02 & & 0,04 \\
\hline $\mathrm{TiO}_{2}$ & & & 0,08 & & & & 0,02 \\
\hline $\mathrm{FeO}$ & 8,77 & 8,85 & 14,23 & 9,4 & 8,85 & 8,77 & 15,49 \\
\hline MnO & 0,12 & 0,11 & 0,17 & 0,14 & 0,11 & 0,12 & 0,18 \\
\hline $\mathrm{MgO}$ & 49,75 & 49,68 & 44,76 & 48,99 & 49,68 & 49,75 & 44,12 \\
\hline $\mathrm{CaO}$ & 0,02 & 0,05 & 0,08 & 0,02 & 0,05 & 0,02 & 0,08 \\
\hline $\mathrm{Na}_{2} \mathrm{O}$ & 0,01 & 0,04 & 0,05 & 0,01 & 0,04 & 0,01 & 0,02 \\
\hline $\mathrm{K}_{2} \mathrm{O}$ & 0,01 & 0,02 & & & 0,02 & 0,01 & 0,02 \\
\hline $\mathrm{NiO}$ & 0,4 & 0,42 & & & 0,42 & 0,4 & 0,31 \\
\hline $\mathrm{Cr}_{2} \mathrm{O}_{3}$ & 0,06 & 0,06 & 0,07 & 0,02 & 0,06 & 0,06 & 0,02 \\
\hline Total & 99,71 & 100,06 & 99,47 & 99,38 & 100,06 & 99,71 & 100,01 \\
\hline \multicolumn{8}{|c|}{ Fórmula estrutural na base de 4 oxigênios (a.p.f.u.) } \\
\hline Si & 0,995 & 0,997 & 1,005 & 1,003 & 0,997 & 0,995 & 1 \\
\hline Al & & 0,001 & 0,002 & & 0,001 & & 0,001 \\
\hline $\mathrm{Ti}$ & & & 0,002 & & & & 0 \\
\hline $\mathrm{Fe}^{2+}$ & 0,18 & 0,181 & 0,299 & 0,193 & 0,181 & 0,18 & 0,326 \\
\hline Mn & 0,002 & 0,002 & 0,004 & 0,003 & 0,002 & 0,002 & 0,004 \\
\hline Mg & 1,818 & 1,809 & 1,677 & 1,796 & 1,809 & 1,818 & 1,657 \\
\hline $\mathrm{Ca}$ & 0,001 & 0,001 & 0,002 & 0,001 & 0,001 & 0,001 & 0,002 \\
\hline $\mathrm{Na}$ & & 0,002 & 0,002 & & 0,002 & & 0,001 \\
\hline $\mathbf{K}$ & & 0,001 & & & 0,001 & & 0,001 \\
\hline $\mathbf{N i}$ & 0,008 & 0,008 & & & 0,008 & 0,008 & 0,006 \\
\hline$\Sigma$ Cátions & 3,004 & 3,002 & 2,993 & 2,996 & 3,002 & 3,004 & 2,998 \\
\hline \multicolumn{8}{|c|}{ Componentes moleculares } \\
\hline Fo & 91,00 & 90,91 & 84,86 & 90,28 & 90,91 & 91,00 & 83,54 \\
\hline $\mathbf{F a}$ & 9,00 & 9,09 & 15,14 & 9,72 & 9,09 & 9,00 & 16,46 \\
\hline
\end{tabular}

${ }^{1}$ Abreviações: Macro (macrocristal).

²ocalização da análise do grão: N (Núcleo). 
Apêndice B - Tabela B.I (continuação): Composição em óxidos (\% massa) e fórmula estrutural das olivinas da intrusão Pântano (continua).

\begin{tabular}{|c|c|c|c|c|c|c|c|}
\hline $\begin{array}{l}\text { Amostra } \\
\text { Grão }\end{array}$ & $\begin{array}{c}\text { PNT3A1 } \\
\text { macro28 }\end{array}$ & $\begin{array}{c}\text { PNT3A1 } \\
\text { macro31 }\end{array}$ & $\begin{array}{l}\text { PNT3A1 } \\
\text { macro32 }\end{array}$ & $\begin{array}{c}\text { PNT3A2 } \\
\text { macro33 }\end{array}$ & $\begin{array}{c}\text { pnt3f2 } \\
\text { ol1_macro }\end{array}$ & $\begin{array}{c}\text { pnt3f2 } \\
\text { ol2_macro }\end{array}$ & $\begin{array}{c}\text { PNT4A4 } \\
\text { macro34 }\end{array}$ \\
\hline Localização² $^{2}$ & $\mathrm{~N}$ & $\mathrm{~N}$ & $\mathrm{~N}$ & $\mathrm{~N}$ & $\mathrm{~N}$ & $\mathrm{~N}$ & $\mathrm{~N}$ \\
\hline $\mathrm{SiO}_{2}$ & 40,1 & 41,23 & 41,04 & 42,04 & 40,93 & 40,54 & 41,32 \\
\hline $\mathrm{Al}_{2} \mathrm{O}_{3}$ & 0,02 & 0,02 & 0,04 & 1,04 & & & \\
\hline $\mathrm{TiO}_{2}$ & 0,04 & 0,05 & 0,06 & 1,06 & & 0,06 & 0,01 \\
\hline $\mathrm{FeO}$ & 15,47 & 8,39 & 8,62 & 9,62 & 9,1 & 8,49 & 8,17 \\
\hline MnO & 0,17 & 0,11 & 0,11 & 0,11 & 0,13 & 0,10 & 0,1 \\
\hline $\mathrm{MgO}$ & 44,23 & 49,85 & 50,11 & 51,11 & 50,42 & 50,38 & 50,42 \\
\hline $\mathrm{CaO}$ & 0,06 & 0,04 & 0,04 & & & & 0,02 \\
\hline $\mathrm{Na}_{2} \mathrm{O}$ & 0,02 & 0,02 & 0,02 & 1,02 & 0,01 & & 0,01 \\
\hline $\mathrm{K}_{2} \mathrm{O}$ & & 0,01 & & 1 & 0,01 & & 0,01 \\
\hline $\mathrm{NiO}$ & 0,29 & 0,4 & 0,4 & 0,4 & 0,41 & 0,35 & 0,4 \\
\hline $\mathrm{Cr}_{2} \mathrm{O}_{3}$ & 0,01 & & 0,04 & 0,04 & 0,01 & 0,06 & 0,01 \\
\hline Total & 100,41 & 100,12 & 100,48 & 111,48 & 101,04 & 100 & 100,47 \\
\hline \multicolumn{8}{|c|}{ Fórmula estrutural na base de 4 oxigênios (a.p.f.u.) } \\
\hline Si & 1,005 & 1,003 & 0,997 & 0,946 & 0,992 & 0,99 & 1,001 \\
\hline Al & 0,001 & 0,001 & 0,001 & 0,028 & & & \\
\hline $\mathrm{Ti}$ & 0,001 & 0,001 & 0,001 & 0,018 & & 0,001 & \\
\hline $\mathrm{Fe}^{2+}$ & 0,324 & 0,171 & 0,175 & 0,181 & 0,184 & 0,173 & 0,166 \\
\hline Mn & 0,004 & 0,002 & 0,002 & 0,021 & 0,003 & 0,002 & 0,002 \\
\hline Mg & 1,652 & 1,808 & 1,815 & 1,714 & 1,821 & 1,834 & 1,821 \\
\hline $\mathrm{Ca}$ & 0,002 & 0,001 & 0,001 & 0,025 & & & 0,001 \\
\hline $\mathrm{Na}$ & 0,001 & 0,001 & 0,001 & 0,044 & 0,001 & & \\
\hline K & & & & 0,029 & & & \\
\hline $\mathrm{Ni}$ & 0,006 & 0,008 & 0,008 & 0,025 & 0,008 & 0,007 & 0,008 \\
\hline$\Sigma$ Cátions & 2,996 & 2,996 & 3,001 & 3,051 & 3,009 & 3,007 & 2,999 \\
\hline \multicolumn{8}{|c|}{ Componentes moleculares } \\
\hline Fo & 83,59 & 91,37 & 91,20 & 90,45 & 90,80 & 91,36 & 91,66 \\
\hline $\mathbf{F a}$ & 16,41 & 8,63 & 8,80 & 9,55 & 9,20 & 8,64 & 8,34 \\
\hline
\end{tabular}

${ }^{1}$ Abreviações: Macro (macrocristal). Amostras pnt3ł2 (análises no fragmento 2).

²Localização da análise do grão: N (Núcleo). 
Apêndice B - Tabela B.I (continuação): Composição em óxidos (\% massa) e fórmula estrutural das olivinas da intrusão Pântano (continua).

\begin{tabular}{|c|c|c|c|c|c|c|c|}
\hline $\begin{array}{l}\text { Amostra } \\
\text { Grão }\end{array}$ & $\begin{array}{c}\text { PNT4A4 } \\
\text { macro37 }\end{array}$ & $\begin{array}{l}\text { PNT5B } \\
\text { macro13 }\end{array}$ & $\begin{array}{l}\text { PNT5B } \\
\text { macro15 }\end{array}$ & $\begin{array}{c}\text { PNT7B1 } \\
\text { macro18 }\end{array}$ & $\begin{array}{l}\text { PNT7B1 } \\
\text { macro20 }\end{array}$ & $\begin{array}{c}\text { PNT8A1 } \\
\text { macro2 }\end{array}$ & $\begin{array}{c}\text { PNT8A1 } \\
\text { macro22 }\end{array}$ \\
\hline Localização & $\mathrm{N}$ & $\mathrm{N}$ & $\mathrm{N}$ & $\mathrm{N}$ & $\mathrm{N}$ & $\mathrm{N}$ & $\mathrm{N}$ \\
\hline $\mathrm{SiO}_{2}$ & 40,46 & 41,42 & 40,72 & 39,39 & 40,89 & 40,99 & 40,89 \\
\hline $\mathrm{Al}_{2} \mathrm{O}_{3}$ & & & 0,02 & 0,08 & & 0,01 & 0,01 \\
\hline $\mathrm{TiO}_{2}$ & 0,04 & & 0,02 & 0,04 & & & 0,01 \\
\hline $\mathrm{FeO}$ & 13,48 & 8,26 & 9,89 & 14,79 & 8,13 & 8,62 & 10,27 \\
\hline MnO & 0,18 & 0,12 & 0,12 & 0,17 & 0,12 & 0,12 & 0,13 \\
\hline $\mathrm{MgO}$ & 45,94 & 50,99 & 49,51 & 44,7 & 49,86 & 50,24 & 49,33 \\
\hline $\mathrm{CaO}$ & 0,03 & 0,04 & 0,08 & 0,1 & 0,02 & 0,05 & 0,04 \\
\hline $\mathrm{Na}_{2} \mathrm{O}$ & 0,01 & 0,01 & 0,01 & 0,05 & 0,01 & 0,02 & 0,01 \\
\hline $\mathrm{K}_{2} \mathrm{O}$ & & & 0,01 & & 0,01 & 0,01 & 0 \\
\hline $\mathrm{NiO}$ & 0,35 & 0,38 & 0,39 & 0,31 & 0,37 & 0,36 & 0,39 \\
\hline $\mathrm{Cr}_{2} \mathrm{O}_{3}$ & & 0,06 & 0,02 & 0,01 & & 0,07 & \\
\hline Total & 100,49 & 101,28 & 100,79 & 99,64 & 99,41 & 100,49 & 101,08 \\
\hline \multicolumn{8}{|c|}{ Fórmula estrutural na base de 4 oxigênios (a.p.f.u.) } \\
\hline Si & 1,004 & 0,996 & 0,992 & 0,994 & 1,001 & 0,996 & 0,995 \\
\hline Al & & & 0,001 & 0,002 & & & \\
\hline $\mathrm{Ti}$ & 0,001 & & & 0,001 & & & \\
\hline $\mathrm{Fe}^{2+}$ & 0,28 & 0,166 & 0,202 & 0,312 & 0,166 & 0,175 & 0,209 \\
\hline Mn & 0,004 & 0,002 & 0,002 & 0,004 & 0,002 & 0,002 & 0,003 \\
\hline Mg & 1,699 & 1,828 & 1,799 & 1,681 & 1,82 & 1,819 & 1,789 \\
\hline $\mathrm{Ca}$ & 0,001 & 0,001 & 0,002 & 0,003 & 0,001 & 0,001 & 0,001 \\
\hline $\mathrm{Na}$ & & & & 0,002 & & 0,001 & \\
\hline \multicolumn{8}{|l|}{ K } \\
\hline $\mathbf{N i}$ & 0,007 & 0,007 & 0,008 & 0,006 & 0,007 & 0,007 & 0,008 \\
\hline$\Sigma$ Cátions & 2,996 & 3 & 3,006 & 3,005 & 2,997 & 3,001 & 3,005 \\
\hline \multicolumn{8}{|c|}{ Componentes moleculares } \\
\hline Fo & 85,86 & 91,67 & 89,92 & 84,34 & 91,62 & 91,22 & 89,54 \\
\hline $\mathbf{F a}$ & 14,14 & 8,33 & 10,08 & 15,66 & 8,38 & 8,78 & 10,46 \\
\hline
\end{tabular}

${ }^{1}$ Abreviações: Macro (macrocristal).

²Localização da análise do grão: N (Núcleo). 
Apêndice B - Tabela B.I (continuação): Composição em óxidos (\% massa) e fórmula estrutural das olivinas da intrusão Pântano (continua).

\begin{tabular}{|c|c|c|c|c|c|c|c|}
\hline $\begin{array}{l}\text { Amostra } \\
\text { Grão }^{1}\end{array}$ & $\begin{array}{c}\text { PNT8A1 } \\
\text { macro24 }\end{array}$ & $\begin{array}{c}\text { P06-04 } \\
\text { MacroR14 }\end{array}$ & $\begin{array}{c}\text { P06-04 } \\
\text { MacroR16 }\end{array}$ & $\begin{array}{c}\text { P06-04 } \\
\text { MacroR22 }\end{array}$ & $\begin{array}{l}\text { P06-04 } \\
\text { MacroR6 }\end{array}$ & $\begin{array}{l}\text { P06-04 } \\
\text { MacroR8 }\end{array}$ & $\begin{array}{c}\text { P10-10 } \\
\text { MacroR10 }\end{array}$ \\
\hline Localização² & $\mathrm{N}$ & B & B & B & B & B & B \\
\hline $\mathrm{SiO}_{2}$ & 41,23 & 40,41 & 40,45 & 39,55 & 40,41 & 40,45 & 38,85 \\
\hline $\mathrm{Al}_{2} \mathrm{O}_{3}$ & 0,01 & & & & & & 0,01 \\
\hline $\mathrm{TiO}_{2}$ & 0,04 & 0,02 & 0,05 & & 0,02 & 0,05 & \\
\hline $\mathrm{FeO}$ & 7,82 & 13,68 & 13,58 & 13,32 & 13,68 & 13,58 & 14,89 \\
\hline MnO & 0,11 & 0,22 & 0,17 & 0,28 & 0,22 & 0,17 & 0,2 \\
\hline $\mathrm{MgO}$ & 51,35 & 46,53 & 46,74 & 46,85 & 46,53 & 46,74 & 44,83 \\
\hline $\mathrm{CaO}$ & & 0,19 & 0,16 & 0,29 & 0,19 & 0,16 & 0,09 \\
\hline $\mathrm{Na}_{2} \mathrm{O}$ & 0,01 & & 0,01 & 0,03 & & 0,01 & \\
\hline $\mathrm{K}_{2} \mathrm{O}$ & & 0,01 & & 0,01 & 0,01 & & 0,01 \\
\hline $\mathrm{NiO}$ & 0,39 & & & & & & 0,3 \\
\hline $\mathrm{Cr}_{2} \mathrm{O}_{3}$ & & & 0,02 & 0,05 & & 0,02 & 0,01 \\
\hline Total & 100,96 & 101,06 & 101,18 & 100,38 & 101,06 & 101,18 & 99,19 \\
\hline
\end{tabular}

Fórmula estrutural na base de 4 oxigênios (a.p.f.u.)

\begin{tabular}{|c|c|c|c|c|c|c|c|}
\hline Si & 0,993 & 0,997 & 0,997 & 0,984 & 0,997 & 0,997 & 0,986 \\
\hline \multicolumn{8}{|l|}{ Al } \\
\hline $\mathrm{Ti}$ & 0,001 & & 0,001 & & & 0,001 & \\
\hline $\mathrm{Fe}^{2+}$ & 0,158 & 0,282 & 0,28 & 0,277 & 0,282 & 0,28 & 0,316 \\
\hline Mn & 0,002 & 0,005 & 0,004 & 0,006 & 0,005 & 0,004 & 0,004 \\
\hline Mg & 1,844 & 1,712 & 1,717 & 1,738 & 1,712 & 1,717 & 1,697 \\
\hline $\mathrm{Ca}$ & & 0,005 & 0,004 & 0,008 & 0,005 & 0,004 & 0,002 \\
\hline $\mathrm{Na}$ & & & & 0,001 & & & \\
\hline \multicolumn{8}{|l|}{ K } \\
\hline $\mathbf{N i}$ & 0,008 & & & & & & 0,006 \\
\hline$\Sigma$ Cátions & 3,006 & 3,001 & 3,003 & 3,014 & 3,001 & 3,003 & 3,011 \\
\hline \multicolumn{8}{|c|}{ Componentes moleculares } \\
\hline Fo & 92,13 & 85,84 & 85,98 & 86,24 & 85,84 & 85,98 & 84,29 \\
\hline $\mathrm{Fa}$ & 7,87 & 14,16 & 14,02 & 13,76 & 14,16 & 14,02 & 15,71 \\
\hline
\end{tabular}

${ }^{1}$ Abreviações: Macro (macrocristal).

2Localização da análise do grão: N (Núcleo); B (Borda). 
Apêndice B - Tabela B.I (continuação): Composição em óxidos (\% massa) e fórmula estrutural das olivinas da intrusão Pântano (continua).

\begin{tabular}{|c|c|c|c|c|c|c|c|}
\hline $\begin{array}{l}\text { Amostra } \\
\text { Grão }^{1}\end{array}$ & $\begin{array}{c}\text { PNT8A1 } \\
\text { macro24 }\end{array}$ & $\begin{array}{c}\text { P06-04 } \\
\text { MacroR14 }\end{array}$ & $\begin{array}{c}\text { P06-04 } \\
\text { MacroR16 }\end{array}$ & $\begin{array}{c}\text { P06-04 } \\
\text { MacroR22 }\end{array}$ & $\begin{array}{l}\text { P06-04 } \\
\text { MacroR6 }\end{array}$ & $\begin{array}{l}\text { P06-04 } \\
\text { MacroR8 }\end{array}$ & $\begin{array}{c}\text { P10-10 } \\
\text { MacroR10 }\end{array}$ \\
\hline Localização $^{2}$ & $\mathrm{~N}$ & B & $\mathrm{B}$ & $\mathrm{B}$ & $B$ & $B$ & B \\
\hline $\mathrm{SiO}_{2}$ & 41,23 & 40,41 & 40,45 & 39,55 & 40,41 & 40,45 & 38,85 \\
\hline $\mathrm{Al}_{2} \mathrm{O}_{3}$ & 0,01 & & & & & & 0,01 \\
\hline $\mathrm{TiO}_{2}$ & 0,04 & 0,02 & 0,05 & & 0,02 & 0,05 & \\
\hline $\mathrm{FeO}$ & 7,82 & 13,68 & 13,58 & 13,32 & 13,68 & 13,58 & 14,89 \\
\hline $\mathrm{MnO}$ & 0,11 & 0,22 & 0,17 & 0,28 & 0,22 & 0,17 & 0,2 \\
\hline $\mathrm{MgO}$ & 51,35 & 46,53 & 46,74 & 46,85 & 46,53 & 46,74 & 44,83 \\
\hline $\mathrm{CaO}$ & & 0,19 & 0,16 & 0,29 & 0,19 & 0,16 & 0,09 \\
\hline $\mathrm{Na}_{2} \mathrm{O}$ & 0,01 & & 0,01 & 0,03 & & 0,01 & \\
\hline $\mathrm{K}_{2} \mathrm{O}$ & & 0,01 & & 0,01 & 0,01 & & 0,01 \\
\hline $\mathrm{NiO}$ & & & & & & & 0,3 \\
\hline $\mathrm{Cr}_{2} \mathrm{O}_{3}$ & & & 0,02 & 0,05 & & 0,02 & 0,01 \\
\hline Total & 100,96 & 101,06 & 101,18 & 100,38 & 101,06 & 101,18 & 99,19 \\
\hline \multicolumn{8}{|c|}{ Fórmula estrutural na base de 4 oxigênios (a.p.f.u.) } \\
\hline Si & 0,993 & 0,997 & 0,997 & 0,984 & 0,997 & 0,997 & 0,986 \\
\hline \multicolumn{8}{|l|}{ Al } \\
\hline $\mathrm{Ti}$ & 0,001 & & 0,001 & & & 0,001 & \\
\hline $\mathrm{Fe}^{2+}$ & 0,158 & 0,282 & 0,28 & 0,277 & 0,282 & 0,28 & 0,316 \\
\hline Mn & 0,002 & 0,005 & 0,004 & 0,006 & 0,005 & 0,004 & 0,004 \\
\hline Mg & 1,844 & 1,712 & 1,717 & 1,738 & 1,712 & 1,717 & 1,697 \\
\hline $\mathbf{C a}$ & & 0,005 & 0,004 & 0,008 & 0,005 & 0,004 & 0,002 \\
\hline $\mathrm{Na}$ & & & & 0,001 & & & \\
\hline \multicolumn{8}{|l|}{$\mathbf{K}$} \\
\hline $\mathbf{N i}$ & 0,008 & & & & & & 0,006 \\
\hline$\Sigma$ Cátions & 3,006 & 3,001 & 3,003 & 3,014 & 3,001 & 3,003 & 3,011 \\
\hline \multicolumn{8}{|c|}{ Componentes moleculares } \\
\hline Fo & 92,13 & 85,84 & 85,98 & 86,24 & 85,84 & 85,98 & 84,29 \\
\hline $\mathbf{F a}$ & 7,87 & 14,16 & 14,02 & 13,76 & 14,16 & 14,02 & 15,71 \\
\hline
\end{tabular}

${ }^{1}$ Abreviações: Macro (macrocristal).

2Localização da análise do grão: N (Núcleo); B (borda). 
Apêndice B - Tabela B.I (continuação): Composição em óxidos (\% massa) e fórmula estrutural das olivinas da intrusão Pântano (continua).

\begin{tabular}{|c|c|c|c|c|c|c|c|}
\hline $\begin{array}{l}\text { Amostra } \\
\text { Grão }^{1}\end{array}$ & $\begin{array}{c}\text { PNT3A1 } \\
\text { macro29 }\end{array}$ & $\begin{array}{l}\text { PNT3A1 } \\
\text { macro30 }\end{array}$ & $\begin{array}{c}\text { pnt3f2 } \\
\text { ol1_macro }\end{array}$ & $\begin{array}{c}\text { pnt3f2 } \\
\text { ol2_macro }\end{array}$ & $\begin{array}{c}\text { PNT4A4 } \\
\text { macro35 }\end{array}$ & $\begin{array}{c}\text { PNT4A4 } \\
\text { macro36 }\end{array}$ & $\begin{array}{l}\text { PNT5B } \\
\text { macro12 }\end{array}$ \\
\hline Localização $^{2}$ & B & B & B & $\mathrm{B}$ & B & $\mathrm{B}$ & $\mathrm{B}$ \\
\hline $\mathrm{SiO}_{2}$ & 40,31 & 40 & 39,84 & 39,38 & 39,54 & 40,67 & 40,09 \\
\hline $\mathrm{Al}_{2} \mathrm{O}_{3}$ & & & & 0,0079 & 0,01 & 0,01 & 0,03 \\
\hline $\mathrm{TiO}_{2}$ & 0,05 & 0,02 & 0,0025 & 0,0537 & 0,03 & 0,06 & 0,06 \\
\hline $\mathrm{FeO}$ & 13,91 & 13,5 & 13,64 & 14,39 & 19,31 & 14,52 & 14,17 \\
\hline MnO & 0,17 & 0,23 & 0,2088 & 0,2269 & 0,24 & 0,28 & 0,22 \\
\hline $\mathrm{MgO}$ & 45,54 & 45,86 & 47,49 & 46,22 & 42,02 & 44,51 & 45,96 \\
\hline $\mathrm{CaO}$ & 0,1 & 0,15 & 0,1262 & 0,1963 & 0,05 & 0,24 & 0,21 \\
\hline $\mathrm{Na}_{2} \mathrm{O}$ & 0,03 & 0,02 & 0,0129 & & & 0,01 & 0,01 \\
\hline $\mathrm{K}_{2} \mathrm{O}$ & 0,02 & & & 0,0094 & 0,01 & 0,01 & 0,01 \\
\hline $\mathrm{NiO}$ & 0,29 & 0,16 & 0,2245 & 0,151 & 0,18 & 0,16 & 0,2 \\
\hline $\mathrm{Cr}_{2} \mathrm{O}_{3}$ & 0,03 & 0,05 & 0,0501 & & 0,04 & 0,03 & 0,06 \\
\hline Total & 100,45 & 99,99 & 101,6 & 100,64 & 101,43 & 100,5 & 101,02 \\
\hline \multicolumn{8}{|c|}{ Fórmula estrutural na base de 4 oxigênios (a.p.f.u.) } \\
\hline Si & 1,003 & 0,998 & 0,981 & 0,983 & 0,999 & 1,013 & 0,994 \\
\hline Al & & & & & & & 0,001 \\
\hline Ti & 0,001 & & & 0,001 & 0,001 & 0,001 & 0,001 \\
\hline $\mathrm{Fe}^{2+}$ & 0,289 & 0,282 & 0,281 & 0,3 & 0,408 & 0,302 & 0,294 \\
\hline Mn & 0,004 & 0,005 & 0,004 & 0,005 & 0,005 & 0,006 & 0,005 \\
\hline Mg & 1,689 & 1,707 & 1,743 & 1,719 & 1,582 & 1,652 & 1,699 \\
\hline $\mathrm{Ca}$ & 0,003 & 0,004 & 0,003 & 0,005 & 0,001 & 0,006 & 0,006 \\
\hline $\mathrm{Na}$ & 0,001 & 0,001 & 0,001 & & & & \\
\hline $\mathbf{K}$ & 0,001 & & & & & & \\
\hline $\mathbf{N i}$ & 0,006 & 0,003 & 0,004 & 0,003 & 0,004 & 0,003 & 0,004 \\
\hline$\Sigma$ Cátions & 2,997 & 3 & 3,017 & 3,016 & 3 & 2,983 & 3,004 \\
\hline \multicolumn{8}{|c|}{ Componentes moleculares } \\
\hline Fo & 85,37 & 85,82 & 86,12 & 85,13 & 79,50 & 84,53 & 85,25 \\
\hline $\mathbf{F a}$ & 14,63 & 14,18 & 13,88 & 14,87 & 20,50 & 15,47 & 14,75 \\
\hline
\end{tabular}

${ }^{1}$ Abreviações: Macro (macrocristal). Amostras pnt3f2 (análises realizadas fragmento 2). 2Localização da análise do grão: B (Borda). 
Apêndice B - Tabela B.I (continuação): Composição em óxidos (\% massa) e fórmula estrutural das olivinas da intrusão Pântano (continua).

\begin{tabular}{|c|c|c|c|c|c|c|c|}
\hline $\begin{array}{l}\text { Amostra } \\
\text { Grão }{ }^{1}\end{array}$ & $\begin{array}{l}\text { PNT5B } \\
\text { macro14 }\end{array}$ & $\begin{array}{c}\text { PNT7B1 } \\
\text { macro16 }\end{array}$ & $\begin{array}{l}\text { PNT7B1 } \\
\text { macro17 }\end{array}$ & $\begin{array}{l}\text { PNT7B1 } \\
\text { macro19 }\end{array}$ & $\begin{array}{c}\text { PNT8A1 } \\
\text { macro1 }\end{array}$ & $\begin{array}{c}\text { PNT8A1 } \\
\text { macro21 }\end{array}$ & $\begin{array}{c}\text { PNT8A1 } \\
\text { macro23 }\end{array}$ \\
\hline Localização² & B & B & B & $\mathrm{B}$ & $\mathrm{B}$ & B & B \\
\hline $\mathrm{SiO}_{2}$ & 39,7 & 38,8 & 40,22 & 39,18 & 40,11 & 40,57 & 40,28 \\
\hline $\mathrm{Al}_{2} \mathrm{O}_{3}$ & 0,02 & 0,03 & 0,02 & 0,03 & 0,02 & & 0,01 \\
\hline $\mathrm{TiO}_{2}$ & 0,02 & 0,08 & 0,05 & 0,05 & 0,09 & 0,03 & 0,01 \\
\hline $\mathrm{FeO}$ & 14,6 & 17,25 & 13,33 & 13,23 & 13,9 & 14,26 & 14,21 \\
\hline MnO & 0,21 & 0,2 & 0,28 & 0,17 & 0,2 & 0,31 & 0,21 \\
\hline MgO & 45,57 & 42,74 & 45,51 & 46,23 & 46,14 & 45,42 & 45,92 \\
\hline $\mathrm{CaO}$ & 0,13 & 0,1 & 0,32 & 0,16 & 0,14 & 0,41 & 0,09 \\
\hline $\mathrm{Na}_{2} \mathrm{O}$ & 0,01 & 0,01 & & 0,02 & & 0,02 & 0,03 \\
\hline $\mathrm{K}_{2} \mathrm{O}$ & 0,03 & & & 0,01 & 0,01 & & \\
\hline $\mathrm{NiO}$ & 0,27 & 0,19 & 0,13 & 0,22 & 0,27 & 0,09 & 0,29 \\
\hline $\mathrm{Cr}_{2} \mathrm{O}_{3}$ & 0,01 & 0,02 & 0,03 & 0,04 & 0,03 & 0,02 & 0,02 \\
\hline Total & 100,57 & 99,42 & 99,89 & 99,34 & 100,91 & 101,13 & 101,07 \\
\hline \multicolumn{8}{|c|}{ Fórmula estrutural na base de 4 oxigênios (a.p.f.u.) } \\
\hline Si & 0,991 & 0,992 & 1,004 & 0,985 & 0,994 & 1,004 & 0,998 \\
\hline Al & 0,001 & 0,001 & 0,001 & 0,001 & 0,001 & & \\
\hline $\mathrm{Ti}$ & & 0,002 & 0,001 & 0,001 & 0,002 & 0,001 & \\
\hline $\mathrm{Fe}^{2+}$ & 0,305 & 0,369 & 0,278 & 0,278 & 0,288 & 0,295 & 0,294 \\
\hline Mn & 0,004 & 0,004 & 0,006 & 0,004 & 0,004 & 0,006 & 0,004 \\
\hline Mg & 1,696 & 1,63 & 1,693 & 1,733 & 1,705 & 1,676 & 1,696 \\
\hline $\mathrm{Ca}$ & 0,003 & 0,003 & 0,009 & 0,004 & 0,004 & 0,011 & 0,002 \\
\hline $\mathrm{Na}$ & & & & 0,001 & & 0,001 & 0,001 \\
\hline K & 0,001 & & & & & & \\
\hline $\mathrm{Ni}$ & 0,005 & 0,004 & 0,003 & 0,004 & 0,005 & 0,002 & 0,006 \\
\hline$\Sigma$ Cátions & 3,006 & 3,005 & 2,995 & 3,011 & 3,003 & 2,996 & 3,001 \\
\hline \multicolumn{8}{|c|}{ Componentes moleculares } \\
\hline Fo & 84,76 & 81,53 & 85,88 & 86,16 & 85,54 & 85,02 & 85,20 \\
\hline $\mathbf{F a}$ & 15,24 & 18,47 & 14,12 & 13,84 & 14,46 & 14,98 & 14,80 \\
\hline
\end{tabular}

${ }^{1}$ Abreviações: Macro (macrocristal).

2Localização da análise do grão: B (Borda). 
Apêndice B - Tabela B.I (continuação): Composição em óxidos (\% massa) e fórmula estrutural das olivinas da intrusão Pântano (continua).

\begin{tabular}{|c|c|c|c|c|c|c|c|}
\hline $\begin{array}{l}\text { Amostra } \\
\text { Grão }\end{array}$ & $\begin{array}{c}\text { PNT3A1 } \\
\text { mega20 }\end{array}$ & $\begin{array}{c}\text { PNT3A1 } \\
\text { mega21 }\end{array}$ & $\begin{array}{c}\text { PNT3A1 } \\
\text { mega25 }\end{array}$ & $\begin{array}{c}\text { PNT3A1 } \\
\text { mega26 }\end{array}$ & $\begin{array}{c}\text { pnt3f2 } \\
\text { ol2_mega }\end{array}$ & $\begin{array}{c}\text { pnt3f2 } \\
\text { ol_mega2 }\end{array}$ & $\begin{array}{c}\text { PNT4A4 } \\
\text { mega27 }\end{array}$ \\
\hline Localização² & $\mathrm{N}$ & $\mathrm{N}$ & $\mathrm{N}$ & $\mathrm{N}$ & $\mathrm{N}$ & $\mathrm{N}$ & $\mathrm{N}$ \\
\hline $\mathrm{SiO}_{2}$ & 40,82 & 40,45 & 41,03 & 41,01 & 41,12 & 40,59 & 40,76 \\
\hline $\mathrm{Al}_{2} \mathrm{O}_{3}$ & & 0,04 & 0,01 & 0,01 & & 0,04 & 0,01 \\
\hline $\mathrm{TiO}_{2}$ & & & & 0,04 & 0,01 & & 0,03 \\
\hline $\mathrm{FeO}$ & 8,71 & 8,62 & 7,86 & 7,92 & 8,91 & 9,60 & 11,01 \\
\hline MnO & 0,12 & 0,12 & 0,1 & 0,09 & 0,10 & 0,14 & 0,16 \\
\hline $\mathrm{MgO}$ & 49,86 & 48,53 & 50,89 & 50,59 & 50,1 & 49,57 & 48,33 \\
\hline $\mathrm{CaO}$ & 0,03 & 0,09 & 0,02 & 0,01 & 0,03 & 0,03 & 0,06 \\
\hline $\mathrm{Na}_{2} \mathrm{O}$ & 0,01 & 0,01 & 0,01 & 0,01 & & & 0,01 \\
\hline $\mathrm{K}_{2} \mathrm{O}$ & & 0,11 & & 0,04 & & & \\
\hline $\mathrm{NiO}$ & 0,38 & 0,34 & 0,39 & 0,41 & 0,41 & 0,38 & 0,33 \\
\hline $\mathrm{Cr}_{2} \mathrm{O}_{3}$ & 0,02 & 0,01 & 0,03 & 0,03 & 0,03 & 0,04 & 0,06 \\
\hline Total & 99,95 & 98,32 & 100,34 & 100,16 & 100,74 & 100,42 & 100,76 \\
\hline \multicolumn{8}{|c|}{ Fórmula estrutural na base de 4 oxigênios (a.p.f.u.) } \\
\hline Si & 0,997 & 1,004 & 0,995 & 0,996 & 0,997 & 0,992 & 0,998 \\
\hline Al & & 0,001 & & & & 0,001 & \\
\hline $\mathrm{Ti}$ & & & & 0,001 & & & 0,001 \\
\hline $\mathrm{Fe}^{2+}$ & 0,178 & 0,179 & 0,159 & 0,161 & 0,181 & 0,196 & 0,225 \\
\hline Mn & 0,002 & 0,003 & 0,002 & 0,002 & 0,002 & 0,003 & 0,003 \\
\hline Mg & 1,816 & 1,796 & 1,839 & 1,832 & 1,812 & 1,805 & 1,764 \\
\hline $\mathrm{Ca}$ & 0,001 & 0,002 & 0,001 & & 0,001 & 0,001 & 0,002 \\
\hline \multicolumn{8}{|l|}{$\mathrm{Na}$} \\
\hline $\mathrm{K}$ & & 0,003 & & 0,001 & & & \\
\hline $\mathbf{N i}$ & 0,007 & 0,007 & 0,008 & 0,008 & 0,008 & 0,008 & 0,007 \\
\hline$\Sigma$ Cátions & 3,001 & 2,995 & 3,004 & 3,001 & 3,001 & 3,006 & 3 \\
\hline \multicolumn{8}{|c|}{ Componentes moleculares } \\
\hline Fo & 91,07 & 90,94 & 92,02 & 91,92 & 90,93 & 90,20 & 88,67 \\
\hline $\mathbf{F a}$ & 8,93 & 9,06 & 7,98 & 8,08 & 9,07 & 9,80 & 11,33 \\
\hline
\end{tabular}

${ }^{1}$ Abreviações: Mega (megacristal). Amostras pnt3f2 (análises realizadas no fragmento 2). 2Localização da análise do grão: N (Núcleo). 
Apêndice B - Tabela B.I (continuação): Composição em óxidos (\% massa) e fórmula estrutural das olivinas da intrusão Pântano (continua).

\begin{tabular}{|c|c|c|c|c|c|c|c|}
\hline $\begin{array}{l}\text { Amostra } \\
\text { Grão }\end{array}$ & $\begin{array}{c}\text { PNT4A4 } \\
\text { mega28 }\end{array}$ & $\begin{array}{c}\text { PNT4A4 } \\
\text { mega30 }\end{array}$ & $\begin{array}{c}\text { PNT5B } \\
\text { mega32 }\end{array}$ & $\begin{array}{c}\text { PNT5B } \\
\text { mega8 }\end{array}$ & $\begin{array}{c}\text { PNT7B1 } \\
\text { mega10 }\end{array}$ & $\begin{array}{c}\text { PNT7B1 } \\
\text { mega13 }\end{array}$ & $\begin{array}{c}\text { PNT8A1 } \\
\text { mega15 }\end{array}$ \\
\hline Localização $^{2}$ & $\mathrm{~N}$ & $\mathrm{~N}$ & $\mathrm{~N}$ & $\mathrm{~N}$ & $\mathrm{~N}$ & $\mathrm{~N}$ & $\mathrm{~N}$ \\
\hline $\mathrm{SiO}_{2}$ & 40,03 & 40,86 & 39,87 & 39,72 & 40,26 & 40,06 & 40,08 \\
\hline $\mathrm{Al}_{2} \mathrm{O}_{3}$ & 0,01 & 0,02 & 0,03 & 0,07 & 0,02 & 0 & 0,12 \\
\hline $\mathrm{TiO}_{2}$ & 0,01 & 0,03 & 0,05 & 0,10 & 0,01 & 0,01 & 0,08 \\
\hline $\mathrm{FeO}$ & 14,76 & 9,28 & 15,76 & 15,65 & 10,86 & 12,39 & 14,46 \\
\hline MnO & 0,2 & 0,14 & 0,19 & 0,18 & 0,13 & 0,16 & 0,16 \\
\hline $\mathrm{MgO}$ & 44,92 & 49,55 & 44,78 & 44,57 & 48,03 & 46,59 & 45,7 \\
\hline $\mathrm{CaO}$ & 0,13 & 0,06 & 0,09 & 0,09 & 0,02 & 0,06 & 0,09 \\
\hline $\mathrm{Na}_{2} \mathrm{O}$ & 0,01 & 0,01 & 0,02 & 0,08 & & 0,01 & 0,04 \\
\hline $\mathrm{K}_{2} \mathrm{O}$ & 0,01 & & 0,01 & 0,03 & & & 0,01 \\
\hline $\mathrm{NiO}$ & 0,26 & 0,42 & 0,30 & 0,33 & 0,4 & 0,32 & 0,35 \\
\hline $\mathrm{Cr}_{2} \mathrm{O}_{3}$ & 0,07 & 0,09 & 0,01 & & 0,05 & & 0,02 \\
\hline Total & 100,41 & 100,46 & 101,11 & 100,82 & 99,78 & 99,60 & 101,11 \\
\hline \multicolumn{8}{|c|}{ Fórmula estrutural na base de 4 oxigênios (a.p.f.u.) } \\
\hline Si & 1,001 & 0,996 & 0,995 & 0,994 & 0,996 & 0,999 & 0,994 \\
\hline Al & & 0,001 & 0,001 & 0,002 & & & 0,004 \\
\hline $\mathrm{Ti}$ & & 0,001 & 0,001 & 0,002 & & & 0,001 \\
\hline $\mathrm{Fe}^{2+}$ & 0,309 & 0,189 & 0,329 & 0,327 & 0,225 & 0,258 & 0,3 \\
\hline Mn & 0,004 & 0,003 & 0,004 & 0,004 & 0,003 & 0,003 & 0,003 \\
\hline Mg & 1,674 & 1,801 & 1,665 & 1,663 & 1,77 & 1,732 & 1,69 \\
\hline $\mathrm{Ca}$ & 0,003 & 0,002 & 0,002 & 0,002 & 0,001 & 0,002 & 0,002 \\
\hline $\mathrm{Na}$ & & & 0,001 & 0,004 & & & 0,002 \\
\hline $\mathbf{K}$ & & & & 0,001 & & & \\
\hline $\mathbf{N i}$ & 0,005 & 0,008 & 0,006 & 0,007 & 0,008 & 0,006 & 0,007 \\
\hline$\Sigma$ Cátions & 2,996 & 3,001 & 3,004 & 3,006 & 3,004 & 3 & 3,003 \\
\hline \multicolumn{8}{|c|}{ Componentes moleculares } \\
\hline Fo & 84,43 & 90,49 & 83,51 & 83,54 & 88,74 & 87,01 & 84,92 \\
\hline $\mathbf{F a}$ & 15,57 & 9,51 & 16,49 & 16,46 & 11,26 & 12,99 & 15,08 \\
\hline
\end{tabular}

${ }^{1}$ Abreviações: Mega (megacristal).

2Localização da análise do grão: N (Núcleo). 
Apêndice B - Tabela B.I (continuação): Composição em óxidos (\% massa) e fórmula estrutural das olivinas da intrusão Pântano (continua).

\begin{tabular}{|c|c|c|c|c|c|c|c|}
\hline $\begin{array}{l}\text { Amostra } \\
\text { Grão }\end{array}$ & $\begin{array}{c}\text { PNT8A1 } \\
\text { mega17 }\end{array}$ & $\begin{array}{c}\text { PNT3A1 } \\
\text { mega22 }\end{array}$ & $\begin{array}{c}\text { PNT3A1 } \\
\text { mega23 }\end{array}$ & $\begin{array}{c}\text { PNT3A1 } \\
\text { mega24 }\end{array}$ & $\begin{array}{c}\text { pnt3f1 } \\
\text { ol1_mc_b }\end{array}$ & $\begin{array}{c}\text { pnt3f1 } \\
\text { ol3_mc_b }\end{array}$ & $\begin{array}{c}\text { pnt3f2 } \\
\text { ol2_mega }\end{array}$ \\
\hline Localização² $^{2}$ & $\mathrm{~N}$ & B & $\mathrm{B}$ & B & $\mathrm{B}$ & B & B \\
\hline $\mathrm{SiO}_{2}$ & 41,39 & 40,13 & 40,45 & 40,39 & 40,07 & 40,47 & 40,36 \\
\hline $\mathrm{Al}_{2} \mathrm{O}_{3}$ & 0,01 & 0,01 & 0,03 & 0,02 & 0,03 & 0,04 & \\
\hline $\mathrm{TiO}_{2}$ & & 0,02 & 0,07 & 0,12 & 0,03 & & 0,03 \\
\hline $\mathrm{FeO}$ & 8,11 & 12,73 & 12,31 & 13,57 & 14,71 & 13,29 & 14,53 \\
\hline MnO & 0,11 & 0,16 & 0,16 & 0,21 & 0,19 & 0,21 & 0,20 \\
\hline $\mathrm{MgO}$ & 50,78 & 46,84 & 46,82 & 45,53 & 44,49 & 45,54 & 45,3 \\
\hline $\mathrm{CaO}$ & 0,02 & 0,06 & 0,06 & 0,25 & 0,11 & 0,16 & 0,15 \\
\hline $\mathrm{Na}_{2} \mathrm{O}$ & 0,02 & 0,01 & & & 0,02 & 0,01 & \\
\hline $\mathrm{K}_{2} \mathrm{O}$ & 0,01 & 0,01 & & & & & \\
\hline $\mathrm{NiO}$ & 0,44 & 0,25 & 0,3 & 0,17 & 0,28 & 0,15 & 0,22 \\
\hline $\mathrm{Cr}_{2} \mathrm{O}_{3}$ & 0,05 & 0,05 & 0,1 & 0,03 & 0,04 & 0,04 & 0,06 \\
\hline Total & 100,94 & 100,27 & 100,3 & 100,29 & 100,01 & 99,94 & 100,88 \\
\hline \multicolumn{8}{|c|}{ Fórmula estrutural na base de 4 oxigênios (a.p.f.u.) } \\
\hline Si & 0,998 & 0,995 & 1,001 & 1,004 & 1,005 & 1,008 & 1,002 \\
\hline Al & & & 0,001 & 0,001 & 0,001 & 0,001 & \\
\hline $\mathrm{Ti}$ & & & 0,001 & 0,002 & 0,001 & & 0,001 \\
\hline $\mathrm{Fe}^{2+}$ & 0,164 & 0,264 & 0,255 & 0,282 & 0,309 & 0,277 & 0,302 \\
\hline Mn & 0,002 & 0,003 & 0,003 & 0,004 & 0,004 & 0,004 & 0,004 \\
\hline Mg & 1,826 & 1,732 & 1,726 & 1,688 & 1,663 & 1,691 & 1,677 \\
\hline $\mathrm{Ca}$ & 0,001 & 0,002 & 0,002 & 0,007 & 0,003 & 0,005 & 0,004 \\
\hline $\mathrm{Na}$ & 0,001 & & & & 0,001 & 0,001 & \\
\hline \multicolumn{8}{|l|}{$\mathbf{K}$} \\
\hline $\mathrm{Ni}$ & 0,009 & 0,005 & 0,006 & 0,003 & 0,006 & 0,003 & 0,004 \\
\hline$\Sigma$ Cátions & 3,001 & 3,001 & 2,995 & 2,991 & 2,993 & 2,99 & 2,994 \\
\hline \multicolumn{8}{|c|}{ Componentes moleculares } \\
\hline Fo & 91,77 & 86,77 & 87,14 & 85,67 & 84,35 & 85,93 & 84,75 \\
\hline $\mathbf{F a}$ & 8,23 & 13,23 & 12,86 & 14,33 & 15,65 & 14,07 & 15,25 \\
\hline
\end{tabular}

${ }^{1}$ Abreviações: Mega (megacristal). Amostras pnt3f1 e pntf2 (análises realizadas nos fragmentos $1 \mathrm{e}$ 2).

2Localização da análise do grão: N (Núcleo); B (Borda). 
Apêndice B - Tabela B.I (continuação): Composição em óxidos (\% massa) e fórmula estrutural das olivinas da intrusão Pântano (continua).

\begin{tabular}{|c|c|c|c|c|c|c|c|}
\hline $\begin{array}{l}\text { Amostra } \\
\text { Grão1 }\end{array}$ & $\begin{array}{l}\text { pnt3f2 } \\
\text { ol_mega }\end{array}$ & $\begin{array}{l}\text { PNT4A4 } \\
\text { mega29 }\end{array}$ & $\begin{array}{l}\text { PNT5B } \\
\text { mega31 }\end{array}$ & $\begin{array}{l}\text { PNT5B } \\
\text { mega7 }\end{array}$ & $\begin{array}{l}\text { PNT7B1 } \\
\text { mega11 }\end{array}$ & $\begin{array}{l}\text { PNT7B1 } \\
\text { mega12 }\end{array}$ & $\begin{array}{l}\text { PNT7B1 } \\
\text { mega9 }\end{array}$ \\
\hline Localizaçao & $\frac{B}{3954}$ & $\frac{B}{1008}$ & $\frac{B}{3978}$ & $\frac{B}{1007}$ & $\frac{B}{3931}$ & $\frac{B}{3962}$ & $\frac{B}{3956}$ \\
\hline $\mathrm{Al}_{2} \mathrm{O}_{3}$ & 0,04 & & 0,02 & 0,05 & 0,03 & 0,01 & 0 \\
\hline $\mathrm{TiO}_{2}$ & 0,05 & 0,07 & & 0,03 & 0,04 & 0,05 & 0,06 \\
\hline $\mathrm{FeO}$ & 13,67 & 14,47 & 14,64 & 15,83 & 15,45 & 13,79 & 13,36 \\
\hline MnO & 0,22 & 0,22 & 0,19 & 0,16 & 0,17 & 0,23 & 0,18 \\
\hline $\mathrm{MgO}$ & 47,06 & 44,59 & 45,63 & 44,18 & 44,64 & 45,95 & 46,19 \\
\hline $\mathrm{CaO}$ & 0,22 & 0,16 & 0,08 & 0,11 & 0,09 & 0,26 & 0,12 \\
\hline $\mathrm{Na}_{2} \mathrm{O}$ & & 0,01 & 0,04 & 0,08 & 0,01 & 0,02 & 0,03 \\
\hline $\mathrm{K}_{2} \mathrm{O}$ & & & 0,03 & 0,01 & 0,01 & & \\
\hline $\mathrm{NiO}$ & 0,17 & 0,24 & 0,35 & 0,31 & 0,24 & 0,15 & 0,27 \\
\hline $\mathrm{Cr}_{2} \mathrm{O}_{3}$ & 0,04 & 0,02 & 0,03 & 0,02 & 0,01 & 0,02 & 0,06 \\
\hline Total & 101,05 & 99,86 & 100,79 & 100,85 & 100 & 100,1 & 99,83 \\
\hline \multicolumn{8}{|c|}{ Fórmula estrutural na base de 4 oxigênios (a.p.f.u.) } \\
\hline Si & 0,98 & 1,006 & 0,991 & 1,002 & 0,991 & 0,99 & 0,99 \\
\hline Al & 0,001 & & 0,001 & 0,001 & 0,001 & & \\
\hline $\mathrm{Ti}$ & 0,001 & 0,001 & & 0,001 & 0,001 & 0,001 & 0,001 \\
\hline $\mathrm{Fe}^{2+}$ & 0,283 & 0,304 & 0,305 & 0,331 & 0,326 & 0,288 & 0,28 \\
\hline Mn & 0,005 & 0,005 & 0,004 & 0,003 & 0,004 & 0,005 & 0,004 \\
\hline Mg & 1,738 & 1,668 & 1,695 & 1,647 & 1,678 & 1,712 & 1,723 \\
\hline $\mathrm{Ca}$ & 0,006 & 0,004 & 0,002 & 0,003 & 0,002 & 0,007 & 0,003 \\
\hline $\mathrm{Na}$ & & & 0,002 & 0,004 & & 0,001 & 0,001 \\
\hline $\mathbf{K}$ & & & 0,001 & & & & \\
\hline $\mathbf{N i}$ & 0,003 & 0,005 & 0,007 & 0,006 & 0,005 & 0,003 & 0,005 \\
\hline$\Sigma$ Cátions & 3,017 & 2,993 & 3,008 & 2,998 & 3,008 & 3,007 & 3,007 \\
\hline \multicolumn{8}{|c|}{ Componentes moleculares } \\
\hline Fo & 85,98 & 84,59 & 84,74 & 83,26 & 83,74 & 85,59 & 86,04 \\
\hline $\mathbf{F a}$ & 14,02 & 15,41 & 15,26 & 16,74 & 16,26 & 14,41 & 13,96 \\
\hline
\end{tabular}

${ }^{1}$ Abreviações: Mega (megacristal). Amostra pntf2 (análise realizada no fragmento 2).

2Localização da análise do grão: B (Borda). 
Apêndice B - Tabela B.I (continuação): Composição em óxidos (\% massa) e fórmula estrutural das olivinas da intrusão Pântano (continua).

\begin{tabular}{|c|c|c|c|}
\hline $\begin{array}{l}\text { Amostra } \\
\text { Grão }\end{array}$ & $\begin{array}{c}\text { PNT8A1 } \\
\text { mega14 }\end{array}$ & $\begin{array}{c}\text { PNT8A1 } \\
\text { mega16 }\end{array}$ & $\begin{array}{l}\text { pnt3f2 } \\
\text { ol1_nod }\end{array}$ \\
\hline Localização $^{2}$ & B & $\mathrm{B}$ & N \\
\hline $\mathrm{SiO}_{2}$ & 39,78 & 40,3 & 39,6 \\
\hline $\mathrm{Al}_{2} \mathrm{O}_{3}$ & 0,02 & & 0,0142 \\
\hline $\mathrm{TiO}_{2}$ & 0,04 & 0,03 & 0,0786 \\
\hline $\mathrm{FeO}$ & 14,86 & 13,22 & 13,88 \\
\hline MnO & 0,17 & 0,23 & 0,1393 \\
\hline $\mathrm{MgO}$ & 45,56 & 46,04 & 46,42 \\
\hline $\mathrm{CaO}$ & 0,09 & 0,22 & 0,1087 \\
\hline $\mathrm{Na}_{2} \mathrm{O}$ & 0,01 & 0,02 & 0,0166 \\
\hline $\mathrm{K}_{2} \mathrm{O}$ & & & 0,0131 \\
\hline $\mathrm{NiO}$ & 0,35 & 0,15 & 0,2856 \\
\hline $\mathrm{Cr}_{2} \mathrm{O}_{3}$ & 0,05 & 0,06 & 0,0303 \\
\hline Total & 100,93 & 100,27 & 100,59 \\
\hline \multicolumn{4}{|c|}{$\begin{array}{l}\text { Fórmula estrutural na base de } 4 \text { oxigênios } \\
\text { (a.p.f.u.) }\end{array}$} \\
\hline Si & 0,991 & 1,001 & 0,986 \\
\hline Al & 0,001 & & \\
\hline $\mathrm{Ti}$ & 0,001 & 0,001 & 0,001 \\
\hline $\mathrm{Fe}^{2+}$ & 0,31 & 0,275 & 0,289 \\
\hline Mn & 0,004 & 0,005 & 0,003 \\
\hline Mg & 1,692 & 1,705 & 1,723 \\
\hline $\mathrm{Ca}$ & 0,002 & 0,006 & 0,003 \\
\hline $\mathrm{Na}$ & & 0,001 & 0,001 \\
\hline \multicolumn{4}{|l|}{ K } \\
\hline $\mathrm{Ni}$ & 0,007 & 0,003 & 0,006 \\
\hline$\Sigma$ Cátions & 3,008 & 2,997 & 3,012 \\
\hline \multicolumn{4}{|c|}{ Componentes moleculares } \\
\hline Fo & 84,53 & 86,12 & 85,63 \\
\hline $\mathbf{F a}$ & 15,47 & 13,88 & 14,37 \\
\hline
\end{tabular}

${ }^{1}$ Abreviações: Mega (megacristal); Nod (nódulo). Amostra pntf2 (análise realizada fragmento 2). ²Localização da análise do grão: N (Núcleo); B (Borda). 
Apêndice B - Tabela B.II: Composição em óxidos (\% massa) e fórmula estrutural das monticelitas da intrusão Pântano (continua).

\begin{tabular}{|c|c|c|c|c|c|c|c|}
\hline $\begin{array}{l}\text { Amostra } \\
\text { Grão' } \\
\text { Localização }^{2}\end{array}$ & $\begin{array}{c}\text { pnt3f1 } \\
\text { mtc1n } \\
N \\
\end{array}$ & $\begin{array}{c}\text { pnt3f1 } \\
\text { mtc1int } \\
\mathrm{N} \\
\end{array}$ & $\begin{array}{c}\text { pnt3f1 } \\
\text { mtc1int2 } \\
\mathrm{N}\end{array}$ & $\begin{array}{c}\text { pnt3f1 } \\
\text { mtc2n } \\
N \\
\end{array}$ & $\begin{array}{c}\text { pnt3f1 } \\
\text { mtc2int } \\
\text { INT } \\
\end{array}$ & $\begin{array}{c}\text { pnt3f1 } \\
\text { mtc2int } \\
\text { INT } \\
\end{array}$ & $\begin{array}{c}\text { pnt3f1 } \\
\text { mtc3n1 } \\
N\end{array}$ \\
\hline $\mathrm{SiO}_{2}$ & 36,34 & 36,55 & 36,85 & 36,47 & 36,86 & 36,64 & 36,56 \\
\hline $\mathrm{Al}_{2} \mathrm{O}_{3}$ & & 0,02 & 0,01 & & 0,02 & 0,01 & \\
\hline $\mathrm{TiO}_{2}$ & 0,11 & 0,09 & 0,06 & 0,12 & 0,07 & 0,09 & 0,09 \\
\hline $\mathrm{FeO}$ & 10,70 & 10,43 & 8,47 & 10,52 & 9,50 & 9,98 & 10,27 \\
\hline MnO & 0,00 & 0,42 & 0,34 & 0,40 & 0,37 & 0,40 & 0,46 \\
\hline $\mathrm{MgO}$ & 0,42 & 18,81 & 20,61 & 19,52 & 20,26 & 19,35 & 20,45 \\
\hline $\mathrm{CaO}$ & 20,29 & 33,02 & 33,15 & 31,98 & 32,11 & 32,51 & 31,59 \\
\hline $\mathrm{Na}_{2} \mathrm{O}$ & 31,17 & 0,07 & 0,06 & 0,10 & 0,13 & 0,06 & 0,15 \\
\hline $\mathrm{K}_{2} \mathrm{O}$ & 0,07 & 0,04 & 0,02 & 0,09 & 0,08 & 0,10 & 0,01 \\
\hline $\mathrm{NiO}$ & 0,03 & 0,02 & 0,02 & 0,02 & 0,02 & 0,02 & 0,00 \\
\hline $\mathrm{Cr}_{2} \mathrm{O}_{3}$ & & & & & & 0,03 & 0,00 \\
\hline Total & 99,14 & 99,47 & 99,57 & 99,22 & 99,41 & 99,18 & 99,58 \\
\hline \multicolumn{8}{|c|}{ Fórmula estrutural na base de 4 oxigênios (a.p.f.u.) } \\
\hline Si & 0,996 & 1,002 & 0,999 & 1,001 & 1,004 & 1,004 & 0,997 \\
\hline Al & & 0,001 & & & & & \\
\hline Ti & 0,002 & 0,002 & 0,001 & 0,003 & 0,001 & 0,002 & 0,002 \\
\hline $\mathrm{Fe}^{2+}$ & 0,245 & 0,239 & 0,192 & 0,241 & 0,216 & 0,229 & 0,234 \\
\hline Mn & 0,010 & 0,010 & 0,008 & 0,009 & 0,009 & 0,009 & 0,011 \\
\hline Mg & 0,829 & 0,769 & 0,833 & 0,798 & 0,822 & 0,791 & 0,831 \\
\hline $\mathrm{Ca}$ & 0,916 & 0,970 & 0,963 & 0,940 & 0,937 & 0,955 & 0,923 \\
\hline $\mathrm{Na}$ & 0,004 & 0,004 & 0,003 & 0,005 & 0,007 & 0,003 & 0,008 \\
\hline K & 0,001 & 0,002 & 0,001 & 0,003 & 0,003 & 0,004 & \\
\hline $\mathrm{Ni}$ & 0,001 & 0,001 & 0,001 & & & 0,000 & \\
\hline $\mathrm{Cr}$ & & & & & & 0,001 & \\
\hline$\Sigma$ Cátions & 3,004 & 2,999 & 3,002 & 3,001 & 2,999 & 2,997 & 3,006 \\
\hline
\end{tabular}

2Localização da análise do grão: N (Núcleo); INT: zona intermediária.

A população de monticelita constitui-se exclusivamente de microcristais. 
Apêndice B - Tabela B.II: Composição em óxidos (\% massa) e fórmula estrutural das monticelitas da intrusão Pântano.

\begin{tabular}{|c|c|c|c|c|c|c|c|}
\hline $\begin{array}{l}\text { Amostra } \\
\text { Grão }\end{array}$ & $\begin{array}{l}\text { pnt3f1 } \\
\text { mtc3n }\end{array}$ & $\begin{array}{l}\text { pnt3f2 } \\
\text { Mtc1n }\end{array}$ & $\begin{array}{l}\text { pnt3f2 } \\
\text { Mtc1bd }\end{array}$ & $\begin{array}{l}\text { pnt3f2 } \\
\text { mtc2n }\end{array}$ & $\begin{array}{l}\text { pnt3f2 } \\
\text { mtc2b }\end{array}$ & $\begin{array}{l}\text { pnt3f2 } \\
\text { Mtc3n }\end{array}$ & $\begin{array}{l}\text { pnt3f2 } \\
\text { Mtc4n }\end{array}$ \\
\hline Localização $^{2}$ & $\mathrm{~N}$ & B & B & $\mathrm{N}$ & B & $\mathrm{N}$ & $\mathbf{N}$ \\
\hline $\mathrm{SiO}_{2}$ & 36,65 & 36,38 & 35,06 & 36,63 & 36,96 & 36,58 & 36,34 \\
\hline $\mathrm{Al}_{2} \mathrm{O}_{3}$ & 0,0982 & & 0,0745 & 0,0221 & 0,024 & 0,0144 & 0,0426 \\
\hline $\mathrm{TiO}_{2}$ & 0,1856 & 0,1031 & 0,0451 & 0,1537 & 0,1315 & 0,1298 & 0,1367 \\
\hline $\mathrm{FeO}$ & 10,03 & 10,16 & 9,27 & 10,11 & 9,87 & 9,8 & 9,69 \\
\hline MnO & 0,0129 & 0,0019 & & 0,0037 & 0,0331 & & 0,0277 \\
\hline $\mathrm{MgO}$ & 0,527 & 0,4125 & 0,456 & 0,433 & 0,3859 & 0,3717 & 0,3844 \\
\hline $\mathrm{CaO}$ & 20,03 & 21,37 & 20,99 & 21,14 & 19,73 & 21,54 & 22,05 \\
\hline $\mathrm{Na}_{2} \mathrm{O}$ & 31,41 & 31,6 & 33,32 & 31,66 & 33,21 & 31,39 & 31,07 \\
\hline $\mathrm{K}_{2} \mathrm{O}$ & 0,2049 & 0,1272 & 0,0879 & 0,106 & 0,0823 & 0,1014 & 0,1987 \\
\hline $\mathrm{NiO}$ & 0,1407 & & 0,1145 & 0,0185 & 0,0796 & 0,0273 & 0,1094 \\
\hline $\mathrm{Cr}_{2} \mathrm{O}_{3}$ & 0,0409 & 0,0213 & 0,0244 & 0,0215 & 0,0323 & 0,0422 & 0,0246 \\
\hline Total & 99,33 & 100,18 & 99,44 & 100,30 & 100,54 & 100,00 & 100,07 \\
\hline \multicolumn{8}{|c|}{ Fórmula estrutural na base de 4 oxigênios (a.p.f.u.) } \\
\hline Si & 1,001 & 0,986 & 0,963 & 0,991 & 1,000 & 0,990 & 0,9830 \\
\hline Al & 0,003 & & 0,002 & 0,001 & 0,001 & & 0,001 \\
\hline Ti & 0,004 & 0,002 & 0,001 & 0,003 & 0,003 & 0,003 & 0,003 \\
\hline $\mathrm{Fe}^{2+}$ & 0,229 & 0,230 & 0,213 & 0,229 & 0,223 & 0,222 & 0,219 \\
\hline Mn & 0,012 & 0,009 & 0,011 & 0,010 & 0,009 & 0,009 & 0,009 \\
\hline Mg & 0,816 & 0,863 & 0,860 & 0,852 & 0,795 & 0,869 & 0,889 \\
\hline $\mathrm{Ca}$ & 0,919 & 0,918 & 0,981 & 0,917 & 0,962 & 0,911 & 0,901 \\
\hline $\mathrm{Na}$ & 0,011 & 0,007 & 0,005 & 0,006 & 0,004 & 0,005 & 0,010 \\
\hline $\mathrm{K}$ & 0,005 & & 0,004 & 0,001 & 0,003 & 0,001 & 0,004 \\
\hline \multicolumn{8}{|l|}{$\mathrm{Ni}$} \\
\hline $\mathrm{Cr}$ & & & & & 0,001 & & 0,001 \\
\hline$\Sigma$ Cátions & 3,001 & 3,015 & 3,039 & 3,009 & 3,001 & 3,010 & 3,020 \\
\hline
\end{tabular}

'Localização da análise do grão: N (Núcleo); B (Borda).

A população de monticelita constitui-se exclusivamente de microcristais. 
Apêndice B - Tabela B.III: Composição em óxidos (\% massa) e fórmula estrutural das flogopitas da intrusão Pântano (continua).

\begin{tabular}{|c|c|c|c|c|c|c|c|}
\hline $\begin{array}{c}\text { Amostra } \\
\text { Grão }{ }^{1}\end{array}$ & $\begin{array}{l}\text { pnt3f1 } \\
\text { mic1_b }\end{array}$ & $\begin{array}{l}\text { pnt3f2 } \\
\text { mic2_b }\end{array}$ & $\begin{array}{c}\text { 8A1 } \\
\text { mic3_b }\end{array}$ & $\begin{array}{c}\text { 8A1 } \\
\text { mic4_b }\end{array}$ & $\begin{array}{c}\text { 8A1 } \\
\text { mic4_b }\end{array}$ & $\begin{array}{c}\text { 8A1 } \\
\text { mac1_b }\end{array}$ & $\begin{array}{c}\text { 8A1 } \\
\text { mac2_b }\end{array}$ \\
\hline Localização² $^{2}$ & B & B & B & B & B & B & B \\
\hline $\mathrm{SiO}_{2}$ & 40,53 & 39,00 & 40,82 & 40,20 & 40,33 & 39,86 & 40,69 \\
\hline $\mathrm{TiO}_{2}$ & 2,79 & 4,98 & 3,48 & 3,37 & 3,71 & 4,64 & 3,53 \\
\hline $\mathrm{Al}_{2} \mathrm{O}_{3}$ & 10,68 & 13,12 & 12,84 & 12,58 & 12,88 & 12,88 & 12,20 \\
\hline $\mathrm{FeO}$ & 8,92 & 6,25 & 6,20 & 6,07 & 5,93 & 6,01 & 8,64 \\
\hline MnO & 0,05 & 0,02 & 0,06 & 0,03 & 0,05 & 0,04 & 0,04 \\
\hline $\mathrm{MgO}$ & 21,53 & 20,31 & 22,25 & 22,51 & 22,31 & 21,20 & 20,79 \\
\hline $\mathrm{CaO}$ & 0,12 & 0,02 & 0,01 & 0,03 & 0,05 & 0,02 & \\
\hline $\mathrm{Na}_{2} \mathrm{O}$ & 0,24 & 0,08 & 0,05 & 0,02 & 0,02 & 0,04 & 0,08 \\
\hline $\mathrm{K}_{2} \mathrm{O}$ & 10,74 & 10,47 & 10,56 & 10,69 & 10,81 & 10,44 & 10,70 \\
\hline $\mathbf{F}$ & 0,71 & 0,29 & 0,33 & 0,32 & 0,31 & 0,31 & 0,14 \\
\hline $\mathrm{Cl}$ & 0,02 & & & 0,03 & & 0,01 & 0,03 \\
\hline $\mathrm{BaO}$ & 0,19 & 0,10 & 0,07 & 0,08 & 0,14 & 0,16 & 0,02 \\
\hline $\mathrm{ZnO}$ & 0,04 & 0,03 & 0,00 & 0,01 & & & \\
\hline Total & 96,37 & 94,56 & 96,61 & 95,86 & 96,41 & 95,46 & 96,84 \\
\hline \multicolumn{8}{|c|}{ Fórmula estrutural calculada na base anidra de 22 oxigênios (a.p.f.u.) } \\
\hline $\mathrm{Si}$ & 5,949 & 5,699 & 5,820 & 5,790 & 5,769 & 5,753 & 5,843 \\
\hline $\mathbf{A l}^{\mathrm{IV}}$ & 1,848 & 2,260 & 2,158 & 2,136 & 2,172 & 2,191 & 2,065 \\
\hline $\mathrm{Fe}^{3+}$ & 0,203 & 0,041 & 0,021 & 0,074 & 0,059 & 0,056 & 0,091 \\
\hline Sum Z (s, tetra) & 8,000 & 8,000 & 8,000 & 8,000 & 8,000 & 8,000 & 8,000 \\
\hline \multicolumn{8}{|l|}{$\mathrm{Al}^{\mathrm{VI}}$} \\
\hline $\mathrm{Ti}$ & 0,308 & 0,547 & 0,373 & 0,365 & 0,399 & 0,504 & 0,381 \\
\hline $\mathrm{Fe}^{2+}$ & 0,892 & 0,723 & 0,718 & 0,657 & 0,650 & 0,670 & 0,947 \\
\hline Mn & 0,006 & 0,002 & 0,007 & 0,004 & 0,005 & 0,005 & 0,005 \\
\hline Mg & 4,711 & 4,424 & 4,730 & 4,833 & 4,757 & 4,561 & 4,451 \\
\hline Sum Y (s, octa) & 5,917 & 5,696 & 5,828 & 5,859 & 5,812 & 5,740 & 5,784 \\
\hline $\mathrm{Ca}$ & 0,019 & 0,002 & 0,002 & 0,004 & 0,008 & 0,004 & 0,000 \\
\hline $\mathrm{Ba}$ & 0,011 & 0,006 & 0,004 & 0,004 & 0,008 & 0,009 & 0,001 \\
\hline $\mathrm{Na}$ & 0,069 & 0,022 & 0,015 & 0,006 & 0,007 & 0,012 & 0,022 \\
\hline K & 2,011 & 1,952 & 1,921 & 1,964 & 1,973 & 1,922 & 1,960 \\
\hline Sum X (inter) & 2,109 & 1,982 & 1,942 & 1,979 & 1,995 & 1,947 & 1,984 \\
\hline Total & 16,027 & 15,678 & 15,770 & 15,839 & 15,807 & 15,687 & 15,768 \\
\hline $\mathbf{F}$ & 0,329 & 0,135 & 0,149 & 0,147 & 0,142 & 0,140 & 0,062 \\
\hline $\mathrm{Cl}$ & 0,006 & & & 0,006 & & 0,004 & 0,007 \\
\hline $\mathrm{OH}$ & 3,665 & 3,865 & 3,851 & 3,847 & 3,858 & 3,856 & 3,931 \\
\hline Total & 4 & 4 & 4 & 4 & 4 & 4 & 4 \\
\hline
\end{tabular}

${ }^{1}$ Abreviações: Mic: microcristal; Mac: macrocristal). Amostra pntf2 (análises realizadas no presente trabalho, fragmento 2); 8A1 (número da lâmina petrográfica).

${ }^{2}$ Localização da análise do grão: B (Borda). 
Apêndice B - Tabela B.III (continuação): Composição em óxidos (\% massa) e fórmula estrutural das flogopitas da intrusão Pântano (continua).

\begin{tabular}{|c|c|c|c|c|c|c|c|}
\hline $\begin{array}{c}\text { Amostra } \\
\text { Grão }{ }^{1}\end{array}$ & $\begin{array}{l}\text { pnt3f1 } \\
\text { mic1_b }\end{array}$ & $\begin{array}{l}\text { pnt3f2 } \\
\text { mic2_b }\end{array}$ & $\begin{array}{c}\text { 8A1 } \\
\text { mi3_b1 }\end{array}$ & $\begin{array}{c}\text { 8A1 } \\
\text { mic4_b }\end{array}$ & $\begin{array}{c}\text { 8A1 } \\
\text { mic4_b2 }\end{array}$ & $\begin{array}{c}\text { 8A1 } \\
\text { mac1_b }\end{array}$ & $\begin{array}{c}\text { 8A1 } \\
\text { mac2_b }\end{array}$ \\
\hline Localização² & B & $\mathrm{B}$ & B & $\mathrm{B}$ & B & $\mathrm{B}$ & $\mathrm{B}$ \\
\hline $\mathrm{SiO}_{2}$ & 40,53 & 39,00 & 40,82 & 40,20 & 40,33 & 39,86 & 40,69 \\
\hline $\mathrm{TiO}_{2}$ & 2,79 & 4,98 & 3,48 & 3,37 & 3,71 & 4,64 & 3,53 \\
\hline $\mathrm{Al}_{2} \mathrm{O}_{3}$ & 10,68 & 13,12 & 12,84 & 12,58 & 12,88 & 12,88 & 12,20 \\
\hline $\mathrm{FeO}$ & 8,92 & 6,25 & 6,20 & 6,07 & 5,93 & 6,01 & 8,64 \\
\hline MnO & 0,05 & 0,02 & 0,06 & 0,03 & 0,05 & 0,04 & 0,04 \\
\hline MgO & 21,53 & 20,31 & 22,25 & 22,51 & 22,31 & 21,20 & 20,79 \\
\hline $\mathrm{CaO}$ & 0,12 & 0,02 & 0,01 & 0,03 & 0,05 & 0,02 & \\
\hline $\mathrm{Na}_{2} \mathrm{O}$ & 0,24 & 0,08 & 0,05 & 0,02 & 0,02 & 0,04 & 0,08 \\
\hline $\mathrm{K}_{2} \mathrm{O}$ & 10,74 & 10,47 & 10,56 & 10,69 & 10,81 & 10,44 & 10,70 \\
\hline $\mathbf{F}$ & 0,71 & 0,29 & 0,33 & 0,32 & 0,31 & 0,31 & 0,14 \\
\hline $\mathrm{Cl}$ & 0,02 & & & 0,03 & 0,00 & 0,01 & 0,03 \\
\hline $\mathrm{BaO}$ & 0,19 & 0,10 & 0,07 & 0,08 & 0,14 & 0,16 & 0,02 \\
\hline Zno & 0,04 & 0,03 & & 0,01 & & & \\
\hline Total & 96,37 & 94,56 & 96,61 & 95,86 & 96,41 & 95,46 & 96,84 \\
\hline \multicolumn{8}{|c|}{ Fórmula estrutural calculada na base anidra de 22 oxigênios (a.p.f.u.) } \\
\hline Si & 5,949 & 5,699 & 5,820 & 5,790 & 5,769 & 5,753 & 5,843 \\
\hline $\mathbf{A l}^{\mathrm{IV}}$ & 1,848 & 2,260 & 2,158 & 2,136 & 2,172 & 2,191 & 2,065 \\
\hline $\mathrm{Fe}^{3+}$ & 0,203 & 0,041 & 0,021 & 0,074 & 0,059 & 0,056 & 0,091 \\
\hline Sum Z (s, tetra) & 8,000 & 8,000 & 8,000 & 8,000 & 8,000 & 8,000 & 8,000 \\
\hline $\mathrm{Al}^{\mathrm{VI}}$ & & & & & & & 0,000 \\
\hline $\mathrm{Ti}$ & 0,308 & 0,547 & 0,373 & 0,365 & 0,399 & 0,504 & 0,381 \\
\hline $\mathrm{Fe}^{2+}$ & 0,892 & 0,723 & 0,718 & 0,657 & 0,650 & 0,670 & 0,947 \\
\hline Mn & 0,006 & 0,002 & 0,007 & 0,004 & 0,005 & 0,005 & 0,005 \\
\hline Mg & 4,711 & 4,424 & 4,730 & 4,833 & 4,757 & 4,561 & 4,451 \\
\hline Sum Y (s, octa) & 5,917 & 5,696 & 5,828 & 5,859 & 5,812 & 5,740 & 5,784 \\
\hline $\mathrm{Ca}$ & 0,019 & 0,002 & 0,002 & 0,004 & 0,008 & 0,004 & \\
\hline $\mathrm{Ba}$ & 0,011 & 0,006 & 0,004 & 0,004 & 0,008 & 0,009 & 0,001 \\
\hline $\mathrm{Na}$ & 0,069 & 0,022 & 0,015 & 0,006 & 0,007 & 0,012 & 0,022 \\
\hline $\mathrm{K}$ & 2,011 & 1,952 & 1,921 & 1,964 & 1,973 & 1,922 & 1,960 \\
\hline Sum X (inter) & 2,109 & 1,982 & 1,942 & 1,979 & 1,995 & 1,947 & 1,984 \\
\hline Total & 16,027 & 15,678 & 15,770 & 15,839 & 15,807 & 15,687 & 15,768 \\
\hline $\mathbf{F}$ & 0,329 & 0,135 & 0,149 & 0,147 & 0,142 & 0,140 & 0,062 \\
\hline $\mathrm{Cl}$ & 0,006 & & & 0,006 & 0,000 & 0,004 & 0,007 \\
\hline $\mathrm{OH}$ & 3,665 & 3,865 & 3,851 & 3,847 & 3,858 & 3,856 & 3,931 \\
\hline Total & 4 & 4 & 4 & 4 & 4 & 4 & 4 \\
\hline
\end{tabular}

${ }^{1}$ Abreviações: Mic: microcristal; Mac: macrocristal. Amostra pntf2 (análises realizadas no presente trabalho, fragmento 2); 8A1 (número da lâmina petrográfica).

2Localização da análise do grão: B (Borda). 
Apêndice B - Tabela B.III (continuação): Composição em óxidos (\% massa) e fórmula estrutural das flogopitas da intrusão Pântano (continua).

\begin{tabular}{|c|c|c|c|c|c|c|c|}
\hline $\begin{array}{c}\text { Amostra } \\
\text { Grão }^{1} \\
\underset{2}{\text { Localização }^{2}}\end{array}$ & $\begin{array}{c}8 A 1 \\
\text { mac4_b }\end{array}$ & $\begin{array}{c}\text { 8A1 } \\
\text { mac4_b } \\
\text { B }\end{array}$ & $\begin{array}{c}\text { 8A1 } \\
\text { mic3_int } \\
2\end{array}$ & $\begin{array}{c}8 A 1 \\
\text { mic3_int } \\
3\end{array}$ & $\begin{array}{c}8 A 1 \\
\text { mic3_int } \\
4\end{array}$ & $\begin{array}{c}\text { 8A1 } \\
\text { mic4_in } \\
t \\
\text { INT }\end{array}$ & $\begin{array}{c}\text { 8A1 } \\
\text { mac2_in } \\
\text { INT }\end{array}$ \\
\hline $\mathrm{SiO}_{2}$ & 41,04 & 42,94 & 40,43 & 40,58 & 40,89 & 38,63 & 40,93 \\
\hline $\mathrm{TiO}_{2}$ & 3,76 & 0,81 & 3,56 & 3,71 & 3,81 & 4,81 & 3,49 \\
\hline $\mathrm{Al}_{2} \mathrm{O}_{3}$ & 11,96 & 4,56 & 12,85 & 12,81 & 12,78 & 12,45 & 12,13 \\
\hline $\mathrm{FeO}$ & 8,61 & 9,13 & 5,94 & 5,98 & 5,91 & 6,98 & 8,53 \\
\hline MnO & 0,04 & 0,01 & 0,04 & 0,03 & 0,01 & 0,05 & 0,04 \\
\hline $\mathrm{MgO}$ & 20,78 & 25,47 & 22,15 & 22,37 & 22,36 & 21,15 & 20,75 \\
\hline $\mathrm{CaO}$ & 0,05 & 0,26 & 0,01 & 0,05 & 0,02 & 0,38 & 0,02 \\
\hline $\mathrm{Na}_{2} \mathrm{O}$ & 0,15 & 1,09 & 0,04 & 0,05 & 0,04 & 0,16 & 0,18 \\
\hline $\mathrm{K}_{2} \mathrm{O}$ & 10,58 & 10,62 & 10,72 & 10,52 & 10,75 & 10,49 & 10,55 \\
\hline $\mathbf{F}$ & 0,14 & 1,20 & 0,38 & 0,37 & 0,33 & 0,19 & 0,12 \\
\hline $\mathrm{Cl}$ & 0,01 & & 0,05 & 0,04 & 0,01 & 0,03 & 0,01 \\
\hline $\mathrm{BaO}$ & 0,00 & 0,38 & 0,09 & 0,11 & 0,13 & 0,30 & 0,07 \\
\hline $\mathrm{ZnO}$ & 0,00 & 0,02 & 0,00 & 0,00 & 0,00 & 0,00 & 0,03 \\
\hline Total & 97,12 & 96,11 & 96,17 & 96,51 & 96,92 & 95,33 & 96,78 \\
\hline \multicolumn{8}{|c|}{ Fórmula estrutural calculada na base anidra de 22 oxigênios (a.p.f.u.) } \\
\hline Si & 5,870 & 6,420 & 5,804 & 5,797 & 5,810 & 5,630 & 5,869 \\
\hline $\mathbf{A l}^{\mathrm{IV}}$ & 2,017 & 0,804 & 2,175 & 2,157 & 2,141 & 2,139 & 2,051 \\
\hline $\mathrm{Fe}^{3+}$ & 0,113 & 0,776 & 0,021 & 0,046 & 0,049 & 0,232 & 0,080 \\
\hline Sum Z (s, tetra) & 8,000 & 8,000 & 8,000 & 8,000 & 8,000 & 8,000 & 8,000 \\
\hline \multicolumn{8}{|l|}{$\mathrm{Al}^{\mathrm{VI}}$} \\
\hline $\mathrm{Ti}$ & 0,405 & 0,091 & 0,384 & 0,399 & 0,407 & 0,527 & 0,376 \\
\hline $\mathrm{Fe}^{2+}$ & 0,917 & 0,366 & 0,692 & 0,668 & 0,653 & 0,619 & 0,943 \\
\hline Mn & 0,005 & 0,001 & 0,005 & 0,003 & 0,002 & 0,006 & 0,005 \\
\hline Mg & 4,431 & 5,677 & 4,740 & 4,764 & 4,736 & 4,595 & 4,436 \\
\hline Sum Y (s, octa) & 5,757 & 6,135 & 5,822 & 5,834 & 5,798 & 5,748 & 5,761 \\
\hline $\mathrm{Ca}$ & 0,007 & 0,042 & 0,002 & 0,008 & 0,002 & 0,059 & 0,003 \\
\hline $\mathrm{Ba}$ & 0,000 & 0,022 & 0,005 & 0,006 & 0,007 & 0,017 & 0,004 \\
\hline $\mathrm{Na}$ & 0,042 & 0,317 & 0,012 & 0,015 & 0,012 & 0,046 & 0,049 \\
\hline $\mathrm{K}$ & 1,931 & 2,026 & 1,963 & 1,917 & 1,949 & 1,950 & 1,930 \\
\hline Sum X (inter) & 1,980 & 2,407 & 1,981 & 1,947 & 1,971 & 2,072 & 1,987 \\
\hline Total & 15,737 & 16,542 & 15,803 & 15,780 & 15,769 & 15,820 & 15,747 \\
\hline $\mathbf{F}$ & 0,063 & 0,567 & 0,171 & 0,167 & 0,150 & 0,088 & 0,054 \\
\hline Cl & 0,004 & 0,000 & 0,012 & 0,009 & 0,003 & 0,008 & 0,003 \\
\hline $\mathrm{OH}$ & 3,933 & 3,433 & 3,818 & 3,824 & 3,848 & 3,904 & 3,943 \\
\hline Total & 4 & 4 & 4 & 4 & 4 & 4 & 4 \\
\hline
\end{tabular}

${ }^{1}$ Abreviações: Mic: microcristal; Mac: macrocristal.

2Localização da análise do grão: B (Borda); INT (zona intermediária). 
Apêndice B - Tabela B.III (continuação): Composição em óxidos (\% massa) e fórmula estrutural das flogopitas da intrusão Pântano (continua).

\begin{tabular}{|c|c|c|c|c|c|c|c|}
\hline $\begin{array}{c}\text { Amostra } \\
\text { Grão }^{1}\end{array}$ & $\begin{array}{c}\text { 8A1 } \\
\text { mac2_int }\end{array}$ & $\begin{array}{c}\text { 8A1 } \\
\text { mac4_int1 }\end{array}$ & $\begin{array}{c}\text { 8A1 } \\
\text { mac4_int2 }\end{array}$ & $\begin{array}{c}\text { 8A1 } \\
\text { mac4_int3 }\end{array}$ & $\begin{array}{c}8 \mathrm{~A} 1 \\
\text { mac4int4 }\end{array}$ & $\begin{array}{l}\text { pnt3f1 } \\
\text { mic1_n }\end{array}$ & $\begin{array}{l}\text { pnt3f2 } \\
\text { mic2_n }\end{array}$ \\
\hline Localização² & INT & INT & INT & INT & INT & $\mathrm{N}$ & $\mathrm{N}$ \\
\hline $\mathrm{SiO}_{2}$ & 40,71 & 40,61 & 40,61 & 41,01 & 40,61 & 40,23 & 40,68 \\
\hline $\mathrm{TiO}_{2}$ & 3,50 & 3,77 & 3,62 & 3,84 & 3,50 & 3,07 & 2,60 \\
\hline $\mathrm{Al}_{2} \mathrm{O}_{3}$ & 12,09 & 11,39 & 11,95 & 11,89 & 12,01 & 11,66 & 12,43 \\
\hline $\mathrm{FeO}$ & 8,43 & 8,52 & 8,92 & 8,90 & 8,82 & 9,36 & 5,64 \\
\hline MnO & 0,03 & 0,03 & 0,02 & 0,04 & 0,03 & 0,04 & 0,05 \\
\hline $\mathrm{MgO}$ & 20,97 & 21,58 & 20,92 & 20,80 & 20,72 & 20,08 & 23,07 \\
\hline $\mathrm{CaO}$ & 0,01 & 0,02 & 0,03 & 0,03 & 0,02 & 0,21 & 0,02 \\
\hline $\mathrm{Na}_{2} \mathrm{O}$ & 0,05 & 0,17 & 0,05 & 0,21 & 0,10 & 0,16 & 0,07 \\
\hline $\mathrm{K}_{2} \mathrm{O}$ & 10,62 & 10,66 & 10,86 & 10,47 & 10,84 & 10,21 & 10,33 \\
\hline $\mathbf{F}$ & 0,20 & 0,48 & 0,29 & 0,13 & 0,20 & 0,48 & 0,15 \\
\hline $\mathrm{Cl}$ & 0,00 & 0,01 & 0,00 & 0,04 & 0,06 & 0,01 & 0,01 \\
\hline $\mathrm{BaO}$ & 0,08 & 0,05 & 0,15 & 0,06 & 0,00 & 0,19 & 0,14 \\
\hline $\mathrm{ZnO}$ & 0,03 & 0,03 & 0,01 & 0,00 & 0,00 & 0,01 & 0,01 \\
\hline Total & 96,64 & 97,28 & 97,28 & 97,35 & 96,91 & 95,53 & 95,06 \\
\hline \multicolumn{8}{|c|}{ Fórmula estrutural calculada na base anidra de 22 oxigênios (a.p.f.u.) } \\
\hline Si & 5,855 & 5,855 & 5,836 & 5,858 & 5,852 & 5,912 & 5,853 \\
\hline $\mathbf{A l}^{\mathrm{IV}}$ & 2,050 & 1,936 & 2,025 & 2,002 & 2,040 & 2,020 & 2,108 \\
\hline $\mathrm{Fe}^{3+}$ & 0,095 & 0,210 & 0,139 & 0,139 & 0,108 & 0,068 & 0,038 \\
\hline Sum Z (s, tetra) & 8,000 & 8,000 & 8,000 & 8,000 & 8,000 & 8,000 & 8,000 \\
\hline \multicolumn{8}{|l|}{$\mathrm{Al}^{\mathrm{VI}}$} \\
\hline $\mathrm{Ti}$ & 0,379 & 0,409 & 0,391 & 0,413 & 0,379 & 0,339 & 0,281 \\
\hline $\mathrm{Fe}^{2+}$ & 0,919 & 0,817 & 0,933 & 0,924 & 0,955 & 1,083 & 0,641 \\
\hline Mn & 0,004 & 0,004 & 0,003 & 0,005 & 0,004 & 0,005 & 0,006 \\
\hline Mg & 4,496 & 4,638 & 4,482 & 4,430 & 4,451 & 4,399 & 4,949 \\
\hline Sum Y (s, octa) & 5,798 & 5,868 & 5,809 & 5,771 & 5,789 & 5,827 & 5,877 \\
\hline $\mathrm{Ca}$ & 0,002 & 0,004 & 0,004 & 0,004 & 0,003 & 0,034 & 0,004 \\
\hline $\mathrm{Ba}$ & 0,005 & 0,003 & 0,009 & 0,004 & 0,000 & 0,011 & 0,008 \\
\hline $\mathrm{Na}$ & 0,015 & 0,048 & 0,015 & 0,057 & 0,027 & 0,047 & 0,019 \\
\hline K & 1,949 & 1,961 & 1,991 & 1,908 & 1,993 & 1,914 & 1,896 \\
\hline Sum X (inter) & 1,970 & 2,015 & 2,019 & 1,973 & 2,023 & 2,005 & 1,927 \\
\hline Total & 15,768 & 15,883 & 15,828 & 15,744 & 15,812 & 15,832 & 15,804 \\
\hline $\mathbf{F}$ & 0,089 & 0,218 & 0,130 & 0,058 & 0,091 & 0,224 & 0,069 \\
\hline Cl & & 0,002 & & 0,009 & 0,015 & 0,003 & 0,002 \\
\hline $\mathrm{OH}$ & 3,911 & 3,780 & 3,870 & 3,933 & 3,895 & 3,773 & 3,930 \\
\hline Total & 4 & 4 & 4 & 4 & 4 & 4 & 4 \\
\hline
\end{tabular}

${ }^{1}$ Abreviações: Mic: microcristal; Mac: macrocristal. Amostras pntf1 e pmtf2 (análises realizadas no presente trabalho, fragmentos 1 e 2); 8A1 (número da lâmina petrográfica).

2Localização da análise do grão: N (Núcleo); B (Borda); INT (zona intermediária). 
Apêndice B - Tabela B.III (continuação): Composição em óxidos (\% massa) e fórmula estrutural das flogopitas da intrusão Pântano (continua).

\begin{tabular}{|c|c|c|c|c|c|c|c|}
\hline $\begin{array}{c}\text { Amostra } \\
\text { Grão }{ }^{1}\end{array}$ & $\begin{array}{l}\text { pnt3f2 } \\
\text { mic2_n }\end{array}$ & $\begin{array}{l}\text { pnt3f2 } \\
\text { mic2_b }\end{array}$ & $\begin{array}{c}\text { 8A1 } \\
\text { mi3_n1 }\end{array}$ & $\begin{array}{l}\text { 8A1 } \\
\text { mi4_n }\end{array}$ & $\begin{array}{c}\text { 8A1 } \\
\text { mi4_n2 }\end{array}$ & $\begin{array}{c}\text { 8A1 } \\
\text { mac1_n }\end{array}$ & $\begin{array}{c}\text { 8A1 } \\
\text { mac2_n }\end{array}$ \\
\hline Localização² $^{2}$ & $\mathrm{~N}$ & $\mathrm{~N}$ & $\mathrm{~N}$ & $\mathrm{~N}$ & $\mathrm{~N}$ & $\mathrm{~N}$ & $\mathrm{~N}$ \\
\hline $\mathrm{SiO}_{2}$ & 40,82 & 39,81 & 39,21 & 38,78 & 40,60 & 40,70 & 40,90 \\
\hline $\mathrm{TiO}_{2}$ & 2,70 & 4,31 & 5,10 & 3,52 & 3,19 & 3,63 & 3,60 \\
\hline $\mathrm{Al}_{2} \mathrm{O}_{3}$ & 12,52 & 13,20 & 13,09 & 12,69 & 12,74 & 12,02 & 12,15 \\
\hline $\mathrm{FeO}$ & 5,94 & 6,15 & 6,56 & 7,83 & 6,21 & 8,70 & 8,65 \\
\hline MnO & 0,01 & 0,04 & 0,01 & 0,03 & 0,06 & 0,04 & 0,03 \\
\hline MgO & 23,13 & 20,99 & 20,77 & 22,21 & 22,66 & 20,70 & 20,81 \\
\hline $\mathrm{CaO}$ & 0,03 & 0,04 & 0,02 & 0,05 & 0,06 & 0,04 & 0,01 \\
\hline $\mathrm{Na}_{2} \mathrm{O}$ & 0,09 & 0,03 & 0,01 & 0,02 & 0,06 & 0,27 & 0,16 \\
\hline $\mathrm{K}_{2} \mathrm{O}$ & 10,60 & 10,39 & 10,38 & 10,53 & 10,60 & 10,52 & 10,49 \\
\hline $\mathbf{F}$ & 0,12 & 0,12 & 0,11 & 0,13 & 0,13 & 0,17 & 0,15 \\
\hline $\mathrm{Cl}$ & 0,06 & 0,00 & 0,02 & 0,01 & 0,01 & 0,02 & 0,02 \\
\hline $\mathrm{BaO}$ & 0,09 & 0,16 & 0,24 & 0,47 & 0,08 & 0,14 & 0,09 \\
\hline $\mathrm{ZnO}$ & 0,00 & 0,00 & 0,00 & 0,01 & 0,00 & 0,02 & 0,02 \\
\hline Total & 96,04 & 95,08 & 95,29 & 95,82 & 96,32 & 96,84 & 96,99 \\
\hline \multicolumn{8}{|c|}{ Fórmula estrutural calculada na base anidra de 22 oxigênios (a.p.f.u.) } \\
\hline Si & 5,832 & 5,744 & 5,665 & 5,622 & 5,791 & 5,850 & 5,857 \\
\hline $\mathrm{Al}^{\mathrm{IV}}$ & 2,109 & 2,245 & 2,230 & 2,169 & 2,142 & 2,037 & 2,051 \\
\hline $\mathrm{Fe}^{3+}$ & 0,059 & 0,011 & 0,105 & 0,209 & 0,067 & 0,114 & 0,091 \\
\hline Sum Z (s, tetra) & 8,000 & 8,000 & 8,000 & 8,000 & 8,000 & 8,000 & 8,000 \\
\hline \multicolumn{8}{|l|}{$\mathrm{Al}^{\mathrm{VI}}$} \\
\hline $\mathrm{Ti}$ & 0,290 & 0,468 & 0,554 & 0,384 & 0,342 & 0,392 & 0,388 \\
\hline $\mathrm{Fe}^{2+}$ & 0,651 & 0,731 & 0,688 & 0,741 & 0,673 & 0,932 & 0,945 \\
\hline Mn & 0,002 & 0,005 & 0,002 & 0,004 & 0,007 & 0,005 & 0,003 \\
\hline Mg & 4,927 & 4,515 & 4,474 & 4,800 & 4,818 & 4,435 & 4,443 \\
\hline Sum Y (s, octa) & 5,870 & 5,719 & 5,718 & 5,929 & 5,841 & 5,765 & 5,778 \\
\hline $\mathrm{Ca}$ & 0,005 & 0,006 & 0,003 & 0,008 & 0,009 & 0,006 & 0,002 \\
\hline $\mathrm{Ba}$ & 0,005 & 0,009 & 0,014 & 0,027 & 0,004 & 0,008 & 0,005 \\
\hline $\mathrm{Na}$ & 0,025 & 0,007 & 0,004 & 0,006 & 0,017 & 0,076 & 0,045 \\
\hline $\mathrm{K}$ & 1,932 & 1,912 & 1,913 & 1,948 & 1,929 & 1,929 & 1,917 \\
\hline Sum X (inter) & 1,968 & 1,935 & 1,934 & 1,988 & 1,959 & 2,018 & 1,969 \\
\hline Total & 15,838 & 15,654 & 15,651 & 15,917 & 15,800 & 15,783 & 15,747 \\
\hline $\mathbf{F}$ & 0,056 & 0,056 & 0,049 & 0,059 & 0,058 & 0,077 & 0,068 \\
\hline $\mathrm{Cl}$ & 0,015 & 0,000 & 0,005 & 0,003 & 0,002 & 0,005 & 0,006 \\
\hline $\mathrm{OH}$ & 3,928 & 3,944 & 3,946 & 3,938 & 3,939 & 3,918 & 3,926 \\
\hline Total & 4 & 4 & 4 & 4 & 4 & 4 & 4 \\
\hline
\end{tabular}

${ }^{1}$ Abreviações: Mic: microcristal; Mac: macrocristal; f2: fragmento 2.

${ }^{2}$ Localização da análise do grão: N (Núcleo). 
Apêndice B - Tabela B.III (continuação): Composição em óxidos (\% massa) e fórmula estrutural das flogopitas da intrusão Pântano (continua).

\begin{tabular}{|c|c|c|c|c|c|c|c|}
\hline $\begin{array}{l}\text { Amostra } \\
\text { Grão } \\
\text { Localizaçãoº }^{2}\end{array}$ & $\begin{array}{c}\text { 8A1 } \\
\text { mac3_n } \\
N\end{array}$ & $\begin{array}{l}\text { PNT4 } \\
\text { poiq1 } \\
\mathrm{N}\end{array}$ & $\begin{array}{c}\text { PNT4 } \\
\text { poiq2 } \\
N\end{array}$ & $\begin{array}{c}\text { PNT4 } \\
\text { poiq3 } \\
N\end{array}$ & $\begin{array}{c}\text { PNT4 } \\
\text { poiq4 } \\
\text { N }\end{array}$ & $\begin{array}{c}\text { PNT4 } \\
\text { poiq5 } \\
N\end{array}$ & $\begin{array}{c}\text { PNT4 } \\
\text { poiq6 } \\
N\end{array}$ \\
\hline $\mathrm{SiO}_{2}$ & 41,13 & 41,54 & 41,16 & 41,12 & 41,59 & 41,92 & 42,22 \\
\hline $\mathrm{TiO}_{2}$ & 3,74 & 1,33 & 1,22 & 1,36 & 0,13 & 0,20 & 1,00 \\
\hline $\mathrm{Al}_{2} \mathrm{O}_{3}$ & 12,06 & 6,58 & 6,66 & 7,06 & 6,02 & 7,00 & 6,72 \\
\hline $\mathrm{FeO}$ & 8,82 & 8,73 & 8,68 & 8,67 & 13,87 & 12,59 & 8,78 \\
\hline MnO & 0,03 & 0,03 & 0,05 & 0,04 & 0,33 & 0,22 & 0,05 \\
\hline $\mathrm{MgO}$ & 20,70 & 24,85 & 24,92 & 25,53 & 20,86 & 21,46 & 23,38 \\
\hline $\mathrm{CaO}$ & 0,00 & 0,06 & 0,07 & 0,04 & 1,88 & 1,51 & 0,12 \\
\hline $\mathrm{Na}_{2} \mathrm{O}$ & 0,26 & 0,43 & 0,39 & 0,34 & 0,44 & 0,38 & 0,76 \\
\hline $\mathrm{K}_{2} \mathrm{O}$ & 10,53 & 10,61 & 10,56 & 10,50 & 6,90 & 7,34 & 11,49 \\
\hline$F$ & 0,14 & 0,89 & 0,88 & 0,96 & 0,01 & 0,01 & 0,94 \\
\hline $\mathrm{Cl}$ & 0,03 & & & & & 0,01 & \\
\hline $\mathrm{BaO}$ & 0,08 & 0,55 & 0,59 & 0,66 & 0,08 & 0,06 & 0,23 \\
\hline $\mathrm{ZnO}$ & & & 0,01 & & 0,02 & 0,04 & 0,01 \\
\hline Total & 97,44 & 95,05 & 94,60 & 95,62 & 92,04 & 92,68 & 95,47 \\
\hline \multicolumn{8}{|c|}{ Fórmula estrutural calculada na base anidra de 22 oxigênios (a.p.f.u.) } \\
\hline Si & 5,867 & 6,211 & 6,185 & 6,115 & 6,361 & 6,321 & 6,324 \\
\hline $\mathbf{A l}^{\mathrm{IV}}$ & 2,028 & 1,160 & 1,180 & 1,238 & 1,085 & 1,244 & 1,187 \\
\hline $\mathrm{Fe}^{3+}$ & 0,105 & 0,630 & 0,636 & 0,647 & 0,554 & 0,435 & 0,489 \\
\hline Sum Z (s, tetra) & 8,000 & 8,000 & 8,000 & 8,000 & 8,000 & 8,000 & 8,000 \\
\hline \multicolumn{8}{|l|}{$\mathrm{Al}^{\mathrm{VI}}$} \\
\hline $\mathrm{Ti}$ & 0,401 & 0,150 & 0,138 & 0,152 & 0,015 & 0,023 & 0,113 \\
\hline $\mathrm{Fe}^{2+}$ & 0,948 & 0,462 & 0,455 & 0,432 & 1,220 & 1,153 & 0,611 \\
\hline Mn & 0,004 & 0,004 & 0,006 & 0,005 & 0,043 & 0,029 & 0,006 \\
\hline Mg & 4,402 & 5,539 & 5,582 & 5,660 & 4,756 & 4,824 & 5,221 \\
\hline Sum Y (s, octa) & 5,755 & 6,155 & 6,181 & 6,249 & 6,034 & 6,029 & 5,950 \\
\hline $\mathrm{Ca}$ & & 0,010 & 0,012 & 0,006 & 0,308 & 0,244 & 0,020 \\
\hline $\mathrm{Ba}$ & 0,005 & 0,032 & 0,035 & 0,038 & 0,005 & 0,004 & 0,014 \\
\hline $\mathrm{Na}$ & 0,071 & 0,124 & 0,114 & 0,099 & 0,129 & 0,111 & 0,221 \\
\hline K & 1,916 & 2,024 & 2,024 & 1,992 & 1,346 & 1,412 & 2,196 \\
\hline Sum X (inter) & 1,992 & 2,190 & 2,185 & 2,136 & 1,788 & 1,770 & 2,450 \\
\hline Total & 15,747 & 16,344 & 16,366 & 16,385 & 15,822 & 15,799 & 16,400 \\
\hline $\mathbf{F}$ & 0,065 & 0,422 & 0,417 & 0,452 & 0,004 & 0,005 & 0,444 \\
\hline $\mathrm{Cl}$ & 0,007 & & & & & 0,002 & \\
\hline $\mathrm{OH}$ & 3,928 & 3,578 & 3,583 & 3,548 & 3,996 & 3,993 & 3,556 \\
\hline Total & 4 & 4 & 4 & 4 & 4 & 4 & 4 \\
\hline
\end{tabular}

${ }^{1}$ Abreviações: Mac: macrocristal; poiq: poiquilítica.

²Localização da análise do grão: N (Núcleo). 
Apêndice B - Tabela B.III (continuação): Composição em óxidos (\% massa) e fórmula estrutural das flogopitas da intrusão Pântano (continua).

\begin{tabular}{|c|c|c|c|c|c|c|c|}
\hline $\begin{array}{c}\text { Amostra } \\
\text { Grão }{ }^{1}\end{array}$ & $\begin{array}{l}\text { PNT4 } \\
\text { poiq7 }\end{array}$ & $\begin{array}{c}\text { PNT4 } \\
\text { poiq8 }\end{array}$ & $\begin{array}{l}\text { PNT4 } \\
\text { poiq9 }\end{array}$ & $\begin{array}{l}\text { PNT4 } \\
\text { poiq10 }\end{array}$ & $\begin{array}{l}\text { PNT4 } \\
\text { poiq11 }\end{array}$ & $\begin{array}{l}\text { PNT4 } \\
\text { poiq12 }\end{array}$ & $\begin{array}{l}\text { PNT4 } \\
\text { poiq13 }\end{array}$ \\
\hline Localização & $\mathrm{N}$ & $\mathrm{N}$ & $\mathrm{N}$ & $\mathrm{N}$ & $\mathrm{N}$ & $\mathrm{N}$ & $\mathrm{N}$ \\
\hline $\mathrm{SiO}_{2}$ & 40,56 & 41,55 & 41,01 & 42,05 & 41,82 & 41,27 & 41,13 \\
\hline $\mathrm{TiO}_{2}$ & 1,28 & 1,20 & 1,37 & 1,31 & 1,20 & 1,19 & 1,43 \\
\hline $\mathrm{Al}_{2} \mathrm{O}_{3}$ & 7,51 & 6,89 & 8,17 & 6,00 & 6,84 & 6,92 & 7,04 \\
\hline $\mathrm{FeO}$ & 8,37 & 8,74 & 7,85 & 8,83 & 8,53 & 8,52 & 8,40 \\
\hline MnO & 0,03 & 0,07 & 0,03 & 0,05 & 0,02 & 0,04 & 0,03 \\
\hline MgO & 25,68 & 25,10 & 25,11 & 24,90 & 24,99 & 25,28 & 25,64 \\
\hline $\mathrm{CaO}$ & 0,03 & 0,04 & 0,05 & 0,02 & 0,05 & & 0,03 \\
\hline $\mathrm{Na}_{2} \mathrm{O}$ & 0,23 & 0,34 & 0,16 & 0,56 & 0,37 & 0,31 & 0,35 \\
\hline $\mathrm{K}_{2} \mathrm{O}$ & 10,32 & 10,57 & 10,42 & 10,29 & 10,51 & 10,58 & 10,76 \\
\hline $\mathbf{F}$ & 0,95 & 0,91 & 0,86 & 0,97 & 0,92 & 0,92 & 0,96 \\
\hline $\mathrm{Cl}$ & & & 0,01 & 0,01 & & & \\
\hline $\mathrm{BaO}$ & 0,98 & 0,74 & 0,89 & 0,30 & 0,52 & 0,47 & 0,57 \\
\hline $\mathrm{ZnO}$ & 0,06 & & & 0,05 & & 0,01 & 0,01 \\
\hline Total & 95,01 & 95,42 & 95,03 & 95,04 & 95,25 & 95,03 & 95,78 \\
\hline \multicolumn{8}{|c|}{ Fórmula estrutural calculada na base anidra de 22 oxigênios (a.p.f.u.) } \\
\hline Si & 6,055 & 6,183 & 6,080 & 6,296 & 6,224 & 6,169 & 6,111 \\
\hline $\mathbf{A l}^{\mathrm{IV}}$ & 1,322 & 1,209 & 1,428 & 1,059 & 1,200 & 1,219 & 1,233 \\
\hline $\mathrm{Fe}^{3+}$ & 0,623 & 0,608 & 0,492 & 0,645 & 0,576 & 0,612 & 0,656 \\
\hline Sum Z (s, tetra) & 8,000 & 8,000 & 8,000 & 8,000 & 8,000 & 8,000 & 8,000 \\
\hline \multicolumn{8}{|l|}{$\mathrm{Al}^{\mathrm{VI}}$} \\
\hline $\mathrm{Ti}$ & 0,144 & 0,134 & 0,153 & 0,148 & 0,134 & 0,134 & 0,160 \\
\hline $\mathrm{Fe}^{2+}$ & 0,422 & 0,480 & 0,481 & 0,461 & 0,486 & 0,453 & 0,388 \\
\hline$M n$ & 0,004 & 0,009 & 0,004 & 0,006 & 0,003 & 0,004 & 0,004 \\
\hline Mg & 5,716 & 5,568 & 5,549 & 5,558 & 5,545 & 5,633 & 5,679 \\
\hline Sum Y (s, octa) & 6,286 & 6,191 & 6,187 & 6,173 & 6,168 & 6,224 & 6,230 \\
\hline $\mathrm{Ca}$ & 0,005 & 0,006 & 0,008 & 0,003 & 0,008 & & 0,005 \\
\hline $\mathrm{Ba}$ & 0,057 & 0,043 & 0,052 & 0,018 & 0,031 & 0,028 & 0,033 \\
\hline $\mathrm{Na}$ & 0,066 & 0,097 & 0,045 & 0,163 & 0,106 & 0,089 & 0,100 \\
\hline $\mathrm{K}$ & 1,966 & 2,007 & 1,971 & 1,966 & 1,996 & 2,017 & 2,039 \\
\hline Sum X (inter) & 2,093 & 2,153 & 2,076 & 2,149 & 2,140 & 2,134 & 2,178 \\
\hline Total & 16,379 & 16,345 & 16,263 & 16,322 & 16,308 & 16,358 & 16,408 \\
\hline $\mathbf{F}$ & 0,446 & 0,428 & 0,401 & 0,461 & 0,431 & 0,434 & 0,451 \\
\hline $\mathrm{Cl}$ & & 0,001 & 0,002 & 0,002 & & & \\
\hline $\mathrm{OH}$ & 3,554 & 3,570 & 3,597 & 3,537 & 3,568 & 3,566 & 3,549 \\
\hline Total & 4 & 4 & 4 & 4 & 4 & 4 & 4 \\
\hline
\end{tabular}

${ }^{1}$ Abreviações: Poiq: poiquilítica.

²Localização da análise do grão: N (Núcleo). 
Apêndice B - Tabela B.III (continuação): Composição em óxidos (\% massa) e fórmula estrutural das flogopitas da intrusão Pântano (continua).

\begin{tabular}{|c|c|c|c|c|c|c|c|}
\hline $\begin{array}{c}\text { Amostra } \\
\text { Grão }{ }^{1}\end{array}$ & $\begin{array}{l}\text { PNT4 } \\
\text { poiq14 }\end{array}$ & $\begin{array}{l}\text { PNT4 } \\
\text { poiq15 }\end{array}$ & $\begin{array}{l}\text { PNT4 } \\
\text { poiq16 }\end{array}$ & $\begin{array}{l}\text { PNT4 } \\
\text { poiq17 }\end{array}$ & $\begin{array}{l}\text { PNT4 } \\
\text { poiq18 }\end{array}$ & $\begin{array}{l}\text { PNT4 } \\
\text { poiq19 }\end{array}$ & $\begin{array}{l}\text { PNT4 } \\
\text { poiq20 }\end{array}$ \\
\hline Localização $^{2}$ & $\mathrm{~N}$ & $\mathrm{~N}$ & $\mathrm{~N}$ & $\mathrm{~N}$ & $\mathrm{~N}$ & $\mathrm{~N}$ & $\mathrm{~N}$ \\
\hline $\mathrm{SiO}_{2}$ & 41,36 & 41,92 & 41,16 & 41,08 & 41,40 & 40,83 & 40,84 \\
\hline $\mathrm{TiO}_{2}$ & 1,23 & 1,32 & 1,33 & 1,23 & 1,38 & 1,27 & 1,41 \\
\hline $\mathrm{Al}_{2} \mathrm{O}_{3}$ & 7,04 & 6,50 & 6,88 & 7,22 & 6,71 & 6,91 & 6,67 \\
\hline $\mathrm{FeO}$ & 8,13 & 8,47 & 8,78 & 8,10 & 9,04 & 8,05 & 8,78 \\
\hline MnO & 0,05 & 0,04 & 0,07 & 0,07 & 0,06 & 0,03 & 0,04 \\
\hline MgO & 25,31 & 25,52 & 25,09 & 25,55 & 25,24 & 25,62 & 25,57 \\
\hline $\mathrm{CaO}$ & 0,02 & 0,05 & 0,06 & 0,08 & 0,04 & 0,06 & 0,03 \\
\hline $\mathrm{Na}_{2} \mathrm{O}$ & 0,39 & 0,41 & 0,36 & 0,32 & 0,38 & 0,44 & 0,38 \\
\hline $\mathrm{K}_{2} \mathrm{O}$ & 10,51 & 10,72 & 10,56 & 10,43 & 10,46 & 10,63 & 10,32 \\
\hline $\mathbf{F}$ & 0,98 & 0,97 & 0,87 & 0,99 & 0,91 & 0,95 & 0,99 \\
\hline $\mathrm{Cl}$ & & & & & 0,01 & 0,01 & 0,01 \\
\hline $\mathrm{BaO}$ & 0,53 & 0,40 & 0,72 & 0,66 & 0,66 & 0,42 & 0,63 \\
\hline Zno & & 0,04 & & & & & 0,02 \\
\hline Total & 95,02 & 95,96 & 95,17 & 95,07 & 95,61 & 94,80 & 95,06 \\
\hline \multicolumn{8}{|c|}{ Fórmula estrutural calculada na base anidra de 22 oxigênios (a.p.f.u.) } \\
\hline Si & 6,175 & 6,215 & 6,146 & 6,130 & 6,159 & 6,124 & 6,123 \\
\hline $\mathbf{A l}^{\mathrm{IV}}$ & 1,239 & 1,136 & 1,211 & 1,270 & 1,177 & 1,222 & 1,179 \\
\hline $\mathrm{Fe}^{3+}$ & 0,586 & 0,649 & 0,643 & 0,601 & 0,664 & 0,654 & 0,698 \\
\hline Sum Z (s, tetra) & 8,000 & 8,000 & 8,000 & 8,000 & 8,000 & 8,000 & 8,000 \\
\hline \multicolumn{8}{|l|}{$\mathrm{Al}^{\mathrm{VI}}$} \\
\hline $\mathrm{Ti}$ & 0,138 & 0,147 & 0,149 & 0,138 & 0,154 & 0,143 & 0,159 \\
\hline $\mathrm{Fe}^{2+}$ & 0,429 & 0,401 & 0,453 & 0,410 & 0,461 & 0,356 & 0,403 \\
\hline Mn & 0,006 & 0,005 & 0,008 & 0,009 & 0,007 & 0,004 & 0,005 \\
\hline Mg & 5,633 & 5,640 & 5,585 & 5,683 & 5,598 & 5,729 & 5,715 \\
\hline Sum Y (s, octa) & 6,206 & 6,194 & 6,196 & 6,241 & 6,221 & 6,232 & 6,281 \\
\hline $\mathrm{Ca}$ & 0,004 & 0,007 & 0,010 & 0,013 & 0,006 & 0,009 & 0,005 \\
\hline $\mathrm{Ba}$ & 0,031 & 0,024 & 0,042 & 0,039 & 0,039 & 0,025 & 0,037 \\
\hline $\mathrm{Na}$ & 0,113 & 0,119 & 0,105 & 0,091 & 0,109 & 0,129 & 0,110 \\
\hline K & 2,002 & 2,028 & 2,012 & 1,985 & 1,985 & 2,034 & 1,974 \\
\hline Sum X (inter) & 2,150 & 2,177 & 2,168 & 2,128 & 2,138 & 2,197 & 2,126 \\
\hline Total & 16,356 & 16,371 & 16,364 & 16,369 & 16,359 & 16,429 & 16,407 \\
\hline $\mathbf{F}$ & 0,462 & 0,456 & 0,409 & 0,466 & 0,428 & 0,448 & 0,471 \\
\hline $\mathrm{Cl}$ & & & & & 0,002 & 0,002 & 0,002 \\
\hline $\mathrm{OH}$ & 3,538 & 3,544 & 3,586 & 3,534 & 3,571 & 3,549 & 3,527 \\
\hline Total & 4 & 4 & 4 & 4 & 4 & 4 & 4 \\
\hline
\end{tabular}

${ }^{1}$ Abreviações: poiq: poiquilítica.

²Localização da análise do grão: N (Núcleo). 
Apêndice C - Análises de Laser Ablation (LA-ICP-MS) 
Apêndice C - Tabela C.I: Concentrações do padrão primário BHVO-2G obtidas a partir das análises de olivinas no fragmento 1 (LA-ICP-MS).

\begin{tabular}{|c|c|c|c|c|c|}
\hline Elemento & GeoRem & Incerteza & LD & BHVO & $2 \sigma$ \\
\hline $\mathbf{L i}$ & 4,4 & 0,8 & 0,236 & 3,5 & 0,82 \\
\hline $\mathrm{Na}$ & 1,78 & 0,2 & 15,4 & 19616,68 & 3464,5 \\
\hline Al & 7,20 & 2 & 2,78 & 58301,53 & 6500,3 \\
\hline $\mathbf{P}$ & 308 & 19 & 27,83 & 999,23 & 2563,42 \\
\hline Sc & 33 & 2 & 0,197 & 35,91 & 5,7 \\
\hline $\mathrm{Ti}$ & 16300 & 7 & 1,27 & 19558,93 & 4932,72 \\
\hline $\mathbf{V}$ & 308 & 11 & 0,0967 & 299,62 & 62,36 \\
\hline $\mathrm{Cr}$ & 293 & 6 & 1,89 & 301,2 & 46,04 \\
\hline Mn & 0,132 & 3 & 0,38 & 1176,84 & 235,44 \\
\hline Co & 44 & 0,1 & 0,0367 & 43,83 & 9,0 \\
\hline $\mathrm{Ni}$ & 116 & 0,04 & 0,474 & 119,58 & 30,04 \\
\hline $\mathrm{Cu}$ & 127 & 1 & 0,195 & 98,54 & 23,66 \\
\hline$Z n$ & 102 & 2 & 0,999 & 117,42 & 33,16 \\
\hline $\mathbf{R b}$ & 9,2 & 7 & 0,0484 & 7,92 & 1,76 \\
\hline Sr & 396 & 0,8 & 0,0301 & 379,12 & 54,42 \\
\hline $\mathbf{Y}$ & 26 & 0,2 & 0,0348 & 26,39 & 4,98 \\
\hline $\mathrm{Zr}$ & 170 & 0,02 & 0,0585 & 167,14 & 33,18 \\
\hline $\mathrm{Nb}$ & 18,3 & 0,02 & 0,0304 & 17,64 & 4,8 \\
\hline $\mathrm{Ba}$ & 131 & 0,6 & 0,314 & 121,22 & 40,84 \\
\hline La & 15,2 & 0,13 & 0,0323 & 15,66 & 4,02 \\
\hline $\mathrm{Ce}$ & 37,6 & 0,02 & 0,0346 & 35,09 & 8,46 \\
\hline $\operatorname{Pr}$ & 5,35 & 2 & 0,0401 & 5,02 & 1,14 \\
\hline Nd & 24,5 & 0,2 & 0,326 & 25,13 & 6,58 \\
\hline Sm & 6,1 & 0,2 & 0,294 & 7,3 & 2,62 \\
\hline Eu & 2,07 & 0,22 & 0,0928 & 2,01 & 0,68 \\
\hline Gd & 6,16 & 0,2 & 0,288 & 6,84 & 2,2 \\
\hline $\mathrm{Tb}$ & 0,92 & 0,03 & 0,0314 & 0,96 & 0,38 \\
\hline Dy & 5,28 & 0,01 & 0,174 & 5,52 & 2,64 \\
\hline Ho & 0,98 & 0,05 & 0,0499 & 1,05 & 0,48 \\
\hline Er & 2,56 & 0,04 & 0,15 & 2,41 & 1,12 \\
\hline $\mathrm{Tm}$ & 0,34 & 0,05 & 0,053 & 0,349 & 0,16 \\
\hline $\mathrm{Yb}$ & 2,01 & 0,04 & 0,271 & 2,27 & 1,2 \\
\hline Lu & 0,279 & 0,02 & 0,0485 & 0,35 & 0,168 \\
\hline Hf & 4,32 & 0,02 & 0,241 & 4,95 & 2,14 \\
\hline Ta & 1,15 & 0,02 & 0,0484 & 1,19 & 0,42 \\
\hline $\mathrm{Pb}$ & 1,70 & 0,003 & 0,105 & 1,61 & 0,62 \\
\hline Th & 1,22 & 0,18 & 0,00 & 1,52 & 0,54 \\
\hline $\mathbf{U}$ & 0,403 & 0,1 & 0,00 & 0,412 & 0,164 \\
\hline
\end{tabular}

LD: Limite de detecção; n.d.: não detectado 
Apêndice C - Tabela C.II: Concentrações do padrão secundário NIST-610 obtidas a partir das análises de olivinas no fragmento 1 (LA-ICP-MS).

\begin{tabular}{|c|c|c|c|c|c|}
\hline Elemento & GeoRem & Incerteza & LD & Nist-610 & $2 \sigma$ \\
\hline Li & 468 & 24 & 0,37 & 421,55 & 109,74 \\
\hline $\mathrm{Na}$ & 9,94 & 0,223 & 31,96 & 8,62 & 2,16 \\
\hline Al & 413 & 46 & 42,9 & 323,29 & 977,84 \\
\hline Si & 455 & 455 & 0,296 & 526,91 & 101,24 \\
\hline $\mathbf{P}$ & 452 & 452 & 1,91 & 563,11 & 180,26 \\
\hline Sc & 450 & 450 & 0,147 & 395,96 & 100,94 \\
\hline $\mathrm{Ti}$ & 408 & 408 & 3,16 & 416,26 & 78,22 \\
\hline V & 444 & 444 & 0,649 & 394,47 & 97,36 \\
\hline $\mathrm{Cr}$ & 410 & 410 & 0,0926 & 363,92 & 91,22 \\
\hline Mn & 458 & 4 & 0,823 & 418,72 & 128,98 \\
\hline Co & 441 & 15 & 0,326 & 356,93 & 105,26 \\
\hline $\mathrm{Ni}$ & 460 & 18 & 1,57 & 377,88 & 130,04 \\
\hline $\mathrm{Cu}$ & 425,7 & 1 & 0,0899 & 354,52 & 93,52 \\
\hline $\mathrm{Zn}$ & 515,5 & 1 & 0,0234 & 483,24 & 83,8 \\
\hline $\mathbf{R b}$ & 462 & 11 & 0,0457 & 513,39 & 118,3 \\
\hline $\mathrm{Sr}$ & 448 & 9 & 0,0955 & 461,98 & 112,34 \\
\hline $\mathbf{Y}$ & 465 & 34 & 0,0523 & 481,35 & 163,58 \\
\hline $\mathrm{Zr}$ & 452 & 9 & 0,338 & 434,27 & 180,18 \\
\hline $\mathrm{Nb}$ & 440 & 10 & 0,0664 & 461,54 & 144,66 \\
\hline $\mathrm{Ba}$ & 453 & 8 & 0,0585 & 440,54 & 131,1 \\
\hline La & 448 & 7 & 0,055 & 441,94 & 120,64 \\
\hline $\mathrm{Ce}$ & 430 & 8 & 0,582 & 423,03 & 131,02 \\
\hline Pr & 453 & 11 & 0,521 & 484,84 & 206,84 \\
\hline Nd & 447 & 12 & 0,115 & 444,22 & 177,14 \\
\hline Sm & 449 & 12 & 0,39 & 467,47 & 173,34 \\
\hline Eu & 437 & 9 & 0,0654 & 461,41 & 216,92 \\
\hline Gd & 437 & 11 & 0,266 & 470,39 & 272,7 \\
\hline $\mathrm{Tb}$ & 449 & 12 & 0,0958 & 495,2 & 267,78 \\
\hline Dy & 455 & 14 & 0,237 & 497 & 274,24 \\
\hline Ho & 435 & 10 & 0,0476 & 487,76 & 236,38 \\
\hline Er & 450 & 9 & 0,394 & 500,32 & 291,58 \\
\hline $\mathrm{Tm}$ & 439 & 8 & 0,0752 & 507,83 & 261,42 \\
\hline $\mathrm{Yb}$ & 435 & 12 & 0,342 & 463,12 & 243,8 \\
\hline Lu & 446 & 33 & 0,116 & 535 & 217,42 \\
\hline $\mathrm{Hf}$ & 426 & 1 & 0,119 & 397,7 & 173,88 \\
\hline Ta & 457,2 & 1 & 0,00 & 498,09 & 208,34 \\
\hline $\mathrm{Pb}$ & 461,5 & 1 & 0,00 & 426,11 & 182,98 \\
\hline Th & 457,2 & 1 & 0,00 & 498,09 & 208,34 \\
\hline $\mathbf{U}$ & 461,5 & 1 & 0,00 & 426,11 & 182,98 \\
\hline
\end{tabular}

LD: Limite de detecção; n.d.: não detectado 
Apêndice C - Tabela C.III: Limites de detecção do padrão secundário NIST-612 obtidas a partir das análises de olivinas do fragmento 1 (LA-ICP-MS).

\begin{tabular}{|c|c|c|c|c|c|c|}
\hline Elemento & Nist-612a & Nist-612b & Nist-612d & Nist-612e & Média LD & DP \\
\hline $\mathbf{L i}$ & 0,376 & 0,443 & 0,354 & 0,441 & 0,4035 & 0,04 \\
\hline $\mathrm{Na}$ & 20,63 & 24,58 & 32,72 & 41,86 & 29,9475 & 9,40 \\
\hline Al & 5,05 & 5,78 & 4,87 & 6,13 & 5,4575 & 0,59 \\
\hline $\mathbf{P}$ & 55,75 & 56,28 & 42,14 & 50,06 & 51,0575 & 6,57 \\
\hline Sc & 0,347 & 0,398 & 0,309 & 0,364 & 0,3545 & 0,03 \\
\hline $\mathrm{Ti}$ & 1,79 & 2,28 & 1,72 & 2,22 & 2,0025 & 0,28 \\
\hline V & 0,143 & 0,193 & 0,139 & 0,153 & 0,157 & 0,02 \\
\hline $\mathrm{Cr}$ & 3,44 & 3,9 & 3,15 & 3,84 & 3,5825 & 0,35 \\
\hline Mn & 0,713 & 0,789 & 0,621 & 0,76 & 0,72075 & 0,07 \\
\hline Co & 0,0982 & 0,0926 & 0,0805 & 0,1 & 0,092825 & 0,008 \\
\hline $\mathbf{N i}$ & 0,897 & 0,965 & 0,693 & 1,14 & 0,92375 & 0,18 \\
\hline $\mathrm{Cu}$ & 0,329 & 0,343 & 0,271 & 0,315 & 0,3145 & 0,03 \\
\hline $\mathrm{Zn}$ & 1,56 & 2,12 & 1,69 & 2,04 & 1,8525 & 0,26 \\
\hline $\mathbf{R b}$ & 0,0804 & 0,0851 & 0,085 & 0,0877 & 0,08455 & 0,003 \\
\hline $\mathrm{Sr}$ & 0,0717 & 0,0573 & 0,0451 & 0,0514 & 0,056375 & 0,01 \\
\hline$Y$ & 0,0602 & 0,0634 & 0,0312 & 0,0551 & 0,052475 & 0,01 \\
\hline $\mathrm{Zr}$ & 0,0804 & 0,0947 & 0,112 & 0,103 & 0,097525 & 0,01 \\
\hline $\mathrm{Nb}$ & 0,0808 & 0,0604 & 0,0772 & 0,0731 & 0,072875 & 0,008 \\
\hline $\mathrm{Ba}$ & 0,497 & 0,702 & 0,651 & 0,469 & 0,57975 & 0,11 \\
\hline La & 0,0674 & 0,103 & 0,0441 & 0,0696 & 0,071025 & 0,02 \\
\hline $\mathrm{Ce}$ & 0,0845 & 0,0742 & 0,0595 & 0,0813 & 0,074875 & 0,01 \\
\hline $\mathrm{Pr}$ & 0,0491 & 0,0647 & 0,0713 & 0,0708 & 0,063975 & 0,01 \\
\hline Nd & 0,559 & 0,655 & 0,54 & 0,539 & 0,57325 & 0,05 \\
\hline Sm & 0,297 & 0,314 & 0,39 & 0,488 & 0,37225 & 0,08 \\
\hline $\mathrm{Eu}$ & 0,116 & 0,129 & 0,138 & 0,0797 & 0,115675 & 0,02 \\
\hline Gd & 0,463 & 0,315 & 0,376 & 0,519 & 0,41825 & 0,09 \\
\hline Tb & 0,0678 & 0,0799 & 0,0515 & 0,0688 & 0,067 & 0,01 \\
\hline Dy & 0,222 & 0,338 & 0,271 & 0,32 & 0,28775 & 0,05 \\
\hline Ho & 0,0729 & 0,102 & 0,0435 & 0,109 & 0,08185 & 0,02 \\
\hline $\mathrm{Er}$ & 0,167 & 0,29 & 0,219 & 0,247 & 0,23075 & 0,05 \\
\hline $\mathrm{Tm}$ & 0,0648 & 0,101 & 0,0531 & 0,0811 & 0,075 & 0,02 \\
\hline Yb & 0,584 & 0,614 & 0,48 & 0,691 & 0,59225 & 0,08 \\
\hline Lu & 0,0702 & 0,0829 & 0,0803 & 0,0857 & 0,079775 & 0,006 \\
\hline Hf & 0,507 & 0,675 & 0,469 & 0,622 & 0,56825 & 0,09 \\
\hline $\mathrm{Ta}$ & 0,0822 & 0,0812 & 0,0911 & 0,0999 & 0,0886 & 0,008 \\
\hline $\mathrm{Pb}$ & 0,116 & 0,18 & 0,0938 & 0,244 & 0,15845 & 0,06 \\
\hline Th & 0,0451 & 0,00 & 0,00 & 0,00 & 0,011275 & 0,02 \\
\hline $\mathbf{U}$ & 0,00 & 0,00 & 0,00 & 0,00 & 0,00 & 0,00 \\
\hline
\end{tabular}

LD: Limite de detecção; n.d.: não detectado 
Apêndice C - Tabela C.IV: Concentrações do padrão secundário NIST-612 obtidas a partir das análises de olivinas do fragmento 1 (LA-ICPMS).

\begin{tabular}{|c|c|c|c|c|c|c|c|c|c|c|}
\hline Elemento & Georem & Incerteza & Nist-612a & Nist-612b & Nist-612c & Nist-612d & Nist-612e & $\begin{array}{l}\text { Média } \\
\text { Análises }\end{array}$ & $\begin{array}{c}\text { Média } \\
\text { Incertezas }\end{array}$ & $\begin{array}{l}\text { Desvio } \\
\text { Padrão }\end{array}$ \\
\hline Li & 40,2 & 1,3 & 39,25 & 43,14 & 45,55 & 39,97 & 41 & 41,782 & 9,452 & 2,56 \\
\hline $\mathrm{Na}$ & 10,16 & 0,223 & 10,44 & 10,67 & 9,64 & 10,33 & 10,93 & 10,40 & 0,209 & 4,82 \\
\hline Al & 1,07 & 0,02 & 1,08 & 1,14 & 1,15 & 1,09 & 1,11 & 1,11 & 1,33 & 0,31 \\
\hline $\mathbf{P}$ & 46,6 & 6,9 & n.d. & 118,51 & 63,36 & n.d. & 82,92 & 88,26 & 175,15 & 27,96 \\
\hline Sc & 39,9 & 2,5 & 39,14 & 42,67 & 43,49 & 39,85 & 40,88 & 41,20 & 7,036 & 1,84 \\
\hline $\mathrm{Ti}$ & 44 & 2,3 & 50,61 & 47,14 & 43,79 & 46,57 & 53,2 & 48,26 & 14,304 & 3,67 \\
\hline V & 38,8 & 1,2 & 37,29 & 40,4 & 43,25 & 37,27 & 39,17 & 39,47 & 8,868 & 2,49 \\
\hline $\mathrm{Cr}$ & 36,4 & 1,5 & 37,99 & 42,45 & 39,86 & 39,16 & 40,67 & 40,02 & 7,368 & 1,67 \\
\hline Mn & 38,7 & 0,9 & 36,69 & 39,48 & 41,89 & 36,37 & 38,89 & 38,66 & 8,38 & 2,25 \\
\hline Co & 35,5 & 1 & 33,68 & 36,57 & 37,58 & 32,84 & 36,79 & 35,49 & 7,856 & 2,09 \\
\hline $\mathbf{N i}$ & 38,8 & 0,2 & 36,98 & 38,36 & 43,7 & 38,4 & 35,74 & 38,63 & 10,932 & 3,03 \\
\hline $\mathrm{Cu}$ & 37,8 & 1,5 & 35,01 & 37,3 & 41,5 & 34,57 & 36,61 & 36,99 & 9,632 & 2,75 \\
\hline $\mathrm{Zn}$ & 39,1 & 1,7 & 36,76 & 37,34 & 44,23 & 35,54 & 37,36 & 38,24 & 12,136 & 3,42 \\
\hline $\mathbf{R b}$ & 31,4 & 0,4 & 30,89 & 31,24 & 35,68 & 30,1 & 31,24 & 31,83 & 7,492 & 2,20 \\
\hline $\mathrm{Sr}$ & 78,4 & 0,2 & 74,32 & 76,43 & 82 & 74,77 & 74,36 & 76,37 & 11,772 & 3,25 \\
\hline $\mathbf{Y}$ & 38,3 & 1,4 & 36,31 & 39,59 & 41,64 & 37,26 & 37,38 & 38,43 & 7,784 & 2,15 \\
\hline $\mathrm{Zr}$ & 37,9 & 1,2 & 34,45 & 36,62 & 39,84 & 34,87 & 35,1 & 36,17 & 7,788 & 2,20 \\
\hline $\mathrm{Nb}$ & 38,9 & 2,1 & 36 & 38,8 & 44,01 & 36,25 & 37,01 & 38,41 & 11,232 & 3,31 \\
\hline $\mathrm{Ba}$ & 39,3 & 0,9 & 35,41 & 38,27 & 45,46 & 35,78 & 36,09 & 38,20 & 14,06 & 4,20 \\
\hline La & 36 & 0,7 & 33,8 & 36,6 & 40,95 & 34,76 & 34,16 & 36,05 & 9,892 & 2,94 \\
\hline $\mathrm{Ce}$ & 38,4 & 0,7 & 36,84 & 38,48 & 43,82 & 36,71 & 37,34 & 38,63 & 10,028 & 2,97 \\
\hline Pr & 37,9 & 1 & 35,78 & 37,33 & 41,96 & 35,71 & 36,24 & 37,40 & 8,924 & 2,62 \\
\hline Nd & 35,5 & 0,7 & 33,79 & 35,25 & 40,55 & 34 & 33,85 & 35,48 & 10,028 & 2,89 \\
\hline $\mathrm{Sm}$ & 37,7 & 0,8 & 35,85 & 35,86 & 43,5 & 32,84 & 38,2 & 37,25 & 13,876 & 3,97 \\
\hline Eu & 35,6 & 0,8 & 32,73 & 34,51 & 41,2 & 32,18 & 33,67 & 34,858 & 12,072 & 3,65 \\
\hline Gd & 37,3 & 0,9 & 34,57 & 37,98 & 43,15 & 34,64 & 36,31 & 37,33 & 12,26 & 3,54 \\
\hline
\end{tabular}




\begin{tabular}{|c|c|c|c|c|c|c|c|c|c|c|}
\hline Elemento & Georem & Incerteza & Nist-612a & Nist-612b & Nist-612c & Nist-612d & Nist-612e & $\begin{array}{c}\text { Média } \\
\text { Análises }\end{array}$ & $\begin{array}{c}\text { Média } \\
\text { Incertezas }\end{array}$ & $\begin{array}{l}\text { Desvio } \\
\text { Padrão }\end{array}$ \\
\hline Dy & 35,5 & 0,7 & 32,56 & 37,88 & 45,45 & 31,66 & 36,66 & 36,842 & 18,548 & 5,48 \\
\hline Er & 38 & 0,9 & 34,12 & 39,67 & 45,34 & 32,44 & 39,82 & 38,278 & 18,236 & 5,13 \\
\hline $\mathrm{Tm}$ & 36,8 & 0,6 & 34,56 & 39,32 & 45,36 & 33,52 & 38,62 & 38,276 & 16,04 & 4,68 \\
\hline $\mathrm{Yb}$ & 39,2 & 0,9 & 35,0 & 44,14 & 49,5 & 35,77 & 40,02 & 40,886 & 20,872 & 6,04 \\
\hline $\mathrm{Ta}$ & 37,6 & 1,9 & 36,26 & 42,74 & 45,77 & 36,94 & 39,76 & 40,294 & 14,096 & 3,99 \\
\hline $\mathbf{P b}$ & 38,57 & 0,2 & 36,54 & 39,54 & 47,28 & 36 & 38,29 & 39,53 & 15,056 & 4,55 \\
\hline Th & 37,79 & 0,08 & 34,7 & 38,41 & 44,27 & 33,99 & 37,49 & 37,772 & 13,796 & 4,07 \\
\hline $\mathbf{U}$ & 37,38 & 0,08 & 35,25 & 37,34 & 44,69 & 33,77 & 37,49 & 37,708 & 14,016 & 4,19 \\
\hline
\end{tabular}

LD: Limite de deteç̧ão; n.d.: não detectado 
Apêndice C - Tabela C.V: Concentrações de elementos-traço obtidas para as olivinas do fragmento 1 , limites de detecção (LD) e erros associados $(2 \sigma)$ utilizados como padrão de qualidade.

\begin{tabular}{|c|c|c|c|c|c|c|}
\hline \multirow[b]{2}{*}{ Elemento } & Análise & LD & $2 \sigma$ & Análise & LD & $2 \sigma$ \\
\hline & \multicolumn{3}{|c|}{ 1OLMICN } & \multicolumn{3}{|c|}{ 2OLMACN } \\
\hline Li & 5,78 & 0,255 & 1,18 & 1,5 & 0,315 & 0,54 \\
\hline $\mathrm{Na}$ & 173,37 & 14,24 & 27,8 & 86 & 20,38 & 24,52 \\
\hline Al & 149,4 & 3,2 & 15,96 & 15,41 & 4,6 & 5,42 \\
\hline $\mathbf{P}$ & n.d. & 34,53 & 56,24 & n.d. & 45,44 & 47,12 \\
\hline $\mathrm{Ca}$ & 1123,56 & 367,26 & 398,14 & n.d. & 499,84 & 511,78 \\
\hline Sc & 3,78 & 0,211 & 0,64 & 0,74 & 0,298 & 0,38 \\
\hline $\mathrm{Ti}$ & 280,52 & 1,29 & 61,14 & 26,39 & 1,91 & 7,62 \\
\hline V & 9,94 & 0,101 & 1,88 & 2,43 & 0,146 & 0,56 \\
\hline $\mathrm{Cr}$ & 277,48 & 2,19 & 37,22 & 59,72 & 3,0 & 8,82 \\
\hline Mn & 1173,15 & 0,45 & 204,58 & 723,72 & 0,607 & 127,7 \\
\hline Co & 198,71 & 0,0639 & 35,7 & 166,76 & 0,0877 & 30,32 \\
\hline $\mathrm{Ni}$ & 2829,69 & 0,703 & 611,58 & 3851,42 & 0,736 & 841,16 \\
\hline $\mathrm{Cu}$ & 1,7 & 0,181 & 0,5 & 0,63 & 0,312 & 0,42 \\
\hline $\mathrm{Zn}$ & 117,21 & 0,934 & 29,4 & 62,95 & 1,57 & 16,66 \\
\hline $\mathbf{R b}$ & n.d. & 0,0629 & 0,046 & 0,077 & 0,077 & 0,1 \\
\hline $\mathrm{Sr}$ & 0,031 & 0,0301 & 0,04 & 0.677 & 0,047 & 0,19 \\
\hline $\mathbf{Y}$ & n.d. & 0,0387 & 0,048 & n.d. & 0,0452 & 0,046 \\
\hline $\mathrm{Zr}$ & 0,252 & 0,0644 & 0,128 & 0,206 & 0,107 & 0,166 \\
\hline $\mathrm{Nb}$ & n.d. & 0,0494 & 0,042 & n.d. & 0,0599 & 0,078 \\
\hline $\mathrm{Ba}$ & n.d. & 0,296 & 0,34 & 1,42 & 0,533 & 0,96 \\
\hline $\mathrm{La}$ & n.d. & 0,0432 & 0,04 & 0,098 & 0,0539 & 0,088 \\
\hline $\mathrm{Ce}$ & n.d. & 0,0331 & 0,036 & 0,134 & 0,0593 & 0,098 \\
\hline Pr & n.d. & 0,0333 & 0,034 & n.d. & 0,0412 & 0,042 \\
\hline Nd & n.d. & 0,307 & 0,28 & n.d. & 0,452 & 0,38 \\
\hline Sm & n.d. & 0,222 & 0,22 & n.d. & 0,269 & 0,28 \\
\hline Eu & n.d. & 0,0911 & 0,07 & 0,174 & 0,0779 & 0,148 \\
\hline Gd & n.d. & 0,286 & 0,24 & n.d. & 0,479 & 0,46 \\
\hline $\mathrm{Tb}$ & n.d. & 0,0393 & 0,038 & n.d. & 0,0581 & 0,058 \\
\hline Dy & n.d. & 0,194 & 0,176 & n.d. & 0,199 & 0,28 \\
\hline Ho & n.d. & 0,0414 & $\mathrm{n}, \mathrm{d}$ & n.d. & 0,0686 & 0,076 \\
\hline Er & n.d. & 0,139 & 0,148 & n.d. & 0,174 & 0,16 \\
\hline $\mathrm{Tm}$ & n.d. & 0,056 & 0,046 & n.d. & 0,0797 & 0,078 \\
\hline Yb & n.d. & 0,322 & 0,28 & n.d. & 0,329 & 0,38 \\
\hline Lu & n.d. & 0,0586 & 0,054 & n.d. & 0,0745 & 0,072 \\
\hline Hf & n.d. & 0,286 & 0,3 & n.d. & 0,382 & 0,34 \\
\hline $\mathrm{Ta}$ & n.d. & 0,0434 & 0,046 & n.d. & 0,0705 & 0,072 \\
\hline $\mathrm{Pb}$ & n.d. & 0,0783 & 0,09 & n.d. & 0,116 & 0,134 \\
\hline Th & 0,0093 & 0,001 & 0,0188 & n.d. & 0,001 & 0,00 \\
\hline $\mathbf{U}$ & n.d. & 0,00 & 0,00 & n.d. & 0,00 & 0,00 \\
\hline
\end{tabular}

MIC: microcristal; MAC: macrocristal; N: núcleo; n.d.: não detectado. 
Apêndice C - Tabela C.VI: Concentrações do padrão primário BHVO-2G obtidas a partir das análises de olivina do fragmento 2, limites de detecção (LD) e erros associados (2 $\sigma$ ) utilizados como padrão de qualidade.

\begin{tabular}{|c|c|c|c|c|c|}
\hline Elemento & GeoRem & Incerteza & LD & BHVO & $2 \sigma$ \\
\hline $\mathbf{L i}$ & 4,4 & 0,8 & 0,181 & 3,82 & 0,62 \\
\hline $\mathrm{Na}$ & 1,78 & 0,2 & 16,66 & 2,38 & 5039,24 \\
\hline Al & 7,20 & 2 & 2,85 & 56,2 & 72,09 \\
\hline $\mathbf{P}$ & 0,127 & 19 & 22,7 & 968,77 & 1819,08 \\
\hline Sc & 33 & 2 & 0,214 & 37,02 & 8,4 \\
\hline $\mathrm{Ti}$ & 16300 & 7 & 1,21 & 18689,03 & 2773,26 \\
\hline $\mathbf{V}$ & 308 & 11 & 0,0912 & 296,26 & 72,46 \\
\hline $\mathrm{Cr}$ & 293 & 6 & 1,14 & 283,54 & 99,02 \\
\hline Mn & 0,132 & 3 & 0,358 & 1133,45 & 249,1 \\
\hline Co & 44 & 0,1 & 0,0536 & 40,21 & 8,16 \\
\hline $\mathrm{Ni}$ & 116 & 0,04 & 0,453 & 107,48 & 29,38 \\
\hline $\mathrm{Cu}$ & 127 & 1 & 0,175 & 90,23 & 13,78 \\
\hline $\mathrm{Zn}$ & 102 & 2 & 1,18 & 119,34 & 42,2 \\
\hline $\mathbf{R b}$ & 9,2 & 7 & 0,046 & 8,76 & 2,22 \\
\hline $\mathrm{Sr}$ & 396 & 0,8 & 0,0396 & 382,55 & 65,1 \\
\hline $\mathbf{Y}$ & 26 & 0,2 & 0,0426 & 25,94 & 4,34 \\
\hline $\mathrm{Zr}$ & 170 & 0,02 & 0,0643 & 168,26 & 30,94 \\
\hline $\mathrm{Nb}$ & 18,3 & 0,02 & 0,038 & 17,66 & 4,56 \\
\hline $\mathrm{Ba}$ & 131 & 0,6 & 0,197 & 119,67 & 31,5 \\
\hline La & 15,2 & 0,13 & 0,0445 & 15,73 & 3,54 \\
\hline $\mathrm{Ce}$ & 37,6 & 0,02 & 0,0406 & 33,8 & 6,96 \\
\hline Pr & 5,35 & 2 & 0,0386 & 5,09 & 1,02 \\
\hline Nd & 24,5 & 0,2 & 0,389 & 24,03 & 6,22 \\
\hline Sm & 6,1 & 0,2 & 0,382 & 6,4 & 1,3 \\
\hline Eu & 2,07 & 0,22 & 0,0995 & 1,92 & 0,4 \\
\hline Gd & 6,16 & 0,2 & 0,239 & 7,39 & 1,46 \\
\hline $\mathrm{Tb}$ & 0,92 & 0,03 & 0,0492 & 0,896 & 0,152 \\
\hline Dy & 5,28 & 0,01 & 0,192 & 6,18 & 0,94 \\
\hline Ho & 0,98 & 0,05 & 0,0481 & 1,27 & 0,156 \\
\hline Er & 2,56 & 0,04 & 0,116 & 2,93 & 0,42 \\
\hline $\mathrm{Tm}$ & 0,34 & 0,05 & 0,0439 & 0,347 & 0,09 \\
\hline $\mathrm{Yb}$ & 2,01 & 0,04 & 0,402 & 1,85 & 0,6 \\
\hline Lu & 0,279 & 0,02 & 0,0439 & 0,304 & 0,098 \\
\hline Hf & 4,32 & 0,02 & 0,299 & 5,22 & 1,7 \\
\hline $\mathrm{Ta}$ & 1,15 & 0,02 & 0,0427 & 1,05 & 0,26 \\
\hline $\mathrm{Pb}$ & 1,7 & 0,003 & 0,0844 & 1,74 & 0,54 \\
\hline Th & 1,22 & 0,18 & 0,00 & 1,42 & 0,32 \\
\hline $\mathbf{U}$ & 0,403 & 0,1 & 0,00 & 0,418 & 0,106 \\
\hline
\end{tabular}


Apêndice C - Tabela C.VII: Concentrações do padrão secundário NIST-610 obtidas a partir das análises de olivina do fragmento 2 , limites de detecção (LD) e erros associados $(2 \sigma)$ utilizados como padrão de qualidade.

\begin{tabular}{|c|c|c|c|c|c|}
\hline Elemento & GeoRem & Incerteza & LD & Nist-610 & $2 \sigma$ \\
\hline $\mathbf{L i}$ & 468 & 0,8 & 0,29 & 413,54 & 73,8 \\
\hline $\mathrm{Na}$ & 9,94 & 0,2 & 30,8 & 9,41 & 27,74 \\
\hline Al & 413 & 2 & 5,15 & 12343,57 & 2112,5 \\
\hline $\mathbf{P}$ & 452 & 19 & 37,51 & 327,9 & 795,02 \\
\hline Sc & 450 & 2 & 0,368 & 544,08 & 167,54 \\
\hline $\begin{array}{l}\mathrm{Ti} \\
\mathrm{V}\end{array}$ & $\begin{array}{l}408 \\
444\end{array}$ & $\begin{array}{c}7 \\
11\end{array}$ & $\begin{array}{c}1,53 \\
0,139\end{array}$ & $\begin{array}{l}550,78 \\
406,06\end{array}$ & $\begin{array}{l}113,12 \\
136,72\end{array}$ \\
\hline $\mathrm{Cr}$ & 410 & 6 & 1,85 & 408,06 & 190,02 \\
\hline Mn & 458 & 3 & 0,657 & 408,18 & 122,64 \\
\hline Co & 441 & 0,1 & 0,0729 & 374,42 & 103,04 \\
\hline $\begin{array}{l}\mathrm{Ni} \\
\mathrm{Cu}\end{array}$ & $\begin{array}{c}460 \\
425,7\end{array}$ & $\begin{array}{c}0,04 \\
1\end{array}$ & $\begin{array}{l}0,885 \\
0,332\end{array}$ & $\begin{array}{l}414,62 \\
367,41\end{array}$ & $\begin{array}{c}156,82 \\
76,02\end{array}$ \\
\hline $\begin{array}{l}\mathrm{Zn} \\
\mathrm{Rb}\end{array}$ & $\begin{array}{c}515,5 \\
462\end{array}$ & $\begin{array}{l}2 \\
7\end{array}$ & $\begin{array}{c}2,14 \\
0,0708\end{array}$ & $\begin{array}{l}424,22 \\
397,86\end{array}$ & $\begin{array}{l}218,5 \\
136,5\end{array}$ \\
\hline $\begin{array}{l}\mathrm{Sr} \\
\mathrm{Y} \\
\mathrm{Zr}\end{array}$ & $\begin{array}{l}448 \\
465 \\
452\end{array}$ & $\begin{array}{c}0,8 \\
0,2 \\
0,02\end{array}$ & $\begin{array}{c}0,0518 \\
0,0702 \\
0,12\end{array}$ & $\begin{array}{l}544,84 \\
554,43 \\
521,06\end{array}$ & $\begin{array}{l}125,94 \\
125,12 \\
132,56\end{array}$ \\
\hline $\mathrm{Nb}$ & 440 & 0,02 & 0,0609 & 514,97 & 184,82 \\
\hline $\begin{array}{l}\mathrm{Ba} \\
\mathrm{La}\end{array}$ & $\begin{array}{l}453 \\
448\end{array}$ & $\begin{array}{c}0,6 \\
0,13\end{array}$ & $\begin{array}{c}0,616 \\
0,0809\end{array}$ & $\begin{array}{l}449,42 \\
492,07\end{array}$ & $\begin{array}{l}159,08 \\
148,62\end{array}$ \\
\hline $\mathrm{Ce}$ & 430 & 0,02 & 0,083 & 439,87 & 121,6 \\
\hline $\mathbf{P r}$ & 453 & 2 & 0,0615 & 474,87 & 125,86 \\
\hline Nd & 447 & 0,2 & 0,582 & 475,7 & 161,38 \\
\hline Sm & 449 & 0,2 & 0,542 & 514,69 & 108,1 \\
\hline $\mathrm{Eu}$ & 437 & 0,22 & 0,168 & 460,33 & 99,52 \\
\hline Gd & 437 & 0,2 & 0,377 & 512,62 & 107,08 \\
\hline $\mathrm{Tb}$ & 449 & 0,03 & 0,0671 & 497,9 & 68,76 \\
\hline $\begin{array}{l}\text { Dy } \\
\text { Ho }\end{array}$ & $\begin{array}{l}455 \\
435\end{array}$ & $\begin{array}{l}0,01 \\
0,05\end{array}$ & $\begin{array}{l}0,381 \\
0,102\end{array}$ & $\begin{array}{l}493,68 \\
518,08\end{array}$ & $\begin{array}{c}70,6 \\
54,02\end{array}$ \\
\hline Er & 450 & 0,04 & 0,217 & 510,7 & 43,82 \\
\hline $\mathrm{Tm}$ & 439 & 0,05 & 0,0914 & 508,29 & 72,44 \\
\hline Yb & 435 & 0,04 & 0,372 & 514 & 92,88 \\
\hline Lu & 446 & 0,02 & 0,0925 & 488,96 & 129,02 \\
\hline $\mathrm{Hf}$ & 426 & 0,02 & 0,59 & 441,19 & 172,64 \\
\hline $\mathrm{Ta}$ & 457,2 & 0,02 & 0,0977 & 480,92 & 138,48 \\
\hline $\mathrm{Pb}$ & 461,5 & 0,003 & 0,0824 & 362,56 & 134,26 \\
\hline Th & 457,2 & 0,18 & 0,00 & 484,39 & 120,98 \\
\hline $\mathbf{U}$ & 461,5 & 0,1 & 0,00 & 388,46 & 86,68 \\
\hline
\end{tabular}


Apêndice C - Tabela C.VIII: Limites de detecção (LD) do padrão secundário NIST-612 obtidas a partir das análises de olivina do fragmento 2.

\begin{tabular}{|c|c|c|c|c|c|c|}
\hline Elemento & Nist-612a & Nist-612b & Nist-612d & Nist-612e & Média LD & DP \\
\hline Li & 0,384 & 0,384 & 0,406 & 0,412 & 0,4042 & 0,02 \\
\hline $\mathrm{Na}$ & 36,51 & 36,8 & 37,71 & 42,96 & 38,65 & 2,64 \\
\hline Al & 6,93 & 6,96 & 6,54 & 7,1 & 6,862 & 0,21 \\
\hline $\mathbf{P}$ & 54,51 & 59,16 & 45,11 & 52,41 & 53,352 & 5,22 \\
\hline Sc & 0,498 & 0,471 & 0,418 & 0,496 & 0,4648 & 0,03 \\
\hline $\mathrm{Ti}$ & 2,1 & 2,11 & 2,6 & 2,99 & 2,484 & 0,38 \\
\hline $\mathbf{V}$ & 0,216 & 0,18 & 0,187 & 0,178 & 0,1942 & 0,02 \\
\hline $\mathrm{Cr}$ & 2,99 & 2,94 & 2,22 & 2,5 & 2,656 & 0,32 \\
\hline Mn & 0,869 & 0,861 & 0,794 & 0,925 & 0,866 & 0,05 \\
\hline Co & 0,105 & 0,069 & 0,0547 & 0,13 & 0,09354 & 0,03 \\
\hline $\mathrm{Ni}$ & 0,53 & 0,92 & 0,918 & 0,997 & 0,8312 & 0,18 \\
\hline $\mathrm{Cu}$ & 0,363 & 0,423 & 0,346 & 0,493 & 0,4006 & 0,06 \\
\hline $\mathrm{Zn}$ & 2,35 & 2,37 & 2,38 & 3,16 & 2,544 & 0,35 \\
\hline $\mathbf{R b}$ & 0,139 & 0,102 & 0,14 & 0,109 & 0,1192 & 0,02 \\
\hline Sr & 0,0875 & 0,0876 & 0,086 & 0,109 & 0,09096 & 0,01 \\
\hline $\mathbf{Y}$ & 0,0702 & 0,0314 & 0,0764 & 0,0829 & 0,07298 & 0,03 \\
\hline $\mathrm{Zr}$ & 0,116 & 0,101 & 0,158 & 0,188 & 0,143 & 0,03 \\
\hline $\mathrm{Nb}$ & 0,115 & 0,0601 & 0,105 & 0,102 & 0,09962 & 0,02 \\
\hline $\mathrm{Ba}$ & 0,789 & 0,836 & 0,736 & 0,436 & 0,7296 & 0,17 \\
\hline La & 0,12 & 0,0626 & 0,0684 & 0,128 & 0,0992 & 0,03 \\
\hline $\mathrm{Ce}$ & 0,0994 & 0,124 & 0,0982 & 0,11 & 0,10142 & 0,02 \\
\hline $\mathrm{Pr}$ & 0,0792 & 0,0947 & 0,0996 & 0,128 & 0,09546 & 0,02 \\
\hline Nd & 0,952 & 0,672 & 0,856 & 0,809 & 0,826 & 0,10 \\
\hline Sm & 0,63 & 0,628 & 0,579 & 0,82 & 0,7048 & 0,13 \\
\hline Eu & 0,18 & 0,203 & 0,2 & 0,226 & 0,1974 & 0,02 \\
\hline Gd & 0,656 & 0,697 & 0,526 & 0,507 & 0,596 & 0,08 \\
\hline $\mathrm{Tb}$ & 0,0892 & 0,096 & 0,0812 & 0,068 & 0,09108 & 0,02 \\
\hline Dy & 0,394 & 0,452 & 0,533 & 0,238 & 0,3944 & 0,11 \\
\hline Ho & 0,0964 & 0,0393 & 0,104 & 0,138 & 0,09346 & 0,04 \\
\hline Er & 0,234 & 0,286 & 0,215 & 0,382 & 0,2858 & 0,07 \\
\hline Tm & 0,111 & 0,135 & 0,0978 & 0,098 & 0,10798 & 0,02 \\
\hline Yb & 0,607 & 0,783 & 0,736 & 0,676 & 0,7282 & 0,09 \\
\hline Lu & 0,109 & 0,0917 & 0,111 & 0,104 & 0,10694 & 0,01 \\
\hline $\mathrm{Hf}$ & 0,763 & 0,807 & 0,704 & 0,834 & 0,7852 & 0,05 \\
\hline $\mathrm{Ta}$ & 0,13 & 0,129 & 0,118 & 0,0809 & 0,11278 & 0,02 \\
\hline $\mathrm{Pb}$ & 0,187 & 0,294 & 0,115 & 0,215 & 0,194 & 0,07 \\
\hline Th & 0,0511 & 0,00 & 0,0474 & 0,00 & 0,04925 & 0,00 \\
\hline $\mathbf{U}$ & 0,00 & 0,00 & 0,0378 & 0,00 & 0,0378 & 0,00 \\
\hline
\end{tabular}


Apêndice C - Tabela C.IX: Concentrações do padrão secundário NIST-612 obtidas a partir das análises de olivina do fragmento 2.

\begin{tabular}{|c|c|c|c|c|c|c|c|c|c|}
\hline Elemento & GeoRem & Incerteza & Nist-612a & Nist-612b & Nist-612c & Nist-612d & Nist-612e & $\begin{array}{c}\text { Média } \\
\text { Análises }\end{array}$ & Desvio Padrão \\
\hline $\mathbf{L i}$ & 40,2 & 0,8 & 41,64 & 40,68 & 43,54 & 39,62 & 42,87 & 41,67 & 1,59 \\
\hline $\mathrm{Na}$ & 10,16 & 0,2 & 105062,6 & 99815,91 & 111955,4 & 96561,93 & 110721,9 & 104823,534 & 6690,30 \\
\hline Al & 46,6 & 2 & 11247,14 & 10917,62 & 11629,55 & 10703,77 & 11554,29 & 11210,474 & 399,28 \\
\hline $\mathbf{P}$ & 44 & 19 & 101,18 & n.d. & n.d. & 68,31 & n.d. & 84,745 & 23,24 \\
\hline Sc & 38,8 & 2 & 42,74 & 38,46 & 43,88 & 38,18 & 43,43 & 41,338 & 2,79 \\
\hline $\mathrm{Ti}$ & 36,4 & 7 & 49,62 & 47,59 & 46,05 & 46,5 & 51,06 & 48,164 & 2,13 \\
\hline $\mathbf{V}$ & 38,7 & 11 & 38,68 & 38,39 & 43,19 & 35,72 & 41,93 & 39,582 & 2,99 \\
\hline $\mathrm{Cr}$ & 35,5 & 6 & 41,02 & 36,75 & 44,04 & 35,48 & 43,57 & 40,172 & 3,90 \\
\hline Mn & 38,8 & 3 & 39,21 & 36,19 & 42,31 & 36,11 & 39,63 & 38,69 & 2,61 \\
\hline Co & 37,8 & 0,1 & 33,51 & 36,49 & 37,37 & 32,85 & 37,13 & 35,47 & 2,13 \\
\hline $\mathrm{Ni}$ & 39,1 & 0,04 & 35,61 & 39,96 & 43,38 & 35,57 & 39,58 & 38,82 & 3,30 \\
\hline $\mathrm{Cu}$ & 31,4 & 1 & 37,46 & 36,16 & 36,45 & 34,81 & 39,17 & 36,81 & 1,62 \\
\hline $\mathrm{Zn}$ & 78,4 & 2 & 34,13 & 40,49 & 42,98 & 34 & 40,51 & 38,422 & 4,10 \\
\hline $\mathbf{R b}$ & 38,3 & 7 & 31,39 & 31,46 & 33,02 & 28,51 & 35,04 & 31,884 & 2,40 \\
\hline $\mathrm{Sr}$ & 37,9 & 0,8 & 74,9 & 76,18 & 79,83 & 71,2 & 80,57 & 76,536 & 3,82 \\
\hline $\mathbf{Y}$ & 38,9 & 0,2 & 37,62 & 38,51 & 39,52 & 35,78 & 40,64 & 38,414 & 1,85 \\
\hline $\mathrm{Zr}$ & 39,3 & 0,02 & 35,09 & 35,79 & 39,1 & 33,8 & 37,2 & 36,196 & 2,04 \\
\hline $\mathrm{Nb}$ & 36 & 0,02 & 35,81 & 39,85 & 40,49 & 34,64 & 41,18 & 38,394 & 2,96 \\
\hline $\mathrm{Ba}$ & 38,4 & 0,6 & 37,14 & 36,86 & 41,98 & 34,14 & 40,29 & 38,082 & 3,08 \\
\hline La & 37,9 & 0,13 & 34,66 & 35,67 & 39,34 & 32,99 & 37,63 & 36,058 & 2,49 \\
\hline $\mathrm{Ce}$ & 35,5 & 0,02 & 36,51 & 39,25 & 41,52 & 35,77 & 39,97 & 38,604 & 2,41 \\
\hline Pr & 37,7 & 2 & 36,83 & 36,73 & 39,37 & 34,36 & 39,65 & 37,388 & 2,18 \\
\hline Nd & 35,6 & 0,2 & 33,39 & 35,67 & 39,47 & 32,4 & 36,71 & 35,528 & 2,80 \\
\hline Sm & 37,3 & 0,2 & 36,74 & 35,61 & 39,62 & 35,06 & 37,43 & 36,892 & 1,79 \\
\hline Eu & 37,6 & 0,22 & 33,2 & 34,58 & 37,55 & 33,12 & 34,56 & 34,602 & 1,79 \\
\hline Gd & 35,5 & 0,2 & 35,46 & 37,37 & 40,01 & 35,56 & 37,14 & 37,108 & 1,84 \\
\hline
\end{tabular}




\begin{tabular}{cccrrrrrrr}
\hline Elemento & GeoRem & Incerteza & Nist-612a & Nist-612b & Nist-612c & Nist-612d & Nist-612e & $\begin{array}{c}\text { Média } \\
\text { Análises }\end{array}$ & Desvio Padrão \\
\hline Tb & 38,3 & 0,03 & 35,72 & 35,72 & 37,02 & 34,55 & 36,98 & 35,998 & 1,03 \\
Dy & 38 & 0,01 & 35,22 & 36,22 & 37,42 & 34,69 & 36,68 & 36,046 & 1,10 \\
Ho & 36,8 & 0,05 & 37,61 & 37,81 & 38,74 & 36,91 & 38,53 & 37,92 & 0,74 \\
Er & 39,2 & 0,04 & 37,25 & 37,23 & 38,36 & 36,98 & 37,51 & 37,466 & 0,53 \\
Tm & 37 & 0,05 & 38,05 & 36,45 & 39,06 & 36,53 & 38,07 & 37,632 & 1,12 \\
Yb & 36,7 & 0,04 & 39,46 & 39,27 & 42,97 & 38,77 & 39,98 & 40,09 & 1,67 \\
Lu & 37,6 & 0,02 & 38,02 & 36,26 & 40,88 & 35,28 & 39,29 & 37,946 & 2,26 \\
Hf & 38,57 & 0,02 & 36,51 & 31,48 & 39,59 & 32,61 & 35,49 & 35,136 & 3,22 \\
Ta & 37,79 & 0,02 & 39,6 & 38,46 & 43,9 & 36,95 & 41,44 & 40,07 & 2,70 \\
Pb & 37,38 & 0,003 & 38,71 & 36,67 & 46,1 & 37,56 & 37,92 & 39,392 & 3,82 \\
Th & 40,2 & 0,18 & 37,54 & 35,64 & 40,7 & 35,29 & 38,07 & 37,448 & 2,17 \\
U & 10,16 & 0,1 & 36,67 & 36,55 & 40,09 & 35,1 & 38,28 & 37,338 & 1,91 \\
\hline
\end{tabular}


Apêndice C - Tabela C.X: Concentrações de elementos-traço obtidas para de olivina do fragmento 2, limites de detecção (LD) e erros associados (2 $\sigma$ ) utilizados como padrão de qualidade.

\begin{tabular}{|c|c|c|c|c|c|c|}
\hline \multirow[b]{2}{*}{ Elemento } & Análise & LD & $2 \sigma$ & Análise & LD & $2 \sigma$ \\
\hline & \multicolumn{3}{|c|}{ 1OLN } & \multicolumn{3}{|c|}{ 1OLB } \\
\hline $\mathbf{L i}$ & 3,53 & 0,204 & 0,6 & 3,5 & 0,212 & 0,76 \\
\hline $\mathrm{Na}$ & 166,95 & 19,9 & 35,7 & 489,98 & 19,46 & 94,74 \\
\hline Al & 54,46 & 3,6 & 7,6 & 62,91 & 3,45 & 9,72 \\
\hline $\mathbf{P}$ & n.d. & 30,54 & 31,38 & 94,68 & 28,62 & 168,2 \\
\hline Sc & 2,19 & 0,239 & 0,54 & 3,96 & 0,227 & 0,96 \\
\hline $\mathrm{Ti}$ & 109,5 & 1,28 & 15,7 & 271,57 & 1,08 & 39,36 \\
\hline $\mathbf{V}$ & 4,52 & 0,111 & 1,02 & 3,03 & 0,0986 & 0,76 \\
\hline $\mathrm{Cr}$ & 201,66 & 1,55 & 62,86 & 176,79 & 1,46 & 55,72 \\
\hline Mn & 704,31 & 0,461 & 135,68 & 1557,23 & 0,435 & 304,1 \\
\hline Co & 147,67 & 0,0591 & 26,22 & 182,42 & 0,058 & 32,92 \\
\hline $\mathrm{Ni}$ & 3301,39 & 0,455 & 774,22 & 1763,96 & 0,448 & 420,68 \\
\hline $\mathrm{Cu}$ & 0,99 & 0,221 & 0,32 & 2,02 & 0,213 & 0,6 \\
\hline $\mathrm{Zn}$ & 71,42 & 1,08 & 21,48 & 105,51 & 1,32 & 32,7 \\
\hline $\mathbf{R b}$ & n.d. & 0,0522 & 0,052 & 0,275 & 0,0649 & 0,16 \\
\hline $\mathrm{Sr}$ & n.d. & 0,0448 & 0,04 & 2,58 & 0,0369 & 0,54 \\
\hline$Y$ & n.d. & 0,0356 & 0,04 & n.d. & 0,0398 & 0,062 \\
\hline $\mathrm{Zr}$ & 0,557 & 0,0936 & 0,186 & 1,88 & 0,074 & 0,52 \\
\hline $\mathrm{Nb}$ & 0,127 & 0,0421 & 0,07 & 0,172 & 0,0528 & 0,12 \\
\hline $\mathrm{Ba}$ & n.d. & 0,445 & 0,42 & 3,65 & 0,404 & 1,56 \\
\hline La & n.d. & 0,0512 & 0,046 & 0,128 & 0,0642 & 0,116 \\
\hline $\mathrm{Ce}$ & n.d. & 0,0565 & 0,048 & 0,273 & 0,0366 & 0,134 \\
\hline $\mathbf{P r}$ & n.d. & 0,0444 & 0,036 & 0,079 & 0,0356 & 0,074 \\
\hline Nd & n.d. & 0,469 & 0,48 & n.d. & 0,445 & 0,52 \\
\hline $\mathrm{Sm}$ & n.d. & 0,304 & 0,28 & n.d. & 0,28 & 0,3 \\
\hline Eu & n.d. & 0,115 & 0,092 & n.d. & 0,0797 & 0,07 \\
\hline Gd & n.d. & 0,347 & 0,28 & n.d. & 0,396 & 0,36 \\
\hline $\mathrm{Tb}$ & n.d. & 0,0409 & 0,034 & n.d. & 0,0605 & 0,054 \\
\hline Dy & n.d. & 0,254 & 0,24 & n.d. & 0,176 & 0,16 \\
\hline Ho & n.d. & 0,0628 & 0,06 & n.d. & 0,057 & 0,078 \\
\hline $\mathrm{Er}$ & n.d. & 0,141 & 0,142 & n.d. & 0,129 & 0,188 \\
\hline $\mathrm{Tm}$ & n.d. & 0,0578 & 0,058 & n.d. & 0,0567 & 0,074 \\
\hline $\mathrm{Yb}$ & n.d. & 0,381 & 0,34 & n.d. & 0,311 & 0,42 \\
\hline Lu & n.d. & 0,0632 & 0,052 & n.d. & 0,0455 & 0,066 \\
\hline $\mathrm{Hf}$ & n.d. & 0,381 & 0,36 & 0,41 & 0,318 & 0,56 \\
\hline $\mathrm{Ta}$ & n.d. & 0,0609 & 0,056 & n.d. & 0,0596 & 0,05 \\
\hline $\mathbf{P b}$ & n.d. & 0,105 & 0,082 & n.d. & 0,0945 & 0,112 \\
\hline Th & n.d. & 0,00 & 0,00 & 0,056 & 0,00 & 0,066 \\
\hline $\mathbf{U}$ & n.d. & 0,00 & 0,00 & n.d. & 0,0171 & 0,0106 \\
\hline
\end{tabular}

B: Borda; N: núcleo; n.d.: não detectado. 
Apêndice C - Tabela C.X (continuação): Concentrações de elementos-traço obtidas para as análises de olivina do fragmento 2 , limites de detecção (LD) e erros associados (2 $\sigma$ ) utilizados como padrão de qualidade.

\begin{tabular}{|c|c|c|c|c|c|c|}
\hline & Análise & LD & $2 \sigma$ & Análise & LD & $2 \sigma$ \\
\hline Elemento & & 3OLN & & & 3OLB & \\
\hline Li & 1,35 & 0,16 & 0,28 & 7,15 & 0,146 & 1,06 \\
\hline $\mathrm{Na}$ & 124,98 & 17,14 & 27,94 & 223,02 & 12,21 & 45,34 \\
\hline Al & 30,26 & 3,06 & 4,76 & 50,03 & 2,19 & 7,04 \\
\hline $\mathbf{P}$ & 31,41 & 24,84 & 58,94 & 70,7 & 17,58 & 126,58 \\
\hline Sc & 2,78 & 0,199 & 0,62 & 2,98 & 0,157 & 0,7 \\
\hline $\mathrm{Ti}$ & 76,16 & 1,2 & 11,18 & 164,48 & 0,611 & 23,98 \\
\hline V & 4,56 & 0,089 & 1,04 & 3,84 & 0,0662 & 0,9 \\
\hline $\mathrm{Cr}$ & 108,92 & 1,25 & 34,72 & 299,35 & 0,881 & 97,1 \\
\hline Mn & 842,42 & 0,387 & 166,72 & 1116,28 & 0,275 & 225,72 \\
\hline Co & 135,01 & 0,0461 & 24,6 & 143,05 & 0,0332 & 26,64 \\
\hline $\mathrm{Ni}$ & 2923,43 & 0,366 & 707,18 & 2089,32 & 0,0995 & 517,66 \\
\hline $\mathrm{Cu}$ & 1,25 & 0,181 & 0,3 & 2,16 & 0,123 & 0,46 \\
\hline $\mathrm{Zn}$ & 69,31 & 1,14 & 21,58 & 71,63 & 0,831 & 23,08 \\
\hline $\mathbf{R b}$ & n.d. & 0,0489 & 0,038 & n.d. & 0,0352 & 0,042 \\
\hline $\mathrm{Sr}$ & n.d. & 0,0364 & 0,034 & 0,036 & 0,029 & 0,042 \\
\hline $\mathbf{Y}$ & n.d. & 0,04 & 0,034 & 0,021 & 0,0204 & 0,03 \\
\hline $\mathrm{Zr}$ & 0,428 & 0,0431 & 0,13 & 0,214 & 0,0491 & 0,112 \\
\hline $\mathrm{Nb}$ & 0,303 & 0,0384 & 0,102 & n.d. & 0,0291 & 0,038 \\
\hline $\mathbf{B a}$ & n.d. & 0,417 & 0,34 & n.d. & 0,262 & 0,24 \\
\hline La & n.d. & 0,0509 & 0,044 & 0,053 & 0,0299 & 0,05 \\
\hline $\mathrm{Ce}$ & n.d. & 0,0496 & 0,042 & n.d. & 0,0259 & 0,022 \\
\hline $\mathrm{Pr}$ & n.d. & 0,0379 & 0,032 & n.d. & 0,0208 & 0,019 \\
\hline Nd & n.d. & 0,331 & 0,28 & n.d. & 0,226 & 0,26 \\
\hline Sm & n.d. & 0,31 & 0,26 & n.d. & 0,254 & 0,26 \\
\hline Eu & n.d. & 0,0845 & 0,074 & n.d. & 0,0524 & 0,066 \\
\hline Gd & n.d. & 0,342 & 0,28 & n.d. & 0,252 & 0,28 \\
\hline $\mathrm{Tb}$ & n.d. & 0,0415 & 0,034 & n.d. & 0,0312 & 0,038 \\
\hline Dy & n.d. & 0,182 & 0,17 & n.d. & 0,154 & 0,166 \\
\hline Ho & n.d. & 0,0589 & 0,048 & n.d. & 0,034 & 0,034 \\
\hline $\mathrm{Er}$ & n.d. & 0,12 & 0,116 & n.d. & 0,0742 & 0,096 \\
\hline $\mathrm{Tm}$ & n.d. & 0,045 & 0,036 & n.d. & 0,0409 & 0,036 \\
\hline $\mathrm{Yb}$ & n.d. & 0,349 & 0,26 & n.d. & 0,214 & 0,22 \\
\hline Lu & n.d. & 0,0496 & 0,04 & n.d. & 0,0322 & 0,044 \\
\hline $\mathrm{Hf}$ & n.d. & 0,338 & 0,3 & n.d. & 0,21 & 0,32 \\
\hline Ta & n.d. & 0,0493 & 0,042 & n.d. & 0,0403 & 0,032 \\
\hline $\mathrm{Pb}$ & n.d. & 0,0817 & 0,074 & n.d. & 0,0413 & 0,04 \\
\hline Th & 0,0053 & 0,0 & 0,0106 & 0,00 & 0,00 & 0,00 \\
\hline $\mathbf{U}$ & n.d. & 0,0148 & 0,0092 & n.d. & 0,0106 & 0,0148 \\
\hline
\end{tabular}

B: Borda; N: núcleo; n.d.: não detectado. 
Apêndice C - Tabela C.X (continuação): Concentrações de elementos-traço obtidas para as análises de olivina do fragmento 2 , limites de detecção (LD) e erros associados (2 $\sigma$ ) utilizados como padrão de qualidade.

\begin{tabular}{|c|c|c|c|c|c|c|}
\hline & Análise & LD & $2 \sigma$ & Análise & LD & $2 \sigma$ \\
\hline Elemento & & 4OLB & & & 4OLN & \\
\hline $\mathbf{L i}$ & 4,35 & 0,218 & 0,96 & 1,8 & 0,147 & 0,38 \\
\hline $\mathrm{Na}$ & 358,01 & 19,89 & 76,94 & 139,22 & 14,55 & 32,12 \\
\hline Al & 343,04 & 3,44 & 44,36 & 36,89 & 2,57 & 5,76 \\
\hline $\mathbf{P}$ & n.d. & 28,5 & 63,94 & 26,77 & 20,4 & 53,48 \\
\hline $\begin{array}{l}\mathrm{Sc} \\
\mathrm{Ti}\end{array}$ & $\begin{array}{c}2,78 \\
1188,67\end{array}$ & $\begin{array}{c}0,245 \\
1,54\end{array}$ & $\begin{array}{c}0,8 \\
171,96\end{array}$ & $\begin{array}{c}2,84 \\
138,53\end{array}$ & $\begin{array}{l}0,177 \\
0,919\end{array}$ & $\begin{array}{c}0,7 \\
21,26\end{array}$ \\
\hline V & 30,95 & 0,108 & 7,28 & 4,89 & 0,0766 & 1,2 \\
\hline $\mathrm{Cr}$ & 5749,37 & 1,4 & 1907,52 & 98,94 & 1,02 & 33,66 \\
\hline Mn & 1224,16 & 0,425 & 254,68 & 927,25 & 0,326 & 197,74 \\
\hline Co & 180,57 & 0,0496 & 34,72 & 137,46 & 0,037 & 26,98 \\
\hline $\mathbf{N i}$ & 2679,42 & 0,445 & 684,32 & 2720,59 & 0,235 & 713,76 \\
\hline $\mathrm{Cu}$ & 5,45 & 0,217 & 1,2 & 1,27 & 0,154 & 0,34 \\
\hline $\mathrm{Zn}$ & 108,37 & 1,23 & 36,62 & 85,76 & 0,917 & 29,4 \\
\hline $\mathbf{R b}$ & 0,214 & 0,0699 & 0,164 & 0,061 & 0,0431 & 0,058 \\
\hline $\mathrm{Sr}$ & 2,67 & 0,0478 & 0,6 & 1,29 & 0,0291 & 0,26 \\
\hline $\mathbf{Y}$ & 0,111 & 0,0474 & 0,104 & n.d. & 0,031 & 0,04 \\
\hline $\mathrm{Zr}$ & 3,08 & 0,0816 & 0,8 & 0,79 & 0,0552 & 0,22 \\
\hline $\mathrm{Nb}$ & 0,49 & 0,0412 & 0,22 & 1,07 & 0,0392 & 0,3 \\
\hline $\mathrm{Ba}$ & 6,02 & 0,457 & 2,38 & 1,72 & 0,329 & 0,76 \\
\hline La & 0,47 & 0,0649 & 0,22 & 0,145 & 0,0507 & 0,08 \\
\hline $\mathrm{Ce}$ & 0,57 & 0,0527 & 0,22 & 0,249 & 0,032 & 0,09 \\
\hline $\mathrm{Pr}$ & 0,088 & 0,0392 & 0,088 & 0,053 & 0,0226 & 0,04 \\
\hline Nd & n.d. & 0,479 & 0,74 & n.d. & 0,336 & 0,38 \\
\hline Sm & n.d. & 0,363 & 0,32 & n.d. & 0,216 & 0,22 \\
\hline Eu & 0,112 & 0,0613 & 0,144 & n.d. & 0,076 & 0,08 \\
\hline Gd & 0,54 & 0,28 & 0,62 & n.d. & 0,319 & 0,26 \\
\hline $\mathrm{Tb}$ & n.d. & 0,049 & 0,046 & n.d. & 0,0439 & 0,04 \\
\hline Dy & n.d. & 0,224 & 0,24 & n.d. & 0,173 & 0,148 \\
\hline Ho & n.d. & 0,0535 & 0,072 & n.d. & 0,0449 & 0,046 \\
\hline $\mathrm{Er}$ & n.d. & 0,143 & 0,176 & n.d. & 0,142 & 0,146 \\
\hline $\mathrm{Tm}$ & n.d. & 0,0534 & 0,062 & n.d. & 0,0522 & 0,042 \\
\hline Yb & n.d. & 0,367 & 0,4 & n.d. & 0,2 & 0,22 \\
\hline Lu & n.d. & 0,0536 & 0,084 & n.d. & 0,0437 & 0,042 \\
\hline Hf & n.d. & 0,311 & 0,48 & n.d. & 0,306 & 0,28 \\
\hline $\mathrm{Ta}$ & n.d. & 0,0465 & 0,074 & 0,062 & 0,0432 & 0,06 \\
\hline $\mathbf{P b}$ & n.d. & 0,0915 & 0,158 & 0,085 & 0,0553 & 0,09 \\
\hline Th & 0,141 & 0,00 & 0,118 & n.d. & 0,0155 & 0,0096 \\
\hline $\mathbf{U}$ & 0,038 & 0,00 & 0,054 & 0,0059 & 0,00 & 0,0118 \\
\hline
\end{tabular}

B: Borda; N: núcleo; n.d.: não detectado. 
Apêndice C - Tabela C.X (continuação): Concentrações de elementos-traço obtidas para as

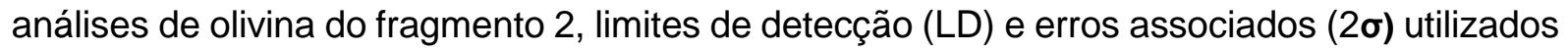
como padrão de qualidade.

\begin{tabular}{|c|c|c|c|c|c|c|}
\hline & Análise & LD & $2 \sigma$ & Análise & LD & $2 \sigma$ \\
\hline Elemento & & 7OLXN & & & $70 L X B$ & \\
\hline $\mathbf{L i}$ & 2,97 & 0,148 & 0,58 & 3,06 & 0,192 & 0,56 \\
\hline $\mathrm{Na}$ & 191,53 & 13,28 & 45,9 & 182,7 & 17,48 & 45,64 \\
\hline Al & 97,38 & 2,31 & 14,08 & 103,64 & 3,08 & 15,16 \\
\hline $\mathbf{P}$ & 18,72 & 17,56 & 41,86 & 36,03 & 23,11 & 76,32 \\
\hline Sc & 3,03 & 0,152 & 0,8 & 2,59 & 0,21 & 0,7 \\
\hline Ti & 270,7 & 0,775 & 44,3 & 271,79 & 0,891 & 45,44 \\
\hline $\mathbf{V}$ & 8,73 & 0,0687 & 2,32 & 8,61 & 0,0736 & 2,36 \\
\hline $\mathrm{Cr}$ & 141,36 & 0,872 & 52,48 & 144,3 & 1,14 & 55,3 \\
\hline Mn & 1024,66 & 0,299 & 240,86 & 978,04 & 0,38 & 238 \\
\hline Co & 148,06 & 0,0334 & 32 & 152,18 & 0,048 & 34 \\
\hline $\mathrm{Ni}$ & 2002,24 & 0,301 & 583,04 & 2090,96 & 0,393 & 631,58 \\
\hline $\mathrm{Cu}$ & 0,347 & 0,119 & 0,188 & 0,37 & 0,192 & 0,2 \\
\hline $\mathrm{Zn}$ & 97,36 & 0,966 & 37,52 & 108,43 & 1,15 & 43,4 \\
\hline $\mathbf{R b}$ & n.d. & 0,0418 & 0,034 & n.d. & 0,0579 & 0,048 \\
\hline Sr & 0,075 & 0,0228 & 0,048 & 0,074 & 0,0363 & 0,046 \\
\hline $\mathbf{Y}$ & n.d. & 0,0199 & 0,028 & 0,075 & 0,0259 & 0,04 \\
\hline $\mathrm{Zr}$ & 0,219 & 0,0443 & 0,112 & 0,304 & 0,0656 & 0,12 \\
\hline $\mathrm{Nb}$ & n.d. & 0,028 & 0,04 & n.d. & 0,0516 & 0,046 \\
\hline $\mathrm{Ba}$ & n.d. & 0,253 & 0,22 & n.d. & 0,328 & 0,3 \\
\hline La & n.d. & 0,0298 & 0,036 & n.d. & 0,0483 & 0,04 \\
\hline $\mathrm{Ce}$ & n.d. & 0,0301 & 0,036 & n.d. & 0,0408 & 0,036 \\
\hline $\operatorname{Pr}$ & n.d. & 0,0372 & 0,032 & n.d. & 0,0374 & 0,032 \\
\hline Nd & n.d. & 0,292 & 0,34 & n.d. & 0,324 & 0,32 \\
\hline Sm & n.d. & 0,223 & 0,24 & n.d. & 0,301 & 0,26 \\
\hline Eu & n.d. & 0,0651 & 0,076 & n.d. & 0,0618 & 0,06 \\
\hline Gd & n.d. & 0,234 & 0,26 & n.d. & 0,325 & 0,24 \\
\hline $\mathrm{Tb}$ & n.d. & 0,0325 & 0,028 & n.d. & 0,0402 & 0,032 \\
\hline Dy & n.d. & 0,17 & 0,136 & n.d. & 0,156 & 0,15 \\
\hline Ho & n.d. & 0,0241 & 0,034 & n.d. & 0,0522 & 0,044 \\
\hline Er & n.d. & 0,0896 & 0,106 & n.d. & 0,184 & 0,15 \\
\hline $\mathrm{Tm}$ & 0,046 & 0,0285 & 0,046 & n.d. & 0,0442 & 0,04 \\
\hline $\mathrm{Yb}$ & n.d. & 0,254 & 0,28 & n.d. & 0,364 & 0,28 \\
\hline Lu & n.d. & 0,0481 & 0,048 & n.d. & 0,059 & 0,046 \\
\hline $\mathrm{Hf}$ & n.d. & 0,22 & 0,28 & n.d. & 0,212 & 0,22 \\
\hline Ta & n.d. & 0,048 & 0,046 & n.d. & 0,0545 & 0,046 \\
\hline $\mathbf{P b}$ & n.d. & 0,049 & 0,066 & n.d. & 0,0633 & 0,058 \\
\hline Th & n.d. & 0,0139 & 0,0086 & n.d. & 0,018 & 0,0112 \\
\hline $\mathbf{U}$ & n.d. & 0,0111 & 0,0146 & n.d. & 0,0144 & 0,012 \\
\hline
\end{tabular}

B: Borda; N: núcleo; n.d.: não detectado. 
Apêndice C - Tabela C.X (continuação): Concentrações de elementos-traço obtidas para as análises de olivina do fragmento 2 , limites de detecção (LD) e erros associados (2 $\sigma$ ) utilizados como padrão de qualidade.

\begin{tabular}{|c|c|c|c|c|c|c|}
\hline & Análise & LD & $2 \sigma$ & Análise & LD & $2 \sigma$ \\
\hline Elemento & & 10OLN & & & 10OLN2 & \\
\hline $\mathbf{L i}$ & 2,23 & 0,181 & 0,54 & 1,23 & 0,183 & 0,32 \\
\hline $\mathrm{Na}$ & 123,41 & 20,16 & 37,14 & 109,95 & 17,51 & 31,98 \\
\hline Al & 15,95 & 3,38 & 4,68 & 13,53 & 3,04 & 3,56 \\
\hline $\mathbf{P}$ & 27,47 & 26,32 & 64,5 & 28,21 & 22,15 & 64,24 \\
\hline Sc & 1,24 & 0,229 & 0,46 & 1,15 & 0,215 & 0,38 \\
\hline $\mathrm{Ti}$ & 77,74 & 1,36 & 15,12 & 70,02 & 1,35 & 13,2 \\
\hline V & 1,55 & 0,107 & 0,5 & 1,28 & 0,0896 & 0,4 \\
\hline $\mathrm{Cr}$ & 83,87 & 1,28 & 33,28 & 75,83 & 1,1 & 31,04 \\
\hline Mn & 847,72 & 0,431 & 213,96 & 776,31 & 0,373 & 202,8 \\
\hline Co & 134,7 & 0,0689 & 31,26 & 125,14 & 0,0424 & 30 \\
\hline $\mathrm{Ni}$ & 2845,88 & 0,37 & 893,28 & 2697,91 & 0,36 & 878,5 \\
\hline $\mathrm{Cu}$ & 0,58 & 0,222 & 0,32 & n.d. & 0,177 & 0,168 \\
\hline $\mathrm{Zn}$ & 64,27 & 1,33 & 27,26 & 63,81 & 1,27 & 27,94 \\
\hline $\mathbf{R b}$ & n.d. & 0,0625 & 0,058 & n.d. & 0,0434 & 0,042 \\
\hline $\mathrm{Sr}$ & n.d. & 0,0433 & 0,042 & 0,037 & 0,0205 & 0,03 \\
\hline $\mathbf{Y}$ & n.d. & 0,0308 & 0,036 & n.d. & 0,0424 & 0,034 \\
\hline $\mathrm{Zr}$ & 0,236 & 0,0738 & 0,15 & 0,188 & 0,0569 & 0,096 \\
\hline $\mathrm{Nb}$ & 3,97 & 0,0377 & 1,24 & 3,81 & 0,0456 & 1,2 \\
\hline $\mathrm{Ba}$ & n.d. & 0,332 & 0,42 & n.d. & 0,36 & 0,3 \\
\hline La & n.d. & 0,0406 & 0,04 & n.d. & 0,0333 & 0,034 \\
\hline $\mathrm{Ce}$ & n.d. & 0,0542 & 0,05 & n.d. & 0,0303 & 0,034 \\
\hline $\operatorname{Pr}$ & n.d. & 0,0364 & 0,038 & 0,037 & 0,0317 & 0,036 \\
\hline Nd & n.d. & 0,479 & 0,46 & n.d. & 0,415 & 0,34 \\
\hline Sm & n.d. & 0,397 & 0,34 & 0,33 & 0,215 & 0,26 \\
\hline Eu & n.d. & 0,0732 & 0,064 & n.d. & 0,064 & 0,068 \\
\hline Gd & n.d. & 0,297 & 0,32 & n.d. & 0,243 & 0,2 \\
\hline $\mathrm{Tb}$ & n.d. & 0,0583 & 0,044 & n.d. & 0,0409 & 0,038 \\
\hline Dy & n.d. & 0,277 & 0,28 & n.d. & 0,177 & 0,152 \\
\hline Ho & n.d. & 0,0439 & 0,054 & n.d. & 0,0451 & 0,042 \\
\hline Er & n.d. & 0,189 & 0,152 & n.d. & 0,132 & 0,108 \\
\hline $\mathrm{Tm}$ & n.d. & 0,0621 & 0,054 & n.d. & 0,0491 & 0,04 \\
\hline $\mathrm{Yb}$ & n.d. & 0,378 & 0,36 & n.d. & 0,333 & 0,26 \\
\hline Lu & 0,057 & 0,0554 & 0,076 & n.d. & 0,0477 & 0,044 \\
\hline $\mathrm{Hf}$ & n.d. & 0,276 & 0,36 & n.d. & 0,32 & 0,28 \\
\hline $\mathrm{Ta}$ & 0,216 & 0,0694 & 0,13 & 0,143 & 0,0549 & 0,078 \\
\hline $\mathrm{Pb}$ & n.d. & 0,112 & 0,118 & n.d. & 0,0865 & 0,074 \\
\hline Th & n.d. & 0,00 & 0,00 & 0,0109 & 0,00 & 0,0156 \\
\hline $\mathbf{U}$ & n.d. & 0,00 & 0,00 & 0,0044 & 0,00 & 0,0088 \\
\hline
\end{tabular}

B: Borda; N: núcleo; n.d.: não detectado. 
Apêndice C - Tabela C.X (continuação): Concentrações de elementos-traço obtidas para as análises de olivina do fragmento 2 , limites de detecção e erros associados $(2 \sigma)$ utilizados como padrão de qualidade.

\begin{tabular}{|c|c|c|c|c|c|c|}
\hline & Análise & LD & $2 \sigma$ & Análise & LD & $2 \sigma$ \\
\hline Elemento & & 10OLB & & & 11OLN & \\
\hline Li & 6,14 & 0,137 & 1,22 & 0,98 & 0,262 & 0,6 \\
\hline $\mathrm{Na}$ & 173,34 & 12,68 & 49,22 & 256,71 & 24,34 & 80,08 \\
\hline Al & 62,17 & 2,19 & 11,04 & 57,39 & 4,09 & 12,9 \\
\hline $\mathbf{P}$ & 44,05 & 16,68 & 101,28 & n.d. & 30,76 & 72,18 \\
\hline Sc & 3,26 & 0,149 & 1 & 2,61 & 0,288 & 1,02 \\
\hline $\mathrm{Ti}$ & 250,57 & 0,784 & 48,04 & 51,4 & 1,63 & 14,18 \\
\hline $\mathbf{V}$ & 4,14 & 0,0642 & 1,32 & 5,51 & 0,121 & 1,88 \\
\hline $\mathrm{Cr}$ & 254,05 & 0,789 & 107,44 & 165,75 & 1,49 & 72,64 \\
\hline Mn & 1400,38 & 0,275 & 379,4 & 775,98 & 0,517 & 218,46 \\
\hline Co & 171,81 & 0,0366 & 42,76 & 128,21 & 0,0694 & 33,3 \\
\hline $\mathrm{Ni}$ & 2022,85 & 0,176 & 684,76 & 2784,03 & 0,473 & 980,46 \\
\hline $\mathrm{Cu}$ & 0,43 & 0,139 & 0,28 & n.d. & 0,292 & 0,5 \\
\hline $\mathrm{Zn}$ & 101,56 & 0,923 & 46,62 & 83,39 & 1,52 & 40,84 \\
\hline $\mathbf{R b}$ & 0,084 & 0,0384 & 0,086 & 0,28 & 0,0615 & 0,22 \\
\hline Sr & 0,067 & 0,0198 & 0,06 & 1,83 & 0,0672 & 0,58 \\
\hline $\mathbf{Y}$ & 0,062 & 0,035 & 0,068 & 0,131 & 0,0534 & 0,138 \\
\hline $\mathrm{Zr}$ & 0,355 & 0,0395 & 0,188 & 2,05 & 0,081 & 0,78 \\
\hline $\mathrm{Nb}$ & 0,055 & 0,0251 & 0,062 & 0,62 & 0,0569 & 0,34 \\
\hline $\mathrm{Ba}$ & n.d. & 0,313 & 0,44 & 2,81 & 0,559 & 1,94 \\
\hline La & 0,033 & 0,0248 & 0,052 & 0,22 & 0,0711 & 0,194 \\
\hline $\mathrm{Ce}$ & n.d. & 0,0352 & 0,044 & 0,29 & 0,0647 & 0,2 \\
\hline Pr & n.d. & 0,0236 & 0,044 & n.d. & 0,0558 & 0,082 \\
\hline Nd & n.d. & 0,213 & 0,36 & n.d. & 0,537 & 1,02 \\
\hline Sm & n.d. & 0,21 & 0,28 & n.d. & 0,379 & 0,62 \\
\hline Eu & n.d. & 0,0693 & 0,046 & n.d. & 0,131 & 0,22 \\
\hline Gd & n.d. & 0,208 & 0,24 & n.d. & 0,375 & 0,52 \\
\hline $\mathrm{Tb}$ & n.d. & 0,029 & 0,028 & 0,072 & 0,0548 & 0,118 \\
\hline Dy & n.d. & 0,131 & 0,122 & n.d. & 0,183 & 0,114 \\
\hline Ho & 0,044 & 0,0286 & 0,06 & n.d. & 0,079 & 0,074 \\
\hline Er & n.d. & 0,094 & 0,148 & n.d. & 0,159 & 0,3 \\
\hline Tm & n.d. & 0,0305 & 0,044 & n.d. & 0,0793 & 0,092 \\
\hline $\mathrm{Yb}$ & n.d. & 0,222 & 0,36 & n.d. & 0,383 & 0,74 \\
\hline Lu & n.d. & 0,0429 & 0,038 & 0,09 & 0,0609 & 0,138 \\
\hline Hf & n.d. & 0,206 & 0,38 & n.d. & 0,468 & 0,48 \\
\hline Ta & n.d. & 0,0309 & 0,054 & 0,062 & 0,0619 & 0,126 \\
\hline $\mathrm{Pb}$ & n.d. & 0,0454 & 0,03 & 0,11 & 0,105 & 0,22 \\
\hline Th & n.d. & 0,0185 & 0,0116 & 0,071 & 0,00 & 0,102 \\
\hline $\mathbf{U}$ & n.d. & 0,00 & 0,00 & n.d. & 0,00 & 0,00 \\
\hline
\end{tabular}

B: Borda; N: núcleo; n.d.: não detectado. 
Apêndice C - Tabela C.X: Concentrações de elementos-traço obtidas para as análises de olivina do fragmento 2, limites de detecção (LD) e erros associados (2 $\sigma)$ utilizados como padrão de qualidade.

\begin{tabular}{|c|c|c|c|}
\hline & Análise & LD & $2 \sigma$ \\
\hline Elemento & & 11OLB & \\
\hline Li & 7 & 0,124 & 1,48 \\
\hline $\mathrm{Na}$ & 200,06 & 13,27 & 60,38 \\
\hline Al & 64,62 & 2,21 & 12,3 \\
\hline $\mathbf{P}$ & 34,68 & 17,14 & 86,02 \\
\hline Sc & 3,52 & 0,157 & 1,16 \\
\hline $\mathrm{Ti}$ & 243,88 & 0,726 & 50,54 \\
\hline V & 6,44 & 0,0514 & 2,18 \\
\hline $\mathrm{Cr}$ & 270,36 & 0,808 & 122,04 \\
\hline Mn & 1185,23 & 0,281 & 344,48 \\
\hline Co & 152,35 & 0,0296 & 40,68 \\
\hline $\mathrm{Ni}$ & 2180,96 & 0,286 & 795,14 \\
\hline $\mathrm{Cu}$ & 1,91 & 0,143 & 0,64 \\
\hline $\mathbf{Z n}$ & 106,15 & 0,709 & 53,06 \\
\hline $\mathbf{R b}$ & n.d. & 0,0422 & 0,072 \\
\hline $\begin{array}{l}\text { Sr } \\
Y\end{array}$ & $\begin{array}{c}0,371 \\
\text { n.d. }\end{array}$ & $\begin{array}{l}0,0227 \\
0,0291\end{array}$ & $\begin{array}{l}0,164 \\
0,046\end{array}$ \\
\hline $\mathrm{Zr}$ & 0,6 & 0,0585 & 0,3 \\
\hline $\mathrm{Nb}$ & n.d. & 0,0266 & 0,052 \\
\hline Ba & 1,1 & 0,258 & 0,86 \\
\hline La & n.d. & 0,0283 & 0,042 \\
\hline $\mathrm{Ce}$ & n.d. & 0,0364 & 0,066 \\
\hline $\mathrm{Pr}$ & n.d. & 0,0298 & 0,054 \\
\hline Nd & n.d. & 0,268 & 0,26 \\
\hline Sm & n.d. & 0,194 & 0,38 \\
\hline $\mathrm{Eu}$ & n.d. & 0,0425 & 0,074 \\
\hline Gd & 0,31 & 0,214 & 0,44 \\
\hline Tb & 0,043 & 0,018 & 0,054 \\
\hline Dy & n.d. & 0,19 & 0,166 \\
\hline Ho & n.d. & 0,0282 & 0,054 \\
\hline Er & n.d. & 0,131 & 0,17 \\
\hline $\mathrm{Tm}$ & n.d. & 0,0448 & 0,064 \\
\hline $\mathrm{Yb}$ & n.d. & 0,219 & 0,34 \\
\hline Lu & n.d. & 0,0367 & 0,058 \\
\hline $\mathrm{Hf}$ & n.d. & 0,281 & 0,34 \\
\hline Ta & n.d. & 0,0392 & 0,05 \\
\hline $\mathrm{Pb}$ & 0,058 & 0,0573 & 0,12 \\
\hline Th & n.d. & 0,00 & 0,00 \\
\hline $\mathbf{U}$ & n.d. & 0,00 & 0,00 \\
\hline
\end{tabular}

B: Borda; n.d.: não detectado. 
Apêndice C - Tabela C.XI: Concentrações do padrão primário BHVO-2G obtidas a partir das

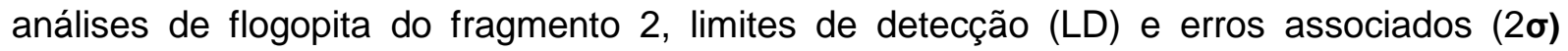
utilizados como padrão de qualidade.

\begin{tabular}{cccccc}
\hline Elemento & GeoRem & Incerteza & LD & BHVO & $\mathbf{2 \sigma}$ \\
\hline $\mathbf{L i}$ & 4,4 & 0,8 & 0,379 & 4,66 & 0,35 \\
$\mathbf{P}$ & 711 & 19 & 45,42 & 958,85 & 218,37 \\
$\mathbf{S c}$ & 33,0 & 2 & 0,264 & 31,51 & 2,51 \\
$\mathbf{T i}$ & 16300 & 7 & 1,47 & 16040,55 & 1130,91 \\
$\mathbf{V}$ & 308 & 11 & 0,173 & 333,59 & 22,2 \\
$\mathbf{C r}$ & 293 & 6 & 1,57 & 298,13 & 18,36 \\
$\mathbf{M n}$ & 1161 & 3 & 0,663 & 1280,4 & 87,93 \\
$\mathbf{C o}$ & 44 & 0,1 & 0,0761 & 42,97 & 3,37 \\
$\mathbf{N i}$ & 116 & 0,04 & 0,243 & 112,23 & 6,97 \\
$\mathbf{C u}$ & 127 & 1 & 0,732 & 106,39 & 4,49 \\
$\mathbf{Z n}$ & 102 & 2 & 1,99 & 124,76 & 11,79 \\
$\mathbf{R b}$ & 9,2 & 7 & 0,117 & 9,26 & 0,7 \\
$\mathbf{S r}$ & 396 & 0,8 & 0,0531 & 393,05 & 32,02 \\
$\mathbf{Y}$ & 26 & 0,2 & 0,053 & 23,9 & 2,11 \\
$\mathbf{Z r}$ & 170 & 0,02 & 0,075 & 164,17 & 11,78 \\
$\mathbf{N b}$ & 18,3 & 0,02 & 0,0576 & 15,45 & 1,49 \\
$\mathbf{B a}$ & 131 & 0,6 & 0,575 & 120,98 & 11,62 \\
$\mathbf{L a}$ & 15,2 & 0,13 & 0,0668 & 15,56 & 1,72 \\
$\mathbf{C e}$ & 37,6 & 0,02 & 0,0746 & 37,07 & 3,22 \\
$\mathbf{P r}$ & 5,35 & 2 & 0,0544 & 4,89 & 0,4 \\
$\mathbf{N d}$ & 24,5 & 0,2 & 0,456 & 24,79 & 2,36 \\
$\mathbf{S m}$ & 6,1 & 0,2 & 0,509 & 6,54 & 0,71 \\
$\mathbf{E u}$ & 2,07 & 0,22 & 0,154 & 2 & 0,24 \\
$\mathbf{G d}$ & 6,16 & 0,2 & 0,397 & 5,49 & 0,71 \\
$\mathbf{T b}$ & 0,92 & 0,03 & 0,0835 & 0,809 & 0,094 \\
$\mathbf{D y}$ & 5,28 & 0,01 & 0,33 & 5,22 & 0,63 \\
$\mathbf{H o}$ & 0,98 & 0,05 & 0,061 & 1,17 & 0,13 \\
$\mathbf{E r}$ & 2,56 & 0,04 & 0,163 & 2,71 & 0,3 \\
$\mathbf{T m}$ & 0,34 & 0,05 & 0,0426 & 0,347 & 0,053 \\
$\mathbf{Y b}$ & 1,94 & 0,04 & 0,316 & 1,9 & 0,3 \\
$\mathbf{L u}$ & 0,279 & 0,02 & 0,0733 & 0,215 & 0,05 \\
$\mathbf{H f}$ & 4,32 & 0,02 & 0,216 & 4,26 & 0,42 \\
$\mathbf{T a}$ & 1,15 & 0,02 & 0,0458 & 1,025 & 0,095 \\
$\mathbf{P b}$ & 1,70 & 0,003 & 0,348 & 2,01 & 0,33 \\
$\mathbf{T h}$ & 1,22 & 0,18 & 0,0391 & 1,27 & 0,13 \\
$\mathbf{U}$ & 0,403 & 0,1 & 0,00 & 0,46 & 0,065 \\
\hline & & & & & \\
\hline
\end{tabular}


Apêndice C - Tabela C.XII: Concentrações do padrão secundário NIST-612 obtidas a partir das análises de flogopita do fragmento 2 , limites de detecção (LD) e erros associados $(2 \sigma)$ utilizados como padrão de qualidade.

\begin{tabular}{|c|c|c|c|c|c|}
\hline Elemento & GeoRem & Incerteza & LD & Nist-612 & $2 \sigma$ \\
\hline $\mathbf{L i}$ & 40,2 & 0,8 & 0,479 & 57,09 & 6,26 \\
\hline $\mathbf{P}$ & 46,6 & 19 & 59,27 & 69,21 & 31,75 \\
\hline Sc & 39,9 & 2 & 0,352 & 38,3 & 5,03 \\
\hline Ti & 44,0 & 7 & 2,36 & 42,97 & 5,99 \\
\hline $\mathbf{V}$ & 38,8 & 11 & 0,201 & 53,22 & 6,56 \\
\hline $\mathrm{Cr}$ & 36,4 & 6 & 2,1 & 50,41 & 6,13 \\
\hline Mn & 38,7 & 3 & 0,905 & 50,04 & 6,25 \\
\hline Co & 35,5 & 0,1 & 0,136 & 47,35 & 6,19 \\
\hline $\mathrm{Ni}$ & 38,8 & 0,04 & 0,573 & 52,11 & 6,38 \\
\hline $\mathrm{Cu}$ & 37,8 & 1 & 0,895 & 50,86 & 5,69 \\
\hline $\mathrm{Zn}$ & 39,1 & 2 & 2,54 & 62,31 & 9,21 \\
\hline $\mathbf{R b}$ & 31,4 & 7 & 0,123 & 44,47 & 5,56 \\
\hline $\mathrm{Sr}$ & 78,4 & 0,8 & 0,0864 & 93,65 & 12,47 \\
\hline $\mathbf{Y}$ & 38,3 & 0,2 & 0,0682 & 36,73 & 5,06 \\
\hline $\mathrm{Zr}$ & 37,9 & 0,02 & 0,151 & 37,5 & 4,77 \\
\hline $\mathrm{Nb}$ & 38,9 & 0,02 & 0,0942 & 41,8 & 6,01 \\
\hline $\mathrm{Ba}$ & 39,3 & 0,6 & 0,712 & 46,09 & 6,79 \\
\hline La & 36,0 & 0,13 & 0,0702 & 38,95 & 6,03 \\
\hline $\mathrm{Ce}$ & 38,4 & 0,02 & 0,105 & 49,04 & 6,7 \\
\hline $\mathrm{Pr}$ & 37,9 & 2 & 0,0661 & 42,66 & 5,53 \\
\hline Nd & 35,5 & 0,2 & 0,771 & 38,06 & 5,38 \\
\hline Sm & 37,7 & 0,2 & 0,516 & 40,1 & 5,22 \\
\hline Eu & 35,6 & 0,22 & 0,222 & 38,76 & 5,32 \\
\hline Gd & 37,3 & 0,2 & 0,602 & 33,69 & 5,07 \\
\hline $\mathrm{Tb}$ & 37,6 & 0,03 & 0,0862 & 36,39 & 4,5 \\
\hline Dy & 35,5 & 0,01 & 0,401 & 34,82 & 4,94 \\
\hline Ho & 38,3 & 0,05 & 0,078 & 36,05 & 4,74 \\
\hline Er & 38,0 & 0,04 & 0,281 & 33,74 & 4,4 \\
\hline $\mathrm{Tm}$ & 36,8 & 0,05 & 0,0856 & 32,71 & 4,08 \\
\hline $\mathrm{Yb}$ & 39,2 & 0,04 & 0,409 & 36,39 & 4,73 \\
\hline Lu & 37,0 & 0,02 & 0,115 & 35,06 & 4,25 \\
\hline $\mathrm{Hf}$ & 36,7 & 0,02 & 0,308 & 33,89 & 4,22 \\
\hline $\mathrm{Ta}$ & 37,6 & 0,02 & 0,102 & 31,11 & 3,6 \\
\hline $\mathrm{Pb}$ & 38,57 & 0,003 & 0,563 & 50 & 5,76 \\
\hline Th & 37,79 & 0,18 & 0,0374 & 35,28 & 4,34 \\
\hline $\mathbf{U}$ & 37,38 & 0,1 & 0,00 & 48,51 & 5,42 \\
\hline
\end{tabular}


Apêndice C - Tabela C.XIII: Limites de detecção do padrão secundário NIST-610 obtidas a partir das análises de flogopita do fragmento 2, limites de detecção (LD) e erros associados $(2 \sigma)$ utilizados como padrão de qualidade.

\begin{tabular}{|c|c|c|c|c|c|c|}
\hline Elemento & Nist-610a & Nist-610b & Nist-610c & Nist-610d & Média LD & DP \\
\hline$\overline{L i}$ & 0,541 & 0,528 & 0,535 & 0,473 & 0,51925 & 0,031 \\
\hline $\mathbf{P}$ & 72,24 & 69,99 & 73,43 & 66,45 & 70,5275 & 3,070 \\
\hline Sc & 0,385 & 0,383 & 0,415 & 0,408 & 0,39775 & 0,016 \\
\hline Ti & 2,36 & 2,29 & 2,43 & 2,52 & 2,4 & 0,098 \\
\hline $\mathbf{V}$ & 0,256 & 0,229 & 0,24 & 0,238 & 0,24075 & 0,011 \\
\hline $\mathrm{Cr}$ & 2,34 & 2,21 & 2,42 & 2,44 & 2,3525 & 0,104 \\
\hline Mn & 1,01 & 0,975 & 1,01 & 1,06 & 1,01375 & 0,035 \\
\hline Co & 0,168 & 0,101 & 0,14 & 0,127 & 0,134 & 0,028 \\
\hline $\mathrm{Ni}$ & 0,816 & 0,773 & 0,779 & 0,694 & 0,7655 & 0,051 \\
\hline $\mathrm{Cu}$ & 1,02 & 0,949 & 1,21 & 1,09 & 1,06725 & 0,111 \\
\hline $\mathrm{Zn}$ & 2,52 & 3,05 & 2,88 & 2,71 & 2,79 & 0,227 \\
\hline $\mathbf{R b}$ & 0,141 & 0,134 & 0,196 & 0,167 & 0,1595 & 0,028 \\
\hline $\mathrm{Sr}$ & 0,0743 & 0,0952 & 0,111 & 0,104 & 0,096125 & 0,016 \\
\hline $\mathbf{Y}$ & 0,0572 & 0,0904 & 0,0628 & 0,0687 & 0,069775 & 0,015 \\
\hline $\mathrm{Zr}$ & 0,143 & 0,127 & 0,136 & 0,195 & 0,15025 & 0,031 \\
\hline $\mathrm{Nb}$ & 0,109 & 0,103 & 0,078 & 0,108 & 0,0995 & 0,015 \\
\hline $\mathrm{Ba}$ & 0,672 & 0,831 & 0,718 & 0,961 & 0,7955 & 0,129 \\
\hline La & 0,112 & 0,0528 & 0,102 & 0,113 & 0,09495 & 0,029 \\
\hline $\mathrm{Ce}$ & 0,0703 & 0,0939 & 0,114 & 0,107 & 0,0963 & 0,019 \\
\hline Pr & 0,0978 & 0,0819 & 0,0746 & 0,0926 & 0,086725 & 0,010 \\
\hline Nd & 0,812 & 0,766 & 0,927 & 0,966 & 0,86775 & 0,094 \\
\hline Sm & 0,793 & 0,59 & 0,579 & 0,675 & 0,65925 & 0,099 \\
\hline $\mathrm{Eu}$ & 0,184 & 0,201 & 0,201 & 0,245 & 0,20775 & 0,026 \\
\hline Gd & 0,526 & 0,619 & 0,655 & 0,663 & 0,61575 & 0,063 \\
\hline $\mathrm{Tb}$ & 0,097 & 0,0916 & 0,101 & 0,103 & 0,09815 & 0,005 \\
\hline Dy & 0,599 & 0,524 & 0,552 & 0,535 & 0,5525 & 0,033 \\
\hline Ho & 0,104 & 0,114 & 0,0821 & 0,104 & 0,101025 & 0,013 \\
\hline Er & 0,385 & 0,264 & 0,329 & 0,281 & 0,31475 & 0,054 \\
\hline $\mathrm{Tm}$ & 0,0882 & 0,0832 & 0,0918 & 0,0777 & 0,085225 & 0,006 \\
\hline Yb & 0,565 & 0,389 & 0,565 & 0,591 & 0,5275 & 0,093 \\
\hline Lu & 0,147 & 0,109 & 0,141 & 0,0871 & 0,121025 & 0,028 \\
\hline $\mathrm{Hf}$ & 0,271 & 0,443 & 0,411 & 0,368 & 0,37325 & 0,075 \\
\hline $\mathrm{Ta}$ & 0,0861 & 0,0976 & 0,128 & 0,0914 & 0,100775 & 0,019 \\
\hline $\mathrm{Pb}$ & 0,358 & 0,275 & 0,598 & 0,402 & 0,40825 & 0,137 \\
\hline Th & n.d. & 0,0576 & 0,0419 & 0,00 & 0,04975 & 0,011 \\
\hline $\mathbf{U}$ & 0,0435 & 0,00 & 0,0423 & 0,00 & 0,0429 & 0,001 \\
\hline
\end{tabular}

n.d.: não detectado. 
Apêndice C - Tabela C.XIV: Concentrações do padrão secundário NIST-610 obtidas a partir das análises de flogopita do fragmento 2.

\begin{tabular}{ccccccccc}
\hline Elemento & GeoRem & Incerteza & Nist-610a & Nist-610b & Nist-610c & Nist-610d & $\begin{array}{c}\text { Média } \\
\text { Análises }\end{array}$ & $\begin{array}{c}\text { Desvio } \\
\text { Padrão* }\end{array}$ \\
\hline $\mathbf{~ L i ~}$ & 468 & 0,8 & 493,16 & 476,17 & 485,05 & 485,16 & 484,88 & 6,94 \\
$\mathbf{P}$ & 413 & 19 & 344,61 & 341,89 & 329,09 & 353,41 & 342,25 & 10,05 \\
$\mathbf{S c}$ & 455 & 2 & 461,34 & 422,25 & 450,74 & 435,49 & 442,45 & 17,14 \\
$\mathbf{T i}$ & 452 & 7 & 452,56 & 416,69 & 437,75 & 432,82 & 434,95 & 14,78 \\
$\mathbf{~ V}$ & 450 & 11 & 455,76 & 427,47 & 453,05 & 434,25 & 442,63 & 13,91 \\
$\mathbf{C r}$ & 408 & 6 & 416,66 & 393,43 & 414,54 & 399 & 405,90 & 11,45 \\
$\mathbf{M n}$ & 444 & 3 & 447,73 & 418,79 & 444,87 & 425,74 & 434,28 & 14,21 \\
$\mathbf{C o}$ & 410 & 0,1 & 421 & 389,32 & 417,16 & 397,21 & 406,17 & 15,32 \\
$\mathbf{N i}$ & 458 & 0,04 & 452,57 & 434 & 457,09 & 434,57 & 444,55 & 12,00 \\
$\mathbf{C u}$ & 441 & 1 & 435,24 & 424,89 & 434,19 & 427,61 & 430,48 & 5,03 \\
$\mathbf{Z n}$ & 460 & 2 & 481,55 & 433,46 & 464,27 & 452,3 & 457,89 & 20,23 \\
$\mathbf{R b}$ & 425,7 & 7 & 445,43 & 416,67 & 442,64 & 423,55 & 432,07 & 14,14 \\
$\mathbf{S r}$ & 515,5 & 0,8 & 520,07 & 476,04 & 510,77 & 489,22 & 499,02 & 20,04 \\
$\mathbf{Y}$ & 462 & 0,2 & 474,01 & 428,17 & 459,99 & 444,3 & 451,61 & 19,78 \\
$\mathbf{Z r}$ & 448 & 0,02 & 458,05 & 422,83 & 447,4 & 435,69 & 440,99 & 15,16 \\
$\mathbf{N b}$ & 465 & 0,02 & 443,79 & 397,68 & 430,44 & 413,12 & 421,25 & 20,11 \\
$\mathbf{B a}$ & 452 & 0,6 & 450,58 & 401,2 & 428,68 & 422,99 & 425,86 & 20,29 \\
$\mathbf{~ L a}$ & 440 & 0,13 & 492,4 & 429,32 & 458,52 & 459,94 & 460,04 & 25,77 \\
$\mathbf{C e}$ & 453 & 0,02 & 472,45 & 426,08 & 454,03 & 445,19 & 449,43 & 19,27 \\
$\mathbf{P r}$ & 448 & 2 & 449,61 & 413,04 & 423,32 & 437,84 & 430,95 & 16,06 \\
$\mathbf{N d}$ & 430 & 0,2 & 455,05 & 409,76 & 431,74 & 432,56 & 432,27 & 18,49 \\
$\mathbf{S m}$ & 453 & 0,2 & 470,65 & 432,61 & 448,95 & 454,09 & 451,57 & 15,67 \\
$\mathbf{E u}$ & 447 & 0,22 & 487 & 438,47 & 465,71 & 459,96 & 462,78 & 19,95 \\
$\mathbf{G d}$ & 449 & 0,2 & 448,04 & 396,75 & 417,34 & 425,11 & 421,81 & 21,18 \\
$\mathbf{T b}$ & 437 & 0,03 & 460,66 & 427,16 & 438,72 & 448,38 & 443,73 & 14,23 \\
$\mathbf{D y}$ & 437 & 0,01 & 450,53 & 406,54 & 419,89 & 435,16 & 428,03 & 19,01
\end{tabular}




\begin{tabular}{ccccccccc}
\hline Elemento & GeoRem & Incerteza & Nist-610a & Nist-610b & Nist-610c & Nist-610d & $\begin{array}{c}\text { Média } \\
\text { Análises }\end{array}$ & $\begin{array}{c}\text { Desvio } \\
\text { Padrão* }\end{array}$ \\
\hline Ho & 449 & 0,05 & 472,31 & 429,77 & 446,7 & 454,24 & 450,75 & 17,64 \\
Er & 455 & 0,04 & 444,62 & 410,21 & 418,35 & 435,13 & 427,07 & 15,63 \\
Tm & 435 & 0,05 & 437,4 & 405,06 & 415,33 & 426,3 & 421,02 & 13,94 \\
Yb & 450 & 0,04 & 482,07 & 443,54 & 457,89 & 466,93 & 462,60 & 16,15 \\
Lu & 439 & 0,02 & 450,22 & 421,09 & 429,56 & 441 & 435,46 & 12,77 \\
Hf & 435 & 0,02 & 432,83 & 403,15 & 424,02 & 414,15 & 418,53 & 12,78 \\
Ta & 446 & 0,02 & 387,75 & 366,35 & 374,88 & 379,34 & 377,08 & 8,92 \\
Pb & 426 & 0,003 & 422,73 & 404,21 & 412,86 & 414,77 & 413,64 & 7,60 \\
Th & 457,2 & 0,18 & 468,34 & 435 & 445,92 & 456,82 & 451,52 & 14,32 \\
U & 461,5 & 0,1 & 467,81 & 446,92 & 456,02 & 459,26 & 457,50 & 8,63 \\
\hline
\end{tabular}


Apêndice C - Tabela C.XV: Concentrações de elementos-traço obtidas partir das análises de flogopita do fragmento 2, limites de detecção (LD) e erros associados (2 $\sigma$ ) utilizados como padrão de qualidade.

\begin{tabular}{|c|c|c|c|c|c|c|}
\hline \multirow[b]{2}{*}{ Elemento } & Análise & LD & $2 \sigma$ & Análise & LD & $2 \sigma$ \\
\hline & \multicolumn{3}{|c|}{$8 f \operatorname{lgn} 1$} & \multicolumn{3}{|c|}{$8 f \operatorname{lgn} 2$} \\
\hline $\mathbf{L i}$ & 27,37 & 0,358 & 1,29 & 25,36 & 0,341 & 1,19 \\
\hline $\mathbf{P}$ & n.d. & 43,13 & 22,39 & 1357,41 & 44,88 & 304,20 \\
\hline Sc & 2,39 & 0,261 & 0,25 & 3,13 & 0,260 & 0,29 \\
\hline $\mathrm{Ti}$ & 13850,87 & 1,46 & 775,72 & 13993,10 & 1,03 & 818,45 \\
\hline V & 143,73 & 0,148 & 7,72 & 157,95 & 0,147 & 8,82 \\
\hline $\mathrm{Cr}$ & 2709,80 & 1,52 & 134,07 & 2783,43 & 1,49 & 143,33 \\
\hline Mn & 222,84 & 0,643 & 12,23 & 222,21 & 0,666 & 12,72 \\
\hline Co & 54,57 & 0,0802 & 3,42 & 67,98 & 0,0804 & 4,40 \\
\hline $\mathrm{Ni}$ & 1169,70 & 0,477 & 56,86 & 1331,70 & 0,498 & 67,01 \\
\hline $\mathrm{Cu}$ & 3,61 & 0,514 & 0,57 & 415,47 & 0,742 & 15,28 \\
\hline $\mathrm{Zn}$ & 53,61 & 1,92 & 4,81 & 55,17 & 1,81 & 4,95 \\
\hline $\mathbf{R b}$ & 567,87 & 0,0882 & 31,08 & 563,39 & 0,0886 & 32,19 \\
\hline $\mathrm{Sr}$ & 16,14 & 0,0656 & 1,10 & 103,24 & 0,0397 & 6,93 \\
\hline$Y$ & n.d. & 0,0372 & 0,026 & 0,087 & 0,0499 & 0,036 \\
\hline $\mathrm{Zr}$ & 23,92 & 0,0993 & 1,49 & 46,22 & 0,137 & 2,85 \\
\hline $\mathrm{Nb}$ & 12,63 & 0,0501 & 0,98 & 12,40 & 0,0569 & 1,00 \\
\hline $\mathrm{Ba}$ & 504,80 & 0,467 & 37,16 & 705,91 & 0,495 & 54,27 \\
\hline La & n.d. & 0,0839 & 0,044 & n.d. & 0,0756 & 0,043 \\
\hline $\mathrm{Ce}$ & n.d. & 0,0679 & 0,041 & n.d. & 0,0710 & 0,037 \\
\hline $\mathrm{Pr}$ & n.d. & 0,0590 & 0,027 & n.d. & 0,0511 & 0,027 \\
\hline Nd & n.d. & 0,608 & 0,26 & n.d. & 0,455 & 0,21 \\
\hline Sm & n.d. & 0,462 & 0,19 & n.d. & 0,338 & 0,20 \\
\hline Eu & n.d. & 0,138 & 0,080 & n.d. & 0,138 & 0,081 \\
\hline Gd & n.d. & 0,360 & 0,15 & n.d. & 0,395 & 0,21 \\
\hline Tb & n.d. & 0,0425 & 0,024 & n.d. & 0,0686 & 0,031 \\
\hline Dy & n.d. & 0,389 & 0,16 & n.d. & 0,312 & 0,15 \\
\hline Ho & n.d. & 0,0731 & 0,032 & n.d. & 0,0702 & 0,033 \\
\hline Er & n.d. & 0,190 & 0,10 & n.d. & 0,181 & 0,095 \\
\hline $\mathrm{Tm}$ & n.d. & 0,0687 & 0,029 & n.d. & 0,0503 & 0,024 \\
\hline $\mathrm{Yb}$ & n.d. & 0,328 & 0,16 & n.d. & 0,300 & 0,14 \\
\hline Lu & n.d. & 0,0809 & 0,035 & n.d. & 0,0468 & 0,029 \\
\hline Hf & 1,22 & 0,227 & 0,25 & 1,45 & 0,268 & 0,26 \\
\hline $\mathrm{Ta}$ & 1,09 & 0,0697 & 0,12 & 1,30 & 0,0721 & 0,12 \\
\hline $\mathrm{Pb}$ & 0,55 & 0,421 & 0,29 & 1,82 & 0,325 & 0,37 \\
\hline Th & n.d. & 0,00 & 0,00 & n.d. & 0,0278 & 0,0086 \\
\hline $\mathbf{U}$ & n.d. & 0,0397 & 0,019 & n.d. & 0,0280 & 0,015 \\
\hline
\end{tabular}

B: Borda; N: núcleo; n.d.: não detectado. 
Apêndice C - Tabela C.XV (continuação): Concentrações de elementos-traço obtidas para partir das análises de flogopita do fragmento 2 , limites de deteç̧ão e erros associados $(2 \sigma)$ utilizados como padrão de qualidade.

\begin{tabular}{|c|c|c|c|c|c|c|}
\hline \multirow[b]{2}{*}{ Elemento } & Análise & LD & $2 \sigma$ & Análise & LD & $2 \sigma$ \\
\hline & \multicolumn{3}{|c|}{$8 f l g b 1$} & \multicolumn{3}{|c|}{$8 f l g b 2$} \\
\hline Li & 20,03 & 0,328 & 1,10 & 8,52 & 0,330 & 0,68 \\
\hline $\mathbf{P}$ & 73,12 & 42,60 & 30,65 & 3655,64 & 38,17 & 822,89 \\
\hline Sc & 4,97 & 0,263 & 0,45 & 7,81 & 0,242 & 0,68 \\
\hline $\mathrm{Ti}$ & 29892,83 & 1,46 & 1847,51 & 28164,94 & 1,13 & 1855,25 \\
\hline V & 233,87 & 0,145 & 13,78 & 142,76 & 0,141 & 9,01 \\
\hline $\mathrm{Cr}$ & 10480,74 & 1,51 & 567,91 & 7325,44 & 1,41 & 421,29 \\
\hline Mn & 268,93 & 0,645 & 16,29 & 318,47 & 0,602 & 20,53 \\
\hline Co & 72,69 & 0,0829 & 5,02 & 65,16 & 0,0824 & 4,83 \\
\hline $\mathbf{N i}$ & 1256,93 & 0,521 & 66,71 & 746,19 & 0,492 & 42,36 \\
\hline $\mathrm{Cu}$ & 2,71 & 0,666 & 0,61 & 71,92 & 0,713 & 3,81 \\
\hline $\mathrm{Zn}$ & 47,25 & 1,94 & 4,94 & 47,45 & 1,77 & 5,36 \\
\hline $\mathbf{R b}$ & 541,46 & 0,102 & 32,76 & 548,36 & 0,0814 & 35,36 \\
\hline $\mathrm{Sr}$ & 40,35 & 0,0546 & 2,94 & 529,15 & 0,0603 & 40,12 \\
\hline$Y$ & 0,165 & 0,0485 & 0,052 & 0,350 & 0,0548 & 0,081 \\
\hline $\mathrm{Zr}$ & 22,45 & 0,125 & 1,57 & 20,10 & 0,0961 & 1,52 \\
\hline $\mathrm{Nb}$ & 10,89 & 0,0452 & 0,96 & 11,07 & 0,0696 & 1,06 \\
\hline $\mathrm{Ba}$ & 1417,89 & 0,481 & 115,72 & 2525,02 & 0,564 & 220,64 \\
\hline La & n.d. & 0,0815 & 0,038 & n.d. & 0,0635 & 0,031 \\
\hline $\mathrm{Ce}$ & n.d. & 0,0745 & 0,045 & n.d. & 0,0773 & 0,044 \\
\hline $\operatorname{Pr}$ & n.d. & 0,0549 & 0,038 & n.d. & 0,0540 & 0,032 \\
\hline Nd & n.d. & 0,488 & 0,32 & n.d. & 0,458 & 0,33 \\
\hline Sm & n.d. & 0,302 & 0,17 & 0,39 & 0,284 & 0,26 \\
\hline Eu & n.d. & 0,109 & 0,078 & 0,130 & 0,120 & 0,097 \\
\hline Gd & n.d. & 0,469 & 0,22 & n.d. & 0,360 & 0,27 \\
\hline $\mathrm{Tb}$ & n.d. & 0,0666 & 0,035 & 0,059 & 0,0426 & 0,040 \\
\hline Dy & n.d. & 0,440 & 0,19 & n.d. & 0,379 & 0,23 \\
\hline Ho & n.d. & 0,0681 & 0,034 & 0,042 & 0,0369 & 0,034 \\
\hline $\mathrm{Er}$ & n.d. & 0,147 & 0,089 & n.d. & 0,165 & 0,10 \\
\hline $\mathrm{Tm}$ & n.d. & 0,0583 & 0,038 & n.d. & 0,0624 & 0,036 \\
\hline Yb & n.d. & 0,344 & 0,16 & n.d. & 0,245 & 0,13 \\
\hline $\mathbf{L u}$ & n.d. & 0,0788 & 0,028 & n.d. & 0,0691 & 0,036 \\
\hline $\mathrm{Hf}$ & 0,66 & 0,209 & 0,22 & 0,38 & 0,253 & 0,21 \\
\hline $\mathrm{Ta}$ & 0,90 & 0,0571 & 0,12 & 0,91 & 0,0588 & 0,13 \\
\hline $\mathbf{P b}$ & 0,56 & 0,363 & 0,30 & 0,65 & 0,339 & 0,33 \\
\hline Th & n.d. & 0,00 & 0,00 & 0,00 & 0,00 & 0,00 \\
\hline $\mathbf{U}$ & 0,056 & 0,00 & 0,032 & 0,022 & 0,00 & 0,022 \\
\hline
\end{tabular}

B: Borda; N: núcleo; n.d.: não detectado. 
Apêndice C - Tabela C.XVI: Concentrações do padrão primário BHVO-2G obtidas a partir das análises de flogopita poiquilítica da lâmina PNT-4.

\begin{tabular}{|c|c|c|c|c|c|}
\hline Elemento & GeoRem & Incerteza & LD & BHVO & $2 \sigma$ \\
\hline $\mathbf{L i}$ & 4,4 & 0,8 & 0,379 & 4,66 & 0,7 \\
\hline $\mathbf{P}$ & 711 & 19 & 45,42 & 958,85 & 436,74 \\
\hline Sc & 33,0 & 2 & 0,264 & 31,51 & 5,02 \\
\hline $\mathrm{Ti}$ & 16300 & 7 & 1,47 & 16040,55 & 2261,82 \\
\hline $\mathbf{V}$ & 308 & 11 & 0,173 & 333,59 & 44,4 \\
\hline $\mathrm{Cr}$ & 293 & 6 & 1,57 & 298,13 & 36,72 \\
\hline Mn & 1161 & 3 & 0,663 & 1280,40 & 175,86 \\
\hline Co & 44 & 0,1 & 0,0761 & 42,97 & 6,74 \\
\hline $\mathbf{N i}$ & 116 & 0,04 & 0,243 & 112,23 & 13,94 \\
\hline $\mathrm{Cu}$ & 127 & 1 & 0,732 & 106,39 & 8,98 \\
\hline $\mathrm{Zn}$ & 102 & 2 & 1,99 & 124,76 & 23,58 \\
\hline $\mathbf{R b}$ & 9,2 & 7 & 0,117 & 9,26 & 1,4 \\
\hline $\mathrm{Sr}$ & 396 & 0,8 & 0,0531 & 393,05 & 64,04 \\
\hline $\mathbf{Y}$ & 26 & 0,2 & 0,0530 & 23,90 & 4,22 \\
\hline $\mathrm{Zr}$ & 170 & 0,02 & 0,0750 & 164,17 & 23,56 \\
\hline $\mathrm{Nb}$ & 18,3 & 0,02 & 0,0576 & 15,45 & 2,98 \\
\hline $\mathrm{Ba}$ & 131 & 0,6 & 0,575 & 120,98 & 23,24 \\
\hline La & 15,2 & 0,13 & 0,0668 & 15,56 & 3,44 \\
\hline $\mathrm{Ce}$ & 37,6 & 0,02 & 0,0746 & 37,07 & 6,44 \\
\hline Pr & 5,35 & 2 & 0,0544 & 4,89 & 0,8 \\
\hline Nd & 24,5 & 0,2 & 0,456 & 24,79 & 4,72 \\
\hline Sm & 6,1 & 0,2 & 0,509 & 6,54 & 1,42 \\
\hline Eu & 2,07 & 0,22 & 0,154 & 2,00 & 0,48 \\
\hline Gd & 6,16 & 0,2 & 0,397 & 5,49 & 1,42 \\
\hline $\mathrm{Tb}$ & 0,92 & 0,03 & 0,0835 & 0,809 & 0,188 \\
\hline Dy & 5,28 & 0,01 & 0,330 & 5,22 & 1,26 \\
\hline Ho & 0,98 & 0,05 & 0,0610 & 1,17 & 0,26 \\
\hline Er & 2,56 & 0,04 & 0,163 & 2,71 & 0,6 \\
\hline Tm & 0,34 & 0,05 & 0,0426 & 0,347 & 0,106 \\
\hline $\mathrm{Yb}$ & 1,94 & 0,04 & 0,316 & 1,90 & 0,6 \\
\hline Lu & 0,279 & 0,02 & 0,0733 & 0,215 & 0,1 \\
\hline $\mathrm{Hf}$ & 4,32 & 0,02 & 0,216 & 4,26 & 0,84 \\
\hline $\mathrm{Ta}$ & 1,15 & 0,02 & 0,0458 & 1,025 & 0,19 \\
\hline $\mathrm{Pb}$ & 1,70 & 0,003 & 0,348 & 2,01 & 0,66 \\
\hline Th & 1,22 & 0,18 & 0,0391 & 1,27 & 0,26 \\
\hline $\mathbf{U}$ & 0,403 & 0,1 & 0,00 & 0,460 & 0,13 \\
\hline
\end{tabular}


Apêndice C - Tabela C.XVII: Concentrações do padrão secundário NIST-612 obtidas a partir das análises de flogopita poiquilítica da lâmina PNT-4.

\begin{tabular}{|c|c|c|c|c|c|}
\hline Elemento & GeoRem & Incerteza & LD & Nist-612 & $2 \sigma$ \\
\hline Li & 40,2 & 0,8 & 0,479 & 57,09 & 12,52 \\
\hline $\mathbf{P}$ & 46,6 & 19 & 59,27 & 69,21 & 63,5 \\
\hline Sc & 39,9 & 2 & 0,352 & 38,30 & 10,06 \\
\hline $\mathrm{Ti}$ & 44,0 & 7 & 2,36 & 42,97 & 11,98 \\
\hline $\mathbf{V}$ & 38,8 & 11 & 0,201 & 53,22 & 13,12 \\
\hline $\mathrm{Cr}$ & 36,4 & 6 & 2,10 & 50,41 & 12,26 \\
\hline Mn & 38,7 & 3 & 0,905 & 50,04 & 12,5 \\
\hline Co & 35,5 & 0,1 & 0,136 & 47,35 & 12,38 \\
\hline $\mathrm{Ni}$ & 38,8 & 0,04 & 0,573 & 52,11 & 12,76 \\
\hline $\mathrm{Cu}$ & 37,8 & 1 & 0,895 & 50,86 & 11,38 \\
\hline $\mathrm{Zn}$ & 39,1 & 2 & 2,54 & 62,31 & 18,42 \\
\hline $\mathbf{R b}$ & 31,4 & 7 & 0,123 & 44,47 & 11,12 \\
\hline $\mathrm{Sr}$ & 78,4 & 0,8 & 0,0864 & 93,65 & 24,94 \\
\hline $\mathbf{Y}$ & 38,3 & 0,2 & 0,0682 & 36,73 & 10,12 \\
\hline $\mathrm{Zr}$ & 37,9 & 0,02 & 0,151 & 37,50 & 9,54 \\
\hline $\mathrm{Nb}$ & 38,9 & 0,02 & 0,0942 & 41,80 & 12,02 \\
\hline $\mathrm{Ba}$ & 39,3 & 0,6 & 0,712 & 46,09 & 13,58 \\
\hline La & 36,0 & 0,13 & 0,0702 & 38,95 & 12,06 \\
\hline $\mathrm{Ce}$ & 38,4 & 0,02 & 0,105 & 49,04 & 13,4 \\
\hline $\mathrm{Pr}$ & 37,9 & 2 & 0,0661 & 42,66 & 11,06 \\
\hline Nd & 35,5 & 0,2 & 0,771 & 38,06 & 10,76 \\
\hline Sm & 37,7 & 0,2 & 0,516 & 40,10 & 10,44 \\
\hline Eu & 35,6 & 0,22 & 0,222 & 38,76 & 10,64 \\
\hline Gd & 37,3 & 0,2 & 0,602 & 33,69 & 10,14 \\
\hline $\mathrm{Tb}$ & 37,6 & 0,03 & 0,0862 & 36,39 & 9 \\
\hline Dy & 35,5 & 0,01 & 0,401 & 34,82 & 9,88 \\
\hline Ho & 38,3 & 0,05 & 0,0780 & 36,05 & 9,48 \\
\hline $\mathrm{Er}$ & 38,0 & 0,04 & 0,281 & 33,74 & 8,8 \\
\hline $\mathrm{Tm}$ & 36,8 & 0,05 & 0,0856 & 32,71 & 8,16 \\
\hline $\mathrm{Yb}$ & 39,2 & 0,04 & 0,409 & 36,39 & 9,46 \\
\hline Lu & 37,0 & 0,02 & 0,115 & 35,06 & 8,5 \\
\hline $\mathrm{Hf}$ & 36,7 & 0,02 & 0,308 & 33,89 & 8,44 \\
\hline $\mathrm{Ta}$ & 37,6 & 0,02 & 0,102 & 31,11 & 7,2 \\
\hline $\mathrm{Pb}$ & 38,57 & 0,003 & 0,563 & 50,00 & 11,52 \\
\hline Th & 37,79 & 0,18 & 0,0374 & 35,28 & 8,68 \\
\hline $\mathbf{U}$ & 37,38 & 0,1 & 0,00 & 48,51 & 10,84 \\
\hline
\end{tabular}


Apêndice C - Tabela C.XVIII: Limites de detecção do padrão secundário NIST-610 obtidas a partir das análises de flogopita poiquilítica da lâmina PNT-4.

\begin{tabular}{|c|c|c|c|c|c|c|}
\hline Elemento & Nist-610a & Nist-610b & Nist-610c & Nist-610d & Média LD & DP \\
\hline $\mathbf{L i}$ & 0,541 & 0,528 & 0,535 & 0,473 & 0,51925 & 0,03 \\
\hline $\mathbf{P}$ & 72,24 & 69,99 & 73,43 & 66,45 & 70,5275 & 3,07 \\
\hline Sc & 0,385 & 0,383 & 0,415 & 0,408 & 0,39775 & 0,02 \\
\hline $\mathrm{Ti}$ & 2,36 & 2,29 & 2,43 & 2,52 & 2,4 & 0,10 \\
\hline $\mathbf{V}$ & 0,256 & 0,229 & 0,24 & 0,238 & 0,24075 & 0,01 \\
\hline $\mathrm{Cr}$ & 2,34 & 2,21 & 2,42 & 2,44 & 2,3525 & 0,10 \\
\hline Mn & 1,01 & 0,975 & 1,01 & 1,06 & 1,01375 & 0,03 \\
\hline Co & 0,168 & 0,101 & 0,14 & 0,127 & 0,134 & 0,03 \\
\hline $\mathrm{Ni}$ & 0,816 & 0,773 & 0,779 & 0,694 & 0,7655 & 0,05 \\
\hline $\mathrm{Cu}$ & 1,02 & 0,949 & 1,21 & 1,09 & 1,06725 & 0,11 \\
\hline$Z n$ & 2,52 & 3,05 & 2,88 & 2,71 & 2,79 & 0,23 \\
\hline $\mathbf{R b}$ & 0,141 & 0,134 & 0,196 & 0,167 & 0,1595 & 0,03 \\
\hline $\mathrm{Sr}$ & 0,0743 & 0,0952 & 0,111 & 0,104 & 0,096125 & 0,02 \\
\hline $\mathbf{Y}$ & 0,0572 & 0,0904 & 0,0628 & 0,0687 & 0,069775 & 0,01 \\
\hline $\mathrm{Zr}$ & 0,143 & 0,127 & 0,136 & 0,195 & 0,15025 & 0,03 \\
\hline $\mathrm{Nb}$ & 0,109 & 0,103 & 0,078 & 0,108 & 0,0995 & 0,01 \\
\hline $\mathrm{Ba}$ & 0,672 & 0,831 & 0,718 & 0,961 & 0,7955 & 0,13 \\
\hline La & 0,112 & 0,0528 & 0,102 & 0,113 & 0,09495 & 0,03 \\
\hline $\mathrm{Ce}$ & 0,0703 & 0,0939 & 0,114 & 0,107 & 0,0963 & 0,02 \\
\hline $\operatorname{Pr}$ & 0,0978 & 0,0819 & 0,0746 & 0,0926 & 0,086725 & 0,01 \\
\hline Nd & 0,812 & 0,766 & 0,927 & 0,966 & 0,86775 & 0,09 \\
\hline Sm & 0,793 & 0,59 & 0,579 & 0,675 & 0,65925 & 0,10 \\
\hline Eu & 0,184 & 0,201 & 0,201 & 0,245 & 0,20775 & 0,03 \\
\hline Gd & 0,526 & 0,619 & 0,655 & 0,663 & 0,61575 & 0,06 \\
\hline $\mathrm{Tb}$ & 0,097 & 0,0916 & 0,101 & 0,103 & 0,09815 & 0,01 \\
\hline Dy & 0,599 & 0,524 & 0,552 & 0,535 & 0,5525 & 0,03 \\
\hline Ho & 0,104 & 0,114 & 0,0821 & 0,104 & 0,101025 & 0,01 \\
\hline Er & 0,385 & 0,264 & 0,329 & 0,281 & 0,31475 & 0,05 \\
\hline $\mathrm{Tm}$ & 0,0882 & 0,0832 & 0,0918 & 0,0777 & 0,085225 & 0,01 \\
\hline $\mathrm{Yb}$ & 0,565 & 0,389 & 0,565 & 0,591 & 0,5275 & 0,09 \\
\hline Lu & 0,147 & 0,109 & 0,141 & 0,0871 & 0,121025 & 0,03 \\
\hline Hf & 0,271 & 0,443 & 0,411 & 0,368 & 0,37325 & 0,07 \\
\hline $\mathrm{Ta}$ & 0,0861 & 0,0976 & 0,128 & 0,0914 & 0,100775 & 0,02 \\
\hline $\mathrm{Pb}$ & 0,358 & 0,275 & 0,598 & 0,402 & 0,40825 & 0,14 \\
\hline Th & n.d. & 0,0576 & 0,0419 & n.d. & 0,04975 & 0,01 \\
\hline $\mathbf{U}$ & 0,0435 & n.d. & 0,0423 & n.d. & 0,0429 & 0,00 \\
\hline
\end{tabular}


Apêndice C - Tabela C.XIX: Concentrações do padrão secundário NIST-610 obtidas a partir das análises de flogopita poiquilítica da lâmina PNT-4.

\begin{tabular}{|c|c|c|c|c|c|c|c|c|}
\hline Elemento & GeoRem & Incerteza & Nist-610a & Nist-610b & Nist-610c & Nist-610d & $\begin{array}{c}\text { Média } \\
\text { Análises }\end{array}$ & $\begin{array}{c}\text { Desvio } \\
\text { Padrão* }\end{array}$ \\
\hline Li & 468 & 0,8 & 493,16 & 476,17 & 485,05 & 485,16 & 484,885 & 6,94 \\
\hline $\mathbf{P}$ & 452 & 19 & 344,61 & 341,89 & 329,09 & 353,41 & 342,25 & 10,06 \\
\hline Sc & 450 & 2 & 461,34 & 422,25 & 450,74 & 435,49 & 442,455 & 17,15 \\
\hline $\mathrm{Ti}$ & 408 & 7 & 452,56 & 416,69 & 437,75 & 432,82 & 434,955 & 14,79 \\
\hline V & 444 & 11 & 455,76 & 427,47 & 453,05 & 434,25 & 442,6325 & 13,92 \\
\hline $\mathrm{Cr}$ & 410 & 6 & 416,66 & 393,43 & 414,54 & 399 & 405,9075 & 11,45 \\
\hline Mn & 458 & 3 & 447,73 & 418,79 & 444,87 & 425,74 & 434,2825 & 14,21 \\
\hline Co & 441 & 0,1 & 421 & 389,32 & 417,16 & 397,21 & 406,1725 & 15,33 \\
\hline $\mathrm{Ni}$ & 460 & 0,04 & 452,57 & 434 & 457,09 & 434,57 & 444,5575 & 12,01 \\
\hline $\mathrm{Cu}$ & 425,7 & 1 & 435,24 & 424,89 & 434,19 & 427,61 & 430,4825 & 5,03 \\
\hline $\mathrm{Zn}$ & 515.5 & 2 & 481.55 & 433,46 & 464.27 & 452,3 & 457.895 & 20,24 \\
\hline $\mathbf{R b}$ & 462 & 7 & 445,43 & 416,67 & 442,64 & 423,55 & 432,0725 & 14,14 \\
\hline $\mathrm{Sr}$ & 448 & 0,8 & 520,07 & 476,04 & 510,77 & 489,22 & 499,025 & 20,04 \\
\hline $\mathbf{Y}$ & 465 & 0,2 & 474,01 & 428,17 & 459,99 & 444,3 & 451,6175 & 19,79 \\
\hline $\mathrm{Zr}$ & 452 & 0,02 & 458,05 & 422,83 & 447,4 & 435,69 & 440,9925 & 15,17 \\
\hline $\mathrm{Nb}$ & 440 & 0,02 & 443,79 & 397,68 & 430,44 & 413,12 & 421,2575 & 20,12 \\
\hline $\mathrm{Ba}$ & 453 & 0,6 & 450,58 & 401,2 & 428,68 & 422,99 & 425,8625 & 20,29 \\
\hline $\mathrm{La}$ & 448 & 0,13 & 492,4 & 429,32 & 458,52 & 459,94 & 460,045 & 25,78 \\
\hline $\mathrm{Ce}$ & 430 & 0,02 & 472,45 & 426,08 & 454,03 & 445,19 & 449,4375 & 19,27 \\
\hline Pr & 453 & 2 & 449,61 & 413,04 & 423,32 & 437,84 & 430,9525 & 16,07 \\
\hline Nd & 447 & 0,2 & 455,05 & 409,76 & 431,74 & 432,56 & 432,2775 & 18,49 \\
\hline $\mathrm{Sm}$ & 449 & 0,2 & 470,65 & 432,61 & 448,95 & 454,09 & 451,575 & 15,67 \\
\hline Eu & 437 & 0,22 & 487 & 438,47 & 465,71 & 459,96 & 462,785 & 19,95 \\
\hline Gd & 437 & 0.2 & 448.04 & 396.75 & 417,34 & 425,11 & 421.81 & 21,19 \\
\hline $\mathrm{Tb}$ & 449 & 0,03 & 460,66 & 427,16 & 438,72 & 448,38 & 443,73 & 14,24 \\
\hline Dy & 455 & 0,01 & 450,53 & 406,54 & 419,89 & 435,16 & 428,03 & 19,02 \\
\hline Ho & 435 & 0,05 & 472,31 & 429,77 & 446,7 & 454,24 & 450,755 & 17,64 \\
\hline $\mathrm{Er}$ & 450 & 0,04 & 444,62 & 410,21 & 418,35 & 435,13 & 427,0775 & 15,63 \\
\hline $\mathrm{Tm}$ & 439 & 0,05 & 437,4 & 405,06 & 415,33 & 426,3 & 421,0225 & 13,94 \\
\hline $\mathrm{Yb}$ & 435 & 0,04 & 482,07 & 443,54 & 457,89 & 466,93 & 462,6075 & 16,16 \\
\hline
\end{tabular}




\begin{tabular}{ccccccccc}
\hline Elemento & GeoRem & Incerteza & Nist-610a & Nist-610b & Nist-610c & Nist-610d & $\begin{array}{c}\text { Média } \\
\text { Análises }\end{array}$ & $\begin{array}{c}\text { Desvio } \\
\text { Padrão* }^{*}\end{array}$ \\
\hline Lu & 446 & 0,02 & 450,22 & 421,09 & 429,56 & 441 & 435,4675 & 12,78 \\
Hf & 426 & 0,02 & 432,83 & 403,15 & 424,02 & 414,15 & 418,5375 & 12,78 \\
Ta & 457,2 & 0,02 & 387,75 & 366,35 & 374,88 & 379,34 & 377,08 & 8,92 \\
Pb & 461,5 & 0,003 & 422,73 & 404,21 & 412,86 & 414,77 & 413,6425 & 7,60 \\
Th & 468 & 0,18 & 468,34 & 435 & 445,92 & 456,82 & 451,52 & 14,32 \\
U & 413 & 0,1 & 467,81 & 446,92 & 456,02 & 459,26 & 457,5025 & 8,63 \\
\hline
\end{tabular}


Apêndice C - Tabela C.XX: Concentrações de elementos-traço obtidas para de flogopita

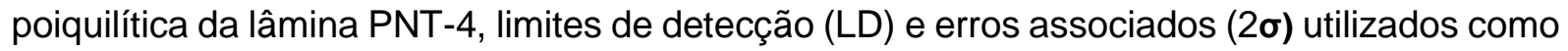
padrão de qualidade.

\begin{tabular}{|c|c|c|c|c|c|c|}
\hline & Análise & LD & $2 \sigma$ & Análise & LD & $2 \sigma$ \\
\hline Elemento & & $8 f \operatorname{lgn} 1$ & & & $8 f \operatorname{lgn} 2$ & \\
\hline $\mathbf{L i}$ & 27,37 & 0,358 & 2,58 & 25,36 & 0,341 & 2,38 \\
\hline $\mathbf{P}$ & n.d. & 43,13 & 44,78 & 1357,41 & 44,88 & 608,4 \\
\hline Sc & 2,39 & 0,261 & 0,5 & 3,13 & 0,26 & 0,58 \\
\hline $\mathrm{Ti}$ & 13850,87 & 1,46 & 1551,44 & 13993,1 & 1,03 & 1636,9 \\
\hline $\mathbf{V}$ & 143,73 & 0,148 & 15,44 & 157,95 & 0,147 & 17,64 \\
\hline $\mathrm{Cr}$ & 2709,8 & 1,52 & 268,14 & 2783,43 & 1,49 & 286,66 \\
\hline Mn & 222,84 & 0,643 & 24,46 & 222,21 & 0,666 & 25,44 \\
\hline Co & 54,57 & 0,0802 & 6,84 & 67,98 & 0,0804 & 8,8 \\
\hline $\mathbf{N i}$ & 1169,7 & 0,477 & 113,72 & 1331,7 & 0,498 & 134,02 \\
\hline $\mathrm{Cu}$ & 3,61 & 0,514 & 1,14 & 415,47 & 0,742 & 30,56 \\
\hline $\mathrm{Zn}$ & 53,61 & 1,92 & 9,62 & 55,17 & 1,81 & 9,9 \\
\hline $\mathbf{R b}$ & 567,87 & 0,0882 & 62,16 & 563,39 & 0,0886 & 64,38 \\
\hline $\mathrm{Sr}$ & 16,14 & 0,0656 & 2,2 & 103,24 & 0,0397 & 13,86 \\
\hline $\mathbf{Y}$ & n.d. & 0,0372 & 0,052 & 0,087 & 0,0499 & 0,072 \\
\hline $\mathrm{Zr}$ & 23,92 & 0,0993 & 2,98 & 46,22 & 0,137 & 5,7 \\
\hline $\mathrm{Nb}$ & 12,63 & 0,0501 & 1,96 & 12,4 & 0,0569 & 2 \\
\hline $\mathrm{Ba}$ & 504,8 & 0,467 & 74,32 & 705,91 & 0,495 & 108,54 \\
\hline La & n.d. & 0,0839 & 0,088 & n.d. & 0,0756 & 0,086 \\
\hline $\mathrm{Ce}$ & n.d. & 0,0679 & 0,082 & n.d. & 0,071 & 0,074 \\
\hline $\mathrm{Pr}$ & n.d. & 0,059 & 0,054 & n.d. & 0,0511 & 0,054 \\
\hline Nd & n.d. & 0,608 & 0,52 & n.d. & 0,455 & 0,42 \\
\hline $\mathrm{Sm}$ & n.d. & 0,462 & 0,38 & n.d. & 0,338 & 0,4 \\
\hline Eu & n.d. & 0,138 & 0,16 & n.d. & 0,138 & 0,162 \\
\hline Gd & n.d. & 0,36 & 0,3 & n.d. & 0,395 & 0,42 \\
\hline Tb & n.d. & 0,0425 & 0,048 & n.d. & 0,0686 & 0,062 \\
\hline Dy & n.d. & 0,389 & 0,32 & n.d. & 0,312 & 0,3 \\
\hline Ho & n.d. & 0,0731 & 0,064 & n.d. & 0,0702 & 0,066 \\
\hline $\mathrm{Er}$ & n.d. & 0,19 & 0,2 & n.d. & 0,181 & 0,19 \\
\hline $\mathrm{Tm}$ & n.d. & 0,0687 & 0,058 & n.d. & 0,0503 & 0,048 \\
\hline $\mathrm{Yb}$ & n.d. & 0,328 & 0,32 & n.d. & 0,3 & 0,28 \\
\hline Lu & n.d. & 0,0809 & 0,07 & n.d. & 0,0468 & 0,058 \\
\hline Hf & 1,22 & 0,227 & 0,5 & 1,45 & 0,268 & 0,52 \\
\hline $\mathrm{Ta}$ & 1,09 & 0,0697 & 0,24 & 1,3 & 0,0721 & 0,24 \\
\hline $\mathrm{Pb}$ & 0,55 & 0,421 & 0,58 & 1,82 & 0,325 & 0,74 \\
\hline Th & n.d. & 0,00 & 0,00 & n.d. & 0,0278 & 0,0172 \\
\hline $\mathbf{U}$ & n.d. & 0,0397 & 0,038 & n.d. & 0,028 & 0,03 \\
\hline
\end{tabular}

B: Borda; N: núcleo; n.d.: não detectado. 
Apêndice C - Tabela C.XX (continuação): Concentrações de elementos-traço obtidas para

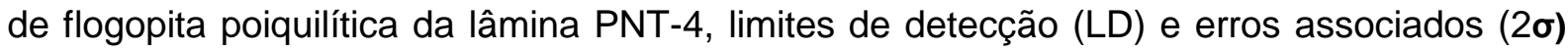
utilizados como padrão de qualidade.

\begin{tabular}{|c|c|c|c|c|c|c|}
\hline \multirow[b]{2}{*}{ Elemento } & Análise & LD & $2 \sigma$ & Análise & LD & $2 \sigma$ \\
\hline & \multicolumn{3}{|c|}{$8 f l g b 1$} & \multicolumn{3}{|c|}{$8 f \operatorname{lgb2}$} \\
\hline $\mathbf{L i}$ & 20,03 & 0,328 & 2,2 & 8,52 & 0,33 & 1,36 \\
\hline $\mathbf{P}$ & 73,12 & 42,6 & 61,3 & 3655,64 & 38,17 & 1645,78 \\
\hline Sc & 4,97 & 0,263 & 0,9 & 7,81 & 0,242 & 1,36 \\
\hline $\mathrm{Ti}$ & 29892,83 & 1,46 & 3695,02 & 28164,94 & 1,13 & 3710,5 \\
\hline $\mathbf{V}$ & 233,87 & 0,145 & 27,56 & 142,76 & 0,141 & 18,02 \\
\hline $\mathrm{Cr}$ & 10480,74 & 1,51 & 1135,82 & 7325,44 & 1,41 & 842,58 \\
\hline Mn & 268,93 & 0,645 & 32,58 & 318,47 & 0,602 & 41,06 \\
\hline Co & 72,69 & 0,0829 & 10,04 & 65,16 & 0,0824 & 9,66 \\
\hline $\mathrm{Ni}$ & 1256,93 & 0,521 & 133,42 & 746,19 & 0,492 & 84,72 \\
\hline $\mathrm{Cu}$ & 2,71 & 0,666 & 1,22 & 71,92 & 0,713 & 7,62 \\
\hline $\mathrm{Zn}$ & 47,25 & 1,94 & 9,88 & 47,45 & 1,77 & 10,72 \\
\hline $\mathbf{R b}$ & 541,46 & 0,102 & 65,52 & 548,36 & 0,0814 & 70,72 \\
\hline $\mathrm{Sr}$ & 40,35 & 0,0546 & 5,88 & 529,15 & 0,0603 & 80,24 \\
\hline $\mathbf{Y}$ & 0,165 & 0,0485 & 0,104 & 0,35 & 0,0548 & 0,162 \\
\hline $\mathrm{Zr}$ & 22,45 & 0,125 & 3,14 & 20,1 & 0,0961 & 3,04 \\
\hline $\mathrm{Nb}$ & 10,89 & 0,0452 & 1,92 & 11,07 & 0,0696 & 2,12 \\
\hline $\mathrm{Ba}$ & 1417,89 & 0,481 & 231,44 & 2525,02 & 0,564 & 441,28 \\
\hline La & n.d. & 0,0815 & 0,076 & n.d. & 0,0635 & 0,062 \\
\hline $\mathrm{Ce}$ & n.d. & 0,0745 & 0,09 & n.d. & 0,0773 & 0,088 \\
\hline $\mathrm{Pr}$ & n.d. & 0,0549 & 0,076 & n.d. & 0,054 & 0,064 \\
\hline Nd & n.d. & 0,488 & 0,64 & n.d. & 0,458 & 0,66 \\
\hline Sm & n.d. & 0,302 & 0,34 & 0,39 & 0,284 & 0,52 \\
\hline Eu & n.d. & 0,109 & 0,156 & 0,13 & 0,12 & 0,194 \\
\hline Gd & n.d. & 0,469 & 0,44 & n.d. & 0,36 & 0,54 \\
\hline $\mathrm{Tb}$ & n.d. & 0,0666 & 0,07 & 0,059 & 0,0426 & 0,08 \\
\hline Dy & n.d. & 0,44 & 0,38 & n.d. & 0,379 & 0,46 \\
\hline Ho & n.d. & 0,0681 & 0,068 & 0,042 & 0,0369 & 0,068 \\
\hline Er & n.d. & 0,147 & 0,178 & n.d. & 0,165 & 0,2 \\
\hline $\mathrm{Tm}$ & n.d. & 0,0583 & 0,076 & n.d. & 0,0624 & 0,072 \\
\hline Yb & n.d. & 0,344 & 0,32 & n.d. & 0,245 & 0,26 \\
\hline Lu & n.d. & 0,0788 & 0,056 & n.d. & 0,0691 & 0,072 \\
\hline Hf & 0,66 & 0,209 & 0,44 & 0,38 & 0,253 & 0,42 \\
\hline $\mathrm{Ta}$ & 0,9 & 0,0571 & 0,24 & 0,91 & 0,0588 & 0,26 \\
\hline $\mathrm{Pb}$ & 0,56 & 0,363 & 0,6 & 0,65 & 0,339 & 0,66 \\
\hline Th & n.d. & 0,00 & 0,00 & n.d. & 0,00 & 0,00 \\
\hline $\mathbf{U}$ & 0,056 & 0,00 & 0,064 & 0,022 & 0,00 & 0,044 \\
\hline
\end{tabular}

B: Borda; N: núcleo; n.d.: não detectado. 
Apêndice C - Tabela C.XXI: Concentrações do padrão primário BHVO-2G obtidas a partir das análises de flogopita da lâmina PNT-8.

\begin{tabular}{cccccc}
\hline Elemento & GeoRem & Incerteza & LD & BHVO & $\mathbf{2 \sigma}$ \\
\hline $\mathbf{L i}$ & 4,4 & 0,8 & 0,202 & 4,88 & 1,12 \\
$\mathbf{P}$ & 711 & 19 & 23,52 & 992 & 570,3 \\
$\mathbf{S c}$ & 33,0 & 2 & 0,145 & 31,93 & 2,92 \\
$\mathbf{T i}$ & 16300 & 7 & 0,834 & 16568,45 & 1472,24 \\
$\mathbf{V}$ & 308 & 11 & 0,0741 & 341,62 & 26,82 \\
$\mathbf{C r}$ & 293 & 6 & 0,731 & 301,4 & 24,7 \\
$\mathbf{M n}$ & 1161 & 3 & 0,34 & 1304,34 & 94,74 \\
$\mathbf{C o}$ & 44 & 0,1 & 0,0422 & 45,41 & 3,08 \\
$\mathbf{N i}$ & 116 & 0,04 & 0,257 & 115,39 & 10,1 \\
$\mathbf{C u}$ & 127 & 1 & 0,352 & 112,69 & 11,88 \\
$\mathbf{Z n}$ & 102 & 2 & 0,713 & 129,91 & 11,1 \\
$\mathbf{R b}$ & 9,2 & 7 & 0,065 & 9,25 & 0,86 \\
$\mathbf{S r}$ & 396 & 0,8 & 0,0261 & 397,29 & 25,84 \\
$\mathbf{Y}$ & 26 & 0,2 & 0,0315 & 23,11 & 2,22 \\
$\mathbf{Z r}$ & 170 & 0,02 & 0,0365 & 157,76 & 12,5 \\
$\mathbf{N b}$ & 18,3 & 0,02 & 0,0327 & 15,8 & 1,26 \\
$\mathbf{B a}$ & 131 & 0,6 & 0,233 & 129,28 & 18,4 \\
$\mathbf{L a}$ & 15,2 & 0,13 & 0,0342 & 16,49 & 2,56 \\
$\mathbf{C e}$ & 37,6 & 0,02 & 0,0295 & 39,06 & 4,26 \\
$\mathbf{P r}$ & 5,35 & 2 & 0,0292 & 5,4 & 0,76 \\
$\mathbf{N d}$ & 24,5 & 0,2 & 0,249 & 26,01 & 4,44 \\
$\mathbf{S m}$ & 6,1 & 0,2 & 0,22 & 6,71 & 1,04 \\
$\mathbf{E u}$ & 2,07 & 0,22 & 0,0612 & 1,99 & 0,34 \\
$\mathbf{G d}$ & 6,16 & 0,2 & 0,299 & 6,07 & 1,1 \\
$\mathbf{T b}$ & 0,92 & 0,03 & 0,0383 & 0,981 & 0,182 \\
$\mathbf{D y}$ & 5,28 & 0,01 & 0,246 & 5,2 & 0,9 \\
$\mathbf{H o}$ & 0,98 & 0,05 & 0,0372 & 1,09 & 0,24 \\
$\mathbf{E r}$ & 2,56 & 0,04 & 0,106 & 2,47 & 0,5 \\
$\mathbf{T m}$ & 0,34 & 0,05 & 0,037 & 0,34 & 0,098 \\
$\mathbf{Y b}$ & 1,94 & 0,04 & 0,139 & 2,23 & 0,58 \\
$\mathbf{L u}$ & 0,279 & 0,02 & 0,0386 & 0,276 & 0,082 \\
$\mathbf{H f}$ & 4,32 & 0,02 & 0,143 & 4,29 & 0,98 \\
$\mathbf{T a}$ & 1,15 & 0,02 & 0,0371 & 0,99 & 0,22 \\
$\mathbf{P b}$ & 1,70 & 0,003 & 0,178 & 2,33 & 0,62 \\
$\mathbf{T h}$ & 1,22 & 0,18 & 0,00 & 1,25 & 0,24 \\
$\mathbf{U}$ & 0,403 & 0,1 & 0,0218 & 0,455 & 0,124 \\
\hline & & & & &
\end{tabular}


Apêndice C - Tabela C.XXII: Concentrações do padrão secundário NIST-612 obtidas a partir das análises de flogopita da lâmina PNT-8.

\begin{tabular}{|c|c|c|c|c|c|}
\hline Elemento & GeoRem & Incerteza & LD & Nist-612 & $2 \sigma$ \\
\hline$\overline{L i}$ & 40,2 & 0,8 & 0,182 & 56,11 & 11,16 \\
\hline $\mathbf{P}$ & 44,0 & 19 & 24,94 & 54,27 & 35,36 \\
\hline Sc & 38,8 & 2 & 0,138 & 35,69 & 4,92 \\
\hline $\mathrm{Ti}$ & 36,4 & 7 & 0,846 & 40,55 & 6,34 \\
\hline $\mathbf{V}$ & 38,7 & 11 & 0,077 & 50,73 & 6,78 \\
\hline $\mathrm{Cr}$ & 35,5 & 6 & 0,774 & 47,28 & 6,42 \\
\hline Mn & 38,8 & 3 & 0,378 & 47,76 & 6,3 \\
\hline Co & 37,8 & 0,1 & 0,0579 & 46,02 & 6 \\
\hline $\mathbf{N i}$ & 39,1 & 0,04 & 0,214 & 49,42 & 6,98 \\
\hline $\mathrm{Cu}$ & 31,4 & 1 & 0,352 & 48,73 & 7,2 \\
\hline $\mathrm{Zn}$ & 78,4 & 2 & 1,06 & 48,15 & 7,16 \\
\hline $\mathbf{R b}$ & 38,3 & 7 & 0,0738 & 47,59 & 6,46 \\
\hline $\mathrm{Sr}$ & 37,9 & 0,8 & 0,0251 & 82,78 & 10,7 \\
\hline $\mathbf{Y}$ & 38,9 & 0,2 & 0,0234 & 33,2 & 4,62 \\
\hline $\mathrm{Zr}$ & 39,3 & 0,02 & 0,0604 & 32,7 & 4,42 \\
\hline $\mathrm{Nb}$ & 36,0 & 0,02 & 0,0264 & 37,23 & 4,96 \\
\hline $\mathrm{Ba}$ & 38,4 & 0,6 & 0,26 & 43,53 & 7,18 \\
\hline $\mathrm{La}$ & 37,9 & 0,13 & 0,0376 & 37,59 & 6,2 \\
\hline $\mathrm{Ce}$ & 35,5 & 0,02 & 0,0385 & 46,14 & 6,66 \\
\hline Pr & 37,7 & 2 & 0,0317 & 40,41 & 6,3 \\
\hline Nd & 35,6 & 0,2 & 0,323 & 35,91 & 6,32 \\
\hline Sm & 37,3 & 0,2 & 0,227 & 37,88 & 5,84 \\
\hline Eu & 37,6 & 0,22 & 0,0592 & 38,54 & 6,12 \\
\hline Gd & 35,5 & 0,2 & 0,174 & 32,51 & 5,42 \\
\hline $\mathrm{Tb}$ & 38,3 & 0,03 & 0,0455 & 34,01 & 5,58 \\
\hline Dy & 38,0 & 0,01 & 0,159 & 33,26 & 5,32 \\
\hline Ho & 36,8 & 0,05 & 0,0423 & 34,26 & 6,24 \\
\hline Er & 39,2 & 0,04 & 0,142 & 32,54 & 5,68 \\
\hline $\mathrm{Tm}$ & 37,0 & 0,05 & 0,0315 & 32,43 & 6,34 \\
\hline Yb & 36,7 & 0,04 & 0,175 & 35,55 & 6,98 \\
\hline Lu & 37,6 & 0,02 & 0,0323 & 32,12 & 5,96 \\
\hline $\mathrm{Hf}$ & 38,57 & 0,02 & 0,117 & 29,87 & 5,9 \\
\hline $\mathrm{Ta}$ & 37,79 & 0,02 & 0,0282 & 28,72 & 5,46 \\
\hline $\mathrm{Pb}$ & 37,38 & 0,003 & 0,184 & 52,38 & 10,1 \\
\hline Th & 40,2 & 0,18 & 0,00 & 34,54 & 5,84 \\
\hline $\mathbf{U}$ & 46,6 & 0,1 & 0,00 & 49,67 & 9,44 \\
\hline
\end{tabular}


Apêndice C - Tabela C.XXIII: Limites de detecção do padrão secundário NIST-610 obtidas a partir das análises de flogopita da lâmina PNT-8.

\begin{tabular}{|c|c|c|c|c|c|c|c|}
\hline Elemento & Nist-610a & Nist-610b & Nist-610c & Nist-610d & Nist-610e & Média LD & DP \\
\hline Li & 0,28 & 0,268 & 0,293 & 0,46 & 0,365 & 0,3332 & 0,08 \\
\hline $\mathbf{P}$ & 31,93 & 29,61 & 33,56 & 61,08 & 50,37 & 41,31 & 13,76 \\
\hline Sc & 0,215 & 0,197 & 0,212 & 0,315 & 0,265 & 0,2408 & 0,05 \\
\hline $\mathrm{Ti}$ & 1,12 & 0,831 & 1,16 & 1,59 & 1,51 & 1,2422 & 0,31 \\
\hline V & 0,107 & 0,0869 & 0,107 & 0,134 & 0,13 & 0,11298 & 0,02 \\
\hline $\mathrm{Cr}$ & 1,1 & 1,02 & 1,13 & 1,72 & 1,47 & 1,288 & 0,30 \\
\hline Mn & 0,522 & 0,484 & 0,542 & 0,808 & 0,702 & 0,6116 & 0,14 \\
\hline Co & 0,0775 & 0,0728 & 0,0688 & 0,108 & 0,131 & 0,09162 & 0,03 \\
\hline $\mathbf{N i}$ & 0,41 & 0,327 & 0,354 & 0,454 & 0,468 & 0,4026 & 0,06 \\
\hline $\mathrm{Cu}$ & 0,616 & 0,431 & 0,632 & 0,824 & 1,45 & 0,7906 & 0,39 \\
\hline $\mathrm{Zn}$ & 1,67 & 1,13 & 1,44 & 1,66 & 4,54 & 2,088 & 1,39 \\
\hline $\mathbf{R b}$ & 0,0771 & 0,0617 & 0,0758 & 0,113 & 0,0748 & 0,08048 & 0,02 \\
\hline $\mathrm{Sr}$ & 0,0404 & 0,0334 & 0,0365 & 0,108 & 0,0536 & 0,05438 & 0,03 \\
\hline $\mathbf{Y}$ & 0,0344 & 0,0373 & 0,0556 & 0,0534 & 0,0431 & 0,04476 & 0,01 \\
\hline $\mathrm{Zr}$ & 0,0738 & 0,0932 & 0,0556 & 0,164 & 0,102 & 0,09772 & 0,04 \\
\hline $\mathrm{Nb}$ & 0,0472 & 0,0418 & 0,0587 & 0,07 & 0,0548 & 0,0545 & 0,01 \\
\hline $\mathrm{Ba}$ & 0,424 & 0,371 & 0,423 & 0,597 & 0,391 & 0,4412 & 0,09 \\
\hline La & 0,0648 & 0,0579 & 0,0647 & 0,109 & 0,0573 & 0,07074 & 0,02 \\
\hline $\mathrm{Ce}$ & 0,0412 & 0,0387 & 0,0507 & 0,107 & 0,0593 & 0,05938 & 0,03 \\
\hline $\mathrm{Pr}$ & 0,0498 & 0,0382 & 0,0482 & 0,0938 & 0,049 & 0,0558 & 0,02 \\
\hline Nd & 0,354 & 0,461 & 0,398 & 0,63 & 0,503 & 0,4692 & 0,11 \\
\hline Sm & 0,358 & 0,251 & 0,331 & 0,409 & 0,37 & 0,3438 & 0,06 \\
\hline Eu & 0,0911 & 0,0926 & 0,108 & 0,104 & 0,131 & 0,10534 & 0,02 \\
\hline Gd & 0,329 & 0,318 & 0,396 & 0,572 & 0,387 & 0,4004 & 0,10 \\
\hline $\mathrm{Tb}$ & 0,0577 & 0,0426 & 0,036 & 0,0624 & 0,0536 & 0,05046 & 0,01 \\
\hline Dy & 0,336 & 0,291 & 0,214 & 0,393 & 0,275 & 0,3018 & 0,07 \\
\hline Ho & 0,0514 & 0,0542 & 0,0592 & 0,0761 & 0,0498 & 0,05814 & 0,01 \\
\hline Er & 0,208 & 0,075 & 0,188 & 0,323 & 0,131 & 0,185 & 0,09 \\
\hline $\mathrm{Tm}$ & 0,0538 & 0,0412 & 0,0537 & 0,0723 & 0,0646 & 0,05712 & 0,01 \\
\hline Yb & 0,256 & 0,24 & 0,213 & 0,505 & 0,331 & 0,309 & 0,12 \\
\hline Lu & 0,0566 & 0,0388 & 0,0532 & 0,0788 & 0,0616 & 0,0578 & 0,01 \\
\hline $\mathrm{Hf}$ & 0,171 & 0,167 & 0,2 & 0,301 & 0,249 & 0,2176 & 0,06 \\
\hline $\mathrm{Ta}$ & 0,0535 & 0,0375 & 0,0491 & 0,0779 & 0,0423 & 0,05206 & 0,02 \\
\hline $\mathrm{Pb}$ & 0,218 & 0,302 & 0,29 & 0,348 & 1,17 & 0,4656 & 0,40 \\
\hline Th & 0,04 & n.d. & n.d. & n.d. & 0,0367 & 0,03835 & 0,00 \\
\hline $\mathbf{U}$ & n.d. & 0,0175 & 0,0232 & n.d. & 0,0259 & 0,0222 & 0,00 \\
\hline
\end{tabular}


Apêndice C - Tabela C.XXIV: Concentrações do padrão secundário NIST-610 obtidas a partir das análises de flogopita da lâmina PNT-8.

\begin{tabular}{|c|c|c|c|c|c|c|c|c|c|}
\hline Elemento & GeoRem & Incerteza & Nist-610a & Nist-610b & Nist-610c & Nist-610d & Nist-610e & $\begin{array}{c}\text { Média } \\
\text { Análises }\end{array}$ & $\begin{array}{c}\text { Desvio } \\
\text { Padrão* }\end{array}$ \\
\hline $\mathbf{L i}$ & 468 & 0,8 & 505,4 & 472,4 & 465,69 & 475,03 & 511,9 & 486,084 & 21,01 \\
\hline $\mathbf{P}$ & 452 & 19 & 326,54 & 342,94 & 380,21 & 336,42 & 319,12 & 341,046 & 23,72 \\
\hline Sc & 450 & 2 & 447,61 & 431,75 & 442,45 & 437,54 & 444,7 & 440,81 & 6,26 \\
\hline $\mathrm{Ti}$ & 408 & 7 & 435,9 & 426,98 & 441,58 & 428,31 & 435,85 & 433,724 & 6,04 \\
\hline $\mathbf{V}$ & 444 & 11 & 444,91 & 434,38 & 446,17 & 442,23 & 438,71 & 441,28 & 4,80 \\
\hline $\mathrm{Cr}$ & 410 & 6 & 405,32 & 400,4 & 412,77 & 403,21 & 402,85 & 404,91 & 4,73 \\
\hline Mn & 458 & 3 & 434,14 & 430,9 & 435,75 & 428,17 & 437,57 & 433,306 & 3,78 \\
\hline Co & 441 & 0,1 & 405,82 & 403,36 & 406,06 & 402,08 & 407,62 & 404,988 & 2,23 \\
\hline $\mathrm{Ni}$ & 460 & 0,04 & 443,46 & 450,12 & 435,79 & 446,45 & 446,42 & 444,448 & 5,39 \\
\hline $\mathrm{Cu}$ & 425,7 & 1 & 423,28 & 441,16 & 429,77 & 436,62 & 423,64 & 430,894 & 7,91 \\
\hline $\mathrm{Zn}$ & 515,5 & 2 & 455,42 & 456,88 & 456,61 & 462,45 & 449,69 & 456,21 & 4,55 \\
\hline $\mathbf{R b}$ & 462 & 7 & 425,97 & 438,67 & 431,06 & 435,44 & 426,25 & 431,478 & 5,60 \\
\hline $\mathrm{Sr}$ & 448 & 0,8 & 496,28 & 499,39 & 496,5 & 500,85 & 494,27 & 497,458 & 2,63 \\
\hline $\mathbf{Y}$ & 465 & 0,2 & 455,9 & 444,41 & 444,78 & 458,62 & 444,77 & 449,696 & 6,97 \\
\hline $\mathrm{Zr}$ & 452 & 0,02 & 443,14 & 437,15 & 436,48 & 446,37 & 435,66 & 439,76 & 4,73 \\
\hline $\mathrm{Nb}$ & 440 & 0,02 & 420,28 & 418,94 & 417,51 & 425,56 & 414,37 & 419,332 & 4,12 \\
\hline $\mathrm{Ba}$ & 453 & 0,6 & 436,14 & 415,24 & 412,53 & 435,42 & 421,07 & 424,08 & 11,12 \\
\hline La & 448 & 0,13 & 474,61 & 444,39 & 443,74 & 462,02 & 462,98 & 457,548 & 13,27 \\
\hline $\mathrm{Ce}$ & 430 & 0,02 & 456,94 & 442,13 & 438,09 & 447,07 & 455,84 & 448,014 & 8,29 \\
\hline $\operatorname{Pr}$ & 453 & 2 & 442,47 & 421,59 & 417,42 & 430,94 & 437,92 & 430,068 & 10,58 \\
\hline Nd & 447 & 0,2 & 444,93 & 423,18 & 415,23 & 428,91 & 445,06 & 431,462 & 13,27 \\
\hline Sm & 449 & 0,2 & 456,62 & 446,02 & 445,74 & 441,1 & 465,3 & 450,956 & 9,83 \\
\hline Eu & 437 & 0,22 & 470,18 & 457,1 & 449,95 & 453,22 & 479 & 461,89 & 12,27 \\
\hline Gd & 437 & 0,2 & 427,72 & 418,96 & 406,62 & 414,56 & 436,17 & 420,806 & 11,48 \\
\hline $\mathrm{Tb}$ & 449 & 0,03 & 452,93 & 441,65 & 425,24 & 441,93 & 457,17 & 443,784 & 12,40 \\
\hline Dy & 455 & 0,01 & 435,43 & 424,05 & 412,83 & 424,91 & 438,49 & 427,142 & 10,21 \\
\hline
\end{tabular}




\begin{tabular}{cccccccccc}
\hline Elemento & GeoRem & Incerteza & Nist-610a & Nist-610b & Nist-610c & Nist-610d & Nist-610e & $\begin{array}{c}\text { Média } \\
\text { Análises }\end{array}$ & $\begin{array}{c}\text { Desvio } \\
\text { Padrão* }\end{array}$ \\
\hline Ho & 435 & 0,05 & 461,84 & 447,33 & 429,5 & 443,89 & 472,1 & 450,932 & 16,50 \\
Er & 450 & 0,04 & 436,78 & 423,33 & 409,61 & 420,86 & 445,11 & 427,138 & 13,94 \\
Tm & 439 & 0,05 & 431,57 & 421,57 & 397,52 & 415,8 & 443,79 & 422,05 & 17,35 \\
Yb & 435 & 0,04 & 477,67 & 454,56 & 442,05 & 452,74 & 488,46 & 463,096 & 19,23 \\
Lu & 446 & 0,02 & 447,51 & 433,1 & 413,37 & 431,74 & 455,5 & 436,244 & 16,21 \\
Hf & 426 & 0,02 & 430,18 & 415,81 & 397,88 & 410,43 & 442,95 & 419,45 & 17,52 \\
Ta & 457,2 & 0,02 & 382,35 & 382,72 & 358,42 & 370,54 & 398,47 & 378,5 & 14,98 \\
Pb & 461,5 & 0,003 & 415,19 & 423,71 & 397,12 & 402,37 & 439,47 & 415,572 & 16,97 \\
Th & 468 & 0,18 & 459,99 & 451,98 & 431,21 & 449,02 & 467,2 & 451,88 & 13,56 \\
U & 413 & 0,1 & 467,62 & 456,8 & 439,02 & 445,63 & 486,15 & 459,044 & 18,67 \\
\hline
\end{tabular}


Apêndice C - Tabela C.XXV: Concentrações de elementos-traço obtidas para de flogopita da lâmina PNT-8, limites de detecção (LD) e erros associados $(2 \sigma)$ utilizados como padrão de qualidade.

\begin{tabular}{|c|c|c|c|c|c|c|}
\hline \multirow[b]{2}{*}{ Elemento } & Análise & LD & $2 \sigma$ & Análise & LD & $2 \sigma$ \\
\hline & \multicolumn{3}{|c|}{ flog1n1 } & \multicolumn{3}{|c|}{ flog1b1 } \\
\hline $\begin{array}{l}\mathrm{Li} \\
\mathrm{P} \\
\mathrm{Sc}\end{array}$ & $\begin{array}{c}39,27 \\
\text { n.d. } \\
1,94\end{array}$ & $\begin{array}{l}0,173 \\
19,77 \\
0,127\end{array}$ & $\begin{array}{c}5,5 \\
20,2 \\
0,26\end{array}$ & $\begin{array}{c}32,23 \\
\text { n.d. } \\
2,33\end{array}$ & $\begin{array}{l}0,184 \\
20,29 \\
0,125\end{array}$ & $\begin{array}{l}4,66 \\
21,8 \\
0,32\end{array}$ \\
\hline $\mathrm{Ti}$ & 22587,24 & 0,633 & 1625,22 & 23631,55 & 1,13 & 1711,74 \\
\hline V & 232,43 & 0,0604 & 15,76 & 238,26 & 0,0499 & 16,28 \\
\hline $\mathrm{Cr}$ & 39,02 & 0,672 & 2,9 & 40,47 & 0,662 & 3,1 \\
\hline Mn & 329,80 & 0,323 & 21,54 & 349,38 & 0,304 & 22,94 \\
\hline Co & 97,25 & 0,0572 & 6,22 & 102,99 & 0,0399 & 6,68 \\
\hline $\mathrm{Ni}$ & 175,91 & 0,229 & 13,06 & 183,19 & 0,246 & 13,98 \\
\hline $\mathrm{Cu}$ & 2,18 & 0,286 & 0,58 & 1,98 & 0,336 & 0,68 \\
\hline $\mathrm{Zn}$ & 89,10 & 0,990 & 7,64 & 96,09 & 0,827 & 8,76 \\
\hline $\mathbf{R b}$ & 820,33 & 0,0469 & 57,48 & 816,31 & 0,0611 & 57,56 \\
\hline $\mathrm{Sr}$ & 14,43 & 0,0235 & 1,02 & 14,70 & 0,0328 & 1,08 \\
\hline$Y$ & 0,047 & 0,0259 & 0,034 & 0,021 & 0,0181 & 0,028 \\
\hline $\mathbf{Z r}$ & 10,37 & 0,0460 & 0,88 & 10,38 & 0,0508 & 0,94 \\
\hline $\mathrm{Nb}$ & 15,48 & 0,0225 & 1,12 & 15,69 & 0,0256 & 1,2 \\
\hline $\mathrm{Ba}$ & 550,78 & 0,235 & 54,14 & 544,03 & 0,318 & 54,42 \\
\hline La & n.d. & 0,0378 & 0,036 & n.d. & 0,0373 & 0,036 \\
\hline $\mathrm{Ce}$ & n.d. & 0,0417 & 0,038 & 0,072 & 0,0217 & 0,048 \\
\hline $\mathrm{Pr}$ & n.d. & 0,0255 & 0,026 & 0,031 & 0,0211 & 0,032 \\
\hline Nd & n.d. & 0,293 & 0,24 & n.d. & 0,289 & 0,32 \\
\hline Sm & n.d. & 0,160 & 0,17 & n.d. & 0,189 & 0,22 \\
\hline Eu & 0,081 & 0,0499 & 0,068 & n.d. & 0,0746 & 0,074 \\
\hline Gd & n.d. & 0,192 & 0,148 & n.d. & 0,226 & 0,22 \\
\hline $\mathrm{Tb}$ & n.d. & 0,0281 & 0,032 & n.d. & 0,0307 & 0,032 \\
\hline Dy & n.d. & 0,197 & 0,182 & 0,164 & 0,0869 & 0,168 \\
\hline Ho & n.d. & 0,0265 & 0,026 & n.d. & 0,0327 & 0,028 \\
\hline Er & n.d. & 0,0855 & 0,08 & n.d. & 0,0844 & 0,108 \\
\hline $\mathrm{Tm}$ & n.d. & 0,0299 & 0,034 & n.d. & 0,0280 & 0,028 \\
\hline $\mathrm{Yb}$ & n.d. & 0,141 & 0,144 & n.d. & 0,140 & 0,162 \\
\hline Lu & 0,035 & 0,0255 & 0,034 & n.d. & 0,0411 & 0,038 \\
\hline $\mathrm{Hf}$ & 0,353 & 0,0996 & 0,176 & 0,38 & 0,104 & 0,22 \\
\hline Ta & 1,130 & 0,0202 & 0,194 & 1,13 & 0,0368 & 0,22 \\
\hline $\mathrm{Pb}$ & n.d. & 0,156 & 0,14 & n.d. & 0,141 & 0,2 \\
\hline Th & n.d. & 0,0135 & 0,0136 & n.d. & 0,00 & 0,00 \\
\hline $\mathbf{U}$ & n.d. & 0,0134 & 0,0082 & n.d. & 0,0229 & 0,026 \\
\hline
\end{tabular}

B:Borda; N: núcleo; n.d.: não detectado. 
Apêndice C - Tabela C.XXV (continuação): Concentrações de elementos-traço obtidas para de flogopita da lâmina PNT-8, limites de detecção (LD) e erros associados (2 $\sigma$ ) utilizados como padrão de qualidade.

\begin{tabular}{|c|c|c|c|c|c|c|}
\hline \multirow[b]{2}{*}{ Elemento } & Análise & LD & $2 \sigma$ & Análise & LD & $2 \sigma$ \\
\hline & \multicolumn{3}{|c|}{$f \log 1 n 2$} & \multicolumn{3}{|c|}{$f \log 1 b 2$} \\
\hline Li & 24,02 & 0,107 & 3,46 & 50,22 & 0,169 & 7,42 \\
\hline $\mathbf{P}$ & 20,84 & 11,44 & 14,04 & n.d. & 20,21 & 17,14 \\
\hline Sc & 1,442 & 0,0718 & 0,154 & 2,16 & 0,115 & 0,24 \\
\hline $\mathrm{Ti}$ & 13997,43 & 0,405 & 1020,8 & 21922,45 & 0,720 & 1615,26 \\
\hline V & 139,86 & 0,0374 & 9,56 & 218,64 & 0,0619 & 15,04 \\
\hline $\mathrm{Cr}$ & 23,72 & 0,394 & 1,74 & 35,92 & 0,664 & 2,68 \\
\hline Mn & 196,86 & 0,187 & 12,92 & 313,99 & 0,302 & 20,7 \\
\hline Co & 58,31 & 0,0219 & 3,72 & 91,75 & 0,0368 & 5,86 \\
\hline $\mathrm{Ni}$ & 104,83 & 0,120 & 7,72 & 168,21 & 0,261 & 12,5 \\
\hline $\mathrm{Cu}$ & 1,75 & 0,190 & 0,34 & 2,08 & 0,293 & 0,48 \\
\hline $\mathrm{Zn}$ & 55,36 & 0,472 & 4,46 & 92,58 & 0,796 & 7,46 \\
\hline $\mathbf{R b}$ & 464,09 & 0,0293 & 32,86 & 763,09 & 0,0415 & 54,48 \\
\hline $\mathrm{Sr}$ & 7,08 & 0,0167 & 0,48 & 15,64 & 0,0280 & 1,06 \\
\hline $\mathbf{Y}$ & n.d. & 0,0150 & 0,0146 & 0,031 & 0,0225 & 0,026 \\
\hline $\mathrm{Zr}$ & 5,83 & 0,0250 & 0,48 & 9,53 & 0,0449 & 0,78 \\
\hline $\mathrm{Nb}$ & 9,01 & 0,0192 & 0,64 & 15,23 & 0,0237 & 1,1 \\
\hline $\mathrm{Ba}$ & 325,36 & 0,144 & 32,78 & 552,89 & 0,253 & 56,8 \\
\hline La & 0,0264 & 0,0117 & 0,017 & 0,052 & 0,0261 & 0,032 \\
\hline $\mathrm{Ce}$ & n.d. & 0,0171 & 0,0168 & n.d. & 0,0346 & 0,032 \\
\hline $\mathbf{P r}$ & n.d. & 0,0133 & 0,0132 & 0,023 & 0,0177 & 0,02 \\
\hline Nd & n.d. & 0,120 & 0,126 & n.d. & 0,226 & 0,22 \\
\hline Sm & n.d. & 0,111 & 0,098 & n.d. & 0,258 & 0,2 \\
\hline $\mathrm{Eu}$ & 0,055 & 0,0290 & 0,036 & n.d. & 0,0522 & 0,052 \\
\hline Gd & n.d. & 0,0969 & 0,086 & n.d. & 0,196 & 0,16 \\
\hline $\mathrm{Tb}$ & n.d. & 0,0231 & 0,0158 & 0,032 & 0,0274 & 0,03 \\
\hline Dy & n.d. & 0,0723 & 0,078 & n.d. & 0,122 & 0,11 \\
\hline Ho & n.d. & 0,0225 & 0,0186 & n.d. & 0,0351 & 0,03 \\
\hline $\mathrm{Er}$ & n.d. & 0,0495 & 0,042 & n.d. & 0,0877 & 0,076 \\
\hline $\mathrm{Tm}$ & n.d. & 0,0190 & 0,0166 & n.d. & 0,0320 & 0,024 \\
\hline Yb & n.d. & 0,0864 & 0,076 & n.d. & 0,138 & 0,12 \\
\hline Lu & n.d. & 0,0160 & 0,016 & n.d. & 0,0351 & 0,028 \\
\hline Hf & 0,273 & 0,0500 & 0,098 & 0,309 & 0,114 & 0,152 \\
\hline $\mathrm{Ta}$ & 0,619 & 0,0157 & 0,104 & 1,198 & 0,0249 & 0,198 \\
\hline $\mathrm{Pb}$ & n.d. & 0,117 & 0,098 & n.d. & 0,197 & 0,174 \\
\hline Th & 0,0023 & 0,00 & 0,0046 & n.d. & 0,00 & 0,00 \\
\hline $\mathbf{U}$ & n.d. & 0,00778 & 0,0066 & 0,0072 & 0,00 & 0,0102 \\
\hline
\end{tabular}

B: Borda, N: núcleo; n.d.: não detectado. 
Apêndice C - Tabela C.XXV (continuação): Concentrações de elementos-traço obtidas para de flogopita da lâmina PNT-8, limites de deteç̧ão (LD) e erros associados (2 $\sigma$ ) utilizados como padrão de qualidade.

\begin{tabular}{|c|c|c|c|c|c|c|}
\hline \multirow[b]{2}{*}{ Elemento } & Análise & LD & $2 \sigma$ & Análise & LD & $2 \sigma$ \\
\hline & \multicolumn{3}{|c|}{ flog2n1 } & \multicolumn{3}{|c|}{ flog2b1 } \\
\hline Li & 47,11 & 0,172 & 7,2 & 2,80 & 0,275 & 0,78 \\
\hline $\mathbf{P}$ & n.d. & 20,38 & 19,24 & n.d. & 26,11 & 32,5 \\
\hline Sc & 2,10 & 0,124 & 0,26 & 14,99 & 0,170 & 1,44 \\
\hline $\mathrm{Ti}$ & 21475,39 & 0,775 & 1602,36 & 26013,47 & 1,11 & 1974,94 \\
\hline V & 216,26 & 0,0518 & 15,02 & 72,95 & 0,0723 & 5,48 \\
\hline $\mathrm{Cr}$ & 35,78 & 0,640 & 2,72 & 997,36 & 0,826 & 71,92 \\
\hline Mn & 308,93 & 0,291 & 20,5 & 391,60 & 0,400 & 26,46 \\
\hline Co & 91,03 & 0,0427 & 5,86 & 62,90 & 0,0497 & 4,5 \\
\hline $\mathrm{Ni}$ & 163,03 & 0,238 & 12,36 & 486,32 & 0,361 & 37,78 \\
\hline $\mathrm{Cu}$ & 2,19 & 0,269 & 0,54 & 1,99 & 0,484 & 0,98 \\
\hline $\mathrm{Zn}$ & 88,81 & 0,817 & 7,48 & 48,25 & 1,14 & 7,02 \\
\hline $\mathbf{R b}$ & 721,34 & 0,0584 & 52,06 & 530,50 & 0,0523 & 39,18 \\
\hline $\mathrm{Sr}$ & 10,02 & 0,0270 & 0,72 & 34,33 & 0,0289 & 2,5 \\
\hline $\mathbf{Y}$ & n.d. & 0,0270 & 0,03 & 0,230 & 0,0142 & 0,1 \\
\hline $\mathrm{Zr}$ & 8,54 & 0,0585 & 0,74 & 27,81 & 0,0567 & 2,46 \\
\hline $\mathrm{Nb}$ & 12,96 & 0,0159 & 0,96 & 16,34 & 0,0358 & 1,42 \\
\hline $\mathrm{Ba}$ & 481,33 & 0,292 & 50,78 & 3639,21 & 0,305 & 392,48 \\
\hline La & 0,021 & 0,0175 & 0,024 & 0,067 & 0,0353 & 0,07 \\
\hline $\mathrm{Ce}$ & 0,050 & 0,0170 & 0,03 & 0,122 & 0,0385 & 0,09 \\
\hline Pr & n.d. & 0,0214 & 0,017 & n.d. & 0,0283 & 0,044 \\
\hline Nd & 0,37 & 0,104 & 0,22 & 0,32 & 0,314 & 0,5 \\
\hline Sm & n.d. & 0,219 & 0,196 & n.d. & 0,238 & 0,22 \\
\hline Eu & 0,099 & 0,0535 & 0,07 & 0,184 & 0,0574 & 0,148 \\
\hline Gd & n.d. & 0,147 & 0,15 & n.d. & 0,276 & 0,3 \\
\hline $\mathrm{Tb}$ & n.d. & 0,0281 & 0,022 & n.d. & 0,0328 & 0,032 \\
\hline Dy & n.d. & 0,183 & 0,144 & 0,14 & 0,126 & 0,24 \\
\hline Ho & n.d. & 0,0373 & 0,026 & n.d. & 0,0302 & 0,04 \\
\hline $\mathrm{Er}$ & n.d. & 0,0851 & 0,084 & 0,056 & 0,0496 & 0,106 \\
\hline Tm & n.d. & 0,0267 & 0,02 & n.d. & 0,0331 & 0,046 \\
\hline $\mathrm{Yb}$ & n.d. & 0,133 & 0,124 & n.d. & 0,201 & 0,172 \\
\hline Lu & n.d. & 0,0232 & 0,022 & n.d. & 0,0513 & 0,032 \\
\hline Hf & 0,412 & 0,127 & 0,19 & 1,00 & 0,174 & 0,48 \\
\hline $\mathrm{Ta}$ & 1,087 & 0,0221 & 0,192 & 0,75 & 0,0418 & 0,22 \\
\hline $\mathrm{Pb}$ & n.d. & 0,221 & 0,22 & n.d. & 0,224 & 0,14 \\
\hline Th & n.d. & 0,00 & 0,00 & n.d. & 0,00 & 0,00 \\
\hline $\mathbf{U}$ & 0,0180 & 0,00 & 0,0182 & n.d. & 0,00 & 0,00 \\
\hline
\end{tabular}

B: Borda, N: núcleo; n.d.: não detectado. 
Apêndice C - Tabela C.XXV (continuação): Concentrações de elementos-traço obtidas de

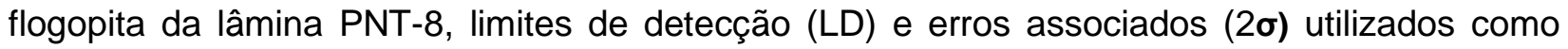
padrão de qualidade.

\begin{tabular}{|c|c|c|c|c|c|c|}
\hline \multirow[b]{2}{*}{ Elemento } & Análise & LD & $2 \sigma$ & Análise & LD & $2 \sigma$ \\
\hline & \multicolumn{3}{|c|}{$f \log 2 n 2$} & \multicolumn{3}{|c|}{$f \log 3 n 1$} \\
\hline $\mathrm{Li}$ & 51,24 & 0,155 & 9,54 & 24,85 & 0,179 & 4,92 \\
\hline $\mathbf{P}$ & n.d. & 19,00 & 20,5 & 40,25 & 22,81 & 34,7 \\
\hline Sc & 2,09 & 0,108 & 0,28 & 2,45 & 0,124 & 0,36 \\
\hline $\mathrm{Ti}$ & 20603,56 & 0,615 & 1676,16 & 21663,87 & 0,910 & 1800,58 \\
\hline v & 204,20 & 0,0577 & 15,12 & 210,44 & 0,0644 & 15,86 \\
\hline $\mathrm{Cr}$ & 33,68 & 0,592 & 2,8 & 31,14 & 0,693 & 2,74 \\
\hline Mn & 287,16 & 0,276 & 19,98 & 337,44 & 0,312 & 23,76 \\
\hline Co & 83,66 & 0,0315 & 5,56 & 95,31 & 0,0424 & 6,4 \\
\hline $\mathrm{Ni}$ & 148,01 & 0,225 & 12,32 & 274,32 & 0,181 & 22,78 \\
\hline $\mathrm{Cu}$ & 2,54 & 0,244 & 0,66 & 2,53 & 0,362 & 0,8 \\
\hline $\mathrm{Zn}$ & 74,94 & 0,714 & 7,28 & 94,29 & 0,883 & 9,36 \\
\hline $\mathrm{Rb}$ & 651,39 & 0,0382 & 50,64 & 756,81 & 0,0592 & 59,92 \\
\hline $\mathrm{Sr}$ & 9,35 & 0,0193 & 0,72 & 30,34 & 0,0211 & 2,12 \\
\hline$Y$ & n.d. & 0,0294 & 0,032 & 0,077 & 0,0255 & 0,05 \\
\hline $\mathrm{Zr}$ & 7,96 & 0,0389 & 0,78 & 10,32 & 0,0536 & 1,02 \\
\hline $\mathrm{Nb}$ & 12,56 & 0,0276 & 1,02 & 14,01 & 0,0329 & 1,16 \\
\hline $\mathrm{Ba}$ & 475,31 & 0,245 & 58,52 & 622,85 & 0,234 & 79,34 \\
\hline La & n.d. & 0,0317 & 0,038 & n.d. & 0,0334 & 0,044 \\
\hline $\mathrm{Ce}$ & n.d. & 0,0400 & 0,04 & 0,078 & 0,0327 & 0,058 \\
\hline $\mathrm{Pr}$ & n.d. & 0,0195 & 0,02 & n.d. & 0,0257 & 0,032 \\
\hline Nd & n.d. & 0,240 & 0,2 & n.d. & 0,254 & 0,24 \\
\hline Sm & n.d. & 0,176 & 0,162 & n.d. & 0,173 & 0,22 \\
\hline $\mathrm{Eu}$ & n.d. & 0,0600 & 0,062 & n.d. & 0,0660 & 0,078 \\
\hline Gd & n.d. & 0,125 & 0,166 & n.d. & 0,194 & 0,24 \\
\hline Tb & n.d. & 0,0307 & 0,024 & n.d. & 0,0311 & 0,034 \\
\hline Dy & n.d. & 0,174 & 0,156 & n.d. & 0,198 & 0,194 \\
\hline Ho & n.d. & 0,0271 & 0,026 & n.d. & 0,0371 & 0,038 \\
\hline Er & n.d. & 0,0889 & 0,108 & n.d. & 0,0745 & 0,088 \\
\hline $\mathrm{Tm}$ & n.d. & 0,0257 & 0,026 & n.d. & 0,0231 & 0,034 \\
\hline $\mathrm{Yb}$ & 0,097 & 0,0950 & 0,138 & n.d. & 0,140 & 0,174 \\
\hline Lu & n.d. & 0,0281 & 0,02 & 0,029 & 0,0252 & 0,04 \\
\hline $\mathrm{Hf}$ & 0,32 & 0,132 & 0,2 & 0,204 & 0,0928 & 0,176 \\
\hline Ta & 1,01 & 0,0247 & 0,22 & 0,97 & 0,0351 & 0,24 \\
\hline $\mathbf{P b}$ & 0,119 & 0,116 & 0,172 & 0,20 & 0,111 & 0,22 \\
\hline Th & n.d. & 0,0124 & 0,0156 & n.d. & 0,0192 & 0,0118 \\
\hline U & n.d. & 0,00 & 0,00 & n.d. & 0,0135 & 0,0084 \\
\hline
\end{tabular}

B: Borda, N: núcleo; n.d.: não detectado. 
Apêndice C - Tabela C.XXV (continuação): Concentrações de elementos-traço obtidas para de flogopita da lâmina PNT-8, limites de detecção e erros associados $(2 \sigma)$ utilizados como padrão de qualidade.

\begin{tabular}{|c|c|c|c|c|c|c|}
\hline \multirow[b]{2}{*}{ Elemento } & Análise & LD & $2 \sigma$ & Análise & LD & $2 \sigma$ \\
\hline & \multicolumn{3}{|c|}{ flog3b1 } & \multicolumn{3}{|c|}{$f \log 3 x$} \\
\hline $\mathbf{L i}$ & 25,49 & 0,146 & 5,38 & 20,97 & 0,187 & 4,44 \\
\hline $\mathbf{P}$ & n.d. & 22,00 & 32,38 & 23,81 & 23,38 & 24,38 \\
\hline Sc & 1,92 & 0,127 & 0,38 & 2,68 & 0,129 & 0,3 \\
\hline $\mathrm{Ti}$ & 18638,32 & 0,611 & 1586,88 & 24395,95 & 0,888 & 2116,52 \\
\hline $\mathbf{V}$ & 184,31 & 0,0708 & 14,3 & 230,63 & 0,0605 & 17,82 \\
\hline $\mathrm{Cr}$ & 25,74 & 0,658 & 2,58 & 35,62 & 0,721 & 3 \\
\hline Mn & 308,41 & 0,310 & 22,16 & 325,54 & 0,341 & 23,38 \\
\hline Co & 88,70 & 0,0361 & 6,24 & 99,38 & 0,0454 & 6,58 \\
\hline $\mathrm{Ni}$ & 281,49 & 0,198 & 24,66 & 382,05 & 0,265 & 31,8 \\
\hline $\mathrm{Cu}$ & 3,29 & 0,326 & 1,16 & 2,02 & 0,381 & 0,54 \\
\hline $\mathrm{Zn}$ & 82,07 & 0,830 & 10,02 & 73,57 & 0,967 & 6,7 \\
\hline $\mathbf{R b}$ & 741,46 & 0,0423 & 60,04 & 762,11 & 0,0583 & 62,5 \\
\hline $\mathrm{Sr}$ & 839,10 & 0,0224 & 54,2 & 15,13 & 0,0336 & 1,06 \\
\hline $\mathbf{Y}$ & 0,785 & 0,0246 & 0,192 & 0,032 & 0,0286 & 0,03 \\
\hline $\mathrm{Zr}$ & 9,94 & 0,0562 & 1,16 & 10,66 & 0,0574 & 0,94 \\
\hline $\mathrm{Nb}$ & 14,71 & 0,0265 & 1,34 & 17,19 & 0,0240 & 1,34 \\
\hline $\mathrm{Ba}$ & 16904,30 & 0,213 & 2209,02 & 603,74 & 0,312 & 81,96 \\
\hline La & 0,099 & 0,0275 & 0,08 & n.d. & 0,0404 & 0,036 \\
\hline $\mathrm{Ce}$ & 0,140 & 0,0301 & 0,094 & n.d. & 0,0259 & 0,026 \\
\hline Pr & n.d. & 0,0222 & 0,038 & n.d. & 0,0247 & 0,024 \\
\hline Nd & n.d. & 0,235 & 0,148 & n.d. & 0,249 & 0,22 \\
\hline Sm & 0,13 & 0,132 & 0,28 & n.d. & 0,255 & 0,2 \\
\hline $\mathrm{Eu}$ & 0,74 & 0,0583 & 0,3 & n.d. & 0,0710 & 0,064 \\
\hline Gd & n.d. & 0,163 & 0,22 & n.d. & 0,200 & 0,166 \\
\hline $\mathrm{Tb}$ & n.d. & 0,0314 & 0,05 & n.d. & 0,0349 & 0,03 \\
\hline Dy & n.d. & 0,140 & 0,24 & n.d. & 0,173 & 0,164 \\
\hline Ho & n.d. & 0,0318 & 0,046 & n.d. & 0,0301 & 0,026 \\
\hline $\mathrm{Er}$ & n.d. & 0,0860 & 0,13 & n.d. & 0,0905 & 0,076 \\
\hline Tm & n.d. & 0,0273 & 0,044 & n.d. & 0,0417 & 0,032 \\
\hline Yb & 0,22 & 0,162 & 0,32 & n.d. & 0,173 & 0,146 \\
\hline Lu & n.d. & 0,0385 & 0,056 & n.d. & 0,0366 & 0,032 \\
\hline Hf & 0,39 & 0,117 & 0,32 & 0,352 & 0,146 & 0,184 \\
\hline $\mathrm{Ta}$ & 0,97 & 0,0339 & 0,28 & 1,36 & 0,0218 & 0,28 \\
\hline $\mathrm{Pb}$ & 0,36 & 0,151 & 0,4 & n.d. & 0,182 & 0,164 \\
\hline Th & 0,017 & 0,00 & 0,034 & 0,0039 & 0,00 & 0,0078 \\
\hline $\mathbf{U}$ & 0,017 & 0,00 & 0,034 & 0,0038 & 0,00 & 0,0078 \\
\hline
\end{tabular}

B: Borda, N: núcleo; n.d.: não detectado. 
Apêndice D - Fundidos calculados para intrusão Pântano, fundido granítico e filito utilizados na modelagem de contaminação 
Apêndice D - Tabela D.I: fundidos calculados para intrusão Pântano obtidos através do desconto das populações xenocristalinas de olivina e flogopita.

\begin{tabular}{|c|c|c|c|c|c|c|c|}
\hline & PNT 3 & PNT 4 & PNT 5 & PNT 6 & PNT 7 & PNT 8 & PNT 9 \\
\hline Olivina (\% rocha) & 24 & 17 & 16 & 33 & 29 & 20 & 33 \\
\hline Flogopita (\% rocha) & 2 & & & & & 2 & 2 \\
\hline $\mathrm{SiO}_{2(\% \text { massa })}$ & 29,24 & 30,08 & 29,30 & 29,25 & 32,26 & 30,19 & 30,75 \\
\hline $\mathrm{TiO}_{2}$ & 6,44 & 7,12 & 7,39 & 7,40 & 6,87 & 6,01 & 7,16 \\
\hline $\mathrm{Al}_{2} \mathrm{O}_{3}$ & 2,91 & 3,39 & 3,67 & 3,37 & 3,24 & 2,59 & 3,11 \\
\hline $\mathrm{FeO}_{\mathrm{T}}$ & 12,18 & 13,78 & 14,10 & 11,84 & 11,95 & 12,20 & 11,29 \\
\hline $\mathrm{Fe}_{2} \mathrm{O}_{3 \mathrm{~T}}$ & 13,53 & 15,32 & 15,67 & 13,16 & 13,28 & 13,56 & 12,55 \\
\hline MnO & 0,25 & 0,26 & 0,26 & 0,26 & 0,25 & 0,24 & 0,25 \\
\hline $\mathrm{MgO}$ & 18,00 & 16,00 & 14,45 & 15,25 & 16,93 & 20,18 & 14,13 \\
\hline $\mathrm{CaO}$ & 15,30 & 13,72 & 13,68 & 17,00 & 13,01 & 14,35 & 15,94 \\
\hline $\mathrm{Na}_{2} \mathrm{O}$ & 0,03 & 0,02 & 0,11 & 0,03 & 0,03 & 0,02 & 0,03 \\
\hline $\mathrm{K}_{2} \mathrm{O}$ & 2,90 & 3,87 & 3,75 & 3,55 & 3,21 & 2,52 & 4,12 \\
\hline $\mathrm{P}_{2} \mathrm{O}_{5}$ & 1,39 & 0,84 & 0,75 & 1,28 & 0,66 & 0,85 & 1,40 \\
\hline $\mathrm{BaO}$ & 0,44 & 0,39 & 0,30 & 0,48 & 0,48 & 0,12 & 0,48 \\
\hline $\mathrm{NiO}$ & 0,06 & 0,03 & 0,02 & 0,02 & 0,04 & 0,16 & 0,01 \\
\hline LOI & 7,32 & 6,60 & 8,08 & 8,10 & 7,82 & 8,05 & 8,51 \\
\hline$S c_{p p m}$ & 34 & 38 & 35 & 32 & 34 & 35 & 34 \\
\hline V & 79 & 72 & 100 & 58 & 78 & 55 & 85 \\
\hline Co & 84 & 77,4 & 79,3 & 79,2 & 78,1 & 84,1 & 83,9 \\
\hline $\mathrm{Be}$ & 4 & 4 & 6 & 3 & 2 & 5 & 3 \\
\hline $\mathrm{Cu}$ & 118 & 137 & 137 & 120 & 119 & 116 & 112 \\
\hline$Z n$ & 89 & 103 & 106 & 91 & 92 & 90 & 85 \\
\hline $\mathrm{Ga}$ & 9,5 & 11,9 & 12,6 & 8,6 & 8,6 & 8,4 & 10,2 \\
\hline $\mathbf{R b}$ & 144,5 & 187,2 & 198,4 & 156,5 & 150 & 140,3 & 163,6 \\
\hline $\mathbf{Y}$ & 22,9 & 24,1 & 25,7 & 23,4 & 22,1 & 23,3 & 23,3 \\
\hline $\mathrm{Nb}$ & 272,9 & 291,9 & 300 & 266,3 & 260,6 & 273 & 270,3 \\
\hline Sn & 4 & 4 & 4 & 3 & 2 & 3 & 3 \\
\hline Cs & 1,8 & 1,6 & 2,2 & 1,7 & 1,5 & 1,4 & 1,4 \\
\hline La & 269,7 & 279,3 & 287,4 & 272,5 & 269 & 278,2 & 273,6 \\
\hline $\mathrm{Ce}$ & 489,4 & 512,5 & 538,1 & 496,3 & 488,6 & 504,4 & 499,4 \\
\hline $\mathrm{Pr}$ & 54,3 & 56,69 & 59,13 & 54,52 & 53,52 & 55,76 & 54,75 \\
\hline Nd & 182,3 & 193,3 & 201,5 & 190,5 & 185,9 & 191,4 & 184,3 \\
\hline Sm & 22,8 & 24,76 & 26,48 & 23,35 & 22,63 & 24,22 & 23,2 \\
\hline Eu & 5,6 & 6,02 & 6,31 & 5,73 & 5,85 & 5,76 & 5,51 \\
\hline Gd & 14,9 & 15,37 & 15,87 & 14,26 & 15,07 & 14,16 & 14,09 \\
\hline $\mathrm{Tb}$ & 1,4 & 1,47 & 1,5 & 1,33 & 1,39 & 1,39 & 1,33 \\
\hline Dy & 6 & 6,96 & 7,15 & 6,37 & 6,17 & 6,59 & 6,44 \\
\hline Ho & 0,8 & 0,89 & 0,91 & 0,79 & 0,81 & 0,82 & 0,79 \\
\hline Er & 1,7 & 1,87 & 1,94 & 1,66 & 1,67 & 1,8 & 1,69 \\
\hline
\end{tabular}


Apêndice D - Tabela D.I: fundidos calculados para intrusão Pântano obtidos através do desconto das populações xenocristalinas de olivina e flogopita (continuação).

\begin{tabular}{|c|c|c|c|c|c|c|c|}
\hline & PNT 3 & PNT 4 & PNT 5 & PNT 6 & PNT 7 & PNT 8 & PNT 9 \\
\hline Olivina (\% rocha) & 24 & 17 & 16 & 33 & 29 & 20 & 33 \\
\hline Flogopita (\% rocha) & 2 & & & & & 2 & 2 \\
\hline $\mathrm{Tm}_{\mathrm{ppm}}$ & 0,2 & 0,24 & 0,24 & 0,2 & 0,2 & 0,23 & 0,2 \\
\hline Yb & 1,3 & 1,33 & 1,4 & 1,24 & 1,27 & 1,27 & 1,23 \\
\hline Lu & 0,2 & 0,16 & 0,18 & 0,16 & 0,15 & 0,15 & 0,17 \\
\hline Hf & 19,1 & 21,2 & 19 & 18,3 & 18,2 & 18,2 & 18,9 \\
\hline $\mathrm{Ta}$ & 15,1 & 17,2 & 17,3 & 15,6 & 14,9 & 15,3 & 15,5 \\
\hline W & 0,7 & 0,5 & 0,8 & 0,8 & 0,7 & 0,9 & 0 \\
\hline $\mathbf{P b}$ & 0 & 0 & 0 & 0 & 0 & 0 & 0 \\
\hline Th & 27 & 27,7 & 28,6 & 27,3 & 27,7 & 27,8 & 26,6 \\
\hline $\mathbf{U}$ & 6 & 6 & 6,3 & 5,8 & 5,6 & 5,8 & 6,2 \\
\hline
\end{tabular}


Apêndice D - Tabela D.II: composição do granito utilizado como possível encaixante na modelagem de contaminação crustal e fundido da rocha, calculado a partir do RhyoliteMelts. Dados de Lima, 2019.

\begin{tabular}{|c|c|c|}
\hline $\begin{array}{l}\text { \% em } \\
\text { massa }\end{array}$ & Encaixante & Fundido Encaixante \\
\hline $\mathrm{SiO}_{2}$ & 71,38 & 73,65 \\
\hline TiO2 & 0,275 & 0,29 \\
\hline $\mathrm{Al}_{2} \mathrm{O}_{3}$ & 14,29 & 12,74 \\
\hline $\mathrm{Fe}_{2} \mathrm{O}_{3}$ & 2,19 & 0,15 \\
\hline $\mathrm{FeO}$ & & 0,14 \\
\hline MnO & 0,034 & 0,1 \\
\hline MgO & 0,56 & 0,3 \\
\hline $\mathrm{CaO}$ & 2,61 & 1,07 \\
\hline $\mathrm{Na}_{2} \mathrm{O}$ & 3,82 & 1,07 \\
\hline $\mathrm{K}_{2} \mathrm{O}$ & 2,42 & 6,4 \\
\hline $\mathrm{P}_{2} \mathrm{O}_{5}$ & 0,073 & 0,25 \\
\hline $\mathrm{H}_{2} \mathrm{O}$ & 1,3 & 3,84 \\
\hline$R b_{p p m}$ & 118 & 222,13 \\
\hline $\mathrm{Sr}$ & 267 & 120,28 \\
\hline $\mathrm{Ba}$ & 831 & 1005,12 \\
\hline $\mathbf{P b}$ & 16,2 & 12,7 \\
\hline $\mathrm{Zr}$ & 165 & 326,66 \\
\hline $\mathbf{Y}$ & 5,65 & 14,65 \\
\hline Nb & 9,65 & 15,58 \\
\hline La & 34,9 & 30 \\
\hline $\mathrm{Ce}$ & 57,2 & 109,38 \\
\hline Nd & 16,9 & 36,12 \\
\hline Sm & 2,59 & 6,81 \\
\hline U & 3,1 & 8,53 \\
\hline Th & 15,93 & 47,84 \\
\hline Gd & 1,6 & 4,63 \\
\hline Eu & 0,7 & 0,26 \\
\hline
\end{tabular}


Apêndice D - Tabela D.III: dados do possível filito encaixante do Grupo Canastra (Saar, 2009) utilizado na modelagem de contaminação.

\begin{tabular}{cc}
\hline $\begin{array}{c}\text { \% em } \\
\text { massa }\end{array}$ & Filito \\
\hline $\mathrm{SiO}_{2}$ & 65 \\
$\mathrm{Al}_{2} \mathbf{O}_{3}$ & 16 \\
$\mathrm{Fe}_{2} \mathrm{O}_{3}$ & 7,26 \\
$\mathbf{M g O}$ & 1,48 \\
$\mathbf{C a O}$ & 0,81 \\
$\mathrm{Na}_{2} \mathbf{O}$ & 1,21 \\
$\mathrm{~K}_{2} \mathbf{O}^{2}$ & 3,51 \\
$\mathrm{TiO}_{2}$ & 0,98 \\
$\mathbf{P}_{2} \mathbf{O}_{5}$ & 0,14 \\
$\mathbf{M n O}$ & 0,06 \\
$\mathrm{Cr}_{2} \mathbf{O}_{3}$ & 0,01 \\
$\mathbf{L O I}$ & 3,67 \\
$\mathbf{A g}$ & 0,13 \\
$\mathbf{A s}$ & 195 \\
$\mathbf{C d}$ & 0,15 \\
$\mathbf{C u}$ & 42,22 \\
$\mathbf{M o}$ & 1,58 \\
$\mathbf{P b}$ & 23 \\
$\mathbf{B a}$ & 472 \\
$\mathbf{C o}$ & 16,48 \\
$\mathbf{N i}$ & 32,48 \\
$\mathbf{S b}$ & 0,29 \\
$\mathbf{Z r}$ & 234 \\
$\mathbf{W}$ & 2,25 \\
$\mathbf{Z n}$ & 93 \\
\hline &
\end{tabular}

